\title{
EFEKTIVITAS MODEL PEMBELAJARAN SIMAYANG TIPE II BERBASIS MULTIPEL REPRESENTASI TERHADAP PENGUASAAN KONSEP DAN ATTITUDES TOWARD CHEMISTRY PADA MATERI LARUTAN PENYANGGA
}

\author{
SKRIPSI \\ Diajukan untuk Memenuhi Sebagian Syarat \\ Guna Memperoleh Gelar Sarjana Pendidikan \\ dalam Ilmu Pendidikan Kimia
}

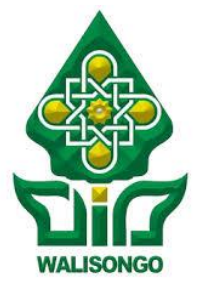

Oleh:

Dini Lestari

NIM: 1608076052

FAKULTAS SAINS DAN TEKNOLOGI

UNIVERSITAS ISLAM NEGERI WALISONGO

SEMARANG

2020 


\section{PERNYATAAN KEASLIAN}

Yang bertandatangan dibawah ini:

Nama $\quad$ : Dini Lestari

NIM : 1608076052

Jurusan $\quad$ : Pendidikan Kimia

Menyatakan bahwa skripsi yang berjudul:

EFEKTIVITAS MODEL PEMBELAJARAN SIMAYANG TIPE II BERBASIS MULTIPEL REPRESENT ASI TERHADAP PENGUASAAN KONSEP DAN ATTITUDES TOWARD CHEMISTRY PADA MATERI LARUT AN PENYANGGA

Secara keseluruhan adalah hasil penelitian/karya saya sendiri, kecuali bagian tertentu yang dirujuk sumbernya.

Semarang, 30 Juni 2020

PembuatPernyataan,

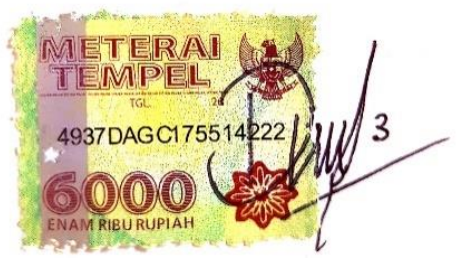

Dini Lestari

NIM : 1608076052 
KEMENTERIAN AGAMA REPUBLIK INDONESIA

UNIVERSITAS ISLAM NEGERI WALISONGO

FAKULTAS SAINS DAN TEKNOLOGI

Jl. Prof. Dr. Hamka (Kampus II) Ngaliyan Semarang

Telp. 024-7601295 Fax. 7615387

\section{PENGESAHAN}

Naskah skripsi berikut ini:

Judul : Efektivitas Model Pembelajaran SiMaYang Tipe II Berbasis Multipel Representasi terhadap Penguasaan Konsep dan Attitudes toward Chemistry pada Materi Larutan Penyangga

Penulis : Dini Lestari

NIM : 1608076052

Jurusan : Pendidikan Kimia

Telah diujikan dalam sidang munaqasyah oleh Dewan Penguji Fakultas Sains dan Teknologi UIN Walisongo dan dapat diterima sebagai salah satu syarat memperoleh gelar sarjana dalam Ilmu Pendidikan Kimia.

Semarang, 8 Juli 2020

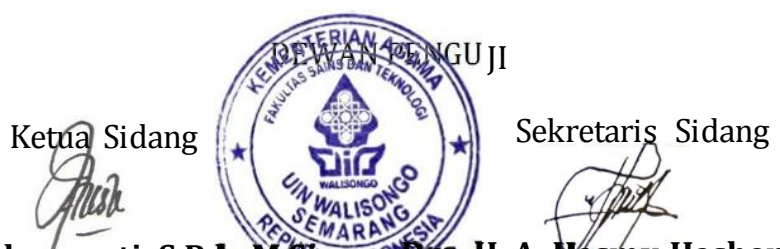

Atik Rahmawati, S.Pd., M.Si I IKINDOO IIS. H. A. Hasmy Hashona, M.A NIP. 197505162006042002 NIP. 196403081993031002

Penguji I

Mulyatun, S.Pd., M.Si.

NIP. 198305042011012008

Pembimbing I

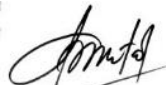

Anita Fibonacci, M.Pd.

NIDN. 2028118701
Penguji II Ulya Lathifa, M.Pd. NIDN. 2012119001

Pembimbing II

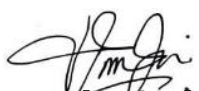

Nur Alawiyah, M.Pd. NIP. 199105032019032026 


\section{NOTA DINAS}

Semarang, 30 Juni 2020

Kepada

Yth. Dekan Fakultas Sains dan Teknologi

UIN Walisongo

di Semarang

Assalamu'alaikum.wr.wb.

Dengan ini diberitahukan bahwa saya telah melakukan bimbingan, arahan dan koreksi naskah skripsi dengan:

Judul : Efektivitas Model Pembelajaran SiMaYang Tipe II Berbasis Multipel Representasi terhadap Penguasaan Konsep dan Attitudes toward Chemistry pada Materi Larutan Penyangga

Nama : Dini Lestari

NIM : 1608076052

Jurusan : Pendidikan Kimia

Saya memandang bahwa naskah skripsi tersebut sudah dapat diajukan kepada Fakultas Sains dan Teknologi UIN Walisongo untuk diujikan dalam Sidang Munaqasyah.

Wassalamu'alaikum.wr. wb.

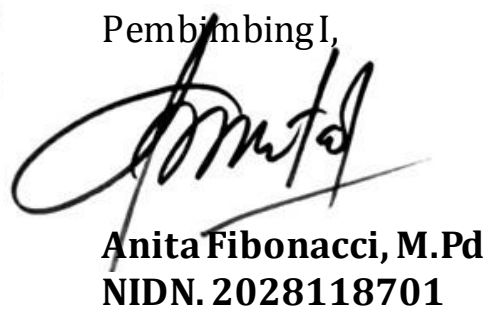




\section{NOTA DINAS}

Semarang, 30 Juni 2020

Kepada

Yth. Dekan Fakultas Sains dan Teknologi

UIN Walisongo

di Semarang

Assalamu'alaikum.wr.wb.

Dengan ini diberitahukan bahwa saya telah melakukan bimbingan, arahan dan koreksi naskah skripsi dengan:

Judul : Efektivitas Model Pembelajaran SiMaYang Tipe II Berbasis Multipel Representasi terhadap Penguasaan Konsep dan Attitudes toward Chemistry pada Materi Larutan Penyangga

Nama : Dini Lestari

NIM : 1608076052

Jurusan : Pendidikan Kimia

Saya memandang bahwa naskah skripsi tersebut sudah dapat diajukan kepada Fakultas Sains dan Teknologi UIN Walisongo untuk diujikan dalam Sidang Munaqasyah.

Wassalamu'alaikum. wr. wb.

Pembimbing II,

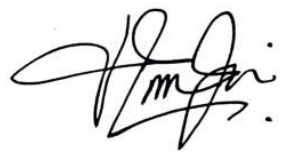

Nur Alawiyah, M.Pd

NIP. 199105032019032026 
Judul : Efektivitas Model Pembelajaran SiMaYang Tipe II Berbasis Multipel Representasi terhadap Penguasaan Konsep dan Attitudes toward Chemistry pada Materi Larutan Penyangga

Penulis : Dini Lestari

NIM : 1608076052

\section{ABSTRAK}

Rendahnya penguasaan konsep pada materi larutan penyangga dapat disebabkan karena tidak terkoneksinya ketiga level representasi dalam kimia dan rendahnya attitudes toward chemistry. Penelitian ini bertujuan untuk mengetahui efektivitas model pembelajaran SiMaYang Tipe II berbasis multipel representasi terhadap penguasaan konsep dan attitudes toward chemistry, serta respon peserta didik terhadap model pembelajaran SiMaYang Tipe II berbasis multipel representasi pada materi larutan penyangga. Metode penelitian yang digunakan adalah eksperimen, dengan desain Nonequivalent Control Group Design. Teknik sampling yang digunakan adalah cluster random sampling. Penelitian ini menggunakan dua sampel yang berbeda, yaitu kelas XI MIPA 6 (kelas kontrol) dan kelas XI MIPA 7 (kelas eksperimen). Berdasarkan uji hipotesis menggunakan uji-t pada data penguasaan konsep, diperoleh bahwa $t_{\text {hitung }}=2,481$ dan $t_{\text {tabel }}=$ 1,668 , sehingga $t_{\text {hitung }}>t_{\text {tabel. }}$. Sedangkan hasil uji-t pada data attitudes toward chemistry menunjukkan bahwa $\mathrm{t}_{\text {hitung }}=0,327$ dan $t_{\text {tabel }}=1,668$, sehingga $t_{\text {hitung }} \leq t_{\text {tabel. }}$. Oleh karena itu, dapat disimpulkan bahwa model pembelajaran SiMaYang Tipe II berbasis multipel representasi efektif terhadap penguasaan konsep dan tidak efektif terhadap attitudes toward chemistry pada materi larutan penyangga. Berdasarkan respon peserta 
didik terhadap model pembelajaran SiMaYang Tipe II diperoleh persentase sebesar 64,11\% dengan kategori "baik".

Kata Kunci: SiMaYang Tipe II, Multipel Representasi, Penguasaan Konsep, Attitudes toward Chemistry, Larutan Penyangga 


\section{PERSEMBAHAN}

Dengan rendah hati, penulis persembahkan skripsi ini kepada orang-orang terdekat sebagai berikut:

1. Orang tuaku tercinta, Hilman Suryaman (alm) dan Neneng Aisah, yang telah membesarkan penulis dengan penuh kasih sayang, serta memberikan dukungan penuh kepada penulis.

2. Kakak-kakak tercinta, Lies Trisna Susanti, Haerul Hidayaturrahman, Yudi Kotari dan Dwi Retnoningtiyas yang telah memberikan do'a dan dukungan penuh kepada penulis.

3. Keponakanku tersayang, Safyah Izzatul Latifah dan Alfariel Arkan Kotari.

4. Almamater tercinta, Program Studi Pendidikan Kimia Fakultas Sains dan Teknologi UIN Walisongo Semarang.

5. Keluarga besar Pendidikan Kimia, khususnya angkatan 2016 yang telah memberikan banyak kenangan, pengalaman dan motivasi selama penulis kuliah di UIN Walisongo Semarang.

6. Untuk sahabat-sahabatku yang kukenal saat menginjak masa perkuliahan, Yeni Hanifah, Rani Puspita Hami, Athi'ul Husna dan Rizka Azkia yang selalu mendengarkan 
keluh kesah dan memberikan semangat kepada penulis. Terimakasih atas do'a dan semangat yang kalian berikan.

7. Sahabat-sahabatku yang kukenal saat di bangku SMA, Sifa Maulina, Amelia Santi Gustian, Novsa Fakhira, Lestari Mela Anggraini dan Rafika Della. Terimakasih untuk do'a, motivasi dan semangat yang selalu kalian berikan.

8. Sahabat dekatku dari zaman putih biru, Devika Sri Rahayu. Terimakasih untuk do'a, motivasi dan semangat yang selalu diberikan.

9. Teman-teman PPL SMAN 2 Semarang 2019, yang telah memberikan kenangan dan pengalaman berharga selama penulis PPL di SMAN 2 Semarang.

10. Teman-teman KKN Reguler Ke-73 Posko 89 di Desa Sumberejo, Kec. Pabelan, Kab. Semarang yang telah memberikan kenangan dan pengalaman berharga bagi penulis.

11. Teman-teman kost 19B: Fela, Devi, Fitri, Lusi, Nisa, Farha, Khusnul dan Indah yang telah mewarnai hari penulis. Terimakasih atas kebersamaan, kekeluargaan dan kebahagiaan yang telah kalian berikan. 


\section{KATA PENGANTAR}

\section{Assalamu'alaikum Wr. Wb.}

Alhamdulillah, puji dan syukur penulis ucapkan ke hadirat Allah SWT yang telah melimpahkan rahmat, taufik, serta hidayah-Nya sehingga penulis dapat menyelesaikan penulisan skripsi dengan baik dan lancar.

Sholawat serta salam senantiasa tercurahkan kepada Nabi Muhammad SAW, yang senantiasa menjadi suri tauladan bagi seluruh umat Islam dalam menuntut ilmu. Semoga kita mendapatkan syafa'at dari Beliau, Aamiin.

Selama penulisan skripsi ini, penulis menyadari bahwa tanpa adanya bantuan dan arahan dari berbagai pihak, skripsi ini tidak akan terselesaikan dengan baik. Oleh karena itu, pada kesempatan ini penulis menyampaikan ucapan terima kasih kepada:

12. Bapak Dr. H. Ismail, M.Ag, selaku Dekan Fakultas Sains dan Teknologi UIN Walisongo Semarang.

13. Ibu Atik Rahmawati, S.Pd, M.Si, selaku Ketua Program Studi Pendidikan Kimia UIN Walisongo Semarang.

14. Ibu Wirda Udaibah, M.Si selaku Sekretaris Program Studi Pendidikan Kimia UIN Walisongo Semarang. 
15. Ibu Anita Fibonacci, M.Pd selaku Dosen Pembimbing I dan Ibu Nur Alawiyah, M.Pd selaku Dosen Pembimbing II yang telah memberikan bimbingan dan pengarahan dalam penyusunan skrispi ini.

16. Ibu Apriliana Drastisianti, M.Pd selaku Dosen Validator yang telah memberikan bimbingan selama penyusunan instrumen penelitian.

17. Ibu Ulya Lathifa, M.Pd selaku Wali Dosen yang telah memberikan bimbingan dan arahan dari awal sampai selesainya perkuliahan.

18. Segenap Bapak/Ibu Dosen Pendidikan Kimia yang telah memberikan ilmu dan motivasinya selama penulis menuntut ilmu di UIN Walisongo Semarang.

19. Ibu Dra. Eny Murtiningsih dan Bapak Siswanto, S.Pd yang telah mengizinkan penulis melakukan uji coba instrumen di SMAN 8 Semarang.

20. Bapak Drs. Khoirul Imdad, M.Ed selaku Kepala SMAN 9 Semarang yang telah memberikan izin penelitian.

21. Ibu Wiwik Indah Kusumaningrum, M.Pd., Ibu Dra. VDR Andri Wulandari dan Ibu Dra. Dewi Handayani selaku guru kimia yang telah memberikan izin observasi pra riset hingga penelitian di SMAN 9 Semarang. 
22. Semua pihak yang telah membantu terselesaikannya skripsi ini, yang tidak dapat penulis sebutkan satu persatu.

Penulis menyadari bahwa penulisan skripsi ini masih terdapat banyak kekurangan dan jauh dari kesempurnaan. Namun, penulis berharap skripsi ini dapat bermanfaat bagi perkembangan ilmu pengetahuan, Amin.

Wassalamu'alaikum Wr. Wb.

Semarang, 30 Juni 2020

Penulis

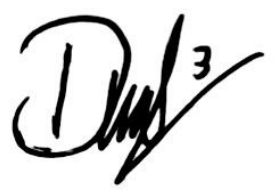

Dini Lestari

NIM. 1608076052 


\section{DAFTAR ISI}

\section{Halaman}

PERNYATAAN KEASLIAN ..............................................................ii

HALAMAN PENGESAHAN ...............................................................ii

NOTA DINAS …...................................................................................

ABSTRAK...................................................................................

PERSEMBAHAN ............................................................................ viii

KATA PENGANTAR ….............................................................

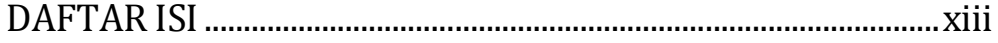

DAFTAR GAMBAR .....................................................................

DAFTAR TABEL ...................................................................................

DAFTAR SINGKATAN ...................................................................

DAFTAR LAMPIRAN .......................................................................

BAB I: PENDAHULUAN

A. Latar Belakang.......................................................... 1

B. Rumusan Masalah.................................................... 8

C. Tujuan dan Manfaat Penelitian .............................. 8

\section{BAB II: LANDASAN TEORI}

A. Kajian Teori................................................................. 11

1. Efektivitas.............................................................11

2. Konsep Multipel Representasi .......................12

3. Model Pembelajaran SiMaYang Tipe II ........16

4. Penguasaan Konsep........................................... 22 
5. Attitudes toward Chemistry..............................25

6. Larutan Penyangga ..............................................27

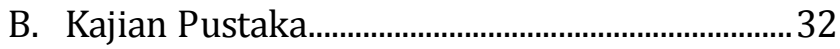

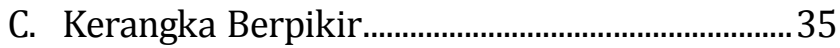

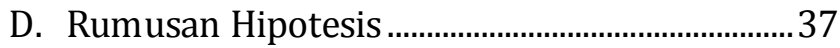

\section{BAB III: METODE PENELITIAN}
A. Jenis dan Pendekatan Penelitian. 38
B. Tempat dan Waktu Penelitian...............................39
C. Populasi dan Sampel................................................40
D. Variabel Penelitian.................................................... 41
E. Teknik Pengumpulan Data...................................... 42
F. Instrumen Penilaian..................................................43
G. Teknik Analisis Data ................................................45

\section{BAB IV: HASIL PENELITIAN DAN PEMBAHASAN}
A. Hasil Penelitian. 67
B. Pembahasan 85

BAB V: PENUTUP
A. Kesimpulan 108
B. Saran 109

DAFTAR PUSTAKA

LAMPIRAN

RIWAYAT HIDUP 


\section{DAFTAR GAMBAR}

Gambar

Judul

Halaman

Gambar 2.1 Konfigurasi Kognitif dan Aktivitas Belajar Menurut OSA.

Gambar 2.2 Peristiwa Respon Lakmus Merah dan Biru terhadap Larutan Asam ...................14

Gambar 2.3 Reaksi Ionisasi $\mathrm{HCl}$ pada Level Submikroskopik...............................................15

Gambar 2.4 Contoh Tiga Level Fenomena Kimia..............16

Gambar 2.5 Fase-Fase Model Pembelajaran SiMaYang Tipe II ..................................................17

Gambar 2.6 Kerangka Berpikir Peneliti ...............................36

Gambar 3.1 Nonequivalent Control Group Design ............39

Gambar 4.1 Soal Level Submikroskopik pada Soal Uraian....................................................................95

Gambar 4.2 Mayoritas Jawaban Kelas Kontrol dan Kelas Eksperimen pada Soal No. 16...............95

Gambar 4.3 Rata-Rata Nilai Penguasaan Konsep Peserta Didik pada Materi Larutan Penyangga 96

Gambar 4.4 Persentase Penguasaan Konsep per Indikator Saat Posttest .....................................97

Gambar 4.5 Persentase Hasil Angket Attitudes toward Chemistry per Indikator Saat Posttest. 


\section{DAFTAR TABEL}

Tabel

Judul

Halaman

Tabel 2.1 Sintaks Model Pembelajaran SiMaYang Tipe II. 20

Tabel 2.2 Kombinasi Jawaban dan Kategori pada Three-tier Multiple Choice....................................25

Tabel 2.3 Indikator Attitudes toward Chemistry ............27

Tabel 3.1 Jumlah Peserta Didik dalam Populasi..............40

Tabel 3.2 Indeks Reliabilitas Soal ...........................................51

Tabel 3.3 Indeks Kesukaran Soal ...........................................52

Tabel 3.4 Indeks Daya Pembeda Soal....................................53

Tabel 3.5 Kategori Nilai N-Gain...............................................59

Tabel 3.6 Tolok Ukur Kategori Persentase Angket.......60

Tabel 3.7 Indikator Keberhasilan Produk..........................66

Tabel 4.1 Hasil Uji Validitas Butir Soal Three-tier Multiple Choice .........................................................71

Tabel 4.2 Hasil Uji Validitas Butir Soal Uraian ..................71

Tabel 4.3 Hasil Uji Tingkat Kesukaran Soal Threetier Multiple Choice ................................................73

Tabel 4.4 Hasil Uji Coba Tingkat Kesukaran Soal Uraian.........................................................................

Tabel 4.5 Hasil Uji Daya Beda Soal Three-tier Multiple Choice. . .74

Tabel 4.6 Hasil Uji Daya Beda Soal Uraian ..........................75 
Tabel 4.7 Hasil Uji Normalitas Pretest Penguasaan

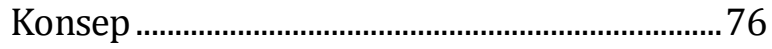

Tabel 4.8 Hasil Uji Normalitas Pretest Attitudes toward Chemistry....................................................77

Tabel 4.9 Hasil Uji Normalitas Posttest Penguasaan Konsep ..................................................................

Tabel 4.10 Hasil Uji Normalitas PosttestAttitudes toward Chemistry ...................................................82

Tabel 4.11 Hasil Uji N-Gain Penguasaan Konsep ................85

Tabel 4.12 Hasil Uji N-Gain Attitudes toward Chemistry 85

Tabel 4.13 Hasil Pretest dan PosttestSoal Three-tier Multiple Choice......................................................91

Tabel 4.14 Hasil Pretest dan Posttest Soal Uraian...............94

Tabel 4.15 Persentase Angket Attitudes toward Chemistry...............................................................100

Tabel 4.16 Persentase Angket Respon Peserta Didik ......105 


\section{DAFTAR SINGKATAN}

UNBK : Ujian Nasional Berbasis Komputer

PAS : Penilaian Akhir Semester

KKM : Kriteria Ketuntasan Minimal

OSA : Onto Semiotic Approach

RPP : Rencana Pelaksanaan Pembelajaran

MIPA : Matematika dan Ilmu Pengetahuan Alam 


\section{DAFTAR LAMPIRAN}

Lampiran 1 Surat Penunjukkan Dosen Pembimbing

Lampiran 2 Surat Izin Observasi Pra Riset

Lampiran 3 Hasil Wawancara dengan Guru Kimia

Lampiran 4 Hasil Angket Pra Riset Peserta Didik

Lampiran 5 Analisis Penguasaan Konsep Peserta Didik Pra Riset

Lampiran 6 Surat Izin Riset ke SMAN 9 Semarang

Lampiran 7 Surat Izin Riset ke Dinas Pendidikan dan Kebudayaan Provinsi Jawa Tengah

Lampiran 8 Silabus Kelas Eksperimen dan Kelas Kontrol

Lampiran 9 RPP Kelas Eksperimen Beserta Lampirannya

Lampiran 10 RPP Kelas Kontrol Beserta Lampirannya

Lampiran 11 Kisi-Kisi Instrumen Tes

Lampiran 12 Instrumen Tes Kelas Uji Coba

Lampiran 13 Daftar Responden Uji Coba Soal

Lampiran 14 Uji Validitas dan Reliabilitas Soal Three-tier Multiple Choice

Lampiran 15 Uji Daya Beda dan Tingkat Kesukaran Soal Three-tier Multiple Choice

Lampiran 16 Uji Reliabilitas, Daya Beda dan Tingkat Kesukaran Soal Uraian

Lampiran 17 Uji Validitas Soal Uraian 
Lampiran 18 Surat Keterangan telah Melakukan Uji Instrumen Tes

Lampiran 19 Soal Pretest dan Posttest

Lampiran 20 Angket Respon Peserta Didik terhadap Model Pembelajaran SiMaYang Tipe II

Lampiran 21 Angket Attitudes toward Chemistry

Lampiran 22 Uji Normalitas dan Homogenitas Populasi

Lampiran 23 Daftar Responden Kelas Kontrol dan Kelas Eksperimen

Lampiran 24 Uji Tahap Awal Penguasaan Konsep

Lampiran 25 Uji Tahap Awal Attitudes toward Chemistry

Lampiran 26 Analisis Pretest Soal Three-tier Multiple Choice

Lampiran 27 Analisis Posttest Soal Three-tier Multiple Choice

Lampiran 28 Analisis Jawaban Soal Uraian

Lampiran 29 Uji N-Gain Penguasaan Konsep

Lampiran 30 Uji Hipotesis Penguasaan Konsep

Lampiran 31 Analisis Pretest Angket Attitudes toward Chemistry

Lampiran 32 Analisis Posttest Angket Attitudes toward Chemistry

Lampiran 33 Uji N-Gain Attitudes toward Chemistry

Lampiran 34 Uji Hipotesis Attitudes toward Chemistry

Lampiran 35 Analisis Angket Respon Peserta Didik terhadap Model Pembelajaran SiMaYang Tipe II

Lampiran 36 Dokumentasi 
Lampiran 37 Surat Keterangan telah Melakukan Penelitian

Lampiran 38 Surat Keterangan telah Melakukan Uji Lab Statistika 


\section{BAB I \\ PENDAHULUAN}

\section{A. Latar Belakang}

Pendidikan adalah sebuah aset berharga untuk memajukan suatu bangsa. Kemajuan di bidang pendidikan dari suatu bangsa akan menentukan kemajuan pada bidangbidang lainnya pada bangsa tersebut (Widodo, 2015). Pendidikan di Indonesia dapat meningkat apabila pembelajaran yang efektif terlaksana dengan baik. Pembelajaran efektif merupakan suatu pembelajaran yang ditandai dengan tercapainya tujuan pembelajaran yang telah direncanakan oleh guru (Setyosari, 2014). Salah satu faktor yang dapat menghasilkan pembelajaran efektif adalah cara mengajar berubah dari metode pembelajaran tradisional menjadi model pembelajaran yang inovatif, sehingga pembelajaran menjadi lebih efektif dan menyenangkan (Shoimin, 2014).

Model pembelajaran merupakan pola interaksi antara pendidik, peserta didik dan materi pembelajaran yang meliputi strategi, pendekatan, metode, dan teknik yang akan digunakan ketika proses belajar mengajar berlangsung (Arends, 2007). Model pembelajaran yang akan digunakan dalam penelitian ini adalah model 
pembelajaran SiMaYang Tipe II. Model pembelajaran SiMaYang Tipe II adalah salah satu model pembelajaran berbasis multipel representasi yang bertujuan untuk membelajarkan konsep-konsep sains yang bersifat abstrak dengan cara mengintegrasikan ketiga level fenomena sains, yaitu level makroskopik, submikroskopik dan simbolik (Sunyono, 2015).

Salah satu mata pelajaran sains adalah kimia. Ilmu kimia adalah bagian dari ilmu alam (sains) yang didalamnya membahas materi, energi dan perubahannya, baik berupa perubahan fisik maupun perubahan kimia (Sunarya, 2007). Ilmu kimia merupakan ilmu yang didalamnya sebagian besar konsepnya bersifat abstrak, sederhana, berjenjang, dan terstruktur (Mentari et al., 2014). Keabstrakan dalam konsep ilmu kimia ini menjadi salah satu faktor kesulitan yang dihadapi peserta didik. Oleh karena itu, model pembelajaran SiMaYang Tipe II dipilih dalam penelitian ini atas pertimbangan bahwa mayoritas peserta didik SMA Negeri 9 Semarang cenderung hanya menghafalkan rumus dan teori, tetapi tidak pernah mengintegrasikan tiga level fenomena sains ketika belajar kimia (Andri, wawancara 20 Mei 2019) 
Penguasaan konsep merupakan pemahaman dan penerapan konsep dalam suatu permasalahan (Sam'un, 2018). Dahar (2003) juga mengemukakan bahwa penguasaan konsep adalah suatu keahlian peserta didik dalam memahami makna ilmiah, baik konsep secara teori maupun penerapannya. Peserta didik yang tidak menguasai konsep akan mengalami kesulitan belajar. Salah satu faktor yang menyebabkan peserta didik kesulitan belajar adalah kurangnya minat peserta didik dalam proses pembelajaran (Ischak, 1987).

Minat yang rendah terhadap pembelajaran kimia merupakan sesuatu yang dapat menghambat proses pembelajaran kimia. Sikap peserta didik terhadap kimia dapat dilihat dari tingkah laku peserta didik saat bereaksi atau menunjukkan respon terhadap kimia ketika proses pembelajaran berlangsung (Rosa, 2012). Istilah lain dari sikap terhadap kimia adalah attitudes toward chemistry. Attitudes toward chemistry ini berasal dari istilah attitudes toward science yang artinya sebuah perasaan terpelajar, positif atau negatif tentang sains yang berfungsi sebagai rekapitulasi yang cocok dari berbagai kepercayaan tentang sains (Koballa dan Crawley, 1985). Mayoritas orang di komunitas pendidikan sains (science education) setuju 
bahwa besar atau kecilnya attitudes toward chemistry yang negatif dapat menyebabkan masalah besar (Salta dan Tzougraki, 2004). Di sisi lain, attitudes toward chemistry yang positif dapat menyebabkan hasil belajar menjadi lebih baik ketika menggunakan metode yang sesuai (Kousa et al., 2018). Oleh karena itu, attitudes toward chemistry yang positif sangat penting dalam proses pembelajaran kimia.

Pembelajaran menjadi efektif apabila bahan-bahan, pengalaman, dan hasil yang diharapkan sesuai dengan tingkat kematangan dan latar belakang peserta didik. Hasil yang diharapkan dari proses pembelajaran adalah adanya prestasi belajar, yaitu hasil yang memberikan perubahan positif kepada peserta didik (Yusuf, 2018). Bentuk perubahan positif tersebut yaitu: (1) pada ranah kognitif terjadi perubahan dalam penguasaan pengetahuan dan keahlian untuk menggunakan pengetahuan tersebut; (2) pada ranah psikomotorik terjadi perubahan dalam segi bentuk-bentuk tindakan motorik; dan (3) pada ranah afektif terjadi perubahan sikap, perasaan dan kesadaran peserta didik (Darajat, 1988).

Pada mata pelajaran kimia, pada umumnya peserta didik di Indonesia masih belum sepenuhnya memahami materi kimia yang mereka pelajari. Hal ini dapat dibuktikan dari nilai rata-rata Ujian Nasional Berbasis Komputer 
(UNBK) yang selalu dilaksanakan tiap tahun sebagai bentuk penilaian tingkat nasional. Berdasarkan penelusuran penulis pada laman puspendik (Kemdikbud 2019, diakses 3 Juli 2019) dihasilkan bahwa nilai rata-rata Ujian Nasional Berbasis Komputer (UNBK) pada mata pelajaran kimia tahun ajaran 2018/2019 untuk tingkat nasional sebesar 50,29, untuk tingkat provinsi Jawa Tengah sebesar 56,54 dan untuk tingkat wilayah Kota Semarang sebesar 58,45. Sedangkan untuk SMAN 9 Semarang, nilai UNBKkimia ratarata sebesar 53,62. Hal ini menunjukkan bahwa rata-rata peserta didik di SMAN 9 Semarang masih mengalami kesulitan dalam memahami mata pelajaran kimia seutuhnya, yang ditandai dengan nilai rata-rata yang masih tergolong rendah (di bawah 55). Berdasarkan nilai PAS (Penilaian Akhir Semester) ganjil tahun ajaran 2019/2020, ditemukan bahwa peserta didik SMAN 9 Semarang yang lulus kriteria ketuntasan minimal (KKM) pada mata pelajaran kimia hanya 73 peserta didik (29\%) dari 249 peserta didik.

Angket pra riset yang diberikan kepada 34 peserta didik kelas XI MIPA 1 tahun ajaran 2018/2019 juga menunjukkan bahwa 50\% peserta didik menyatakan tidak paham dengan materi yang diajarkan. Berdasarkan nilai 
UNBK, nilai PAS dan angket pra riset diperoleh bahwa pada umumnya peserta didik belum menguasai konsep kimia. Padahal penguasaan konsep merupakan salah satu aspek kognitif yang seharusnya dikuasai peserta didik untuk mencapai prestasi belajar dalam pembelajaran kimia.

Selain itu dari hasil angket tersebut juga menunjukkan bahwa 70\% peserta didik selalu melakukan belajar sistem kebut semalam. Data tersebut menunjukkan bahwa kurangnya minat peserta didik dalam mempelajari kimia, sehingga attitudes toward chemistry peserta didik masih tergolong rendah. Padahal, attitudes toward chemistryyang tinggi (positif) merupakan salah satu aspek yang harus dikuasai peserta didik pada ranah afektif untuk memperoleh prestasi belajar dalam kimia sesuai yang diharapkan.

Materi yang dianggap sulit oleh peserta didik SMAN 9 Semarang adalah sangat bervariasi. Berdasarkan angket yang diberikan, persentase terbesar materi yang dianggap sulit adalah termokimia (sebesar 20\%), larutan penyangga (sebesar 20\%), dan kelarutan dan hasil kali kelarutan (sebesar 20\%).

Pada umumnya peserta didik SMAN 9 Semarang kesulitan dalam menentukan pH suatu larutan, yakni pada materi asam dan basa, hidrolisis dan larutan penyangga 
(Andri, wawancara 20 Mei 2019). Dilansir dari puspendik (Kemdikbud 2019, diakses pada 3 Juli 2019), dari hasil UNBK kota Semarang pada tahun ajaran 2018/2019 terdapat beberapa indikator soal yang menghasilkan persentase nilai rata-rata peserta didik rendah, yaitu mengenai reaksi hidrolisis sebesar 44,92\%, titrasi asambasa sebesar 45,97\%, larutan penyangga sebesar 35,15\% dan asam dan basa sebesar 50,73\%. Dari data tersebut, dapat kita ketahui bahwa sebagian besar peserta didik mengalami kesulitan dalam mengerjakan materi larutan penyangga.

Selain itu, berdasarkan hasil pra riset, dimana peneliti memberikan soal diagnostik kesulitan belajar pada materi larutan penyangga yang dikembangkan oleh Ambarwati (2018) diperoleh bahwa kesulitan belajar dengan kategori sangat tinggi adalah dalam menentukan campuran yang bukan larutan penyangga (sebesar 81,25\%) dan menentukan volume salah satu senyawa pembentuk larutan penyangga jika pH-nya diketahui (sebesar 96,875\%). Oleh karena itu, peneliti memutuskan mengambil materi larutan penyangga untuk diteliti lebih lanjut. 
Berdasarkan latar belakang diatas maka penulis mengajukan penelitian yang berjudul:

\section{“EFEKTIVITAS MODEL PEMBELAJARANSIMAYANG TIPE II BERBASIS MULTIPEL REPRESENTASI TERHADAP PENGUASAAN KONSEP DAN ATTITUDES TOWARD CHEMISTRY PADA MATERI LARUTAN PENYANGGA"}

\section{B. Rumusan Masalah}

Rumusan masalah dalam penelitian ini adalah sebagai berikut.

1. Apakah model pembelajaran SiMaYang Tipe II berbasis multipel representasi efektif terhadap penguasaan konsep pada materi larutan penyangga?

2. Apakah model pembelajaran SiMaYang Tipe II berbasis multipel representasi efektif terhadap attitudes toward chemistry pada materi larutan penyangga?

3. Bagaimana respon peserta didik terhadap model pembelajaran SiMaYang Tipe II berbasis multipel representasi?

\section{Tujuan dan Manfaat Penelitian}

Berdasarkan rumusan masalah tersebut, tujuan dari penelitian ini adalah sebagai berikut.

1. Untuk mengetahui efektivitas model pembelajaran SiMaYang Tipe II berbasis multipel representasi 
terhadap penguasaan konsep pada materi larutan penyangga.

2. Untuk mengetahui efektivitas model pembelajaran SiMaYang Tipe II berbasis multipel representasi terhadap attitudes toward chemistry pada materi larutan penyangga.

3. Untuk mengetahui respon peserta didik terhadap model pembelajaran SiMaYang Tipe II berbasis multipel representasi.

Penelitian ini juga diharapkan dapat memberikan manfaat sebagai berikut.

1. Manfaat bagi Peserta didik

a. Mampu meningkatkan sikap positif peserta didik pada materi larutan penyangga.

b. Mampu meningkatkan penguasaan konsep peserta didik pada materi larutan penyangga.

2. Manfaat bagi Guru

a. Mampu meningkatkan kreatifitas guru dalam memilih model pembelajaran.

b. Mampu memberikan alternatif model pembelajaran yang digunakan untuk mencapai tujuan pembelajaran yang telah direncanakan. 
3. Manfaat bagi Sekolah

a. Dapat memberikan sumbangan yang baik untuk sekolah untuk memperbaiki kegiatan belajar mengajar.

b. Dapat digunakan sebagai acuan penelitian.

4. Manfaat bagi Peneliti

a. Mendapat pengalaman langsung dalam melaksanakan pembelajaran dengan menggunakan model pembelajaran SiMaYang Tipe II.

b. Mendapat bekal sebagai calon guru untuk meningkatkan penguasaan konsep dan attitudes toward chemistry. 


\section{BAB II}

\section{LANDASAN TEORI}

\section{A. Kajian Teori}

\section{Efektivitas}

Kata efektif berasal dari bahasa Inggris yaitu effective yang artinya berhasil (Echols dan Shadily, 1975). Husman (2011) mengemukakan bahwa efektif merupakan hasil guna atau tingkat keberhasilan pencapaian tujuan sesuai yang diharapkan (outcomes) dengan cara melakukan sesuatu yang benar (do the right things).

Efektivitas merupakan suatu ukuran yang mengemukakan seberapa jauh target berhasil dicapai, yang mana semakin besar persentase target yang dicapai maka semakin tinggi efektivitasnya (Hidayat, 1986). Sudjana (1990) juga menjelaskan bahwa efektivitas adalah keberhasilan peserta didik dalam mencapai tujuan pembelajaran yang dapat membawa hasil belajar secara maksimal.

Mengacu pada beberapa pengertian efektivitas dari para ahli di atas, maka dapat disimpulkan bahwa efektivitas adalah pencapaian peserta didik dalam suatu pembelajaran dengan adanya hasil belajar, dimana 
semakin besar hasil belajar peserta didik maka semakin besar pula efektivitasnya.

\section{Konsep Multipel Representasi}

Konsep representasi merupakan pondasi praktik ilmiah, karena konsep tersebut digunakan untuk berkomunikasi dan memecahkan masalah (Sunyono, 2015). Representasi dapat dikelompokkan sebagai berikut (Heuvelen dan Zou, 2001):

a. Representasi internal, yaitu konfigurasi kognitif individu dari tingkah laku peserta didik yang menunjukkan berbagai aspek dalam proses pemecahan masalah dan fisik.

b. Representasi eksternal, yaitu suatu fisik yang terstruktur dengan cara mewujudkan ide-ide fisik.

Menurut pandangan konstruktivist, representasi internal terdapat di dalam kepala peserta didik, sedangkan representasi eksternal terdapat di dalam lingkungan (Meltzer, 2005). Konfigurasi kognitif merupakan struktur atau susunan dari kognisi manusia (Sunyono, 2015). Konfigurasi kognitif berdasarkan teori OSA dimodelkan seperti gambar 2.1 berikut (Godino et al., 2007). 


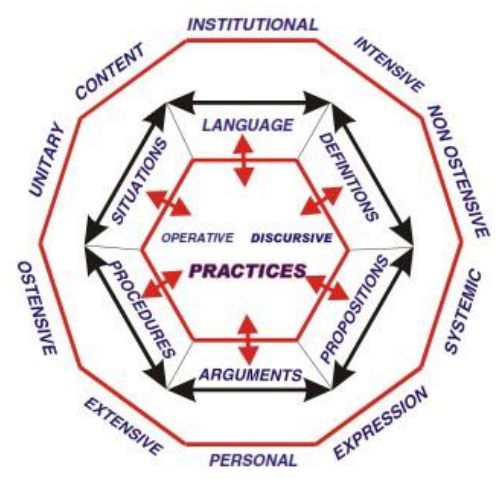

Gambar 2.1 Konfigurasi Kognitif dan Aktivitas Belajar Menurut OSA

Konfigurasi kognitif versi OSA berhubungan erat dengan penerimaan informasi melalui multipel representasi (Sunyono, 2015). Ainsworth (2008) mengemukakan bahwa peran multipel representasi yaitu untuk saling melengkapi, menjelaskan tafsiran mengenai suatu representasi dan membantu peserta didik dalam memahami lebih dalam mengenai suatu materi yang dipelajarinya.

Representasi kimia diklasifikasikan menjadi tiga level representasi, yaitu sebagai berikut:

a. Representasi makroskopik, yaitu representasi yang diperoleh dan dipersepsi oleh panca indra atau pengalaman yang pernah dialami peserta didik terhadap suatu fenomena yang dapat dilihat 
(Johnstone, 1993). Contoh: perubahan suhu, warna, pH larutan, pembentukan endapan dan gas saat suatu reaksi berlangsung. Salah satu contoh representasi makroskopis adalah pada larutan asam yang ditetesi lakmus merah dan lakmus biru yang digambarkan sebagai berikut (Susiloningsih et al., 2017).
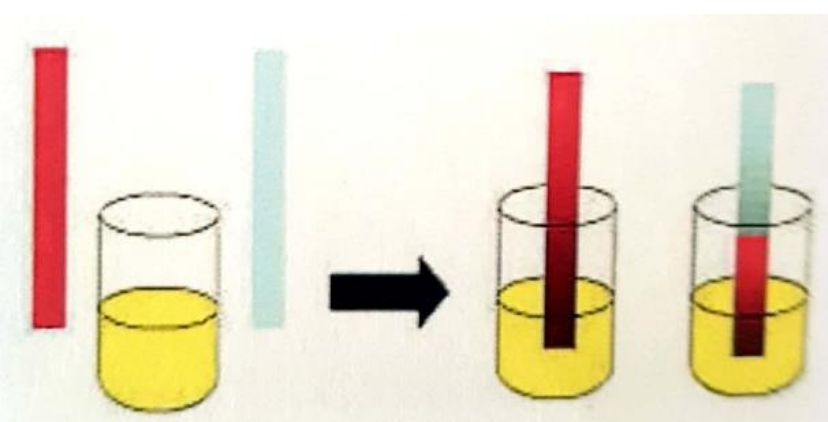

Gambar 2.2 Peristiwa Respon Lakmus Merah dan Biru terhadap Larutan Asam

b. Representasi submikroskopik, yaitu representasi yang menggambarkan proses dan struktur pada level partikel (atom atau molekular) terhadap fenomena yang terjadi, biasanya diekspresikan secara simbolik seperti menggunakan simulasi, kata-kata, gambar dua dimensi, gambar tiga dimensi maupun animasi (Sunyono, 2015). Salah satu contoh representasi submikroskopik adalah teori asam menurut Arrhenius yang menyatakan bahwa asam dalam air akan terionisasi menjadi ion-ionnya, menghasilkan 
$\mathrm{H}^{+}$, misalnya reaksi ionisasi $\mathrm{HCl}$ yang disajikan dalam gambar 2.3 sebagai berikut (Susiloningsih et al., 2017).

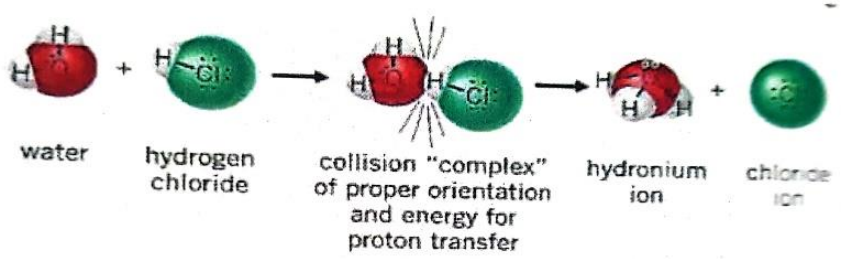

Gambar 2.3 Reaksi Ionisasi HCl pada Level Submikroskopik

c. Representasi simbolik, yaitu representasi secara kualitatif dan kuantitatif dengan menggunakan simbol, contoh: rumus kimia, persamaan reaksi dan perhitungan matematika (Johnstone, 1993). Salah satu contoh representasi simbolik adalah larutan $\mathrm{HCl}$ yang dapat terionisasi sebagai berikut.

$$
\mathrm{HCl}(a q)+\mathrm{H}_{2} \mathrm{O}(l) \longrightarrow \mathrm{H}_{3} \mathrm{O}^{+}(a q)+\mathrm{Cl}^{-}(a q)
$$

Salah satu contoh interkoneksi dari level makro, sub-mikro, dan simbolik yang saling berkaitan dapat digambarkan sebagai berikut (Silberberg, 2007). 


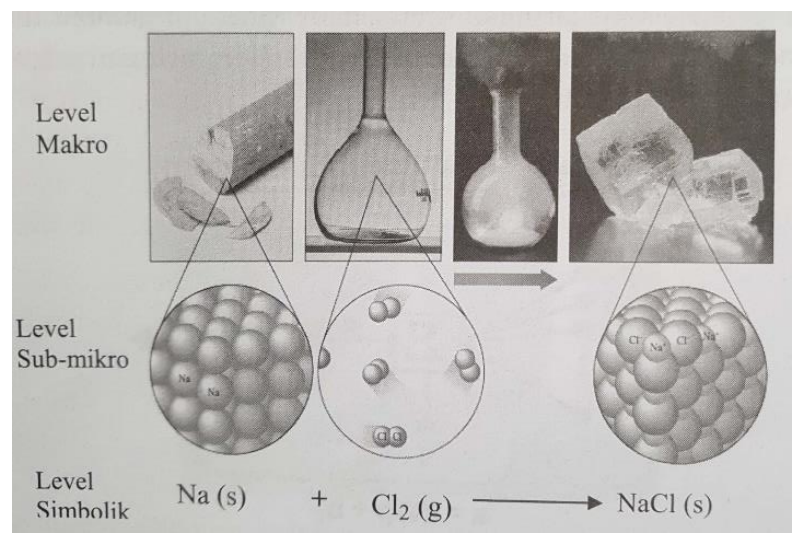

Gambar 2.4 Contoh Tiga Level Fenomena Kimia

\section{Model Pembelajaran SiMaYang Tipe II}

\section{a. Pengertian Model Pembelajaran SiMaYang Tipe}

\section{II}

Arends (2007) menyatakan bahwa model pembelajaran merupakan suatu kegiatan pembelajaran yang didalamnya terdapat tujuan, sintak atau langkah-langkah, lingkungan dan sistem pengelolaannya. Banyak model pembelajaran telah dikembangkan oleh guru untuk memberikan kemudahan bagi peserta didik dalam memahami materi. Penggunaan model pembelajaran sangat bergantung pada mata pelajaran ataupun materi yang akan diajarkan kepada peserta didik (Shoimin, 2014). 
Model pembelajaran yang digunakan pada penelitian ini adalah model pembelajaran SiMaYang Tipe II yang berbasis multipel representasi. Model pembelajaran SiMaYang Tipe II ini terdiri dari empat fase yang memiliki suku kata akhiran yang sama yaitu "si" sebanyak lima kali dan disusun dalam bentuk layang-layang seperti gambar 2.5, sehingga dinamakan si-5 layang-layang atau SiMaYang (Sunyono, 2015).

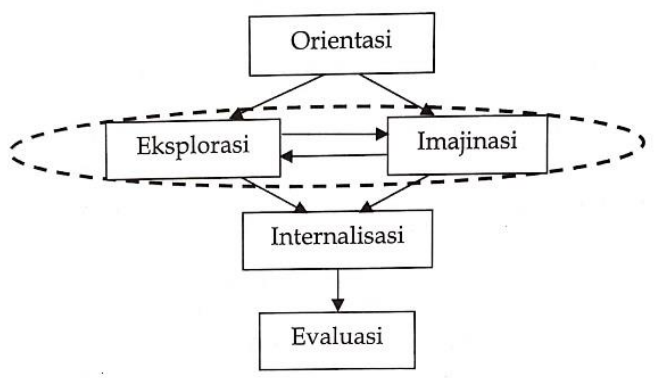

Fase I

Fase II

Fase III

Fase IV

Gambar 2.5 Fase-Fase Model Pembelajaran SiMaYang Tipe II

Multipel representasi pada model pembelajaran SiMaYang yaitu representasirepresentasi dari fenomena sains baik dari skala riil maupun abstrak (Sunyono, 2015). Model pembelajaran SiMaYang mengalami perubahan sintaks karena adanya pendekatan saintifik yang 
dipadukan ke dalam sintak pembelajaran SiMaYang, sehingga model ini disebut Saintifik - SiMaYang atau SiMaYang Tipe II (Sunyono dan Yulianti, 2014).

Model pembelajaran SiMaYang Tipe II adalah model pembelajaran yang mampu mengintegrasikan ketiga level representasi kimia (makroskopik, submikroskopik dan simbolik) yang cocok diterapkan pada pokok-pokok materi yang bersifat abstrak (Hasanah, Sunyono \& Efkar, 2015).

\section{b. Ciri-Ciri Model Pembelajaran SiMaYang Tipe II}

Model pembelajaran SiMaYang memiliki ciriciri sebagai berikut (Sunyono, 2015).

1) Hanya cocok untuk materi-materi yang bersifat abstrak dan mengandung level makroskopik, submikroskopik, dan simbolik.

2) Terdapat berbagai macam visual (animasi, diagram dan lain-lain) yang membantu peserta didik mengintegrasikan ketiga level fenomena sains.

3) Peserta didik harus berperan aktif dalam mencari informasi, menemukan konsep, menyelesaikan permasalahan dengan cara 
mengamati dan membayangkan dengan imajinasinya.

4) Peserta didik dapat mengembangkan kemampuan kognitifnya melalui kegiatan eksplorasi dan imajinasi representasi.

5) Peserta didik ditekankan aktif dalam belajar kelompok maupun individu.

6) Guru berperan sebagai fasilitator dalam kegiatan diskusi kelompok.

7) Guru membimbing peserta didik yang mengalami kesulitan, baik keika belajar kelompok maupun individu.

8) Peserta didik dapat mempresentasikan hasil belajarnya.

\section{c. Sintaks Model Pembelajaran SiMaYang Tipe II}

Sintaks model pembelajaran SiMaYang Tipe II terdiri dari empat fase pembelajaran, yaitu orientasi, eksplorasi-imajinasi, internalisasi, dan evaluasi. (Sunyono, 2015) sebagaimana dijelaskan pada tabel 2.1 sebagai berikut: 
Tabel 2.1 Sintaks Model Pembelajaran SiMaYang Tipe II

\begin{tabular}{|c|c|c|}
\hline Fase & Aktivitas Guru & $\begin{array}{c}\text { Aktivitas Peserta } \\
\text { Didik }\end{array}$ \\
\hline $\begin{array}{l}\text { Fase I: } \\
\text { Orientasi }\end{array}$ & $\begin{array}{l}\text { 1. Menyampaikan tujuan } \\
\text { pembelajaran. } \\
\text { 2. Memberikan motivasi } \\
\text { dan apersepsi } \\
\text { menggunakan } \\
\text { fenomena yang terkait } \\
\text { dengan pengalaman } \\
\text { peserta didik. }\end{array}$ & $\begin{array}{l}\text { 1. Mendengarkan } \\
\text { penyampaian tujuan } \\
\text { dan memberikan } \\
\text { tanggapan. } \\
\text { 2. Menjawab } \\
\text { pertanyaan yang } \\
\text { ditanyakan. }\end{array}$ \\
\hline $\begin{array}{l}\text { Fase II: } \\
\text { Eksplorasi } \\
\text { - Imajinasi }\end{array}$ & $\begin{array}{l}\text { 1. Mengenalkan konsep } \\
\text { dengan memberikan } \\
\text { beberapa abstraksi } \\
\text { yang berbeda mengenai } \\
\text { fenomena alam } \\
\text { (demonstrasi, } \\
\text { visualisasi, dan lain- } \\
\text { lain) yang diikuti oleh } \\
\text { peserta didik. } \\
\text { Mendorong, } \\
\text { membimbing, } \\
\text { memfasilitasi diskusi } \\
\text { peserta didik untuk } \\
\text { membuat interkoneksi } \\
\text { di antara level-level } \\
\text { fenomena alam yang } \\
\text { dituangkan ke dalam } \\
\text { LKS. }\end{array}$ & $\begin{array}{l}\text { 1. Mengamati dan tanya } \\
\text { jawab dengan guru } \\
\text { mengenai fenomena } \\
\text { yang diperkenalkan } \\
\text { (Menanya). } \\
\text { 2. Melakukan } \\
\text { penelusuran } \\
\text { informasi melalui } \\
\text { webpage/ weblog } \\
\text { dan/atau buku teks } \\
\text { (Menggali informasi). } \\
\text { 3. Bekerja dalam } \\
\text { kelompok untuk } \\
\text { melakukan imajinasi } \\
\text { terhadap fenomena } \\
\text { alam melalui LKS. } \\
\text { 4. Berdiskusi dengan } \\
\text { teman dalam } \\
\text { kelompok dalam } \\
\text { melakukan latihan } \\
\text { imajinasi } \\
\text { representasi } \\
\text { (Menalar/ } \\
\text { Mengasosiasi). }\end{array}$ \\
\hline
\end{tabular}


Tabel 2.1 Lanjutan

\begin{tabular}{|c|c|c|}
\hline Fase & Aktivitas Guru & $\begin{array}{c}\text { Aktivitas Peserta } \\
\text { Didik }\end{array}$ \\
\hline $\begin{array}{l}\text { Fase III: } \\
\text { Internali- } \\
\text { sasi }\end{array}$ & 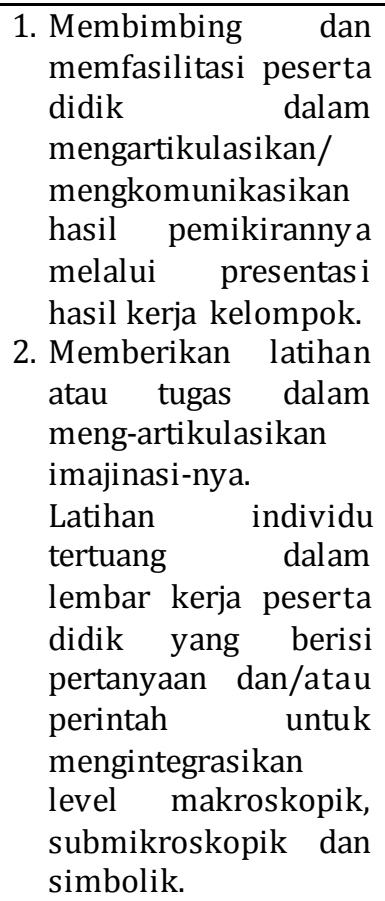 & $\begin{array}{l}\text { 1. Perwakilan kelompok } \\
\text { melakukan presentasi } \\
\text { terhadap hasil kerja } \\
\text { kelompok } \\
\text { (Mengkomuni- } \\
\text { kasikan). } \\
\text { 2. Memberikan } \\
\text { tanggapan/ pertanyaan } \\
\text { terhadap kelompok } \\
\text { yang melakukan } \\
\text { presentasi (Menanya } \\
\text { dan Menjawab). } \\
\text { 3. Melakukan latihan } \\
\text { individu melalui LKS } \\
\text { individu (Menggali } \\
\text { informasi dan } \\
\text { mengasosiasi). }\end{array}$ \\
\hline $\begin{array}{l}\text { Fase IV: } \\
\text { Evaluasi }\end{array}$ & $\begin{array}{l}\text { 1. Mengevaluasi } \\
\text { kemajuan belajar } \\
\text { peserta didik dan } \\
\text { mereview hasil kerja } \\
\text { peserta didik. } \\
\text { 2. Memberikan tugas } \\
\text { latihan interkoneksi } \\
\text { level makroskopik, } \\
\text { submikroskopik dan } \\
\text { simbolik. }\end{array}$ & $\begin{array}{l}\text { 1. Menyimak hasil reviu } \\
\text { dan } \\
\text { mengkomunikasikan } \\
\text { hasil kerjanya, serta } \\
\text { bertanya tentang } \\
\text { pembelajaran yang } \\
\text { akan datang. }\end{array}$ \\
\hline
\end{tabular}




\section{Penguasaan Konsep}

Konsep adalah pemikiran seseorang atau beberapa orang yang menghasilkan produk pengetahuan diantaranya hukum-hukum, prinsip dan teori yang diperoleh dari peristiwa, fakta, dan pengalaman (Sagala, 2003). Sementara Dahar (2003) mengemukakan konsep adalah batu-batu landasan berpikir yang didapat melalui fakta-fakta dan digunakan dalam memecahkan masalah.

Penguasaan konsep adalah kemampuan peserta didik dalam memahami makna secara ilmiah baik teori maupun penerapannya (Rachman, Prastowo \& Lesmono, 2018). Penguasaan konsep diperoleh dari hasil belajar yang merupakan proses kognitif, dimana proses tersebut melibatkan tiga proses secara bersamaan diantaranya mendapatkan informasi baru, mentransformasikan informasi dan menguji relevansi ketetapan pengetahuan (Pradina, 2010).

Sanjaya (2013) menyatakan bahwa indikator penguasaan konsep terdiri dari:

a. Dapat membedakan dan mengatasi keadaan dengan berbagai macam cara;

b. Dapat mengelompokkan objek-objek yang tersedia untuk membentuk suatu konsep; 
c. Dapat menginterkoneksikan antara prosedur dan konsep;

d. Dapat menyebutkan contoh dari konsep yang dipelajarinya.

Penguasaan konsep yang dimaksud pada penelitian ini adalah hasil belajar pada aspek kognitif. Dimensi proses kognitif menurut revisi taksonomi Bloom, yaitu mengingat (remembering), memahami (understanding), mengaplikasikan (applying), menganalisis (analyzing), mengevaluasi (evaluating) dan mencipta (creating) (Anderson dan Krathwohl, 2010).

Materi larutan penyangga adalah salah satu materi kimia yang membutuhkan pemahaman konsep yang benar, karena pada materi tersebut banyak mengandung konsep abstrak yang cukup kompleks (Alighiri, Drastisianti \& Susilaningsih, 2018). Namun, beberapa hasil penelitian menunjukkan bahwa masih banyak peserta didik yang mengalami kesulitan memahami materi larutan penyangga. Penelitian yang dilakukan oleh Mangara Sihaloho (2013) juga menunjukkan bahwa pemahaman konsep peserta didik dalam memberikan gambaran mikroskopik larutan penyangga yang 
berkaitan dengan pengertian larutan penyangga dan menentukan jenis larutan penyangga termasuk kategori rendah, sedangkan dalam menentukan spesies-spesies larutan penyangga yang terbentuk dalam larutan termasuk kategori sangat rendah. Selain itu, Dante Alighiri dkk. (2018) menemukan bahwa hanya 45,53\% peserta didik yang paham konsep larutan penyangga.

Penguasaan konsep yang rendah merupakan sebuah kendala dalam kegiatan pembelajaran dan dapat mengakibatkan hasil belajar menjadi rendah. Salah satu penyebab penguasaan konsep peserta didik rendah adalah karena adanya miskonsepsi (Fitria, 2014). Miskonsepsi adalah keadaan dimana peserta didik memahami konsep yang tidak sesuai dengan penjelasan ilmiah (Ross, Tronson \& Raymond, 2006).

Penguasaan konsep yang diukur pada penelitian ini adalah hasil belajar peserta didik dengan menggunakan tes dalam bentuk soal three-tier multiple choice dan uraian. Penelitian ini mengadopsi kombinasi jawaban dan kategori pada three-tier multiple choice yang dikembangkan oleh Şen dan Yilmaz (2017) sebagaimana pada tabel 2.2 berikut ini. 
Tabel 2.2 Kombinasi Jawaban dan Kategori pada Threetier Multiple Choice

\begin{tabular}{|c|c|c|c|}
\hline $\begin{array}{c}\text { Tingkat } \\
1 \\
\end{array}$ & $\begin{array}{c}\text { Tingkat } \\
2 \\
\end{array}$ & $\begin{array}{c}\text { Tingkat } \\
3 \\
\end{array}$ & Kategori \\
\hline Benar & Benar & Yakin & Paham \\
\hline Benar & Benar & $\begin{array}{l}\text { Tidak } \\
\text { Yakin }\end{array}$ & $\begin{array}{l}\text { Terkaan (Lack of } \\
\text { confidence, Luckyguess) }\end{array}$ \\
\hline Benar & Salah & Yakin & $\begin{array}{l}\text { Miskonsepsi } \\
\text { (Misconception, False } \\
\text { Positive) }\end{array}$ \\
\hline Benar & Salah & $\begin{array}{l}\text { Tidak } \\
\text { Yakin }\end{array}$ & $\begin{array}{l}\text { Tidak Paham (Lack of } \\
\text { Knowledge) }\end{array}$ \\
\hline Salah & Benar & Yakin & $\begin{array}{l}\text { Miskonsepsi } \\
\text { (Misconception, False } \\
\text { Negative) }\end{array}$ \\
\hline Salah & Benar & $\begin{array}{l}\text { Tidak } \\
\text { Yakin }\end{array}$ & $\begin{array}{l}\text { Tidak Paham (Lack of } \\
\text { Knowledge) }\end{array}$ \\
\hline Salah & Salah & Yakin & $\begin{array}{l}\text { Miskonsepsi } \\
\text { (Misconception) }\end{array}$ \\
\hline Salah & Salah & $\begin{array}{l}\text { Tidak } \\
\text { Yakin }\end{array}$ & $\begin{array}{l}\text { Tidak Paham (Lack of } \\
\text { Knowledge) }\end{array}$ \\
\hline
\end{tabular}

Sumber: (Şen dan Yilmaz, 2017)

\section{Attitudes toward Chemistry}

Reber (dalam Anwar, 2009) mengemukakan bahwa attitude (sikap) berasal dari bahasa Latin, "aptitudo" yang artinya kemampuan, sehingga sikap (attitude) menjadi acuan untuk menentukan seseorang mampu atau tidak terhadap suatu pekerjaan tertentu. Sikap (attitude) yang baik dalam kegiatan pembelajaran dapat mempengaruhi keberlangsungan peserta didik 
dalam belajar kimia di jenjang selanjutnya (Saddam, Sudarmin \& Siadi, 2013).

Attitudes toward chemistry dapat diartikan sebagai sikap terhadap kimia. Attitudes toward chemistry merupakan sikap positif atau negatif terhadap kimia (Salta dan Tzougraki, 2004). Mayoritas peserta didik yang memiliki sikap positif terhadap kimia disebabkan karena mereka melakukan sebuah percobaan dan guru mahir dalam mengajarkan kimia. Namun, masih ditemukan sikap negatif terhadap kimia yang disebabkan karena sulitnya dalam memahami kimia dalam waktu yang singkat (Yunus dan Ali, 2012).

Cheung (2011) menyatakan bahwa dalam pelaksanaan pembelajaran kimia harus disertai perencanaan agar mampu menumbuhkan sikap positif peserta didik terhadap kimiayaitu:

a. Mengurangi laju pembelajaran kimia agar peserta didik mampu memahami konsep kimia dengan baik.

b. Membiarkan peserta didik mengeksplor secara langsung.

c. Merancang soal tes yang terdiri dari pertanyaan rendah sampai pertanyaan tingkat tinggi.

d. Memodifikasi pembelajaran yang runtut sehingga dapat mengurangi konsep yang abstrak. 
Adapun angket yang digunakan untuk mengukur attitudes toward chemistry pada penelitian ini adalah angket yang dikembangkan Cheung (2009), yang memiliki indikator sebagai berikut:

Tabel 2.3 Indikator Attitudes toward Chemistry

\begin{tabular}{ll}
\hline No. & \multicolumn{1}{c}{ Indikator } \\
\hline 1. & Liking for chemistry theory lessons \\
2. & Liking for chemistry laboratory work \\
3. & Evaluative beliefs about school chemistry \\
4. & Behavioral tendencies to learn chemistry \\
\hline
\end{tabular}

Sumber: (Cheung, 2009)

\section{Larutan Penyangga}

\section{a. Pengertian dan Komponen Larutan Penyangga}

Larutan penyangga atau larutan buffer merupakan larutan yang terdiri dari asam lemah atau basa lemah dengan garamnya. Larutan tersebut dapat mempertahankan $\mathrm{pH}$ suatu larutan ketika terjadi sedikit penambahan asam atau sedikit basa (Chang, 2004).

Larutan penyangga dikelompokkan menjadi dua macam, yaitu: 
1) Larutan penyangga asam

Larutan penyangga asam merupakan larutan yang terdiri dari suatu asam lemah dan basa konjugasinya (Sudarmo, 2013). Larutan ini dapat dibuat dengan cara sebagai berikut (Kalsum et al., 2009):

a) Mencampurkan larutan asam lemah (HA) dengan garamnya.

b) Mencampurkan larutan asam lemah berlebih dengan larutan basa kuat.

2) Larutan penyangga basa

Larutan penyangga basa merupakan larutan yang terdiri dari suatu basa lemah dan asam konjugasinya (Sudarmo, 2013). Larutan penyangga basa dapat dibuat sebagai berikut (Kalsum et al., 2009):

a) Mencampurkan larutan basa lemah dengan garamnya.

b) Mencampurkan larutan basa lemah berlebih dengan larutan asam kuat.

\section{b. Cara Kerja Larutan Penyangga}

1) Larutan Penyangga Asam

Penambahan asam $\left(\mathrm{H}^{+}\right)$akan menggeser kesetimbangan kekiri (Fauziah, 2009). Jika terjadi 
penambahan basa pada larutan penyangga asam, ion $\mathrm{OH}^{-}$dari basa tersebut akan bereaksi dengan ion $\mathrm{H}^{+}$membentuk air. Hal ini akan menyebabkan kesetimbangan bergeser ke kanan sehingga konsentrasi ion $\mathrm{H}^{+}$dapat dipertahankan. Jadi, penambahan basa menyebabkan berkurangnya komponen asam, bukannya ion $\mathrm{H}^{+}$(Kalsum et al., 2009).

2) Larutan Penyangga Basa

Jika terjadi penambahan asam pada larutan penyangga basa, ion $\mathrm{H}^{+}$dari asam tersebut akan mengikat ion $\mathrm{OH}^{-}$. Hal itu menyebabkan kesetimbangan bergeser ke kanan sehingga konsentrasi ion $\mathrm{OH}^{-}$dapat dipertahankan. Jadi, penambahan asam menyebabkan berkurangnya komponen basa, bukannya ion $\mathrm{OH}^{-}$(Kalsum et al., 2009).

Apabila terjadi penambahan suatu basa pada larutan penyangga basa, maka kesetimbangan akan bergeser ke kiri sehingga konsentrasi ion $\mathrm{OH}^{-}$dapat dipertahankan. Basa tersebut akan bereaksi dengan komponen asam, menghasilkan larutan basa dan air (Fauziah, 2009). 


\section{c. Menghitung pH Larutan Penyangga}

$\mathrm{pH}$ larutan penyangga dapat dihitung, namun terlebih dahulu harus menghitung jumlah $\mathrm{H}^{+}$yang terdapat pada larutan. Contohnya, 1 L larutan penyangga yang terdiri dari x mol asam lemah HA dan y mol basa konjugasi $\mathrm{A}^{-}$dari suatu garam. $\mathrm{A}^{-}$tersebut akan mendesak reaksi kesetimbangan HA kearah HA, sehingga konsentrasi HA dianggap tetap. Oleh karena itu, harga Ka untuk reaksi kesetimbangan HA adalah: (Kalsum et al., 2009).

$$
\begin{gathered}
\mathrm{Ka}=\frac{\left[\mathrm{H}^{+}\right]\left[\mathrm{A}^{-}\right]}{[\mathrm{HA}]} \\
{\left[\mathrm{H}^{+}\right]=\mathrm{Ka} \times \frac{[\mathrm{HA}]}{\left[A^{-}\right]} \text {atau }\left[\mathrm{H}^{+}\right]=\mathrm{Ka} \times \frac{[\mathrm{HA}]}{[\text { Basa konjugasi }]}}
\end{gathered}
$$

$\mathrm{pH}=-\log \left[\mathrm{H}^{+}\right]$maka $\mathrm{pH}$ larutan penyangga adalah:

$$
\mathrm{pH}=-\log \left(K a \times \frac{[\text { Asam }]}{[\text { Basa konjugasi }]}\right)
$$

Dengan cara yang sama untuk larutan penyangga yang terdiri dari basa lemah dengan asam konjugasinya didapat rumus:

$$
\mathrm{pOH}=-\log \left(K b \times \frac{[\text { Basa }]}{[\text { Asam konjugasi }]}\right)
$$

\section{d. Fungsi Larutan Penyangga}

Fungsi larutan penyangga sangat luas, baik dalam bidang biokimia, analisis, fotografi, 
bakteriologi, serta industri kulit dan zat warna. Pada tiap bidang tersebut, terutama dalam bakteriologi dan biokimia memerlukan trayek $\mathrm{pH}$ tertentu untuk mendapatkan hasil optimum. (Purba dan Sarwiyati, 2017).

Cairan tubuh, baik cairan intrasel maupun cairan luar sel termasuk larutan penyangga. Komponen penyangga dalam cairan intrasel adalah pasangan dihidrogenfosfat-monohidrogenfosfat $\left(\mathrm{H}_{2} \mathrm{PO}_{4}{ }^{-} / \mathrm{HPO}_{4}{ }^{2-}\right)$. Sistem ini bereaksi dengan asam dan basa sebagai berikut.

$$
\begin{aligned}
& \mathrm{HPO}_{4}^{2-}(a q)+\mathrm{H}^{+}(a q) \longrightarrow \mathrm{H}_{2} \mathrm{PO}_{4}^{-}(a q) \\
& \mathrm{H}_{2} \mathrm{PO}_{4}^{-}(a q)+\mathrm{OH}^{-}(a q) \longrightarrow \mathrm{HPO}_{4}{ }^{2-}(a q)+\mathrm{H}_{2} \mathrm{O}(\mathrm{l}) \\
& \text { Adapun komponen penyangga dalam cairan } \\
& \text { luar sel (darah) adalah pasangan asam karbonat- } \\
& \text { bikarbonat }\left(\mathrm{H}_{2} \mathrm{CO}_{3} / \mathrm{HCO}_{3}^{-}\right) \text {. Sistem ini bereaksi } \\
& \text { dengan asam dan basa sebagai berikut. }
\end{aligned}
$$

$$
\begin{gathered}
\mathrm{H}_{2} \mathrm{CO}_{3}(a q)+\mathrm{OH}^{-}(a q) \longrightarrow \mathrm{HCO}_{3}^{-}(a q)+\mathrm{H}_{2} \mathrm{O}(\mathrm{l}) \\
\mathrm{HCO}_{3}^{-}(a q)+\mathrm{H}^{+}(a q) \longrightarrow \mathrm{H}_{2} \mathrm{CO}_{3}(a q)
\end{gathered}
$$

Sistem penyangga tersebut menjaga $\mathrm{pH}$ darah hampir konstan, yaitu sekitar 7,4 (Purba dan Sarwiyati, 2017:296). 


\section{B. Kajian Pustaka}

Dalam penelitian ini, peneliti mengacu pada penelitian-penelitian terdahulu sebagai rujukan dan untuk memperkuat penelitian yang akan dilakukan. Adapun kajian pustaka yang digunakan pada penelitian ini akan diuraikan di bawah ini.

1. Penelitian yang dilakukan oleh Amalia Fitri (2016) yang berjudul "Meningkatkan Hasil Belajar Peserta didik Menggunakan Model Pembelajaran SiMaYang Materi Kelarutan dan Hasil Kali Kelarutan (Ksp)". Hasil dari penelitian tersebut menyatakan bahwa hasil belajar peserta didik yang menggunakan model SiMaYang mengalami peningkatan, antara lain hasil belajar kognitif peserta didik meningkat dari 53,57\% menjadi 90,625\%, hasil belajar afektif meningkat dari kategori cukup baik menjadi kategori baik, dan hasil belajar psikomotorik meningkat dari kategori cukup menjadi kategori terampil. Persamaan dari penelitian tersebut dengan penelitian yang dilakukan penulis adalah sama-sama menggunakan model pembelajaran SiMaYang. Di sisi lain, perbedaan penelitian tersebut dengan penelitian ini adalah pada penelitian tersebut yang diukur adalah hasil belajar peserta didik pada ranah kognitif, psikomotorik dan afektif, sedangkan pada penelitian ini yang diukur 
adalah penguasaan konsep peserta didik berdasarkan hasil belajar pada ranah kognitif dan sikap terhadap kimia (attitudes toward chemistry). Selain itu, pada penelitian tersebut menggunakan materi kelarutan dan hasil kelarutan, sedangkan materi pada penelitian ini adalah larutan penyangga.

2. Penelitian yang dilakukan oleh Verlia Santi, Sunyono dan Ila Rosilawati (2018), yang berjudul "Pengaruh Scaffolding dalam Pembelajaran SiMaYang untuk Meningkatkan Efikasi Diri dan Penguasaan Konsep". Hasil dari penelitian tersebut menunjukkan bahwa pembelajaran menggunakan model pembelajaran SiMaYang dengan strategi scaffolding mampu meningkatkan efikasi diri dan penguasaan konsep peserta didik pada materi reaksi redoks. Persamaan penelitian tersebut dengan penelitian ini adalah samasama menggunakan model pembelajaran SiMayang dan mengukur penguasaan konsep peserta didik. Perbedaan penelitian tersebut dengan penelitian ini adalah pada penelitian tersebut menggunakan strategi scaffolding dan mengukur efikasi diri, sedangkan pada penelitian ini menggunakan strategi pendekatan saintifik (saintific 
approach) dan mengukur sikap terhadap kimia (attitudes toward chemistry).

3. Penelitian yang dilakukan oleh Aylin Çam dan Ömer Geban (2016), yang berjudul "Effectiveness ofCase-Based Learning Instruction on Pre-service Teacher's Chemistry Motivation and Attitudes toward Chemistry". Hasil dari penelitian tersebut menunjukkan bahwa skor sikap terhadap kimia (attitudes toward chemistry) secara signifikan meningkat menjadi lebih baik setelah menggunakan model pembelajaran Case Based Learning . Persamaan dari penelitian tersebut dengan penelitian ini adalah sama-sama mengukur sikap terhadap kimia (attitudes toward chemistry). Perbedaan dari penelitian tersebut dengan penelitian ini adalah pada penelitian tersebut menggunakan model pembelajaran Case Based Learning, sedangkan pada penelitian ini menggunakan model pembelajaran SiMaYang Tipe II.

4. Penelitian yang dilakukan oleh Senol Sen dan Ozge Ozyalcin Oskay (2017), yang berjudul "The Effects of $5 E$ Inquiry Learning Activities on Achievement and Attitude toward Chemistry". Hasil dari penelitian tersebut menunjukkan bahwa hasil belajar dan sikap terhadap kimia (attitudes toward chemistry) kelas eksperimen yang menggunakan model pembelajarn inkuiri 5E lebih 
tinggi daripada kelas kontrol yang menggunakan metode pembelajaran tradisional. Persamaan penelitian tersebut dengan penelitian ini adalah sama-sama mengukur sikap terhadap kimia (attitudes toward chemistry). Perbedaan penelitian tersebut dengan penelitian ini adalah pada penelitian tersebut menggunakan model pembelajaran inkuiri 5E pada materi kesetimbangan kimia dan mengukur hasil belajar peserta didik, sedangkan pada penelitian ini menggunakan model pembelajaran SiMaYang Tipe II pada materi larutan penyangga dan mengukur penguasaan konsep.

\section{Kerangka Berpikir}

Dari hasil studi lapangan didapatkan bahwa pembelajaran kimia di SMAN 9 Semarang masih sering menggunakan metode ceramah. Oleh karena itu, pada umumnya peserta didik cenderung pasif, tidak tertarik, mengantuk, merasa bosan dan malas bertanya. Hal ini mengakibatkan rendahnya penguasaan konsep dan attitudes toward chemistry pada peserta didik. Maka dari itu, diperlukan sebuah model pembelajaran yang mampu meningkatkan penguasaan konsep dan attitudes toward chemistry peserta didik. Model pembelajaran yang 
ditawarkan adalah model pembelajaran SiMaYang Tipe II, dimana model ini lebih menekankan pada belajar yang menginterkoneksikan level representasi makroskopik, submikroskopik dan simbolik. Kerangka berpikir peneliti adalah sebagai berikut.

Studi Pendahuluan

didapatkan

\section{Fakta:}

1. Peserta didik mengalami kesulitan dalam mempelajari kimia, terutama materi larutan penyangga

2. Penguasaan konsep kurang

3. Nilai hasil belajar di bawah KKM

4. Minat belajar kurang

\section{Sebab:}

1. Pembelajaran masih menggunakan metode konvensional (ceramah)

2. Kurangnya kemandirian siswa dalam belajar

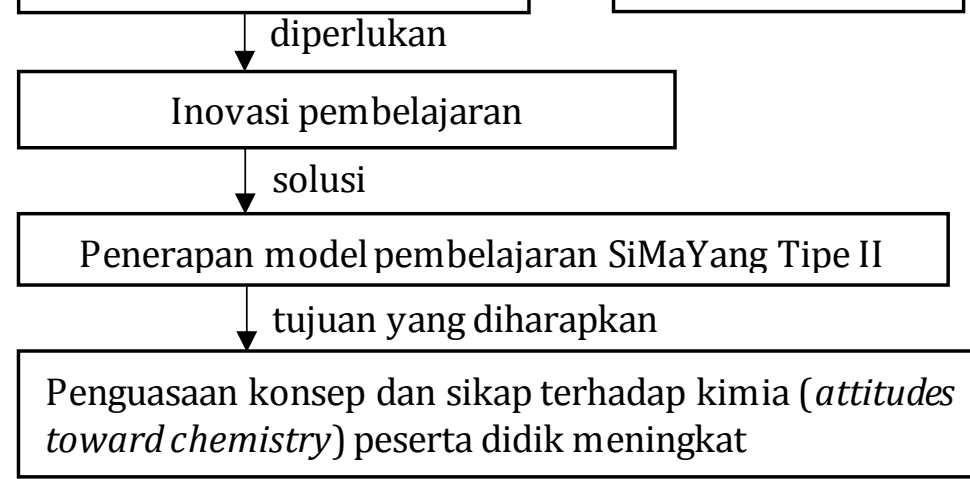

Gambar 2.6 Kerangka Berpikir Peneliti 


\section{Rumusan Hipotesis}

Dari hasil kajian teori dan kerangka berpikir, maka diajukan hipotesis penelitian sebagai berikut.

Hipotesis 1:

$\mathrm{H}_{01}=$ Model pembelajaran SiMaYang Tipe II berbasis multipel representasi tidak efektif terhadap penguasaan konsep peserta didik pada materi larutan penyangga.

$\mathrm{H}_{a 1}=$ Model pembelajaran SiMaYang Tipe II berbasis multipel representasi efektif terhadap penguasaan konsep peserta didik kelas XI MIPA pada materi larutan penyangga.

Hipotesis 2:

$\mathrm{H}_{02}=$ Model pembelajaran SiMaYang Tipe II berbasis multipel representasi tidak efektif terhadap attitudes toward chemistry kelas XI MIPA pada materi larutan penyangga.

$\mathrm{H}_{a 2}=$ Model pembelajaran SiMaYang Tipe II berbasis multipel representasi efektif terhadap attitudes toward chemistry kelas XI pada materi larutan penyangga. 


\section{BAB III \\ METODE PENELITIAN}

\section{A. Jenis dan Pendekatan Penelitian}

Penelitian ini menggunakan pendekatan kuantitatif dengan metode eksperimen. Penelitian eksperimen adalah penelitian yang mencari hubungan sebab akibat antara variabel bebas dan variabel terikat, dimana variabel bebas sengaja dimanipulasi (dibedakan perlakuan) dan dikendalikan oleh peneliti (Jakni, 2016).

Desain eksperimen yang digunakan dalam penelitian ini adalah Quasi Experimental Design. Quasi Experimental Design adalah desain penelitian dimana kelompok kontrol tidak seluruhnya mengontrol variabel-variabel luar yang mampu mempengaruhi penelitian (Sugiyono, 2016a). Bentuk Quasi Experimental Design yang dipilih adalah Nonequivalent Control Group Design. Pada desain tersebut terdapat dua kelas yang dipilih secara random, kemudian diberi pretest untuk mengetahui keadaan awal, adakah perbedaan antara kelas eksperimen dan kelas kontrol.

Pada penelitian ini kelas eksperimen diberi perlakuan dengan menggunakan model pembelajaran SiMaYang tipe II, sedangkan kelas kontrol tetap menggunakan metode ceramah. Setelah diberi perlakuan kedua kelas diberi 
posttest. Rancangan eksperimen dalam penelitian ini adalah sebagai berikut.

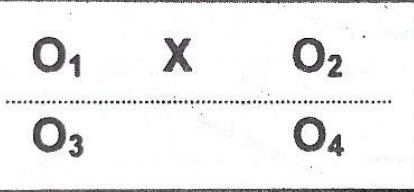

Gambar 3.1. Nonequivalent Control Group Design

(Sumber: Sugiyono, 2016a)

Keterangan:

$\mathrm{O}_{1} \quad$ : Pretest kelas eksperimen

$\mathrm{O}_{2} \quad$ : Posttest kelas eksperimen

$\mathrm{O}_{3} \quad$ : Pretest kelas kontrol

$\mathrm{O}_{4} \quad$ : Posttest kelas kontrol

X : Pembelajaran menggunakan model SiMaYang tipe II

\section{B. Tempat dan Waktu Penelitian}

1. Tempat Penelitian

Tempat penelitian dilakukan di SMAN 9 Semarang, yang berlokasi di Jalan Cemara Raya, Padangsari, Kec. Banyumanik, Kota Semarang, Jawa Tengah - 50267.

2. Waktu Penelitian

Penelitian ini dilakukan pada tanggal 20 Mei 2019 sampai dengan 5 Mei 2020. 


\section{Populasi danSampel}

1. Populasi

Populasi merupakan keseluruhan subjek penelitian (Arikunto dan Supardi, 2007:173). Sugiyono (2016) mengemukakan bahwa populasi adalah wilayah generalisasi yang didalamnya terdapat objek atau subjek dengan kuantitas dan karakteristik tertentu. Populasi dalam penelitian ini adalah seluruh peserta didik kelas XI MIPA SMAN 9 Semarang yang berjumlah 249 peserta didik.

Tabel 3.1 Jumlah Peserta Didik dalam Populasi

\begin{tabular}{ccc}
\hline No. & Kelas & Jumlah Peserta didik \\
\hline 1. & XI MIPA 1 & 36 \\
2. & XI MIPA 2 & 35 \\
3. & XI MIPA 3 & 36 \\
4. & XI MIPA 4 & 35 \\
5. & XI MIPA 5 & 37 \\
6. & XI MIPA 6 & 34 \\
7. & XI MIPA 7 & 36 \\
\hline & Jumlah & 249 \\
\hline
\end{tabular}

(Sumber: Administrasi SMAN 9 Semarang tahun pelajaran 2019/2020)

2. Sampel

Sampel adalah sebagian populasi yang diteliti (Arikunto dan Supardi, 2007). Pada penelitian ini, sampel diambil dengan teknik cluster random sampling (probability sampling). Sebelum sampel dipilih, populasi 
harus dipastikan normal dan homogen dengan cara mengukur normalitas dan homogenitasnya. Pemilihan kelas eksperimen, kelas kontrol dan kelas uji coba dilakukan secara random (Random Assignment). Random assignment merupakan penempatan subjek ke dalam kelompok sedemikian rupa, dimana setiap sampel mendapat peluang yang sama untuk ditempatkan pada kelompok manapun (Furchan, 2007).

Pada penelitian ini, sampel yang terpilih adalah kelas XI MIPA 6 sebagai kelas kontrol dan kelas XI MIPA 7 sebagai kelas eksperimen.

\section{Variabel Penelitian}

Pada penelitian ini, ada dua macam variabel, yaitu variabel bebas (independen) dan variabel terikat (dependen).

1. Variabel bebas (Independen)

Variabel bebas adalah variabel yang menimbulkan adanya variabel terikat (Sugiyono, 2016). Pada penelitian ini variabel bebasnya adalah model pembelajaran SiMaYang Tipe II.

2. Variabel terikat (Dependen)

Variabel terikat adalah variabel yang dipengaruhi oleh variabel bebas (Sugiyono, 2016:4). Dalam 
penelitian ini yang menjadi variabel terikatnya Attitudes toward Chemistry dan penguasaan konsep peserta didik pada materi larutan penyangga di kelas XI SMAN 9 Semarang.

\section{E. Teknik Pengumpulan Data}

Teknik pengumpulan data yang digunakan dalam penelitian ini yaitu teknik nontes dan teknik tes.

1. Teknik Non Tes

Teknik non tes dilakukan melalui:

a. Observasi

Pada riset pendahuluan, peneliti melakukan observasi permasalahan di lingkungan sekolah untuk dikaji lebih lanjut.

b. Wawancara

Wawancara ini dilakukan untuk menemukan permasalahan yang harus diteliti dan mencari data secara mendalam (Sugiyono, 2016a). Jenis wawancara yang digunakan dalam penelitian ini adalah wawancara terstruktur, dimana peneliti sudah menyiapkan pedoman wawancara sebelumnya.

c. Angket

Angket adalah cara pengambilan data dengan memberikan pertanyaan kepada orang lain untuk 
mendapatkan respons sesuai harapan peneliti (Jakni, 2016). Pada penelitian ini, peneliti menggunakan angket pra riset, angket sikap terhadap kimia (Attitudes toward Chemistry) dan respons peserta didik terhadap model pembelajaran SiMaYang Tipe II.

d. Dokumentasi

Dokumentasi dalam penelitian ini digunakan untuk mendapatkan data-data peserta didik kelas XI MIPA SMAN 9 Semarang, nilai peserta didik kelas eksperimen dan kelas kontrol pada materi larutan penyangga, foto-foto hasil penelitian maupun dokumen-dokumen lain dari sekolah.

2. Teknik Tes

Teknik tes dilakukan dengan memberikan pretest dan posttest, sebelum dan sesudah penerapan model pembelajaran SiMaYang Tipe II. Teknik tes ini digunakan untuk memperoleh data penguasaan konsep peserta didik kelas eksperimen dan kelas kontrol pada materi larutan penyangga.

\section{F. Instrumen Penilaian}

Instrumen penilaian yang akan digunakan adalah sebagai berikut. 
1. Tes Penguasaan Konsep Peserta didik

Instrumen tes penguasaan konsep peserta didik ini menggunakan instrumen pilihan ganda beralasan (Three-Tier Multiple Choice Diagnostic Test) dan uraian. Namun sebelum tes diujikan, terlebih dahulu diujicobakan kepada kelas uji coba untuk mengetahui validitas, reliabilitas, daya beda dan tingkat kesukaran soal. Setelah terpenuhi dan layak untuk dipakai, maka soal tersebut dapat diujikan kepada kelas eksperimen dan kelas kontrol. Hasil tes tersebut dijadikan sebagai acuan untuk menginterpretasikan penguasaan konsep peserta didik pada materi larutan penyangga dan menarik kesimpulan pada akhir penelitian.

2. Angket Attitudes toward Chemistry

Angket ini digunakan untuk mengetahui sikap peserta didik terhadap kimia (Attitudes toward Chemistry) yang diadopsi dari penelitian Cheung (2011).

3. Lembar Respons Peserta didik terhadap Pelaksanaan Model Pembelajaran SiMaYang Tipe II

Setelah pembelajaran menggunakan model SiMaYang Tipe II selesai dilaksanakan, peserta didik diberikan lembar respons peserta didik untuk 
mengetahui bagaimana keterlaksanaan model SiMaYang Tipe II.

\section{G. Teknik Analisis Data}

1. Analisis Populasi

Pada tahap analisis populasi yang digunakan adalah nilai PAS semester ganjil tahun ajaran 2019/2020 yang kemudian diuji normalitas dan homogenitasnya.

a. Uji Normalitas

Uji normalitas berfungsi untuk menentukan statistik yang akan digunakan dalam pengelolaan data, yaitu statistik parametrik atau non parametrik (Sugiyono, 2016a). Statistik parametris dapat digunakan dengan syarat bahwa data setiap variabel yang akan dianalisis berdistribusi normal. Uji normalitas yang digunakan yaitu dengan menggunakan rumus Chi Kuadrat (Sugiyono, 2016b).

Adapun langkah-langkah untuk melakukan uji normalitas data adalah sebagai berikut: (Jakni, 2016)

1) Menentukan rentang kelas, dengan rumus:

Rentang $=\mathrm{X}_{\mathrm{mak}}-\mathrm{X}_{\mathrm{min}}$

2) Menentukan banyak kelas, dengan rumus:

Banyak kelas $=1+3,3 \log n$ 
3) Menentukan panjang kelas, dengan rumus:

Panjang kelas $=\frac{\text { Rentang }}{\text { Banyak kelas }}$

4) Membuat tabel bantu uji normalitas data

5) Menentukan chi kuadrat hitung $\left(\chi^{2}\right)$

$$
\chi_{\text {hitung }}^{2}=\sum \frac{\left(f_{o}-f_{h}\right)^{2}}{f_{h}}
$$

Keterangan:

$\chi_{\text {hitung }}^{2}=$ Chi kuadrat hitung

$f_{o} \quad=$ Frekuensi observasi

$f_{h} \quad=$ Frekuensi harapan

6) Menentukan harga tabel chi kuadrat $\left(\chi_{\text {tabel }}^{2}\right)$

$$
\chi_{\text {tabel }}^{2}=\chi^{2}(1-\alpha)(d k)
$$

Keterangan:

$$
\begin{array}{ll}
\chi_{\text {tabel }}^{2} & =\text { Chi kuadrat tabel } \\
\alpha & =0,05 \text { (taraf kesalahan) } \\
d k & =\text { banyak kelas dikurangi } 1
\end{array}
$$

Apabila $\chi_{\text {hitung }}^{2}<\chi_{\text {tabel }}^{2}$ maka populasi berdistribusi normal.

b. Uji Homogenitas

Uji homogenitas populasi digunakan untuk menentukan subjek populasi, apakah bersifat homogen atau heterogen dengan tujuan agar sampel yang diambil benar-benar representatif 
(dapat mewakili dari seluruh populasi) (Jakni, 2016).

Uji homogenitas populasi dilakukan dengan menggunakan rumus uji Bartlett menurut Sudjana (2005:275) yaitu:

$$
\chi_{\text {hitung }}^{2}=(\ln 10) \cdot\left(B-\sum(d k) \cdot \log s_{i}^{2}\right.
$$

dengan:

$$
\begin{gathered}
s^{2}=\frac{\sum\left(n_{i}-1\right) s_{i}^{2}}{\left(n_{i}-1\right)} \\
B=\log s^{2} \cdot \sum\left(n_{i}-1\right)
\end{gathered}
$$

Keterangan:

$s^{2}$

: Varians gabungan

$n_{i} \quad$ : Jumlah subjek

$B \quad$ : Harga satuan B (Bartlett)

$d k \quad$ : Derajat kebebasan

$\chi_{\text {hitung }}^{2} \quad$ : Chi Kuadrat

Apabila $\chi_{\text {hitung }}^{2} \leq \chi_{\text {tabel }}^{2}$, maka data tersebut homogen. Namun, jika $\chi_{\text {hitung }}^{2}>\chi_{\text {tabel }}^{2}$, maka data tersebut heterogen.

2. Analisis Instrumen Tes

Tes adalah kumpulan pertanyaan yang digunakan untuk mengetahui aspek pengetahuan (kognitif) peserta didik setelah mempelajari suatu materi pelajaran (Jakni, 2016). Instrumen tes yang digunakan oleh peneliti 
adalah soal-soal pilihan ganda beralasan bentuk threetier multiple choice dan uraian. Analisis instrumen tes ini dilakukan dengan beberapa uji yaitu:

a. Uji Validitas

Sebuah tes dinyatakan valid apabila tes tersebut dapat mengukur secara benar terhadap yang diukur. Instrumen tes diujikan ke kelas uji coba, dimana sebelumnya instrumen tes telah diuji oleh validator dan telah di revisi sesuai masukan dan saran dari validator. Adapun rumus yang digunakan untuk mencari validitas empirik instrumen tes bentuk uraian yaitu dengan menggunakan teknik korelasi Pearson product moment, yaitu: (Sudijono, 2015:93)

$$
r_{x y}=\frac{N \sum X Y-\left(\sum X\right)\left(\sum Y\right)}{\sqrt{\left\{N \sum X^{2}-\left(\sum X\right)^{2}\right\}\left\{N \sum Y^{2}-\left(\sum Y\right)^{2}\right\}}}
$$

Keterangan:

$r_{x y} \quad:$ koefisien korelasi tiap item

$N \quad$ : Jumlah responden

$\sum X \quad$ : Jumlah skor tiap item

$\sum Y \quad$ : Jumlah skor total

$\sum X^{2} \quad$ : Jumlah kuadrat skor item

$\sum Y^{2} \quad$ : Jumlah kuadrat skor total

$\sum X Y \quad$ : Jumlah perkalian skor item dan skor total 
Sedangkan untuk mengetahui validitas soal pilihan ganda beralasan digunakan rumus korelasi point biserial: (Sudijono, 2015:185)

$$
r_{b p i}=\frac{M_{p}-M_{t}}{S_{t}} \sqrt{\frac{p}{q}}
$$

Keterangan:

$r_{b p i}$ : Koefisien korelasi biserial

$M_{p}$ : Rerata skor dari subjek yang menjawab betul untuk item yang dicari validitasnya

$M_{t}$ : Rerata skor soal

$S_{t} \quad$ : Standar deviasi dari skor total

$p \quad$ : proporsi peserta didik yang menjawab benar

$q \quad$ : proporsi peserta didik yang menjawab salah

Selanjutnya nilai $\mathrm{r}_{\text {hitung }}$ dibandingkan dengan nilai $r_{\text {tabel }}$ dengan taraf signifikansi 5\%. Apabila nilai $r_{\text {hitung }} \geq r_{\text {tabel }}$ maka korelasi signifikan, artinya item soal yang digunakan sudah valid. Sebaliknya jika $r_{\text {hitung }}$ $<r_{\text {tabel }}$ maka soal tersebut tidak valid.

b. Reliabilitas

Instrumen tes dinyatakan reliabel apabila hasil yang diperoleh bersifat ajeg dan stabil, artinya apabila instrumen tes tersebut diberikan kepada subjek dengan jumlah yang sama pada waktu yang berbeda, maka hasilnya relatif sama (Sudijono, 2015). Analisis reliabilitas tes bentuk uraian pada penelitian 
ini diukur dengan menggunakan rumus Cronbach Alpha sebagai berikut. (Sudijono, 2015:208)

$$
r_{11}=\left|\frac{n}{n-1}\right|\left|1-\frac{\sum S_{i}^{2}}{S_{t}^{2}}\right|
$$

Keterangan:

$r_{11} \quad$ : Reliabitas instrumen

$n$ : Banyaknya butir item

1 : Bilangan konstan

$\sum S_{i}^{2} \quad$ : Jumlah varians skor tiap-tiap item

$S_{t}^{2} \quad$ : Varians total

Sedangkan perhitungan reliabilitas untuk soal pilihan ganda beralasan menggunakan rumus Kuder dan Richardson (KR-20) sebagai berikut: (Sudijono, 2015: 254)

$$
r_{11}=\left(\frac{n}{n-1}\right)\left(\frac{s^{2}-\sum p q}{s^{2}}\right)
$$

Keterangan:

$$
\begin{array}{ll}
r_{11} & : \text { Koefisien reliabilitas tes } \\
n & : \text { Banyaknya butir item } \\
1 & \text { : Bilangan konstan } \\
s^{2} & \text { : Varians total } \\
p & \text { : Proporsi yang menjawab benar butir item } \\
& \quad \text { yang bersangkutan } \\
q & \text { : Proporsi yang menjawab salah } \\
\sum p q & \text { : Jumlah dari hasil perkalian antara } \mathrm{p} \text { dan } \mathrm{q}
\end{array}
$$


Interpretasi nilai $r_{11}$ pada penelitian ini mengacu pada kategori koefisien reliabilitas sebagai berikut.

Tabel 3.2 Indeks Reliabilitas Soal

\begin{tabular}{ccl}
\hline No. & Indeks r & \multicolumn{1}{c}{ Kategori } \\
\hline 1. & $0,80<r_{11} \leq 1,00$ & $\begin{array}{l}\text { Reliabilitas } \\
\text { tinggi }\end{array}$ \\
& & sangat \\
2. & $0,60<r_{11} \leq 0,80$ & Reliabilitas tinggi \\
3. & $0,40<r_{11} \leq 0,60$ & Reliabilitas sedang \\
4. & $0,20<r_{11} \leq 0,40$ & Reliabilitas rendah \\
5. & $-1,00<r_{11} \leq 0,20$ & $\begin{array}{l}\text { Reliabilitas } \quad \text { sangat } \\
\end{array}$ \\
\hline
\end{tabular}

(Sumber: Guilford, 1956: 145)

c. Tingkat kesukaran

Uji tingkat kesukaran dilakukan untuk mengetahui seberapa besar derajat kesukaran suatu soal. Sebuah tes dinyatakan baik apabila tes tersebut tidak terlalu sukar dan tidak pula terlalu mudah, artinya tes mempunyai tingkat kesukaran sedang (Sudijono, 2015:370).

Rumus yang digunakan untuk mencari tingkat kesukaran soal bentuk uraian adalah sebagai berikut.

Tingkat kesukaran $=\frac{\text { rata-rata } \text { skor } \text { sisw a dalam item }}{\text { Skor } \text { maksimum yang ditetapkan }}$ Sedangkan rumus untuk mencari tingkat kesukaran soal pilihan ganda beralasan adalah sebagai berikut.

$$
P=\frac{B}{J S}
$$


Keterangan:

$P$ : Tingkat kesukaran soal

$B$ : Banyaknya peserta didik yang menjawab soal dengan benar

$J S$ : Jumlah seluruh peserta tes

Kriteria yang digunakan dalam penelitian ini adalah sebagai berikut.

Tabel 3.3 Indeks Kesukaran Soal

\begin{tabular}{ccc}
\hline No. & Nilai P & Kategori Soal \\
\hline 1. & $0,00-0,30$ & Sukar \\
2. & $0,31-0,70$ & Sedang \\
3. & $0,71-1,00$ & Mudah \\
\hline
\end{tabular}

(Sumber: Arikunto, 2010)

d. Daya Pembeda

Daya pembeda soal digunakan untuk membedakan peserta didik yang berkemampuan tinggi dengan peserta didik yang berkemampuan rendah (Sudijono, 2015:385). Semakin tinggi daya pembeda suatu butir soal, maka semakin mampu butir soal tersebut membedakan peserta didik yang berkemampuan tinggi dengan peserta didik yang berkemampuan rendah.

Rumus yang digunakan untuk daya pembeda adalah sebagai berikut (Sudijono, 2015:389).

$$
D=\frac{B_{A}}{J_{A}}-\frac{B_{B}}{J_{B}}=P_{A}-P_{B}
$$


Keterangan:

D : Daya pembeda

J : Jumlah peserta tes

$J_{A} \quad$ : Banyaknya peserta kelompok atas

$J_{B} \quad$ : Banyaknya peserta kelompok bawah

$B_{A}$ : Banyaknya peserta kelompok atas yang menjawab soal dengan benar

$B_{B} \quad$ : Banyaknya peserta kelompok bawah yang menjawab soal dengan benar

Kriteria yang digunakan dalam penelitian ini adalah sebagai berikut:

Tabel 3.4 Indeks Daya Pembeda Soal

\begin{tabular}{ccc}
\hline No. & Nilai D & Kategori \\
\hline 1. & $0,00-0,20$ & Jelek \\
2. & $0,21-0,40$ & Cukup \\
3. & $0,41-0,70$ & Baik \\
4. & $0,71-1,00$ & Baik Sekali \\
\hline
\end{tabular}

(Sumber: Arikunto, 2010)

3. Analisis Data Awal

Analisis data awal ini menggunakan nilai pretest sebelum digunakan perlakuan. Pretest ini dilakukan untuk mengetahui sejauh mana materi yang akan dipelajari telah dikuasai oleh peserta didik. Pelaksanaan pretest dilakukan sebelum materi diberikan kepada peserta didik (Sudijono, 2015).

Terdapat beberapa uji dalam analisis hasil pretest peserta didik antara lain: 
a. Uji Normalitas

Data hasil pretest digunakan untuk uji normalitas pada uji tahap awal. Uji ini bertujuan untuk mengetahui apakah data berdistribusi normal atau tidak. Uji normalitas dilakukan dengan uji Chi Kuadrat. Langkah-langkah uji normalitas menggunakan Chi-Kuadrat sama seperti uji normalitas data populasi. Hipotesis yang digunakan yaitu:

$H_{0}=$ data berdistribusi normal

$H_{a}$ = data berdistribusi tidak normal

$H_{0}$ diterima jika $\chi_{\text {hitung }}^{2} \leq \chi_{\text {tabel }}^{2}$ dengan taraf signifikansi 5\%.

b. Uji Homogenitas

Uji homogenitas digunakan untuk memperoleh asumsi bahwa sampel penelitian berangkat dari kondisi yang sama atau homogen, yang selanjutnya untuk menentukan statistik yang akan digunakan dalam pengujian hipotesis. Hipotesis yang dilakukan dalam uji homogenitas adalah sebagai berikut. $\mathrm{H}_{0}: \sigma_{1}^{2}=\sigma_{2}^{2}$ (kedua kelompok mempunyai varian yang sama) 
$\mathrm{H}_{a}: \sigma_{1}^{2} \neq \sigma_{2}^{2}$ (kedua kelompok mempunyai varian yang berbeda)

Untuk menguji kesamaan dua varians digunakan rumus sebagai berikut.

$$
\mathrm{F}_{\text {hitung }}=\frac{\text { varians terbesar }}{\text { varians terkecil }}
$$

Taraf signifikansi yang digunakan adalah 5\%. Pengujian dilakukan dengan membandingkan $\mathrm{F}_{\text {hitung }}$ dengan $\mathrm{F}_{\text {tabel. }}$. Jika $\mathrm{F}_{\text {hitung }}<\mathrm{F}_{\text {tabel }}$ maka $\mathrm{H}_{0}$ diterima (Sudjana, 2005:250).

c. Uji Kesamaan Dua Rata-Rata

Uji kesamaan rata-rata pada tahap awal berfungsi untuk menguji apakah ada kesamaan ratarata antara kelas eksperimen dan kelas kontrol. Langkah-langkah uji kesamaan dua rata-rata adalah sebagai berikut.

a) Menentukan rumusan hipotesis

$\mathrm{H}_{0}: \mu_{1}=\mu_{2}$ (tidak ada perbedaan rata-rata awal kedua kelas sampel)

$\mathrm{H}_{1}: \mu_{1} \neq \mu_{2}$ (terdapat perbedaan rata-rata awal kedua kelas sampel)

Dengan:

$\mu_{1}=$ rata-rata nilai awal kelompok eksperimen $\mu_{2}=$ rata-rata nilai awal kelompok kontrol 
b) Menentukan statistik yang digunakan yaitu uji-t dua pihak

c) Menentukan taraf signifikan. Dalam penelitian ini digunakan $\alpha=5 \%$

d) Kriteria pengujiannya adalah diterima $\mathrm{H}_{0}$ apabila:

$$
-t_{\text {tabel }} \leq t_{\text {hitung }} \leq t_{\text {tabel }}
$$

e) Menentukan statistik hitung menggunakan rumus sebagai berikut.

Apabila varians homogen $\left(\sigma_{1}^{2}=\sigma_{2}^{2}\right)$, rumus yang digunakan adalah sebagai berikut.

$$
t=\frac{\overline{X_{1}}-\overline{X_{2}}}{\sqrt{\frac{\left(n_{1}-1\right) s_{1}^{2}+\left(n_{2}-1\right) s_{2}^{2}}{n_{1}+n_{2}-2}\left(\frac{1}{n_{1}}+\frac{1}{n_{2}}\right)}}
$$

dengan $\mathrm{dk}=\mathrm{n}_{1}+\mathrm{n}_{2}-2$

Keterangan:

$\bar{x}_{1}$ : Nilai rata-rata dari kelompok eksperimen

$\bar{x}_{2}$ : Nilai rata-rata dari kelompok kontrol

$s_{1}{ }^{2}$ : Varians dari kelompokeksperimen

$s_{2}^{2}$ : Varians dari kelompok kontrol

$\mathrm{n}_{1} \quad$ : Jumlah subjek dari kelompok eksperimen

$\mathrm{n}_{2} \quad$ : Jumlah subjek dari kelompok kontrol

Apabila varians tidak homogen $\left(\sigma_{1} \neq \sigma_{2}\right)$, rumus yang digunakan adalah sebagai berikut. 


$$
t=\frac{\bar{x}_{1}-\bar{x}_{2}}{\sqrt{\frac{s_{1}^{2}}{n_{1}}+\frac{s_{2}^{2}}{n_{2}}}}
$$

Keterangan:

$\bar{x}_{1} \quad$ : Skor rata-rata dari kelompok eksperimen

$\bar{x}_{2} \quad$ : Skor rata-rata dari kelompok kontrol

$s_{1}{ }^{2}$ : Varians dari kelompok eksperimen

$s_{2}{ }^{2}$ : Varians dari kelompok kontrol

$s \quad$ : Standar deviasi

$\mathrm{n}_{1} \quad$ : Jumlah subjek dari kelompok eksperimen

$\mathrm{n}_{2} \quad$ : Jumlah subjek dari kelompok kontrol

Kriteria pengujian:

$\mathrm{H}_{0}$ diterima jika $t_{\text {hitung }} \leq \mathrm{t}$ pengganti harga $\mathrm{t}_{\text {tabel. }}$. Harga t sebagai pengganti harga $t_{\text {tabel }}$ dihitung dari selisih harga $t_{\text {tabel }}$ dengan $d k=n_{1}-1$ dan $d k=n_{2}-1$, dibagi dua dan kemudian ditambah dengan harga tyang terkecil (Sugiyono, 2016b: 139).

4. Analisis Penguasaan Konsep Peserta didik

Hasil pretest dan posttest kelas eksperimen dan kelas kontrol dianalisis untuk mengetahui penguasaan konsep peserta didik sebelum dan sesudah diberi perlakuan.

Data yang diperoleh dari hasil tes bentuk pilihan ganda beralasan (three-tier multiple choice) dianalisis untuk mendapatkan data berapa persen peserta didik 
yang miskonsepsi, terkaan, kurang paham, dan paham konsep. Selain itu, pada soal uraian juga dianalisis untuk mengetahui persentase jawaban benar. Data yang diperoleh tersebut kemudian dihitung persentasenya dari setiap kategori, dengan rumus:

$$
P=\frac{f}{N} \times 100 \%
$$

Keterangan:

$\mathrm{P}=$ angka persentase (\% kategori)

$\mathrm{f}=$ jumlah peserta didik dalam kelompok

$\mathrm{N}=$ jumlah total peserta didik

Nilai penguasaan konsep diambil dari nilai soal three-tier multiple choice dan nilai soal uraian. Peningkatan penguasaan konsep peserta didik sebelum dan sesudah pembelajaran dapat menggunakan uji Ngain, dengan rumus: (Meirita, 2013: 77)

$$
g=\frac{T_{f}-T_{i}}{S I-T_{i}}
$$

Keterangan:

$\mathrm{T}_{\mathrm{f}}=$ nilai hasil tes akhir (posttest)

$\mathrm{T}_{\mathrm{i}}=$ nilai hasil tes awal (pretest)

Kategori N-Gain dapat digambarkan dengan tingkat pencapaian pada Tabel 3.5. 
Tabel 3.5 Kategori Nilai N-Gain

\begin{tabular}{cc}
\hline Nilai N-Gain & Kategori \\
\hline$N>0,7$ & Tinggi \\
$0,3<N<0,7$ & Sedang \\
$N<0,3$ & Rendah \\
\hline
\end{tabular}

(Sumber: Hake, 1999)

5. Analisis Angket Sikap terhadap Kimia (Attitudes Toward Chemistry)

Hasil angket sikap terhadap kimia (Attitudes Toward Chemistry) dapat dicari dengan menghitung skor rata-rata dari setiap item pertanyaan yang kemudian dijadikan dalam bentuk persentase dengan menggunakan rumus:

$$
X \%=\frac{\sum S A}{\sum S I} \times 100 \%
$$

Keterangan:

$X \%=$ Persentase angket

$\sum S A=$ Jumlah Skor Aktual (diperoleh dari jumlah hasil transformasi data angket)

$\sum S I=$ Jumlah Skor Ideal (diperoleh dari jumlah subjek/ sampel dikali dengan skor maksimal bobot angket)

Sedangkan untuk tolok ukurnya dapat dilihat seperti tabel di bawah ini: 
Tabel 3.6 Tolok Ukur Kategori Persentase Angket

\begin{tabular}{cc}
\hline Persentase & Kategori \\
\hline $80,00-100,00$ & Sangat Baik \\
$60,00-79,99$ & Baik \\
$40,00-59,99$ & Cukup \\
$00,00-39,99$ & Kurang \\
\hline
\end{tabular}

(Sumber: Jakni, 2016: 107)

Setelah dihitung persentase dari angket sikap terhadap kimia, langkah selanjutnya yaitu menghitung uji n-gain untuk mengetahui peningkatan sikap peserta didik terhadap kimia. Rumus yang digunakan sama seperti ujin-gain pada penguasaan konsep peserta didik.

6. Uji Tahap Akhir

Setelah kedua sampel diberi perlakuan yang berbeda, maka dilaksanakan tes akhir (posttest). Hasil posttest ini digunakan untuk menguji hipotesis penelitian, yaitu hipotesis diterima atau ditolak. Sebelum dilakukan uji hipotesis terlebih dahulu dilakukan uji normalitas dan uji homogenitas sebagai prasarat uji hipotesis. Adapun langkah-langkah untuk uji normalitas dan homogenitas sama seperti pada langkah-langkah uji normalitas dan homogenitas pada analisis tahap awal. Ketentuan uji hipotesis pada penelitian ini adalah sebagai berikut. 
1) Rumus Hipotesis Uji Perbedaan Dua Rata-Rata

Penguasaan Konsep:

$\mathrm{H}_{01}: \mu_{1}=\mu_{2}$

$\mathrm{H} a_{1}: \mu_{1} \neq \mu_{2}$

Keterangan:

$\mu_{1}$ : Rata-rata penguasaan konsep peserta didik kelas XI MIPA yang diajar dengan model SiMaYang Tipe II

$\mu_{2}$ : Rata-rata penguasaan konsep peserta didik kelas XI MIPA yang diajar dengan metode konvensional

Attitudes toward Chemistry:

$\mathrm{H}_{01}: \mu_{1}=\mu_{2}$

$\mathrm{H} a_{1}: \mu_{1} \neq \mu_{2}$

Keterangan:

$\mu_{1}$ : $\quad$ Rata-rata attitudes toward chemistry peserta didik kelas XI MIPAyang diajar dengan model SiMaYang Tipe II

$\mu_{2}$ : Rata-rata attitudes toward chemistry peserta didik kelas XI MIPA yang diajar dengan metode konvensional

2) Uji Perbedaan Dua Rata-rata

Apabila varians homogen $\left(\sigma_{1}^{2}=\sigma_{2}^{2}\right)$, rumus yang digunakan adalah sebagai berikut. 


$$
t=\frac{\overline{X_{1}}-\overline{X_{2}}}{\sqrt{\frac{\left(n_{1}-1\right) s_{1}^{2}+\left(n_{2}-1\right) s_{2}^{2}}{n_{1}+n_{2}-2}\left(\frac{1}{n_{1}}+\frac{1}{n_{2}}\right)}}
$$

dengan $d k=n_{1}+n_{2}-2$ dengan taraf signifikansi $5 \%$.

Keterangan:

$\bar{x}_{1}$ : Nilai rata-rata dari kelompok eksperimen

$\bar{x}_{2}$ : Nilai rata-rata dari kelompok kontrol

$s_{1}{ }^{2}$ : Varians dari kelompok eksperimen

$s_{2}{ }^{2}$ : Varians dari kelompok kontrol

$\mathrm{n}_{1}$ : Jumlah subjek dari kelompok eksperimen

$\mathrm{n}_{2} \quad$ : Jumlah subjek dari kelompok kontrol

$\mathrm{H}_{0}$ diterima apabila $-\mathrm{t}_{\text {tabel }} \leq \mathrm{t}_{\text {hitung }} \leq \mathrm{t}_{\text {tabel }}$

Apabila varians tidak homogen $\left(\sigma_{1} \neq \sigma_{2}\right)$, rumus yang digunakan adalah sebagai berikut.

$$
t=\frac{\bar{x}_{1}-\bar{x}_{2}}{\sqrt{\frac{s_{1}^{2}}{n_{1}}+\frac{s_{2}^{2}}{n_{2}}}}
$$

Keterangan:

$\bar{x}_{1} \quad$ : Skor rata-rata dari kelompok eksperimen

$\bar{x}_{2} \quad$ : Skor rata-rata dari kelompok kontrol

$s_{1}{ }^{2}$ : Varians dari kelompok eksperimen

$s_{2}{ }^{2}$ : Varians dari kelompok kontrol

$s \quad$ : Standar deviasi

$\mathrm{n}_{1} \quad$ : Jumlah subjek dari kelompok eksperimen

$\mathrm{n}_{2} \quad$ : Jumlah subjek dari kelompok kontrol 
Kriteria pengujian:

$\mathrm{H}_{0}$ diterima jika $\mathrm{t}_{\text {hitung }} \leq \mathrm{t}$ pengganti harga $\mathrm{t}_{\text {tabel. }}$. Harga t sebagai pengganti harga $t_{\text {tabel }}$ dihitung dari selisih harga $t_{\text {tabel }}$ dengan $\mathrm{dk}=\mathrm{n}_{1}-1$ dan $\mathrm{dk}=\mathrm{n}_{2}-1$, dibagi dua dan kemudian ditambah dengan harga t yang terkecil (Sugiyono, 2016b: 139). Taraf signifikansi yang digunakan adalah 5\%.

3) Rumus Hipotesis Uji Pihak Kanan

Penguasaan Konsep:

$$
\begin{aligned}
& H_{01}: \mu_{1} \leq \mu_{2} \\
& H_{a 1}: \mu_{1}>\mu_{2}
\end{aligned}
$$

Keterangan:

$\mu_{1}$ : Rata-rata penguasaan konsep peserta didik kelas XI MIPA yang diajar dengan model SiMaYang Tipe II

$\mu_{2}$ : Rata-rata penguasaan konsep peserta didik kelas XI MIPA yang diajar dengan metode konvensional

Attitudes toward Chemistry:

$$
\begin{aligned}
& H_{02}: \mu_{1} \leq \mu_{2} \\
& H_{a 2}: \mu_{1}>\mu_{2}
\end{aligned}
$$

Keterangan:

$\mu_{1}$ : Rata-rata attitudes toward chemistry kelas XI MIPAyang diajar dengan model SiMaYang Tipe II 
$\mu_{2}$ : Rata-rata attitudes toward chemistry kelas XI MIPAyang diajar dengan metodekonvensional

4) Uji Pihak Kanan

Uji hipotesis ini bergantung pada hasil uji normalitas. Apabila data berdistribusi normal, maka statistik yang digunakan adalah statistik parametrik. Sedangkan apabila data berdistribusi tidak normal, maka statistik yang digunakan adalah statistik nonparametrik.

Penelitian ini menggunakan statistik parametrik. Statistik parametrik yang digunakan adalah t-test. Rumus t-test yang digunakan untuk menguji hipotesis komparatif dua sampel independen adalah sebagai berikut (Sugiyono, 2016b):

$$
t=\frac{\overline{X_{1}}-\overline{X_{2}}}{\sqrt{\frac{\left(n_{1}-1\right) s_{1}^{2}+\left(n_{2}-1\right) s_{2}^{2}}{n_{1}+n_{2}-2}\left(\frac{1}{n_{1}}+\frac{1}{n_{2}}\right)}}
$$

Keterangan:

$\bar{X}_{1}=$ Rata-rata sampel yang menggunakan model SiMaYang Tipe II

$\bar{X}_{2}=$ Rata-rata sampel yang menggunakan metode ceramah

$s_{1}{ }^{2}=$ varians sampel yang menggunakan model SiMaYang Tipe II 
$s_{2}{ }^{2}=$ varians sampel yang menggunakan metode ceramah

$\mathrm{n}_{1}=$ Jumlah responden kelas eksperimen

$\mathrm{n}_{2}=$ Jumlah responden kelas kontrol

Harga $t$ tersebut selanjutnya dibandingkan dengan harga $t_{\text {tabel }}$ dengan $\mathrm{dk}=\mathrm{n}_{1}+\mathrm{n}_{2}-2$ dan taraf kesalahannya $5 \%$. Apabila harga $t_{\text {hitung }} \leq t_{\text {tabel, }}$ maka $\mathrm{H}_{0}$ diterima dan $\mathrm{H}_{\mathrm{a}}$ ditolak.

7. Respons Peserta didik

Respons peserta didik ini diisi oleh peserta didik mengenai tanggapan terhadap model pembelajaran SiMaYang Tipe II yang digunakan dalam pembelajaran. Hasil angket tersebut dianalisis dengan teknik deskriptif kuantitatif. Angket respons peserta didik ini berperingkat $1-7$, yaitu:

Sangat Setuju (SS)

Setuju (S)

$=$ nilai 7

Agak Setuju (AS)

= nilai 6

Netral (N)

$=$ nilai 5

Agak Tidak Setuju (ATS)

$=$ nilai 4

Tidak Setuju (TS)

= nilai 3

Sangat Tidak Setuju (STS)

= nilai 2

= nilai 1

Persentase $=\frac{\text { jumlah } \text { skor } \text { keseluruhan }}{\text { jumlah skor maksimal }} \times 100 \%$

Persentase yang dihasilkan dikonversi ke dalam bentuk indikator keberhasilan produk sebagai berikut. 
Tabel 3.7 Indikator Keberhasilan Produk

\begin{tabular}{ll}
\hline \multicolumn{1}{c}{ Rentang Nilai } & \multicolumn{1}{c}{ Kategori } \\
\hline $81 \%-100 \%$ & Sangat Baik \\
$61 \%-80 \%$ & Baik \\
$41 \%-60 \%$ & Cukup \\
$21 \%-40 \%$ & Kurang \\
$<21 \%$ & Sangat Kurang \\
\hline
\end{tabular}

(Sumber: Arikunto, 2010)

8. Analisis Efektivitas Pembelajaran

Pembelajaran dikatakan efektif apabila memenuhi indikator-indikator sebagai berikut: (Mardini, 2015)

a) Adanya peningkatan nilai dari nilai pretest ke posttest pada kelas eksperimen dengan kategori sedang atau tinggi.

b) Adanya perbedaan rata-rata nilai posttest antara kelas eksperimen dan kelas kontrol.

c) Adanya hasil respons peserta didik yang baik terhadap penggunaan model pembelajaran SiMaYang Tipe II di kelas eksperimen. 


\section{BAB IV}

\section{HASIL PENELITIAN DAN PEMBAHASAN}

\section{A. Hasil Penelitian}

Penelitian ini dilakukan untuk mengetahui efektivitas model pembelajaran SiMaYang Tipe II berbasis multipel representasi terhadap penguasaan konsep dan attitudes toward chemistry pada materi larutan penyangga. Desain penelitian ini adalah Quasi Experimental Design dengan bentuk Nonequivalent Control Group Design.

Populasi pada penelitian ini adalah seluruh peserta didik XI jurusan MIPA yang terdiri dari 249 peserta didik yang terdistribusi ke dalam 7 kelas sebagaimana terdapat dalam Tabel 3.1. Sampel yang digunakan pada penelitian ini adalah kelas XI MIPA 6 (sebagai kelas kontrol) dan XI MIPA 7 (sebagai kelas eksperimen). Pemilihan kelas kontrol dan kelas eksperimen ini menggunakan teknik cluster random sampling. Kelas kontrol dan kelas eksperimen diberikan pretest dan posttest yang sama, tetapi kelas eksperimen mendapatkan perlakuan berupa model pembelajaran SiMaYang Tipe II yang berbasis multipel representasi, sedangkan kelas kontrol menggunakan metode ceramah. 
Hasil penelitian yang diperoleh terdiri dari data populasi, data instrumen penilaian, data tahap awal dan data tahap akhir yang disajikan sebagai berikut.

\section{Analisis Data Populasi}

a. Uji Normalitas Populasi

Sebelum dilakukan pengambilan sampel menggunakan teknik cluster random sampling, populasi harus dipastikan berdistribusi normal. Pengujian normalitas populasi ini menggunakan rumus chi kuadrat $\left(\chi^{2}\right)$. Hasil perhitungan uji normalitas populasi dapat dilihat pada Lampiran 22. Berdasarkan Lampiran 22, diketahui bahwa semua kelompok sampel dalam populasi memiliki nilai $\chi_{\text {hitung }}^{2}<\chi_{\text {tabel, }}^{2}$ sehingga populasi dinyatakan berdistribusi normal.

b. Uji Homogenitas Populasi

Penentuan sampel tidak hanya sebatas menguji normalitas populasi saja, tetapi juga harus menguji homogenitas dari populasi itu sendiri. Berdasarkan perhitungan menggunakan rumus uji Bartlett yang disajikan dalam Lampiran 22, dengan taraf signifikansi yang digunakan sebesar 5\% diperoleh $\chi_{\text {hitung }}^{2}=8,015$ dan $\chi_{\text {tabel }}^{2}=12,592$. Hasil 
perhitungan menunjukkan bahwa $\chi_{\text {hitung }}^{2} \leq \chi_{\text {tabel }}^{2}$, sehingga populasi dalam penelitian ini homogen.

Dari uji normalitas dan homogenitas populasi terlihat bahwa semua kelas berdistribusi normal dan bervarian sama, sehingga semua data dalam populasi tersebut dapat dijadikan sebagai sampel. Oleh karena itu, pada penelitian ini teknik sampling yang digunakan adalah cluster random sampling dan sampel yang tepilih adalah XI MIPA 6 (sebagai kelas kontrol) dan XI MIPA 7 (sebagai kelas eksperimen).

\section{Analisis Data Instrumen Penelitian}

Penelitian ini menggunakan instrumen tes dan instrumen non tes. Instrumen tes digunakan untuk mengukur penguasaan konsep peserta didik sebelum dan sesudah menggunakan model pembelajaran SiMaYang Tipe II, sedangkan instrumen nontes digunakan untuk mengukur attitudes toward chemistry dan respon siswa terhadap model pembelajaran SiMaYang Tipe II.

a. Analisis Data Instrumen Tes

Instrumen tes yang digunakan dalam penelitian ini adalah soal berbentuk three-tier multiple choice dan soal uraian. Instrumen tes yang telah di periksa 
oleh dosen validator kemudian diujikan ke kelas uji coba. Uji coba dilaksanakan di kelas XII MIPA 4 SMAN 8 Semarang, dikarenakan kelas XII MIPA SMAN 9 Semarang sedang ada ujian praktek sehingga peneliti tidak bisa melakukan uji coba di tempat penelitian, SMAN 9 Semarang. Instrumen tes yang telah diujicobakan kemudian dilakukan uji validitas, reliabilitas, daya beda dan tingkat kesukaran yang dibahas berikut ini.

1) Uji validitas

Uji validitas digunakan untuk menentukan valid atau tidaknya butir soal yang akan digunakan untuk mengukur penguasaan konsep peserta didik. Butir soal yang dinyatakan valid dapat dipakai, sedangkan butir soal yang dinyatakan tidak valid tidak dapat dipakai atau dibuang.

Rumus yang digunakan untuk menguji validitas butir soal dengan bentuk three-tier multiple choice adalah korelasi point biserial. Berdasarkan hasil perhitungan yang disajikan pada Lampiran 14, dapat disimpulkan dalam Tabel 4.1 berikut ini. 
Tabel 4.1 Hasil Uji Validitas Butir Soal Three-Tier Multiple Choice

\begin{tabular}{clcc}
\hline Kriteria & \multicolumn{1}{c}{ Nomor Soal } & Jumlah & $\begin{array}{c}\text { Persentase } \\
\text { (\%) }\end{array}$ \\
\hline Valid & $\begin{array}{l}2,3,4,5,6,7,9, \\
11,13,14,16,\end{array}$ & 15 & 60 \\
& $\begin{array}{l}18,22,23,24 \\
\text { Tidak }\end{array}$ & & \\
Valid & $\begin{array}{l}1,8,10,12,15, \\
\text { 17, 19, 20,21, }\end{array}$ & 10 & 40 \\
& 25 & & \\
\hline & Jumlah & 25 & 100 \\
\hline
\end{tabular}

Pada butir soal dengan bentuk uraian, rumus untuk uji validitas yang digunakan adalah teknik korelasi pearson product moment. Berdasarkan hasil perhitungan pada Lampiran 17, dapat disimpulkan dalam Tabel 4.2 berikut ini.

Tabel 4.2 Hasil Uji Validitas Butir Soal Uraian

\begin{tabular}{clcc}
\hline Kriteria & \multicolumn{1}{c}{ Nomor Soal } & Jumlah & $\begin{array}{c}\text { Persentase } \\
\text { (\%) }\end{array}$ \\
\hline Valid & $\begin{array}{l}26,27,28,29, \\
\text { 33, 34 }\end{array}$ & 6 & 46,15 \\
Tidak & $\begin{array}{l}30,31,32,35, \\
\text { Valid }\end{array}$ & 7 & 53,85 \\
\hline \multicolumn{2}{l}{ Jumlah } & 15 & 100 \\
\hline
\end{tabular}

2) Uji reliabilitas soal

Uji reliabilitas digunakan untuk mengetahui keajegan suatu instrumen tes. Pada butir soal 
bentuk three-tier multiple choice, rumus uji reliabilitas yang digunakan adalah rumus Kuder dan Richardson 20 (KR-20). Hasil dari analisis data yang disajikan pada Lampiran 14 menunjukkan bahwa $r_{11}=0,722$. Interpretasi nilai $r_{11}$ pada penelitian ini mengacu pada indeks reliabilitas soal menurut Guilford (1956). Dari $r_{11}$ yang diperoleh, dapat disimpulkan bahwa $0,60<\mathrm{r}_{11}<0,70$ sehingga reliabilitas soal tergolong tinggi.

Pada butir soal berbentuk uraian, rumus uji reliabilitas yang digunakan adalah Cronbach Alpha. Berdasarkan hasil analisa pada Lampiran 16 nilai $r_{11}=0,602$, maka dapat disimpulkan bahwa relibilitas soal tergolong tinggi.

3) Uji tingkat kesukaran soal

Uji tingkat kesukaran soal digunakan untuk menentukan seberapa besar kesukaran suatu soal, apakah soal tersebut tergolong mudah, sedang atau sukar. Berdasarkan uji tingkat kesukaran pada soal berbentuk three-tier multiple choice yang disajikan pada Lampiran 15, dapat disimpulkan sebagai berikut. 
Tabel 4.3 Hasil Uji Tingkat Kesukaran Soal Threetier Multiple Choice

\begin{tabular}{|c|c|c|c|}
\hline $\begin{array}{c}\text { Tingkat } \\
\text { Kesukaran }\end{array}$ & Nomor Soal & Jumlah & $\begin{array}{c}\text { Persentase } \\
(\%)\end{array}$ \\
\hline Mudah & $\begin{array}{l}1,2,9,10,16, \\
20\end{array}$ & 6 & 24 \\
\hline Sedang & $\begin{array}{l}4,5,6,7,8 \\
11,13,15,21 \\
22,23,24,25\end{array}$ & 13 & 52 \\
\hline Sukar & $\begin{array}{l}3,12,14,17 \\
18,19,\end{array}$ & 6 & 24 \\
\hline \multicolumn{2}{|c|}{ Jumlah } & 25 & 100 \\
\hline
\end{tabular}

Tingkat kesukaran soal uraian yang disajikan pada Lampiran 15 dapat disimpulkan sebagai berikut.

Tabel 4.4 Hasil Uji Coba Tingkat Kesukaran Soal Uraian

\begin{tabular}{llcc}
\hline $\begin{array}{c}\text { Tingkat } \\
\text { Kesukaran }\end{array}$ & Nomor Soal & Jumlah & $\begin{array}{c}\text { Persentase } \\
\text { (\%) }\end{array}$ \\
\hline Mudah & 33 & 1 & 7,69 \\
Sedang & $27,28,32,34$ & 4 & 30,77 \\
Sukar & $26, \quad 29, \quad 30$, & 8 & 61,54 \\
& $\begin{array}{l}31, \quad 35, \quad 36, \\
\end{array}$ & & \\
\hline \multicolumn{2}{l}{ Jumlah 38 } & 13 & 100 \\
\hline
\end{tabular}

4) Uji daya beda soal

Uji daya beda soal berfungsi untuk menentukan seberapa besar kemampuan butir 
soal dalam membedakan peserta didik yang berkemampuan tinggi dengan peserta didik yang berkemampuan rendah. Hasil analisa uji daya beda soal bentuk three-tier multiple choice dapat dilihat pada tabel berikut ini.

Tabel 4.5 Hasil Uji Daya Beda Soal Three-tier Multiple Choice

\begin{tabular}{|c|c|c|c|}
\hline $\begin{array}{l}\text { Daya } \\
\text { Beda } \\
\end{array}$ & $\begin{array}{c}\text { Nomor } \\
\text { Soal }\end{array}$ & Jumlah & $\begin{array}{c}\text { Persentasi } \\
(\%)\end{array}$ \\
\hline $\begin{array}{l}\text { Baik } \\
\text { Sekali }\end{array}$ & - & 0 & 0 \\
\hline Baik & $\begin{array}{l}2,5,6,7, \\
9,13,14, \\
16,18,22, \\
23\end{array}$ & 11 & 44 \\
\hline Cukup & $\begin{array}{l}3,4,8,11, \\
19,24\end{array}$ & 6 & 24 \\
\hline Jelek & $\begin{array}{l}1,10,12, \\
15,17,20, \\
21,25\end{array}$ & 8 & 32 \\
\hline \multicolumn{2}{|c|}{ Jumlah } & 25 & 100 \\
\hline
\end{tabular}

Hasil analisa uji daya beda soal bentuk uraian yang disajikan di Lampiran 16 dapat disimpulkan sebagai berikut. 
Tabel 4.6 Hasil Uji Daya Beda Soal Uraian

\begin{tabular}{llcc}
\hline $\begin{array}{c}\text { Daya } \\
\text { Beda }\end{array}$ & \multicolumn{1}{c}{$\begin{array}{c}\text { Nomor } \\
\text { Soal }\end{array}$} & Jumlah & $\begin{array}{c}\text { Persentasi } \\
\text { (\%) }\end{array}$ \\
\hline Baik & - & 0 & 0 \\
Sekali & & 2 & 15,38 \\
Baik & 26,28 & 3 & 23,08 \\
Cukup & $27,33,34$ & & \\
Jelek & $\begin{array}{l}29,30,31, \\
\text { 32, 35, 36, }\end{array}$ & 8 & 61,54 \\
& 37,38 & & 100 \\
\hline
\end{tabular}

Berdasarkan analisa uji validitas, reliabilitas, tingkat kesukaran dan daya beda, maka butir soal dari instrumen tes ini hanya 20 butir soal yang dapat digunakan, dimana 15 butir soal diambil dari soal three-tier multiple choice dan 5 butir soal dari soal uraian.

b. Analisis Data Instrumen Non-tes

Instrumen nontes yang digunakan dalam penelitian ini adalah angket sikap terhadap kimia (attitudes toward chemistry) dan angket respon siswa terhadap model pembelajaran SiMaYang Tipe II. Angket sikap terhadap kimia (attitudes toward chemistry) dalam penelitian ini mengadopsi angket SATCL (Student Attitudes Toward Chemistry Lesson) yang dikembangkan oleh Cheung (2011), yang 
berjumlah 12 butir pertanyaan sebagaimana disajikan di Lampiran 21. Sedangkan angket respon siswa terhadap model pembelajaran SiMaYang Tipe II terdiri dari 20 pertanyaan yang terbagi menjadi pertanyaan positif dan pertanyaan negatif sebagaimana disajikan dalam Lampiran 20.

Kedua angket yang digunakan pada penelitian ini berbentuk skala Likert yang terdiri atas tujuh skala penilaian yaitu: Sangat Setuju (SS), Setuju (S), Agak Setuju (AS), Netral (N), Agak Tidak Setuju (ATS), Tidak Setuju (TS) , dan Sangat Tidak Setuju (STS).

\section{Analisis Data Tahap Awal}

a. Uji Normalitas Pretest

Uji normalitas pretest pada penelitian ini menggunakan langkah-langkah dan rumusyang sama seperti uji normalitas populasi, yaitu menggunakan chi kuadrat. Berdasarkan perhitungan pada Lampiran 24 dan Lampiran 25 diperoleh data sebagai berikut.

Tabel 4.7 Hasil Uji Normalitas Pretest Penguasaan Konsep

\begin{tabular}{llccc}
\hline No. & \multicolumn{1}{c}{ Kelas } & $\boldsymbol{\chi}_{\text {hitung }}^{2}$ & $\boldsymbol{\chi}_{\text {tabel }}^{2}$ & Kesimpulan \\
\hline 1. & Eksperimen & $-41,623$ & 11,071 & Normal \\
2. & Kontrol & $-69,944$ & 11,071 & Normal \\
\hline
\end{tabular}


Tabel 4.8 Hasil Uji Normalitas Pretest Attitudes toward Chemistry

\begin{tabular}{llccc}
\hline No. & \multicolumn{1}{c}{ Kelas } & $\boldsymbol{\chi}_{\text {hitung }}^{2}$ & $\boldsymbol{\chi}_{\text {tabel }}^{2}$ & Kesimpulan \\
\hline 1. & Eksperimen & $-64,234$ & 12,592 & Normal \\
2. & Kontrol & $-41,364$ & 12,592 & Normal \\
\hline
\end{tabular}

Berdasarkan tabel 4.7 dan 4.8, diperoleh data bahwa kelas eksperimen dan kelas kontrol memiliki $\chi_{\text {hitung }}^{2}<\chi_{\text {tabel }}^{2}$, sehingga dapat disimpulkan bahwa kelas eksperimen dan kelas kontrol keduanya berdistribusi normal.

b. Uji Homogenitas Pretest

Kelas kontrol dan kelas eksperimen sebelum diberi perlakuan, diuji homogenitasnya terlebih dahulu. Berdasarkan perhitungan menggunakan rumus uji Fisher yang disajikan dalam Lampiran 24 dan Lampiran 25, pada penguasaan konsep diperoleh data bahwa dengan taraf signifikansi 5\% dihasilkan $F_{\text {hitung }}=1,056$ dan $F_{\text {tabel }}=3,134$. Sedangkan pada attitudes toward chemistry diperoleh $\mathrm{F}_{\text {hitung }}=1,475$ dan $F_{\text {tabel }}=3,134$. Dari hasil uji homogenitas penguasaan konsep dan attitudes toward chemistry 
diperoleh bahwa $F_{\text {hitung }}<F_{\text {tabel, }}$, sehingga sampel dalam penelitian ini homogen.

c. Uji Kesamaan Dua Rata-Rata

Uji kesamaan dua rata-rata digunakan untuk mengetahui apakah kelas kontrol dan kelas eksperimen memiliki kesamaan rata-rata atau tidak. Berdasarkan perhitungan yang disajikan di Lampiran 24 dan Lampiran 25, pada penguasaan konsep diperoleh rata-rata kelas eksperimen $\mu_{1}=16,972$ dan rata-rata kelas kontrol $\mu_{2}=27,824$ dengan $n_{1}=36$ dan $\mathrm{n}_{2}=35$ diperoleh $\mathrm{t}_{\text {hitung }}=-4,831$. Taraf signifikansi yang digunakan adalah $5 \%$ dengan $\mathrm{dk}=68$, sehingga diperoleh $t_{\text {tabel }}=1,995$. Sedangkan pada attitudes toward chemistry diperoleh rata-rata kelas eksperimen $\mu_{1}=41,556$ dan rata-rata kelas kontrol $\mu_{2}=46,382$ dengan $\mathrm{n}_{1}=36$ dan $\mathrm{n}_{2}=35$, sehingga diperoleh $t_{\text {hitung }}=-2,061$. Taraf signifikansi yang digunakan adalah 5\% dengan $\mathrm{dk}=68$, sehingga diperoleh $t_{\text {tabel }}=1,995$.

Berdasarkan hasil perhitungan uji kesamaan dua rata-rata penguasaan konsep dan attitudes toward chemistry tersebut dapat diketahui bahwa $-t_{\text {tabel }} \leq t_{\text {hitung }} \leq t_{\text {tabel, }}$, sehingga $\mathrm{H}_{0}$ diterima dan $\mathrm{Ha}$ 
ditolak. Dari data tersebut dapat disimpulkan bahwa kelas kontrol dan kelas eksperimen tidak ada perbedaan rata-rata, atau dengan kata lain kedua sampel mempunyai kesamaan rata-rata.

\section{Analisis Data Tahap Akhir}

Analisis data tahap akhir digunakan untuk menganalisis penguasaan konsep dan attitudes toward chemistry peserta didik pada materi larutan penyangga. Analisis akhir yang digunakan meliputi uji hipotesis penguasaan konsep, uji hipotesis attitudes toward chemistry, uji N-Gain penguasaan konsep dan uji N-Gain attitudes toward chemistry.

a. Uji Hipotesis Penguasaan Konsep

Uji hipotesis penguasaan konsep peserta didik sangat bergantung dengan uji normalitas dan uji homogenitas. Apabila datanya normal dan homogen, maka dapat menggunakan statistik parametrik. Sedangkan apabila datanya tidak normal, tidak homogen, atau tidak normal dan tidak homogen, maka statistik yang digunakan adalah statistik nonparametrik. 
1) Uji Normalitas

Data yang digunakan untuk uji normalitas adalah data hasil tes pada posttest. Berdasarkan perhitungan menggunakan rumus Chi Kuadrat pada Lampiran 30, dapat disimpulkan sebagai berikut.

Tabel 4.9 Hasil Uji Normalitas Posttest Penguasaan Konsep

\begin{tabular}{llccc}
\hline No. & \multicolumn{1}{c}{ Kelas } & $\boldsymbol{\chi}_{\text {hitung }}^{2}$ & $\boldsymbol{\chi}_{\text {tabel }}^{2}$ & Kesimpulan \\
\hline 1. & Eksperimen & $-45,197$ & 12,592 & Normal \\
2. & Kontrol & 7,176 & 12,592 & Normal \\
\hline
\end{tabular}

Berdasarkan tabel 4.9 kelas eksperimen dan kelas kontrol memiliki $\chi_{\text {hitung }}^{2}<\chi_{\text {tabel, }}^{2}$ sehingga dapat disimpulkan bahwa kelas eksperimen dan kelas kontrol keduanya berdistribusi normal.

2) Uji Homogenitas

Kelas kontrol dan kelas eksperimen yang datanya sudah normal kemudian diuji homogenitasnya. Berdasarkan perhitungan menggunakan rumus uji Fisher yang disajikan dalam Lampiran 30, diperoleh data bahwa dengan taraf signifikansi 5\% dihasilkan $\mathrm{F}_{\text {hitung }}=1,070$ dan 
$\mathrm{F}_{\text {tabel }}=3,134$. Hasil perhitungan menunjukkan bahwa $F_{\text {hitung }}<F_{\text {tabel, }}$ sehingga sampel dalam penelitian ini homogen.

3) Uji Perbedaan Dua Rata-Rata

Berdasarkan uji perbedaan dua rata-rata diperoleh $t_{\text {hitung }}=2,481$, dengan taraf signifikansi $5 \%$ dan $\mathrm{dk}=68$ diperoleh $\mathrm{t}_{\text {tabel }}=1,995$. Karena $t_{\text {hitung }}>\mathrm{t}_{\text {tabel, }}$ sehingga $\mathrm{H}_{0}$ ditolak dan $\mathrm{H}_{a}$ diterima. Jadi, dapat disimpulkan bahwa terdapat perbedaan rata-rata penguasaan konsep peserta didik kelas XI MIPA yang diajar menggunakan model pembelajaran SiMaYang Tipe II dengan yang diajar menggunakan metode ceramah.

4) Uji Pihak Kanan

Berdasarkan uji pihak kanan diperoleh data bahwa $\mathrm{t}_{\text {hitung }}=2,481$, dengan taraf signifikansi $5 \%$ dan $\mathrm{dk}=68$, sehingga $\mathrm{t}_{\text {tabel }}=1,668$. Karena $\mathrm{t}_{\text {hitung }}>$

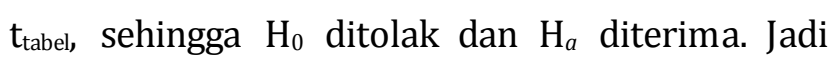
dapat disimpulkan bahwa rata-rata penguasaan konsep peserta didik kelas XI MIPA yang diajar dengan model pembelajaran SiMaYang Tipe II lebih besar dari pada rata-rata penguasaan konsep 
peserta didik kelas XI MIPA yang diajar dengan metode konvensional.

b. Uji Hipotesis Attitudes toward Chemistry

Data yang digunakan untuk uji hipotesis ini adalah angket Attitudes toward Chemistry saat posttest. Uji hipotesis attitudes toward chemistry ini langkahnya sama seperti uji hipotesis penguasaan konsep, dimana terlebih dahulu harus di diuji normalitas dan homogenitasnya, sebagaimana dibahas berikut ini.

1) Uji Normalitas

Perhitungan uji normalitas data angket attitudes toward chemistry pada posttest dapat dilihat di Lampiran 34. Berdasarkan perhitungan menggunakan rumus Chi Kuadrat, dapat disimpulkan sebagai berikut.

Tabel 4.10 Hasil Uji Normalitas Posttest Attitudes toward Chemistry

\begin{tabular}{llccc}
\hline No. & \multicolumn{1}{c}{ Kelas } & $\chi_{\text {hitung }}^{2}$ & $\chi_{\text {tabel }}^{2}$ & Kesimpulan \\
\hline 1. & Eksperimen & $-28,282$ & 11,071 & Normal \\
2. & Kontrol & $-38,895$ & 11,071 & Normal \\
\hline
\end{tabular}

Berdasarkan tabel 4.10 kelas eksperimen dan kelas kontrol memiliki $\chi_{\text {hitung }}^{2}<\chi_{\text {tabel }}^{2}$, 
sehingga dapat disimpulkan bahwa kelas eksperimen dan kelas kontrol keduanya berdistribusi normal.

2) Uji Homogenitas

Kelas kontrol dan kelas eksperimen yang datanya sudah normal kemudian dilakukan uji homogenitas. Berdasarkan perhitungan menggunakan rumus uji Fisher diperoleh data bahwa dengan taraf signifikansi 5\% dihasilkan $F_{\text {hitung }}=1,836$ dan $F_{\text {tabel }}=3,134$. Hasil perhitungan menunjukkan bahwa $F_{\text {hitung }}<F_{\text {tabel, sehingga }}$ sampel dalam penelitian ini homogen.

3) Uji Perbedaan Dua Rata-Rata

Berdasarkan uji perbedaan dua rata-rata yang disajikan di Lampiran 34, diperoleh thitung $=$ 0,327. Taraf signifikansi yang digunakan adalah $5 \%$, sehingga $t_{\text {tabel }}=1,995$. Karena $t_{\text {hitung }} \leq t_{\text {tabel}}$, sehingga $\mathrm{H}_{0}$ diterima dan $\mathrm{H}_{a}$ ditolak. Jadi, dapat disimpulkan bahwa tidak terdapat perbedaan rata-rata attitudes toward chemistry kelas XI MIPA yang diajar menggunakan model pembelajaran SiMaYang Tipe II dengan yang diajar menggunakan metode ceramah. 
4) Uji Pihak Kanan

Nilai penguasaan konsep diperoleh dari soal three-tier multiple choice dan uraian. Berdasarkan uji normalitas dan homogenitas dari nilai penguasaan konsep, dihasilkan bahwa sampel berdistribusi normal dan homogen. Oleh karena itu, pada pengujian hipotesis ini menggunakan statistik parametrik, yakni uji-t. Berdasarkan perhitungan menggunakan uji-t yang disajikan di Lampiran 34, diperoleh $t_{\text {hitung }}=0,327$. Taraf signifikansi yang digunakan adalah 5\%, sehingga $t_{\text {tabel }}=1,668$. Karena $t_{\text {hitung }} \leq t_{\text {tabel, }}$ sehingga $H_{0}$ diterima dan $\mathrm{H}_{a}$ ditolak. Jadi dapat disimpulkan bahwa rata-rata attitudes toward chemistry kelas XI MIPA yang diajar dengan model SiMaYang Tipe II lebih kecil atau sama dengan dari pada rata-rata attitudes toward chemistry kelas XI MIPA yang diajar dengan metode ceramah.

c. Uji N-Gain Penguasaan Konsep

Nilai pretest dan posttest data penguasaan konsep selanjutnya diuji N-Gain untuk menghitung peningkatan penguasaan konsep peserta didik. Nilai penguasaan konsep ini diperoleh dari soal three-tier 
multiple choice dan uraian. Berdasarkan perhitungan uji N-Gain penguasaan konsep peserta didik diperoleh data sebagai berikut.

Tabel 4.11 Hasil Uji N-Gain Penguasaan Konsep

\begin{tabular}{lcc}
\hline \multicolumn{1}{c}{ Sampel } & Nilai N-Gain & Kategori \\
\hline Kelas Kontrol & 0,409 & Sedang \\
Kelas Eksperimen & 0,617 & Sedang \\
\hline
\end{tabular}

d. Uji N-Gain Attitudes toward Chemistry

Peningkatan attitudes toward chemistry diukur berdasarkan jawaban angket attitudes toward chemistry pada saat pretest dan posttest dengan menggunakan uji N-Gain. Berdasarkan perhitungan uji N-Gain attitudes toward chemistry diperoleh data sebagai berikut.

Tabel 4.12 Hasil Uji N-Gain Attitudes toward Chemistry

\begin{tabular}{lcc}
\hline \multicolumn{1}{c}{ Sampel } & Nilai N-Gain & Kategori \\
\hline Kelas Kontrol & 0,195 & Rendah \\
Kelas Eksperimen & 0,326 & Sedang \\
\hline
\end{tabular}

\section{B. Pembahasan}

Penelitian ini menggunakan model pembelajaran SiMaYang Tipe II yang berbasis multipel representasi. Penggunaan model pembelajaran SiMaYang Tipe II ini dilatarbelakangi karena rendahnya penguasaan konsep 
peserta didik dalam memahami materi larutan penyangga. Hal ini sesuai dengan data pra riset yang peneliti peroleh bahwa hanya 35,55\% peserta didik yang memahami konsep dengan benar. Di sisi lain, peserta didik tidak pernah mengintegrasikan tiga level fenomena sains dalam proses pembelajaran kimia. Padahal, rendahnya penguasaan konsep tersebut dapat terjadi karena tidak terkoneksinya ketiga level fenomena sains, yang dapat menyebabkan terhambatnya pemahaman konsep-konsep sains, bahkan dapat menimbulkan terjadinya kesalahan konsep (Sunyono, 2015).

Faktor lain yang menyebabkan penguasaan konsep peserta didik rendah adalah karena attitudes toward chemistryyang rendah. Peserta didik yang attitudes toward chemistry-nya rendah, biasanya cenderung menganggap kimia itu sulit dan tidak menarik untuk dipelajari. Sikap tersebut menyebabkan ia malas dan tidak ikhlas dalam belajar, sehingga hasil belajarnya tidak memuaskan (Rosa, 2012). Oleh karena itu, penggunaan model pembelajaran SiMaYang Tipe II pada penelitian ini diharapkan dapat efektif meningkatkan attitudes toward chemistry dan penguasaan konsep peserta didik pada materi larutan penyangga. 
Pada penelitian ini kelas eksperimen diberikan perlakuan menggunakan model pembelajaran SiMaYang Tipe II yang berbasis multipel representasi, sedangkan kelas kontrol menggunakan metode pembelajaran ceramah. Sebelum perlakuan menggunakan model pembelajaran SiMaYang Tipe II pada kelas eksperimen dan perlakuan metode ceramah pada kelas kontrol diterapkan, peneliti terlebih dahulu memberikan pretest soal penguasaan konsep dan angket attitudes toward chemistry. Pemberian pretest tersebut bertujuan untuk mengetahui keadaan awal peserta didik sebelum diberi perlakuan. Berdasarkan analisis data tahap awal, yaitu uji normalitas, uji homogenitas dan uji kesamaan dua rata-rata pretest, diperoleh bahwa kelas kontrol dan kelas eksperimen berdistribusi normal dan memiliki varians yang homogen, serta tidak ada perbedaan rata-rata antara kelas kontrol dengan kelas eksperimen. Oleh karena itu, dapat disimpulkan bahwa kelas kontrol dan kelas eksperimen memiliki keadaan awal yang sama.

Pembelajaran menggunakan model pembelajaran SiMaYang Tipe II ini terdapat lima fase yang harus dilalui, yaitu: 
1. Orientasi

Pada tahap ini peneliti memberikan motivasi dan mengkondisikan peserta didik untuk mengikuti pembelajaran, serta menyampaikan tujuan pembelajaran yang akan berlangsung (Sunyono, 2015). Selain itu, peneliti juga memberikan beberapa pertanyaan mengenai larutan asam dan basa.

Pada tahap ini, peserta didik terlihat aktif menjawab pertanyaan yang diberikan, namun rata-rata jawaban peserta didik belum sesuai konsep. Contohnya, saat peneliti menanyakan pertanyaan berikut:

"Mengapa asam cuka termasuk larutan asam?"

Terdapat peserta didik yang menjawab bahwa asam cuka termasuk larutan asam karena rasanya masam. Peserta didik tersebut tidak dapat menjelaskan level submikroskopik yang menjelaskan bahwa sifat asam pada asam cuka itu adalah karena adanya ion $\mathrm{H}^{+}$.

Contoh lainnya adalah pada saat peneliti menanyakan apa perbedaan asam kuat dan asam lemah, tidak ada satupun peserta didik yang bisa menjawab pertanyaan tersebut. Hal ini menunjukkan bahwa kurangnya pemahaman konsep peserta didik pada level submikroskopik. 
2. Eksplorasi - Imajinasi

Pada tahap ini, peserta didik dalam kelompok berdiskusi dan belajar menginterkoneksikan tiga level fenomena sains (makroskopik, submikroskopik dan simbolik) yang dituangkan ke dalam LKS kelompok. Pada tahap ini, peserta didik terlihat aktif berdiskusi, bahkan beberapa peserta didik berani bertanya kepada peneliti apabila mengalami kesulitan dalam berdiskusi. Kegiatan diskusi ini sangat penting dilakukan karena diskusi dapat memberikan kesempatan pada peserta didik untuk menggunakan pengetahuan dan informasi yang diperolehnya dan membagikannya dengan teman kelompoknya (Ermi, 2015).

3. Internalisasi

Pada tahap internalisasi, peserta didik mempresentasikan hasil kerja kelompok dan memberikan tanggapan atau pertanyaan kepada yang presentasi. Selama penelitian pada tahap internalisasi ini, hanya beberapa orang saja yang berani bertanya dan memberikan tanggapan, tidak seperti pada saat diskusi berlangsung.

Oleh karena itu, setelah presentasi peserta didik diberikan LKS individu yang berfungsi untuk melihat 
sejauh mana peserta didik memahami materi yang sedang mereka pelajari. LKS ini juga dapat membantu peserta didik dalam mengembangkan konsep (Harnoko dan Prianto, 1997)

4. Evaluasi

Pada tahap ini, peserta didik belajar menyimpulkan materi yang telah dipelajari, namun tetap dengan adanya bimbingan dari guru.

Setelah perlakuan menggunakan model pembelajaran SiMaYang Tipe II selesai dilaksanakan, peneliti memberikan posttest. Posttest ini berfungsi untuk menguji penguasaan konsep dan attitudes toward chemistry setelah diberikan perlakuan. Selain itu, peneliti juga memberikan angket respon peserta didik terhadap model pembelajaran SiMaYang Tipe II kepada kelas eksperimen.

Hasil analisis data penguasaan konsep, attitudes toward chemistry dan respon peserta didik terhadap model pembelajaran SiMaYang Tipe II adalah sebagai berikut.

1. Penguasaan Konsep Peserta Didik

Pada penelitian ini, penguasaan konsep peserta didik diambil dari hasil tes yang terdiri dari soal threetier multiple choice dan soal uraian. Berdasarkan analisis dan pengkategorian soal three-tier multiple choice yang 
merujuk pada Şen dan Yilmaz (2017) diperoleh data sebagai berikut.

Tabel 4.13 Hasil Pretest dan Posttest Soal Three-tier Multiple Choice

\begin{tabular}{lcccc}
\hline \multirow{2}{*}{ Kategori } & \multicolumn{2}{c}{ Kelas Kontrol } & \multicolumn{2}{c}{ Kelas Eksperimen } \\
\cline { 2 - 5 } & $\begin{array}{c}\text { Pretest } \\
\text { (\%) }\end{array}$ & $\begin{array}{c}\text { Posttest } \\
\mathbf{( \% )}\end{array}$ & $\begin{array}{c}\text { Pretest } \\
\mathbf{( \% )}\end{array}$ & $\begin{array}{c}\text { Posttest } \\
\mathbf{( \% )}\end{array}$ \\
\hline Paham & 18,63 & 24,31 & 2,96 & 38,70 \\
Terkaan & 5,10 & 7,84 & 6,30 & 3,52 \\
Miskonsepsi & 45,10 & 45,88 & 27,41 & 43,33 \\
Kurang & 31,18 & 21,96 & 63,33 & 14,44 \\
Paham & & & & \\
\hline
\end{tabular}

Berdasarkan tabel 4.13, dapat kita ketahui bahwa persentase pemahaman konsep kelas kontrol sebelum diberikan perlakuan lebih tinggi dari pada persentase pemahaman kelas eksperimen. Setelah diberikan perlakuan berbeda, yakni kelas kontrol menggunakan metode pembelajaran ceramah dan kelas eksperimen menggunakan model pembelajaran SiMaYang Tipe II, persentase pemahaman konsep peserta didik pada kedua kelas tersebut meningkat. Pada kelas kontrol terjadi peningkatan persentase pemahaman konsep dari 18,63\% menjadi 24,31\%, sedangkan pada kelas eksperimen terjadi peningkatan persentase pemahaman konsep dari 2,96\% menjadi 38,7\%. 
Dari tabel 4.13 tersebut juga dapat kita ketahui bahwa walaupun terjadi kenaikan pemahaman konsep pada kelas eksperimen, tetapi di sisi lain pada kelas eksperimen juga terjadi peningkatan miskonsepsi yaitu dari 27,41\% menjadi 43,33\%, walaupun persentase miskonsepsi kelas eksperimen setelah diberi perlakuan lebih kecil daripada kelas kontrol. Adapun penyebab miskonsepsi ini adalah sebagai berikut.

a. Masih banyak peserta didik yang belum memahami materi asam basa dan kesetimbangan

Larutan penyangga adalah salah satu materi kimia yang bersifat abstrak dan kompleks, serta membutuhkan interkoneksi antara level makroskopik, submikroskopik dan simbolik untuk memahaminya. Sifat kompleks dari materi ini terletak pada hubungan materi yang dipelajari dengan materi sebelumnya (Maratusholihah et al., 2017). Materi sebelumnya yang menjadi prasyarat untuk mempelajari larutan penyangga adalah asam basa dan kesetimbangan. Oleh karena itu, peserta didik yang belum memahami materi asam basa dan kesetimbangan dapat menyebabkan miskonsepsi pada materi larutan penyangga. Hal ini sesuai dengan 
teori yang menyatakan bahwa penyebab miskonsepsi dapat berasal dari pengetahuan awal (prakonsepsi) peserta didik (Yuliati, 2017).

b. Alokasi waktu pembelajaran yang tergolong singkat

Peserta didik yang belum memahami materi prasyarat larutan penyangga, yaitu asam basa dan kesetimbangan, cenderung mengalami kesulitan dalam memahami materi larutan penyangga. Oleh karena itu, peserta didik membutuhkan waktu lebih banyak untuk memahami materi larutan penyangga.

Pada penelitian ini, alokasi waktu pembelajaran yang digunakan hanyalah tiga pertemuan, sementara masih banyak peserta didik yang belum memahami materi prasyarat larutan penyangga, sehingga alokasi waktu pembelajaran tersebut tergolong singkat. Hal ini sesuai dengan yang dikemukakan oleh (Nakhleh, 1992) bahwa alokasi waktu pembelajaran terbatas dapat menyebabkan peserta didik kurang menguasai materi dan melahirkan miskonsepsi.

Sedangkan dari soal uraian diperoleh persentase yang menjawab soal dengan benar adalah sebagai berikut. 
Tabel 4.14 Hasil Pretest dan Posttest Soal Uraian

\begin{tabular}{ccccc}
\hline & \multicolumn{2}{c}{ Kelas Kontrol } & \multicolumn{2}{c}{ Kelas Eksperimen } \\
\cline { 2 - 5 } No. Soal & $\begin{array}{c}\text { Pretest } \\
\text { (\%) }\end{array}$ & $\begin{array}{c}\text { Posttest } \\
\mathbf{( \% )}\end{array}$ & $\begin{array}{c}\text { Pretest } \\
\mathbf{( \% )}\end{array}$ & $\begin{array}{c}\text { Posttest } \\
\mathbf{( \% )}\end{array}$ \\
\hline 1 & 8,92 & 28,73 & 13,52 & 48,15 \\
2 & 0,59 & 46,24 & 0,22 & 55,78 \\
3 & 0,00 & 45,53 & 0,22 & 50,56 \\
4 & 6,62 & 50,00 & 0,00 & 68,33 \\
5 & 0,00 & 44,85 & 0,00 & 43,75 \\
\hline Rata-rata & 3,23 & 43,07 & 2,79 & 53,31 \\
\hline
\end{tabular}

Berdasarkan Tabel 4.14 diperoleh bahwa persentase kelas kontrol maupun kelas eksperimen mengalami kenaikan. Persentase rata-rata jawaban posttest pada soal uraian kelas eksperimen sebesar 53,31\% dan persentase jawaban kelas kontrol sebesar $43,07 \%$, sehingga persentase jawaban kelas eksperimen lebih besar dari pada kelas kontrol. Pada soal uraian ini terdapat 1 butir soal level submikroskopik dan 4 butir soal level simbolik. Pada soal simbolik, tidak ada perbedaan yang signifikan pada jawaban peserta didik kelas eksperimen dan kelas kontrol, semua peserta didik mengetahui rumus yang digunakan namun ada beberapa peserta didik salah mereaksikan larutan dan kurang teliti dalam perhitungan matematikanya. Akan tetapi pada soal level submikroskopik terdapat perbedaan 
jawaban yang cukup signifikan antara kelas eksperimen dan kelas kontrol. Pada soal level submikroskopik, peserta didik diminta untuk menjelaskan maksud gambar berikut.
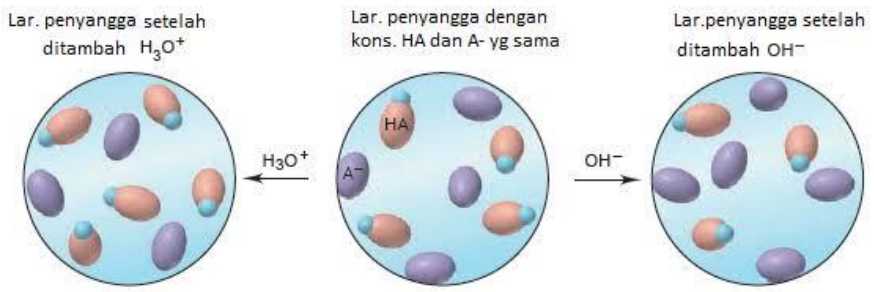

Gambar 4.1 Soal Level Submikroskopik pada Soal Uraian

Berikut ini adalah mayoritas jawaban kelas kontrol dan kelas eksperimen mengenai penjelasan Gambar 4.1 tersebut.

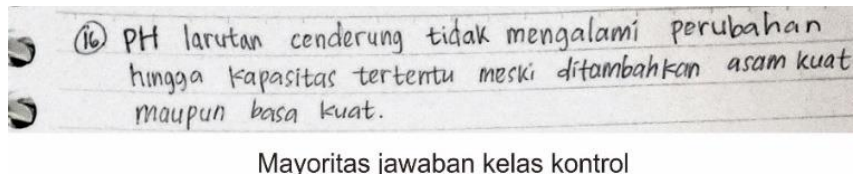

Mayoritas jawaban kelas kontrol

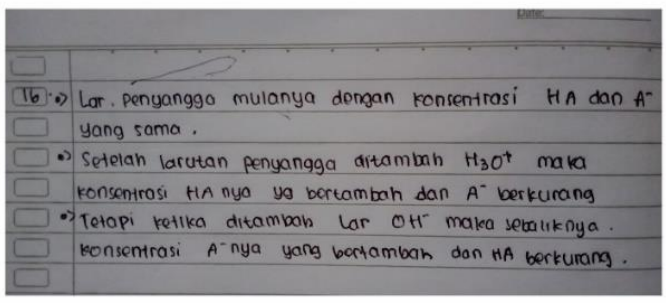

Mayoritas jawaban kelas eksperimen

Gambar 4.2 Mayoritas Jawaban Kelas Kontrol dan Kelas Eksperimen pada Soal No. 16 
Berdasarkan Gambar 4.2 dapat dilihat bahwa mayoritas kelas eksperimen bisa menjelaskan maksud Gambar 4.1 dengan baik dari pada kelas kontrol.

Pada penilaian ini, nilai penguasaan konsep peserta didik didapatkan dari gabungan nilai soal threetier multiple choice dan soal uraian. Berikut ini adalah rata-rata nilai penguasaan konsep sebelum dan sesudah diberikan perlakuan.

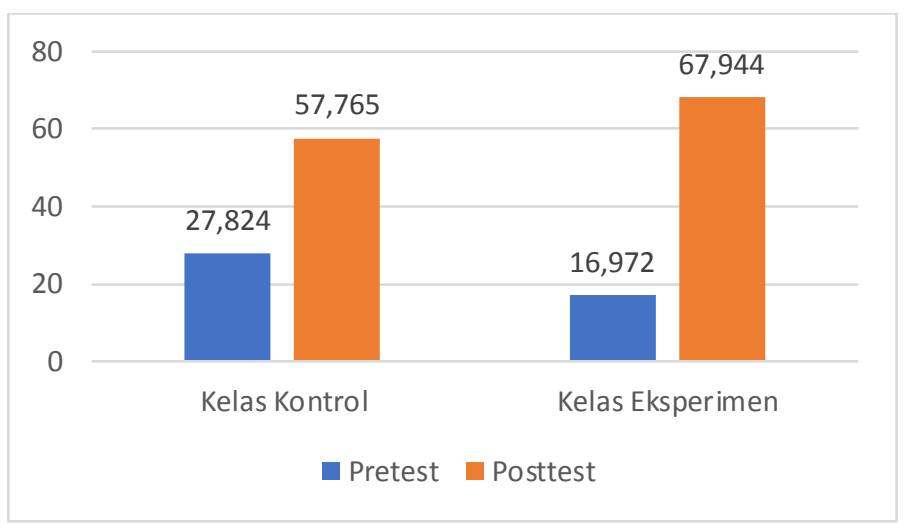

Gambar 4.3 Rata-Rata Nilai Penguasaan Konsep Peserta Didik pada Materi Larutan Penyangga Apabila dilihat dari per indikator pembelajaran, maka persentase penguasaan konsep setelah diberikan perlakuan adalah sebagai berikut. 


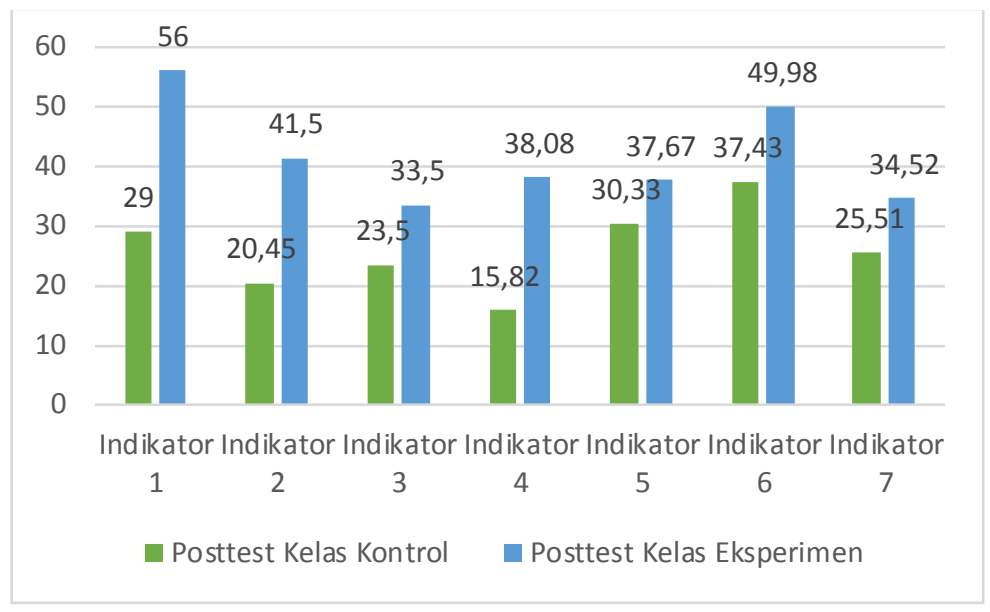

Gambar 4.4 Persentase Penguasaan Konsep per Indikator Saat Posttest

Penjelasan mengenai indikator 1 sampai dengan indikator 7 yang tercantum dalam Gambar 4.4 yaitu sebagai berikut.

1. Peserta didik dapat menjelaskan pengertian larutan penyangga;

2. Peserta didik dapat memahami komponen larutan penyangga;

3. Peserta didik dapat menghitung $\mathrm{pH}$ larutan penyangga;

4. Peserta didik dapat memahami pengaruh penambahan sedikit asam, sedikit basa dan pengenceran pada larutan penyangga; 
5. Peserta didik dapat menyebutkan kegunaan larutan penyangga dalam kehidupan sehari-hari;

6. Peserta didik dapat membuat larutan penyangga; dan

7. Peserta didik dapat menguji $\mathrm{pH}$ larutan penyangga sebelum dan sesudah penambahan sedikit asam, sedikit basa dan pengenceran.

Berdasarkan Gambar 4.3 dan Gambar 4.4 dapat dilihat bahwa penguasaan konsep kelas eksperimen lebih baik dari pada kelas kontrol. Berdasarkan uji NGain pada penguasaan konsep peserta didik diperoleh bahwa nilai N-Gain kelas kontrol sebesar 0,409 dengan kategori "sedang" dan nilai N-Gain kelas eksperimen sebesar 0,617 dengan kategori "sedang”. Oleh karena itu, dapat disimpulkan bahwa model pembelajaran SiMaYang Tipe II dapat meningkatkan penguasaan konsep peserta didik pada materi larutan penyangga dengan N-Gain kategori “sedang”. Hal ini sesuai dengan penelitian yang dilakukan Anwar dkk (2015) yang menyatakan bahwa model pembelajaran SiMaYang Tipe II mampu meningkatkan penguasaan konsep peserta didik dengan N-Gain kategori "sedang".

Pengujian hipotesis penguasaan konsep pada penelitian ini menggunakan uji-t. Berdasarkan uji 
perbedaan dua rata-rata (uji dua pihak) diperoleh bahwa $t_{\text {hitung }}=2,481$ dan $t_{\text {tabel }}=1,995$, sehingga $t_{\text {hitung }}>t_{\text {tabel }}$. Dengan demikian, $\mathrm{Ha}$ diterima yang artinya terdapat perbedaan rata-rata penguasaan konsep antara kelas eksperimen dan kelas kontrol. Sedangkan berdasarkan uji pihak kanan (uji satu pihak) diperoleh $t_{\text {hitung }}=2,481$ dan $t_{\text {tabel }}=1,668$. Dengan demikian $t_{\text {hitung }}>t_{\text {tabel, }}$ maka Ha diterima yang artinya rata-rata penguasaan konsep yang menggunakan model pembelajaran SiMaYang Tipe II lebih besar dari pada yang menggunakan metode ceramah. Oleh karena itu, hasil belajar pada ranah kognitif kelas eksperimen lebih tinggi dari kelas kontrol. Hal ini sesuai dengan penelitian yang dilakukan oleh Herawati (2013) yang mengemukakan bahwa hasil belajar pada ranah kognitif peserta didik yang menggunakan pembelajaran multipel representasi lebih tinggi daripada pembelajaran konvensional.

2. Attitudes toward Chemistry Peserta Didik

Angket attitudes toward chemistry digunakan untuk mengidentifikasi sikap peserta didik terhadap kimia. Angket ini diberikan kepada kelas kontrol dan kelas eksperimen sebelum dan sesudah perlakuan. 
Berdasarkan analisis pada Lampiran 31 dan Lampiran 32 diperoleh data sebagai berikut.

Tabel 4.15 Persentase Angket Attitudes toward Chemistry

\begin{tabular}{lcccc}
\hline \multirow{2}{*}{ Sampel } & \multicolumn{4}{c}{ Persentase Angket } \\
\cline { 2 - 5 } & $\begin{array}{c}\text { Pretest } \\
\text { (\%) }\end{array}$ & Kategori & $\begin{array}{c}\text { Posttest } \\
\text { (\%) }\end{array}$ & Kategori \\
\hline Kelas Kontrol & 55,22 & Cukup & 62,82 & Baik \\
Kelas & 49,47 & Cukup & 64,12 & Baik \\
Eksperimen & & & & \\
\hline
\end{tabular}

Berdasarkan Tabel 4.15 diperoleh bahwa persentase angket attitudes toward chemistry kelas kontrol dan kelas eksperimen dari pretest ke posttest mengalami peningkatan. Pada kelas kontrol mengalami peningkatan dari 55,22\% dengan kategori "cukup" menjadi 62,82\% dengan kategori "sedang”, sedangkan pada kelas eksperimen mengalami peningkatan dari 34,47\% dengan kategori "cukup" menjadi 64,12\% dengan kategori "sedang". Dari persentase tersebut dapat diketahui bahwa persentase attitudes toward chemistry kelas eksperimen sebelum diberi perlakuan lebih rendah dari kelas kontrol, namun setelah diberi perlakuan menggunakan model pembelajaran SiMaYang Tipe II persentasenya meningkat dan lebih tinggi dari kelas kontrol. 
Apabila dilihat berdasarkan indikator attitudes toward chemistry, maka diperoleh data sebagai berikut.

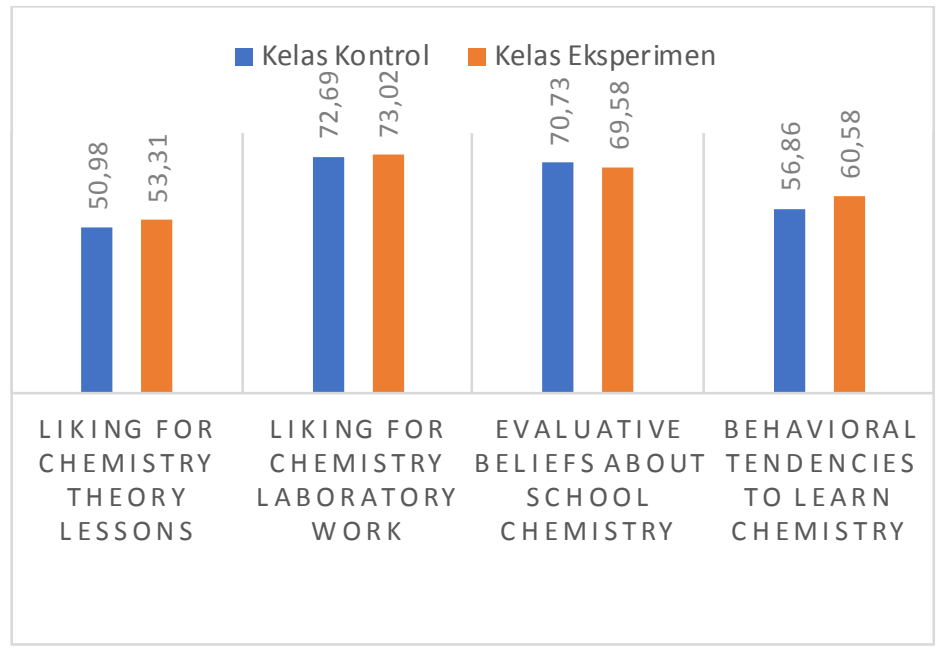

Gambar 4.5 Persentase Hasil Angket Attitudes toward Chemistry per Indikator Saat Posttest

Berdasarkan Gambar 4.5 dapat disimpulkan bahwa persentase kelas eksperimen lebih tinggi daripada kelas kontrol, kecuali pada indikator "evaluative beliefs about school chemistry". Pada indikator "evaluative beliefs about school chemistry" terdapat tiga butir pernyataan yaitu:

a. Kimia bermanfaat untuk menyelesaikan berbagai permasalahan sehari-hari;

b. Orang-orang harus memahami kimia karena kimia mempengaruhi kehidupan mereka; dan 
c. Kimia adalah salah satu mata pelajaran yang sangat penting untuk dipelajari.

Adapun penyebab persentase pada indikator "evaluative beliefs about school chemistry" kelas eksperimen lebih kecil dari kelas kontrol adalah karena keyakinan terhadap kimia kelas kontrol lebih tinggi dari pada kelas eksperimen. Keyakinan (beliefs) peserta didik terhadap kimia termasuk sesuatu yang sulit diubah, karena keyakinan tersebut terdapat pada diri peserta didik itu sendiri. Pengalaman atau pengetahuan sebelumnya memiliki efek signifikan terhadap keyakinan (Spiess dan Cooper, 2019). Jadi, walaupun terjadi peningkatan pada attitudes toward chemistry setelah menggunakan model pembelajaran SiMaYang Tipe II, namun untuk persentase indikator "evaluative beliefs about school chemistry" kelas eksperimen belum tentu lebih tinggi dari kelas kontrol, karena didalamnya terdapat faktor keyakinan masing-masing peserta didik.

Berdasarkan hasil uji N-Gain pada attitudes toward chemistry yang disajikan pada tabel 4.12, diperoleh bahwa nilai N-Gain kelas kontrol adalah sebesar 0,195 dengan kategori "rendah", sedangkan nilai N-Gain kelas eksperimen sebesar 0,323 dengan kategori "sedang". 
Oleh karena itu, dapat disimpulkan bahwa model pembelajaran SiMaYang Tipe II dapat meningkatkan attitudes toward chemistry pada materi larutan penyangga dengan $\mathrm{N}$-Gain kategori "sedang".

Pengujian hipotesis attitudes toward chemistry pada penelitian ini menggunakan uji-t. Berdasarkan uji perbedaan dua rata-rata diperoleh bahwa $t_{\text {hitung }}=0,327$ dan $t_{\text {tabel }}=1,995$. Dengan demikian $t_{\text {hitung }} \leq t_{\text {tabel }}$, maka $H_{0}$ diterima yang artinya tidak terdapat perbedaan ratarata antara attitudes toward chemistry kelas eksperimen dengan kelas kontrol. Sedangkan berdasarkan uji-t pada uji pihak kanan diperoleh $t_{\text {hitung }}=0,327$ dan $t_{\text {tabel }}=1,668$. Dengan demikian $t_{\text {hitung }} \leq \mathrm{t}_{\text {tabel, }}$, maka $\mathrm{H}_{0}$ diterima yang artinya rata-rata attitudes toward chemistry yang menggunakan model pembelajaran SiMaYang Tipe II lebih kecil atau sama dengan rata-rata attitudes toward chemistry yang menggunakan metode ceramah.

Adapun alasan tidak terdapat perbedaan rata-rata antara kelas eksperimen dengan kelas kontrol adalah karena rata-rata kelas eksperimen hampir sama dengan rata-rata kelas kontrol, dimana rata-rata kelas eksperimen adalah 52,765 dan rata-rata kelas kontrol adalah 53,861. Berdasarkan uji pihak kanan, diperoleh 
bahwa rata-rata kelas eksperimen lebih kecil atau sama dengan kelas kontrol. Hal ini diduga karena penggunaan model pembelajaran SiMaYang Tipe II tidak dapat meningkatkan attitudes toward chemistry secara signifikan. Peningkatan attitudes toward chemistry tersebut dapat dilihat berdasarkan nilai rata-rata saat pretest dan posttest, serta berdasarkan nilai N-Gain. Berdasarkan nilai rata-rata attitudes toward chemistry kelas eksperimen diperoleh bahwa rata-rata pretest adalah 41,556 dan rata-rata posttest 53,861, sehingga pada kelas eksperimen hanya mengalami kenaikan nilai sebesar 12,305, dimana kenaikan tersebut tergolong rendah. Selain itu, berdasarkan hasil uji N-Gain diperoleh data bahwa nilai N-Gain kelas eksperimen adalah 0,326 dengan kategori "sedang”. Nilai N-Gain kelas eksperimen tersebut mendekati kategori rendah, dimana nilai $\mathrm{N}-$ Gain termasuk kategori rendah apabila nilai $\mathrm{N}-$ Gain $<0,30$. Oleh karena itu, attitudes toward chemistry kelas eksperimen tidak mengalami peningkatan secara signifikan, sehingga nilai rata-rata kelas eksperimen hampir sama dengan kelas kontrol. 
3. Respon Peserta Didik terhadap Model Pembelajaran SiMaYang Tipe II

Angket respon peserta didik yang digunakan adalah angket respon peserta didik terhadap model pembelajaran SiMaYang Tipe II. Angket ini diisi oleh kelas eksperimen setelah selesai diberikan perlakuan menggunakan model pembelajaran SiMaYang Tipe II. Berdasarkan hasil analisis yang disajikan di Lampiran 35, dapat disimpulkan dalam tabel berikut.

Tabel 4.16 Persentase Angket Respon Peserta Didik

\begin{tabular}{cc}
\hline \%Angket & Kategori \\
\hline 64,11 & Baik \\
\hline
\end{tabular}

Tabel 4.16 di atas menunjukkan bahwa persentase angket respon peserta didik total adalah $64,11 \%$, sehingga angket ini termasuk kategori baik.

Suatu model pembelajaran dapat dikatakan efektif apabila memenuhi tiga kriteria, yaitu: (Mardini, 2015).

1. Adanya peningkatan nilai dari nilai pretest ke posttest pada kelas eksperimen dengan kategori sedang atau tinggi.

Pada penelitian ini diperoleh nilai N-Gain penguasaan konsep kelas eksperimen sebesar 0,617 dengan kategori "sedang", sedangkan nilai N-Gain 
attitudes toward chemistry kelas eksperimen sebesar 0,326 dengan kategori "sedang".

2. Adanya perbedaan rata-rata nilai posttest antara kelas eksperimen dan kelas kontrol

Pada penelitian ini rata-rata nilai posttest penguasaan konsep kelas kontrol adalah 57,765, sedangkan rata-rata nilai posttest penguasaan konsep kelas eksperimen adalah 67,944. Berdasarkan kesimpulan dari uji perbedaan rata-rata diperoleh bahwa terdapat perbedaan rata-rata penguasaan konsep antara kelas eksperimen dan kelas kontrol. Sedangkan berdasarkan uji pihak kanan, diperoleh bahwa rata-rata penguasaan konsep kelas eksperimen lebih besar daripada kelas kontrol. Sehingga dapat disimpulkan bahwa terdapat perbedaan rata-rata nilai posttest antara kelas eksperimen dan kelas kontrol.

Di sisi lain, nilai posttest attitudes toward chemistry kelas kontrol adalah 52,765, sedangkan rata-rata nilai posttest attitudes toward chemistry kelas eksperimen adalah 53,861. Berdasarkan kesimpulan dari uji perbedaan dua rata-rata diperoleh bahwa tidak terdapat perbedaan rata-rata attitudes toward chemistry antara kelas eksperimen dan kelas kontrol. Sedangkan 
berdasarkan uji pihak kanan, diperoleh bahwa rata-rata attitudes toward chemistry kelas eksperimen lebih kecil atau sama dengan kelas kontrol. Sehingga dapat disimpulkan bahwa tidak terdapat perbedaan rata-rata nilai posttest antara kelas eksperimen dan kelas kontrol.

3. Adanya hasil respon peserta didik yang baik terhadap penggunaan model pembelajaran SiMaYang Tipe II

Berdasarkan Tabel 4.16 diperoleh bahwa persentase angket respon peserta didik terhadap model pembelajaran SiMaYang Tipe II adalah sebesar 64,11\% dengan kategori "baik".

Dari hasil uji hipotesis dan tiga kriteria pembelajaran efektif tersebut, dapat disimpulkan bahwa model pembelajaran SiMaYang Tipe II berbasis multipel representasi efektif terhadap penguasaan konsep pada materi larutan penyangga. Namun, model pembelajaran SiMaYang Tipe II berbasis multipel representasi ini tidak efektif terhadap attitudes toward chemistry, karena ratarata attitudes toward chemistry kelas eksperimen hampir sama dengan kelas kontrol. 


\section{BAB V}

PENUTUP

\section{A. Kesimpulan}

Dari penelitian yang telah dilaksanakan, dapat disimpulkan sebagai berikut.

1. Model pembelajaran SiMaYang Tipe II berbasis multipel representasi efektif terhadap penguasaan konsep peserta didik pada materi larutan penyangga. Hal ini berdasarkan uji hipotesis menggunakan uji pihak kanan, dimana diperoleh $t_{\text {hitung }}=2,481$ dan $t_{\text {tabel }}=1,668$, sehingga $t_{\text {hitung }}>t_{\text {tabel }}$ yang artinya rata-rata penguasaan konsep kelas eksperimen lebih besar dari kelas kontrol. Dengan demikian, penguasaan konsep kelas eksperimen lebih baik daripada penguasaan konsep kelas kontrol.

2. Model pembelajaran SiMaYang Tipe II berbasis multipel representasi tidak efektif terhadap attitudes toward chemistry pada materi larutan penyangga. Hal ini berdasarkan uji hipotesis menggunakan uji pihak kanan, dimana $t_{\text {hitung }}=0,327$ dan $t_{\text {tabel }}=1,668$, sehingga $t_{\text {hitung }} \leq$ $t_{\text {tabel, }}$ artinya rata-rata attitudes toward chemistry kelas eksperimen lebih kecil atau sama dengan kelas kontrol.

3. Respon peserta didik terhadap model pembelajaran SiMaYang Tipe II berbasis multipel representasi 
tergolong baik. Hal ini berdasarkan persentase angket respon peserta didik terhadap model pembelajaran SiMaYang Tipe II sebesar 64,11\% dengan kategori "baik".

\section{B. Saran}

Berdasarkan proses dan hasil peneitian, saran yang dapat peneliti sampaikan adalah sebagai berikut.

1. Bagi peneliti, disarankan melakukan penelitian lebih lanjut untuk mengetahui efektivitas model pembelajaran SiMaYang Tipe II pada materi lain.

2. Bagi guru yang akan menggunakan model pembelajaran SiMaYang Tipe II, disarankan mempersiapkan sebaik mungkin media pembelajaran multipel representasi yang digunakan untuk membantu proses KBM.

3. Peserta didik yang belum pernah mengintegrasikan tiga level representasi dalam kimia akan membutuhkan waktu belajar yang cukup lama. Sehingga guru harus senantiasa membimbing peserta didik dalam proses pembelajaran multipel representasi. 


\section{DAFT AR PUSTAKA}

Ainsworth, Shaaron. 2008. The Educational Value of Multiple-

Representations When Learning Complex Scientific Concepts. In (Gilbert, J.K, Reiner M and Nakhlek M. Eds).

Visualization: Theory and Practice in Science Education. U.K: Springer.

Alighiri, Dante, Apriliana Drastisianti, dan Endang Susilaningsih. 2018. Pemahaman Konsep Siswa Materi Larutan Penyangga dalam Pembelajaran Multiple Representasi. Jurnal Inovasi Pendidikan Kimia. 12(2): 2192-2200.

Ambarwati, Rizka Juniar. 2018. Analisis Kesulitan Belajar Siswa SMA pada Materi Larutan Penyangga Menggunakan Three-tier Multiple Choice Diagnostic Instrument. Skripsi. Jakarta: UIN Syarif Hidayatullah.

Anderson, L. W. dan D. R. Krathwohl. 2010. Kerangka Landasan untuk Pembelajaran, Pengajaran dan Asesmen (Revisi Taksonomi Bloom). Terjemahan Agung Prihantoro. Yogyakarta: Pustaka Pelajar.

Anwar, Herson. 2009. Penilaian Sikap Ilmiah dalam Pembelajaran Sains. Jurnal Pelangi Ilmu. 2(5): 103-114.

Anwar, K., Sunyono, dan N. Kadaritna. 2015. Pembelajaran Model SiMaYang Tipe II untuk Meningkatkan Model Mental dan Penguasaan Konsep. Jurnal Pendidikan Kimia. 4(3): $795-806$.

Arends, R. I. 2007. Learning to Teach. Terjemahan H. P. Soetjipto dan S. M. Soetjipto. Yogyakarta: Pustaka Pelajar. Arikunto, Suharsimi. 2010. Dasar-Dasar Evaluasi Pendidikan. Jakarta: PT. Rineka Cipta.

Arikunto dan Supardi. 2007. Penelitian Tindakan Kelas. Jakarta: PT. Bumi Angkasa. 
Çam, Aylin dan Ömer Geban. 2016. Effectiveness of Case-Based Learning Instruction on Pre-Service Teachers' Chemistry Motivation and Attitudes toward Chemistry. Research in Science \& Technological Education: 1-14.

Chang, Raymond. 2004. Kimia Dasar. Edisi Ketiga. Terjemahan Muhammad Abdul Kadir, dkk. Jakarta: Erlangga.

Cheung, Derek. 2009. Developing a Scale to Measure Students' Attitudes toward Chemistry Lessons. International Journal of Science Education. 31(16): 2185-2203.

Cheung, Derek. 2011. Evaluating Student Attitudes toward Chemistry Lessons to Enhance Teaching in the Secondary School. 2011 International Year of Chemistry (Attitude toward Chemistry). 22(2): 117-122.

Dahar, R. W. 2003. Teori-teori Belajar dan Pembelajaran. Jakarta: Erlangga.

Darajat. 1988. Proses Belajar Mengajar. Bandung: Remaja Karya.

Echols, John M dan Hassan Shadily. 1975. Kamus InggrisIndonesia. Jakarta: PT. Gramedia Pustaka Utama.

Ermi, Netti. 2015. Penggunaan Metode Diskusi untuk Meningkatkan Hasil Belajar Materi Perubahan Sosial pada Siswa Kelas XII SMA Negeri 4 Pekanbaru. Jurnal SOROT. 10(2): 155 - 168.

Fauziah, Nenden. 2009. Kimia 2: SMA dan MA Kelas XI IPA. Jakarta: Pusat Perbukuan, Departemen Pendidikan Nasional.

Fitri, Amalia. 2016. Meningkatkan Hasil Belajar Siswa Menggunakan Model Pembelajaran SiMaYang Materi Kelarutan dan Hasil Kali Kelarutan. Jurnal Inovasi Pendidikan Sains. 7(2): 109-120.

Fitria, Analisa. 2014. Miskonsepsi Mahasiswa dalam Menentukan Grup pada Struktur Aljabar Menggunakan Certainty of Response Index (CRI) di Jurusan Pendidikan 
Matematika IAIN Antasari. JPM IAIN Antasari.1(2): 4560.

Furchan, Arief. 2007. Pengantar Penelitian dalam Pendidikan. Yogyakarta: Pustaka Pelajar.

Godino, Juan D, Carmen Batanero, dan Vicenc, Font. 2007. The Onto-Semiotic Approach to Research in Mathematics Education. ZDM Mathematics Education. 39(1-2): 127135.

Guilford, J. P. 1956. Fundamental Statistics in Psychology and Education. New York: McGraw-Hill Book Co. Inc.

Hake, R. R. 1999. Analyzing Change/Gain Scores. USA: Dept. of Physics Indiana University.

Hasanah, Siti, Sunyono, dan Tasviri Efkar. 2015. Penerapan Pembelajaran SiMaYang Tipe II pada Materi Asam. Jurnal Pendidikan dan Pembelajaran Kimia.4(1): 157-171.

Herawati, R. F., S. Mulyani, dan T. Redjeki. 2013. Pembelajaran Kimia Berbasis Multiple Representasi Ditinjau dari Kemampuan Awal terhadap Prestasi Belajar Laju Reaksi Siswa SMA Negeri 1 Karanganyar Tahun Pelajaran 2011/2012. Jurnal Pendidikan Kimia (JPK). 2(2): 38 - 43.

Heuvelen, Alan Van dan Xueli Zou. 2001. Multiple Representations of Work - Energy Processes. American Journal of Physics. 184(69): 184-194.

Hidayat. 1986. Definisi Efektivitas. Bandung: Angkasa.

Husman, Husaini. 2011. Manajemen Teori Praktik dan Riset Pendidikan. Jakarta: PT. Bumi Aksara.

Ischak, Warji. 1987. Program Remidial dalam Proses Belajar Mengajar. Yogyakarta: Liberty.

Jakni. 2016. Metodologi Penelitian Eksperimen Bidang Pendidikan. Bandung: CV. Alfabeta. 
Johnstone, A.H. 1993. The Development of Chemistry Teaching: A Charging Response to Changing Demand. Journal of Chemical.70(9): 701-705.

Kalsum, Siti, dkk. 2009. Kimia 2: SMA dan MA Kelas XI. Jakarta: Pusat Perbukuan, Departemen Pendidikan Nasional.

Kemdikbud. 2019. Capaian Nilai Ujian Nasional. Diunduh di https://puspendik.kemdikbud.go.id/hasil-un/ tanggal 3 Juli 2019.

Kobala, Thomas R. dan Frank E. Crawley. 1985. The Influence of Attitude on Science Teaching and Learning. School Science and Mathematics. 85(3): 222-232.

Kousa, P., R. Kavonius, dan M. Aksela. 2018. Low-achieving Students' Attitudes Towards Learning Chemistry and Chemistry Teaching Methods. Chemistry Education Research and Practice. 19(431): 431-441.

Maratusholihah, Noor Fathi, Sri Rahayu, dan Fauziatul Fajaroh. 2017. Analisis Miskonsepsi Siswa SMA pada Materi Hidrolisis Garam dan Larutan Penyangga. Jurnal Pendidikan: Teori, Penelitian, dan Pengembangan. 2(2): 919-926.

Mardini, Riana Lissay. 2015. Efektivitas Penggunaan Modul IPA Berbasis Joyful Learning pada Tema Pencemaran Lingkungan terhadap Pemahaman Konsep dan Kemandirian Siswa SMP. Skripsi. Semarang: Universitas Negeri Semarang.

Meltzer, David E. 2005. Relation Between Students' ProblemSolving Performance and Representational Format. American Journal of Physics. 463(73): 463-478.

Mentari, Luh, I Nyoman Suardana, dan I Wayan Subagia. 2014. Analisis Miskonsepsi Siswa SMA pada Pembelajaran Kimia untuk Materi Larutan Penyangga. E-Journal Kimia Visvitalis. 2(1): 76-78. 
Nakhleh, Mary B. 1992. Why Some Students Don't Learn Chemistry: Chemical Misconceptions. Journal of Chemical Education. 69(3): 191-196.

Pradina, Resti Ari. 2010. Penguasaan Konsep Sistem Reproduksi dengan Pembelajaran Aktif Menggunakan Kartu Sortir. Skripsi. Bandung: Universitas Pendidikan Indonesia.

Purba, Michael dan Eti Sarwiyati. 2017. Kimia. Jakarta: Erlangga.

Rachman, Khosida A., Sri Handono B. P., dan Albertus Djoko L. 2018. Analisis Penguasaan Konsep Teori Kinetik Gas Menggunakan Taksonomi Solo pada Siswa SMAN 1 Jember. Seminar Nasional Pendidikan Fisika 2018: "Implementasi Pendidikan Karakter dan IPTEK untuk Generasi Milenial Indonesia dalam Menuju SDGs 2030." Jember 11 Maret 2018.

Rosa, Novrita Mulya. 2012. Pengaruh Sikap pada Mata Pelajaran Kimia dan Konsep Diri terhadap Prestasi Belajar Kimia. Jurnal Formatif. 2(22): 218-226.

Ross, P., D. Tronson, dan J. R. Raymond. 2006. Modelling Photosynthesis to Increase Conceptual Understanding. Journal of Biological Education. 40(2): 84-88.

Saddam, D., Sudarmin, dan K. Siadi. 2013. Penggunaan Peta Konsep dan Diagram Vee untuk Meningkatkan Attitude toward Chemistry. Chemistry in Education. 2(2): 172177.

Sagala, Syaiful. 2003. Konsep dan Makna Pembelajaran. Bandung: Alfabeta.

Salta, Katerina dan Chryssa Tzougraki. 2004. Among 11th Grade Students in High Schools in Greece. Sci Ed. (88): 535-547.

Sam'un. 2018. Pengaruh Model Pembelajaran terhadap Penguasaan Konsep Kimia dan Sikap Ilmiah Siswa. Jurnal Pendidikan MIPA. 1(1): 101 - 111. 
Sanjaya, Wina. 2013. Penelitian Pendidikan: Jenis, Metode dan Prosedur. Bandung: Prenada Media Group.

Santi, Verlia, Ila Rosilawati, dan Sunyono. 2018. Pengaruh Scaffolding dalam Pembelajaran SiMaYang untuk Meningkatkan Efikasi Diri dan Penguasaan Konsep. Jurnal Pendidikan dan Pembelajaran Kimia. 7(1): 38-49.

Şen, Şenol dan Ayhan Yilmaz. 2017. The Development of a Three-Tier Chemical Bonding Concept Test. Journal of Turkish Science Education. 14(1): 110-126.

Sen, Senol dan Ozge Ozyalcin Oskay. 2017. The Effects of 5E Inquiry Learning Activities on Achievement and Attitude toward Chemistry. Journal of Education and Learning. 6(1): 1-9.

Setyosari, Punaji. 2014. Menciptakan Pembelajaran yang Efektif dan Berkualitas. Inovasi dan Teknologi Pembelajaran. 1(1): 20-30.

Shoimin, Aris. 2014. 68 Model Pembelajaran Inovatif dalam Kurikulum 2013. Yogyakarta: Ar-Ruzz Media.

Sihaloho, Mangara. 2013. Analisis Kesalahan Siswa dalam Memahami Konsep Larutan Buffer pada Tingkat Makroskopis dan Mikroskopis. Jurnal Entropi.8(1).

Silberberg, M. 2007. Principles of General Chemistry. First Edition. New York: The McGraw-Hill Companies.

Spiess, Joseph F. dan Robyn Cooper. 2019. Examining the Relationship Between Beliefs About Mind-Set, Beliefs About Knowledge, and Cultural Proficiency Development for K-12 Public School Teachers. Education and Urban Society. 00(0): 1-27.

Sudarmo, Unggul. 2013. Kimia untuk SMA/MA Kelas XI. Jakarta: Erlangga.

Sudijono, Anas. 2015. Pengantar Evaluasi Pendidikan. Jakarta: Rajawali Pers. 
Sudjana. 2005. Metode Statistika. Bandung: Tarsito Bandung. Sudjana, Nana. 1990. Penilaian Hasil Proses Belajar Mengajar. Bandung: PT. Remaja Rosdakarya.

Sugiyono. 2016. Metode Penelitian Pendidikan. Bandung: Alfabeta.

Sugiyono. 2016. Statistika untuk Penelitian. Bandung: Alfabeta.

Sunarya, Y. 2007. Kimia Umum. Bandung: Grafindo.

Sunyono. 2015. Model Pembelajaran Multipel Representasi. Yogyakarta: Media Akademi.

Sunyono dan Yulianti. 2014. Pengembangan Model

Pembelajaran Kimia SMA Berbasis Multipel Representasi dalam Menumbuhkan Model Mental dan Meningkatkan Penguasaan Konsep Siswa Kelas X. Laporan Penelitian Hibah Bersaing (Dikti) Tahun I. Lampung: Universitas Negeri Lampung.

Susiloningsih, Endang dkk. 2017. Asam Basa Titrasi Asam Basa. Semarang.

Widodo, Heri. 2015. Potret Pendidikan di Indonesia dan Kesiapannya dalam Menghadapi Masyarakat Ekonomi Asia (MEA).Cendekia.13(2): 293-307.

Yunus, Farhana Wan dan Zainun Mat Ali. 2012. Urban Students' Attitude towards Learning Chemistry. Procedia - Social and Behavioral Sciences. 68: 295-304.

Yuliati, Yuyu. 2017. Miskonsepsi Siswa pada Pembelajaran IPA serta Remediasinya. Jurnal Bio Education. 2(2): 50-58.

Yusuf, Bistari Basuni. 2018. Konsep dan Indikator Pembelajaran Efektif. Jurnal Kajian Pembelajaran dan Keilmuan. 1(2): 13-20. 


\title{
Lampiran 1. Surat Penunjukkan Dosen Pembimbing
}

\author{
KEMENTERIAN AGAMA REPUBLIK INDONESIA \\ UNIVERSITAS ISLAM NEGERI WALISONGO \\ FAKULTAS SAINS DAN TEKNOLOGI
}

Jl. Prof. Dr. Hamka Km. 02 Ngaliyan (024) 76466633 Semarang 50185

\footnotetext{
Nomor : B-3848/Un.10.8/J7/PP.009/10/2019

Semarang, 3 Oktober 2019

Lamp :-

Hal : Penunjukan Pembimbing Skripsi

Kepada Yth:

1. Anita Fibonacci, M.Pd

2. Nur Alawiyah, M.Pd

di Tempat

Assalamu'alaikum Wr.Wb.

Diberitahukan dengan hormat, bahwa mahasiswa tersebut di bawah ini:

Nama : Dini Lestari

NIM : : 1608076052

Telah diizinkan untuk memulai menyusun rencana/ proposal skripsi dengan judul:

"Efektivitas Model Pembelajaran Simayang Tipe II Berbasis Multipel Representasi

Terhadap Penguasaan Konsep dan Attitudes Toward Chemistry pada Materi Larutan

Penyangga"

Sehubungan dengan hal tersebut, Ketua Jurusan Pendidikan Kimia menunjuk Saudara

1. Anita Fibonacci, M.Pd sebagai dosen pembimbing 1

2. Nur Alawiyah, M.Pd sebagai dosen pembimbing 2

Demikian atas perkenan dan perhatiannya, kami sampaikan terima kasih.

Wassalamu'alaikum Wr.Wb.
}

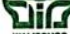

mussonos

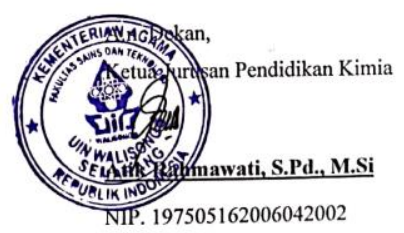

Tembusan:

1. Mahasiswa yang bersangkutan

2. Arsip 


\title{
Lampiran 2. Surat Izin Observasi Pra Riset
}

\author{
KEMENTERIAN AGAMA REPUBLIK INDONESIA \\ UNIVERSTTAS ISLAM NEGERI WALISONGO SEMARANG \\ FAKULTAS SAINS DAN TEKNOLOGI
}

Alamat: Jl.Prof. Dr. Hamka Km. 1 Semarang Telp. 02476433366 Semarang 50185

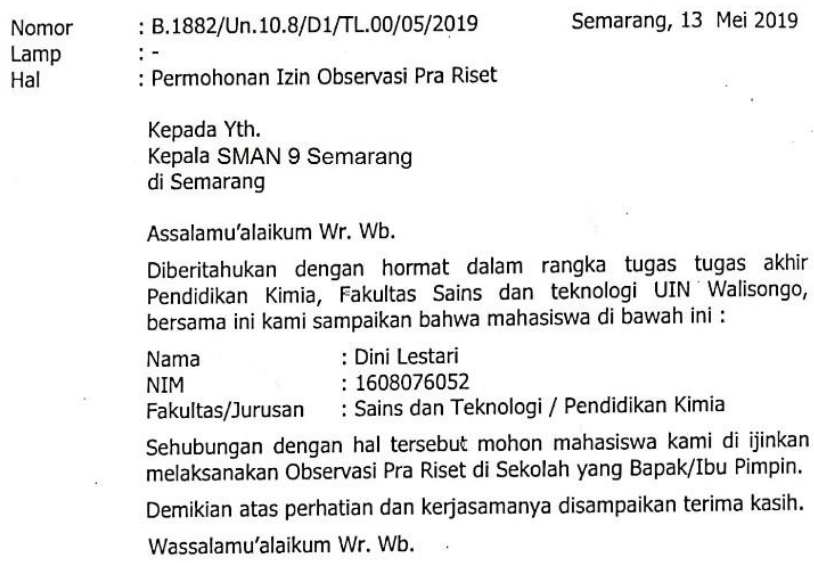

Diberitahukan dengan hormat dalam rangka tugas tugas akhir Pendidikan Kimia, Fakultas Sains dan teknologi UIN Walisongo, bersama ini kami sampaikan bahwa mahasiswa di bawah ini :

Sehubungan dengan hal tersebut mohon mahasiswa kami di ijinkan melaksanakan Observasi Pra Riset di Sekolah yang Bapak/Ibu Pimpin. Demikian atas perhatian dan kerjasamanya disampaikan terima kasih. Wassalamu'alaikum Wr. Wb.

Tembusan Yth.

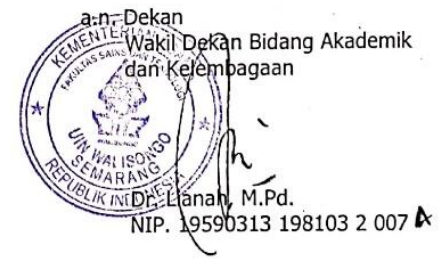

1. Dekan Fakultas Sains dan Teknologi UIN Walisongo ( sebagai laporan ) 
Lampiran 3. Hasil Wawancara dengan Guru Kimia

Nama Responden

: Dra. VDR Andri Wulandari, M.Ed

Sekolah Tempat Mengajar : SMAN 9 Semarang

\begin{tabular}{|c|c|c|}
\hline No. & Pertanyaan & Jawaban \\
\hline 1. & $\begin{array}{l}\text { Apakah fasilitas di sekolah } \\
\text { sudah memadai dalam } \\
\text { mendukung pembelajaran } \\
\text { kimia di sini? }\end{array}$ & $\begin{array}{l}\text { Ya, fasilitas di sini sudah } \\
\text { lengkap. }\end{array}$ \\
\hline 2. & $\begin{array}{l}\text { Apa hambatan yang Ibu } \\
\text { temui dalam proses } \\
\text { pembelajaran kimia? }\end{array}$ & $\begin{array}{l}\text { Hambatan yang saya temui } \\
\text { ada beberapa diantaranya: } \\
\text { 1. Ada hari libur yang } \\
\text { 2. Ada kegiatan-kegiatan di } \\
\text { sekolah } \\
\text { 3. Ada beberapa peserta } \\
\text { didik yang tidak fokus } \\
\text { dalam KBM kimia. }\end{array}$ \\
\hline 3. & $\begin{array}{l}\text { Berdasarkan pengamatan } \\
\text { Ibu, bagaimana minat } \\
\text { peserta didik terhadap } \\
\text { pembelajaran kimia? }\end{array}$ & $\begin{array}{l}\text { Karena kimia itu adalah mata } \\
\text { pelajaran peminatan di } \\
\text { jurusan IPA, sehingga } \\
\text { mayoritas peserta didik minat } \\
\text { belajar kimia. Namun masih } \\
\text { terdapat beberapa peserta } \\
\text { didik yang kurang fokus, } \\
\text { sehingga ia kesulitan } \\
\text { memahami materi. }\end{array}$ \\
\hline 4. & $\begin{array}{l}\text { Bagaimana cara Ibu untuk } \\
\text { meningkatkan minat } \\
\text { peserta didik yang tidak } \\
\text { fokus dalam belajar } \\
\text { kimia? }\end{array}$ & $\begin{array}{l}\text { Ya saya lakukan beberapa } \\
\text { pendekatan, misalnya } \\
\text { memberikan latihan-latihan } \\
\text { soal. Kemudian didekati dan } \\
\text { dimotivasi. }\end{array}$ \\
\hline 5. & $\begin{array}{l}\text { Apakah Ibu tahu peserta } \\
\text { didik itu memiliki gaya } \\
\text { belajar berbeda? }\end{array}$ & Ya, saya tahu. \\
\hline 6. & $\begin{array}{l}\text { Bagaimana cara Ibu } \\
\text { menghadapi gaya belajar } \\
\text { peserta didik yang } \\
\text { berbeda tersebut? }\end{array}$ & $\begin{array}{l}\text { Gaya belajar peserta didik } \\
\text { memang beda-beda, sehingga } \\
\text { saya tidak } \\
\text { mempermasalahkan hal }\end{array}$ \\
\hline
\end{tabular}




\begin{tabular}{|c|c|c|}
\hline No. & Pertanyaan & Jawaban \\
\hline & & $\begin{array}{l}\text { tersebut selama tujuan } \\
\text { pembelajaran tercapai. }\end{array}$ \\
\hline 7. & $\begin{array}{l}\text { Sumber belajar yang } \\
\text { digunakan peserta didik di } \\
\text { sekolah ini apa saja, Bu? }\end{array}$ & $\begin{array}{l}\text { 1. Buku dari perpustakaan } \\
\text { 2. PPT dari guru } \\
\text { 3. Internet }\end{array}$ \\
\hline 8. & $\begin{array}{l}\text { Metode apa yang biasa Ibu } \\
\text { gunakan dalam } \\
\text { pembelajaran kimia? }\end{array}$ & $\begin{array}{l}\text { Ceramah. Tetapi untuk materi } \\
\text { sistem koloid biasanya } \\
\text { menggunakan metode diskusi. }\end{array}$ \\
\hline 9. & $\begin{array}{l}\text { Bagaimana respon peserta } \\
\text { didik apabila } \\
\text { menggunakan metode } \\
\text { diskusi? }\end{array}$ & $\begin{array}{l}\text { Biasanya per kelompok aktif } \\
\text { mengikuti diskusi }\end{array}$ \\
\hline 10. & $\begin{array}{l}\text { Model pembelajaran apa } \\
\text { saja yang pernah } \\
\text { digunakan? }\end{array}$ & $\begin{array}{l}\text { Saya tidak menggunakan } \\
\text { model pembelajaran saat } \\
\text { mengajar, saya cenderung } \\
\text { menggunakan metode } \\
\text { konvensional atau diskusi. }\end{array}$ \\
\hline 11. & $\begin{array}{l}\text { Media pembelajaran apa } \\
\text { saja yang pernah } \\
\text { digunakan di dalam kelas? }\end{array}$ & PPT, praktikum. \\
\hline 12. & $\begin{array}{l}\text { Apakah di sini pernah } \\
\text { menggunakan tiga level } \\
\text { kimia dalam } \\
\text { pembelajaran? }\end{array}$ & Tidak \\
\hline 13. & $\begin{array}{l}\text { Materi apa yang dianggap } \\
\text { sulit oleh peserta didik? }\end{array}$ & $\begin{array}{l}\text { Biasanya peserta didik } \\
\text { kesulitan dalam materi } \\
\text { larutan. Ada beberapa peserta } \\
\text { didik yang masih salah dalam } \\
\text { perhitungan pH larutan dan } \\
\text { masih bingung apakah larutan } \\
\text { tersebut harus menggunakan } \\
\text { konsep hidrolisis atau buffer. }\end{array}$ \\
\hline 14. & $\begin{array}{l}\text { Berapa KKM yang } \\
\text { diterapkan di sekolah ini? }\end{array}$ & 70 \\
\hline 15. & $\begin{array}{l}\text { Kira-kira berapa persen } \\
\text { peserta didik yang lulus } \\
\text { KKM pada saat ulangan } \\
\text { harian? }\end{array}$ & Sekitar 50\% \\
\hline
\end{tabular}


Lampiran 4. Hasil Angket Pra Riset Peserta Didik

Responden: XI MIPA 1 tahun ajaran 2018/2019 (34 peserta didik)

\begin{tabular}{|c|c|c|}
\hline No. & Pertanyaan & Jawaban Peserta Didik \\
\hline 1. & $\begin{array}{l}\text { Menurut Anda, } \\
\text { apakah kimia } \\
\text { menarik untuk } \\
\text { dipelajari? }\end{array}$ & $\begin{array}{ll} & \text { Menarik }(70 \%) \\
\text { - } & \text { Ragu-ragu }(30 \%)\end{array}$ \\
\hline 2. & $\begin{array}{l}\text { Selama mengikuti } \\
\text { pelajaran kimia, } \\
\text { apakah Anda serius } \\
\text { dalam menyimak } \\
\text { penjelasan guru? }\end{array}$ & $\begin{array}{l}\text { - } \text { Cukup memperhatikan (50\%) } \\
\text { - Serius memperhatikan (30\%) } \\
\text { - Sangat serius memperhatikan } \\
(20 \%)\end{array}$ \\
\hline 3. & $\begin{array}{l}\text { Apa yang } \\
\text { menyebabkan Anda } \\
\text { kesulitan dalam } \\
\text { menyimak dan } \\
\text { memahami materi- } \\
\text { materi kimia? }\end{array}$ & 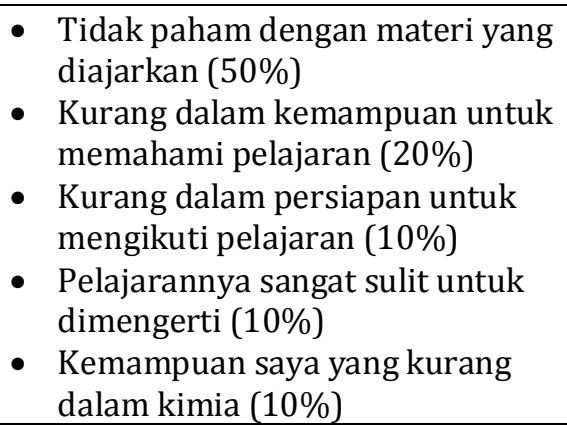 \\
\hline 4. & $\begin{array}{l}\text { Ketika Anda } \\
\text { kesulitan dalam } \\
\text { memahami Kimia, } \\
\text { apakah Anda suka } \\
\text { meminta bantuan } \\
\text { teman. guru, orang } \\
\text { tua atau kerabat } \\
\text { untuk mengajari } \\
\text { Anda? }\end{array}$ & $\begin{array}{ll}\text { - } & \text { Sering }(60 \%) \\
\text { - } & \text { Kadang-kadang }(30 \%) \\
\text { - } & \text { Sangat sering }(10 \%)\end{array}$ \\
\hline 5. & $\begin{array}{l}\text { Menurut Anda, apa } \\
\text { yang dapat } \\
\text { memotivasi Anda } \\
\text { agar dapat } \\
\text { memahami } \\
\text { persoalan kimia? }\end{array}$ & $\begin{array}{ll}\text { - } & \text { Metode belajar yang menarik } \\
& (40 \%) \\
\text { - } & \text { Guru yang cakap dalam mengajar } \\
& (30 \%) \\
\text { - } & \text { Latihan yang menarik dan inovatif } \\
& (20 \%)\end{array}$ \\
\hline
\end{tabular}




\begin{tabular}{|c|c|c|}
\hline No. & Pertanyaan & Jawaban Peserta Didik \\
\hline & & $\begin{array}{l}\text { - Guru yang cakap dalam mengajar, } \\
\text { latihan yang menarik dan inovatif, } \\
\text { metode belajar yang menarik, } \\
\text { buku pelajaran yang kreatif dan } \\
\text { inovatif, serta media } \\
\text { pembelajaran yang menarik } \\
(10 \%)\end{array}$ \\
\hline 6. & $\begin{array}{l}\text { Apakah dalam } \\
\text { belajar Anda selalu } \\
\text { menghafal } \\
\text { pelajaran? }\end{array}$ & $\begin{array}{l}\text { - } \text { Kadang-kadang }(70 \%) \\
\text { - Ya }(30 \%)\end{array}$ \\
\hline 7. & $\begin{array}{l}\text { Apakah Anda } \\
\text { membentuk } \\
\text { kelompok belajar } \\
\text { dengan teman- } \\
\text { teman untuk } \\
\text { belajar bersama? }\end{array}$ & $\begin{array}{l}\text { - } \quad \text { Tidak }(60 \%) \\
\text { - } \quad \text { Ya }(40 \%)\end{array}$ \\
\hline 8. & $\begin{array}{l}\text { Apakah Anda } \\
\text { senang belajar } \\
\text { dengan cara diskusi } \\
\text { kelompok? }\end{array}$ & $\begin{array}{ll}\text { - } & \text { Ya }(60 \%) \\
\text { - } & \text { Mungkin }(40 \%)\end{array}$ \\
\hline 9. & $\begin{array}{l}\text { Apakah Anda } \\
\text { melakukan sistem } \\
\text { SKS (Sistem Kebut } \\
\text { Semalam) ketika } \\
\text { akan menghadapi } \\
\text { ujian? }\end{array}$ & $\begin{array}{l}\text { - } \quad \text { Ya }(80 \%) \\
\text { - } \quad \text { Kadang-kadang }(20 \%)\end{array}$ \\
\hline 10. & $\begin{array}{l}\text { Bagaimana variasi } \\
\text { soal-soal yang } \\
\text { diberikan guru? }\end{array}$ & $\begin{array}{l}\text { - Seimbang antara yang mudah dan } \\
\text { sukar }(60 \%) \\
\text { - Sangat sukar dan memusingkan } \\
(40 \%)\end{array}$ \\
\hline 11. & $\begin{array}{l}\text { Menurut Anda, } \\
\text { materi mana yang } \\
\text { sulit Anda pahami? }\end{array}$ & $\begin{array}{ll}\text { - } & \text { Larutan penyangga (20\%) } \\
\text { - } & \text { Termokimia }(20 \%) \\
\text { - } & \text { Kelarutan dan hasil kali kelarutan } \\
& (20 \%) \\
\text { - } & \text { Kesetimbangan kimia }(10 \%) \\
\text { - } & \text { Hidrolisis }(10 \%) \\
\text { - } & \text { Titrasi asam dan basa }(10 \%) \\
\text { - } & \text { Sistem koloid }(10 \%) \\
\end{array}$ \\
\hline
\end{tabular}


Lampiran 5. Analisis Penguasaan Konsep Peserta Didik pada Saat Pra Riset

Daftar Responden Pra Riset:

\begin{tabular}{|c|l|c|c|}
\hline No. & \multicolumn{1}{|c|}{ Nama } & Kelas & Kode \\
\hline 1 & Agnes Kristina Widyawati & XII MIPA 5 & PP-01 \\
\hline 2 & Andien Anggita Auliya & XII MIPA 5 & PP-02 \\
\hline 3 & Angelina Sita Anindya & XI MIPA 5 & PP-03 \\
\hline 4 & Aryadewa N. P & XII MIPA 5 & PP-04 \\
\hline 5 & Auliya Shinta C. & XII MIPA 5 & PP-05 \\
\hline 6 & Aziz Assalama Alkhoir & XII MIPA 5 & PP-06 \\
\hline 7 & Balqist Asyawa A. P. & XII MIPA 5 & PP-07 \\
\hline 8 & Bernadetta Olivia Priwandita & XII MIPA 5 & PP-08 \\
\hline 9 & Celsa Alfreza Sena & XII MIPA 5 & PP-09 \\
\hline 10 & Daffa Fenderina P. & XII MIPA 5 & PP-10 \\
\hline 11 & Divani Salma Ningrum & XI MIPA 5 & PP-11 \\
\hline 12 & Edna Ayu Fahira D. & XII MIPA 5 & PP-12 \\
\hline 13 & Fadhilla S. & XII MIPA 5 & PP-13 \\
\hline 14 & FX Herry Christyanto & XII MIPA 5 & PP-14 \\
\hline 15 & Garinda Kusuma P. & XII MIPA 5 & PP-15 \\
\hline 16 & Hanifah Meita Putri & XII MIPA 5 & PP-16 \\
\hline 17 & Irene Ardelia Candra & XII MIPA 5 & PP-17 \\
\hline 18 & Khasandra Nur P. R. & XII MIPA 5 & PP-18 \\
\hline 19 & Laila Hilda Intania Ramadhani & XII MIPA 5 & PP-19 \\
\hline 20 & M. Hafid Bagas S. & XII MIPA 5 & PP-20 \\
\hline 21 & Maria Angella Putri R. & XII MIPA 5 & PP-21 \\
\hline 22 & Maria Rosary M.P. & XII MIPA 5 & PP-22 \\
\hline 23 & Nicholaw Chrisnanta & XII MIPA 5 & PP-23 \\
\hline 24 & Ricko Chandra Saputra & XII MIPA 5 & PP-24 \\
\hline 25 & Ridho Pamungkas & XII MIPA 5 & PP-25 \\
\hline 26 & Rizal Septiaria N. & XII MIPA 5 & PP-26 \\
\hline 27 & Salma Azzahra & XII MIPA 5 & PP-27 \\
\hline 28 & Sekar Rengganis & XII MIPA 5 & PP-28 \\
\hline 29 & Syahda Vania Whardhany & XII MIPA 5 & PP-29 \\
\hline 30 & Taufik Juananta Putra & XII MIPA 5 & PP-30 \\
\hline 31 & Valentina Pradestyana Deby & XII MIPA 5 & PP-31 \\
\hline 32 & Wahyu Fitri Adi & XII MIPA 5 & PP-32 \\
\hline & & & \\
\hline
\end{tabular}


Soal yang digunakan: (Sumber: Ambarwati, 2018)

\section{Berilah tanda silang (x) pada jawaban yang benar!}

1. Apakah yang dapat terjadi jika ke dalam $50 \mathrm{~mL}$ larutan penyangga dengan $\mathrm{pH} 5$ ditambahkan $5 \mathrm{~mL}$ aquades?

a. $\mathrm{pH}$ akan naik menjadi netral

b. pH akan turun menjadi lebih asam

c. pH tidak akan berubah

d. pH akan naik drastis

e. $\mathrm{pH}$ akan turun drastis

\section{Pilihan alasan:}

1) Larutan penyangga basa akan tetap pHnya jika diencerkan

2) Pengenceran tidak mengubah $\mathrm{pH}$ larutan penyangga

3) Larutan penyangga asam akan berubah menjadi basa jika ditambahkan air

4) Penambahan air dalam larutan penyangga menyebabkan pH larutan berubah

5) Larutan penyangga basa akan berubah menjadi netral jika ditambahkan air

\section{Apakah Anda yakin dengan jawaban Anda?}<smiles>C1C[Al]C1</smiles><smiles>CCCCCCCCCCCC</smiles>

2. Dalam larutan penyangga yang terdiri dari $\mathrm{CH}_{3} \mathrm{COOH}$ dan $\mathrm{CH}_{3} \mathrm{COO}^{-}$ditambahkan beberapa tetes asam $\left(\mathrm{H}^{+}\right)$. Ternyata $\mathrm{pH}$ larutan tersebut tidak berubah secara signifikan. Bagaimana hal tersebut bisa terjadi?

a. Ion $\mathrm{H}^{+}$akan bereaksi dengan $\mathrm{CH}_{3} \mathrm{COO}^{-}$

b. Ion $\mathrm{H}^{+}$akan bereaksi dengan $\mathrm{CH}_{3} \mathrm{COOH}$

c. Ion $\mathrm{H}^{+}$akan menggeser kesetimbangan ke kanan

d. Ion $\mathrm{H}^{+}$tidak bereaksi dengan spesi manapun

e. Ion $\mathrm{H}^{+}$tidak menggeser kesetimbangan

\section{Pilihan alasan:}

1) $\mathrm{H}^{+}$akan bereaksi dengan spesi yang bersifat lebih asam

2) $\mathrm{H}^{+}$akan bereaksi dengan spesi yang bersifat lebih basa

3) Larutan penyangga hanya memiliki komponen asam

4) Larutan penyangga hanya memiliki komponen basa 
5) Larutan penyangga tidak memiliki komponen asam ataupun basa

\section{Apakah Anda yakin dengan jawaban Anda?}
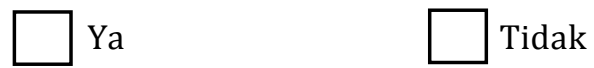

3. Campuran larutan-larutan berikut bersifat penyangga, kecuali...
a. Larutan $\mathrm{NaH}_{2} \mathrm{PO}_{4}$ dengan larutan $\mathrm{Na}_{2} \mathrm{HPO}_{4}$
b. Larutan $\mathrm{HCOOH}$ dengan larutan $\mathrm{Ba}(\mathrm{HCOO})_{2}$
c. Larutan $\mathrm{NaOH}$ dengan larutan $\mathrm{Ba}(\mathrm{HCOO})_{2}$
d. Larutan $\mathrm{NH}_{3}$ dengan larutan $\left(\mathrm{NH}_{4}\right)_{2} \mathrm{SO}_{4}$
e. Larutan $\mathrm{H}_{3} \mathrm{PO}_{4}$ dengan larutan $\mathrm{NaH}_{2} \mathrm{PO}_{4}$

\section{Pilihan Alasan:}

1) Larutan penyangga adalah larutan yang berasal dari campuran asam kuat dan basa kuat

2) Larutan penyangga adalah larutan yang berasal dari campuran asam lemah atau basa lemah dan garamnya

3) Larutan penyangga adalah larutan yang berasal dari campuran asam lemah dan basa lemah

4) Larutan penyangga adalah larutan yang berasal dari campuran asam kuat atau basa kuat dan garamnya

5) Larutan penyangga adalah larutan yang berasal dari campuran asam kuat atau basa kuat dan konjugasinya

\section{Apakah Anda yakin dengan jawaban Anda?}<smiles>[Al]C1CCC1</smiles>

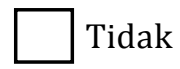

4. Suatu larutan yang mengandung $0,1 \mathrm{~mol} \mathrm{CH}_{3} \mathrm{COOH}(\mathrm{Ka}$ asam asetat $=10^{-5}$ ) dengan $0,01 \mathrm{~mol} \mathrm{CH}_{3} \mathrm{COONa}$ memiliki $\mathrm{pH}$...
a. 3
b. 4
c. 5
d. 6
e. 7

\section{Pilihan Alasan:}
1) $\mathrm{pH}=-\log \left[\mathrm{H}^{+}\right]$
2) $\mathrm{pH}=-\log \left[\mathrm{OH}^{-}\right]$
3) $\mathrm{pH}=+\log \left[\mathrm{H}^{+}\right]$ 
4) $\mathrm{pH}=+\log \left[\mathrm{OH}^{-}\right]$

5) $\mathrm{pH}=14+\mathrm{pOH}$

\section{Apakah Anda yakin dengan jawaban Anda?}
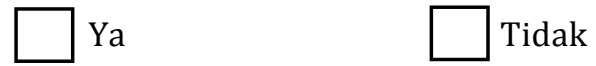

5. Untuk membuat larutan penyangga dengan $\mathrm{pH}$ 9, maka ke dalam $40 \mathrm{~mL}$ larutan $\mathrm{NH}_{3} 0,5 \mathrm{M}\left(\mathrm{Kb}=10^{-5}\right)$ harus ditambahkan larutan $\mathrm{HCl} 0,2 \mathrm{M}$ sebanyak...
a. $10 \mathrm{~mL}$
b. $20 \mathrm{~mL}$
c. $30 \mathrm{~mL}$
d. $\quad 40 \mathrm{~mL}$
e. $50 \mathrm{~mL}$

Pilihan Alasan:

1) Volume $=22,4 \mathrm{~L} \times \mathrm{mol}$

2) Volume $=\frac{\mathrm{mol}}{\mathrm{M}}$

3) Volume $=\mathrm{mol} \times \mathrm{M}$

4) Volume $=\mathrm{mol} \times \mathrm{Mr}$

5) Volume $=\frac{m o l}{M r}$

Apakah Anda yakin dengan jawaban Anda?

$\square$ Ya

$\square$ Tidak

6. Suatu larutan penyangga dapat dibuat dari campuran $100 \mathrm{~mL}$ $\mathrm{NH}_{3}$ 0,1 M ditambah $50 \mathrm{~mL} \mathrm{NH}_{4} \mathrm{Cl}$ 0,1 $\mathrm{M}\left(\mathrm{Kb} \mathrm{NH}_{3}=10-5\right)$. Jika

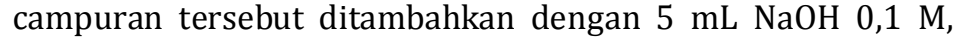
maka pH akan berubah dari...
a. $\quad 5-\log 2$ menjadi $5-\log 2,3$
b. $\quad 4-\log 2$ menjadi $4-\log 2,3$
c. $8-\log 2$ menjadi $8-\log 2,3$
d. $8+\log 2$ menjadi $8+\log 2,3$
e. $9+\log 2$ menjadi $9+\log 2,3$

Pilihan Alasan:
1) $\left[\mathrm{OH}^{-}\right]=\sqrt{M \times K b}$
2) $\left[\mathrm{OH}^{-}\right]=K b \times \frac{\text { mol basa }}{\text { valensi } \times \text { mol garam }}$
3) $\left[\mathrm{OH}^{-}\right]=K b \times \frac{\text { mol basa }}{\text { mol garam }}$ 
4) $\left[\mathrm{H}^{+}\right]=K a \times \frac{\text { mol asam }}{\text { valensi } \times \text { mol garam }}$
5) $\left[\mathrm{H}^{+}\right]=K a \times \frac{\text { mol asam }}{\text { mol garam }}$

Apakah Anda yakin dengan jawaban Anda?<smiles>[Y10]C1CCC1</smiles>

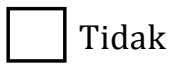

7. Berikut terdapat beberapa senyawa dan ion.
(1) $\mathrm{H}_{3} \mathrm{PO}_{4}$
(2) $\mathrm{H}_{2} \mathrm{CO}_{3}$
(3) $\mathrm{H}_{2} \mathrm{PO}_{4}$
(4) $\mathrm{HCO}_{3}^{-}$
(5) $\mathrm{HPO}_{4}^{2-}$

Pasangan senyawa atau ion tersebut yang berperan menjaga $\mathrm{pH}$ cairan sel pada tubuh manusia adalah...
a. 1 dan 3
b. 1 dan 5
c. 2 dan 3
d. 2 dan 4
e. 3 dan 5

\section{Pilihan Alasan:}

1) Penyangga karbonat terdapat dalam darah dan air liur

2) Penyangga fosfat terdapat dalam cairan sel tubuh dan air liur

3) $\mathrm{H}_{3} \mathrm{PO}_{4}$ dan $\mathrm{H}_{2} \mathrm{PO}_{4}^{-}$adalah penyangga fosfat, terdapat dalam darah

4) Penyangga karbonat terdiri dari $\mathrm{H}_{2} \mathrm{PO}_{4}$ - dan $\mathrm{HPO}_{4}{ }^{2-}$

5) $\mathrm{H}_{2} \mathrm{CO}_{3}$ dan $\mathrm{HCO}_{3}{ }^{-}$adalah larutan penyangga fosfat

\section{Apakah Anda yakin dengan jawaban Anda?}<smiles>C1C[14CH]C1</smiles><smiles>CCCCCCCCCCCCC</smiles>

8. Perhatikan pasangan larutan asam basa berikut ini.
(1) $100 \mathrm{~mL} \mathrm{NH}_{4} \mathrm{OH} \mathrm{0,2} \mathrm{M+100} \mathrm{mL} \mathrm{HCl} \mathrm{0,1} \mathrm{M}$
(2) $100 \mathrm{~mL} \mathrm{NH}_{4} \mathrm{OH} \mathrm{0,2} \mathrm{M+100} \mathrm{mL} \mathrm{HCl} \mathrm{0,2} \mathrm{M}$
(3) $100 \mathrm{~mL} \mathrm{NH}_{4} \mathrm{OH} 0,2 \mathrm{M}+100 \mathrm{~mL} \mathrm{HCl} \mathrm{0,3} \mathrm{M}$
(4) $100 \mathrm{~mL} \mathrm{NH}_{4} \mathrm{OH} \mathrm{0,1} \mathrm{M+100} \mathrm{mL} \mathrm{HCl} \mathrm{0,1} \mathrm{M}$
(5) $100 \mathrm{~mL} \mathrm{NH}_{4} \mathrm{OH} \mathrm{0,1} \mathrm{M} \mathrm{+} 100 \mathrm{~mL} \mathrm{HCl} \mathrm{0,2} \mathrm{M}$ Larutan penyangga basa dapat dibuat dari... 

a. 1
b. 2
c. 3
d. 4
e. 5

\section{Pilihan Alasan:}

1) Pasangan asam lemah berlebih dan basa kuat

2) Pasangan asam lemah dan basa kuat berlebih

3) Pasangan basa lemah berlebih dan asam kuat

4) Pasangan basa lemah dan asam kuat berlebih

5) Pasangan basa lemah dan asam kuat

\section{Apakah Anda yakin dengan jawaban Anda?}

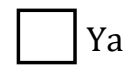

Tidak

Analisis pemahaman konsep peserta didik:

\begin{tabular}{|l|l|c|c|c|c|c|c|c|c|}
\hline \multirow{2}{*}{ No } & \multirow{2}{*}{ Kode } & \multicolumn{9}{|c|}{ Koding Kategori Three Tier } \\
\cline { 3 - 10 } & & $\mathbf{1}$ & $\mathbf{2}$ & $\mathbf{3}$ & $\mathbf{4}$ & $\mathbf{5}$ & $\mathbf{6}$ & $\mathbf{7}$ & $\mathbf{8}$ \\
\hline 1. & $\mathrm{PP}-01$ & $\mathrm{P}$ & $\mathrm{M}$ & $\mathrm{M}$ & $\mathrm{P}$ & $\mathrm{M}$ & $\mathrm{M}$ & $\mathrm{M}$ & $\mathrm{M}$ \\
\hline 2. & $\mathrm{PP}-02$ & $\mathrm{P}$ & $\mathrm{P}$ & $\mathrm{P}$ & $\mathrm{P}$ & $\mathrm{M}$ & $\mathrm{M}$ & $\mathrm{M}$ & $\mathrm{M}$ \\
\hline 3. & $\mathrm{PP}-03$ & $\mathrm{M}$ & $\mathrm{M}$ & $\mathrm{M}$ & $\mathrm{M}$ & $\mathrm{M}$ & $\mathrm{M}$ & $\mathrm{P}$ & $\mathrm{M}$ \\
\hline 4. & $\mathrm{PP}-04$ & $\mathrm{M}$ & $\mathrm{M}$ & $\mathrm{KP}$ & $\mathrm{P}$ & $\mathrm{M}$ & $\mathrm{M}$ & $\mathrm{P}$ & $\mathrm{M}$ \\
\hline 5. & $\mathrm{PP}-05$ & $\mathrm{P}$ & $\mathrm{M}$ & $\mathrm{M}$ & $\mathrm{P}$ & $\mathrm{M}$ & $\mathrm{P}$ & $\mathrm{M}$ & $\mathrm{P}$ \\
\hline 6. & $\mathrm{PP}-06$ & $\mathrm{P}$ & $\mathrm{M}$ & $\mathrm{M}$ & $\mathrm{P}$ & $\mathrm{M}$ & $\mathrm{M}$ & $\mathrm{M}$ & $\mathrm{M}$ \\
\hline 7. & $\mathrm{PP}-07$ & $\mathrm{KP}$ & $\mathrm{KP}$ & $\mathrm{KP}$ & $\mathrm{P}$ & $\mathrm{M}$ & $\mathrm{P}$ & $\mathrm{KP}$ & $\mathrm{KP}$ \\
\hline 8. & $\mathrm{PP}-08$ & $\mathrm{P}$ & $\mathrm{M}$ & $\mathrm{M}$ & $\mathrm{P}$ & $\mathrm{M}$ & $\mathrm{P}$ & $\mathrm{KP}$ & $\mathrm{M}$ \\
\hline 9. & $\mathrm{PP}-09$ & $\mathrm{P}$ & $\mathrm{M}$ & $\mathrm{KP}$ & $\mathrm{M}$ & $\mathrm{M}$ & $\mathrm{M}$ & $\mathrm{P}$ & $\mathrm{M}$ \\
\hline 10. & $\mathrm{PP}-10$ & $\mathrm{P}$ & $\mathrm{M}$ & $\mathrm{M}$ & $\mathrm{P}$ & $\mathrm{M}$ & $\mathrm{P}$ & $\mathrm{M}$ & $\mathrm{P}$ \\
\hline 11. & $\mathrm{PP}-11$ & $\mathrm{M}$ & $\mathrm{M}$ & $\mathrm{M}$ & $\mathrm{M}$ & $\mathrm{M}$ & $\mathrm{M}$ & $\mathrm{P}$ & $\mathrm{M}$ \\
\hline 12. & $\mathrm{PP}-12$ & $\mathrm{P}$ & $\mathrm{KP}$ & $\mathrm{KP}$ & $\mathrm{P}$ & $\mathrm{M}$ & $\mathrm{KP}$ & $\mathrm{P}$ & $\mathrm{M}$ \\
\hline 13. & $\mathrm{PP}-13$ & $\mathrm{P}$ & $\mathrm{P}$ & $\mathrm{KP}$ & $\mathrm{P}$ & $\mathrm{M}$ & $\mathrm{M}$ & $\mathrm{M}$ & $\mathrm{M}$ \\
\hline 14. & $\mathrm{PP}-14$ & $\mathrm{M}$ & $\mathrm{M}$ & $\mathrm{KP}$ & $\mathrm{P}$ & $\mathrm{KP}$ & $\mathrm{KP}$ & $\mathrm{P}$ & $\mathrm{M}$ \\
\hline 15. & $\mathrm{PP}-15$ & $\mathrm{KP}$ & $\mathrm{P}$ & $\mathrm{KP}$ & $\mathrm{P}$ & $\mathrm{KP}$ & $\mathrm{KP}$ & $\mathrm{KP}$ & $\mathrm{KP}$ \\
\hline 16. & $\mathrm{PP}-16$ & $\mathrm{P}$ & $\mathrm{P}$ & $\mathrm{P}$ & $\mathrm{P}$ & $\mathrm{M}$ & $\mathrm{M}$ & $\mathrm{M}$ & $\mathrm{M}$ \\
\hline 17. & $\mathrm{PP}-17$ & $\mathrm{P}$ & $\mathrm{M}$ & $\mathrm{M}$ & $\mathrm{P}$ & $\mathrm{P}$ & $\mathrm{P}$ & $\mathrm{P}$ & $\mathrm{M}$ \\
\hline
\end{tabular}




\begin{tabular}{|c|c|c|c|c|c|c|c|c|c|}
\hline \multirow{2}{*}{ No } & \multirow{2}{*}{ Kode } & \multicolumn{8}{|c|}{ Koding Kategori Three Tier } \\
\hline & & 1 & 2 & 3 & 4 & 5 & 6 & 7 & 8 \\
\hline 18. & PP-18 & $\mathrm{P}$ & $\mathrm{M}$ & $\mathrm{P}$ & M & KP & $\mathrm{P}$ & M & $\mathrm{P}$ \\
\hline 19. & PP-19 & KP & KP & KP & $\mathrm{P}$ & $\mathrm{M}$ & KP & KP & KP \\
\hline 20. & PP-20 & $\mathrm{P}$ & $\mathrm{P}$ & $\mathrm{P}$ & $\mathrm{P}$ & M & $\mathrm{M}$ & $\mathrm{M}$ & $\mathrm{M}$ \\
\hline 21. & PP-21 & KP & $\mathrm{M}$ & $\mathrm{M}$ & $\mathrm{P}$ & $\mathrm{KP}$ & KP & $\mathrm{P}$ & $\mathrm{M}$ \\
\hline 22. & PP-22 & $\mathrm{KP}$ & KP & KP & KP & $\mathrm{KP}$ & KP & KP & KP \\
\hline 23. & PP-23 & $\mathrm{P}$ & $\mathrm{M}$ & $\mathrm{P}$ & $\mathrm{P}$ & KP & KP & $\mathrm{M}$ & $\mathrm{P}$ \\
\hline 24. & PP-24 & $\mathrm{P}$ & KP & $\mathrm{M}$ & $\mathrm{P}$ & $\mathrm{M}$ & $\mathrm{P}$ & $\mathrm{M}$ & $\mathrm{M}$ \\
\hline 25. & PP-25 & $\mathrm{P}$ & $\mathrm{M}$ & $\mathrm{P}$ & $\mathrm{P}$ & $\mathrm{M}$ & $\mathrm{P}$ & $\mathrm{M}$ & $\mathrm{M}$ \\
\hline 26. & PP-26 & $\mathrm{P}$ & $\mathrm{KP}$ & $M$ & $\mathrm{P}$ & $\mathrm{M}$ & $M$ & $M$ & $\mathrm{M}$ \\
\hline 27. & PP-27 & $\mathrm{P}$ & $\mathrm{P}$ & $\mathrm{M}$ & $\mathrm{KP}$ & $\mathrm{M}$ & M & $\mathrm{M}$ & $\mathrm{M}$ \\
\hline 28. & PP-28 & $\mathrm{P}$ & $\mathrm{M}$ & $\mathrm{M}$ & KP & KP & $\mathrm{P}$ & $\mathrm{M}$ & $\mathrm{P}$ \\
\hline 29. & PP-29 & $\mathrm{P}$ & KP & $\mathrm{M}$ & $\mathrm{P}$ & $\mathrm{M}$ & $\mathrm{P}$ & $\mathrm{KP}$ & $\mathrm{KP}$ \\
\hline 30. & PP-30 & $\mathrm{P}$ & $\mathrm{P}$ & $\mathrm{M}$ & $\mathrm{P}$ & $\mathrm{M}$ & $\mathrm{M}$ & $\mathrm{M}$ & $\mathrm{P}$ \\
\hline 31. & PP-31 & $P$ & KP & $\mathrm{M}$ & $\mathrm{P}$ & $\mathrm{M}$ & $\mathrm{P}$ & $P$ & $M$ \\
\hline 32. & PP-32 & $\mathrm{P}$ & $\mathrm{P}$ & $\mathrm{M}$ & $\mathrm{P}$ & $\mathrm{M}$ & $\mathrm{P}$ & $\mathrm{M}$ & $\mathrm{P}$ \\
\hline \multicolumn{2}{|c|}{$\sum \mathbf{P}$} & 23 & 8 & 6 & 25 & 1 & 12 & 9 & 7 \\
\hline \multicolumn{2}{|c|}{$\sum \mathbf{M}$} & 4 & 16 & 17 & 4 & 24 & 13 & 17 & 20 \\
\hline \multicolumn{2}{|c|}{$\sum \mathrm{KP}$} & 5 & 8 & 9 & 3 & 7 & 7 & 5 & 5 \\
\hline \multicolumn{2}{|c|}{$\% \mathrm{P}$} & 71,9 & 25 & 18,8 & 78,1 & 3,13 & 37,5 & 28,1 & 21,9 \\
\hline \multicolumn{2}{|c|}{$\% \mathrm{M}$} & 12,5 & 50 & 53,1 & 12,5 & 75 & 40,6 & 53,1 & 62,5 \\
\hline \multicolumn{2}{|c|}{$\% \mathrm{KP}$} & 15,6 & 25 & 28,1 & 9,38 & 21,9 & 21,9 & 15,6 & 15,6 \\
\hline \multicolumn{2}{|c|}{ \% P total } & \multicolumn{8}{|c|}{35,546875} \\
\hline \multicolumn{2}{|c|}{$\begin{array}{l}\text { \%Kesulitan } \\
\text { Belajar }\end{array}$} & \multicolumn{8}{|c|}{64,0625} \\
\hline
\end{tabular}




\title{
Lampiran 6. Surat Permohonan Izin Riset ke SMAN 9 Semarang
}

\author{
KEMENTERIAN AGAMA REPUBLIK INDONESIA \\ UNIVERSITAS ISLAM NEGERI WALISONGO SEMARANG \\ FAKULTAS SAINS DAN TEKNOLOGI
}

Alamat: JI.Prof. Dr. Hamka Km. 1 Semarang Telp. 02476433366 Semarang 50185

\author{
Nomor : B. 798/Un.10.8/D1/TL.00/02/2020 Semarang, 27 Februari 2020 \\ Lamp : :- \\ Hal : Permohonan Izin Riset \\ Kepada Yth. \\ Kepala Sekolah SMA N 9 Semarang \\ di tempat \\ Assalamu'alaikum Wr. Wb.
}

Diberitahukan dengan hormat dalam rangka penulisan skripsi, bersama ini kami sampaikan bahwa mahasiswa di bawah ini :

$\begin{array}{ll}\text { Nama } & : \text { Dini Lestari } \\ \text { NIM } & : 1608076052 \\ \text { Fakultas/Jurusan } & : \text { Sains dan Teknologi / Pendidikan Kimia } \\ \text { Judul Sekripsi } & : " E f e k t i v i t a s \text { Model Pembelajaran Simayang Tipe II } \\ & \text { Berbasis Multipel Representasi terhadap Penguasaan } \\ & \text { Konsep dan Attitudes Toward Chemistry pada Materi } \\ & \text { Larutan Penyangga" }\end{array}$

Pembimbing $\quad:$ 1. Anita Fibonacci, M.Pd

2. Nur Alawiyah, M.Pd

Mahasiswa tersebut membutuhkan data-data dengan tema/judul skripsi yang sedang disusun, oleh karena itu kami mohon mahasiswa tersebut di ijinkan melaksanakan Riset pada di Sekolah yang Bapak/Ibu pimpin

Demikian atas perhatian dan kerjasamanya disampaikan terima kasih.

Wassalamu'alaikum Wr. Wb.

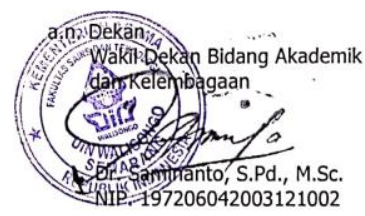

Tembusan Yth.

1. Dekan Fakultas Sains dan Teknologi UIN Walisongo ( sebagai laporan )

2. Arsip 


\title{
Lampiran 7. Surat Permohonan Izin Riset ke Dinas Pendidikan dan Kebudayaan Provinsi Jawa Tengah
}

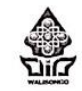 \\ KEMENTERIAN AGAMA REPUBLIK INDONESIA \\ UNIVERSITAS ISLAM NEGERI WALISONGO SEMARANG \\ FAKULTAS SAINS DAN TEKNOLOGI \\ Alamat: Jl.Prof. Dr. Hamka Km. 1 Semarang Telp. 02476433366 Semarang 50185

$\begin{array}{ll}\text { Nomor } & : \text { B. 798/Un.10.8/D1/TL.00/02/2020 Semarang, 27 Februari } 2020 \\ \text { Lamp } & :- \\ \text { Hal } & : \text { Permohonan Izin Riset } \\ & \text { Kepada Yth. } \\ & \text { Kepala Dinas Pendidikan dan Kebudayaan Provinsi Jawa Tengah } \\ & \text { di tempat } \\ & \text { Assalamu'alaikum Wr. Wb. }\end{array}$ \\ Diberitahukan dengan hormat dalam rangka penulisan skripsi, bersama ini \\ kami sampaikan bahwa mahasiswa di bawah ini :
Nama : Dini Lestari
NIM : 1608076052
Fakultas/Jurusan : Sains dan Teknologi / Pendidikan Kimia Berbasis Multipel Representasi terhadap Penguasaan Konsep dan Attitudes Toward Chemistry pada Materi Larutan Penyangga" \\ Judul Sekripsi : :"Efektivitas Model Pembelajaran Simayang Tipe II \\ Pembimbing $\quad: 1$. Anita Fibonacci, M.Pd \\ 2. Nur Alawiyah, M.Pd \\ Mahasiswa tersebut membutuhkan data-data dengan tema/judul skripsi \\ yang sedang disusun, oleh karena itu kami mohon mahasiswa tersebut di \\ ijinkan melaksanakan Riset pada di Sekolah SMA N 9 Semarang. \\ Demikian atas perhatian dan kerjasamanya disampaikan terima kasih. \\ Wassalamu'alaikum Wr. Wb.

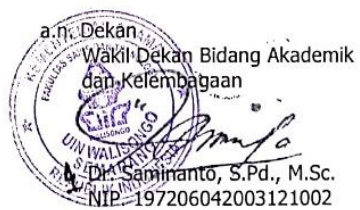 \\ Tembusan Yth. \\ 1. Dekan Fakultas Sains dan Teknologi UIN Walisongo ( sebagai laporan ) \\ 2. Arsip
}


Lampiran 8. Silabus Kelas Eksperimen dan Kelas Kontrol

\section{SILABUS KELAS ESKPERIMEN}

\section{Satuan Pendidikan : SMA Negeri 9 Semarang \\ Kelas \\ : XI MIPA 7 (Kelas Eksperimen) \\ Semester \\ : 2}

\section{Kompetensi Inti:}

KI 1 : Menghayati dan mengamalkan ajaran agama yang dianutnya.

KI 2 : Menunjukkan perilaku jujur, disiplin, tanggung jawab, peduli (gotong royong, kerjasama, toleran, damai), santun, responsif dan proaktif, dan menunjukkan sikap sebagai bagian dari solusi atas berbagai permasalahan dalam berinteraksi secara efektif dengan lingkungan sosial dan alam serta dalam menempatkan diri sebagai cerminan bangsa dalam pergaulan dunia.

KI 3 : Memahami, menerapkan, dan menganalisis pengetahuan faktual, konseptual, prosedural, dan metakognitif berdasarkan rasa ingin tahunya tentang ilmu pengetahuan, teknologi, seni, budaya, dan humaniora dengan wawasan kemanusiaan, kebangsaan, kenegaraan, dan peradaban terkait penyebab fenomena dan kejadian, serta menerapkan pengetahuan prosedural pada bidang kajian yang spesifik sesuai dengan bakat dan minatnya untuk memecahkan masalah

KI 4 : Mengolah, menalar, dan menyaji dalam ranah konkrit dan ranah abstrak terkait dengan pengembangan dari yang dipelajarinya di sekolah secara mandiri, bertindak secara efektif dan kreatif, serta mampu menggunakan metode sesuai kaidah keilmuan.

\begin{tabular}{|c|c|c|c|c|c|c|}
\hline \multicolumn{2}{|r|}{ Kompetensi Dasar } & Materi Pokok & Pembelajaran & Penilaian & $\begin{array}{l}\text { Alokasi } \\
\text { Waktu }\end{array}$ & $\begin{array}{l}\text { Sumber } \\
\text { Belajar }\end{array}$ \\
\hline 3.12 & $\begin{array}{l}\text { Menjelaskan prinsip kerja, } \\
\text { perhitungan pH, dan peran } \\
\text { larutan penyangga dalam } \\
\text { tubuh makhluk hidup. }\end{array}$ & \multirow{2}{*}{$\begin{array}{l}\text { - Sifat larutan } \\
\text { penyangga } \\
\text { - Prinsip } \\
\text { kerja larutan } \\
\text { penyangga }\end{array}$} & \multirow{2}{*}{$\begin{array}{l}\text { Orientasi } \\
\text { - Menyimak penyampaian tujuan } \\
\text { pembelajaran pada materi larutan } \\
\text { penyangga. } \\
\text { - Menjawab pertanyaan mengenai } \\
\text { fenomena dalam kehidupan }\end{array}$} & \multirow{2}{*}{$\begin{array}{l}\text { Tugas } \\
\text { - Mengerjakan soal } \\
\text { latihan mengenai } \\
\text { perhitungan pH larutan } \\
\text { penyangga. }\end{array}$} & \multirow[t]{2}{*}{$2 \underset{\mathrm{JP}}{\operatorname{minggu}} \times 4$} & \multirow[t]{2}{*}{$\begin{array}{ll}\text { - } & \text { Buku Kimia } \\
& \text { kelas XI } \\
\text { - } & \text { Lembar } \\
\text { Kerja }\end{array}$} \\
\hline 4.12 & $\begin{array}{l}\text { Membuat larutan penyangga } \\
\text { dengan } \mathrm{pH} \text { tertentu. }\end{array}$ & & & & & \\
\hline
\end{tabular}




\begin{tabular}{|c|c|c|c|c|}
\hline & $\begin{array}{l}\text { - pH larutan } \\
\text { penyangga } \\
\text { - Pengaruh } \\
\text { penambahan } \\
\text { sedikit } \\
\text { asam, } \\
\text { sedikit basa } \\
\text { dan } \\
\text { pengenceran } \\
\text { - Peranan } \\
\text { larutan } \\
\text { penyangga } \\
\text { dalam tubuh } \\
\text { makhluk } \\
\text { hidup }\end{array}$ & 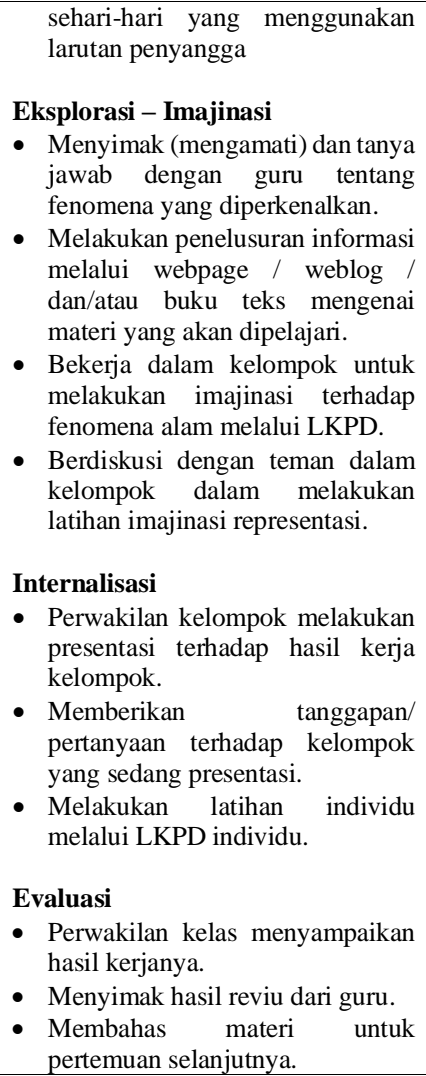 & $\begin{array}{l}\text { - } \text { Mengerjakan soal } \\
\text { latihan mengenai } \\
\text { pengaruh penambahan } \\
\text { sedikit asam, sedikit } \\
\text { basa dan pengenceran. } \\
\text { Observasi } \\
\text { - Sikap ilmiah dalam } \\
\text { melakukan percobaan } \\
\text { dan presentasi, } \\
\text { misalnya: cara } \\
\text { menggunakan pipet, } \\
\text { melihat skala volume, } \\
\text { cara menggunakan } \\
\text { indikator universal, } \\
\text { kerjasama, keaktifan, } \\
\text { komunikatif, dsb. } \\
\text { Portofolio } \\
\text { - Laporan praktikum } \\
\text { Tes tertulis } \\
\text { - Menganalisis data untuk } \\
\text { menyimpulkan larutan } \\
\text { yang bersifat penyangga } \\
\text { - Menghitung pH larutan } \\
\text { penyangga } \\
\text { - Menganalisis pengaruh } \\
\text { penambahan sedikit } \\
\text { asam, sedikit basa, dan } \\
\text { pengenceran }\end{array}$ & $\begin{array}{ll}\text { - } & \text { Berbagai } \\
\text { sumber } \\
\text { lainnya }\end{array}$ \\
\hline
\end{tabular}




\section{SILABUS KELAS KONTROL}

\section{Satuan Pendidikan ： SMA Negeri 9 Semarang}

\section{Kelas : XI MIPA 6 (Kelas Kontrol) \\ Semester \\ : 2}

\section{Kompetensi Inti:}

KI 1 : Menghayati dan mengamalkan ajaran agama yang dianutnya.

KI 2 : Menunjukkan perilaku jujur, disiplin, tanggung jawab, peduli (gotong royong, kerjasama, toleran, damai), santun, responsif dan proaktif, dan menunjukkan sikap sebagai bagian dari solusi atas berbagai permasalahan dalam berinteraksi secara efektif dengan lingkungan sosial dan al am serta dalam menempatkan diri sebagai cerminan bangsa dalam pergaulan dunia.

KI 3 : Memahami, menerapkan, dan menganalisis pengetahuan faktual, konseptual, prosedural, dan metakognitif berdasarkan rasa ingin tahunya tentang ilmu pengetahuan, teknologi, seni, budaya, dan humaniora dengan wawasan kemanusiaan, kebangsaan, kenegaraan, dan peradaban terkait penyebab fenomena dan kejadian, serta menerapkan pengetahuan prosedural pada bidang kajian yang spesifik sesuai dengan bakat dan minatnya untuk memecahkan masalah.

KI 4 : Mengolah, menalar, dan menyaji dalam ranah konkrit dan ranah abstrak terkait dengan pengembangan dari yang dipelajarinya di sekolah secara mandiri, bertindak secara efektif dan kreatif, serta mampu menggunakan metode sesuai kaidah keilmuan.

\begin{tabular}{|c|c|c|c|c|c|c|}
\hline \multicolumn{2}{|r|}{ Kompetensi Dasar } & Materi Pokok & Pembelajaran & Penilaian & $\begin{array}{l}\text { Alokasi } \\
\text { Waktu }\end{array}$ & Sumber Belajar \\
\hline & $\begin{array}{l}\text { Menjelaskan prinsip kerja, } \\
\text { perhitungan pH, dan peran } \\
\text { larutan penyangga dalam } \\
\text { tubuh makhluk hidup. }\end{array}$ & \multirow{2}{*}{$\begin{array}{l}\text { - Sifat larutan } \\
\text { penyangga } \\
\text { - Prinsip } \\
\text { kerja larutan } \\
\text { penyangga } \\
\text { - pH larutan } \\
\text { penyangga } \\
\text { - Pengaruh } \\
\text { penambahan }\end{array}$} & \multirow{2}{*}{$\begin{array}{l}\text { Kegiatan Awal } \\
\text { - Menyimak penyampaian tujuan } \\
\text { pembelajaran pada materi larutan } \\
\text { penyangga. } \\
\text { - Menjawab pertanyaan mengenai } \\
\text { fenomena dalam kehidupan } \\
\text { sehari-hari yang menggunakan } \\
\text { larutan penyangga. }\end{array}$} & \multirow{2}{*}{$\begin{array}{l}\text { Tugas } \\
\text { - Mengerjakan soal } \\
\text { latihan mengenai } \\
\text { perhitungan pH larutan } \\
\text { penyangga. } \\
\text { - Mengerjakan soal } \\
\text { latihan mengenai } \\
\text { pengaruh penambahan }\end{array}$} & \multirow[t]{2}{*}{$2 \underset{\mathrm{JP}}{\operatorname{minggu}} \times 4$} & \multirow{2}{*}{$\begin{array}{ll}\text { - } & \text { Buku Kimia } \\
\text { kelas XI } \\
\text { - } & \text { Berbagai } \\
\text { sumber } \\
\text { lainnya }\end{array}$} \\
\hline 4.12 & $\begin{array}{l}\text { Membuat larutan penyangga } \\
\text { dengan } \mathrm{pH} \text { tertentu. }\end{array}$ & & & & & \\
\hline
\end{tabular}




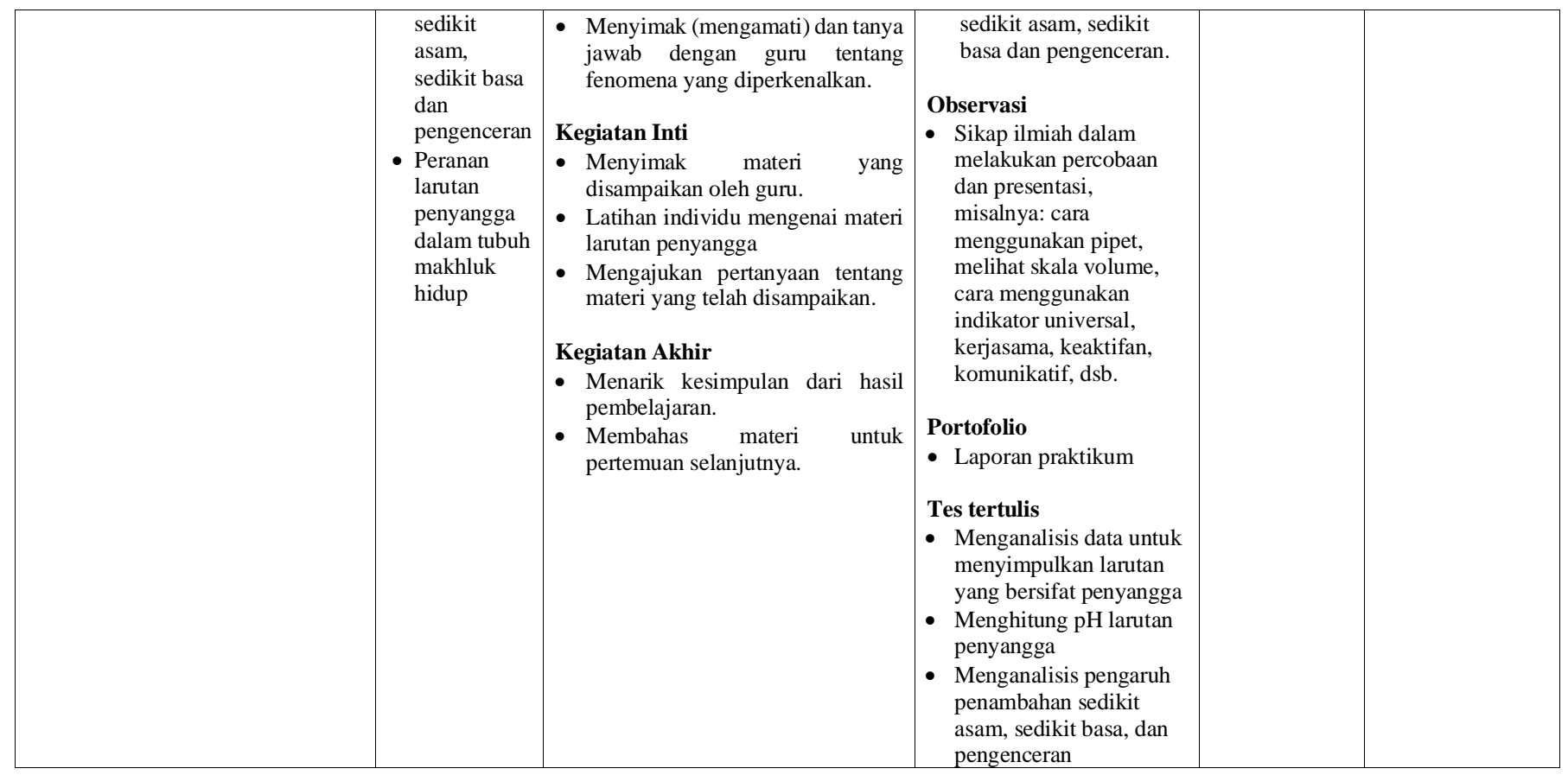


Lampiran 9. RPP Kelas Eksperimen Beserta Lampirannya

\section{RENCANA PELAKSANAAN PEMBELAJARAN}

$\begin{array}{lll}\text { Nama Sekolah } & : & \text { SMAN 9 Semarang } \\ \text { Mata Pelajaran } & : & \text { Kimia } \\ \text { Kelas/Semester } & : & \text { XI (Kelas Eksperimen)/2 } \\ \text { Materi Pokok } & : & \text { Larutan Penyangga } \\ \text { Alokasi Waktu } & : & 2 \times 45 \text { menit (2 JPL) @3 pertemuan }\end{array}$

\section{A. Kompetensi Inti}

Kompetensi Sikap Spiritual dan Kompetensi Sikap Sosial dicapai melalui pembelajaran tidak langsung (indirect teaching) pada pembelajaran Kompetensi Pengetahuan dan Kompetensi Keterampilan melalui keteladanan, pembiasaan, dan budaya sekolah dengan memperhatikan karakteristik mata pelajaran, serta kebutuhan dan kondisi peserta didik.

KI-1 : Menghayati dan mengamalkan agama yang dianutnya.

KI-2 : Menunjukkan perilaku jujur, disiplin, tanggung jawab, peduli (gotong royong, kerjasama, toleran, damai), santun, responsif dan pro aktif dan menunjukkan sikap sebagai bagian dari solusi atas berbagai permasalahan dalam berinteraksi secara efektif dengan lingkungan sosial dan alam serta dalam menempatkan diri sebagai cerminan bangsa dalam pergaulan dunia.

KI-3 : Memahami, menerapkan dan menganalisis pengetahuan faktual, konseptual, prosedural, dan metakognitif berdasarkan rasa ingin tahunya tentang ilmu pengetahuan, teknologi, seni, budaya, dan humaniora dengan wawasan kemanusiaan, kebangsaan, kenegaraan, dan peradaban terkait penyebab fenomena dan kejadian, serta menerapkan pengetahuan prosedural pada bidang kajian yang spesifik sesuai dengan bakat dan minatnya untuk memecahkan masalah.

KI-4 : Mengolah, menalar, dan menyaji dalam ranah konkrit dan ranah abstrak terkait dengan pengembangan dari yang dipelajarinya di sekolah secara mandiri, bertindak secara efektif dan kreatif, serta mampu menggunakan metode sesuai kaidah keilmuan.

\section{B. Kompetensi Dasar dan Indikator Pencapaian Kompetensi (IPK)}

\section{Kompetensi Dasar}

Siswa dapat:

3.12 Menjelaskan prinsip kerja, perhitungan $\mathrm{pH}$, dan peran larutan penyangga dalam tubuh makhluk hidup.

\section{Indikator}

Siswa dapat:

- Menjelaskan pengertian larutan penyangga

- Memahami komponen larutan penyangga

- Menghitung $\mathrm{pH}$ larutan penyangga

- Memahami pengaruh penambahan sedikit asam, sedikit basa dan pengenceran pada larutan penyangga

- Menyebutkan kegunaan larutan penyangga dalam kehidupan sehari-hari

4.12 Membuat larutan penyangga dengan $\mathrm{pH}$ tertentu.
- Membuat larutan penyangga 


\section{\begin{tabular}{|l|l|}
\hline$\bullet$ & $\begin{array}{l}\text { Menguji pH larutan penyangga sebelum } \\
\text { dan sesudah penambahan sedikit asam, } \\
\text { sedikit basa, dan pengenceran }\end{array}$ \\
\hline
\end{tabular}}

C. Tujuan Pembelajaran

Melalui model pembelajaran SiMaYang Tipe II diharapkan siswa mampu:

1. Menjelaskan pengertian larutan penyangga dengan benar.

2. Memahami komponen larutan penyangga dengan benar.

3. Menghitung $\mathrm{pH}$ larutan penyangga dengan benar.

4. Memahami pengaruh penambahan sedikit asam kuat, sedikit basa kuat dan pengenceran pada larutan penyangga dengan baik.

5. Menyebutkan kegunaan larutan penyangga dalam kehidupan sehari-hari dengan benar.

6. Membuat larutan penyangga dengan benar.

7. Menguji $\mathrm{pH}$ larutan penyangga sebelum dan sesudah penambahan sedikit asam, sedikit basa, dan pengenceran dengan teliti.

\section{Materi Pembelajaran}

\section{Pertemuan Pertama:}

1. Pengertian larutan penyangga

2. Pembentukan larutan penyangga

3. $\mathrm{pH}$ larutan penyangga

\section{Pertemuan Kedua:}

1. Pengaruh penambahan sedikit asam, sedikit basa dan pengenceran pada larutan penyangga.

2. Kegunaan larutan penyangga.

\section{Pertemuan Ketiga:}

1. Perubahan $\mathrm{pH}$ setelah penambahan sedikit asam, sedikit basa dan pengenceran pada larutan penyangga.

\section{E. Pendekatan, Metode, dan Model Pembelajaran}

1. Pendekatan : Saintific Approach;

2. Metode : Diskusi, Ceramah, Demonstrasi;

3. Model Pembelajaran : SiMaYang Tipe II

\section{F. Media dan Alat Pembelajaran}
1. Media
2. Alat
: LKS, Power point, buku paket Kimia
: LCD, alat tulis, spidol, papan tulis, Laptop

\section{G. Sumber Belajar}

1. Sudarmo, Unggul. 2013. Kimia Untuk SMA/MA Kelas XI. Jakarta: Penerbit Erlangga.

2. Kalsum, Siti. 2009. Kimia 2: Kelas XI SMA dan MA. Jakarta: Pusat Perbukuan Departemen Pendidikan Nasional.

3. Permana, Irvan. 2009. Memahami Kimia 2: SMA/MA Untuk Kelas XI. Jakarta: Pusat Perbukuan Departemen Pendidikan Nasional.

4. Buku kimia sumber lain yang relevan 
5. Internet

H. Langkah-Langkah Kegiatan

Pertemuan Pertama $(2 \times 45$ menit $)$ :

\begin{tabular}{|c|c|c|c|}
\hline Kegiatan & $\begin{array}{l}\text { Langkah-Langkah } \\
\text { SiMaYang Tipe II }\end{array}$ & Deskripsi Kegiatan & $\begin{array}{l}\text { Alokasi } \\
\text { Waktu }\end{array}$ \\
\hline Pendahuluan & - Orientasi & $\begin{array}{l}\text { - Guru membuka pembelajaran } \\
\text { dengan mengucapkan salam. } \\
\text { - Guru mengkondisikan peserta } \\
\text { didik untuk siap belajar dengan } \\
\text { berdoa bersama yang dipimpin } \\
\text { oleh salah seorang peserta } \\
\text { didik. } \\
\text { Guru mengecek kehadiran } \\
\text { peserta didik. } \\
\text { Peserta didik dirangsang } \\
\text { dengan diberikan pertanyaan } \\
\text { seperti berikut: "Apakah kalian } \\
\text { pernah minum minuman } \\
\text { bersoda?" Jika peserta didik } \\
\text { menjawab "Ya", kemudian kita } \\
\text { tanyakan lagi, "Tahukah kalian } \\
\text { bahwa dalam minuman bersoda } \\
\text { tersebut terdapat zat pengatur } \\
\text { keasaman?". Jika peserta didik } \\
\text { menjawab "Ya", kita beritahu } \\
\text { bahwa pengatur keasaman itu } \\
\text { adalah larutan penyangga. } \\
\text { Guru menyampaikan tujuan dan } \\
\text { manfaat mempelajari larutan } \\
\text { penyangga. }\end{array}$ & 5 menit \\
\hline
\end{tabular}




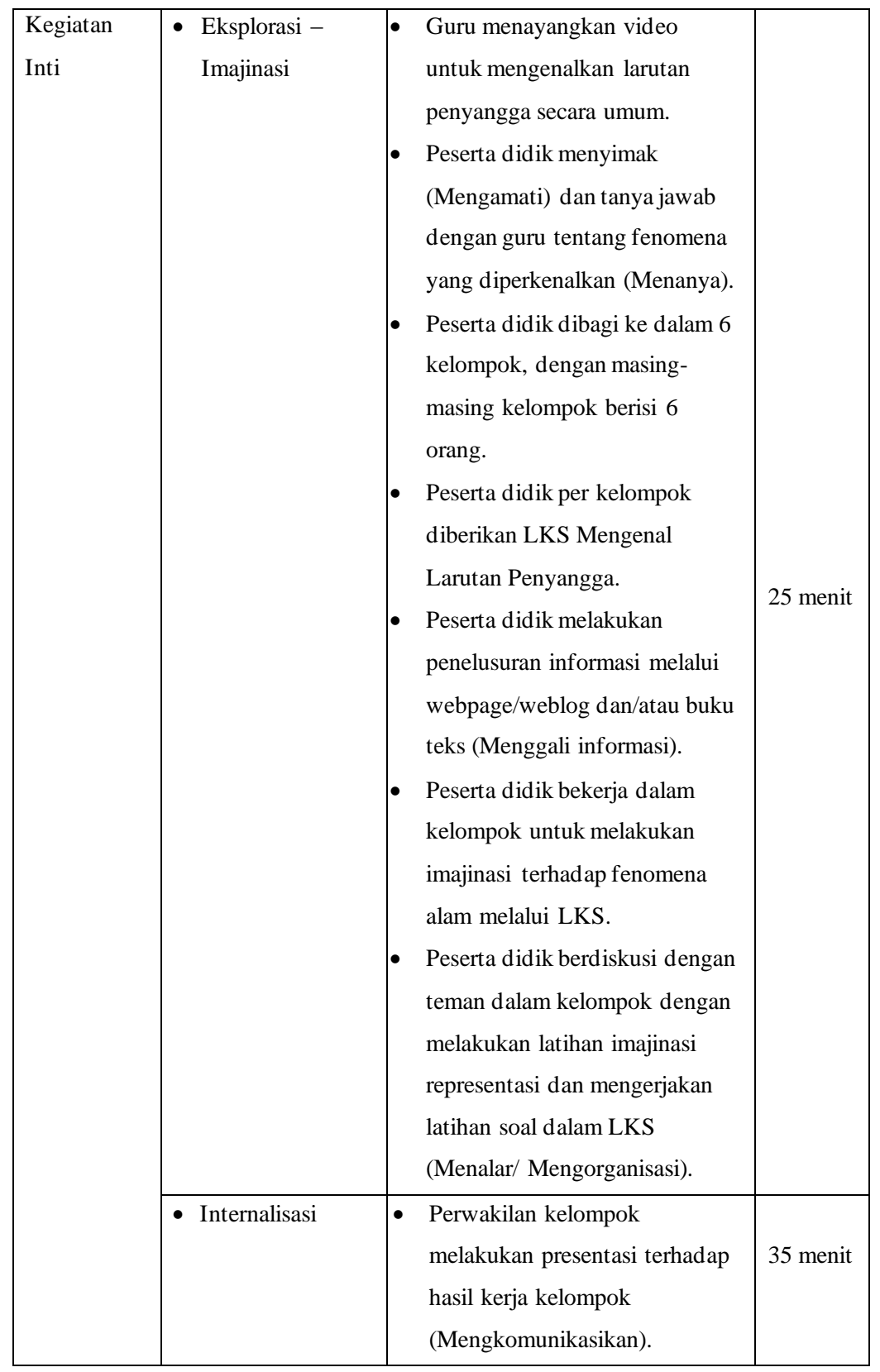




\begin{tabular}{|c|c|c|c|}
\hline & & $\begin{array}{l}\text { Peserta didik memberikan } \\
\text { tanggapan/pertanyaan terhadap } \\
\text { kelompok yang sedang } \\
\text { presentasi (Menanya dan } \\
\text { menjawab). } \\
\text { Peserta didik melakukan latihan } \\
\text { individu melalui LKS individu } \\
\text { (Menggali informasi dan } \\
\text { mengasosiasi). }\end{array}$ & \\
\hline & - Evaluasi & $\begin{array}{l}\text { - Perwakilan peserta didik } \\
\text { menyampaikan hasil kerjanya } \\
\text { (Mengkomunikasikan). } \\
\text { - Guru mengevaluasi kemajuan } \\
\text { belajar peserta didik dan } \\
\text { mereviu hasil kerja peserta } \\
\text { didik. }\end{array}$ & 20 menit \\
\hline Penutup & & 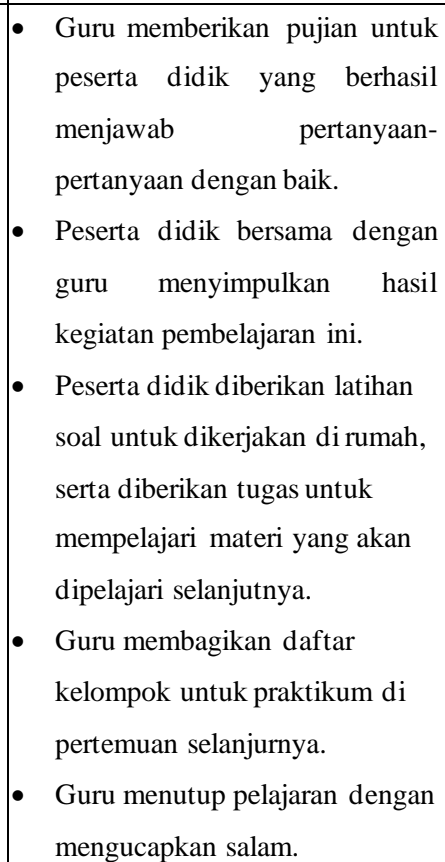 & 5 menit \\
\hline
\end{tabular}


Pertemuan Kedua $(2 \times 45$ menit $)$ :

\begin{tabular}{|c|c|c|c|}
\hline Kegiatan & $\begin{array}{l}\text { Langkah-Langkah } \\
\text { SiMaYang Tipe II }\end{array}$ & Deskripsi Kegiatan & $\begin{array}{l}\text { Alokasi } \\
\text { Waktu }\end{array}$ \\
\hline Pendahuluan & - Orientasi & $\begin{array}{l}\text { - Guru membuka pembelajaran } \\
\text { - } \text { dengan mengucapkan salam. } \\
\text { didik untuk siap belajar } \\
\text { dengan berdoa bersama yang } \\
\text { dipimpin oleh salah seorang } \\
\text { peserta didik. } \\
\text { - Guru mengecek kehadiran } \\
\text { peserta didik. } \\
\text { Peserta didik dirangsang } \\
\text { dengan diberikan pertanyaan } \\
\text { seperti berikut: “Kemarin } \\
\text { kalian sudah belajar mengenai } \\
\text { perhitungan pH larutan } \\
\text { penyangga. Nah, menurut } \\
\text { kalian apakah penambahan } \\
\text { sedikit asam, sedikit basa dan } \\
\text { pengenceran dapat merubah } \\
\text { pH larutan penyangga?" } \\
\text { dan manfaat mempelajari } \\
\text { penambahan sedikit asam, } \\
\text { sedikit basa dan pengenceran } \\
\text { pada larutan penyangga, serta } \\
\text { manfaatnya bagi kehidupan } \\
\text { sehari-hari. }\end{array}$ & 10 menit \\
\hline $\begin{array}{l}\text { Kegiatan } \\
\text { Inti }\end{array}$ & $\begin{array}{l}\text { - } \text { Eksplorasi - } \\
\text { Imajinasi }\end{array}$ & $\begin{array}{l}\text { - Peserta didik mengamati } \\
\text { gambar mengenai fenomena } \\
\text { alam mengenai maanfaat } \\
\text { larutan penyangga dan }\end{array}$ & 25 menit \\
\hline
\end{tabular}




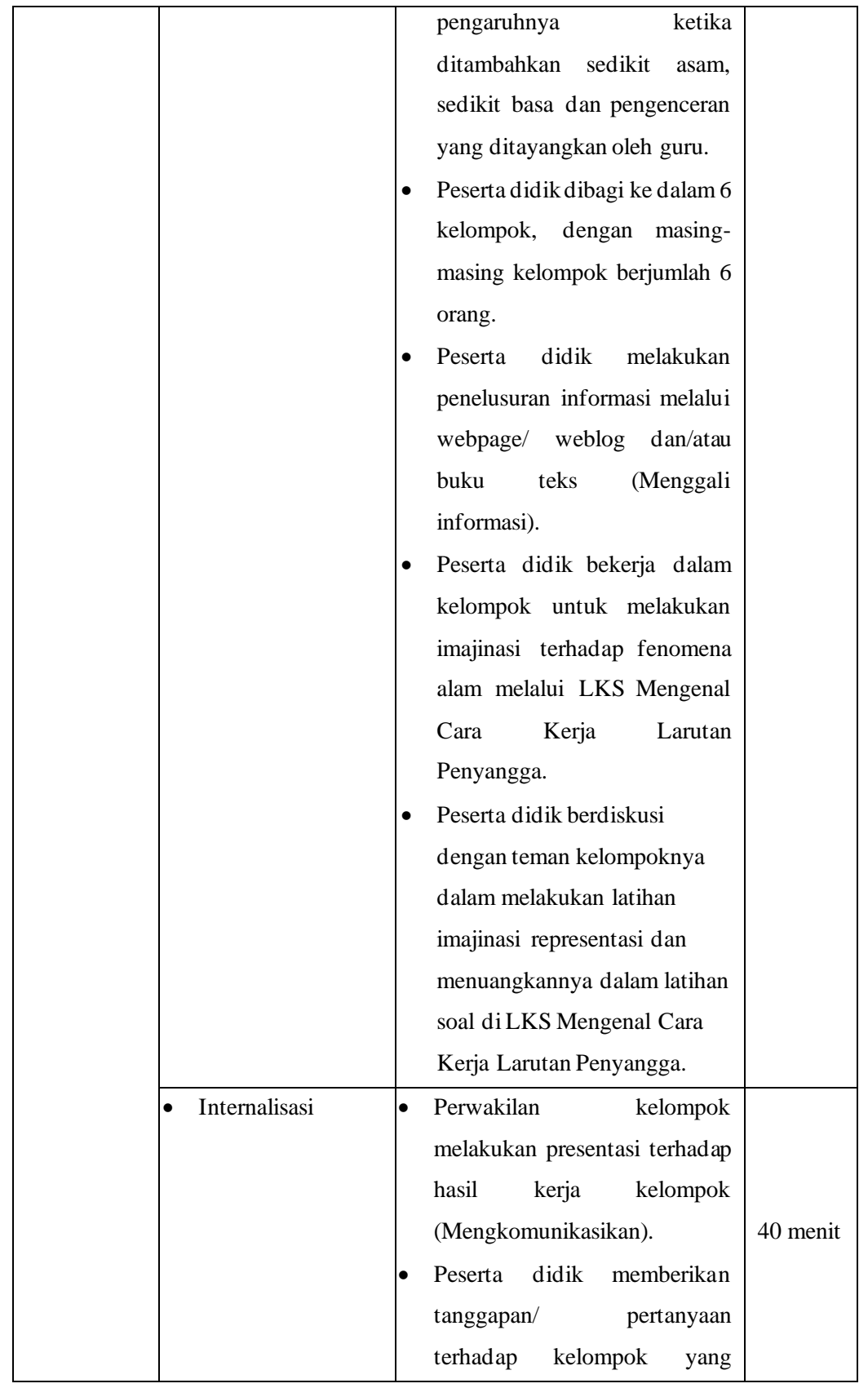




\begin{tabular}{|c|c|c|c|}
\hline & & $\begin{array}{l}\text { sedang presentasi (Menanya } \\
\text { dan Menjawab). } \\
\text { Peserta didik melakukan } \\
\text { latihan individu melalui LKS } \\
\text { individu (Menggali informasi } \\
\text { dan mengasosiasi). }\end{array}$ & \\
\hline & - Evaluasi & $\begin{array}{l}\text { - Salah satu peserta didik } \\
\text { menyampaikan hasil kerjanya } \\
\text { (Mengkomunikasikan). } \\
\text { - Guru mengevaluasi kemajuan } \\
\text { belajar peserta didik dan } \\
\text { mereviu hasil kerja peserta } \\
\text { didik. }\end{array}$ & 10 menit \\
\hline Penutup & & $\begin{array}{l}\text { - Peserta didik dipandu oleh } \\
\text { guru menyimpulkan materi } \\
\text { yang telah dipelajari tadi. } \\
\text { - Guru memberikan pujian untuk } \\
\text { peserta didik yang berhasil } \\
\text { menjawab pertanyaan- } \\
\text { pertanyaan dengan baik. } \\
\text { - Guru memberitahu peserta } \\
\text { didik mengenai kegiatan } \\
\text { pembelajaran selanjutnya. } \\
\text { Guru menutup pelajaran } \\
\text { dengan mengucapkan salam. }\end{array}$ & 5 menit \\
\hline
\end{tabular}

Pertemuan Ketiga $(2 \times 45$ menit):

\begin{tabular}{|c|c|c|c|}
\hline Kegiatan & $\begin{array}{c}\text { Langkah-Langkah } \\
\text { SiMaYang Tipe II }\end{array}$ & Deskripsi Kegiatan & $\begin{array}{c}\text { Alokasi } \\
\text { Waktu }\end{array}$ \\
\hline Pendahuluan & $\bullet$ Orientasi & $\begin{array}{c}\text { Guru membuka pembelajaran } \\
\text { dengan mengucapkan salam. }\end{array}$ & 10 menit \\
\hline
\end{tabular}




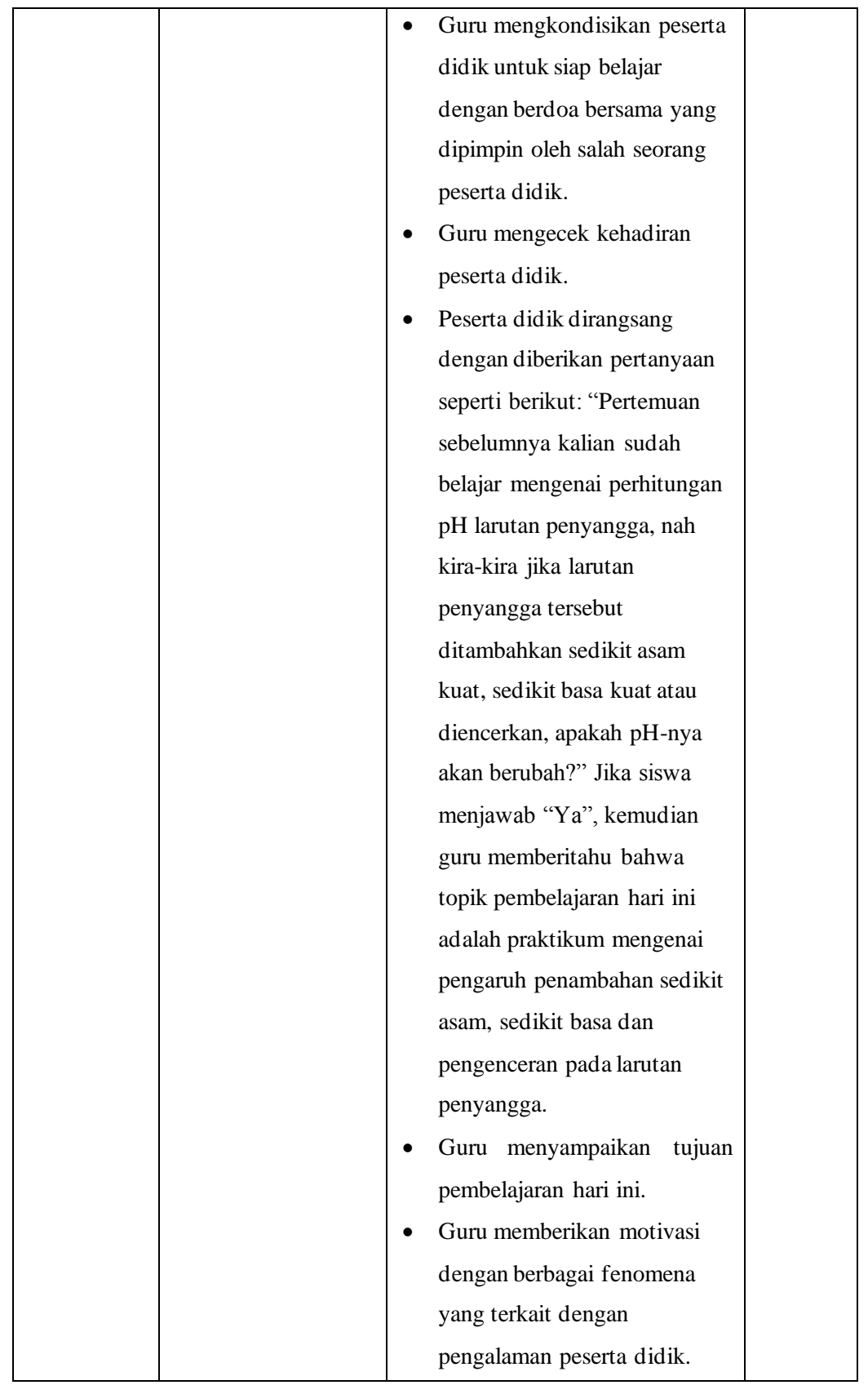




\begin{tabular}{|c|c|c|c|}
\hline $\begin{array}{l}\text { Kegiatan } \\
\text { Inti }\end{array}$ & $\begin{array}{l}\text { - Eksplorasi - } \\
\text { Imajinasi }\end{array}$ & 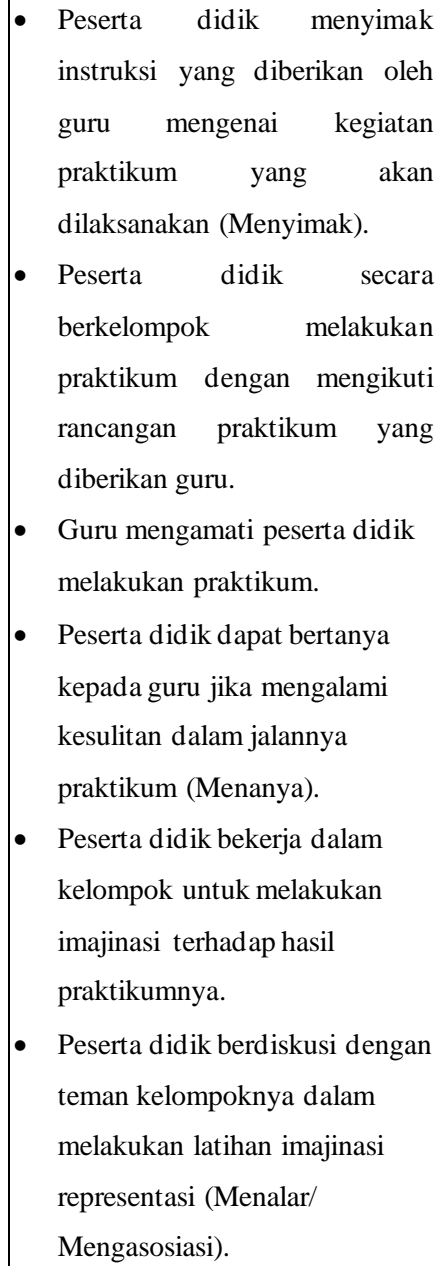 & 45 menit \\
\hline & - Internalisasi & $\begin{array}{l}\text { Peserta didik menuliskan hasil } \\
\text { pemikirannya dalam lembar } \\
\text { pengamatan. } \\
\text { Peserta didik mengumpulkan } \\
\text { lembar pengamatannya di akhir } \\
\text { kepada guru. }\end{array}$ & 15 menit \\
\hline Penutup & - $\quad$ Evaluasi & $\begin{array}{l}\text { - Guru mengevaluasi kemajuan } \\
\text { belajar peserta didik dan }\end{array}$ & 10 menit \\
\hline
\end{tabular}




\begin{tabular}{|l|l|l|}
\hline & $\begin{array}{l}\text { mereviu hasil kerja peserta } \\
\text { didik. } \\
\text { Guru memberikan pujian untuk } \\
\text { peserta didik yang telah } \\
\text { melaksanakan praktikum } \\
\text { dengan baik. } \\
\text { Peserta didik diberikan tugas } \\
\text { untuk membuat laporan } \\
\text { praktikum. } \\
\text { Guru menutup pelajaran } \\
\text { dengan mengucapkan salam. }\end{array} \mid$ \\
\hline
\end{tabular}

\section{Instrumen Penilaian}

1. Jenis Penilaian

\begin{tabular}{|c|c|c|c|}
\hline No. & Aspek & Teknik & Bentuk Instrumen \\
\hline 1. & Pengetahuan & Penugasan & $\begin{array}{ll}\text { - } & \text { Penugasan berupa latihan soal } \\
\text { - } & \text { Penyang Mengenal Larutan } \\
\text { - } & \text { LKS Mengenal Cara Kerja } \\
& \text { Larutan Penyangga } \\
\text { - } & \text { LKS Individu Mengenal } \\
& \text { Larutan Penyangga } \\
\text { - } & \text { LKS Individu Mengenal Cara } \\
& \text { Kerja Larutan Penyangga } \\
\text { - } & \text { Laporan praktikum }\end{array}$ \\
\hline 2. & Keterampilan & Observasi & $\begin{array}{l}\text { - Lembar observasi keaktifan } \\
\text { siswa } \\
\text { - Rubrik penilaian kegiatan } \\
\text { praktikum }\end{array}$ \\
\hline 3. & Sikap & Observasi & - Rubrik Penilaian Sikap \\
\hline
\end{tabular}

Semarang, 27 Januari 2020

Mengetahui,

Guru Mapel Kimia

Peneliti

Dra. Dewi Handayani

NIP. 196507261995122001
Dini Lestari

NIM. 1608076052 


\section{Lembar Kerja Siswa}

\section{MENGENAI IARU'TAN PENY ANGGA}

\section{Larutan Buffer}

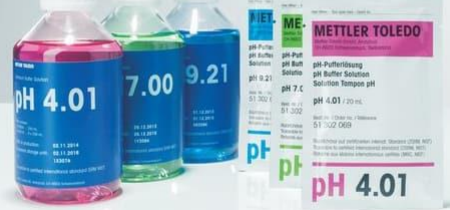

Kelas

Kelompok

Anggota Kelompok :

1.

2.

3.

4.

5.

6.

\section{Kompetensi Dasar:}

3.12 Menjelaskan prinsip kerja, perhitungan $\mathrm{pH}$, dan peran larutan penyangga dalam tubuh makhluk hidup.

4.12 Membuat larutan penyangga dengan $\mathrm{pH}$ tertentu.

\section{Indikator:}

1. Menjelaskan pengertian larutan penyangga

2. Memahami komponen larutan penyangga

3. Menghitung $\mathrm{pH}$ larutan penyangga 


\section{Tahukah Kamu?}

Gigi dapat larut jika dimasukkan pada larutan asam yang kuat. Email gigi yang rusak dapat menyebabkan kuman masuk ke dalam gigi. Air ludah dapat mempertahankan $\mathrm{pH}$ pada mulut sekitar 6,8. Air liur mengandung larutan penyangga fosfat yang dapat menetralisir asam yang terbentuk darifermentasisisa-sisa makanan.

\section{Sumber: rumushitung.com}

\section{Mengenal Larutan Penyangga}

\section{A. Pengertian Larutan Penyangga}

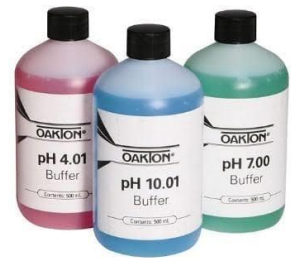

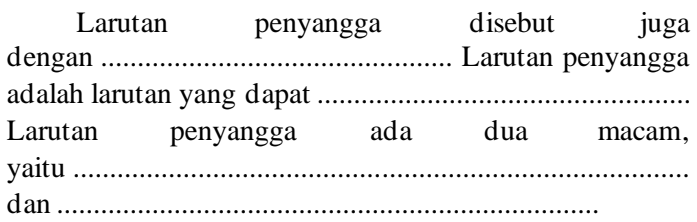

\section{B. Komponen Larutan Penyangga}

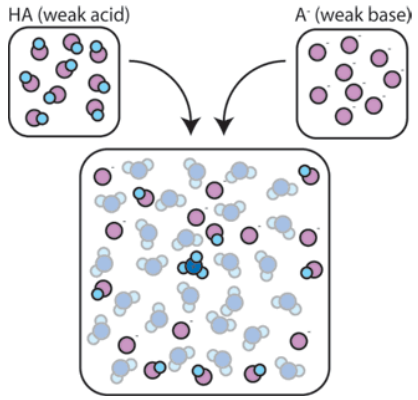

1. Larutan Penyangga Asam

Larutan penyangga asam terdiri dari dan

Larutan penyangga asam dapat dibuat dari dan basa kuat, selain itu, larutan penyangga asam dapat dibuat dari asam lemah dan

2. Larutan Penyangga Basa

Larutan penyangga basa terdiri dari dan Larutan penyangga basa dapat dibuat dari dan asam kuat, selain itu, larutan penyangga basa dapat dibuat daribasa lemah dan 


\section{Contoh Soal}

a. Sebutkan komponen larutan penyangga dari campuran larutan $\mathrm{H}_{2} \mathrm{CO}_{3}$ dengan larutan $\mathrm{NaHCO}_{3}$ ?

b. Apakah terjadi larutan penyangga jika $100 \mathrm{~mL} \mathrm{CH} \mathrm{CHOH}_{3} \mathrm{CO} \mathrm{M}$ direaksikan dengan $200 \mathrm{~mL} \mathrm{NaOH} \mathrm{0,2} \mathrm{M?} \mathrm{Jika} \mathrm{terbentuk,} \mathrm{sebutkan} \mathrm{komponen-komponennya!}$

\section{Penyelesaian}

a. $\mathrm{H}_{2} \mathrm{CO}_{3}$ dicampur dengan $\mathrm{NaHCO}_{3}$

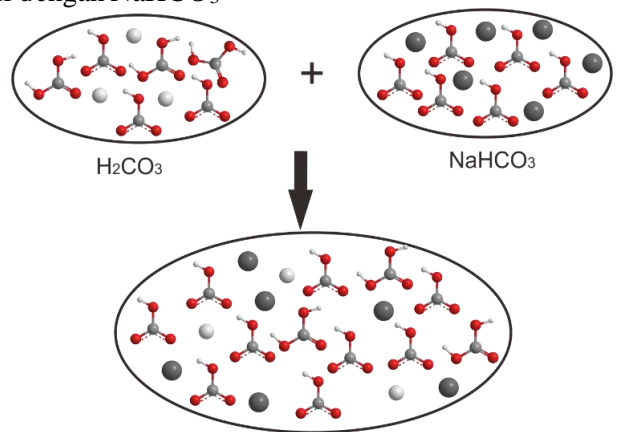

$\mathrm{H}_{2} \mathrm{CO}_{3}$ adalah asam lemah, sed angkan $\mathrm{NaHCO}_{3}$ adalah garamnya.

$\mathrm{NaHCO}_{3} \rightarrow \mathrm{Na}^{+}+\mathrm{HCO}_{3}^{-}$

Karena $\mathrm{NaHCO}_{3}$ membentuk ion $\mathrm{HCO}_{3}^{-}$, sehingga komponen larutan penyangganya adalah $\mathrm{H}_{2} \mathrm{CO}_{3} / \mathrm{HCO}_{3}{ }^{-}$

b. Diketahui:

$$
\begin{aligned}
& \mathrm{V} \mathrm{CH}_{3} \mathrm{COOH}=100 \mathrm{~mL} \quad \mathrm{~V} \mathrm{NaOH}=200 \mathrm{~mL} \\
& \mathrm{M} \mathrm{CH}_{3} \mathrm{COOH}=0,5 \mathrm{M} \quad \mathrm{M} \mathrm{NaOH}=0,2 \mathrm{M} \\
& \text { Jumlah mol } \mathrm{CH}_{3} \mathrm{COOH}=\mathrm{V} \mathrm{CH}_{3} \mathrm{COOH} \times \mathrm{MCH}_{3} \mathrm{COOH} \\
& =100 \mathrm{~mL} \times 0,5 \mathrm{M} \\
& =50 \mathrm{mmol} \\
& \text { Jumlah mol NaOH } \quad=\mathrm{V} \mathrm{NaOH} \times \mathrm{M} \mathrm{NaOH} \\
& =200 \mathrm{~mL} \times 0,2 \mathrm{M} \\
& =40 \mathrm{mmol}
\end{aligned}
$$$$
\mathrm{CH}_{3} \mathrm{COOH}(a q)+\mathrm{NaOH}(a q) \longrightarrow \mathrm{CH}_{3} \mathrm{COONa}(a q)+\mathrm{H}_{2} \mathrm{O}(l)
$$

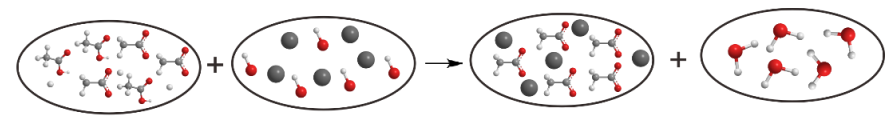

$$
\begin{array}{rrrrrr}
\mathrm{m} & : & 50 \mathrm{mmol} & 40 \mathrm{mmol} & - & - \\
\mathrm{r} & : & -40 \mathrm{mmol} & -40 \mathrm{mmol} & +40 \mathrm{mmol} & +40 \mathrm{mmol} \\
\mathrm{s} & : & 10 \mathrm{mmol} & - & 40 \mathrm{mmol} & 40 \mathrm{mmol}
\end{array}
$$


Karena terdapat sisa pada asam lemah, maka pada larutan tersebut terbentuk larutan penyangga, dengan komponen larutan penyangganya adalah $\mathrm{CH}_{3} \mathrm{COOH} / \mathrm{CH}_{3} \mathrm{COO}^{-}$.

\section{Latihan Soal}

1. Sebutkan komponen larutan penyangga dari:

a. HF dicampur dengan $\mathrm{NaF}$

b. $\mathrm{NH}_{3}$ dicampur dengan $\mathrm{NH}_{4} \mathrm{Cl}$

2. Apakah terjadi larutan penyangga pada campuran-campuran berikut? Jika terjadi, sebutkan komponen-komponennya!

a. $\quad 100 \mathrm{~mL} \mathrm{NH}_{3} 0,1 \mathrm{M}$ dengan $100 \mathrm{~mL} \mathrm{HCl} \mathrm{0,05} \mathrm{M}$

b. $\quad 100 \mathrm{~mL} \mathrm{CH}_{3} \mathrm{COOH} 0,1 \mathrm{M}$ dengan $200 \mathrm{~mL} \mathrm{NaOH} \mathrm{0,1} \mathrm{M}$

Jawaban: 


\section{C. pH Larutan Penyangga}

Harga $\mathrm{pH}$ larutan penyangga akan bergantung pada harga $\mathrm{K}_{a}$ dari dan $\mathrm{K}_{b}$ dari serta perbandingan konsentrasi

dengan basa konjugasinya maupun perbandingan konsentrasi basa lemah dengan

1. Larutan Penyangga Asam

Asam lemah akan mengalami kesetimbangan

$$
\mathrm{HA}(a q) \rightleftharpoons \mathrm{H}^{+}(a q)+\mathrm{A}^{-}(a q)
$$

Konstanta disosiasi asam:

$\mathrm{K}_{a}=\frac{\left[H^{+}\right]\left[A^{-}\right]}{[H A]}$

Untuk menentukan efek ion penyangga dan $\mathrm{pH}$ larutan penyangga, maka:

$$
\left[\mathrm{H}^{+}\right]=\mathrm{K}_{a} \frac{[\text { Asam lemah }]}{[\text { Basa konjugat }]}
$$

Konsentrasi $=[]=\mathrm{M}=\frac{n}{v}$, maka:

$$
\left[\mathrm{H}^{+}\right]=\mathrm{K}_{a} \frac{[\mathrm{HA}]}{\left[\mathrm{A}^{-}\right]}=K_{a} \frac{\text { Mol asam lemah }}{\text { Mol basa konjugat }} \quad \mathrm{pH}=-\log \left[\mathrm{H}^{+}\right]
$$

tampak bahwa $[\mathrm{H}+]$, dapat dihubungkan sebagai :

$$
\begin{aligned}
-\log \left[\mathrm{H}^{+}\right] & =-\log \left(K_{a} \frac{\text { mol asam lemah }}{\text { mol basa konjugat }}\right) \\
\mathrm{pH} & =-\log \mathrm{K}_{a}-\log \frac{\text { mol asam lemah }}{\text { mol basa konjugat }} \\
\mathrm{pH} & =\mathrm{pK}_{a}-\log \frac{\text { mol asam lemah }}{\text { mol basa konjugat }} \\
\mathrm{pH} & =\mathrm{pK}_{a}+\log \frac{\text { mol basa konjugat }}{\text { mol asam lemah }}
\end{aligned}
$$

2. Larutan Penyangga Basa

Dengan cara yang sama, untuk sistem penyangga basa lemah dan asam konjugasinya, diperoleh konsentrasi $\left[\mathrm{OH}^{-}\right]$sebagai berikut:

$$
\left[\mathrm{OH}^{-}\right]=\mathrm{K}_{b} \frac{\text { mol basa lemah }}{\text { mol asam konjugat }} \quad \mathrm{pOH}=-\log \left[\mathrm{OH}^{-}\right]
$$

$\mathrm{pOH} \quad=\mathrm{pK}_{b}+\log \frac{\text { mol asam konjugat }}{\text { mol basa lemah }}$

$\mathrm{pH}=14-\mathrm{pOH}$

\section{Latihan Soal}

1. Jika $100 \mathrm{~mL}$ larutan $\mathrm{CH}_{3} \mathrm{COOH} 0,1 \mathrm{M}$ dicampur dengan $25 \mathrm{~mL}$ larutan $\mathrm{CH}_{3} \mathrm{COONa} 0,2 \mathrm{M}, \mathrm{K}_{a} \mathrm{CH}_{3} \mathrm{COOH}=1,8 \times 10^{-5}$. Tentukan $\mathrm{pH}$ campuran!

2. Sebanyak $100 \mathrm{~mL}$ larutan $\mathrm{NH}_{3} 0,8 \mathrm{M}$ dicampurkan dengan $50 \mathrm{~mL}$ larutan $\mathrm{HCl} \mathrm{0,2} \mathrm{M.} \mathrm{Bila} \mathrm{K}_{b} \mathrm{NH}_{3}=1,8 \times 10^{-5}$, tentukan $\mathrm{pH}$ campuran! 
Jawaban: 


\section{LEMBAR KERJA SISWA (LKS) INDIVIDU}

\section{Latihan Soal}

1. Manakah di antara campuran berikut yang merupakan larutan penyangga dan berikan alasannya!

a. $\quad 50 \mathrm{~mL} \mathrm{KOH} \mathrm{0,2} \mathrm{M+50} \mathrm{mL} \mathrm{HCN} \mathrm{0,5} \mathrm{M}$

b. $100 \mathrm{~mL} \mathrm{KOH} \mathrm{0,05} \mathrm{M} \mathrm{+} \mathrm{50} \mathrm{mL} \mathrm{HCOOH} \mathrm{0,1} \mathrm{M}$

2. Hitunglah $\mathrm{pH}$ jika dicampurkan larutan asam asetat dan natrium asetat dengan perbandingan $2: 5\left(\mathrm{Ka}=1,8 \times 10^{-5}\right)$ !

3. Ke dalam $100 \mathrm{~mL}$ larutan $\mathrm{CH}_{3} \mathrm{COOH} 0,1 \mathrm{M}\left(\mathrm{Ka}=1,8 \times 10^{-5}\right)$ ditambahkan sejumlah garam $\mathrm{CH}_{3} \mathrm{COONa}(\mathrm{Mr}=82)$ hingga $\mathrm{pH}$ naik menjadi $5-\log 1,8$. Massa natrium asetat yang ditambahkan adalah ...

4. Sebanyak $100 \mathrm{~mL}$ larutan $\mathrm{HF} 0,2 \mathrm{M}$ dicampur dengan $100 \mathrm{~mL}$ larutan $\mathrm{NaOH} 0,1 \mathrm{M}\left(\mathrm{Ka} \mathrm{HF}=7,1 \times 10^{-4}\right)$. Tentukan $\mathrm{pH}$ larutan tersebut!

5. Volume $\mathrm{KOH} \mathrm{0,1} \mathrm{M} \mathrm{yang} \mathrm{harus} \mathrm{ditambahkan} \mathrm{ke} \mathrm{dalam} 100$ $\mathrm{mL}$ larutan asam asetat $0,3 \mathrm{M}$ agar diperoleh larutan penyangga dengan $\mathrm{pH}$ sebesar $5-\log 5,4\left(\mathrm{Ka}=1,8 \times 10^{-5}\right)$ !

\section{Catatan:}

Sertakan gambar molekul pada level submikroskopik sesuai dengan imajinasi pada saat proses pembelajaran!
Kompetensi Dasar:

3.12 Menjelaskan prinsip kerja, perhitungan $\mathrm{pH}$, dan peran larutan penyangga dalam tubuh makhluk hidup.

4.12 Membuat larutan penyangga dengan $\mathrm{pH}$ tertentu.

\section{Indikator:}

4. Menjelaskan pengertian larutan penyangga

5. Memahami komponen larutan penyangga

6. Menghitung $\mathrm{pH}$ larutan penyangga

\section{Tahukah Kamu?}

Zaman modern ini, lensa kontak sudah menjadi trend di kalangan kaum wanita. Lensa kontak banyak digunakan untuk memperindah mata dan juga dapat berfungsi sebagai pengganti kacamata. Pemakaian dan perawatan lensa kontak tidak boleh sembarangan, harus sesuai dengan prosedur yang tepat. Lensa kontak harus disimpan di dalam cairan khusus. Demikian pula ketika lensa kontak akan dipakai, maka lensa kontak harus dicuci/direndam terlebih dahulu menggunakan cairan khusus tersebut. Cairan lensa kontak umumnya mengandung 4 jenis bahan yaitu aqueous (saline) vehicle, wetting agent, polymer, dan buffering agent (larutan penyangga). Biasanya buffering agent yang digunakan pada cairan lensa kontak tersebut adalah campuran larutan asam borat dan natrium borat. 
Lampiran 3: Rubrik Penilaian Sikap

RUBRIK PENILAIAN SIKAP

(Untuk Pertemuan 1-3)

\begin{tabular}{|c|l|l|l|l|}
\hline No. & Nama siswa & Disiplin & Tanggung jawab & Santun \\
\hline 1. & & & & \\
\hline 2. & & & & \\
\hline 3. & & & & \\
\hline 4. & & & & \\
\hline 5. & & & & \\
\hline
\end{tabular}

\section{Keterangan:}

$3=$ jika tiga indikator terlihat.

$2=$ jika dua indikator terlihat.

$1=$ jika satu indikator terlihat.

\section{Indikator penilaian sikap:}

\section{Disiplin}
a. Tertib mengikuti instruksi.
b. Mengerjakan tugas tepat waktu.
c. Tidak membuat kondisi kelas menjadi tidak kondusif.

\section{Tanggung Jawab}

a. Mengerjakan tugas sesuai yang ditugaskan.

b. Merapikan kembali ruang, alat, dan peralatan belajar yang telah dipergunakan.

c. Mampu mempertanggungjawabkan apa yang telah diucapkan dan dilakukan.

\section{Santun}

a. Berinteraksi dengan teman secara ramah.

b. Berkomunikasi dengan bahasa yang tidak menyinggung perasaan.

c. Berperilaku sopan.

*Skor maksimal $=9$

Nilai $=\frac{\text { Skor total }}{\text { Skor maksimal }} \times 100$ 
Lampiran 4: LKS Kelompok

(Untuk Pertemuan 2)

\section{Lembar Kerja Siswa}
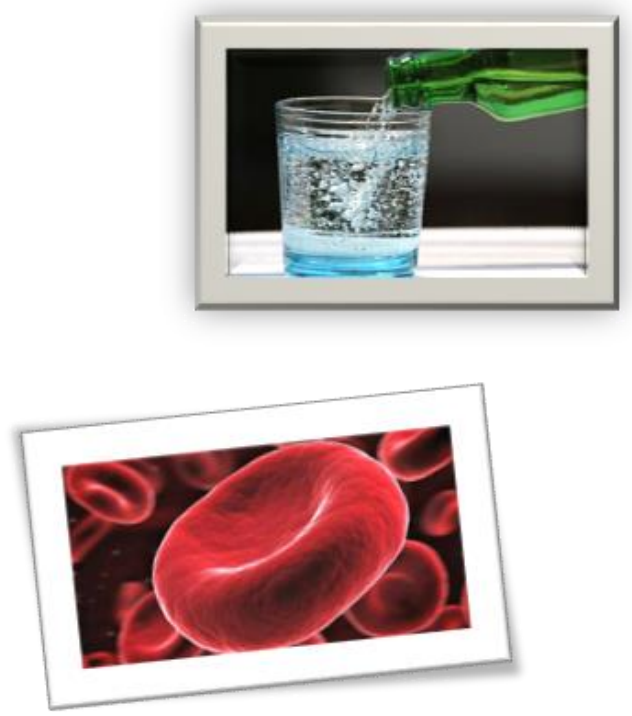

\section{Kompetensi Dasar:}

3.12 Menjelaskan prinsip kerja, perhitungan $\mathrm{pH}$, dan peran larutan penyangga dalam tubuh makhluk hidup.

4.12 Membuat larutan penyangga dengan $\mathrm{pH}$ tertentu.

\section{Indikator:}

1. Memahami pengaruh penambahan sedikit asam, sedikit basa dan pengenceran pada larutan penyangga

2. Menyebutkan kegunaan larutan penyangga dalam kehidupan sehari-hari.

\section{MENGENAL CARA KER.JA IARU'TAN PENY ANGGA}

Kelas

Kelompok

Anggota Kelompok :

1.

2.

3.

4.

5.

6.

"Learn from yesterday, live for today, hope for tomorrow. The important thing is not to stop questioning. (Belajar dari hari kemarin, hidup untuk hari ini, berharap untuk hari esok. Yang terpenting tidak berhenti bertanya)" 


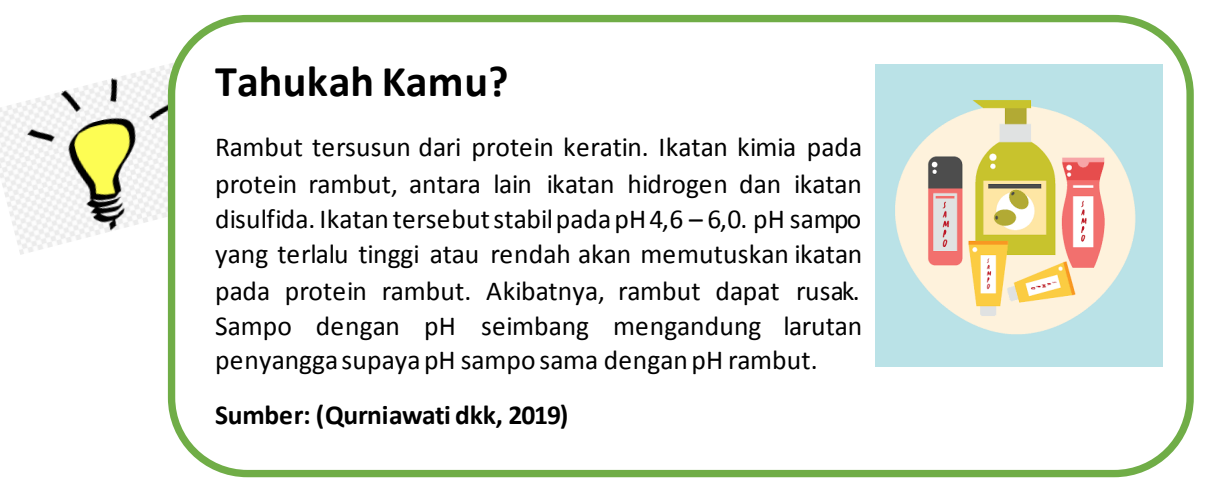

\section{Mengenal Cara Kerja Larutan Penyangga}

\section{A. Pengaruh Pengenceran Pada Larutan Penyangga}

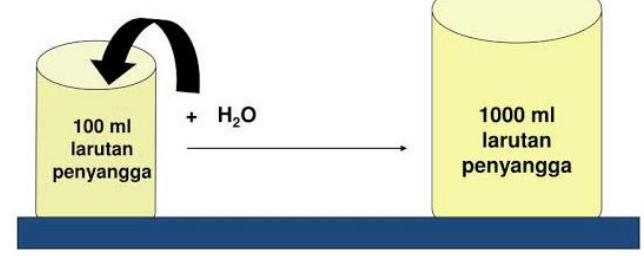

Bagaimana pengaruh pengenceran pada $\mathrm{pH}$ larutan penyangga? Pengenceran atau penambahan air akan ............................. volume komponen-komponen larutan penyangga. Untuk mengetahui $\mathrm{pH}-$ nya, kerjakan soal berikut ini.

\section{SOAL}

1. Pada 1 liter larutan yang terbentuk oleh $\mathrm{NH}_{4} \mathrm{OH} 1 \mathrm{M}$ dan $\mathrm{NH}_{4} \mathrm{Cl} 1 \mathrm{M}$. Jika $\mathrm{K}_{\mathrm{b}}$ $\mathrm{NH}_{4} \mathrm{OH}=1,8 \times 10^{-5}$, tentukan:

a. $\mathrm{pH}$ larutan penyangga!

b. $\mathrm{pH}$ larutan penyangga yang diencerkan dengan 9 liter air!

2. Pada $500 \mathrm{~mL}$ larutan yang terbentuk dari $\mathrm{CH}_{3} \mathrm{COOH} 0,1 \mathrm{M}$ dan $\mathrm{CH}_{3} \mathrm{COONa} 0,1$ M. Jika $\mathrm{K}_{a} \mathrm{CH}_{3} \mathrm{COOH}=1,8 \times 10^{-5}$, tentukan:

a. $\mathrm{pH}$ larutan penyangga!

b. pH larutan penyangga yang diencerkan dengan $300 \mathrm{~mL}$ air!

\section{Catatan:}

Sertakan gambar molekul pada level submikroskopik sesuai dengan imajinasi pada saat proses pembelajaran! 


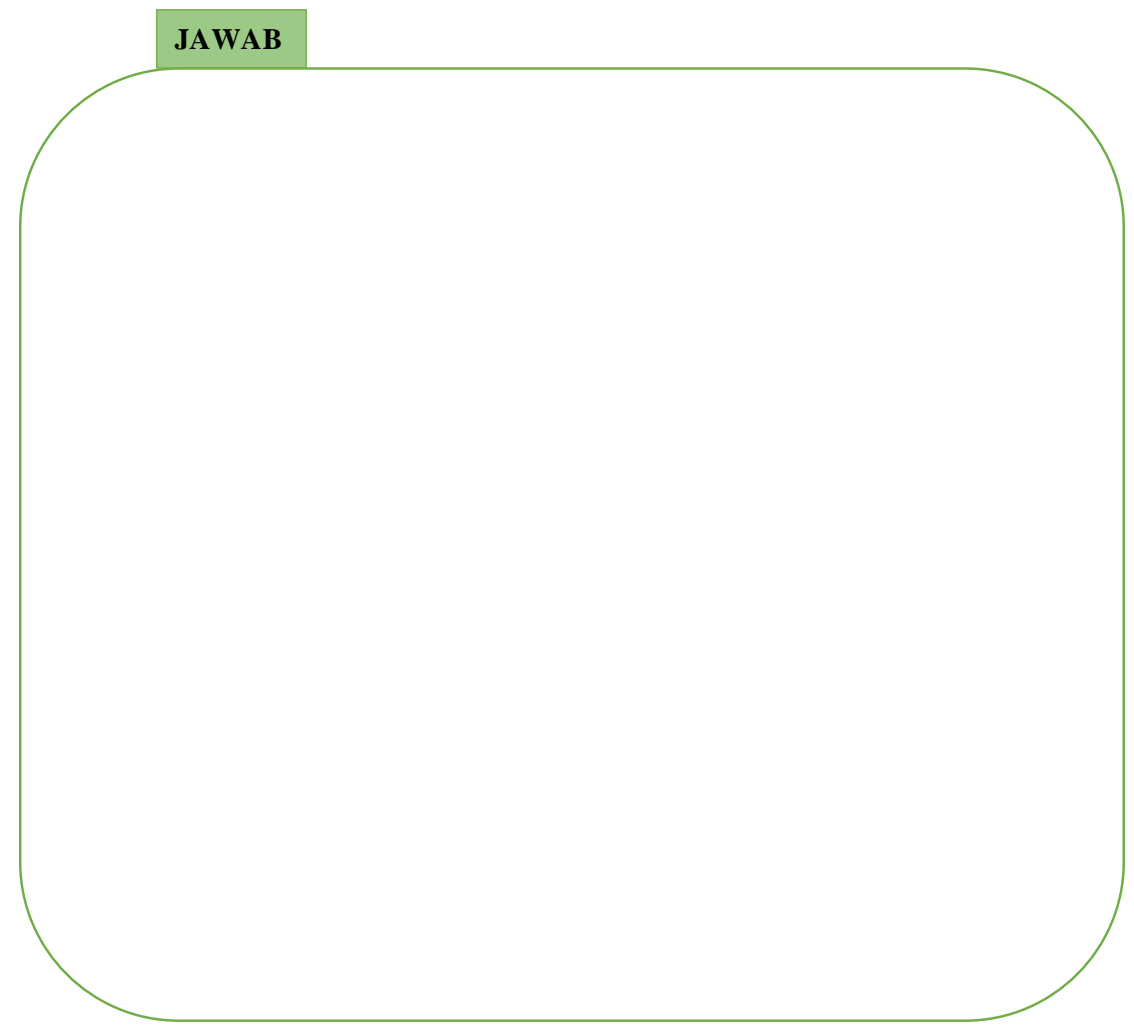

Berdasarkan soal di atas, dapat kita ketahui bahwa ketika larutan penyangga ditambahkan air sehingga larutan menjadi encer, konsentrasi dari basa lemah dan asam konjugatnya maupun konsentrasi dari asam lemah dan basa konjugatnya akan dengan faktor yang sama. Akan tetapi perbandingan konsentrasi dari spesi penyusunnya dalam larutan penyangga tersebut sehingga harga $\mathrm{pH}$ juga dikatakan

\section{B. Pengaruh Penambahan Sedikit Asam dan Sedikit Basa Pada Larutan Penyangga}
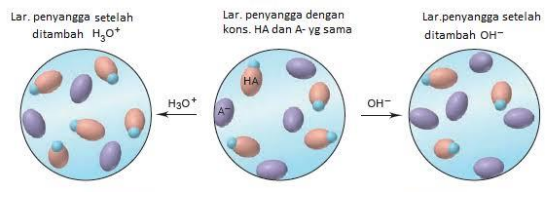

Bagaimana pengaruh penambahan sedikit asam pada larutan penyangga?

Misalnya, kalian memiliki larutan penyangga yang mengandung $\mathrm{NH}_{3}$ dan $\mathrm{NH}_{4}{ }^{+}$. Jika kalian menambahkan sedikit asam kuat ke dalam larutan penyangga tersebut, ion $\mathrm{H}^{+}$dari 
asam kuat bereaksi dengan

dan membentuk

Sebaliknya, ketika kalian menambahkan sedikit basa kuat ke dalam larutan penyangga tersebut, ion $\mathrm{OH}^{-}$dari basa kuat akan bereaksi dengan

membentuk Sehingga reaksi yang terjadi pada penambahan asam kuat dan basa kuat pada larutan penyangga tersebut adalah sebagai berikut.
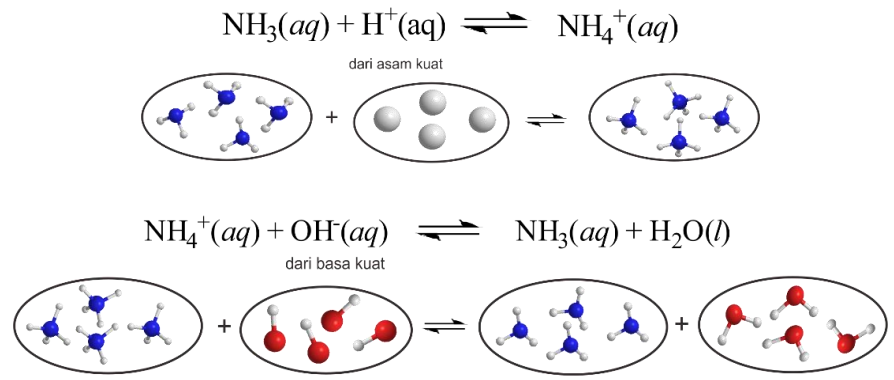

\section{SOAL}

1. Bila 2 liter larutan $\mathrm{NH}_{4} \mathrm{OH} 0,2 \mathrm{M}$ dicampurkan dengan 2 liter larutan $\mathrm{NH}_{4} \mathrm{Cl} 0,2$ $\mathrm{M}$ dan $\mathrm{K}_{\mathrm{b}} \mathrm{NH}_{4} \mathrm{OH}=1,8 \times 10^{-5}$. Tentukan:

a. $\mathrm{pH}$ larutan penyangga!

b. $\mathrm{pH}$ larutan penyangga setelah penambahan $10 \mathrm{~mL} \mathrm{HCl} \mathrm{0,1} \mathrm{M!}$

c. $\mathrm{pH}$ larutan penyangga setelah penambahan $10 \mathrm{~mL} \mathrm{NaOH} 0,1 \mathrm{M}$ !

2. Larutan penyangga yang terdiri dari $50 \mathrm{~mL} \mathrm{CH}_{3} \mathrm{COOH} 0,1 \mathrm{M}$ dengan $50 \mathrm{~mL}$ $\mathrm{CH}_{3} \mathrm{COONa} 0,1 \mathrm{M}\left(\mathrm{Ka} \mathrm{CH}_{3} \mathrm{COOH}=1,8 \times 10^{-5}\right.$ mempunyai $\mathrm{pH}=5-\log 1,8$.

Tentukan:

a. pH larutan penyangga setelah penambahan $20 \mathrm{~mL} \mathrm{HCl} \mathrm{0,1} \mathrm{M!}$

b. $\mathrm{pH}$ larutan penyangga setelah penambahan $20 \mathrm{~mL} \mathrm{NaOH} \mathrm{0,1} \mathrm{M}$ !

\section{Catatan:}

Sertakan gambar molekul pada level submikroskopik sesuai dengan imajinasi pada saat proses pembelajaran!

\section{JAWAB}


Berdasarkan penyelesaian soal di atas, dapat disimpulkan bahwa

\section{Peranan Larutan Penyangga dalam Kehidupan Sehari-hari}

Larutan penyangga banyak digunakan dalam kehidupan sehari-hari, contohnya seperti pada bacaan berikut ini.

\section{PERAN LARUTAN PENYANGGA DALAM TUBUH}
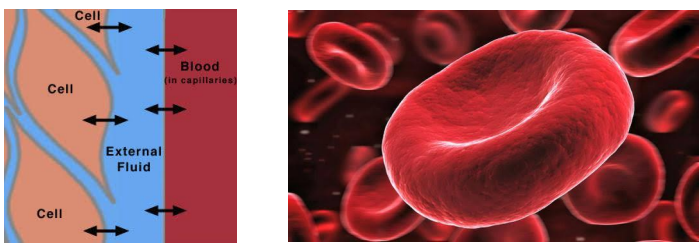

Pada makhluk hidup terdapat berbagai macam cairan seperti air, sel darah, dan kelenjar. Cairan ini berfungsi sebagai pengangkut zat makanan dan pelarut zat kimia di dalamnya. Berlangsungnya reaksi itu bergantung pada enzim tertentu, dan tiap enzim bekerja efektif pada $\mathrm{pH}$ tertentu ( $\mathrm{pH}$ optimum). Oleh sebab itu, cairan dalam makhluk hidup mengandung larutan penyangga untuk mempertahankan $\mathrm{pH}$-nya.

Larutan penyangga dalam sel adalah pasangan asam-basa konjugasi $\mathrm{H}_{2} \mathrm{PO}_{4}^{-}$dan $\mathrm{HPO}_{4}{ }^{2-}$. Jika pada sistem ada asam dan basa, larutan akan bereaksi dengan asam dan basa sebagai berikut.

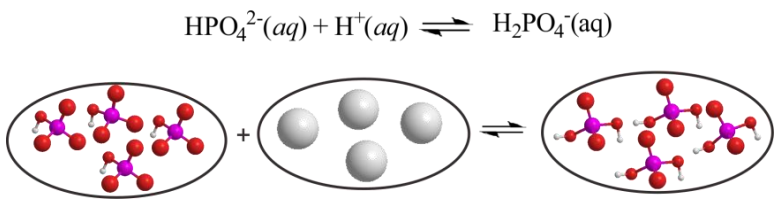

$$
\mathrm{H}_{2} \mathrm{PO}_{4}^{-}(\mathrm{aq})+\mathrm{OH}^{-}(\mathrm{aq}) \rightleftharpoons \mathrm{HPO}_{4}^{2-}(a q)+\mathrm{H}_{2} \mathrm{O}(l)
$$
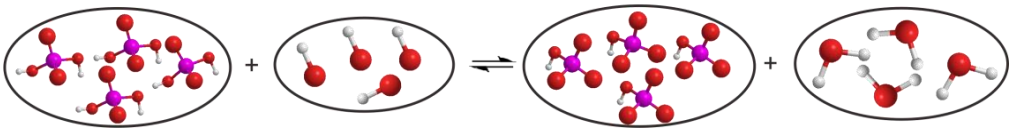

Akibat reaksi tersebut pada sel ini tetap terdapat cairan penyangga $\mathrm{H}_{2} \mathrm{PO}_{4}^{-}$dengan $\mathrm{HPO}_{4}{ }^{2-}$.

Larutan penyangga pada darah adalah pasangan asam basa konjugasi $\mathrm{H}_{2} \mathrm{CO}_{3}$ dan $\mathrm{HCO}_{3}{ }^{-}$. Jika larutan penyangga bereaksi dengan asam dan basa, maka akan terjadi reaksi: 


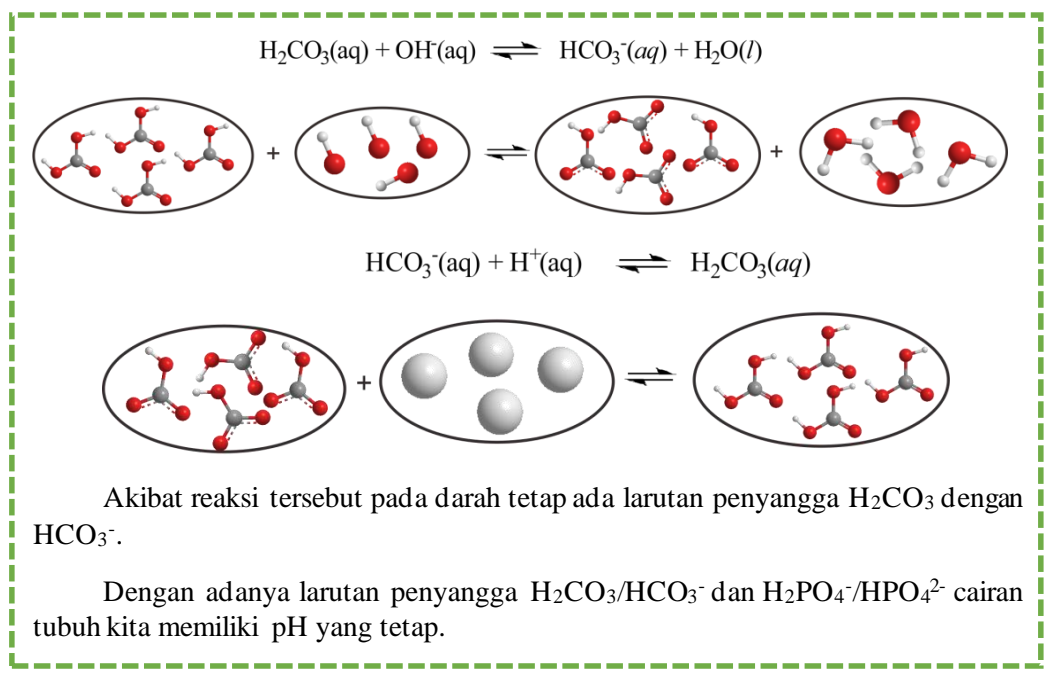

\section{TUGAS}

Carilah 3 peranan larutan penyangga yang lain dalam kehidupan sehari-hari selain contoh di atas! 


\section{LEMBAR KERJA SISWA (LKS) INDIVIDU}

\section{Latihan Soal}

1. Tentukan $\mathrm{pH} 1 \mathrm{~L}$ larutan penyangga yang mengandung $0,1 \mathrm{~mol} \mathrm{NH}_{3}$ dan $0,1 \mathrm{~mol} \mathrm{NH}_{4} \mathrm{Cl}$ dan tentukan pula $\mathrm{pH}$ larutan jika pada larutan ditambahkan $10 \mathrm{~mL} \mathrm{HCl} \mathrm{0,1} \mathrm{M}$ ! $\left(\mathrm{Kb}=1,8 \times 10^{-5}\right)$

2. Tentukan $\mathrm{pH}$ dari $200 \mathrm{~mL}$ larutan $\mathrm{CH}_{3} \mathrm{COOH} \mathrm{0,2} \mathrm{M}$ dicampur dengan $300 \mathrm{~mL}$ larutan $\mathrm{CH}_{3} \mathrm{COOK} 0,2 \mathrm{M}$. Tentukan pula $\mathrm{pH}$ larutan jika ditambahkan $10 \mathrm{~mL}$ larutan $\mathrm{KOH} 0,1 \mathrm{M}$ ! $\left(\mathrm{Ka} \mathrm{CH}_{3} \mathrm{COOH}=1,8 \times 10^{-5}\right)$

3. Jelaskan dengan grafik terjadinya larutan penyangga pada titrasi $20 \mathrm{~mL} \mathrm{CH}_{3} \mathrm{COOH} 1 \mathrm{M}$ dengan $20 \mathrm{~mL}$ $\mathrm{NaOH} 1 \mathrm{M}$ !

\section{Catatan:}

Sertakan gambar molekul pada level submikroskopik sesuai dengan imajinasi pada saat proses pembelajaran!

\section{Kompetensi Dasar:}

3.12 Menjelaskan prinsip kerja, perhitungan $\mathrm{pH}$, dan peran larutan penyangga dalam tubuh makhluk hidup.

4.12 Membuat larutan penyangga dengan $\mathrm{pH}$ tertentu.

\section{Indikator:}

3. Memahami pengaruh penambahan sedikit asam, sedikit basa dan pengenceran pada larutan penyangga

4. Menyebutkan kegunaan larutan penyangga dalam kehidupan sehari-hari.

\section{Tahukah Kamu?}

Larutan penyangga mengandung konsepkonsep yang dekat dengan kehidupan sehari-hari. Peranan larutan penyangga tidak hanya terbatas pada tubuh makhluk hidup, larutan penyangga juga digunakan dalam industri minuman. Menjaga $\mathrm{pH}$ dalam minuman merupakan hal yang sangat penting agar minuman tersebut dapat bertahan lama. Oleh karena itu, dalam industri minuman, penggunaan larutan penyangga dalam pembuatan produknya merupakan hal yang wajib dilakukan. Salah satunya adalah pada gambar kemasan produk di samping. Pada komposisi yang tercantum pada kemasan minuman tersebut, yang berfungsi sebagai larutan penyangga adalah asam sitrat dan natrium sitrat.

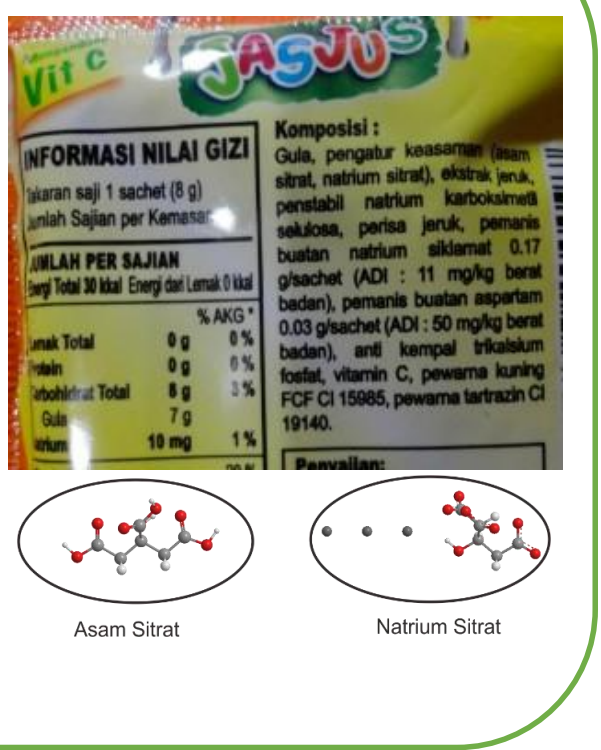




\section{RUBRIK PENILAIAN KETERAMPILAN \\ PRAKTIKUM LARUTAN PENYANGGA}

\begin{tabular}{|c|c|c|c|}
\hline No. & Keterampilan & Skor & Kriteria Penskoran \\
\hline \multirow{4}{*}{1.} & \multirow{4}{*}{$\begin{array}{l}\text { Menggunakan } \\
\text { pipet tetes dengan } \\
\text { benar }\end{array}$} & 4 & $\begin{array}{l}\text { 1) Jika peserta didik mengambil larutan dengan cara } \\
\text { memencet balon karet di luar, lalu dilepas di dalam } \\
\text { larutan dan diangkat. } \\
\text { 2) Jika peserta didik meneteskan larutan dengan } \\
\text { memencet kembali balon karet pada pipet dan ujung } \\
\text { pipet ditempelkan pada dinding dalam bagian atas. }\end{array}$ \\
\hline & & 3 & $\begin{array}{l}\text { 1) Jika peserta didik mengambil larutan dengan cara } \\
\text { memencet balon karet di luar, lalu dilepas diluar } \\
\text { larutan dan diangkat. } \\
\text { 2) Jika peserta didik meneteskan larutan dengan } \\
\text { memencet kembali balon karet pada pipet dan ujung } \\
\text { pipet masuk ke dalam bagian larutan. }\end{array}$ \\
\hline & & 2 & $\begin{array}{l}\text { 1) Jika peserta didik mengambil larutan dengan cara } \\
\text { memencet balon karet di dalam larutan, lalu dilepas } \\
\text { didalam larutan dan diangkat. } \\
\text { 2) Jika peserta didik meneteskan larutan dengan } \\
\text { memencet kembali balon karet pada pipet dan ujung } \\
\text { pipet ditempelkan pada dinding dalam bagian atas. }\end{array}$ \\
\hline & & 1 & $\begin{array}{l}\text { 1) Jika peserta didik mengambil larutan dengan cara } \\
\text { memencet balon karet di luar, lalu dilepas diluar } \\
\text { larutan dan diangkat. } \\
\text { 2) Jika peserta didik meneteskan larutan dengan } \\
\text { memencet kembali balon karet pada pipet dan ujung } \\
\text { pipet berada jauh di atas gelas ukur. }\end{array}$ \\
\hline \multirow{2}{*}{2.} & \multirow{2}{*}{$\begin{array}{l}\text { Membaca skala } \\
\text { hasil pengukuran } \\
\text { volume suatu } \\
\text { larutan tidak } \\
\text { berwarna pada } \\
\text { gelas ukur dengan } \\
\text { benar }\end{array}$} & 4 & $\begin{array}{l}\text { 1) Jika peserta didik menempatkan gelas ukur pada } \\
\text { tempat yang datar ketika melihat meniskus dari } \\
\text { larutan. } \\
\text { 2) Jika peserta didik membaca meniskus bawah pada } \\
\text { gelas ukur dengan melihat pada permukaan larutan } \\
\text { secara mendatar atau horizontal (mata sejajar } \\
\text { dengan meniskus). }\end{array}$ \\
\hline & & 3 & $\begin{array}{l}\text { 1) Jika peserta didik menempatkan gelas ukur pada } \\
\text { tempat yang tidak datar ketika melihat meniskus } \\
\text { bawah dari larutan, misalnya sambil diangkat. } \\
\text { 2) Jika peserta didik membaca meniskus pada gelas } \\
\text { ukur dengan melihat pada permukaan larutan secara } \\
\text { mendatar atau horizontal (mata sejajar dengan } \\
\text { meniskus) }\end{array}$ \\
\hline
\end{tabular}




\begin{tabular}{|c|c|c|c|}
\hline & & 2 & $\begin{array}{l}\text { 1) Jika peserta didik menempatkan gelas ukur pada } \\
\text { tempat yang datar ketika melihat meniskus dari } \\
\text { larutan. } \\
\text { 2) Jika peserta didik membaca meniskus bawah pada } \\
\text { gelas ukur dengan melihat pada permukaan larutan } \\
\text { dari arah atas atau arah bawah (mata tidak sejajar } \\
\text { dengan meniskus). }\end{array}$ \\
\hline & & 1 & $\begin{array}{l}\text { 1) Jika peserta didik menempatkan gelas ukur pada } \\
\text { tempat yang tidak datar ketika melihat meniskus } \\
\text { dari larutan, misalnya dengan diangkat. } \\
\text { 2) Jika peserta didik membaca meniskus bawah pada } \\
\text { gelas ukur dengan melihat pada permukaan larutan } \\
\text { dari arah atas atau bawah (mata tidak sejajar dengan } \\
\text { meniskus). }\end{array}$ \\
\hline \multirow{4}{*}{3.} & \multirow{4}{*}{$\begin{array}{l}\text { Menuang larutan } \\
\text { dari gelas ukur ke } \\
\text { dalam gelas kimia }\end{array}$} & 4 & $\begin{array}{l}\text { Jika peserta didik pada saat menuang larutan, gelas } \\
\text { ukur menempel pada dinding atau mulut gelas kimia } \\
\text { dan dilakukan secara perlahan. }\end{array}$ \\
\hline & & 3 & $\begin{array}{l}\text { Jika peserta didik pada saat menuang larutan, gelas } \\
\text { ukur menempel pada dinding atau mulut gelas kimia } \\
\text { namun tidak dilakukan secara perlahan. }\end{array}$ \\
\hline & & 2 & $\begin{array}{l}\text { Jika peserta didik pada saat menuang larutan, gelas } \\
\text { ukur tidak menempel pada dinding atau mulut gelas } \\
\text { kimia dan dilakukan secara perlahan. }\end{array}$ \\
\hline & & 1 & $\begin{array}{l}\text { Jika peserta didik pada saat menuang larutan, gelas } \\
\text { ukur tidak menempel pada dinding atau mulut gelas } \\
\text { kimia dan tidak dilakukan secara perlahan. }\end{array}$ \\
\hline \multirow{4}{*}{4.} & \multirow{4}{*}{$\begin{array}{l}\text { Membaca hasil } \\
\text { pengukuran } \mathrm{pH}\end{array}$} & 4 & $\begin{array}{l}\text { Jika peserta didik dapat membandingkan warna dari } \\
\text { kertas pH dengan indikator universal pada saat telah } \\
\text { kering dengan tepat. }\end{array}$ \\
\hline & & 3 & $\begin{array}{l}\text { Jika peserta didik dapat membandingkan warna dari } \\
\text { kertas pH dengan indikator universal pada saat telah } \\
\text { kering tetapi kurang tepat. }\end{array}$ \\
\hline & & 2 & $\begin{array}{l}\text { Jika peserta didik dapat membandingkan warna dari } \\
\text { kertas pH dengan indikator universal secara langsung } \\
\text { (masih basah) dengan tepat. }\end{array}$ \\
\hline & & 1 & $\begin{array}{l}\text { Jika peserta didik dapat membandingkan warna dari } \\
\text { kertas pH dengan indikator universal secara langsung } \\
\text { (masih basah) tetapi kurang tepat. }\end{array}$ \\
\hline \multirow{4}{*}{5.} & \multirow{4}{*}{$\begin{array}{l}\text { Mendiskusikan } \\
\text { hasil praktikum }\end{array}$} & 4 & $\begin{array}{l}\text { Jika peserta didik mendiskusikan hasil praktikum sesuai } \\
\text { konteks dan kompak. }\end{array}$ \\
\hline & & 3 & $\begin{array}{l}\text { Jika peserta didik mendiskusikan hasil praktikum sesuai } \\
\text { konteks namun tidak kompak. }\end{array}$ \\
\hline & & 2 & Jika peserta didik mendiskusikan tetapi di luar konteks. \\
\hline & & 1 & Jika peserta didik tidak mendiskusikan hasil praktikum. \\
\hline \multirow[t]{2}{*}{6.} & \multirow{2}{*}{$\begin{array}{l}\text { Melakukan } \\
\text { pengamatan } \\
\text { terhadap } \\
\text { perubahan pH } \\
\text { yang terjadi pada } \\
\text { jenis-jenis larutan }\end{array}$} & 4 & $\begin{array}{l}\text { Jika peserta didik mengamati dan menuliskan } \mathrm{pH} \text { awal, } \\
\text { perubahan } \mathrm{pH} \text { yang terjadi pada larutan saat ditambah } \\
\text { sedikit asam, sedikit basa, dan pengenceran dengan } \\
\text { lengkap }(20 \mathrm{pH}) \text {. }\end{array}$ \\
\hline & & 3 & $\begin{array}{l}\text { Jika peserta didik mengamati dan menuliskan } \mathrm{pH} \text { awal, } \\
\text { perubahan } \mathrm{pH} \text { yang terjadi pada larutan saat ditambah }\end{array}$ \\
\hline
\end{tabular}




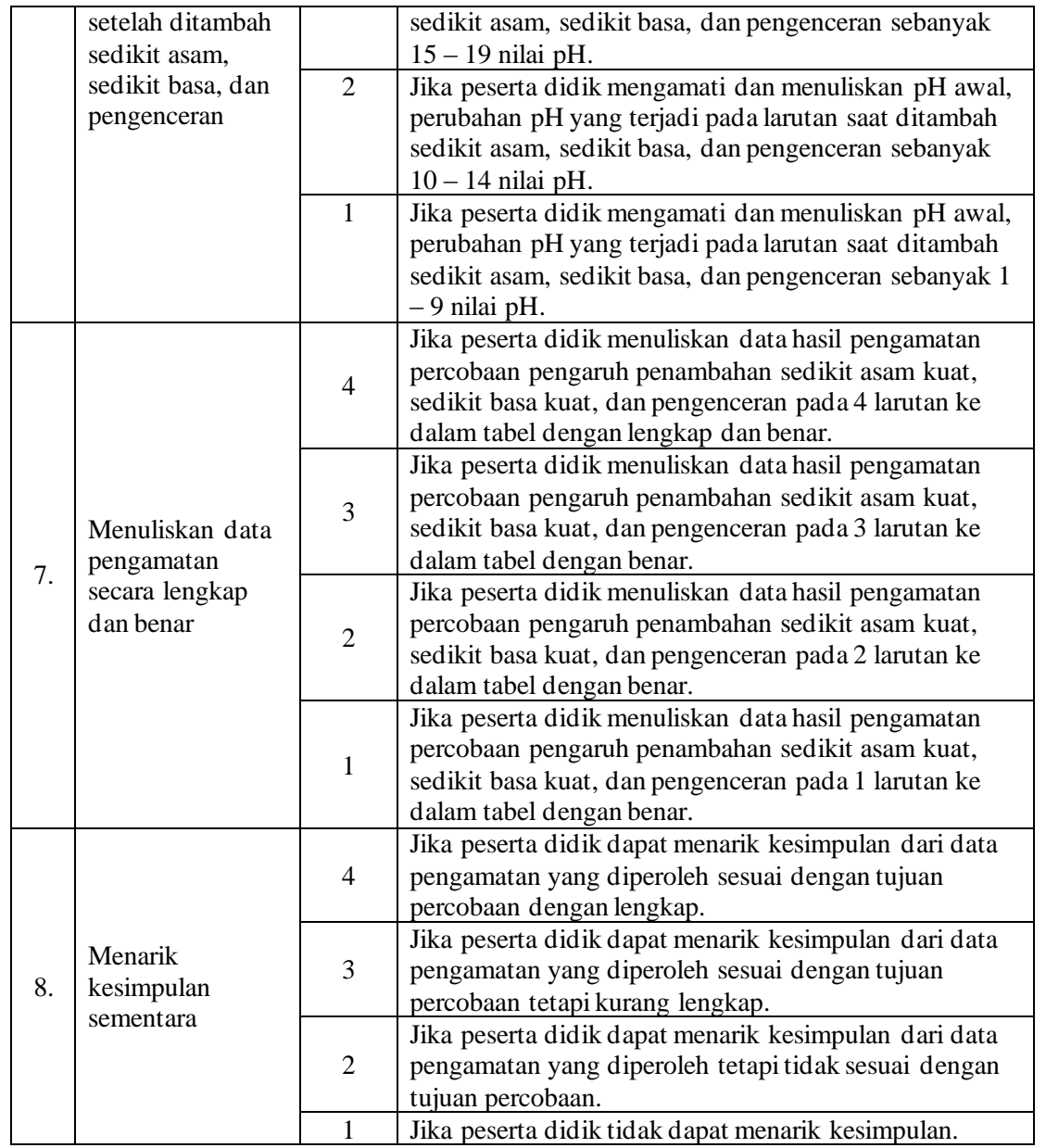

Skor maksimal $=32$

Nilai $=\frac{\text { Jumlah } \text { skor }}{\text { Skor maksimal }} \times 100$ 
Lampiran 7: Petunjuk Praktikum (Untuk Pertemuan 3)

\section{PETUNJUK PRAKTIKUM KIMIA LARU'I'AN PENYANGGA}

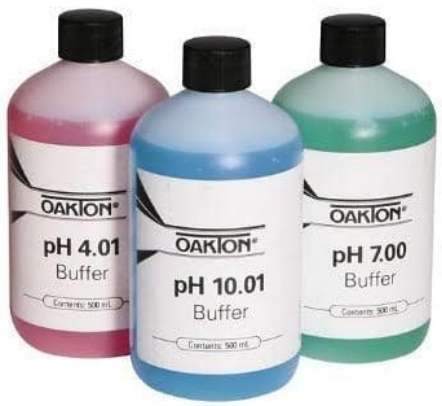

\section{Kompetensi Dasar:}

3.12 Menjelaskan prinsip kerja, perhitungan $\mathrm{pH}$, dan peran larutan penyangga dalam tubuh makhluk hidup.

4.12 Membuat larutan penyangga dengan $\mathrm{pH}$ tertentu.

\section{Indikator:}

7. Membuat larutan penyangga.

8. Menguji $\mathrm{pH}$ larutan penyangga sebelum dan sesudah penambahan sedikit asam, sedikit basa, dan pengenceran.

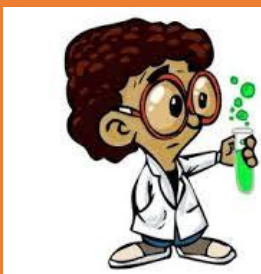

Kelas

Kelompok

Anggota Kelompok

1.

2.

3.

4.

5.

6.

"The only source of knowledge is experience (Satu-satunya sumber pengetahuan adalah pengalaman)" 


\section{Larutan Penyangga}

\section{A. Tujuan}

1. Mempelajari pembuatan larutan penyangga

2. Mempelajari pengaruh penambahan sedikit asam kuat, sedikit basa kuat dan pengenceran pada larutan penyangga

\section{B. Dasar Teori}

Larutan penyangga atau larutan buffer adalah larutan yang mengandung asam lemah dan basa konjugasinya atau basa lemah dan asam konjugasinya. Larutan penyangga merupakan larutan yang dapat mempertahankan $\mathrm{pH}$-nya. Larutan penyangga memiliki dua komponen yaitu asam dan basa. Asam akan berperan jika ada upaya untuk menaikkan $\mathrm{pH}$, sedangkan basa akan berperan jika ada upaya untuk menurunkan $\mathrm{pH}$. Asam dan basa disini merupakan pasangan asam dan basa konjugasi.

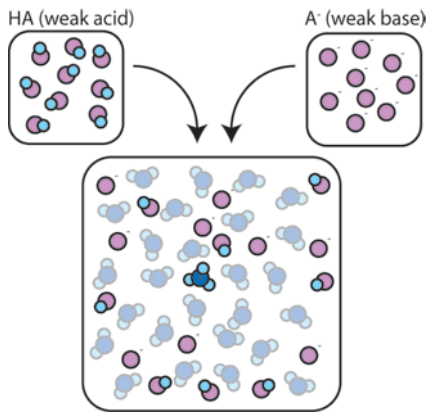

Larutan penyangga dapat dibagi menjadi dua, yaitu larutan penyangga asam dan larutan penyangga basa.

1) Larutan penyangga asam mengandung suatu asam lemah (HA) dan basa konjugasinya $\left(\mathrm{A}^{-}\right)$. Larutan penyangga asam mempertahankan $\mathrm{pH}$ pada daerah asam $(\mathrm{pH}<7)$, contoh $\mathrm{HCOOH} / \mathrm{HCOO}^{-}$. Persamaan umum reaksinya dapat dituliskan senagai berikut.

$$
\mathrm{HA}(a q) \rightleftharpoons \mathrm{H}^{+}(a q)+\mathrm{A}^{-}(a q)
$$

Asam lemah

$$
\text { Basa konjugasi }
$$

2) Larutan penyangga basa mengandung basa lemah (B) dan asam konjugasinya $\left(\mathrm{BH}^{+}\right)$. Larutan penyangga basa mempertahankan $\mathrm{pH}$ pada daerah basa $(\mathrm{pH}>7)$, contoh $\mathrm{NH}_{3} / \mathrm{NH}_{4}{ }^{+}$. Persamaan umum reaksinya dapat dituliskan sebagai berikut.

$$
\underset{\text { Basa lemah }}{\mathrm{B}(a q)+\mathrm{H}_{2} \mathrm{O}(l) \rightleftharpoons} \underset{\text { Asam konjugasi }}{\mathrm{BH}^{+}(a q)+\mathrm{OH}^{-}(a q)}
$$

Larutan penyangga dapat dibuat dengan dua cara. Pertama, dengan cara mencampurkan langsung komponen-komponennya yaitu suatu asam lemah dengan garamnya atau suatu basa 
lemah dengan garamnya. Kedua, dengan cara mencampurkan asam lemah dan basa kuat dengan jumlah asam lemah yang berlebih atau mencampurkan basa lemah dan asam kuat dengan jumlah basa lemah berlebih.

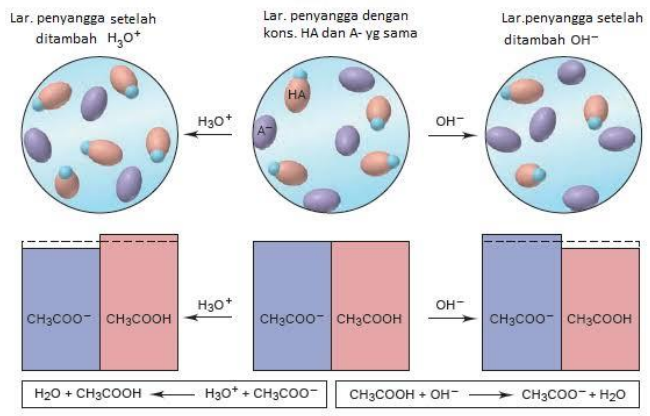

Harga $\mathrm{pH}$ larutan penyangga bergantung pada perbandingan konsentrasi asam lemah dengan konsentrasi basa konjugatnya atau basa lemah dengan konsentrasi asam konjugatnya. Penambahan sedikit asam kuat atau basa kuat ke dalam larutan penyangga tidak akan mengubah harga $\mathrm{pH}$ larutan penyangga tersebut.

Ketika ke dalam larutan penyangga ditambahkan air sehingga larutan menjadi lebih encer, konsentrasi dari asam lemah dan basa konjugatnya maupun konsentrasi basa lemah dan asam konjugatnya akan menurun dengan faktor yang sama. Akan tetapi perbandingan konsentrasi dari spesi penyusunnya dalam larutan penyangga tersebut tidak mengalami perubahan sehingga harga $\mathrm{pH}$ juga tidak berubah.

\section{Alat dan Bahan}

Alat:

1. Gelas kimia

2. Gelas ukur

3. Pipet Tetes

4. Tabung reaksi

5. Batang pengaduk

6. Indikator universal

\section{Bahan:}

1. Larutan $\mathrm{CH}_{3} \mathrm{COOH} 0,1 \mathrm{M}$

2. Larutan $\mathrm{NH}_{3} 0,1 \mathrm{M}$

3. Larutan $\mathrm{NH}_{4} \mathrm{Cl} 0,1 \mathrm{M}$

4. Larutan $\mathrm{NaOH} 0,1 \mathrm{M}$

5. Larutan $\mathrm{NaCl} 0,1 \mathrm{M}$

6. Aquades

7. Minuman bersoda 


\section{Langkah Kerja}

1. Sediakan 5 buah gelas kimia dan berilah label A, B, C, D dan E.

2. Pada gelas kimia A, masukkan $4 \mathrm{~mL} \mathrm{CH}_{3} \mathrm{COOH} \mathrm{0,1} \mathrm{M} \mathrm{dan} 2 \mathrm{~mL} \mathrm{NaOH} \mathrm{0,1} \mathrm{M.} \mathrm{Kemudian}$ campuran diaduk.

3. Pada gelas kimia $\mathrm{B}$, masukkan $3 \mathrm{~mL} \mathrm{NH}_{3} 0,1 \mathrm{M}$ lalu tambahkan $3 \mathrm{~mL} \mathrm{NH} 4 \mathrm{Cl} 0,1 \mathrm{M}$. Kemudian campuran diaduk.

4. Pada gelas kimia $\mathrm{C}$, masukkan $6 \mathrm{~mL} \mathrm{NaCl} \mathrm{0,1} \mathrm{M}$.

5. Pada gelas kimia $\mathrm{D}$, masukkan $6 \mathrm{~mL}$ aquades.

6. Pada gelas kimia E, masukkan $6 \mathrm{~mL}$ minuman bersoda

7. Periksa $\mathrm{pH}$ larutan pada masing-masing gelas kimia dengan kertas indikator universal dan catat hasilnya.

8. Sediakan 3 tabung reaksi (A, B dan C), lalu isilah masing-masing tabung dengan $2 \mathrm{~mL}$ larutan yang ada di gelas kimia A (campuran larutan $\mathrm{CH}_{3} \mathrm{COOH}$ dan $\mathrm{NaOH}$ ).

9. Tetesi:
a. tabung a dengan $1 \mathrm{~mL}$ larutan $\mathrm{HCl} 0,1 \mathrm{M}$
b. tabung b dengan $1 \mathrm{~mL}$ larutan $\mathrm{NaOH} 0,1 \mathrm{M}$
c. tabung c dengan $1 \mathrm{~mL}$ aquades

10. Ukur $\mathrm{pH}$ masing-masing larutan dalam tabung reaksi (tabung $\mathrm{a}, \mathrm{b}, \mathrm{dan} \mathrm{c}$ ) dengan menggunakan indikator universal dan catat hasilnya.

11. Lakukan perlakuan yang sama seperti no. $8-10$, tetapi larutannya diganti:

a. Larutan yang ada di gelas kimia $\mathrm{B}$ (campuran larutan $\mathrm{NH}_{3}$ dan $\mathrm{NH}_{4} \mathrm{Cl}$ )

b. Larutan $\mathrm{NaCl} 0,1 \mathrm{M}$

c. Aquades

d. Minuman bersoda

\section{Data Pengamatan}

Diketahui jenis larutan:

- $\mathrm{CH}_{3} \mathrm{COOH}$ 0,1 $\mathrm{M}+\mathrm{NaOH} 0,1 \mathrm{M}$ : sebagai larutan A

Gambar level submikroskopik:

- $\mathrm{NH}_{3} 0,1 \mathrm{M}+\mathrm{NH}_{4} \mathrm{Cl}$ 0,1 M : sebagai larutan B

Gambar level submikroskopik: 
- $\mathrm{NaCl} \mathrm{0,1} \mathrm{M} \mathrm{:} \mathrm{sebagai} \mathrm{larutan} \mathrm{C}$

Gambar level submikroskopik:

- $\mathrm{H}_{2} \mathrm{O}$ : sebagai larutan $\mathrm{D}$

Gambar level submikroskopik:

- Minuman bersoda: sebagai larutan E

Gambar level submikroskopik:

1. Tentukan $\mathrm{pH}$ awal dari masing-masing jenis larutan!

\begin{tabular}{|c|c|}
\hline Jenis Larutan & pH Awal \\
\hline Larutan A & \\
\hline Larutan B & \\
\hline Larutan C & \\
\hline Larutan D & \\
\hline Larutan E & \\
\hline
\end{tabular}

2. Tentukan $\mathrm{pH}$ dari masing-masing larutan setelah ditambah sedikit asam kuat, sedikit basa kuat, dan pengenceran!

\begin{tabular}{|c|c|c|c|}
\hline \multirow{2}{*}{ Jenis Larutan } & \multicolumn{3}{|c|}{ pH setelah penambahan } \\
\hline & HCl 0,1 M & NaOH 0,1 M & Aquades \\
\hline Larutan A & & & \\
\hline Larutan B & & & \\
\hline Larutan C & & & \\
\hline Larutan D & & & \\
\hline Larutan E & & & \\
\hline
\end{tabular}

3. Tentukan selisih perubahan $\mathrm{pH}$ !

\begin{tabular}{|c|c|c|c|}
\hline Jenis larutan & pH awal & pH akhir & Selisih penambahan pH \\
\hline Larutan A & & & \\
\hline Larutan B & & & \\
\hline Larutan C & & & \\
\hline
\end{tabular}




\begin{tabular}{|l|l|l|l|}
\hline Larutan D & & & \\
\hline Larutan E & & & \\
\hline
\end{tabular}

4. Kategorikan perubahan $\mathrm{pH}$ masing-masing jenis larutan!

\begin{tabular}{|c|c|c|c|}
\hline \multirow{2}{*}{ Jenis larutan } & \multirow{2}{*}{$\begin{array}{c}\text { Selisih perubahan } \\
\mathbf{p H}\end{array}$} & \multicolumn{2}{|c|}{ Kategori jumlah selisih perubahan $\mathbf{~ H}$} \\
\cline { 3 - 4 } & & $\begin{array}{c}\text { Sedikit/relatif } \\
\text { tetap }\end{array}$ & Banyak \\
\hline Larutan A & & & \\
\hline Larutan B & & & \\
\hline Larutan C & & & \\
\hline Larutan D & & & \\
\hline Larutan E & & & \\
\hline
\end{tabular}

5. Kelompokkan masing-masing jenis larutan berdasarkan kategori perubahan $\mathrm{pH}$ !

\begin{tabular}{|c|c|}
\hline Perubahan pH dalam jumlah & Jenis larutan \\
\hline Sedikit/relatif tetap & \\
\hline Banyak & \\
\hline
\end{tabular}

6. Tentukan larutan yang termasuk larutan penyangga dan bukan larutan penyangga!

\begin{tabular}{|c|c|c|c|c|c|c|}
\hline \multirow[b]{2}{*}{ No. } & \multirow[b]{2}{*}{ Jenis Larutan } & \multirow{2}{*}{$\begin{array}{c}\text { pH } \\
\text { Awal }\end{array}$} & \multicolumn{3}{|c|}{ pH setelah penambahan } & \multirow{2}{*}{$\begin{array}{c}\text { Larutan } \\
\text { Penyangga } \\
\text { atau Bukan }\end{array}$} \\
\hline & & & HCl 0,1 M & $\mathrm{NaOH} \mathrm{0,1} \mathrm{M}$ & Aquades & \\
\hline & & & & & & \\
\hline & & & & & & \\
\hline & & & & & & \\
\hline & & & & & & \\
\hline & & & & & & \\
\hline
\end{tabular}

\section{Kesimpulan:}




\section{LEMBAR PENILAIAN LAPORAN PRAKTIKUM}

\begin{tabular}{|c|c|c|}
\hline No. & Nama siswa & Nilai \\
\hline 1. & & \\
\hline 2. & & \\
\hline 3. & & \\
\hline 4. & & \\
\hline 5. & & \\
\hline
\end{tabular}

\section{Indikator penilaian:}

\begin{tabular}{|c|c|c|}
\hline No. & Komponen Penilaian & Skor \\
\hline 1. & $\begin{array}{l}\text { Cover (Judul praktikum, identitas peserta didik, identitas sekolah, tahun } \\
\text { ajaran) }\end{array}$ & \\
\hline 2. & Tujuan Praktikum & \\
\hline 3. & Dasar Teori & \\
\hline 4. & Alat dan Bahan & \\
\hline 5. & Prosedur Kerja & \\
\hline 6. & Hasil Pengamatan dan Data Hasil Pengamatan & \\
\hline 7. & Pembahasan & \\
\hline 8. & Kesimpulan & \\
\hline 9. & Kolom Tanda Tangan Praktikan dan Guru & \\
\hline 10. & Daftar Pustaka & \\
\hline & Total & \\
\hline
\end{tabular}

Skor maksimum $=145$

Nilai $=\frac{\text { Skor yang didapatkan }}{\text { Skor maksimum }} \times 100$ 


\section{LEMBAR OBSERVASI KEAKTIFAN SISWA}

Hari/Tanggal :

Kelas

Berikan penilaian sesuai dengan rubrik yang dilaksanakan oleh tiap-tiap siswa dengan cara memberi tanda cek $(\sqrt{ })$ pada kolom yang sesuai!

\section{Keterangan:}

- Jika tidak memenuhi rubrik, kosongkon kolom (kolom tidak dicentang, berarti nilainya dihitung nol)!

- Skala penilaian: $0-4$

\section{Aspek yang dinilai :}

A = Kesiapan mengikuti pelajaran

$\mathrm{B}=$ Menyimak penjelasan guru

$\mathrm{C}=$ Aktif bertanya saat KBM

$\mathrm{D}=$ Merespon tugas

\begin{tabular}{|c|c|c|c|c|c|c|c|c|c|c|c|c|c|c|c|c|c|c|}
\hline \multirow{2}{*}{ No. } & \multirow{2}{*}{ Nama } & \multicolumn{4}{|c|}{$\mathbf{A}$} & \multicolumn{4}{|c|}{$\mathbf{B}$} & \multicolumn{4}{|c|}{$\mathbf{C}$} & \multicolumn{4}{|c|}{ D } & \multirow{2}{*}{ Rata-rata } \\
\hline & & 1 & 2 & 3 & 4 & 1 & 2 & 3 & 4 & 1 & 2 & 3 & 4 & 1 & 2 & 3 & 4 & \\
\hline 1. & & & & & & & & & & & & & & & & & & \\
\hline 2. & & & & & & & & & & & & & & & & & & \\
\hline 3. & & & & & & & & & & & & & & & & & & \\
\hline 4. & & & & & & & & & & & & & & & & & & \\
\hline 5. & & & & & & & & & & & & & & & & & & \\
\hline
\end{tabular}

Skor maksimal $=16$

Nilai $=\frac{\text { jumlah skor }}{\text { Skor maksimal }} \times 100$ 
Lampiran 10. RPP Kelas Kontrol Beserta Lampirannya

\section{RENCANA PELAKSANAAN PEMBELAJARAN}

$\begin{array}{lll}\text { Nama Sekolah } & : & \text { SMAN 9 Semarang } \\ \text { Mata Pelajaran } & : & \text { Kimia } \\ \text { Kelas/Semester } & : & \text { XI (Kelas Kontrol)/2 } \\ \text { Materi Pokok } & : & \text { Larutan Penyangga } \\ \text { Alokasi Waktu } & : & 2 \times 45 \text { menit (2 JPL) @3 pertemuan }\end{array}$

\section{A. Kompetensi Inti}

Kompetensi Sikap Spiritual dan Kompetensi Sikap Sosial dicapai melalui pembelajaran tidak langsung (indirect teaching) pada pembelajaran Kompetensi Pengetahuan dan Kompetensi Keterampilan melalui keteladanan, pembiasaan, dan budaya sekolah dengan memperhatikan karakteristik mata pelajaran, serta kebutuhan dan kondisi peserta didik.

KI-1 : Menghayati dan mengamalkan agama yang dianutnya.

KI-2 : Menunjukkan perilaku jujur, disiplin, tanggung jawab, peduli (gotong royong, kerjasama, toleran, damai), santun, responsif dan pro aktif dan menunjukkan sikap sebagai bagian dari solusi atas berbagai permasalahan dalam berinteraksi secara efektif dengan lingkungan sosial dan alam serta dalam menempatkan diri sebagai cerminan bangsa dalam pergaulan dunia.

KI-3 : Memahami, menerapkan dan menganalisis pengetahuan faktual, konseptual, prosedural, dan metakognitif berdasarkan rasa ingin tahunya tentang ilmu pengetahuan, teknologi, seni, budaya, dan humaniora dengan wawasan kemanusiaan, kebangsaan, kenegaraan, dan peradaban terkait penyebab fenomena dan kejadian, serta menerapkan pengetahuan prosedural pada bidang kajian yang spesifik sesuai dengan bakat dan minatnya untuk memecahkan masalah.

KI-4 : Mengolah, menalar, dan menyaji dalam ranah konkrit dan ranah abstrak terkait dengan pengembangan dari yang dipelajarinya di sekolah secara mandiri, bertindak secara efektif dan kreatif, serta mampu menggunakan metode sesuai kaidah keilmuan.

B. Kompetensi Dasar dan Indikator Pencapaian Kompetensi (IPK)

\begin{tabular}{|l|l|}
\hline \multicolumn{1}{|c|}{ Kompetensi Dasar } & \multicolumn{1}{|c|}{ Indikator } \\
\hline Siswa dapat: & Siswa dapat: \\
3.12 $\begin{array}{l}\text { Menjelaskan prinsip kerja, } \\
\text { perhitungan pH, dan peran }\end{array}$ & - Menjelaskan pengertian larutan penyangga \\
$\begin{array}{l}\text { larutan penyangga dalam } \\
\text { tubuh makhluk hidup. }\end{array}$ & - Memahami komponen larutan penyangga \\
& - Menghitung pH larutan penyangga \\
& $\begin{array}{l}\text { Memahami pengaruh penambahan sedikit } \\
\text { larutan penyangga }\end{array}$ \\
\hline
\end{tabular}




\begin{tabular}{|c|c|}
\hline & $\begin{array}{l}\text { - Menyebutkan kegunaan larutan penyangga } \\
\text { dalam kehidupan sehari-hari }\end{array}$ \\
\hline $\begin{array}{l}\text { 4.12 Membuat larutan penyangga } \\
\text { dengan } \mathrm{pH} \text { tertentu. }\end{array}$ & $\begin{array}{l}\text { - Membuat larutan penyangga } \\
\text { - Menguji pH larutan penyangga sebelum } \\
\text { dan sesudah penambahan sedikit asam, } \\
\text { sedikit basa, dan pengenceran }\end{array}$ \\
\hline
\end{tabular}

\section{Tujuan Pembelajaran}

Melalui metode ceramah diharapkan siswa mampu:

1. Menjelaskan pengertian larutan penyangga dengan benar.

2. Memahami komponen larutan penyangga dengan benar.

3. Menghitung $\mathrm{pH}$ larutan penyangga dengan benar.

4. Memahami pengaruh penambahan sedikit asam kuat, sedikit basa kuat dan pengenceran pada larutan penyangga dengan baik.

5. Menyebutkan kegunaan larutan penyangga dalam kehidupan sehari-hari dengan benar.

6. Membuat larutan penyangga dengan benar.

7. Menguji $\mathrm{pH}$ larutan penyangga sebelum dan sesudah penambahan sedikit asam, sedikit basa, dan pengenceran dengan teliti.

\section{Materi Pembelajaran}

\section{Pertemuan Pertama:}

1. Pengertian larutan penyangga

2. Pembentukan larutan penyangga

3. $\mathrm{pH}$ larutan penyangga

\section{Pertemuan Kedua:}

1. Pengaruh penambahan sedikit asam, sedikit basa dan pengenceran pada larutan penyangga.

2. Kegunaan larutan penyangga.

\section{Pengertian Ketiga:}

1. Perubahan $\mathrm{pH}$ setelah penambahan sedikit asam, sedikit basa dan pengenceran pada larutan penyangga.

E. Pendekatan, Metode, dan Model Pembelajaran
1. Pendekatan
: Saintific Approach;
2. Metode
: Ceramah;
3. Model Pembelajaran

F. Media dan Alat Pembelajaran
1. Media
: LKS, Power point, buku paket Kimia
2. Alat
: LCD, alat tulis, spidol, papan tulis, Laptop

\section{G. Sumber Belajar}

1. Sudarmo, Unggul. 2013. Kimia Untuk SMA/MA Kelas XI. Jakarta: Penerbit Erlangga. 
2. Kalsum, Siti. 2009. Kimia 2: Kelas XI SMA dan MA. Jakarta: Pusat Perbukuan Departemen Pendidikan Nasional.

3. Permana, Irvan. 2009. Memahami Kimia 2: SMA/MA Untuk Kelas XI. Jakarta: Pusat Perbukuan Departemen Pendidikan Nasional.

4. Buku kimia sumber lain yang relevan

5. Internet

\section{H. Langkah-Langkah Kegiatan}

Pertemuan Pertama $(2 \times 45$ menit $)$ :

\begin{tabular}{|c|c|c|}
\hline Kegiatan & Deskripsi Kegiatan & $\begin{array}{l}\text { Alokasi } \\
\text { Waktu }\end{array}$ \\
\hline Pendahuluan & $\begin{array}{l}\text { - Guru membuka pembelajaran dengan mengucapkan } \\
\text { salam. } \\
\text { - Guru mengkondisikan peserta didik untuk siap } \\
\text { belajar dengan berdoa bersama yang dipimpin oleh } \\
\text { salah seorang peserta didik. } \\
\text { - Guru mengecek kehadiran peserta didik. } \\
\text { - Peserta didik dirangsang dengan diberikan } \\
\text { pertanyaan seperti berikut: "Apakah kalian pernah } \\
\text { minum minuman bersoda?" Jika peserta didik } \\
\text { menjawab "Ya", kemudian kita tanyakan lagi, } \\
\text { "Tahukah kalian bahwa dalam minuman bersoda } \\
\text { tersebut terdapat zat pengatur keasaman?". Jika } \\
\text { siswa menjawab "Ya”, kita beritahu bahwa pengatur } \\
\text { keasaman itu adalah larutan penyangga. }\end{array}$ & 5 menit \\
\hline $\begin{array}{l}\text { Kegiatan } \\
\text { Inti }\end{array}$ & $\begin{array}{l}\text { - Guru menyampaikan tujuan dan manfaat mempelajari } \\
\text { larutan penyangga. } \\
\text { - } \text { Guru menyampaikan materi mengenai: } \\
\text { - } \text { Komgertian larutan penyangga } \\
\text { - } \text { pH larutan penyangga } \\
\text { - Peserta didik diberikan kesempatan untuk bertanya } \\
\text { mengenai materi yang belum dipahami. }\end{array}$ & 80 menit \\
\hline
\end{tabular}




\begin{tabular}{|l|l|l|}
\hline & $\begin{array}{l}\text { Guru memberikan satu contoh soal mengenai } \\
\text { menentukan komponen pembentuk larutan } \\
\text { penyangga dan pH larutan penyangga dan } \\
\text { menjelaskan cara mengerjakannya. }\end{array}$ & \\
\hline $\begin{array}{l}\text { Peserta didik diberikan latihan soal mengenai } \\
\text { menentukan komponen pembentuk larutan } \\
\text { penyangga dan pH larutan penyangga. }\end{array}$ & $\begin{array}{l}\text { Peserta didik dipandu oleh guru menyimpulkan } \\
\text { materi yang telah dipelajari tadi. } \\
\text { Penutup }\end{array}$ & $\begin{array}{l}\text { Guru memberikan pujian untuk peserta didik yang } \\
\text { berhasil menjawab pertanyaan-pertanyaan dengan } \\
\text { baik. }\end{array}$ \\
$\begin{array}{l}\text { Peserta didik diberikan latihan soal untuk dikerjakan } \\
\text { di rumah, serta diberikan tugas untuk mempelajari } \\
\text { materi yang akan dipelajari selanjutnya. } \\
\text { Guru membagikan daftar kelompok untuk praktikum } \\
\text { di pertemuan selanjurnya. } \\
\text { Guru menutup pelajaran dengan mengucapkan } \\
\text { salam. }\end{array}$ & 5 menit \\
\hline
\end{tabular}

Pertemuan Kedua $(2 \times 45$ menit $)$ :

\begin{tabular}{|c|c|c|}
\hline Kegiatan & \multicolumn{1}{|c|}{ Deskripsi Kegiatan } & $\begin{array}{c}\text { Alokasi } \\
\text { Waktu }\end{array}$ \\
\hline Pendahuluan & $\begin{array}{c}\text { Guru membuka pembelajaran dengan mengucapkan } \\
\text { salam. }\end{array}$ & \\
& $\begin{array}{l}\text { - Guru mengkondisikan peserta didik untuk siap } \\
\text { belajar dengan berdoa bersama yang dipimpin oleh } \\
\text { salah seorang peserta didik. }\end{array}$ & 5 menit \\
& $\begin{array}{l}\text { - Guru mengecek kehadiran peserta didik. } \\
\text { pertanyaan seperti berikut: Kemarin kalian sudah } \\
\text { belajar mengenai perhitungan pH larutan penyangga. }\end{array}$ & \\
\hline
\end{tabular}




\begin{tabular}{|c|c|c|}
\hline & $\begin{array}{l}\text { Nah, menurut kalian apakah penambahan sedikit } \\
\text { asam, sedikit basa dan pengenceran dapat merubah } \\
\text { pH larutan penyangga?" }\end{array}$ & \\
\hline $\begin{array}{l}\text { Kegiatan } \\
\text { Inti }\end{array}$ & $\begin{array}{l}\text { - Guru menyampaikan tujuan dan manfaat mempelajari } \\
\text { penambahan sedikit asam, sedikit basa dan } \\
\text { pengenceran pada larutan penyangga, serta } \\
\text { manfaatnya bagi kehidupan sehari-hari. } \\
\text { - Guru menyampaikan materi mengenai: } \\
\text { - Pengaruh penambahan sedikit asam, sedikit basa } \\
\text { dan pengenceran pada larutan penyangga. } \\
\text { - Manfaat larutan penyangga dalam kehidupan } \\
\text { - Peserta didik diberikan kesempatan untuk bertanya } \\
\text { mengenai materi yang belum dipahami. } \\
\text { Guru memberikan satu contoh soal mengenai } \\
\text { perhitungan perubahan pH pada larutan penyangga } \\
\text { setelah penambahan sedikit asam, sedikit basa dan } \\
\text { pengenceran. } \\
\text { Peserta didik diberikan latihan soal mengenai } \\
\text { menentukan komponen pembentuk larutan } \\
\text { penyangga dan pH larutan penyangga. }\end{array}$ & 80 menit \\
\hline Penutup & $\begin{array}{l}\text { - Peserta didik dipandu oleh guru menyimpulkan } \\
\text { materi yang telah dipelajari tadi. } \\
\text { - Guru memberikan pujian untuk peserta didik yang } \\
\text { berhasil menjawab pertanyaan-pertanyaan dengan } \\
\text { baik. } \\
\text { - Peserta didik diberikan latihan soal untuk dikerjakan } \\
\text { di rumah, serta diberikan tugas untuk mempelajari } \\
\text { materi yang akan dipelajari selanjutnya. } \\
\text { Guru menutup pelajaran dengan mengucapkan } \\
\text { salam. }\end{array}$ & 5 menit \\
\hline
\end{tabular}


Pertemuan Ketiga $(2 \times 45$ menit $)$ :

\begin{tabular}{|c|c|c|}
\hline Kegiatan & Deskripsi Kegiatan & $\begin{array}{l}\text { Alokasi } \\
\text { Waktu }\end{array}$ \\
\hline Pendahuluan & $\begin{array}{l}\text { - Guru membuka pembelajaran dengan mengucapkan } \\
\text { salam. } \\
\text { - Guru mengkondisikan peserta didik untuk siap } \\
\text { belajar dengan berdoa bersama yang dipimpin oleh } \\
\text { salah seorang peserta didik. } \\
\text { - Guru mengecek kehadiran peserta didik. } \\
\text { - Peserta didik dirangsang dengan diberikan } \\
\text { pertanyaan seperti berikut: "Pertemuan sebelumnya } \\
\text { kalian sudah belajar mengenai perhitungan pH } \\
\text { larutan penyangga, nah kira-kira jika larutan } \\
\text { penyangga tersebut ditambahkan sedikit asam kuat, } \\
\text { sedikit basa kuat atau diencerkan, apakah pH-nya } \\
\text { akan berubah?" Jika peserta didik menjawab "Ya", } \\
\text { kemudian guru memberitahu bahwa topik } \\
\text { pembelajaran hari ini adalah praktikum mengenai } \\
\text { pengaruh penambahan sedikit asam, sedikit basa dan } \\
\text { pengenceran pada larutan penyangga. }\end{array}$ & 5 menit \\
\hline $\begin{array}{l}\text { Kegiatan } \\
\text { Inti }\end{array}$ & $\begin{array}{l}\text { - Guru menyampaikan tujuan pembelajaran hari ini. } \\
\text { - Guru memberikan instruksi kepada peserta didik } \\
\text { mengenai kegiatan praktikum yang akan } \\
\text { dilaksanakan. } \\
\text { - Peserta didik secara berkelompok melakukan } \\
\text { praktikum dengan mengikuti rancangan praktikum } \\
\text { yang diberikan guru. } \\
\text { - Guru mengamati peserta didik melakukan } \\
\text { praktikum. } \\
\text { Peserta didik bertanya kepada guru jika mengalami } \\
\text { kesulitan dalam jalannya praktikum. } \\
\text { Peserta didik mengerjakan lembar pengamatan dan } \\
\text { mengumpulkannya di akhir jam pelajaran. }\end{array}$ & 80 menit \\
\hline
\end{tabular}




\begin{tabular}{|l|l|l|}
\hline & $\bullet \begin{array}{l}\text { Guru memberikan pujian untuk semua peserta didik } \\
\text { yang telah melaksanakan praktikum dengan baik. }\end{array}$ & \\
& $\begin{array}{l}\text { Peserta didik diberikan tugas untuk membuat laporan } \\
\text { praktikum. }\end{array}$ & 5 menit \\
& $\begin{array}{l}\text { Guru menutup pelajaran dengan mengucapkan } \\
\text { salam. }\end{array}$ & \\
\hline
\end{tabular}

\section{Instrumen Penilaian}

1. Jenis/Teknik Penilaian

\begin{tabular}{|c|l|l|l|}
\hline No. & \multicolumn{1}{|c|}{ Aspek } & \multicolumn{1}{|c|}{ Teknik } & \multicolumn{1}{c|}{ Bentuk Instrumen } \\
\hline 1. & Pengetahuan & Penugasan & $\begin{array}{l}\text { Penugasan berupa } \\
\text { latihan soal } \\
\text { Laporan praktikum }\end{array}$ \\
\hline 2. & Keterampilan & Observasi & $\begin{array}{l}\text { Lembar observasi } \\
\text { keaktifan siswa. } \\
\text { Rubrik penilaian } \\
\text { kegiatan praktikum }\end{array}$ \\
\hline 3. & Sikap & Observasi & $\bullet$ Rubrik Penilaian Sikap \\
\hline
\end{tabular}

Mengetahui,

Guru Mapel Kimia

Peneliti

Dra. Dewi Handayani

NIP. 196507261995122001

\section{Dini Lestari}

NIM. 1608076052 
RUBRIK PENILAIAN SIKAP

\begin{tabular}{|c|c|c|c|c|}
\hline No. & Nama siswa & Disiplin & Tanggung jawab & Santun \\
\hline 1. & & & & \\
\hline 2. & & & & \\
\hline 3. & & & & \\
\hline 4. & & & & \\
\hline 5. & & & & \\
\hline
\end{tabular}

\section{Keterangan:}

$3=$ jika tiga indikator terlihat.

$2=$ jika dua indikator terlihat.

$1=$ jika satu indikator terlihat.

\section{Indikator penilaian sikap:}

\section{Disiplin}
a. Tertib mengikuti instruksi.
b. Mengerjakan tugas tepat waktu.
c. Tidak membuat kondisi kelas menjadi tidak kondusif.

\section{Tanggung Jawab}
a. Mengerjakan tugas sesuai yang ditugaskan.
b. Merapikan kembali ruang, alat, dan peralatan belajar yang telah dipergunakan.
c. Mampu mempertanggungjawabkan apa yang telah diucapkan dan dilakukan.

\section{Santun}

a. Berinteraksi dengan teman secara ramah.

b. Berkomunikasi dengan bahasa yang tidak menyinggung perasaan.

c. Berperilaku sopan.

*Skor maksimal $=9$

Nilai $=\frac{\text { Skor total }}{\text { Skor maksimal }} \times 100$ 


\section{PETUNJUK PRAKTIKUM KIMIA}

\section{IARU'TAN PENYANGGA}

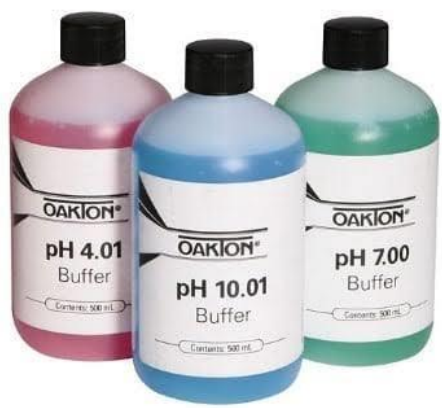

\section{Kelas}

Kelompok

Anggota Kelompok :

1.

2.

3.

4.

\section{Kompetensi Dasar:}

3.12 Menjelaskan prinsip kerja, perhitungan $\mathrm{pH}$, dan peran larutan penyangga dalam tubuh makhluk hidup.

4.12 Membuat larutan penyangga dengan $\mathrm{pH}$ tertentu.

\section{Indikator:}

1. Membuat larutan penyangga.

2. Menguji $\mathrm{pH}$ larutan penyangga sebelum dan sesudah penambahan sedikit asam, sedikit basa, dan pengenceran. 


\section{Larutan Penyangga}

\section{A. Tujuan}

1. Mempelajari pembuatan larutan penyangga

2. Mempelajari pengaruh penambahan sedikit asam kuat, sedikit basa kuat dan pengenceran pada larutan penyangga

\section{B. Dasar Teori}

Larutan penyangga atau larutan buffer adalah larutan yang mengandung asam lemah dan basa konjugasinya atau basa lemah dan asam konjugasinya. Larutan penyangga merupakan larutan yang dapat mempertahankan $\mathrm{pH}$-nya. Larutan penyangga memiliki dua komponen yaitu asam dan basa. Asam akan berperan jika ada upaya untuk menaikkan $\mathrm{pH}$, sedangkan basa akan berperan jika ada upaya untuk menurunkan $\mathrm{pH}$. Asam dan basa disini merupakan pasangan asam dan basa konjugasi.

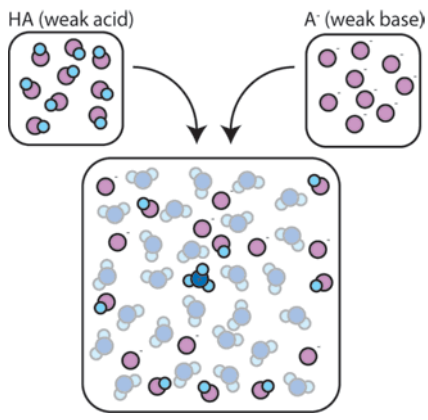

Larutan penyangga dapat dibagi menjadi dua, yaitu larutan penyangga asam dan larutan penyangga basa.

1) Larutan penyangga asam mengandung suatu asam lemah (HA) dan basa konjugasinya $\left(\mathrm{A}^{-}\right)$. Larutan penyangga asam mempertahankan $\mathrm{pH}$ pada daerah asam $(\mathrm{pH}<7)$, contoh $\mathrm{HCOOH} / \mathrm{HCOO}^{-}$. Persamaan umum reaksinya dapat dituliskan senagai berikut.

$$
\begin{aligned}
\mathrm{HA}(a q) \rightleftharpoons & \mathrm{H}^{+}(a q)+\mathrm{A}^{-}(a q) \\
\text { Asam lemah } & \text { Basa konjugasi }
\end{aligned}
$$

2) Larutan penyangga basa mengandung basa lemah (B) dan asam konjugasinya $\left(\mathrm{BH}^{+}\right)$. Larutan penyangga basa mempertahankan $\mathrm{pH}$ pada daerah basa $(\mathrm{pH}>7)$, contoh $\mathrm{NH}_{3} / \mathrm{NH}_{4}{ }^{+}$. Persamaan umum reaksinya dapat dituliskan sebagai berikut.

$$
\underset{\text { Basa lemah }}{\mathrm{B}(a q)+\mathrm{H}_{2} \mathrm{O}(l) \rightleftharpoons} \underset{\text { Asam konjugasi }}{\mathrm{BH}^{+}(a q)+\mathrm{OH}^{-}(a q)}
$$

Larutan penyangga dapat dibuat dengan dua cara. Pertama, dengan cara mencampurkan langsung komponen-komponennya yaitu suatu asam lemah dengan garamnya atau suatu basa 
lemah dengan garamnya. Kedua, dengan cara mencampurkan asam lemah dan basa kuat dengan jumlah asam lemah yang berlebih atau mencampurkan basa lemah dan asam kuat dengan jumlah basa lemah berlebih.

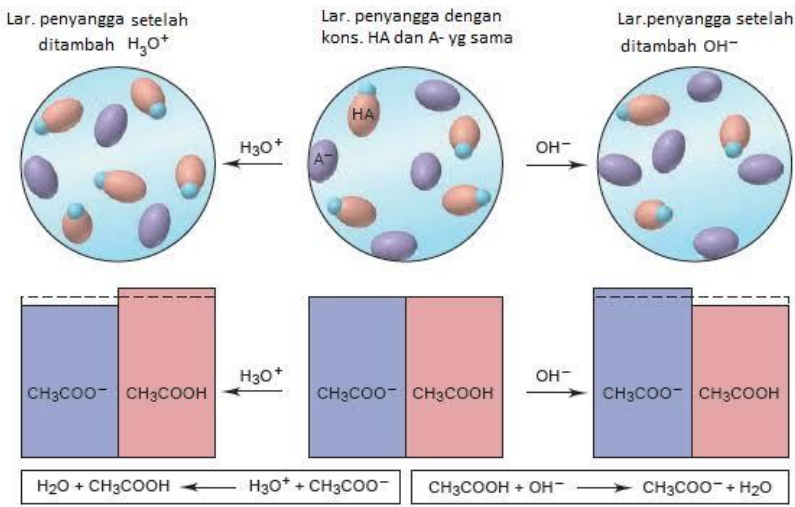

Harga $\mathrm{pH}$ larutan penyangga bergantung pada perbandingan konsentrasi asam lemah dengan konsentrasi basa konjugatnya atau basa lemah dengan konsentrasi asam konjugatnya. Penambahan sedikit asam kuat atau basa kuat ke dalam larutan penyangga tidak akan mengubah harga $\mathrm{pH}$ larutan penyangga tersebut.

Ketika ke dalam larutan penyangga ditambahkan air sehingga larutan menjadi lebih encer, konsentrasi dari asam lemah dan basa konjugatnya maupun konsentrasi basa lemah dan asam konjugatnya akan menurun dengan faktor yang sama. Akan tetapi perbandingan konsentrasi dari spesi penyusunnya dalam larutan penyangga tersebut tidak mengalami perubahan sehingga harga $\mathrm{pH}$ juga tidak berubah.

\section{Alat dan Bahan}

\section{Alat:}

1. Gelas kimia

2. Gelas ukur

3. Pipet Tetes

4. Tabung reaksi

5. Batang pengaduk

6. Indikator universal

\section{Bahan:}

1. Larutan $\mathrm{CH}_{3} \mathrm{COOH} 0,1 \mathrm{M}$

2. Larutan $\mathrm{NH}_{3} 0,1 \mathrm{M}$

3. Larutan $\mathrm{NH}_{4} \mathrm{Cl} 0,1 \mathrm{M}$

4. Larutan $\mathrm{NaOH} 0,1 \mathrm{M}$

5. Larutan $\mathrm{NaCl} 0,1 \mathrm{M}$

6. Aquades

7. Minuman bersoda 


\section{Langkah Kerja}

1. Sediakan 5 buah gelas kimia dan berilah label A, B, C, D dan E.

2. Pada gelas kimia A, masukkan $4 \mathrm{~mL} \mathrm{CH}_{3} \mathrm{COOH} 0,1 \mathrm{M}$ dan $2 \mathrm{~mL} \mathrm{NaOH} \mathrm{0,1} \mathrm{M.} \mathrm{Kemudian}$ campuran diaduk.

3. Pada gelas kimia $\mathrm{B}$, masukkan $3 \mathrm{~mL} \mathrm{NH}_{3} 0,1 \mathrm{M}$ lalu tambahkan $3 \mathrm{~mL} \mathrm{NH}_{4} \mathrm{Cl} 0,1 \mathrm{M}$. Kemudian campuran diaduk.

4. Pada gelas kimia $\mathrm{C}$, masukkan $6 \mathrm{~mL} \mathrm{NaCl} \mathrm{0,1} \mathrm{M.}$

5. Pada gelas kimia $\mathrm{D}$, masukkan $6 \mathrm{~mL}$ aquades.

6. Pada gelas kimia E, masukkan $6 \mathrm{~mL}$ minuman bersoda

7. Periksa $\mathrm{pH}$ larutan pada masing-masing gelas kimia dengan kertas indikator universal dan catat hasilnya.

8. Sediakan 3 tabung reaksi (A, B dan C), lalu isilah masing-masing tabung dengan $2 \mathrm{~mL}$ larutan yang ada di gelas kimia $\mathrm{A}$ (campuran larutan $\mathrm{CH}_{3} \mathrm{COOH}$ dan $\mathrm{NaOH}$ ).

9. Tetesi:
a. tabung a dengan $1 \mathrm{~mL}$ larutan $\mathrm{HCl} 0,1 \mathrm{M}$
b. tabung b dengan $1 \mathrm{~mL}$ larutan $\mathrm{NaOH} 0,1 \mathrm{M}$
c. tabung c dengan $1 \mathrm{~mL}$ aquades

10. Ukur $\mathrm{pH}$ masing-masing larutan dalam tabung reaksi (tabung $\mathrm{a}, \mathrm{b}$, dan $\mathrm{c}$ ) dengan menggunakan indikator universal dan catat hasilnya.

11. Lakukan perlakuan yang sama seperti no. 8 - 10, tetapi larutannya diganti:

a. Larutan yang ada di gelas kimia $\mathrm{B}$ (campuran larutan $\mathrm{NH}_{3}$ dan $\mathrm{NH}_{4} \mathrm{Cl}$ )

b. Larutan $\mathrm{NaCl} 0,1 \mathrm{M}$

c. Aquades

d. Minuman bersoda

\section{Data Pengamatan}

Diketahui jenis larutan:

- $\mathrm{CH}_{3} \mathrm{COOH} 0,1 \mathrm{M}+\mathrm{NaOH}$ 0,1 M : sebagai larutan $\mathrm{A}$

- $\mathrm{NH}_{3} 0,1 \mathrm{M}+\mathrm{NH}_{4} \mathrm{Cl} \mathrm{0,1} \mathrm{M}$ : sebagai larutan B

1. Tentukan $\mathrm{pH}$ awal dari masing-masing jenis larutan!

\begin{tabular}{|c|c|}
\hline Jenis Larutan & pH Awal \\
\hline Larutan A & \\
\hline Larutan B & \\
\hline Larutan C & \\
\hline Larutan D & \\
\hline Larutan E & \\
\hline
\end{tabular}

2. Tentukan $\mathrm{pH}$ dari masing-masing larutan setelah ditambah sedikit asam kuat, sedikit basa kuat, dan pengenceran!

\begin{tabular}{|c|c|c|c|}
\hline \multirow{2}{*}{ Jenis Larutan } & \multicolumn{3}{|c|}{ pH setelah penambahan } \\
\cline { 2 - 4 } & HCl 0,1 M & NaOH 0,1 M & Aquades \\
\hline Larutan A & & & \\
\hline
\end{tabular}

- $\mathrm{NaCl} 0,1 \mathrm{M}$ : sebagai larutan $\mathrm{C}$

- $\mathrm{H}_{2} \mathrm{O}$ : sebagai larutan $\mathrm{D}$

- Minuman bersoda: sebagai larutan E 


\begin{tabular}{|l|l|l|l|}
\hline Larutan B & & & \\
\hline Larutan C & & & \\
\hline Larutan D & & & \\
\hline Larutan E & & & \\
\hline
\end{tabular}

3. Tentukan selisih perubahan $\mathrm{pH}$ !

\begin{tabular}{|c|c|c|c|}
\hline Jenis larutan & $\mathbf{p H}$ awal & $\mathbf{p H}$ akhir & Selisih penambahan $\mathbf{p H}$ \\
\hline Larutan A & & & \\
\hline Larutan B & & & \\
\hline Larutan C & & & \\
\hline Larutan D & & & \\
\hline Larutan E & & & \\
\hline
\end{tabular}

4. Kategorikan perubahan $\mathrm{pH}$ masing-masing jenis larutan!

\begin{tabular}{|c|c|c|c|}
\hline \multirow{2}{*}{ Jenis larutan } & $\begin{array}{c}\text { Selisih perubahan } \\
\mathbf{p H}\end{array}$ & \multicolumn{2}{|c|}{ Kategori jumlah selisih perubahan pH } \\
\cline { 3 - 4 } & & $\begin{array}{c}\text { Sedikit/relatif } \\
\text { tetap }\end{array}$ & Banyak \\
\hline Larutan A & & & \\
\hline Larutan B & & & \\
\hline Larutan C & & & \\
\hline Larutan D & & & \\
\hline Larutan E & & & \\
\hline
\end{tabular}

5. Kelompokkan masing-masing jenis larutan berdasarkan kategori perubahan $\mathrm{pH}$ !

\begin{tabular}{|c|c|}
\hline Perubahan pH dalam jumlah & Jenis larutan \\
\hline Sedikit/relatif tetap & \\
\hline Banyak & \\
\hline
\end{tabular}

6. Tentukan larutan yang termasuk larutan penyangga dan bukan larutan penyangga!

\begin{tabular}{|c|c|c|c|c|c|c|}
\hline \multirow[b]{2}{*}{ No. } & \multirow[b]{2}{*}{ Jenis Larutan } & \multirow[b]{2}{*}{$\begin{array}{c}\text { pH } \\
\text { Awal }\end{array}$} & \multicolumn{3}{|c|}{ pH setelah penambahan } & \multirow{2}{*}{$\begin{array}{c}\text { Larutan } \\
\text { Penyangga } \\
\text { atau Bukan }\end{array}$} \\
\hline & & & HCl 0,1 M & $\mathrm{NaOH} \mathrm{0,1} \mathrm{M}$ & Aquades & \\
\hline & & & & & & \\
\hline & & & & & & \\
\hline & & & & & & \\
\hline & & & & & & \\
\hline & & & & & & \\
\hline
\end{tabular}

\section{Kesimpulan:}


RUBRIK PENILAIAN KETERAMPILAN

PRAKTIKUM LARUTAN PENYANGGA

\begin{tabular}{|c|c|c|c|}
\hline No. & Keterampilan & Skor & $\begin{array}{l}\text { Kriteria Penskoran } \\
\end{array}$ \\
\hline \multirow{4}{*}{1.} & \multirow{4}{*}{$\begin{array}{l}\text { Menggunakan } \\
\text { pipet tetes dengan } \\
\text { benar }\end{array}$} & 4 & $\begin{array}{l}\text { 1) Jika peserta didik mengambil larutan dengan cara } \\
\text { memencet balon karet di luar, lalu dilepas di dalam } \\
\text { larutan dan diangkat. } \\
\text { 2) Jika peserta didik meneteskan larutan dengan } \\
\text { memencet kembali balon karet pada pipet dan ujung } \\
\text { pipet ditempelkan pada dinding dalam bagian atas. }\end{array}$ \\
\hline & & 3 & $\begin{array}{l}\text { 1) Jika peserta didik mengambil larutan dengan cara } \\
\text { memencet balon karet di luar, lalu dilepas diluar } \\
\text { larutan dan diangkat. } \\
\text { 2) Jika peserta didik meneteskan larutan dengan } \\
\text { memencet kembali balon karet pada pipet dan ujung } \\
\text { pipet masuk ke dalam bagian larutan. }\end{array}$ \\
\hline & & 2 & $\begin{array}{l}\text { 1) Jika peserta didik mengambil larutan dengan cara } \\
\text { memencet balon karet di dalam larutan, lalu dilepas } \\
\text { didalam larutan dan diangkat. } \\
\text { 2) Jika peserta didik meneteskan larutan dengan } \\
\text { memencet kembali balon karet pada pipet dan ujung } \\
\text { pipet ditempelkan pada dinding dalam bagian atas. }\end{array}$ \\
\hline & & 1 & $\begin{array}{l}\text { 1) Jika peserta didik mengambil larutan dengan cara } \\
\text { memencet balon karet di luar, lalu dilepas diluar } \\
\text { larutan dan diangkat. } \\
\text { 2) Jika peserta didik meneteskan larutan dengan } \\
\text { memencet kembali balon karet pada pipet dan ujung } \\
\text { pipet berada jauh di atas gelas ukur. }\end{array}$ \\
\hline \multirow{3}{*}{2.} & \multirow{3}{*}{$\begin{array}{l}\text { Membaca skala } \\
\text { hasil pengukuran } \\
\text { volume suatu } \\
\text { larutan tidak } \\
\text { berwarna pada } \\
\text { gelas ukur dengan } \\
\text { benar }\end{array}$} & 4 & $\begin{array}{l}\text { 1) Jika peserta didik menempatkan gelas ukur pada } \\
\text { tempat yang datar ketika melihat meniskus dari } \\
\text { larutan. } \\
\text { 2) Jika peserta didik membaca meniskus bawah pada } \\
\text { gelas ukur dengan melihat pada permukaan larutan } \\
\text { secara mendatar atau horizontal (mata sejajar } \\
\text { dengan meniskus). }\end{array}$ \\
\hline & & 3 & $\begin{array}{l}\text { 1) Jika peserta didik menempatkan gelas ukur pada } \\
\text { tempat yang tidak datar ketika melihat meniskus } \\
\text { bawah dari larutan, misalnya sambil diangkat. } \\
\text { 2) Jika peserta didik membaca meniskus pada gelas } \\
\text { ukur dengan melihat pada permukaan larutan secara } \\
\text { mendatar atau horizontal (mata sejajar dengan } \\
\text { meniskus) }\end{array}$ \\
\hline & & 2 & $\begin{array}{l}\text { 1) Jika peserta didik menempatkan gelas ukur pada } \\
\text { tempat yang datar ketika melihat meniskus dari } \\
\text { larutan. } \\
\text { 2) Jika peserta didik membaca meniskus bawah pada } \\
\text { gelas ukur dengan melihat pada permukaan larutan }\end{array}$ \\
\hline
\end{tabular}




\begin{tabular}{|c|c|c|c|}
\hline & & & $\begin{array}{l}\text { dari arah atas atau arah bawah (mata tidak sejajar } \\
\text { dengan meniskus). }\end{array}$ \\
\hline & & 1 & $\begin{array}{l}\text { 1) Jika peserta didik menempatkan gelas ukur pada } \\
\text { tempat yang tidak datar ketika melihat meniskus } \\
\text { dari larutan, misalnya dengan diangkat. } \\
\text { 2) Jika peserta didik membaca meniskus bawah pada } \\
\text { gelas ukur dengan melihat pada permukaan larutan } \\
\text { dari arah atas atau bawah (mata tidak sejajar dengan } \\
\text { meniskus). }\end{array}$ \\
\hline \multirow{4}{*}{3.} & \multirow{4}{*}{$\begin{array}{l}\text { Menuang larutan } \\
\text { dari gelas ukur ke } \\
\text { dalam gelas kimia }\end{array}$} & 4 & $\begin{array}{l}\text { Jika peserta didik pada saat menuang larutan, gelas } \\
\text { ukur menempel pada dinding atau mulut gelas kimia } \\
\text { dan dilakukan secara perlahan. }\end{array}$ \\
\hline & & 3 & $\begin{array}{l}\text { Jika peserta didik pada saat menuang larutan, gelas } \\
\text { ukur menempel pada dinding atau mulut gelas kimia } \\
\text { namun tidak dilakukan secara perlahan. }\end{array}$ \\
\hline & & 2 & $\begin{array}{l}\text { Jika peserta didik pada saat menuang larutan, gelas } \\
\text { ukur tidak menempel pada dinding atau mulut gelas } \\
\text { kimia dan dilakukan secara perlahan. }\end{array}$ \\
\hline & & 1 & $\begin{array}{l}\text { Jika peserta didik pada saat menuang larutan, gelas } \\
\text { ukur tidak menempel pada dinding atau mulut gelas } \\
\text { kimia dan tidak dilakukan secara perlahan. }\end{array}$ \\
\hline \multirow{4}{*}{4.} & \multirow{4}{*}{$\begin{array}{l}\text { Membaca hasil } \\
\text { pengukuran } \mathrm{pH}\end{array}$} & 4 & $\begin{array}{l}\text { Jika peserta didik dapat membandingkan warna dari } \\
\text { kertas pH dengan indikator universal pada saat telah } \\
\text { kering dengan tepat. }\end{array}$ \\
\hline & & 3 & $\begin{array}{l}\text { Jika peserta didik dapat membandingkan warna dari } \\
\text { kertas pH dengan indikator universal pada saat telah } \\
\text { kering tetapi kurang tepat. }\end{array}$ \\
\hline & & 2 & $\begin{array}{l}\text { Jika peserta didik dapat membandingkan warna dari } \\
\text { kertas pH dengan indikator universal secara langsung } \\
\text { (masih basah) dengan tepat. }\end{array}$ \\
\hline & & 1 & $\begin{array}{l}\text { Jika peserta didik dapat membandingkan warna dari } \\
\text { kertas pH dengan indikator universal secara langsung } \\
\text { (masih basah) tetapi kurang tepat. }\end{array}$ \\
\hline \multirow{4}{*}{5.} & \multirow{4}{*}{$\begin{array}{l}\text { Mendiskusikan } \\
\text { hasil praktikum }\end{array}$} & 4 & $\begin{array}{l}\text { Jika peserta didik mendiskusikan hasil praktikum sesuai } \\
\text { konteks dan kompak. }\end{array}$ \\
\hline & & 3 & $\begin{array}{l}\text { Jika peserta didik mendiskusikan hasil praktikum sesuai } \\
\text { konteks namun tidak kompak. }\end{array}$ \\
\hline & & 2 & Jika peserta didik mendiskusikan tetapi di luar konteks. \\
\hline & & 1 & Jika peserta didik tidak mendiskusikan hasil praktikum. \\
\hline \multirow{3}{*}{6.} & \multirow{3}{*}{$\begin{array}{l}\text { Melakukan } \\
\text { pengamatan } \\
\text { terhadap } \\
\text { perubahan pH } \\
\text { yang terjadi pada } \\
\text { jenis-jenis larutan } \\
\text { setelah ditambah } \\
\text { sedikit asam, } \\
\text { sedikit basa, dan } \\
\text { pengenceran }\end{array}$} & 4 & $\begin{array}{l}\text { Jika peserta didik mengamati dan menuliskan } \mathrm{pH} \text { awal, } \\
\text { perubahan } \mathrm{pH} \text { yang terjadi pada larutan saat ditambah } \\
\text { sedikit asam, sedikit basa, dan pengenceran dengan } \\
\text { lengkap }(20 \mathrm{pH}) \text {. }\end{array}$ \\
\hline & & 3 & $\begin{array}{l}\text { Jika peserta didik mengamati dan menuliskan } \mathrm{pH} \text { awal, } \\
\text { perubahan } \mathrm{pH} \text { yang terjadi pada larutan saat ditambah } \\
\text { sedikit asam, sedikit basa, dan pengenceran sebanyak } \\
15-19 \text { nilai } \mathrm{pH} \text {. }\end{array}$ \\
\hline & & 2 & $\begin{array}{l}\text { Jika peserta didik mengamati dan menuliskan } \mathrm{pH} \text { awal, } \\
\text { perubahan } \mathrm{pH} \text { yang terjadi pada larutan saat ditambah } \\
\text { sedikit asam, sedikit basa, dan pengenceran sebanyak } \\
10-14 \text { nilai } \mathrm{pH} \text {. }\end{array}$ \\
\hline
\end{tabular}




\begin{tabular}{|c|c|c|c|}
\hline & & 1 & $\begin{array}{l}\text { Jika peserta didik mengamati dan menuliskan } \mathrm{pH} \text { awal, } \\
\text { perubahan } \mathrm{pH} \text { yang terjadi pada larutan saat ditambah } \\
\text { sedikit asam, sedikit basa, dan pengenceran sebanyak } 1 \\
-9 \text { nilai } \mathrm{pH} \text {. }\end{array}$ \\
\hline \multirow{4}{*}{7.} & \multirow{4}{*}{$\begin{array}{l}\text { Menuliskan data } \\
\text { pengamatan } \\
\text { secara lengkap } \\
\text { dan benar }\end{array}$} & 4 & $\begin{array}{l}\text { Jika peserta didik menuliskan data hasil pengamatan } \\
\text { percobaan pengaruh penambahan sedikit asam kuat, } \\
\text { sedikit basa kuat, dan pengenceran pada } 4 \text { larutan ke } \\
\text { dalam tabel dengan lengkap dan benar. }\end{array}$ \\
\hline & & 3 & $\begin{array}{l}\text { Jika peserta didik menuliskan data hasil pengamatan } \\
\text { percobaan pengaruh penambahan sedikit asam kuat, } \\
\text { sedikit basa kuat, dan pengenceran pada } 3 \text { larutan ke } \\
\text { dalam tabel dengan benar. }\end{array}$ \\
\hline & & 2 & $\begin{array}{l}\text { Jika peserta didik menuliskan data hasil pengamatan } \\
\text { percobaan pengaruh penambahan sedikit asam kuat, } \\
\text { sedikit basa kuat, dan pengenceran pada } 2 \text { larutan ke } \\
\text { dalam tabel dengan benar. }\end{array}$ \\
\hline & & 1 & $\begin{array}{l}\text { Jika peserta didik menuliskan data hasil pengamatan } \\
\text { percobaan pengaruh penambahan sedikit asam kuat, } \\
\text { sedikit basa kuat, dan pengenceran pada } 1 \text { larutan ke } \\
\text { dalam tabel dengan benar. }\end{array}$ \\
\hline \multirow{4}{*}{8.} & \multirow{4}{*}{$\begin{array}{l}\text { Menarik } \\
\text { kesimpulan } \\
\text { sementara }\end{array}$} & 4 & $\begin{array}{l}\text { Jika peserta didik dapat menarik kesimpulan dari data } \\
\text { pengamatan yang diperoleh sesuai dengan tujuan } \\
\text { percobaan dengan lengkap. }\end{array}$ \\
\hline & & 3 & $\begin{array}{l}\text { Jika peserta didik dapat menarik kesimpulan dari data } \\
\text { pengamatan yang diperoleh sesuai dengan tujuan } \\
\text { percobaan tetapi kurang lengkap. }\end{array}$ \\
\hline & & 2 & $\begin{array}{l}\text { Jika peserta didik dapat menarik kesimpulan dari data } \\
\text { pengamatan yang diperoleh tetapi tidak sesuai dengan } \\
\text { tujuan percobaan. }\end{array}$ \\
\hline & & 1 & Jika peserta didik tidak dapat menarik kesimpulan. \\
\hline
\end{tabular}

Skor maksimal $=32$

Nilai $=\frac{\text { Jumlah } \text { skor }}{\text { Skor } \text { maksimal }} \times 100$ 
LEMBAR PENILAIAN LAPORAN PRAKTIKUM

\begin{tabular}{|c|c|c|}
\hline No. & Nama siswa & Nilai \\
\hline 1. & & \\
\hline 2. & & \\
\hline 3. & & \\
\hline 4. & & \\
\hline 5. & & \\
\hline
\end{tabular}

\section{Indikator penilaian:}

\begin{tabular}{|c|c|c|}
\hline No. & Komponen Penilaian & Skor \\
\hline 1. & $\begin{array}{l}\text { Cover (Judul praktikum, identitas peserta didik, identitas sekolah, tahun } \\
\text { ajaran) }\end{array}$ & \\
\hline 2. & Tujuan Praktikum & \\
\hline 3. & Dasar Teori & \\
\hline 4. & Alat dan Bahan & \\
\hline 5. & Prosedur Kerja & \\
\hline 6. & Hasil Pengamatan dan Data Hasil Pengamatan & \\
\hline 7. & Pembahasan & \\
\hline 8. & Kesimpulan & \\
\hline 9. & Kolom Tanda Tangan Praktikan dan Guru & \\
\hline 10. & Daftar Pustaka & \\
\hline & Total & \\
\hline
\end{tabular}

Skor maksimum $=145$

Nilai $=\frac{\text { Skor yang didapatkan }}{\text { Skor } \text { maksimum }} \times 100$ 


\section{LEMBAR OBSERVASI KEAKTIFAN SISWA}

\section{Hari/Tanggal :}

Kelas

Berikan penilaian sesuai dengan rubrik yang dilaksanakan oleh tiap-tiap siswa dengan cara memberi tanda cek ( $\sqrt{ })$ pada kolom yang sesuai!

\section{Keterangan:}

- Jika tidak memenuhi rubrik, kosongkon kolom (kolom tidak dicentang, berarti nilainya dihitung nol)!

- Skala penilaian: $0-4$

\section{Aspek yang dinilai :}

A = Kesiapan mengikuti pelajaran

$\mathrm{B}=$ Menyimak penjelasan guru

$\mathrm{C}=$ Aktif bertanya saat $\mathrm{KBM}$

$\mathrm{D}=$ Merespon tugas

\begin{tabular}{|c|c|c|c|c|c|c|c|c|c|c|c|c|c|c|c|c|c|c|}
\hline \multirow{2}{*}{ No. } & \multirow{2}{*}{ Nama } & \multicolumn{4}{|c|}{$\mathbf{A}$} & \multicolumn{4}{|c|}{ B } & \multicolumn{4}{|c|}{ C } & \multicolumn{4}{|c|}{ D } & \multirow{2}{*}{ Rata-rata } \\
\hline & & 1 & 2 & 3 & 4 & 1 & 2 & 3 & 4 & 1 & 2 & 3 & 4 & 1 & 2 & 3 & 4 & \\
\hline 1. & & & & & & & & & & & & & & & & & & \\
\hline 2. & & & & & & & & & & & & & & & & & & \\
\hline 3. & & & & & & & & & & & & & & & & & & \\
\hline 4. & & & & & & & & & & & & & & & & & & \\
\hline 5. & & & & & & & & & & & & & & & & & & \\
\hline
\end{tabular}

Skor maksimal $=16$

Nilai $=\frac{\text { jumlah } \text { skor }}{\text { Skor } \text { maksimal }} \times 100$ 
Lampiran 11. Kisi-Kisi Instrumen Tes

\section{KISI-KISI INSTRUMEN TES}

\section{Kompetensi Dasar:}

Siswa mampu:

3.12 Menjelaskan prinsip kerja, perhitungan $\mathrm{pH}$ dan peran larutan penyangga dalam tubuh makhluk hidup.

4.12 Membuat larutan penyangga dengan $\mathrm{pH}$ tertentu.

\begin{tabular}{|c|l|l|c|c|c|}
\hline \multirow{2}{*}{ No } & \multicolumn{1}{|c|}{ Indikator } & \multicolumn{1}{|c|}{ Indikator Soal } & $\begin{array}{c}\text { Ranah } \\
\text { Kognitif }\end{array}$ & $\begin{array}{c}\text { No. } \\
\text { Soal }\end{array}$ & Bentuk Soal \\
\hline \multirow{2}{*}{1.} & $\begin{array}{l}\text { Menjelaskan } \\
\text { pengertian larutan } \\
\text { penyangga }\end{array}$ & $\begin{array}{l}\text { Menyebutkan pengertian larutan } \\
\text { penyangga }\end{array}$ & $\mathrm{C} 1$ & 1 & $\begin{array}{c}\text { Three-tier } \\
\text { multiple choice }\end{array}$ \\
\cline { 3 - 6 } & Menyebutkan sifat larutan penyangga & $\mathrm{C} 1$ & 7 & $\begin{array}{c}\text { Three-tier } \\
\text { multiple choice }\end{array}$ \\
\cline { 3 - 6 } & & $\begin{array}{l}\text { Membedakan larutan penyangga dan } \\
\text { bukan larutan penyangga }\end{array}$ & $\mathrm{C} 4$ & 15 & $\begin{array}{c}\text { Three-tier } \\
\text { multiple choice }\end{array}$ \\
\cline { 3 - 6 } & & & 32 & Uraian \\
\hline
\end{tabular}




\begin{tabular}{|c|c|c|c|c|c|}
\hline No & Indikator & Indikator Soal & $\begin{array}{c}\text { Ranah } \\
\text { Kognitif }\end{array}$ & $\begin{array}{l}\text { No. } \\
\text { Soal }\end{array}$ & Bentuk Soal \\
\hline \multirow[t]{2}{*}{2.} & \multirow[t]{2}{*}{$\begin{array}{l}\text { Memahami } \\
\text { komponen larutan } \\
\text { penyangga }\end{array}$} & \multirow{2}{*}{$\begin{array}{l}\text { Menyebutkan komponen penyangga pada } \\
\text { larutan penyangga asam dan larutan } \\
\text { penyangga basa }\end{array}$} & \multirow[t]{2}{*}{$\mathrm{C} 4$} & $\begin{array}{l}16 \\
17 \\
24\end{array}$ & $\begin{array}{l}\text { Three-tier } \\
\text { multiple choice }\end{array}$ \\
\hline & & & & 38 & Uraian \\
\hline \multirow[t]{2}{*}{3.} & \multirow[t]{2}{*}{$\begin{array}{l}\text { Menghitung } \mathrm{pH} \\
\text { larutan penyangga }\end{array}$} & \multirow{2}{*}{ Menghitung pH larutan penyangga } & \multirow{2}{*}{ C3 } & $\begin{array}{l}13 \\
22\end{array}$ & $\begin{array}{c}\text { Three-tier } \\
\text { multiple choice }\end{array}$ \\
\hline & & & & 35 & Uraian \\
\hline \multirow[t]{3}{*}{4.} & \multirow{3}{*}{$\begin{array}{l}\text { Memahami } \\
\text { pengaruh } \\
\text { penambahan sedikit } \\
\text { asam, sedikit basa } \\
\text { dan pengenceran } \\
\text { pada larutan } \\
\text { penyangga }\end{array}$} & $\begin{array}{l}\text { Menjelaskan cara kerja larutan penyangga } \\
\text { dalam mempertahankan } \mathrm{pH}\end{array}$ & $\mathrm{C} 2$ & 9,10 & $\begin{array}{l}\text { Three-tier } \\
\text { multiple choice }\end{array}$ \\
\hline & & \multirow{2}{*}{$\begin{array}{l}\text { Menyimpulkan suatu permasalahan } \\
\text { berdasarkan data-data ilmiah }\end{array}$} & \multirow{2}{*}{$\mathrm{C} 5$} & 21 & $\begin{array}{c}\text { Three-tier } \\
\text { multiple choice }\end{array}$ \\
\hline & & & & 26 & Uraian \\
\hline 5. & $\begin{array}{l}\text { Menyebutkan } \\
\text { kegunaan larutan } \\
\text { penyangga dalam }\end{array}$ & $\begin{array}{l}\text { Menjelaskan peranan larutan penyangga } \\
\text { dalam kehidupan sehari-hari }\end{array}$ & $\mathrm{C} 1$ & 2 & $\begin{array}{l}\text { Three-tier } \\
\text { multiple choice }\end{array}$ \\
\hline
\end{tabular}




\begin{tabular}{|c|c|c|c|c|c|}
\hline No & Indikator & Indikator Soal & $\begin{array}{c}\text { Ranah } \\
\text { Kognitif }\end{array}$ & $\begin{array}{l}\text { No. } \\
\text { Soal }\end{array}$ & Bentuk Soal \\
\hline & $\begin{array}{l}\text { kehidupan sehari- } \\
\text { hari }\end{array}$ & $\begin{array}{l}\text { Menganalisis produk-produk dalam } \\
\text { kehidupan sehari-hari yang menggunakan } \\
\text { larutan penyangga }\end{array}$ & $\mathrm{C} 4$ & 6,11 & $\begin{array}{l}\text { Three-tier } \\
\text { multiple choice }\end{array}$ \\
\hline \multirow[t]{8}{*}{6.} & \multirow[t]{8}{*}{$\begin{array}{l}\text { Membuat larutan } \\
\text { penyangga }\end{array}$} & $\begin{array}{l}\text { Menganalisis bahan-bahan yang dapat } \\
\text { digunakan untuk membuat larutan } \\
\text { penyangga }\end{array}$ & $\mathrm{C} 4$ & 3,4 & $\begin{array}{l}\text { Three-tier } \\
\text { multiple choice }\end{array}$ \\
\hline & & \multirow{2}{*}{$\begin{array}{l}\text { Menentukan volume larutan yang dapat } \\
\text { ditambahkan pada pembuatan larutan } \\
\text { penyangga }\end{array}$} & \multirow[b]{2}{*}{ C3 } & 5 & $\begin{array}{c}\text { Three-tier } \\
\text { multiple choice }\end{array}$ \\
\hline & & & & $\begin{array}{l}27 \\
33 \\
34\end{array}$ & Uraian \\
\hline & & \multirow{2}{*}{$\begin{array}{l}\text { Menjelaskan cara pembuatan larutan } \\
\text { penyangga dengan tepat }\end{array}$} & \multirow[t]{2}{*}{ C3 } & 8 & $\begin{array}{c}\text { Three-tier } \\
\text { multiple choice }\end{array}$ \\
\hline & & & & 30 & Uraian \\
\hline & & $\begin{array}{l}\text { Mengevaluasi rancangan prediksi hasil } \\
\text { pengamatan }\end{array}$ & C5 & 19 & $\begin{array}{c}\text { Three-tier } \\
\text { multiple choice }\end{array}$ \\
\hline & & $\begin{array}{l}\text { Menghitung massa suatu zat untuk } \\
\text { membuat larutan penyangga }\end{array}$ & $\mathrm{C} 3$ & $\begin{array}{l}12, \\
23\end{array}$ & $\begin{array}{c}\text { Three-tier } \\
\text { multiple choice }\end{array}$ \\
\hline & & $\begin{array}{l}\text { Menghitung jumlah mol suatu larutan } \\
\text { yang digunakan dalam membuat larutan } \\
\text { penyangga. }\end{array}$ & C3 & 31 & Uraian \\
\hline
\end{tabular}




\begin{tabular}{|c|c|c|c|c|c|}
\hline No & Indikator & Indikator Soal & $\begin{array}{c}\text { Ranah } \\
\text { Kognitif }\end{array}$ & $\begin{array}{l}\text { No. } \\
\text { Soal }\end{array}$ & Bentuk Soal \\
\hline \multirow[t]{3}{*}{7.} & \multirow{3}{*}{$\begin{array}{l}\text { Menguji pH larutan } \\
\text { peyangga sebelum } \\
\text { dan sesudah } \\
\text { penambahan sedikit } \\
\text { asam, sedikit basa, } \\
\text { dan pengenceran }\end{array}$} & $\begin{array}{l}\text { Menjelaskan cara melakukan identifikasi } \\
\text { larutan penyangga pada suatu produk }\end{array}$ & $\mathrm{C} 4$ & 18 & $\begin{array}{l}\text { Three-tier } \\
\text { multiple choice }\end{array}$ \\
\hline & & \multirow[b]{2}{*}{$\begin{array}{l}\text { Menghitung } \mathrm{pH} \text { larutan penyangga } \\
\text { dengan penambahan sedikit asam, basa } \\
\text { atau pengenceran }\end{array}$} & \multirow[b]{2}{*}{$\mathrm{C} 3$} & 14 & $\begin{array}{c}\text { Three-tier } \\
\text { multiple choice }\end{array}$ \\
\hline & & & & $\begin{array}{l}28, \\
29 \\
36 \\
37\end{array}$ & Uraian \\
\hline
\end{tabular}




\section{INSTRUMEN TES KELAS UJI COBA}

\section{PETUNJUK}

1. Tulis nama, kelas, dan nomor absen pada lembar jawab

2. Jawablah soal-soal berikut dengan cara menyilang salah satu huruf pada lembar jawaban dan tuliskan alasan jawaban di kolom yang telah disediakan

3. Cara mengganti jawaban yang salah
A
來
$\Rightarrow$
D

4. Periksalah jawaban sebelum diserahkan kepada pengawas

\section{A. Pilihan Ganda Beralasan}

Kerjakan soal-soal berikut dengan memilih jawaban yang paling tepat dan benar pada lembar jawaban yang tersedia dan pilihlah alasan mengapa memilih jawaban tersebut serta yakin atau tidaknya terhadap jawaban yang dipilih!

\section{Bacaan Untuk Soal No. 1 dan 2}

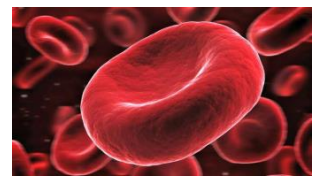

Banyak reaksi kimia dalam tubuh kita yang berlangsung dalam lingkungan $\mathrm{pH}$ yang terkontrol. Misalnya, reaksi pengikatan oksigen oleh darah dapat berlangsung dengan baik jika $\mathrm{pH}$ darah berada pada rentang $\mathrm{pH} 7,35$ - 7,45. Jika mekanisme pengaturan $\mathrm{pH}$ dalam tubuh gagal, misalnya saat sakit dan $\mathrm{pH}$ darah turun sampai $<7$ atau naik sampai $\mathrm{pH}$ 7,8, maka dapat menyebabkan kerusakan permanen pada organ tubuh atau bahkan kematian. Oleh karena itu, dalam darah terdapat larutan penyangga yang dapat mempertahankan $\mathrm{pH}$ di dalam darah.

1. Larutan penyangga adalah...

a. Larutan yang mengandung asam lemah dengan basa konjugasinya atau basa lemah dengan asam konjugasinya

b. Larutan yang mengandung asam kuat dengan basa konjugasinya atau basa kuat dengan asam konjugasinya

c. Larutan yang mengandung asam kuat dan basa kuat

d. Larutan yang mengandung asam lemah dan basa lemah

e. Larutan yang hanya mengandung asam lemah saja

\section{Pilihan Alasan:}

1) Larutan penyangga dapat dibentuk dari pencampuran asam lemah atau basa lemah dengan garamnya

2) Larutan penyangga dapat dibentuk dari pencampuran asam lemah dengan basa lemah

3) Larutan penyangga dapat dibentuk dari pencampuran asam kuat atau basa kuat dengan garamnya

4) Larutan penyangga dapat dibentuk dari pencampuran asam kuat dengan basa kuat

5) Larutan penyangga dapat dibentuk dari pencampuran asam kuat dengan asam kuat

\section{Apakah Anda yakin dengan jawaban Anda?}<smiles>C1C[14CH]C1</smiles><smiles>CCCCCCCC</smiles>

2. Di bawah ini yang merupakan pasangan asam basa konjugasi larutan penyangga dalam darah adalah...
a. $\mathrm{HPO}_{4}{ }^{2-}$ dan $\mathrm{H}_{2} \mathrm{PO}_{4}{ }_{4}^{-}$
b. $\mathrm{H}_{3} \mathrm{PO}_{4}$ dan $\mathrm{H}_{2} \mathrm{PO}_{4}^{-}$
c. $\mathrm{H}_{3} \mathrm{PO}_{4}$ dan $\mathrm{H}_{2} \mathrm{CO}_{3}$
d. $\mathrm{H}_{2} \mathrm{CO}_{3}$ dan $\mathrm{HCO}_{3}$
e. $\mathrm{H}_{2} \mathrm{PO}_{4}^{-}$dan $\mathrm{HCO}_{3}$ 


\section{Pilihan Alasan:}

1) $\mathrm{H}_{2} \mathrm{CO}_{3}$ yang bertindak sebagai asam lemah dan $\mathrm{HCO}_{3}{ }^{-}$sebagai basa konjugasinya.

2) $\mathrm{H}_{3} \mathrm{PO}_{4}$ yang bertindak sebagai asam lemah dan $\mathrm{H}_{2} \mathrm{CO}_{3}$ sebagai basa konjugasinya.

3) $\mathrm{H}_{2} \mathrm{PO}_{4}^{-}$yang bertindak sebagai asam lemah dan $\mathrm{HCO}_{3}^{-}$sebagai basa konjugasinya.

4) $\mathrm{H}_{3} \mathrm{PO}_{4}$ yang bertindak sebagai asam lemah dan $\mathrm{H}_{2} \mathrm{PO}_{4}{ }^{-}$yang bertindak sebagai basa konjugasinya.

5) Penyangga karbonat terdiri dari $\mathrm{HPO}_{4}{ }^{2-}$ yang bertindak sebagai asam lemah dan $\mathrm{H}_{2} \mathrm{PO}_{4}{ }^{-}$sebagai basa konjugasinya.

\section{Apakah Anda yakin dengan jawaban Anda?}

Ya

Tidak

Bacaan Untuk Soal No. 3 - 5

Siswa kelas XI MIPA diberi tugas oleh guru kimia untuk membuat larutan penyangga. Larutan yang disediakan di laboratorium adalah sebagai berikut.

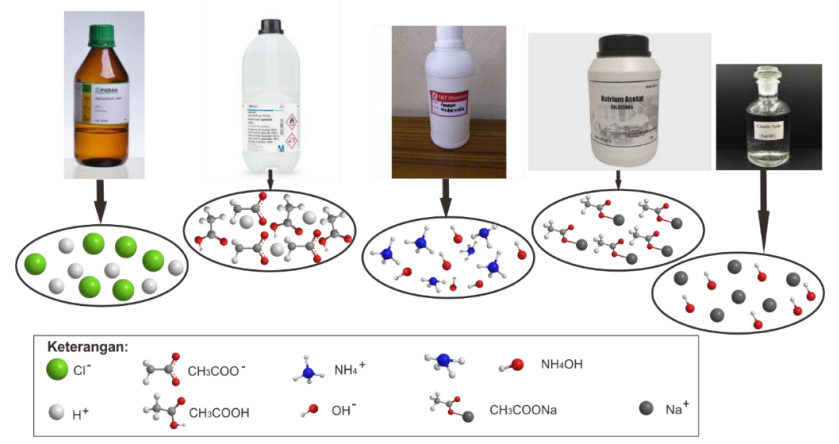

3. Pasangan larutan yang dapat digunakan untuk membuat larutan penyangga asam adalah...
a. $\mathrm{CH}_{3} \mathrm{COOH}$ dan $\mathrm{NaOH}$ berlebih
b. $\mathrm{HCl}$ dan $\mathrm{NaOH}$ berlebih
c. $\mathrm{CH}_{3} \mathrm{COOH}$ berlebih dan $\mathrm{NaOH}$
d. $\mathrm{HCl}$ berlebih dan $\mathrm{NaOH}$
e. $\mathrm{CH}_{3} \mathrm{COOH}$ dan $\mathrm{NH}_{4} \mathrm{OH}$

\section{Pilihan Alasan:}

1) Larutan penyangga asam dapat dibuat dari campuran asam lemah dan basa konjugasinya

\section{Apakah Anda yakin dengan jawaban Anda?}<smiles></smiles><smiles>CCCCCCCCC</smiles>

2) Larutan penyangga asam dapat dibuat dari campuran asam lemah dan basa kuat berlebih

3) Larutan penyangga asam dapat dibuat dari campuran asam lemah berlebih dan basa kuat

4) Larutan penyangga asam dapat dibuat dari campuran asam kuat dan basa kuat berlebih

5) Larutan penyangga asam dapat dibuat dari campuran asam kuat berlebih dan basa kuat

4. Pasangan larutan yang dapat digunakan untuk membuat larutan penyangga basa adalah...
a. $\mathrm{HCl}$ dan $\mathrm{NaOH}$
b. $\mathrm{NH}_{4} \mathrm{OH}$ berlebih dan $\mathrm{HCl}$
c. $\mathrm{CH}_{3} \mathrm{COOH}$ berlebih dan $\mathrm{NaOH}$
d. $\mathrm{CH}_{3} \mathrm{COOH}$ dan $\mathrm{NaOH}$ berlebih
e. $\mathrm{NH}_{4} \mathrm{OH}$ dan $\mathrm{HCl}$ berlebih

\section{Pilihan Alasan:}

1) Larutan penyangga basa dapat dibuat dari campuran asam kuat dan basa kuat 
2) Larutan penyangga basa dapat dibuat dari campuran asam lemah berlebih dan basa kuat

3) Larutan penyangga basa dapat dibuat dari campuran asam lemah dan basa kuat berlebih
4) Larutan penyangga basa dapat dibuat dari campuran basa lemah dan asam kuat berlebih

5) Larutan penyangga basa dapat dibuat dari campuran basa lemah berlebih dan asam kuat

\section{Apakah Anda yakin dengan jawaban Anda?}<smiles>[Al]C1CCC1</smiles>

5. Jika $50 \mathrm{~mL}$ asam asetat $0,1 \mathrm{M}$ dicampurkan dengan larutan natrium asetat $0,1 \mathrm{M}(\mathrm{Ka}$ asam asetat $=1,8 \times 10^{-5}$ ) mempunyai $\mathrm{pH}=5$ $-\log 1,8$, volume larutan natrium asetat yang harus digunakan adalah...
a. $10 \mathrm{~mL}$
b. $20 \mathrm{~mL}$
c. $30 \mathrm{~mL}$
d. $40 \mathrm{~mL}$
e. $50 \mathrm{~mL}$

\section{Pilihan Alasan:}

1) Volume $=\mathrm{mol} \times \mathrm{M}$

2) Volume $=\mathrm{mol} \times \mathrm{Mr}$

3) Volume $=\frac{\mathrm{mol}}{\mathrm{Mr}}$

4) Volume $=\frac{\mathrm{mol}}{\mathrm{M}}$

5) Volume $=22,4 \mathrm{~L} \times \mathrm{mol}$

\section{Apakah Anda yakin dengan jawaban Anda?} Ya Tidak

\section{Bacaan Untuk Soal No. 6 dan 7}

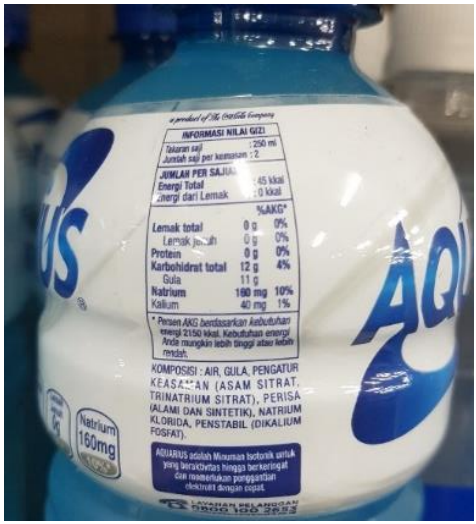

Larutan penyangga tidak hanya terdapat dalam tubuh manusia, tetapi juga banyak digunakan di industri makanan atau minuman. Larutan penyangga tersebut digunakan untuk mengatur $\mathrm{pH}$ dari suatu produk sehingga produk tersebut dapat bertahan lama. Oleh karena, dalam industri makanan dan minuman, penggunaan larutan penyangga adalah hal wajib yang harus digunakan. Gambar di bawah merupakan salah satu contoh minuman yang mengandung larutan penyangga.

6. Komponen larutan penyangga pada gambar tersebut adalah...
a. Air dan gula
b. Natrium klorida dan Asam Sitrat
c. Natrium klorida dan Dikalium Fosfat
d. Asam sitrat dan Trinatrium sitrat
e. Dikalium fosfat dan Asam Sitrat

\section{Pilihan Alasan:}

1) Asam sitrat dan natrium klorida merupakan pasangan asam lemah basa konjugasi

2) Asam sitrat dan dikalium fosfat merupakan pasangan basa lemah asam konjugasi

Apakah Anda yakin dengan jawaban Anda?
3) Air dan gula apabila dicampurkan dapat membentuk larutan penyangga

4) Natrium klorida dan dikalium fosfat dapat membentuk larutan penyangga

5) Asam sitrat dan trinatrium sitrat adalah pasangan asam lemah - basa konjugasi Ya 
7. Larutan penyangga pada minuman tersebut bersifat...
a. Asam
b. Basa
c. Netral
d. Lemah
e. Kuat

\section{Pilihan Alasan:}

1) Larutan penyangga tersebut terdiri dari asam lemah dan basa lemah

\section{Apakah Anda yakin dengan jawaban Anda?}

Ya Tidak

Bacaan Untuk Soal No. 8 - 10

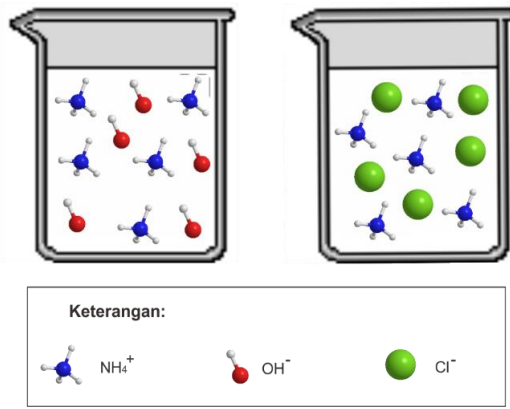

2) Larutan penyangga tersebut terdiri dari asam lemah dan basa konjugasinya

3) Larutan penyangga tersebut terdiri dari basa lemah dan asam kuat

4) Larutan penyangga tersebut terdiri dari basa lemah dan asam konjugasinya

5) Larutan penyangga tersebut terdiri dari asam kuat dan basa kuat

Siswa kelas XI MIPA diberi tugas untuk membuat larutan penyangga. Di laboratorium kimia tersedia larutan amoniak $0,2 \mathrm{M}\left(\mathrm{Kb}=1,8 \times 10^{-5}\right)$ dan larutan ammonium klorida 0,2 $\mathrm{M}$ seperti pada gambar di bawah ini. Mereka ingin membuat larutan penyangga dengan $\mathrm{pH}=9,26$. (Diketahui: $5-\log 1,8=4,74$ )

8. Cara membuat larutan penyangga tersebut adalah...

a. Mencampurkan $10 \mathrm{~mL}$ larutan $\mathrm{NH}_{3} 0,2$ M dengan $15 \mathrm{~mL}$ larutan $\mathrm{NH}_{4} \mathrm{Cl}$ 0,2 M

b. Mencampurkan $10 \mathrm{~mL}$ larutan $\mathrm{NH}_{3} 0,2$ $\mathrm{M}$ dengan $20 \mathrm{~mL}$ larutan $\mathrm{NH}_{4} \mathrm{Cl}$ 0,2 M

c. Mencampurkan $10 \mathrm{~mL}$ larutan $\mathrm{NH}_{3} 0,2$

$\mathrm{M}$ dengan $10 \mathrm{~mL}$ larutan $\mathrm{NH}_{4} \mathrm{Cl} 0,2 \mathrm{M}$

d. Mencampurkan $15 \mathrm{~mL}$ larutan $\mathrm{NH}_{3}$ 0,2 $\mathrm{M}$ dengan $10 \mathrm{~mL}$ larutan $\mathrm{NH}_{4} \mathrm{Cl}$ 0,2 $\mathrm{M}$

e. Mencampurkan $20 \mathrm{~mL}$ larutan $\mathrm{NH}_{3} 0,2 \mathrm{M}$ dengan $10 \mathrm{~mL}$ larutan $\mathrm{NH}_{4} \mathrm{Cl}$ 0,2 $\mathrm{M}$

\section{Pilihan Alasan:}

1) Agar diperoleh $\mathrm{pH}=9,26$ maka $\left[\mathrm{OH}^{-}\right]$harus sama dengan $\mathrm{Kb}$

2) Agar diperoleh $\mathrm{pH}=9,26$ maka $\left[\mathrm{OH}^{-}\right]$harus berbeda dengan $\mathrm{Kb}$

3) $\mathrm{pH}=-\log \left[\mathrm{OH}^{-}\right]$

4) $\mathrm{pH}=-\log \left[\mathrm{H}^{+}\right]$

5) Volume $\mathrm{NH}_{3}$ harus lebih besar daripada $\mathrm{NH}_{4} \mathrm{Cl}$

\section{Apakah Anda yakin dengan jawaban Anda?}

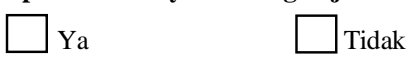

9. Apabila pada larutan penyangga tersebut ditambah larutan $\mathrm{HCl}$, maka...
a. $\mathrm{HCl}$ akan bereaksi dengan spesi yang bersifat asam
b. $\mathrm{HCl}$ akan bereaksi dengan spesi yang bersifat basa
c. $\mathrm{HCl}$ tidak bereaksi dengan spesi manapun
d. $\mathrm{HCl}$ tidak menggeser kesetimbangan
e. $\mathrm{HCl}$ tidak merubah $\mathrm{pH}$ larutan

\section{Pilihan Alasan:}

1) $\mathrm{H}^{+}$dari $\mathrm{HCl}$ bereaksi dengan $\mathrm{NH}_{3}$

2) $\mathrm{Cl}^{-}$dari $\mathrm{HCl}$ bereaksi dengan $\mathrm{NH}_{4}{ }^{+}$

3) $\mathrm{HCl}$ akan membuat larutan menjadi lebih asam
4) $\mathrm{HCl}$ akan membuat larutan menjadi lebih basa

5) $\mathrm{HCl}$ akan membuat larutan menjadi netral 


\section{Apakah Anda yakin dengan jawaban Anda?}

Ya Tidak

10. Apabila larutan penyangga tersebut ditambah $5 \mathrm{~mL}$ aquades, maka...
a. pH larutan menjadi lebih basa
b. pH larutan menjadi lebih asam
c. $\mathrm{pH}$ larutan tetap
d. $\mathrm{pH}$ larutan $=7$
e. $\mathrm{pH}$ larutan $<9$

\section{Pilihan Alasan:}

1) Larutan penyangga asam akan tetap pHnya jika diencerkan

2) Larutan penyangga basa akan berubah menjadi asam jika ditambahkan aquades

3) Larutan penyangga basa akan berubah menjadi netral jika ditambahkan aquades

4) Pengenceran tidak akan mengubah $\mathrm{pH}$ larutan penyangga

5) Penambahan aquades menyebabkan $\mathrm{pH}$ larutan penyangga berubah

\section{Apakah Anda yakin dengan jawaban Anda?}

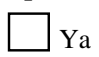
Tidak

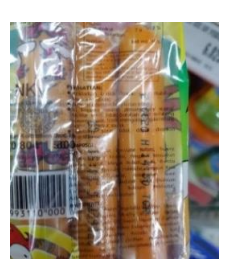

\section{Bacaan Untuk Soal No. 11}

Yeni membeli sosis kemasan siap makan. Saat melihat kemasan sosis tersebut, diketahui bahwa komposisi sosis tersebut antara lain daging ayam, air, penstabil nabati, tepung tapioka, protein kedelai, natrium laktat, minyak nabati, gula, bumbu, garam, penstabil fosfat, asam laktat dan antioksidan natrium eritorbat.

11.Berdasarkan komposisi di atas, komponen yang berfungsi sebagai larutan penyangga adalah...
a. Gula dan garam
b. Natrium laktat dan natrium eritorbat
c. Natrium eritorbat dan asam eritorbat
d. Minyak nabati dan penstabil fosfat
e. Natrium laktat dan asam laktat

\section{Alasan Pilihan:}

1) Minyak nabati dan penstabil fosfat jika dicampurkan dapat membentuk larutan penyangga

2) Natrium eritorbat merupakan garam dari asam eritorbat, sehingga kedua

Apakah Anda yakin dengan jawaban Anda?

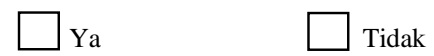
komponen tersebut dapat membentuk larutan penyangga

3) Natrium laktat dan natrium eritorbat merupakan zat yang dapat menstabilkan $\mathrm{pH}$

4) Gula dan garam keduanya dapat menstabilkan $\mathrm{pH}$

5) Natrium laktat merupakan garam dari asam laktat, sehingga keduanya berfungsi mengatur keasaman suatu produk

\section{Bacaan Untuk No. 12 - 14}

Guru kimia kelas XI merancang percobaan praktikum pada materi larutan penyangga. Tujuan dari praktikum tersebut adalah untuk mengetahui pengaruh penambahan asam dan basa pada larutan penyangga. Bahan-bahan yang disediakan di laboratorium adalah sebagai berikut. 


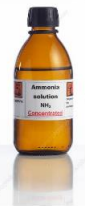

Larutan $\mathrm{NH}_{3}$

a. $3,56 \mathrm{mg}$

b. $356 \mathrm{mg}$

c. $0,02 \mathrm{mg}$

d. $200 \mathrm{mg}$

e. $140 \mathrm{mg}$
12. Banyaknya $\left(\mathrm{NH}_{4}\right)_{2} \mathrm{SO}_{4}$ yang dilarutkan dalam $300 \mathrm{~mL}$ larutan $\mathrm{NH}_{3} 0,1 \mathrm{M}$ agar $\mathrm{pH}-\mathrm{nya}=10+\log 2$ adalah... (Ar $\mathrm{N}=14, \mathrm{~S}=32$, dan $\mathrm{O}=16$, serta $\mathrm{Kb} \mathrm{NH}_{3}=1,8$ $\times 10^{-5}$ )

\section{Pilihan Alasan:}

1) Massa $=\mathrm{mol} \times \mathrm{Mr}$

2) Massa $=\operatorname{mol} \times 6,02 \times 10^{23}$

3) Massa $=\frac{\mathrm{mol}}{\mathrm{Mr}}$

4) Massa $=\frac{\mathrm{mol}}{\mathrm{M}}$

5) Massa $=22,4 \mathrm{~L} \times \mathrm{mol}$

\section{Apakah Anda yakin dengan jawaban Anda?}

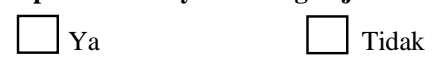

13. Apabila $100 \mathrm{~mL}$ larutan $\left(\mathrm{NH}_{4}\right)_{2} \mathrm{SO}_{4}$ 0,2 $\mathrm{M}$ dicampurkan dengan $200 \mathrm{~mL}$ larutan $\mathrm{NH}_{3} 0,2 \mathrm{M}$, maka $\mathrm{pH}$ campuran tersebut adalah... $\left(\mathrm{Kb} \mathrm{NH}_{3}=1,8 \times 10^{-5}\right)$
a. $5-\log 3,6$
b. $5-\log 1,8$
c. $9+\log 3,6$
d. $9-\log 3,6$
e. $9+\log 1,8$

Pilihan Alasan:

1) $\mathrm{pH}=-\log \left[\mathrm{H}^{+}\right]$

2) $\mathrm{pH}=+\log \left[\mathrm{H}^{+}\right]$

3) $\mathrm{pH}=-\log \left[\mathrm{OH}^{-}\right]$

4) $\mathrm{pH}=+\log \left[\mathrm{OH}^{-}\right]$

5) $\mathrm{pH}=14-\mathrm{pOH}$

Apakah Anda yakin dengan jawaban Anda?

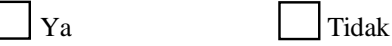

14. $\mathrm{pH}$ dari $100 \mathrm{~mL}$ larutan $\left(\mathrm{NH}_{4}\right)_{2} \mathrm{SO}_{4} 0,1 \mathrm{M}$ yang dicampurkan dengan $200 \mathrm{~mL} \mathrm{NH}_{3} 0,1 \mathrm{M}$ adalah 9 $+\log$ 3,6. Apabila $20 \mathrm{~mL}$ larutan $\mathrm{HCl} 0,1 \mathrm{M}$ ditambahkan ke dalam larutan, maka $\mathrm{pH}$ larutan menjadi... $\left(\mathrm{Kb} \mathrm{NH}_{3}=1,8 \times 10^{-5}\right)$
a. $9+\log 3,6$
b. $9+\log 2,7$
c. $\quad 9-\log 2,7$
d. $5-\log 2,7$
e. $5+\log 2,7$

\section{Pilihan Alasan:}

1) $\mathrm{pH}=-\log \left[\mathrm{H}^{+}\right]$

2) $\mathrm{pH}=+\log \left[\mathrm{H}^{+}\right]$

3) $\mathrm{pH}=-\log \left[\mathrm{OH}^{-}\right]$

4) $\mathrm{pH}=+\log \left[\mathrm{OH}^{-}\right]$

5) $\mathrm{pH}=14-\mathrm{pOH}$

\section{Apakah Anda yakin dengan jawaban Anda?}<smiles>C1C[Al]C1</smiles>
Tidak

\section{Bacaan Untuk Soal No. 15 - 17}

Bu Rani menyediakan 4 macam larutan yang dimasukkan ke dalam gelas beaker dengan komposisi berbeda. Bu Dewi memberi tugas kepada para siswa untuk mengidentifikasi larutan yang termasuk penyangga dan bukan penyangga. Isi larutan tersebut adalah sebagai berikut. 


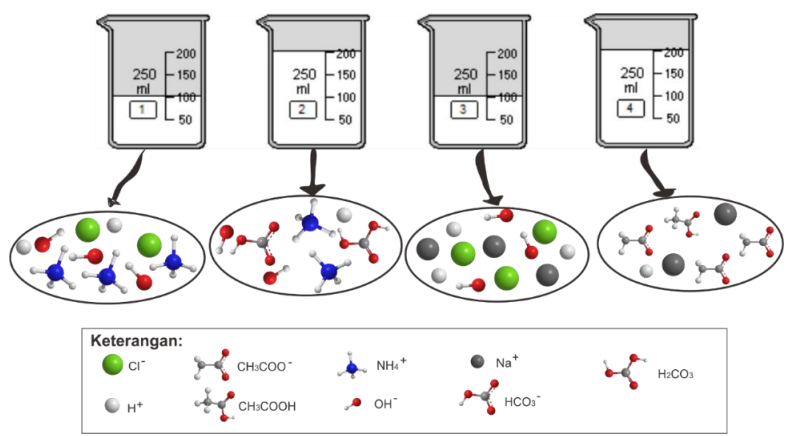

15. Campuran yang bukan penyangga terdapat pada gelas beaker nomor...
a. 1 dan 2
b. 4 saja
c. 2 dan 3
d. 1 dan 4
e. 1 saja

\section{Pilihan Alasan:}

1) Larutan pada gelas beaker 2 adalah campuran asam lemah dan basa lemah, sedangkan larutan pada gelas beaker 3 adalah campuran asam kuat dan basa kuat, sehingga keduanya bukan larutan penyangga.

2) Larutan pada gelas beaker 1 terdiri dari campuran basa lemah dan asam lemah sehingga bukan termasuk larutan penyangga.

3) Larutan pada gelas beaker 1 terdiri dari campuran basa lemah dan asam

\section{Apakah Anda yakin dengan jawaban Anda?}

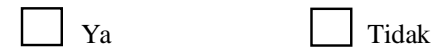

16. Komponen larutan penyangga asam pada larutan di atas adalah....
a. $\mathrm{NH}_{3}$ dan $\mathrm{NH}_{4}^{+}$
b. $\mathrm{NH}_{4}^{+}$dan $\mathrm{Cl}^{-}$
c. $\mathrm{CH}_{3} \mathrm{COOH}$ dan $\mathrm{CH}_{3} \mathrm{COO}^{-}$
d. $\mathrm{CH}_{3} \mathrm{COO}^{-}$dan $\mathrm{H}^{+}$
e. $\mathrm{CH}_{3} \mathrm{COOH}$ dan $\mathrm{OH}^{-}$

\section{Pilihan Alasan:}

1) $\mathrm{CH}_{3} \mathrm{COOH}$ adalah asam lemah dan $\mathrm{OH}^{-}$adalah basa konjugasinya

2) $\mathrm{CH}_{3} \mathrm{COOH}$ adalah asam lemah dan $\mathrm{CH}_{3} \mathrm{COO}^{-}$adalah basa konjugasinya

3) $\mathrm{NH}_{4}{ }^{+}$adalah asam lemah dan $\mathrm{NH}_{3}$ adalah basa konjugasinya

4) $\mathrm{NH}_{4}{ }^{+}$adalah asam lemah dan $\mathrm{Cl}^{-}$ adalah basa konjugasinya

5) $\mathrm{CH}_{3} \mathrm{COO}^{-}$adalah basa konjugasi dari $\mathrm{H}^{+}$

\section{Apakah Anda yakin dengan jawaban Anda?}


17. Komponen larutan penyangga basa pada larutan di atas adalah...
a. $\mathrm{CH}_{3} \mathrm{COOH}$ dan $\mathrm{CH}_{3} \mathrm{COO}^{-}$
b. $\mathrm{NH}_{3}$ dan $\mathrm{NH}_{4}{ }^{+}$
c. $\mathrm{CH}_{3} \mathrm{COO}^{-}$dan $\mathrm{H}^{+}$
d. $\mathrm{NH}_{4}{ }^{+}$dan $\mathrm{Cl}^{-}$
e. $\mathrm{CH}_{3} \mathrm{COOH}$ dan $\mathrm{OH}^{-}$

\section{Pilihan Alasan:}

1) $\mathrm{NH}_{3}$ adalah basa lemah dan $\mathrm{NH}_{4}{ }^{+}$adalah asam konjugasinya

2) $\mathrm{CH}_{3} \mathrm{COO}^{-}$adalah basa lemah dan $\mathrm{CH}_{3} \mathrm{COOH}$ adalah asam konjugasinya

3) $\mathrm{Cl}^{-}$adalah basa lemah dan $\mathrm{NH}_{4}{ }^{+}$adalah asam konjugasinya

4) $\mathrm{CH}_{3} \mathrm{COO}^{-}$adalah basa lemah dan $\mathrm{H}^{+}$adalah asam konjugasinya

5) $\mathrm{CH}_{3} \mathrm{COOH}$ adalah asam konjugasi dari $\mathrm{OH}^{-}$

\section{Apakah Anda yakin dengan jawaban Anda?}
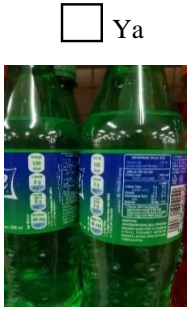

Tidak

\section{Bacaan Untuk Soal No. 11}

Minuman bersoda merupakan jenis minuman dalam kemasan yang mengalami proses karbonasi. Karbonasi terjadi apabila gas $\mathrm{CO}_{2}$ terlarut sempurna dalam air. Hasil proses karbonasi dalam minuman bersoda ditandai dengan adanya buih. Minuman bersoda diketahui mengandung larutan penyangga yang berfungsi untuk mengatur $\mathrm{pH}$ atau tingkat keasaman pada minuman tersebut. Siswa kelas XI melakukan percobaan yang bertujuan untuk menguji pengaruh pengenceran dan penambahan asam dan basa pada minuman tersebut.

18. Tahapan yang tepat dalam pengujian pengaruh pengenceran dan penambahan asam dan basa pada minuman tersebut adalah...

a. Mengukur $\mathrm{pH}$ awal minuman bersoda ketika busanya masih banyak, menambahkan sedikit asam/basa/aquades, mengukur $\mathrm{pH}$ setelah penambahan

b. Mengukur $\mathrm{pH}$ awal minuman bersoda langsung setelah dituang, menambahkan sedikit asam/basa/aquades, mengukur $\mathrm{pH}$ setelah penambahan

c. Mengukur $\mathrm{pH}$ awal minuman bersoda ketika busanya tinggal sedikit, menambahkan sedikit asam/basa/aquades, mengukur $\mathrm{pH}$ setelah penambahan

d. Mengukur $\mathrm{pH}$ awal minuman bersoda ketika busanya sudah hilang, menambahkan sedikit asam/basa/aquades, mengukur $\mathrm{pH}$ setelah penambahan

e. Menambahkan sedikit asam/basa/aquades, mengukur $\mathrm{pH}$ setelah penambahan

\section{Pilihan Alasan:}

1) Pengukuran $\mathrm{pH}$ awal minuman bersoda harus dilakukan ketika $\mathrm{CO}_{2}$ di dalam larutan masih banyak

2) Dengan penambahan asam atau basa kita dapat mengetahui larutan tersebut merupakan larutan penyangga atau bukan

3) Pengukuran $\mathrm{pH}$ awal minuman bersoda harus dilakukan ketika busanya tinggal sedikit agar masih ada $\mathrm{CO}_{2}$ di dalam larutan

4) Pengukuran $\mathrm{pH}$ awal minuman dilakukan ketika $\mathrm{CO}_{2}$ sudah hilang, agar yang tersisa dalam minuman hanya larutan penyangganya saja.

5) Pengukuran $\mathrm{pH}$ awal minuman bersoda langsung setelah dituang dapat mencegah $\mathrm{CO}_{2}$ hilang.

\section{Apakah Anda yakin dengan jawaban Anda?}

Ya 


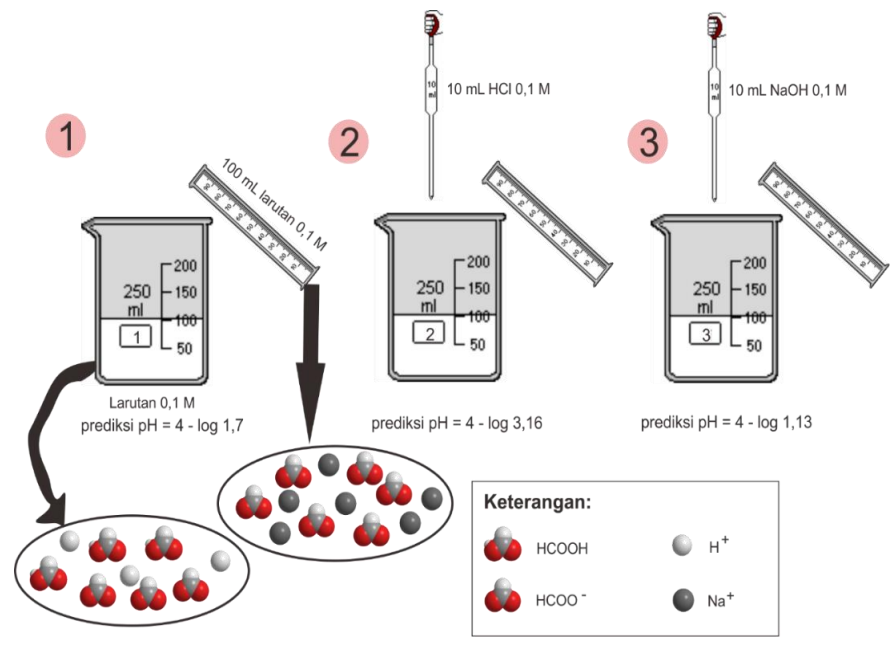

Bacaan Untuk

Soal No. 19 - 20

Kelompok $\quad 1$

membuat rancangan praktikum mengenai larutan penyangga, mulai dari merancang cara kerja sampai membuat tabel pengamatan yang berisi prediksi hasil. Prediksi hasil kelompok 1 adalah sebagai berikut.

$\left(\mathrm{Ka}=1,7 \times 10^{-4}\right)$

19. Dari gambar di samping, prediksi hasil yang benar yang dibuat kelompok 1 yaitu...
a. Hanya prediksi hasil 1 dan 2 saja yang
c. Semua prediksi hasil salah benar
d. Hanya prediksi hasil 1 saja yang benar
e. Semua prediksi hasil benar
b. Hanya prediksi hasil 2 dan 3 saja yang benar

\section{Pilihan Alasan:}

1) Jumlah mol $\mathrm{HCOOH}, \mathrm{HCOONa}, \mathrm{HCl}$ dan $\mathrm{NaOH}$ berturut-turut adalah $10 \mathrm{mmol}, 10 \mathrm{mmol}, 1$ mmol dan 1 mmol. Sehingga berdasarkan perhitungan menggunakan rumus $\mathrm{pH}=-\log \left[\mathrm{H}^{+}\right]$, prediksi $\mathrm{pH}$ yang benar adalah prediksi hasil 1 dan 2

2) Jumlah mol $\mathrm{HCOOH}, \mathrm{HCOONa}, \mathrm{HCl}$ dan $\mathrm{NaOH}$ secara berturut-turut adalah 10 mmol, 10 mmol, $1 \mathrm{mmol}$ dan $1 \mathrm{mmol}$. Sehingga berdasarkan perhitungan menggunakan rumus $\mathrm{pH}=-$ $\log \left[\mathrm{H}^{+}\right]$, prediksi $\mathrm{pH}$ yang benar adalah prediksi hasil 1 saja

3) Jumlah mol $\mathrm{HCOOH}, \mathrm{HCOONa}, \mathrm{HCl}$ dan $\mathrm{NaOH}$ secara berturut-turut adalah 100 mmol, 100 $\mathrm{mmol}, 10 \mathrm{mmol}$ dan $10 \mathrm{mmol}$. Sehingga berdasarkan perhitungan menggunakan rumus $\mathrm{pH}=$ - $\log \left[\mathrm{H}^{+}\right]$, prediksi $\mathrm{pH}$ yang benar adalah prediksi hasil 2 dan 3 saja

4) Jumlah mol $\mathrm{HCOOH}, \mathrm{HCOONa}, \mathrm{HCl}$ dan $\mathrm{NaOH}$ secara berturut-turut adalah $10 \mathrm{mmol}, 10$ mmol, $1 \mathrm{mmol}$ dan $1 \mathrm{mmol}$. Sehingga berdasarkan perhitungan menggunakan rumus $\mathrm{pH}=-$ $\log \left[\mathrm{H}^{+}\right]$, prediksi $\mathrm{pH}$ yang benar adalah semua prediksi hasil benar

5) Jumlah mol $\mathrm{HCOOH}, \mathrm{HCOONa}, \mathrm{HCl}$ dan $\mathrm{NaOH}$ secara berturut-turut adalah $100 \mathrm{mmol}, 100$ mmol, $10 \mathrm{mmol}$ dan $10 \mathrm{mmol}$. Sehingga berdasarkan perhitungan menggunakan rumus $\mathrm{pH}=$ - $\log \left[\mathrm{H}^{+}\right]$, prediksi $\mathrm{pH}$ yang benar adalah semua prediksi hasil salah

\section{Apakah Anda yakin dengan jawaban Anda?}

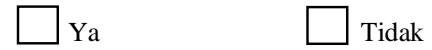

20. Larutan penyangga yang dibuat kelompok 1 bersifat...
a. Asam
b. Basa
c. Netral
d. Lemah
e. Kuat 


\section{Pilihan Alasan:}

1) Pada larutan tersebut terdapat $\mathrm{Na}^{+}$yang bertindak sebagai asam

2) Pada larutan tersebut terdapat $\mathrm{H}^{+}$yang merupakan pembawa sifat asam

3) Pada larutan tersebut terdapat $\mathrm{HCOO}^{-}$yang membawa sifat sebagai basa

4) Semua ion pada larutan tersebut tidak berpengaruh terhadap sifat dari larutan penyangga

5) Larutan tersebut terdiri dari asam lemah dan garamnya yang menyebabkan sifatnya menjadi lemah

\section{Apakah Anda yakin dengan jawaban Anda?}

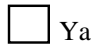

Tidak

Bacaan Untuk Soal No. 21

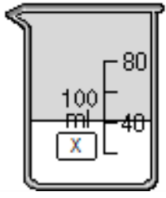

$\mathrm{pH}=7$

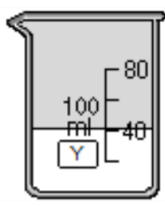

$\mathrm{pH}=4,75$

Siswa kelas XI menguji dua sampel larutan yang diberi label $\mathrm{X}$ dan Y. pH awal larutan $\mathrm{X}$ adalah 7, sedangkan $\mathrm{pH}$ awal larutan $\mathrm{Y}$ adalah 4,75. Kedua larutan tersebut ditambahkan masingmasing $5 \mathrm{~mL}$ larutan $\mathrm{HCl} 0,1 \mathrm{M}$. Ternyata $\mathrm{pH}$ larutan $\mathrm{X}$ berubah drastis menjadi 1,70. Sedangkan $\mathrm{pH}$ larutan $\mathrm{Y}$ adalah 4,70. Kemudian, pada larutan yang sama ditambahkan masingmasing $5 \mathrm{~mL}$ larutan $\mathrm{NaOH} 0,1 \mathrm{M}$. Setelah penambahan larutan $\mathrm{NaOH}, \mathrm{pH}$ larutan $\mathrm{X}$ mengalami peningkatan yaitu menjadi 12,30, sedangkan $\mathrm{pH}$ larutan $\mathrm{Y}$ hanya mengalami sedikit peningkatan menjadi 4,79.

21. Dari permasalahan di atas, maka kesimpulan yang tepat adalah...

a. Larutan $\mathrm{X}$ adalah larutan bersifat basa, sedangkan larutan $\mathrm{Y}$ adalah larutan bersifat asam

b. Larutan $\mathrm{X}$ bukan larutan penyangga, sedangkan larutan $\mathrm{Y}$ adalah larutan penyangga

c. Larutan $\mathrm{Y}$ bukan larutan penyangga, sedangkan larutan $\mathrm{X}$ adalah larutan penyangga

d. Larutan $\mathrm{Y}$ dan $\mathrm{X}$ adalah larutan penyangga

e. Larutan $\mathrm{X}$ dan $\mathrm{Y}$ bukan larutan penyangga

\section{Pilihan Alasam:}

1) Larutan $\mathrm{X}$ ketika ditambahkan asam kuat $\mathrm{pH}$-nya menjadi $<7$

2) Larutan $\mathrm{X}$ ketika ditambahkan basa kuat $\mathrm{pH}$-nya menjadi $>7$

3) $\mathrm{pH}$ larutan $\mathrm{X}$ mengalami perubahan drastis ketika ditambahkan asam kuat dan basa kuat berbeda dengan larutan $\mathrm{Y}$ yang perubahannya sangat kecil

4) $\mathrm{pH}$ larutan $\mathrm{X}$ dan larutan $\mathrm{Y}$ tidak mengalami perubahan $\mathrm{pH}$ yang drastis

5) Larutan $\mathrm{X}$ dan larutan $\mathrm{Y}$ mengalami perubahan $\mathrm{pH}$ ketika ditambahkan asam kuat atau basa kuat

\section{Apakah Anda yakin dengan jawaban Anda?}

Ya

Tidak 


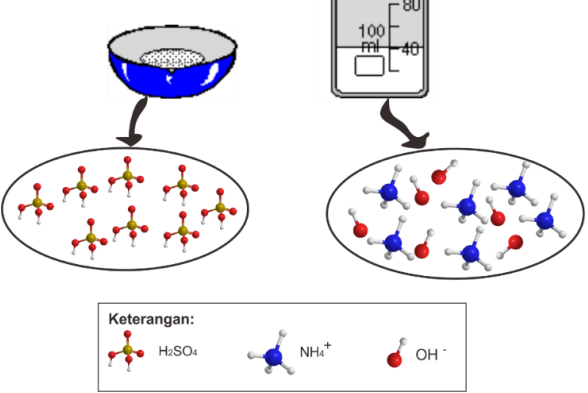
a. $9+\log 5,4$
b. $9-\log 5,4$
c. $9+\log 7,2$
d. $5-\log 5,4$
e. $5-\log 7,2$

22. Zat yang terdapat di dalam cawan porselin tersebut dibuat menjadi larutan dengan volume $10 \mathrm{~mL}$ dan konsentrasinya adalah 0,2 M. Larutan yang telah dibuat kemudian dicampurkan dengan $40 \mathrm{~mL}$ larutan di dalam gelas beaker dengan konsentrasi $0,2 \mathrm{M}$. $\mathrm{pH}$ larutan tersebut adalah... $\left(\mathrm{Kb}=1,8 \times 10^{-}\right.$ $\left.{ }^{5}\right)$

\section{Pilihan Alasan:}

1) $\mathrm{pH}=-\log \left[\mathrm{H}^{+}\right]$

2) $\mathrm{pH}=-\log \left[\mathrm{OH}^{-}\right]$

3) $\mathrm{pH}=14-\mathrm{pOH}$

4) $\mathrm{pH}=+\log \left[\mathrm{OH}^{-}\right]$

5) $\mathrm{pH}=+\log \left[\mathrm{H}^{+}\right]$

\section{Apakah Anda yakin dengan jawaban Anda?}

\section{$\square \mathrm{Ya}$}

Tidak

23. Massa zat yang terdapat di dalam cawan porselin tersebut apabila $\mathrm{pH}$ larutan penyangga $=9+\log$ $5,4$ adalah... (Ar $\mathrm{H}=1, \mathrm{O}=16, \mathrm{~S}=32)$
a. $\quad 98 \mathrm{mg}$
b. $196 \mathrm{mg}$
c. $49 \mathrm{mg}$
d. $4,9 \mathrm{mg}$
e. $19,6 \mathrm{mg}$

\section{Pilihan Alasan:}
1) Massa $=\frac{m o l}{M r}$
2) Massa $=\mathrm{mol} \times \mathrm{Mr}$
3) Massa $=22,4 \mathrm{~L} \times \mathrm{mol}$
4) Massa $=\operatorname{mol} \times 6,02 \times 10^{23}$
5) Massa $=\frac{\mathrm{mol}}{\mathrm{M}}$

\section{Apakah Anda yakin dengan jawaban Anda?}<smiles></smiles>

\section{Tidak}

24. Komponen penyangga dari larutan penyangga di atas adalah....
a. $\mathrm{H}_{2} \mathrm{SO}_{4}$ dan $\mathrm{NH}_{4}^{+}$
b. $\mathrm{H}_{2} \mathrm{SO}_{4}$ dan $\mathrm{NH}_{4} \mathrm{OH}$
c. $\mathrm{NH}_{4} \mathrm{OH}$ dan $\mathrm{NH}_{4}^{+}$
d. $\mathrm{NH}_{4} \mathrm{OH}$ dan $\mathrm{HSO}_{4}$
e. $\mathrm{NH}_{4} \mathrm{OH}$ dan $\mathrm{H}^{+}$

\section{Pilihan Alasan:}

1) $\mathrm{NH}_{4} \mathrm{OH}$ merupakan basa lemah, sedangkan $\mathrm{NH}_{4}{ }^{+}$adalah asam konjugasinya.

2) $\mathrm{NH}_{4} \mathrm{OH}$ merupakan asam lemah, sedangkan $\mathrm{HSO}_{4}{ }^{-}$adalah basa konjugasinya

3) $\mathrm{NH}_{4} \mathrm{OH}$ merupakan basa lemah, sedangkan $\mathrm{H}^{+}$adalah asam konjugasinya

4) $\mathrm{NH}_{4} \mathrm{OH}$ merupakan basa lemah, sedangkan $\mathrm{H}_{2} \mathrm{SO}_{4}$ adalah asam kuat

5) $\mathrm{H}_{2} \mathrm{SO}_{4}$ adalah asam kuat, sedangkan $\mathrm{NH}_{4}{ }^{+}$adalah asam konjugasinya.

Apakah Anda yakin dengan jawaban Anda?

Ya 

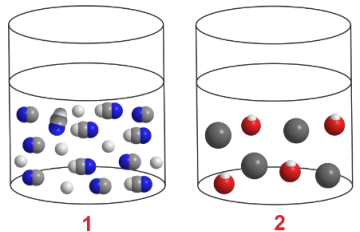

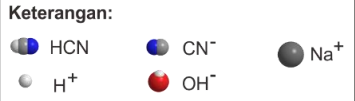

25. Apabila larutan di gelas 1 dan gelas 2 dicampurkan maka larutan tersebut akan membentuk larutan penyangga yang bersifat...
a. Basa
b. Asam
c. Netral
d. Kuat
e. Lemah

1) $\mathrm{OH}^{-}$merupakan zat pembawa sifat basa

2) $\mathrm{Na}^{+}$membuat larutan menjadi bersifat kuat

3) $\mathrm{OH}^{-}$dan $\mathrm{H}^{+}$bertemu membentuk larutan yang $\mathrm{pH}$-nya netral

4) $\mathrm{H}^{+}$merupakan zat pembawa sifat asam

5) $\mathrm{CN}^{-}$membuat larutan menjadi bersifat lemah

\section{Pilihan Alasan:}

Apakah Anda yakin dengan jawaban Anda?<smiles>[Y16]1CCC1</smiles>
Tidak

B. Uraian

Isilah pertanyaan-pertanyaan di bawah ini dengan benar!

\section{Perhatikan gambar berikut ini!}
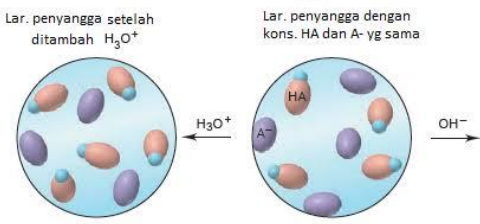

Lar.penyangga setelah ditambah $\mathrm{OH}^{-}$

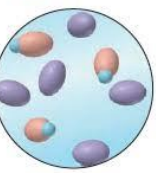

tersebut adalah seperti di samping.

26. Jelaskan maksud gambar di atas!

Bacaan Untuk Soal No. 27 - 29

Athi diberi tugas untuk menguji pengaruh penambahan sedikit asam dan sedikit basa ke dalam larutan penyangga. Larutan penyangga yang ia gunakan terbuat dari larutan $100 \mathrm{~mL} \mathrm{H}_{2} \mathrm{CO}_{3}$ 0,3 $\mathrm{M}$ dan larutan $\mathrm{NaHCO}_{3}$ $0,1 \mathrm{M}$ yang mempunyai $\mathrm{pH}=7-\log 4,2\left(\mathrm{Ka} \mathrm{H}_{2} \mathrm{CO}_{3}=\right.$ $\left.4,2 \times 10^{-7}\right)$.
27. Berapakah volume $\mathrm{NaHCO}_{3}$ yang digunakan untuk membuat larutan penyangga tersebut?

28. Berapa $\mathrm{pH}$ larutan tersebut apabila ditambahkan $20 \mathrm{~mL}$ larutan $\mathrm{NaOH}$ $0,1 \mathrm{M}$ ?

29. Berapa $\mathrm{pH}$ larutan tersebut apabila ditambahkan $20 \mathrm{~mL}$ larutan $\mathrm{HCl}$ 0,1 M? 
30. Bagaimanakah cara membuat larutan penyangga dengan $\mathrm{pH}=3$ dari $\mathrm{CH}_{3} \mathrm{COOH}$ ? $\left(\mathrm{Ka}=1,8 \times 10^{-5}\right)$

31. $100 \mathrm{~mL}$ asam lemah (HA) dengan konsentrasi $0,1 \mathrm{M}$ memiliki $\mathrm{pKa}=3,2$. Pada larutan tersebut ditambahkan x mol KA sehingga menghasilkan $\mathrm{pH}$ larutan 3,5. Jumlah mol KA yang ditambahkan adalah... $(\log 2=0,3)$

\section{Bacaan Untuk Soal No. 32}

Di laboratorium kimia terdapat berbagai larutan asam dan basa. Siswa kelas XI diberi tugas untuk menentukan pasangan larutan asam dan basa yang dapat membentuk larutan penyangga. Berikut ini adalah daftar larutan asam dan basa yang tersedia di laboratorium kimia.

\begin{tabular}{|c|l|c|c|}
\hline No. & \multicolumn{1}{|c|}{ Larutan Asam atau Basa } & Konsentrasi & Volume \\
\hline 1. & Larutan $\mathrm{NaOH}$ & $0,1 \mathrm{M}$ & $100 \mathrm{~mL}$ \\
\hline 2. & Larutan $\mathrm{NH}_{3}$ & $0,3 \mathrm{M}$ & $150 \mathrm{~mL}$ \\
\hline 3. & Larutan $\mathrm{HCl}$ & $0,1 \mathrm{M}$ & $100 \mathrm{~mL}$ \\
\hline 4. & Larutan $\mathrm{CH}_{3} \mathrm{COOH}$ & $0,1 \mathrm{M}$ & $200 \mathrm{~mL}$ \\
\hline 5. & Larutan $\mathrm{HClO}_{3}$ & $0,2 \mathrm{M}$ & $150 \mathrm{~mL}$ \\
\hline
\end{tabular}

32. Tuliskan pasangan larutan asam dan basa yang dapat membentuk larutan penyangga dan yang bukan larutan penyangga!

33. Perbandingan volume $\mathrm{CH}_{3} \mathrm{COOH} 0,1 \mathrm{M}\left(\mathrm{Ka}=1,8 \times 10^{-5}\right)$ dan $\mathrm{CH}_{3} \mathrm{COONa} 0,1 \mathrm{M}$ yang harus dicampurkan untuk membuat larutan penyangga dengan $\mathrm{pH}=5-\log 3,6$ adalah....

34. Diketahui larutan $\mathrm{HCOOH} 0,2 \mathrm{M}$ dan $(\mathrm{HCOO})_{2} \mathrm{Ba} 0,1 \mathrm{M}$. Jika kedua larutan tersebut dibuat larutan penyangga yang memiliki $\mathrm{pH} 4$, tentukan perbandingan volume $\mathrm{HCOOH}$ dan $(\mathrm{HCOO})_{2} \mathrm{Ba}$ ! ( $\mathrm{Ka}$ $\mathrm{HCOOH}=2 \times 10^{-4}$ )

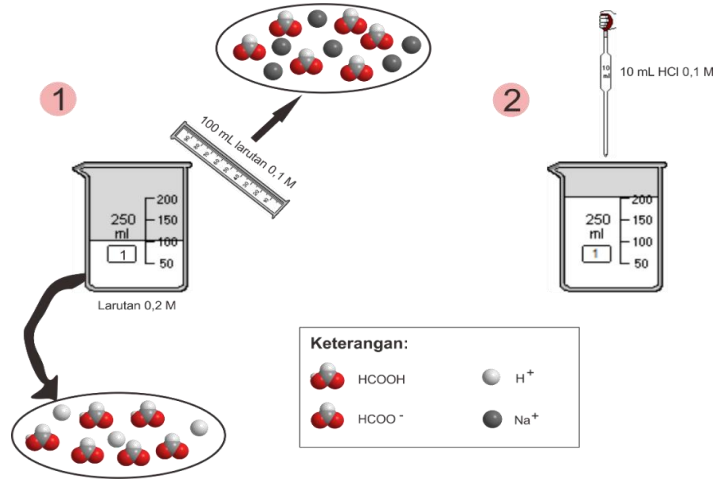

Perhatikan gambar di samping! (Untuk No. 35 - 37)

35. Hitunglah $\mathrm{pH}$ larutan penyangga sebelum penambahan asam berdasarkan ilustrasi gambar di atas!

36. Hitunglah $\mathrm{pH}$ larutan penyangga setelah penambahan asam berdasarkan ilustrasi gambar di atas!

37. Jelaskan sifat larutan sebelum penambahan asam dan setelah penambahan asam!

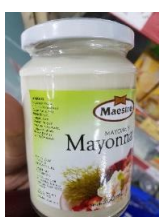

\section{Bacaan Untuk Soal No. 38}

Diketahui sebuah produk mayonnais mengandung komposisi diantaranya air, minyak kedelai, gula, pati termodifikasi, garam, kuning telur, bubuk mustard, pengental gom xanthan, pengatur keasaman asam asetat, pengawet (natrium benzoat dan kalium sorbat) dan sekuestran.

38. Sebutkan komponen penyangga pada produk tersebut, beserta sifatnya! 
Lampiran 13. Daftar Responden Uji Coba Soal

\begin{tabular}{|c|l|l|c|}
\hline No. & \multicolumn{1}{|c|}{ Nama } & Kelas & Kode \\
\hline 1 & Aan Syaiful A. & XII MIPA 4 & UC-01 \\
\hline 2 & Annisa Nurisandi & XII MIPA 4 & UC-02 \\
\hline 3 & Arnita Febriyanti & XII MIPA 4 & UC-03 \\
\hline 4 & Bekti Prihanto & XII MIPA 4 & UC-04 \\
\hline 5 & Dionicius Cita B.L & XII MIPA 4 & UC-05 \\
\hline 6 & Diana Anggita Putri & XII MIPA 4 & UC-06 \\
\hline 7 & Dyah Ayu P. T. & XII MIPA 4 & UC-07 \\
\hline 8 & Dzaky Ammor F. & XII MIPA 4 & UC-08 \\
\hline 9 & Faradeva Puspa & XII MIPA 4 & UC-09 \\
\hline 10 & Fathan Ghifar Ahsani & XII MIPA 4 & UC-10 \\
\hline 11 & Geli Ambarwati & XII MIPA 4 & UC-11 \\
\hline 12 & Imanuel Dimas C. & XII MIPA 4 & UC-12 \\
\hline 13 & Inayah Dwi C. & XII MIPA 4 & UC-13 \\
\hline 14 & Laila U. M & XII MIPA 4 & UC-14 \\
\hline 15 & Linda Kurnia Putri & XII MIPA 4 & UC-15 \\
\hline 16 & Marcela A. M. & XII MIPA 4 & UC-16 \\
\hline 17 & M. Iqra Orisha I. & XII MIPA 4 & UC-17 \\
\hline 18 & M. R. Abdurrahman Auf A. & XII MIPA 4 & UC-18 \\
\hline 19 & Muyasyaroh & XII MIPA 4 & UC-19 \\
\hline 20 & Nathanael Y. & XII MIPA 4 & UC-20 \\
\hline 21 & Nurma Nathalia Utami & XII MIPA 4 & UC-21 \\
\hline 22 & Regina Dinda P. & XII MIPA 4 & UC-22 \\
\hline 23 & Ridwan T. W. & XII MIPA 4 & UC-23 \\
\hline 24 & Safira Alyaa Fafaza & XII MIPA 4 & UC-24 \\
\hline 25 & Sekar Ajeng P. & XII MIPA 4 & UC-25 \\
\hline 26 & Selma Marsya F. & XII MIPA 4 & UC-26 \\
\hline 27 & Shyfau Ramadhani & XII MIPA 4 & UC-27 \\
\hline 28 & Wanadya A. D. K. & XII MIPA 4 & UC-28 \\
\hline 29 & Yolanda Khairunnisa & XII MIPA 4 & UC-29 \\
\hline 30 & Yoseph Ardianto & XII MIPA 4 & UC-30 \\
\hline
\end{tabular}




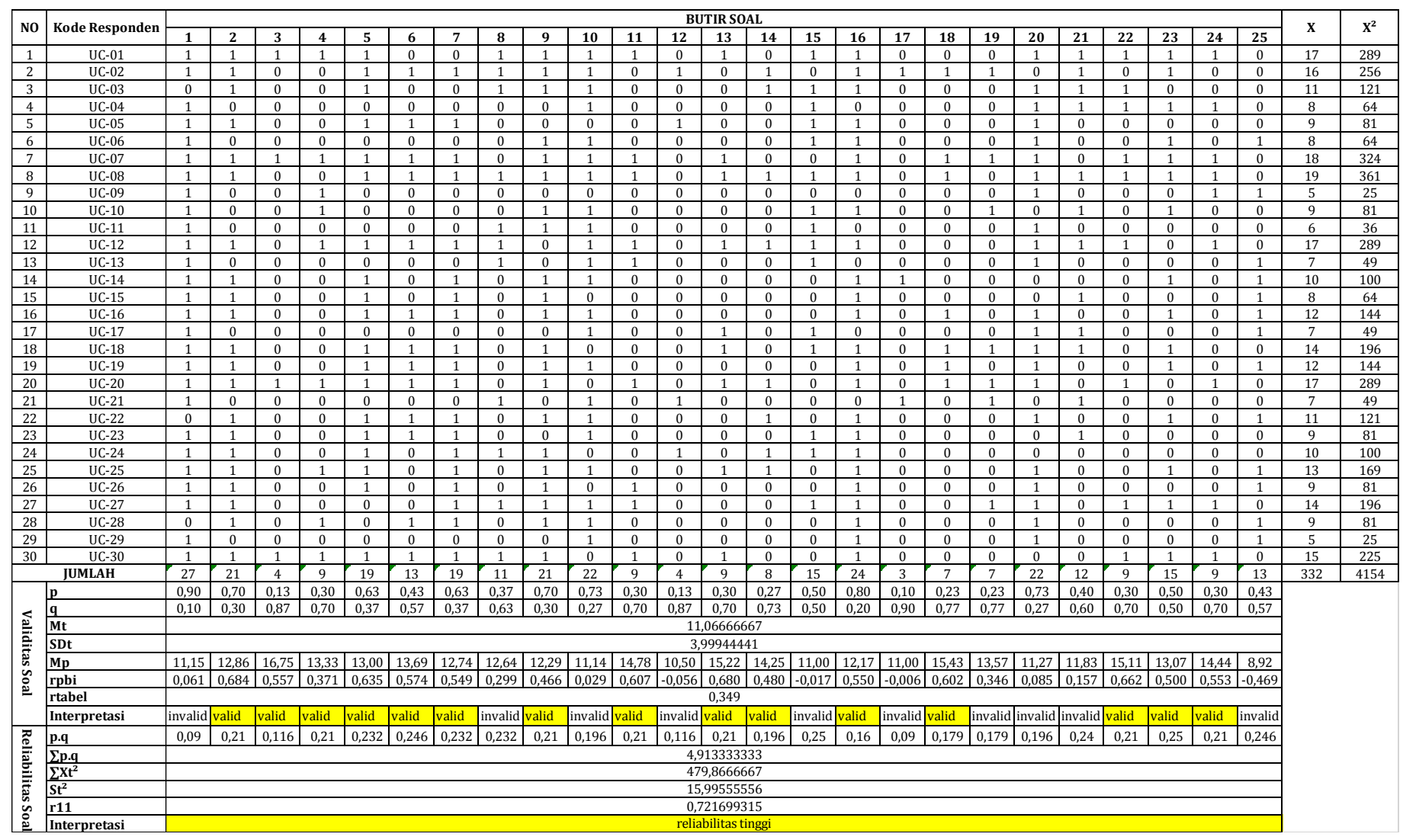

Keterangan: Uji validitas menggunakan korelasi point biserial dan uji reliabilitas menggunakan KR-20 
Lampiran 15. Uji Daya Beda dan Tingkat Kesukaran Soal Three-tier Multiple Choice

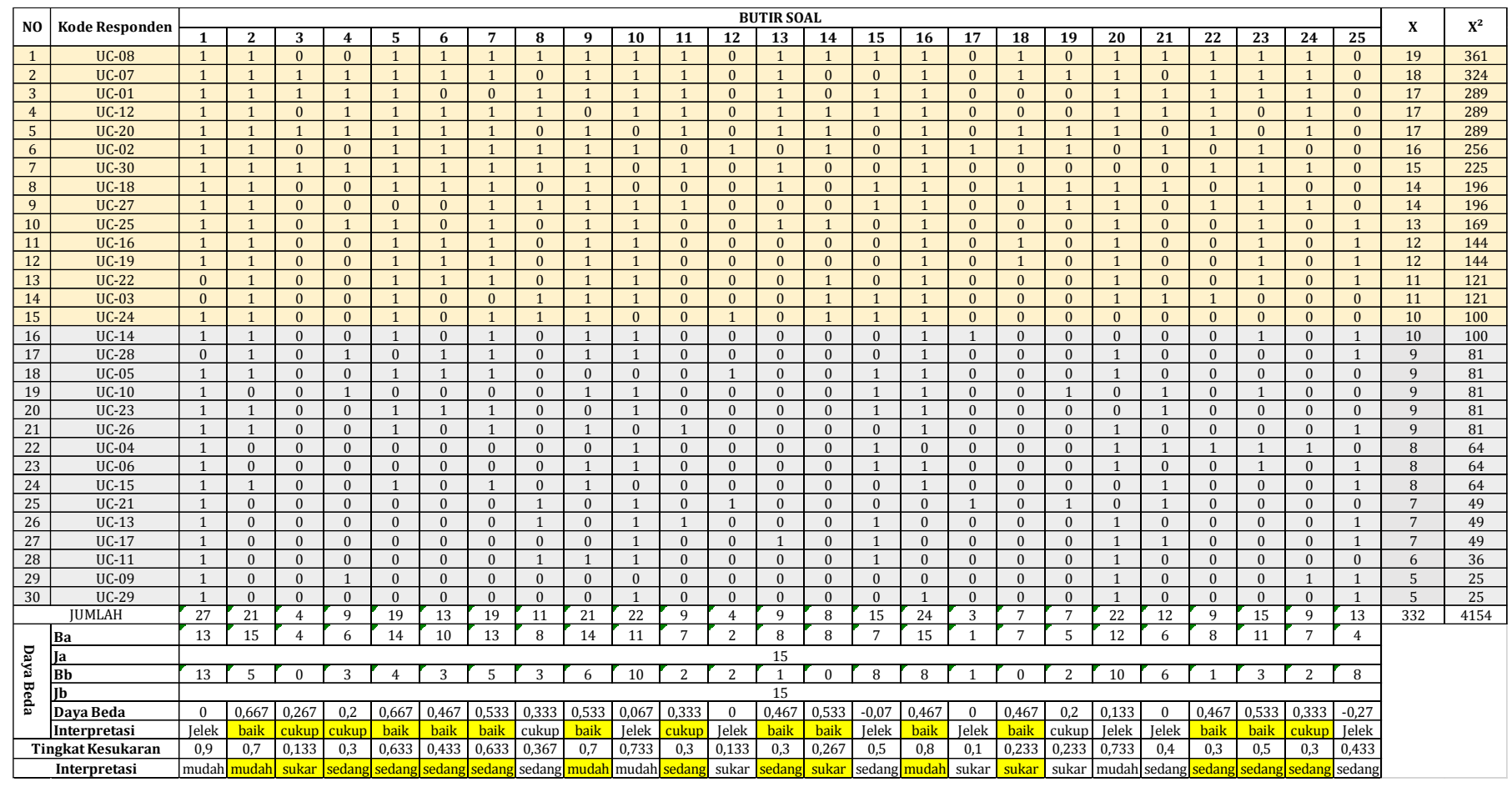

*Catatan:

Interpretasi daya beda dan tingkat kesukaran yang diberikan highlight warna kuning adalah butir soal yang valid. 
Lampiran 16. Uji Reliabilitas, Daya Beda dan Tingkat Kesukaran Soal Uraian

\begin{tabular}{|c|c|c|c|c|c|c|c|c|c|c|c|c|c|c|c|c|}
\hline \multirow[b]{2}{*}{ No. } & \multirow{2}{*}{ Kode Responden } & \multicolumn{13}{|c|}{ Butir Soal } & \multirow[b]{2}{*}{ JML } & \multirow{2}{*}{$\mathrm{JML}^{2}$} \\
\hline & & 26 & 27 & 28 & 29 & 30 & 31 & \begin{tabular}{|l|}
32 \\
\end{tabular} & 33 & 34 & 35 & 36 & 37 & 38 & & \\
\hline 1. & UC-09 & 15 & 15 & 25 & 5 & 0 & 5 & 5 & 20 & 17 & 0 & 0 & 5 & 10 & 122 & 14884 \\
\hline 2. & UC-04 & 15 & 15 & 25 & 5 & 0 & 5 & 7 & 20 & 17 & 0 & 0 & 5 & 0 & 114 & 12996 \\
\hline 3. & UC-30 & 15 & 15 & 25 & 5 & 0 & 5 & 7 & 20 & 17 & 0 & 0 & 5 & 0 & 114 & 12996 \\
\hline 4. & UC-06 & 25 & 15 & 25 & 0 & 0 & 0 & 7 & 20 & 17 & 0 & 0 & 0 & 0 & 109 & 11881 \\
\hline 5. & UC-26 & 15 & 15 & 25 & 5 & 0 & 5 & 7 & 20 & 17 & 0 & 0 & 0 & 0 & 109 & 11881 \\
\hline 6. & UC-13 & 15 & 15 & 20 & 5 & 0 & 5 & 5 & 20 & 17 & 0 & 0 & 5 & 0 & 107 & 11449 \\
\hline 7. & UC-11 & 15 & 15 & 25 & 5 & 3 & 0 & 5 & 20 & 17 & 0 & 0 & 0 & 0 & 105 & 11025 \\
\hline 8. & UC-29 & 15 & 15 & 25 & 5 & 0 & 0 & 7 & 20 & 17 & 0 & 0 & 0 & 0 & 104 & 10816 \\
\hline 9. & UC-16 & 15 & 15 & 25 & 0 & 0 & 0 & 5 & 20 & 17 & 0 & 0 & 0 & 0 & 97 & 9409 \\
\hline 10. & UC-21 & 15 & 15 & 25 & 5 & 0 & 5 & 0 & 20 & 0 & 5 & 5 & 0 & 0 & 95 & 9025 \\
\hline 11. & UC-17 & 15 & 15 & 25 & 5 & 0 & 30 & 0 & 0 & 0 & 0 & 0 & 0 & 0 & 90 & 8100 \\
\hline 12. & UC-10 & 10 & 15 & 20 & 5 & 0 & 0 & 0 & 17 & 0 & 0 & 0 & 0 & 0 & 67 & 4489 \\
\hline 13. & UC-01 & 15 & 0 & 0 & 3 & 0 & 0 & 5 & 20 & 17 & 0 & 0 & 5 & 0 & 65 & 4225 \\
\hline 14. & UC-15 & 10 & 0 & 20 & 0 & 0 & 5 & 7 & 20 & 0 & 0 & 0 & 0 & 0 & 62 & 3844 \\
\hline 15. & UC-08 & 20 & 0 & 0 & 0 & 0 & 0 & 0 & 20 & 17 & 0 & 0 & 5 & 0 & 62 & 3844 \\
\hline 16. & UC-05 & 0 & 15 & 25 & 0 & 0 & 0 & 10 & 5 & 5 & 0 & 0 & 0 & 0 & 60 & 3600 \\
\hline 17. & UC-14 & 0 & 15 & 25 & 0 & 0 & 0 & 0 & 20 & 0 & 0 & 0 & 0 & 0 & 60 & 3600 \\
\hline 18. & UC-25 & 0 & 0 & 0 & 0 & 0 & 0 & 7 & 20 & 17 & 0 & 0 & 5 & 10 & 59 & 3481 \\
\hline 19. & UC- 03 & 0 & 0 & 0 & 0 & 0 & 0 & 5 & 20 & 17 & 0 & 0 & 5 & 10 & 57 & 3249 \\
\hline 20. & UC-07 & 10 & 0 & 0 & 3 & 0 & 0 & 7 & 15 & 17 & 0 & 0 & 0 & 5 & 57 & 3249 \\
\hline 21. & UC-28 & 0 & 0 & 0 & 0 & 0 & 0 & 7 & 20 & 17 & 0 & 0 & 0 & 10 & 54 & 2916 \\
\hline 22. & UC-02 & 15 & 0 & 0 & 5 & 0 & 0 & 0 & 20 & 0 & 5 & 5 & 0 & 0 & 50 & 2500 \\
\hline 23. & UC-12 & 0 & 0 & 0 & 0 & 0 & 0 & 7 & 20 & 17 & 0 & 0 & 0 & 0 & 44 & 1936 \\
\hline 24. & UC-19 & 0 & 0 & 0 & 0 & 0 & 0 & 7 & 20 & 17 & 0 & 0 & 0 & 0 & 44 & 1936 \\
\hline 25. & UC-24 & 10 & 0 & 20 & 0 & 0 & 10 & 0 & 0 & 0 & 0 & 0 & 0 & 0 & 40 & 1600 \\
\hline 26. & UC-27 & 0 & 0 & 0 & 0 & 0 & 0 & 0 & 15 & 17 & 0 & 0 & 5 & 0 & 37 & 1369 \\
\hline 27. & UC-23 & 0 & 15 & 20 & 0 & 0 & 0 & 0 & 0 & 0 & 0 & 0 & 0 & 0 & 35 & 1225 \\
\hline 28. & UC-22 & 0 & 0 & 0 & 0 & 0 & 0 & 7 & 20 & 0 & 0 & 0 & 0 & 0 & 27 & 729 \\
\hline 29. & UC-20 & 0 & 0 & 0 & 0 & 0 & 0 & 7 & 15 & 0 & 0 & 0 & 0 & 0 & 22 & 484 \\
\hline 30. & UC-18 & 0 & 0 & 0 & 0 & 0 & 0 & 0 & 0 & 0 & 0 & 0 & 0 & 0 & 0 & 0 \\
\hline \multicolumn{2}{|r|}{ Jumlah } & 265 & 225 & 400 & 61 & 3 & 75 & 131 & 487 & 311 & 10 & 10 & 45 & 45 & 2068 & 172738 \\
\hline \multirow{5}{*}{ 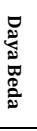 } & Skor Maksimum & 30 & 25 & 25 & 25 & 25 & 30 & 10 & 20 & 20 & 20 & 20 & 10 & 10 & & \\
\hline & Mean A & 15,3333 & 12 & 20,6667 & 3,53333 & 0,2 & 4,33333 & 4,46667 & 18,4667 & 12,4667 & 0,33333 & 0,33333 & 2 & 0,66667 & & \\
\hline & Mean B & 2,33333 & 3 & 6 & 0,53333 & 0 & 0,66667 & 4,26667 & 14 & 8,26667 & 0,33333 & 0,33333 & 1 & 2,33333 & & \\
\hline & Daya Beda & 0,43333 & 0,36 & 0,58667 & \begin{tabular}{|l|}
0,12 \\
\end{tabular} & 0,008 & 0,12222 & 0,02 & 0,22333 & 0,21 & 0 & 0 & 0,1 & $-0,1667$ & & \\
\hline & Interpretasi & baik & cukup & baik & Jelek & Jelek & Jelek & Jelek & \begin{tabular}{|l|} 
cukup \\
\end{tabular} & cukup & Jelek & Jelek & Jelek & Jelek & & \\
\hline \multicolumn{2}{|r|}{ Mean } & 8,83333 & 7,5 & 13,3333 & 2,03333 & 0,1 & 2,5 & 4,36667 & 16,2333 & 10,3667 & 0,33333 & 0,33333 & 1,5 & 1,5 & & \\
\hline \multicolumn{2}{|r|}{ Tingkat Kesukaran } & 0,29444 & 0,3 & 0,53333 & 0,08133 & 0,004 & 0,08333 & 0,43667 & 0,81167 & 0,51833 & 0,01667 & 0,01667 & 0,15 & 0,15 & & \\
\hline \multicolumn{2}{|r|}{ Interpretasi } & sukar & sedang & sedang & sukar & sukar & sukar & sedang & mudah & sedang & sukar & sukar & sukar & sukar & & \\
\hline
\end{tabular}

\section{CATATAN}

1. Uji reliabilitas pada soal uraian ini

menggunakan

rumus Cronbach

Alpha.

2. Interpretasi daya beda yang diberikan highlight warna

kuning adalah butir soal yang valid. 


\section{Lampiran 17. Uji Validitas Soal Uraian Menggunakan Korelasi Product Moment}

Nomor 26:

\begin{tabular}{|c|c|c|c|c|c|}
\hline No. & $\mathbf{x}$ & $\mathrm{y}$ & $\mathrm{xy}$ & $\mathrm{x}^{2}$ & $y^{2}$ \\
\hline 1. & 15 & 65 & 975 & 225 & 4225 \\
\hline 2. & 15 & 50 & 750 & 225 & 2500 \\
\hline 3. & 0 & 57 & 0 & 0 & 3249 \\
\hline 4. & 15 & 114 & 1710 & 225 & 12996 \\
\hline 5. & 0 & 60 & 0 & 0 & 3600 \\
\hline 6. & 25 & 109 & 2725 & 625 & 11881 \\
\hline 7. & 10 & 57 & 570 & 100 & 3249 \\
\hline 8. & 20 & 62 & 1240 & 400 & 3844 \\
\hline 9. & 15 & 122 & 1830 & 225 & 14884 \\
\hline 10. & 10 & 67 & 670 & 100 & 4489 \\
\hline 11. & 15 & 105 & 1575 & 225 & 11025 \\
\hline 12. & 0 & 44 & 0 & 0 & 1936 \\
\hline 13. & 15 & 107 & 1605 & 225 & 11449 \\
\hline 14. & 0 & 60 & 0 & 0 & 3600 \\
\hline 15. & 10 & 62 & 620 & 100 & 3844 \\
\hline 16. & 15 & 97 & 1455 & 225 & 9409 \\
\hline 17. & 15 & 90 & 1350 & 225 & 8100 \\
\hline 18. & 0 & 0 & 0 & 0 & 0 \\
\hline 19. & 0 & 44 & 0 & 0 & 1936 \\
\hline 20. & 0 & 22 & 0 & 0 & 484 \\
\hline 21. & 15 & 95 & 1425 & 225 & 9025 \\
\hline 22. & 0 & 27 & 0 & 0 & 729 \\
\hline 23. & 0 & 35 & 0 & 0 & 1225 \\
\hline 24. & 10 & 40 & 400 & 100 & 1600 \\
\hline 25. & 0 & 59 & 0 & 0 & 3481 \\
\hline 26. & 15 & 109 & 1635 & 225 & 11881 \\
\hline 27. & 0 & 37 & 0 & 0 & 1369 \\
\hline 28. & 0 & 54 & 0 & 0 & 2916 \\
\hline 29. & 15 & 104 & 1560 & 225 & 10816 \\
\hline 30. & 15 & 114 & 1710 & 225 & 12996 \\
\hline JML & 265 & 2068 & 23805 & 4125 & 172738 \\
\hline \multicolumn{2}{|c|}{ rxy } & \multicolumn{4}{|c|}{0,754608448} \\
\hline \multicolumn{2}{|c|}{ r tabel } & \multicolumn{4}{|c|}{0,349} \\
\hline \multicolumn{2}{|c|}{ Interpretasi } & \multicolumn{4}{|c|}{ valid } \\
\hline
\end{tabular}

Nomor 27:

\begin{tabular}{|l|c|c|c|c|c|}
\hline No. & $\mathbf{x}$ & $\mathbf{y}$ & $\mathbf{x y}$ & $\mathbf{x}^{\mathbf{2}}$ & $\mathbf{y}^{\mathbf{2}}$ \\
\hline 1. & 0 & 65 & 0 & 0 & 4225 \\
\hline 2. & 0 & 50 & 0 & 0 & 2500 \\
\hline 3. & 0 & 57 & 0 & 0 & 3249 \\
\hline 4. & 15 & 114 & 1710 & 225 & 12996 \\
\hline 5. & 15 & 60 & 900 & 225 & 3600 \\
\hline 6. & 15 & 109 & 1635 & 225 & 11881 \\
\hline 7. & 0 & 57 & 0 & 0 & 3249 \\
\hline 8. & 0 & 62 & 0 & 0 & 3844 \\
\hline 9. & 15 & 122 & 1830 & 225 & 14884 \\
\hline 10. & 15 & 67 & 1005 & 225 & 4489 \\
\hline 11. & 15 & 105 & 1575 & 225 & 11025 \\
\hline 12. & 0 & 44 & 0 & 0 & 1936 \\
\hline 13. & 15 & 107 & 1605 & 225 & 11449 \\
\hline 14. & 15 & 60 & 900 & 225 & 3600 \\
\hline 15. & 0 & 62 & 0 & 0 & 3844 \\
\hline 16. & 15 & 97 & 1455 & 225 & 9409 \\
\hline 17. & 15 & 90 & 1350 & 225 & 8100 \\
\hline 18. & 0 & 0 & 0 & 0 & 0 \\
\hline 19. & 0 & 44 & 0 & 0 & 1936 \\
\hline 20. & 0 & 22 & 0 & 0 & 484 \\
\hline 21. & 15 & 95 & 1425 & 225 & 9025 \\
\hline 22. & 0 & 27 & 0 & 0 & 729 \\
\hline 23. & 15 & 35 & 525 & 225 & 1225 \\
\hline 24. & 0 & 40 & 0 & 0 & 1600 \\
\hline 25. & 0 & 59 & 0 & 0 & 3481 \\
\hline 26. & 15 & 109 & 1635 & 225 & 11881 \\
\hline 27. & 0 & 37 & 0 & 0 & 1369 \\
\hline 28. & 0 & 54 & 0 & 0 & 2916 \\
\hline 29. & 15 & 104 & 1560 & 225 & 10816 \\
\hline 30. & 15 & 114 & 1710 & 225 & 12996 \\
\hline JML & 225 & 2068 & 20820 & 3375 & 172738 \\
\hline & rxy & \multicolumn{5}{|c|}{0,744021} & \\
\hline & rtabel & \multicolumn{5}{|c|}{0,349} & \\
\hline Interpretasi & & & valid & \\
\hline & & & & \\
\hline
\end{tabular}

Nomor 28:

\begin{tabular}{|l|c|c|c|c|c|}
\hline No. & $\mathbf{x}$ & $\mathbf{y}$ & $\mathbf{x y}$ & $\mathbf{x}^{\mathbf{2}}$ & $\mathbf{y}^{\mathbf{2}}$ \\
\hline 1. & 0 & 65 & 0 & 0 & 4225 \\
\hline 2. & 0 & 50 & 0 & 0 & 2500 \\
\hline 3. & 0 & 57 & 0 & 0 & 3249 \\
\hline 4. & 25 & 114 & 2850 & 625 & 12996 \\
\hline 5. & 25 & 60 & 1500 & 625 & 3600 \\
\hline 6. & 25 & 109 & 2725 & 625 & 11881 \\
\hline 7. & 0 & 57 & 0 & 0 & 3249 \\
\hline 8. & 0 & 62 & 0 & 0 & 3844 \\
\hline 9. & 25 & 122 & 3050 & 625 & 14884 \\
\hline 10. & 20 & 67 & 1340 & 400 & 4489 \\
\hline 11. & 25 & 105 & 2625 & 625 & 11025 \\
\hline 12. & 0 & 44 & 0 & 0 & 1936 \\
\hline 13. & 20 & 107 & 2140 & 400 & 11449 \\
\hline 14. & 25 & 60 & 1500 & 625 & 3600 \\
\hline 15. & 20 & 62 & 1240 & 400 & 3844 \\
\hline 16. & 25 & 97 & 2425 & 625 & 9409 \\
\hline 17. & 25 & 90 & 2250 & 625 & 8100 \\
\hline 18. & 0 & 0 & 0 & 0 & 0 \\
\hline 19. & 0 & 44 & 0 & 0 & 1936 \\
\hline 20. & 0 & 22 & 0 & 0 & 484 \\
\hline 21. & 25 & 95 & 2375 & 625 & 9025 \\
\hline 22. & 0 & 27 & 0 & 0 & 729 \\
\hline 23. & 20 & 35 & 700 & 400 & 1225 \\
\hline 24. & 20 & 40 & 800 & 400 & 1600 \\
\hline 25. & 0 & 59 & 0 & 0 & 3481 \\
\hline 26. & 25 & 109 & 2725 & 625 & 11881 \\
\hline 27. & 0 & 37 & 0 & 0 & 1369 \\
\hline 28. & 0 & 54 & 0 & 0 & 2916 \\
\hline 29. & 25 & 104 & 2600 & 625 & 10816 \\
\hline 30. & 25 & 114 & 2850 & 625 & 12996 \\
\hline JML & 400 & 2068 & 35695 & 9500 & 172738 \\
\hline & rxy & & 0,724208045 & \\
\hline & rtabel & & & 0,349 & \\
\hline Interpretasi & & & & \\
\hline & & & & & \\
\hline & & & & \\
\hline
\end{tabular}


Nomor 29:

\begin{tabular}{|l|c|c|c|c|c|}
\hline No. & $\mathbf{X}$ & $\mathbf{y}$ & $\mathbf{x y}$ & $\mathbf{x}^{\mathbf{2}}$ & $\mathbf{y}^{\mathbf{2}}$ \\
\hline 1. & 3 & 65 & 195 & 9 & 4225 \\
\hline 2. & 5 & 50 & 250 & 25 & 2500 \\
\hline 3. & 0 & 57 & 0 & 0 & 3249 \\
\hline 4. & 5 & 114 & 570 & 25 & 12996 \\
\hline 5. & 0 & 60 & 0 & 0 & 3600 \\
\hline 6. & 0 & 109 & 0 & 0 & 11881 \\
\hline 7. & 3 & 57 & 171 & 9 & 3249 \\
\hline 8. & 0 & 62 & 0 & 0 & 3844 \\
\hline 9. & 5 & 122 & 610 & 25 & 14884 \\
\hline 10. & 5 & 67 & 335 & 25 & 4489 \\
\hline 11. & 5 & 105 & 525 & 25 & 11025 \\
\hline 12. & 0 & 44 & 0 & 0 & 1936 \\
\hline 13. & 5 & 107 & 535 & 25 & 11449 \\
\hline 14. & 0 & 60 & 0 & 0 & 3600 \\
\hline 15. & 0 & 62 & 0 & 0 & 3844 \\
\hline 16. & 0 & 97 & 0 & 0 & 9409 \\
\hline 17. & 5 & 90 & 450 & 25 & 8100 \\
\hline 18. & 0 & 0 & 0 & 0 & 0 \\
\hline 19. & 0 & 44 & 0 & 0 & 1936 \\
\hline 20. & 0 & 22 & 0 & 0 & 484 \\
\hline 21. & 5 & 95 & 475 & 25 & 9025 \\
\hline 22. & 0 & 27 & 0 & 0 & 729 \\
\hline 23. & 0 & 35 & 0 & 0 & 1225 \\
\hline 24. & 0 & 40 & 0 & 0 & 1600 \\
\hline 25. & 0 & 59 & 0 & 0 & 3481 \\
\hline 26. & 5 & 109 & 545 & 25 & 11881 \\
\hline 27. & 0 & 37 & 0 & 0 & 1369 \\
\hline 28. & 0 & 54 & 0 & 0 & 2916 \\
\hline 29. & 5 & 104 & 520 & 25 & 10816 \\
\hline 30. & 5 & 114 & 570 & 25 & 12996 \\
\hline JML & 61 & 2068 & 5751 & 293 & 172738 \\
\hline & rxy & & 0,684605307 & \\
\hline & r tabel & & & 0,349 & \\
\hline Interpretasi & & & valid & \\
\hline & & & & & \\
\hline & & & & & \\
\hline & & & & & \\
\hline & & & & & \\
\hline
\end{tabular}

Nomor 30:

\begin{tabular}{|c|c|c|c|c|c|}
\hline No. & $\mathbf{x}$ & $\mathbf{y}$ & xy & $x^{2}$ & $y^{2}$ \\
\hline 1. & 0 & 65 & 0 & 0 & 4225 \\
\hline 2. & 0 & 50 & 0 & 0 & 2500 \\
\hline 3. & 0 & 57 & 0 & 0 & 3249 \\
\hline 4. & 0 & 114 & 0 & 0 & 12996 \\
\hline 5. & 0 & 60 & 0 & 0 & 3600 \\
\hline 6. & 0 & 109 & 0 & 0 & 11881 \\
\hline 7. & 0 & 57 & 0 & 0 & 3249 \\
\hline 8. & 0 & 62 & 0 & 0 & 3844 \\
\hline 9. & 0 & 122 & 0 & 0 & 14884 \\
\hline 10. & 0 & 67 & 0 & 0 & 4489 \\
\hline 11. & 3 & 105 & 315 & 9 & 11025 \\
\hline 12. & 0 & 44 & 0 & 0 & 1936 \\
\hline 13. & 0 & 107 & 0 & 0 & 11449 \\
\hline 14. & 0 & 60 & 0 & 0 & 3600 \\
\hline 15. & 0 & 62 & 0 & 0 & 3844 \\
\hline 16. & 0 & 97 & 0 & 0 & 9409 \\
\hline 17. & 0 & 90 & 0 & 0 & 8100 \\
\hline 18. & 0 & 0 & 0 & 0 & 0 \\
\hline 19. & 0 & 44 & 0 & 0 & 1936 \\
\hline 20. & 0 & 22 & 0 & 0 & 484 \\
\hline 21. & 0 & 95 & 0 & 0 & 9025 \\
\hline 22. & 0 & 27 & 0 & 0 & 729 \\
\hline 23. & 0 & 35 & 0 & 0 & 1225 \\
\hline 24. & 0 & 40 & 0 & 0 & 1600 \\
\hline 25. & 0 & 59 & 0 & 0 & 3481 \\
\hline 26. & 0 & 109 & 0 & 0 & 11881 \\
\hline 27. & 0 & 37 & 0 & 0 & 1369 \\
\hline 28. & 0 & 54 & 0 & 0 & 2916 \\
\hline 29. & 0 & 104 & 0 & 0 & 10816 \\
\hline 30. & 0 & 114 & 0 & 0 & 12996 \\
\hline JML & 3 & 2068 & 315 & 9 & 172738 \\
\hline \multicolumn{2}{|c|}{ rxy } & \multicolumn{4}{|c|}{0,211144706} \\
\hline \multicolumn{2}{|c|}{$\mathrm{r}$ tabel } & \multicolumn{4}{|c|}{0,349} \\
\hline \multicolumn{2}{|c|}{ Interpretasi } & \multicolumn{4}{|c|}{ invalid } \\
\hline
\end{tabular}

Nomor 31:

\begin{tabular}{|c|c|c|c|c|c|}
\hline No. & $\mathbf{x}$ & $y$ & $x y$ & $x^{2}$ & $y^{2}$ \\
\hline 1. & 0 & 65 & 0 & 0 & 4225 \\
\hline 2. & 0 & 50 & 0 & 0 & 2500 \\
\hline 3. & 0 & 57 & 0 & 0 & 3249 \\
\hline 4. & 5 & 114 & 570 & 25 & 12996 \\
\hline 5. & 0 & 60 & 0 & 0 & 3600 \\
\hline 6. & 0 & 109 & 0 & 0 & 11881 \\
\hline 7. & 0 & 57 & 0 & 0 & 3249 \\
\hline 8. & 0 & 62 & 0 & 0 & 3844 \\
\hline 9. & 5 & 122 & 610 & 25 & 14884 \\
\hline 10. & 0 & 67 & 0 & 0 & 4489 \\
\hline 11. & 0 & 105 & 0 & 0 & 11025 \\
\hline 12. & 0 & 44 & 0 & 0 & 1936 \\
\hline 13. & 5 & 107 & 535 & 25 & 11449 \\
\hline 14. & 0 & 60 & 0 & 0 & 3600 \\
\hline 15. & 5 & 62 & 310 & 25 & 3844 \\
\hline 16. & 0 & 97 & 0 & 0 & 9409 \\
\hline 17. & 30 & 90 & 2700 & 900 & 8100 \\
\hline 18. & 0 & 0 & 0 & 0 & 0 \\
\hline 19. & 0 & 44 & 0 & 0 & 1936 \\
\hline 20. & 0 & 22 & 0 & 0 & 484 \\
\hline 21. & 5 & 95 & 475 & 25 & 9025 \\
\hline 22. & 0 & 27 & 0 & 0 & 729 \\
\hline 23. & 0 & 35 & 0 & 0 & 1225 \\
\hline 24. & 10 & 40 & 400 & 100 & 1600 \\
\hline 25. & 0 & 59 & 0 & 0 & 3481 \\
\hline 26. & 5 & 109 & 545 & 25 & 11881 \\
\hline 27. & 0 & 37 & 0 & 0 & 1369 \\
\hline 28. & 0 & 54 & 0 & 0 & 2916 \\
\hline 29. & 0 & 104 & 0 & 0 & 10816 \\
\hline 30. & 5 & 114 & 570 & 25 & 12996 \\
\hline JML & 75 & 2068 & 6715 & 1175 & 172738 \\
\hline \multicolumn{2}{|c|}{$\mathrm{rxy}$} & \multicolumn{4}{|c|}{0,282990916} \\
\hline \multicolumn{2}{|c|}{ r tabel } & \multicolumn{4}{|c|}{0,349} \\
\hline \multicolumn{2}{|c|}{ Interpretasi } & \multicolumn{4}{|c|}{ invalid } \\
\hline
\end{tabular}




\section{Nomor 32:}

\begin{tabular}{|c|c|c|c|c|c|}
\hline No. & $\mathbf{x}$ & $\mathbf{y}$ & $x y$ & $x^{2}$ & $y^{2}$ \\
\hline 1. & 5 & 65 & 325 & 25 & 4225 \\
\hline 2. & 0 & 50 & 0 & 0 & 2500 \\
\hline 3. & 5 & 57 & 285 & 25 & 3249 \\
\hline 4. & 7 & 114 & 798 & 49 & 12996 \\
\hline 5. & 10 & 60 & 600 & 100 & 3600 \\
\hline 6. & 7 & 109 & 763 & 49 & 11881 \\
\hline 7. & 7 & 57 & 399 & 49 & 3249 \\
\hline 8. & 0 & 62 & 0 & 0 & 3844 \\
\hline 9. & 5 & 122 & 610 & 25 & 14884 \\
\hline 10. & 0 & 67 & 0 & 0 & 4489 \\
\hline 11. & 5 & 105 & 525 & 25 & 11025 \\
\hline 12. & 7 & 44 & 308 & 49 & 1936 \\
\hline 13. & 5 & 107 & 535 & 25 & 11449 \\
\hline 14. & 0 & 60 & 0 & 0 & 3600 \\
\hline 15. & 7 & 62 & 434 & 49 & 3844 \\
\hline 16. & 5 & 97 & 485 & 25 & 9409 \\
\hline 17. & 0 & 90 & 0 & 0 & 8100 \\
\hline 18. & 0 & 0 & 0 & 0 & 0 \\
\hline 19. & 7 & 44 & 308 & 49 & 1936 \\
\hline 20. & 7 & 22 & 154 & 49 & 484 \\
\hline 21. & 0 & 95 & 0 & 0 & 9025 \\
\hline 22. & 7 & 27 & 189 & 49 & 729 \\
\hline 23. & 0 & 35 & 0 & 0 & 1225 \\
\hline 24. & 0 & 40 & 0 & 0 & 1600 \\
\hline 25. & 7 & 59 & 413 & 49 & 3481 \\
\hline 26. & 7 & 109 & 763 & 49 & 11881 \\
\hline 27. & 0 & 37 & 0 & 0 & 1369 \\
\hline 28. & 7 & 54 & 378 & 49 & 2916 \\
\hline 29. & 7 & 104 & 728 & 49 & 10816 \\
\hline 30. & 7 & 114 & 798 & 49 & 12996 \\
\hline JML & 131 & 2068 & 9798 & 887 & 172738 \\
\hline \multicolumn{2}{|c|}{ rxy } & \multicolumn{4}{|c|}{0,248995021} \\
\hline \multicolumn{2}{|c|}{$\mathrm{r}$ tabel } & \multicolumn{4}{|c|}{0,349} \\
\hline \multicolumn{2}{|c|}{ Interpretasi } & \multicolumn{4}{|c|}{ invalid } \\
\hline
\end{tabular}

Nomor 33:

\begin{tabular}{|c|c|c|c|c|c|}
\hline No. & $\mathbf{x}$ & $\mathbf{y}$ & $x y$ & $\mathrm{x}^{2}$ & $y^{2}$ \\
\hline 1. & 20 & 65 & 1300 & 400 & 4225 \\
\hline 2. & 20 & 50 & 1000 & 400 & 2500 \\
\hline 3. & 20 & 57 & 1140 & 400 & 3249 \\
\hline 4. & 20 & 114 & 2280 & 400 & 12996 \\
\hline 5. & 5 & 60 & 300 & 25 & 3600 \\
\hline 6. & 20 & 109 & 2180 & 400 & 11881 \\
\hline 7. & 15 & 57 & 855 & 225 & 3249 \\
\hline 8. & 20 & 62 & 1240 & 400 & 3844 \\
\hline 9. & 20 & 122 & 2440 & 400 & 14884 \\
\hline 10. & 17 & 67 & 1139 & 289 & 4489 \\
\hline 11. & 20 & 105 & 2100 & 400 & 11025 \\
\hline 12. & 20 & 44 & 880 & 400 & 1936 \\
\hline 13. & 20 & 107 & 2140 & 400 & 11449 \\
\hline 14. & 20 & 60 & 1200 & 400 & 3600 \\
\hline 15. & 20 & 62 & 1240 & 400 & 3844 \\
\hline 16. & 20 & 97 & 1940 & 400 & 9409 \\
\hline 17. & 0 & 90 & 0 & 0 & 8100 \\
\hline 18. & 0 & 0 & 0 & 0 & 0 \\
\hline 19. & 20 & 44 & 880 & 400 & 1936 \\
\hline 20. & 15 & 22 & 330 & 225 & 484 \\
\hline 21. & 20 & 95 & 1900 & 400 & 9025 \\
\hline 22. & 20 & 27 & 540 & 400 & 729 \\
\hline 23. & 0 & 35 & 0 & 0 & 1225 \\
\hline 24. & 0 & 40 & 0 & 0 & 1600 \\
\hline 25. & 20 & 59 & 1180 & 400 & 3481 \\
\hline 26. & 20 & 109 & 2180 & 400 & 11881 \\
\hline 27. & 15 & 37 & 555 & 225 & 1369 \\
\hline 28. & 20 & 54 & 1080 & 400 & 2916 \\
\hline 29. & 20 & 104 & 2080 & 400 & 10816 \\
\hline 30. & 20 & 114 & 2280 & 400 & 12996 \\
\hline JML & 487 & 2068 & 36379 & 9389 & 172738 \\
\hline \multicolumn{2}{|c|}{ rxy } & \multicolumn{4}{|c|}{0,419717985} \\
\hline \multicolumn{2}{|c|}{$r$ tabel } & \multicolumn{4}{|c|}{0,349} \\
\hline \multicolumn{2}{|c|}{ Interpretasi } & \multicolumn{4}{|c|}{ valid } \\
\hline
\end{tabular}

Nomor 34:

\begin{tabular}{|l|c|c|c|c|c|}
\hline No. & $\mathbf{x}$ & $\mathbf{y}$ & $\mathbf{x y}$ & $\mathbf{x}^{\mathbf{2}}$ & $\mathbf{y}^{\mathbf{2}}$ \\
\hline 1. & 17 & 65 & 1105 & 289 & 4225 \\
\hline 2. & 0 & 50 & 0 & 0 & 2500 \\
\hline 3. & 17 & 57 & 969 & 289 & 3249 \\
\hline 4. & 17 & 114 & 1938 & 289 & 12996 \\
\hline 5. & 5 & 60 & 300 & 25 & 3600 \\
\hline 6. & 17 & 109 & 1853 & 289 & 11881 \\
\hline 7. & 17 & 57 & 969 & 289 & 3249 \\
\hline 8. & 17 & 62 & 1054 & 289 & 3844 \\
\hline 9. & 17 & 122 & 2074 & 289 & 14884 \\
\hline 10. & 0 & 67 & 0 & 0 & 4489 \\
\hline 11. & 17 & 105 & 1785 & 289 & 11025 \\
\hline 12. & 17 & 44 & 748 & 289 & 1936 \\
\hline 13. & 17 & 107 & 1819 & 289 & 11449 \\
\hline 14. & 0 & 60 & 0 & 0 & 3600 \\
\hline 15. & 0 & 62 & 0 & 0 & 3844 \\
\hline 16. & 17 & 97 & 1649 & 289 & 9409 \\
\hline 17. & 0 & 90 & 0 & 0 & 8100 \\
\hline 18. & 0 & 0 & 0 & 0 & 0 \\
\hline 19. & 17 & 44 & 748 & 289 & 1936 \\
\hline 20. & 0 & 22 & 0 & 0 & 484 \\
\hline 21. & 0 & 95 & 0 & 0 & 9025 \\
\hline 22. & 0 & 27 & 0 & 0 & 729 \\
\hline 23. & 0 & 35 & 0 & 0 & 1225 \\
\hline 24. & 0 & 40 & 0 & 0 & 1600 \\
\hline 25. & 17 & 59 & 1003 & 289 & 3481 \\
\hline 26. & 17 & 109 & 1853 & 289 & 11881 \\
\hline 27. & 17 & 37 & 629 & 289 & 1369 \\
\hline 28. & 17 & 54 & 918 & 289 & 2916 \\
\hline 29. & 17 & 104 & 1768 & 289 & 10816 \\
\hline 30. & 17 & 114 & 1938 & 289 & 12996 \\
\hline JML & 311 & 2068 & 25120 & 5227 & 172738 \\
\hline & rxy & & 0,473508775 & \\
\hline & rtabel & & & 0,349 & \\
\hline Interpretasi & & & valid & \\
\hline & & & & \\
\hline
\end{tabular}


Nomor 35:

\begin{tabular}{|l|c|c|c|c|c|}
\hline No. & $\mathbf{x}$ & $\mathbf{y}$ & $\mathbf{x y}$ & $\mathbf{x}^{\mathbf{2}}$ & $\mathbf{y}^{\mathbf{2}}$ \\
\hline 1. & 0 & 65 & 0 & 0 & 4225 \\
\hline 2. & 5 & 50 & 250 & 25 & 2500 \\
\hline 3. & 0 & 57 & 0 & 0 & 3249 \\
\hline 4. & 0 & 114 & 0 & 0 & 12996 \\
\hline 5. & 0 & 60 & 0 & 0 & 3600 \\
\hline 6. & 0 & 109 & 0 & 0 & 11881 \\
\hline 7. & 0 & 57 & 0 & 0 & 3249 \\
\hline 8. & 0 & 62 & 0 & 0 & 3844 \\
\hline 9. & 0 & 122 & 0 & 0 & 14884 \\
\hline 10. & 0 & 67 & 0 & 0 & 4489 \\
\hline 11. & 0 & 105 & 0 & 0 & 11025 \\
\hline 12. & 0 & 44 & 0 & 0 & 1936 \\
\hline 13. & 0 & 107 & 0 & 0 & 11449 \\
\hline 14. & 0 & 60 & 0 & 0 & 3600 \\
\hline 15. & 0 & 62 & 0 & 0 & 3844 \\
\hline 16. & 0 & 97 & 0 & 0 & 9409 \\
\hline 17. & 0 & 90 & 0 & 0 & 8100 \\
\hline 18. & 0 & 0 & 0 & 0 & 0 \\
\hline 19. & 0 & 44 & 0 & 0 & 1936 \\
\hline 20. & 0 & 22 & 0 & 0 & 484 \\
\hline 21. & 5 & 95 & 475 & 25 & 9025 \\
\hline 22. & 0 & 27 & 0 & 0 & 729 \\
\hline 23. & 0 & 35 & 0 & 0 & 1225 \\
\hline 24. & 0 & 40 & 0 & 0 & 1600 \\
\hline 25. & 0 & 59 & 0 & 0 & 3481 \\
\hline 26. & 0 & 109 & 0 & 0 & 11881 \\
\hline 27. & 0 & 37 & 0 & 0 & 1369 \\
\hline 28. & 0 & 54 & 0 & 0 & 2916 \\
\hline 29. & 0 & 104 & 0 & 0 & 10816 \\
\hline 30. & 0 & 114 & 0 & 0 & 12996 \\
\hline JML & 10 & 2068 & 725 & 50 & 172738 \\
\hline & rxy & & 0,030051883 & \\
\hline & r tabel & & & 0,349 & \\
\hline Interpretasi & & & invalid & \\
\hline & & & & & \\
\hline
\end{tabular}

\section{Nomor 37:}

\begin{tabular}{|c|c|c|c|c|c|}
\hline No. & $\mathbf{x}$ & $\mathbf{y}$ & xy & $\mathrm{x}^{2}$ & $y^{2}$ \\
\hline 1. & 5 & 65 & 325 & 25 & 4225 \\
\hline 2. & 0 & 50 & 0 & 0 & 2500 \\
\hline 3. & 5 & 57 & 285 & 25 & 3249 \\
\hline 4. & 5 & 114 & 570 & 25 & 12996 \\
\hline 5. & 0 & 60 & 0 & 0 & 3600 \\
\hline 6. & 0 & 109 & 0 & 0 & 11881 \\
\hline 7. & 0 & 57 & 0 & 0 & 3249 \\
\hline 8. & 5 & 62 & 310 & 25 & 3844 \\
\hline 9. & 5 & 122 & 610 & 25 & 14884 \\
\hline 10. & 0 & 67 & 0 & 0 & 4489 \\
\hline 11. & 0 & 105 & 0 & 0 & 11025 \\
\hline 12. & 0 & 44 & 0 & 0 & 1936 \\
\hline 13. & 5 & 107 & 535 & 25 & 11449 \\
\hline 14. & 0 & 60 & 0 & 0 & 3600 \\
\hline 15. & 0 & 62 & 0 & 0 & 3844 \\
\hline 16. & 0 & 97 & 0 & 0 & 9409 \\
\hline 17. & 0 & 90 & 0 & 0 & 8100 \\
\hline 18. & 0 & 0 & 0 & 0 & 0 \\
\hline 19. & 0 & 44 & 0 & 0 & 1936 \\
\hline 20. & 0 & 22 & 0 & 0 & 484 \\
\hline 21. & 0 & 95 & 0 & 0 & 9025 \\
\hline 22. & 0 & 27 & 0 & 0 & 729 \\
\hline 23. & 0 & 35 & 0 & 0 & 1225 \\
\hline 24. & 0 & 40 & 0 & 0 & 1600 \\
\hline 25. & 5 & 59 & 295 & 25 & 3481 \\
\hline 26. & 0 & 109 & 0 & 0 & 11881 \\
\hline 27. & 5 & 37 & 185 & 25 & 1369 \\
\hline 28. & 0 & 54 & 0 & 0 & 2916 \\
\hline 29. & 0 & 104 & 0 & 0 & 10816 \\
\hline 30. & 5 & 114 & 570 & 25 & 12996 \\
\hline JML & 45 & 2068 & 3685 & 225 & 172738 \\
\hline \multicolumn{2}{|c|}{ rxy } & \multicolumn{4}{|c|}{0,267387339} \\
\hline \multicolumn{2}{|c|}{$\mathrm{r}$ tabel } & \multicolumn{4}{|c|}{0,349} \\
\hline \multicolumn{2}{|c|}{ Interpretasi } & \multicolumn{4}{|c|}{ invalid } \\
\hline
\end{tabular}

Nomor 36:

\begin{tabular}{|l|c|c|c|c|c|}
\hline No. & $\mathbf{x}$ & $\mathbf{y}$ & $\mathbf{x y}$ & $\mathbf{x}^{\mathbf{2}}$ & $\mathbf{y}^{\mathbf{2}}$ \\
\hline 1. & 0 & 65 & 0 & 0 & 4225 \\
\hline 2. & 5 & 50 & 250 & 25 & 2500 \\
\hline 3. & 0 & 57 & 0 & 0 & 3249 \\
\hline 4. & 0 & 114 & 0 & 0 & 12996 \\
\hline 5. & 0 & 60 & 0 & 0 & 3600 \\
\hline 6. & 0 & 109 & 0 & 0 & 11881 \\
\hline 7. & 0 & 57 & 0 & 0 & 3249 \\
\hline 8. & 0 & 62 & 0 & 0 & 3844 \\
\hline 9. & 0 & 122 & 0 & 0 & 14884 \\
\hline 10. & 0 & 67 & 0 & 0 & 4489 \\
\hline 11. & 0 & 105 & 0 & 0 & 11025 \\
\hline 12. & 0 & 44 & 0 & 0 & 1936 \\
\hline 13. & 0 & 107 & 0 & 0 & 11449 \\
\hline 14. & 0 & 60 & 0 & 0 & 3600 \\
\hline 15. & 0 & 62 & 0 & 0 & 3844 \\
\hline 16. & 0 & 97 & 0 & 0 & 9409 \\
\hline 17. & 0 & 90 & 0 & 0 & 8100 \\
\hline 18. & 0 & 0 & 0 & 0 & 0 \\
\hline 19. & 0 & 44 & 0 & 0 & 1936 \\
\hline 20. & 0 & 22 & 0 & 0 & 484 \\
\hline 21. & 5 & 95 & 475 & 25 & 9025 \\
\hline 22. & 0 & 27 & 0 & 0 & 729 \\
\hline 23. & 0 & 35 & 0 & 0 & 1225 \\
\hline 24. & 0 & 40 & 0 & 0 & 1600 \\
\hline 25. & 0 & 59 & 0 & 0 & 3481 \\
\hline 26. & 0 & 109 & 0 & 0 & 11881 \\
\hline 27. & 0 & 37 & 0 & 0 & 1369 \\
\hline 28. & 0 & 54 & 0 & 0 & 2916 \\
\hline 29. & 0 & 104 & 0 & 0 & 10816 \\
\hline 30. & 0 & 114 & 0 & 0 & 12996 \\
\hline JML & 10 & 2068 & 725 & 50 & 172738 \\
\hline & rxy & & 0,030051883 & \\
\hline & rtabel & & & 0,349 & \\
\hline Interpretasi & & & invalid & \\
\hline & & & & & \\
\hline
\end{tabular}

\section{Nomor 38:}

\begin{tabular}{|c|c|c|c|c|c|}
\hline No. & $\mathbf{x}$ & $\mathbf{y}$ & $x y$ & $\mathrm{x}^{2}$ & $y^{2}$ \\
\hline 1. & 0 & 65 & 0 & 0 & 4225 \\
\hline 2. & 0 & 50 & 0 & 0 & 2500 \\
\hline 3. & 10 & 57 & 570 & 100 & 3249 \\
\hline 4. & 0 & 114 & 0 & 0 & 12996 \\
\hline 5. & 0 & 60 & 0 & 0 & 3600 \\
\hline 6. & 0 & 109 & 0 & 0 & 11881 \\
\hline 7. & 5 & 57 & 285 & 25 & 3249 \\
\hline 8. & 0 & 62 & 0 & 0 & 3844 \\
\hline 9. & 10 & 122 & 1220 & 100 & 14884 \\
\hline 10. & 0 & 67 & 0 & 0 & 4489 \\
\hline 11. & 0 & 105 & 0 & 0 & 11025 \\
\hline 12. & 0 & 44 & 0 & 0 & 1936 \\
\hline 13. & 0 & 107 & 0 & 0 & 11449 \\
\hline 14. & 0 & 60 & 0 & 0 & 3600 \\
\hline 15. & 0 & 62 & 0 & 0 & 3844 \\
\hline 16. & 0 & 97 & 0 & 0 & 9409 \\
\hline 17. & 0 & 90 & 0 & 0 & 8100 \\
\hline 18. & 0 & 0 & 0 & 0 & 0 \\
\hline 19. & 0 & 44 & 0 & 0 & 1936 \\
\hline 20. & 0 & 22 & 0 & 0 & 484 \\
\hline 21. & 0 & 95 & 0 & 0 & 9025 \\
\hline 22. & 0 & 27 & 0 & 0 & 729 \\
\hline 23. & 0 & 35 & 0 & 0 & 1225 \\
\hline 24. & 0 & 40 & 0 & 0 & 1600 \\
\hline 25. & 10 & 59 & 590 & 100 & 3481 \\
\hline 26. & 0 & 109 & 0 & 0 & 11881 \\
\hline 27. & 0 & 37 & 0 & 0 & 1369 \\
\hline 28. & 10 & 54 & 540 & 100 & 2916 \\
\hline 29. & 0 & 104 & 0 & 0 & 10816 \\
\hline 30. & 0 & 114 & 0 & 0 & 12996 \\
\hline \begin{tabular}{|l|} 
JML \\
\end{tabular} & 45 & 2068 & 3205 & 425 & 172738 \\
\hline \multicolumn{2}{|c|}{$\mathrm{rxy}$} & \multicolumn{4}{|c|}{0,031355358} \\
\hline \multicolumn{2}{|c|}{$r$ tabel } & \multicolumn{4}{|c|}{0,349} \\
\hline \multicolumn{2}{|c|}{ Interpretasi } & \multicolumn{4}{|c|}{ invalid } \\
\hline
\end{tabular}




\title{
Lampiran 18. Surat Keterangan Telah Melakukan Uji Instrumen Tes
}

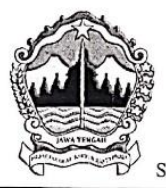

\author{
PEMERINTAH PROVINSI JAWA TENGAII \\ DINAS PENDIDIKAN DAN KEBUDAYAAN \\ SEKOLAH MENENGAH ATAS NEGERI 8 \\ SEMARANG
}

Jl. Raya Tugu Semarang $\mathbf{Z}$ 8661798-8664553 Fax. (024) 8661798 \50185

Surat Elektronik : sman8smg@yahoo.com, Lamaan : http://www.sman8-smg.sch.id

SURAT KETERANGAN

Nomor: $423.4 / 113 / 11 / 2020$

Yang bertanda tangan di bawah ini Kepala SMA Negeri 8 Semarang, menerangkan bahwa

Sâudara iersebut dii bawah ini:

$\begin{array}{ll}\text { Nama } & : \text { DINI LESTARI } \\ \text { N IM } & : 1608076052 \\ \text { Fak./Prodi } & : \text { Sains dan Teknologi / Pendidikan Kimia } \\ & \text { Universitas Islam Negeri Walisongo Semarang }\end{array}$

telah melakukan uji instrument penelitian di SMA N 8 Semarang untuk keperluan penyusunan skripsi :
Waktu
: 18 Februari 2020
Judul Skripsi- : "Efektivitas Model Pembelajaran SiMaYang Tipe II Berbasis Mutipel
Representasi terhadap Penguasaan Konsep dan Attitudes Toward
Chemistry pada Materi Larutan Penyangga"

Demikian surat keterangan ini dibuat untuk digunakan sebagaimana mestinya.

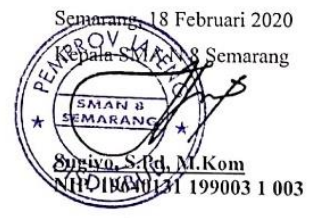




\section{ULANGAN LARUTAN PENYANGGA}

$\begin{array}{lll}\text { Mata Pelajaran } & : & \text { Kimia } \\ \text { Materi } & : & \text { Larutan Penyangga } \\ \text { Kelas/Semester } & : & \text { XI/2 } \\ \text { Alokasi Waktu } & : & 90 \text { menit }\end{array}$

\section{PETUNJUK}

1. Tulis nama, kelas, dan nomor absen pada lembar jawab

2. Lembar soal tidak boleh dicoret-coret

3. Jawablah soal-soal berikut dengan cara menyilang salah satu huruf pada lembar jawaban dan tuliskan alasan jawaban di kolom yang telah disediakan

4. Cara mengganti jawaban yang salah
A
承
$\Rightarrow$
D

5. Periksalah jawaban sebelum diserahkan kepada pengawas

\section{A. Pilihan Ganda Beralasan}

Kerjakan soal-soal berikut dengan memilih jawaban yang paling tepat dan benar pada lembar jawaban yang tersedia dan pilihlah alasan mengapa memilih jawaban tersebut serta yakin atau tidaknya terhadap jawaban yang dipilih!

\section{Bacaan Untuk Soal No. 1}

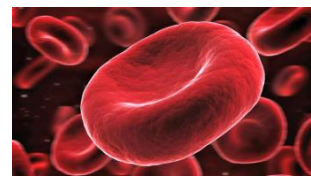

Banyak reaksi kimia dalam tubuh kita yang berlangsung dalam lingkungan $\mathrm{pH}$ yang terkontrol. Misalnya, reaksi pengikatan oksigen oleh darah dapat berlangsung dengan baik jika $\mathrm{pH}$ darah berada pada rentang $\mathrm{pH} 7,35$ - 7,45. Jika mekanisme pengaturan $\mathrm{pH}$ dalam tubuh gagal, misalnya saat sakit dan $\mathrm{pH}$ darah turun sampai $<7$ atau naik sampai $\mathrm{pH}$ 7,8, maka dapat menyebabkan kerusakan permanen pada organ tubuh atau bahkan kematian. Oleh karena itu, dalam darah terdapat larutan penyangga yang dapat mempertahankan $\mathrm{pH}$ di dalam darah.

1. Di bawah ini yang merupakan pasangan asam basa konjugasi larutan penyangga dalam darah adalah...
a. $\mathrm{HPO}_{4}{ }^{2-}$ dan $\mathrm{H}_{2} \mathrm{PO}_{4}{ }^{-}$
b. $\mathrm{H}_{3} \mathrm{PO}_{4}$ dan $\mathrm{H}_{2} \mathrm{PO}_{4}^{-}$
c. $\mathrm{H}_{3} \mathrm{PO}_{4}$ dan $\mathrm{H}_{2} \mathrm{CO}_{3}$
d. $\mathrm{H}_{2} \mathrm{CO}_{3}$ dan $\mathrm{HCO}_{3}{ }^{-}$
e. $\mathrm{H}_{2} \mathrm{PO}_{4}^{-}$dan $\mathrm{HCO}_{3}{ }^{-}$

\section{Pilihan Alasan:}

1) $\mathrm{H}_{2} \mathrm{CO}_{3}$ yang bertindak sebagai asam lemah dan $\mathrm{HCO}_{3}{ }^{-}$sebagai basa konjugasinya.

2) $\mathrm{H}_{3} \mathrm{PO}_{4}$ yang bertindak sebagai asam lemah dan $\mathrm{H}_{2} \mathrm{CO}_{3}$ sebagai basa konjugasinya.

3) $\mathrm{H}_{2} \mathrm{PO}_{4}^{-}$yang bertindak sebagai asam lemah dan $\mathrm{HCO}_{3}{ }^{-}$sebagai basa konjugasinya.

4) $\mathrm{H}_{3} \mathrm{PO}_{4}$ yang bertindak sebagai asam lemah dan $\mathrm{H}_{2} \mathrm{PO}_{4}^{-}$yang bertindak sebagai basa konjugasinya.

5) Penyangga karbonat terdiri dari $\mathrm{HPO}_{4}{ }^{2-}$ yang bertindak sebagai asam lemah dan $\mathrm{H}_{2} \mathrm{PO}_{4}{ }^{-}$ sebagai basa konjugasinya.

Apakah Anda yakin dengan jawaban Anda?

$\mathrm{Ya}$ 


\section{Bacaan Untuk Soal No. 2 - 4}

Siswa kelas XI MIPA diberi tugas oleh guru kimia untuk membuat larutan penyangga. Larutan yang disediakan di laboratorium adalah sebagai berikut.

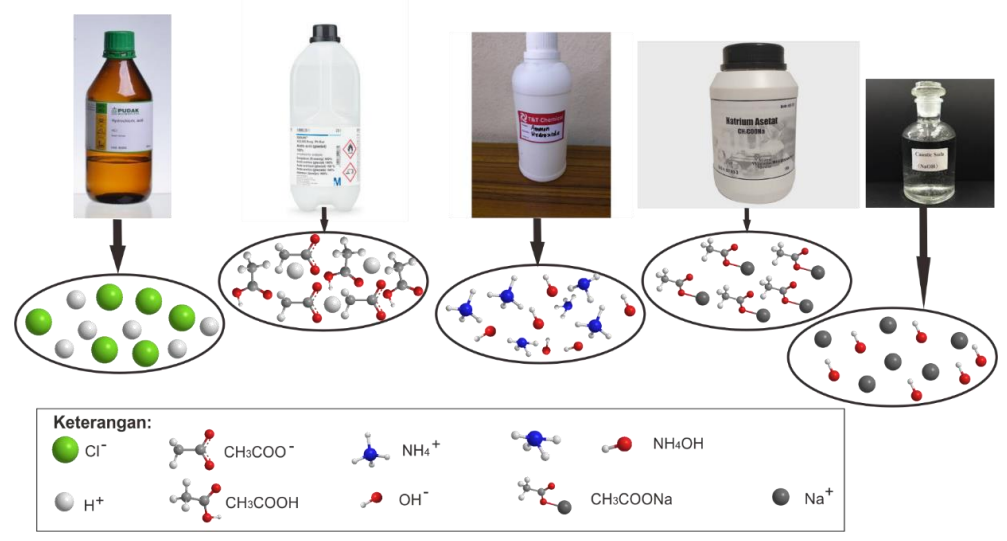

2. Pasangan larutan yang dapat digunakan untuk membuat larutan penyangga asam adalah...
a. $\mathrm{CH}_{3} \mathrm{COOH}$ dan $\mathrm{NaOH}$ berlebih
b. $\mathrm{HCl}$ dan $\mathrm{NaOH}$ berlebih
c. $\mathrm{CH}_{3} \mathrm{COOH}$ berlebih dan $\mathrm{NaOH}$
d. $\mathrm{HCl}$ berlebih dan $\mathrm{NaOH}$
e. $\mathrm{CH}_{3} \mathrm{COOH}$ dan $\mathrm{CH}_{3} \mathrm{COO}^{-}$

\section{Pilihan Alasan:}

1) Larutan penyangga asam dapat dibuat dari campuran asam lemah dan basa konjugasinya

2) Larutan penyangga asam dapat dibuat dari campuran asam lemah dan basa kuat berlebih

3) Larutan penyangga asam dapat dibuat dari campuran asam lemah berlebih dan basa kuat

4) Larutan penyangga asam dapat dibuat dari campuran asam kuat dan basa kuat berlebih

5) Larutan penyangga asam dapat dibuat dari campuran asam kuat berlebih dan basa kuat

\section{Apakah Anda yakin dengan jawaban Anda?}

Ya Tidak

3. Pasangan larutan yang dapat digunakan untuk membuat larutan penyangga basa adalah....

a. $\mathrm{HCl}$ dan $\mathrm{NaOH}$

b. $\mathrm{NH}_{4} \mathrm{OH}$ berlebih dan $\mathrm{HCl}$

c. $\mathrm{CH}_{3} \mathrm{COOH}$ berlebih dan $\mathrm{NaOH}$

d. $\mathrm{CH}_{3} \mathrm{COOH}$ dan $\mathrm{NaOH}$ berlebih

e. $\mathrm{NH} 4 \mathrm{OH}$ dan $\mathrm{HCl}$ berlebih

\section{Pilihan Alasan:}

1) Larutan penyangga basa dapat dibuat dari campuran asam kuat dan basa kuat

2) Larutan penyangga basa dapat dibuat dari campuran asam lemah berlebih dan basa kuat

3) Larutan penyangga basa dapat dibuat dari campuran asam lemah dan basa kuat berlebih

4) Larutan penyangga basa dapat dibuat dari campuran basa lemah dan asam kuat berlebih

5) Larutan penyangga basa dapat dibuat dari campuran basa lemah berlebih dan asam kuat 


\section{Apakah Anda yakin dengan jawaban Anda?}

Ya

Tidak

4. Jika $50 \mathrm{~mL}$ asam asetat $0,1 \mathrm{M}$ dicampurkan dengan larutan natrium asetat $0,1 \mathrm{M}(\mathrm{Ka}$ asam asetat $=$ $1,8 \times 10^{-5}$ ) mempunyai $\mathrm{pH}=5-\log 1,8$, volume larutan natrium asetat yang harus digunakan adalah...
a. $\quad 10 \mathrm{~mL}$
b. $20 \mathrm{~mL}$
c. $30 \mathrm{~mL}$
d. $40 \mathrm{~mL}$
e. $50 \mathrm{~mL}$

\section{Pilihan Alasan:}

1) Volume $=\mathrm{mol} \times \mathrm{M}$

2) Volume $=\mathrm{mol} \times \mathrm{Mr}$

3) Volume $=\frac{m o l}{M r}$

4) Volume $=\frac{\mathrm{mol}}{\mathrm{M}}$

5) Volume $=22,4 \mathrm{~L} \times \mathrm{mol}$

\section{Apakah Anda yakin dengan jawaban Anda?}

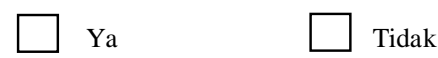

\section{Bacaan Untuk Soal No. 5 dan 6}

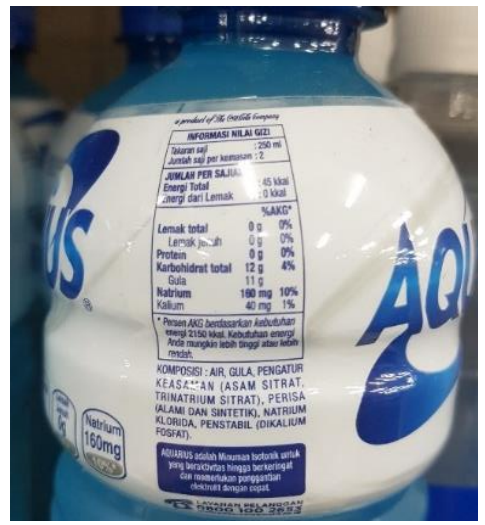

Larutan penyangga tidak hanya terdapat dalam tubuh manusia, tetapi juga banyak digunakan di industri makanan atau minuman. Larutan penyangga tersebut digunakan untuk mengatur $\mathrm{pH}$ dari suatu produk sehingga produk tersebut dapat bertahan lama. Oleh karena, dalam industri makanan dan minuman, penggunaan larutan penyangga adalah hal wajib yang harus digunakan. Gambar di samping merupakan salah satu contoh minuman yang mengandung larutan penyangga.

5. Komponen larutan penyangga pada gambar tersebut adalah...
a. Air dan gula
b. Natrium klorida dan Asam Sitrat
c. Natrium klorida dan Dikalium Fosfat
d. Asam sitrat dan Trinatrium sitrat
e. Dikalium fosfat dan Asam Sitrat

\section{Alasan Pilihan:}

1) Asam sitrat dan natrium klorida merupakan pasangan asam lemah - basa konjugasi

2) Asam sitrat dan dikalium fosfat merupakan pasangan basa lemah - asam konjugasi

3) Air dan gula apabila dicampurkan dapat membentuk larutan penyangga

4) Natrium klorida dan dikalium fosfat dapat membentuk larutan penyangga

5) Asam sitrat dan trinatrium sitrat adalah pasangan asam lemah - basa konjugasi

\section{Apakah Anda yakin dengan jawaban Anda?}

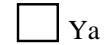


6. Larutan penyangga pada minuman tersebut bersifat...
a. Asam
b. Basa
c. Netral
d. Lemah
e. Kuat

\section{Pilihan Alasan:}

1) Larutan penyangga tersebut terdiri dari asam lemah dan basa lemah

2) Larutan penyangga tersebut terdiri dari asam lemah dan basa konjugasinya

3) Larutan penyangga tersebut terdiri dari basa lemah dan asam kuat

4) Larutan penyangga tersebut terdiri dari basa lemah dan asam konjugasinya

5) Larutan penyangga tersebut terdiri dari asam kuat dan basa kuat

\section{Apakah Anda yakin dengan jawaban Anda?}

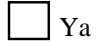
Tidak

\section{Bacaan Untuk Soal No. 7}
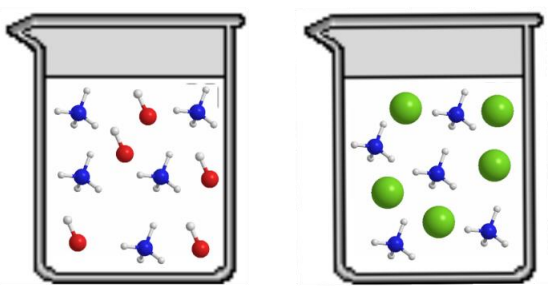

Keterangan:

if $\mathrm{NH}_{4}^{+}$ $\mathrm{OH}^{-}$ $\mathrm{Cl}^{-}$
Siswa kelas XI MIPA diberi tugas untuk membuat larutan penyangga. Di laboratorium kimia tersedia larutan amoniak $0,2 \mathrm{M}\left(\mathrm{Kb}=1,8 \times 10^{-5}\right)$ dan larutan ammonium klorida $0,2 \mathrm{M}$ seperti pada gambar di bawah ini. Mereka ingin membuat larutan penyangga dengan $\mathrm{pH}=9,26$. (Diketahui: $5-\log 1,8=4,74)$

7. Apabila pada larutan penyangga tersebut ditambah larutan $\mathrm{HCl}$, maka...
a. $\mathrm{HCl}$ akan bereaksi dengan spesi yang bersifat asam
b. $\mathrm{HCl}$ akan bereaksi dengan spesi yang bersifat basa
c. $\mathrm{HCl}$ tidak bereaksi dengan spesi manapun
d. $\mathrm{HCl}$ tidak menggeser kesetimbangan
e. $\mathrm{HCl}$ tidak merubah $\mathrm{pH}$ larutan

\section{Pilihan Alasan:}

1) $\mathrm{H}^{+}$dari $\mathrm{HCl}$ bereaksi dengan $\mathrm{NH}_{3}$

2) $\mathrm{Cl}^{-}$dari $\mathrm{HCl}$ bereaksi dengan $\mathrm{NH}_{4}^{+}$

3) $\mathrm{HCl}$ akan membuat larutan menjadi lebih asam

4) $\mathrm{HCl}$ akan membuat larutan menjadi lebih basa

5) $\mathrm{HCl}$ akan membuat larutan menjadi netral

\section{Apakah Anda yakin dengan jawaban Anda?}




\section{Bacaan Untuk Soal No. 8}

Yeni membeli sosis kemasan siap makan. Saat melihat kemasan sosis tersebut, diketahui bahwa komposisi sosis tersebut antara lain daging ayam, air, penstabil nabati, tepung tapioka, protein kedelai, natrium laktat, minyak nabati, gula, bumbu, garam, penstabil fosfat, asam laktat dan antioksidan natrium eritorbat.

8. Berdasarkan komposisi di atas, bahan yang berfungsi sebagai larutan penyangga adalah...

a. Gula dan garam

b. Natrium laktat dan natrium eritorbat

c. Natrium eritorbat dan asam eritorbat

d. Minyak nabati dan penstabil fosfat

e. Natrium laktat dan asam laktat

\section{Alasan Pilihan:}

1) Minyak nabati dan penstabil fosfat jika dicampurkan dapat membentuk larutan penyangga

2) Natrium eritorbat merupakan garam dari asam eritorbat, sehingga kedua komponen tersebut dapat membentuk larutan penyangga

3) Natrium laktat dan natrium eritorbat merupakan zat yang dapat menstabilkan $\mathrm{pH}$

4) Gula dan garam keduanya dapat menstabilkan $\mathrm{pH}$

5) Natrium laktat merupakan garam dari asam laktat, sehingga keduanya berfungsi mengatur keasaman suatu produk

\section{Apakah Anda yakin dengan jawaban Anda?}

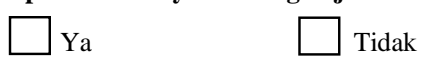

Bacaan Untuk No. 9 - 10

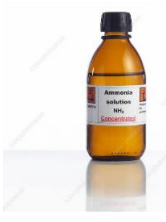

Larutan $\mathrm{NH}_{3}$

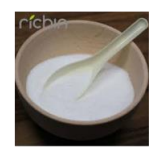

$\left(\mathrm{NH}_{4}\right)_{2} \mathrm{SO}_{4}$

d. $9-\log 3,6$

e. $9+\log 1,8$

\section{Pilihan Alasan:}

1) $\mathrm{pH}=-\log \left[\mathrm{H}^{+}\right]$

2) $\mathrm{pH}=+\log \left[\mathrm{H}^{+}\right]$

3) $\mathrm{pH}=-\log \left[\mathrm{OH}^{-}\right]$

4) $\mathrm{pH}=+\log \left[\mathrm{OH}^{-}\right]$

5) $\mathrm{pH}=14-\mathrm{pOH}$

\section{Apakah Anda yakin dengan jawaban Anda?}

Ya

Guru kimia kelas XI merancang percobaan praktikum pada materi larutan penyangga. Tujuan dari praktikum tersebut adalah untuk mengetahui pengaruh penambahan asam dan basa pada larutan penyangga. Bahan-bahan yang disediakan di laboratorium adalah seperti gambar di samping.

9. Apabila $100 \mathrm{~mL}$ larutan $\left(\mathrm{NH}_{4}\right)_{2} \mathrm{SO}_{4} 0,2 \mathrm{M}$ dicampurkan dengan $200 \mathrm{~mL}$ larutan $\mathrm{NH}_{3}$ 0,2 M, maka $\mathrm{pH}$ campuran tersebut adalah... $\left(\mathrm{Kb} \mathrm{NH}_{3}=1,8 \times 10^{-5}\right)$
a. $5-\log 3,6$
b. $5-\log 1,8$
c. $9+\log 3,6$ 
10. $\mathrm{pH}$ dari $100 \mathrm{~mL}$ larutan $\left(\mathrm{NH}_{4}\right)_{2} \mathrm{SO}_{4} 0,1 \mathrm{M}$ yang dicampurkan dengan $200 \mathrm{~mL} \mathrm{NH}_{3} 0,1 \mathrm{M}$ adalah 9 $+\log$ 3,6. Apabila $20 \mathrm{~mL}$ larutan $\mathrm{HCl} 0,1 \mathrm{M}$ ditambahkan ke dalam larutan, maka $\mathrm{pH}$ larutan menjadi... $\left(\mathrm{Kb} \mathrm{NH}_{3}=1,8 \times 10^{-5}\right)$
a. $9+\log 3,6$
b. $9+\log 2,7$
c. $9-\log 2,7$
d. $5-\log 2,7$
e. $5+\log 3,6$

\section{Pilihan Alasan:}

1) $\mathrm{pH}=-\log \left[\mathrm{H}^{+}\right]$

2) $\mathrm{pH}=+\log \left[\mathrm{H}^{+}\right]$

3) $\mathrm{pH}=-\log \left[\mathrm{OH}^{-}\right]$

4) $\mathrm{pH}=+\log \left[\mathrm{OH}^{-}\right]$

5) $\mathrm{pH}=14-\mathrm{pOH}$

\section{Apakah Anda yakin dengan jawaban Anda?}

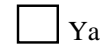
Tidak

\section{Bacaan Untuk Soal No. 11}

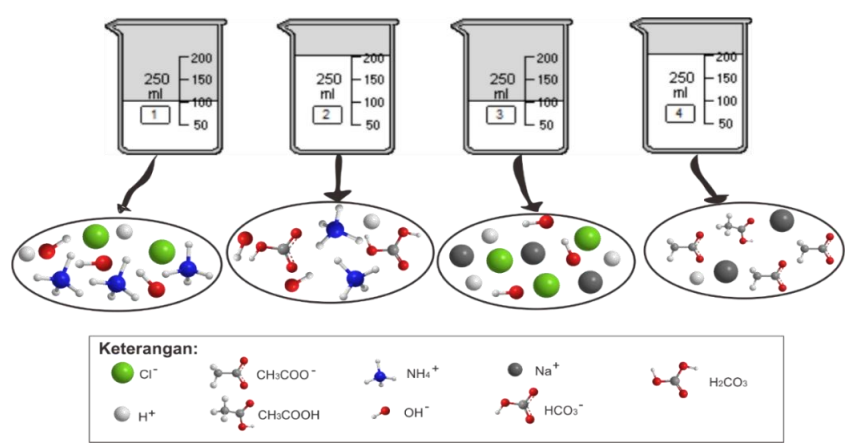

Bu Rani menyediakan 4 macam larutan yang dimasukkan ke dalam gelas beaker dengan komposisi berbeda. $\mathrm{Bu}$ Dewi memberi tugas kepada para siswa untuk mengidentifikasi larutan yang termasuk penyangga dan bukan penyangga. Isi larutan tersebut adalah seperti gambar di samping.

11. Komponen larutan penyangga asam pada larutan di atas adalah....
a. $\mathrm{NH}_{3}$ dan $\mathrm{NH}_{4}{ }^{+}$
b. $\mathrm{NH}_{4}^{+}$dan $\mathrm{Cl}^{-}$
c. $\mathrm{CH}_{3} \mathrm{COOH}$ dan $\mathrm{CH}_{3} \mathrm{COO}^{-}$
d. $\mathrm{CH}_{3} \mathrm{COO}^{-}$dan $\mathrm{H}^{+}$
e. $\mathrm{CH}_{3} \mathrm{COOH}$ dan $\mathrm{OH}^{-}$

\section{Pilihan Alasan:}

1) $\mathrm{CH}_{3} \mathrm{COOH}$ adalah asam lemah dan $\mathrm{OH}^{-}$adalah basa konjugasinya

2) $\mathrm{CH}_{3} \mathrm{COOH}$ adalah asam lemah dan $\mathrm{CH}_{3} \mathrm{COO}^{-}$adalah basa konjugasinya

3) $\mathrm{NH}_{4}{ }^{+}$adalah asam lemah dan $\mathrm{NH}_{3}$ adalah basa konjugasinya

4) $\mathrm{NH}_{4}{ }^{+}$adalah asam lemah dan $\mathrm{Cl}^{-}$adalah basa konjugasinya

5) $\mathrm{CH}_{3} \mathrm{COO}^{-}$adalah basa konjugasi dari $\mathrm{H}^{+}$

\section{Apakah Anda yakin dengan jawaban Anda?}




\section{Bacaan Untuk Soal No. 12}

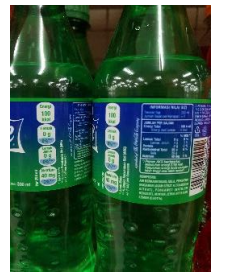

Minuman bersoda merupakan jenis minuman dalam kemasan yang mengalami proses karbonasi. Karbonasi terjadi apabila gas $\mathrm{CO}_{2}$ terlarut sempurna dalam air. Hasil proses karbonasi dalam minuman bersoda ditandai dengan adanya buih. Minuman bersoda diketahui mengandung larutan penyangga didalamnya yang berfungsi untuk mengatur $\mathrm{pH}$ atau tingkat keasaman pada minuman tersebut. Siswa kelas XI melakukan percobaan yang bertujuan untuk menguji pengaruh pengenceran dan penambahan asam dan basa pada minuman tersebut.

12. Tahapan yang tepat dalam pengujian pengaruh pengenceran dan penambahan asam dan basa pada minuman tersebut adalah...

a. Mengukur $\mathrm{pH}$ awal minuman bersoda ketika busanya masih banyak, menambahkan sedikit asam/basa/aquades, mengukur $\mathrm{pH}$ setelah penambahan

b. Mengukur $\mathrm{pH}$ awal minuman bersoda langsung setelah dituang, menambahkan sedikit asam/basa/aquades, mengukur $\mathrm{pH}$ setelah penambahan

c. Mengukur $\mathrm{pH}$ awal minuman bersoda ketika busanya tinggal sedikit, menambahkan sedikit asam/basa/aquades, mengukur $\mathrm{pH}$ setelah penambahan

d. Mengukur $\mathrm{pH}$ awal minuman bersoda ketika busanya sudah hilang, menambahkan sedikit asam/basa/aquades, mengukur $\mathrm{pH}$ setelah penambahan

e. Menambahkan sedikit asam/basa/aquades, mengukur $\mathrm{pH}$ setelah penambahan

\section{Pilihan Alasan:}

1) Pengukuran $\mathrm{pH}$ awal minuman bersoda harus dilakukan ketika $\mathrm{CO}_{2}$ di dalam larutan masih banyak

2) Dengan penambahan asam atau basa kita dapat mengetahui larutan tersebut merupakan larutan penyangga atau bukan

3) Pengukuran $\mathrm{pH}$ awal minuman bersoda harus dilakukan ketika busanya tinggal sedikit agar masih ada $\mathrm{CO}_{2}$ di dalam larutan

4) Pengukuran $\mathrm{pH}$ awal minuman dilakukan ketika $\mathrm{CO}_{2}$ sudah hilang, agar yang tersisa dalam minuman hanya larutan penyangganya saja.

5) Pengukuran $\mathrm{pH}$ awal minuman bersoda langsung setelah dituang dapat mencegah $\mathrm{CO}_{2}$ hilang.

\section{Apakah Anda yakin dengan jawaban Anda?}

Ya

Tidak

Perhatikan gambar di bawah ini! (Untuk No. 13-15)
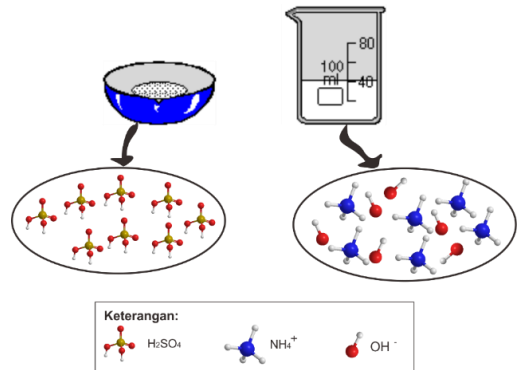
13. Zat yang terdapat di dalam cawan porselin tersebut dibuat menjadi larutan dengan volume $10 \mathrm{~mL}$ dan konsentrasinya adalah 0,2 M. Larutan tersebut kemudian dicampurkan dengan $40 \mathrm{~mL}$ larutan di dalam gelas beaker dengan konsentrasi $0,2 \mathrm{M}$. pH larutan tersebut adalah... $\left(\mathrm{Kb}=1,8 \times 10^{-5}\right)$
a. $9+\log 5,4$
b. $9-\log 5,4$
c. $9+\log 7,2$
d. $5-\log 5,4$
e. $5-\log 7,2$

\section{Pilihan Alasan:}

1) $\mathrm{pH}=-\log \left[\mathrm{H}^{+}\right]$

2) $\mathrm{pH}=-\log \left[\mathrm{OH}^{-}\right]$

3) $\mathrm{pH}=14-\mathrm{pOH}$

4) $\mathrm{pH}=+\log \left[\mathrm{OH}^{-}\right]$

5) $\mathrm{pH}=+\log \left[\mathrm{H}^{+}\right]$

\section{Apakah Anda yakin dengan jawaban Anda?}

Ya

Tidak

14. Massa zat yang terdapat di dalam cawan porselin tersebut apabila $\mathrm{pH}$ larutan penyangga $=9+\log$ $5,4$ adalah... (Ar $\mathrm{H}=1, \mathrm{O}=16, \mathrm{~S}=32)$
a. $98 \mathrm{mg}$
b. $196 \mathrm{mg}$
c. $49 \mathrm{mg}$
d. $4,9 \mathrm{mg}$
e. $19,6 \mathrm{mg}$

\section{Pilihan Alasan:}
1) Massa $=\frac{\mathrm{mol}}{\mathrm{Mr}}$
2) Massa $=\mathrm{mol} \times \mathrm{Mr}$
3) Massa $=22,4 \mathrm{~L} \times \mathrm{mol}$
4) Massa $=\operatorname{mol} \times 6,02 \times 10^{23}$
5) Massa $=\frac{m o l}{M}$

\section{Apakah Anda yakin dengan jawaban Anda?}

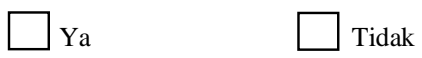

15. Komponen penyangga dari larutan penyangga di atas adalah....
a. $\mathrm{H}_{2} \mathrm{SO}_{4}$ dan $\mathrm{NH}_{4}^{+}$
b. $\mathrm{H}_{2} \mathrm{SO}_{4}$ dan $\mathrm{NH}_{4} \mathrm{OH}$
c. $\mathrm{NH}_{4} \mathrm{OH}$ dan $\mathrm{NH}_{4}{ }^{+}$
d. $\mathrm{NH}_{4} \mathrm{OH}$ dan $\mathrm{HSO}_{4}{ }^{-}$
e. $\mathrm{NH}_{4} \mathrm{OH}$ dan $\mathrm{H}^{+}$

\section{Pilihan Alasan:}

1) $\mathrm{NH}_{4} \mathrm{OH}$ merupakan basa lemah, sedangkan $\mathrm{NH}_{4}{ }^{+}$adalah asam konjugasinya.

2) $\mathrm{NH}_{4} \mathrm{OH}$ merupakan asam lemah, sedangkan $\mathrm{HSO}_{4}{ }^{-}$adalah basa konjugasinya

3) $\mathrm{NH}_{4} \mathrm{OH}$ merupakan basa lemah, sedangkan $\mathrm{H}^{+}$adalah asam konjugasinya

4) $\mathrm{NH}_{4} \mathrm{OH}$ merupakan basa lemah, sedangkan $\mathrm{H}_{2} \mathrm{SO}_{4}$ adalah asam kuat

5) $\mathrm{H}_{2} \mathrm{SO}_{4}$ adalah asam kuat, sedangkan $\mathrm{NH}_{4}{ }^{+}$adalah asam konjugasinya.

\section{Apakah Anda yakin dengan jawaban Anda?}




\section{B. Uraian}

\section{Isilah pertanyaan-pertanyaan di bawah ini dengan benar!}

\section{Perhatikan gambar berikut ini!}

Diketahui terdapat larutan penyangga asam dengan konsentrasi HA dan $\mathrm{A}^{-}$yang sama. Siswa kelas XI ingin menguji pengaruh penambahan sedikit asam dan sedikit basa pada larutan penyangga tersebut. Gambar submikroskopik dari hasil uji coba tersebut adalah sebagai berikut.
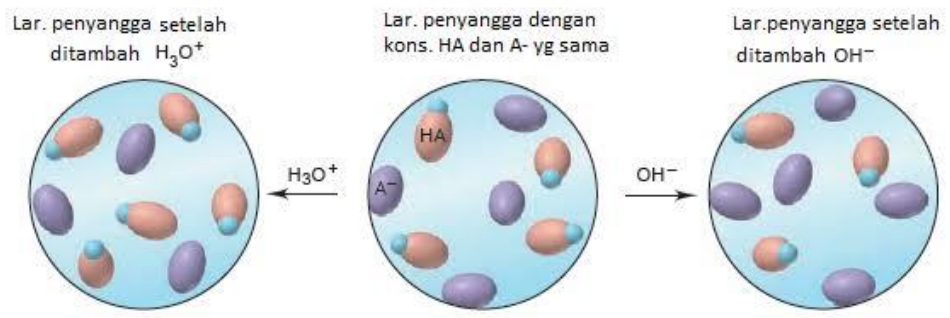

16. Jelaskan maksud gambar di atas!

\section{Bacaan Untuk Soal No. 17 - 18}

Athi diberi tugas untuk menguji pengaruh penambahan sedikit asam dan sedikit basa ke dalam larutan penyangga. Larutan penyangga yang ia gunakan terbuat dari larutan $100 \mathrm{~mL}$ $\mathrm{H}_{2} \mathrm{CO}_{3} \quad 0,3 \mathrm{M}$ dan larutan $\mathrm{NaHCO}_{3} 0,1 \mathrm{M}$ yang mempunyai $\mathrm{pH}=7-\log 4,2(\mathrm{Ka}$ $\mathrm{H}_{2} \mathrm{CO}_{3}=4,2 \times 10^{-7}$ ).
17. Berapakah volume $\mathrm{NaHCO}_{3}$ yang digunakan untuk membuat larutan penyangga tersebut?

18. Berapa $\mathrm{pH}$ larutan tersebut apabila ditambahkan $20 \mathrm{~mL}$ larutan $\mathrm{NaOH}$ 0,1 M?

19. Perbandingan volume $\mathrm{CH}_{3} \mathrm{COOH} 0,1 \mathrm{M}\left(\mathrm{Ka}=1,8 \times 10^{-5}\right)$ dan $\mathrm{CH}_{3} \mathrm{COONa} 0,1 \mathrm{M}$ yang harus dicampurkan untuk membuat larutan penyangga dengan $\mathrm{pH}=5-\log 3,6$ adalah....

20. Diketahui larutan $\mathrm{HCOOH} 0,2 \mathrm{M}$ dan $(\mathrm{HCOO})_{2} \mathrm{Ba} 0,1 \mathrm{M}$. Jika kedua larutan tersebut dibuat larutan penyangga yang memiliki $\mathrm{pH} 4$, tentukan perbandingan volume $\mathrm{HCOOH}$ dan $(\mathrm{HCOO}){ }_{2} \mathrm{Ba}$ ! (Ka $\left.\mathrm{HCOOH}=2 \times 10^{-4}\right)$ 
Lampiran 20. Angket Respon Peserta Didik terhadap Model Pembelajaran SiMaYang Tipe II

\section{ANGKET RESPON PESERTA DIDIK TERHADAP MODEL PEMBELAJARAN SIMAYANG TIPE II}

Nama

No. Absen

Kelas

\section{Petunjuk:}

1. Jawablah pertanyaan-pertanyaan di bawah ini dengan jujur sesuai dengan pendapatmu, karena tidak akan berpengaruh pada penilaian pelajaran ini.

2. Berilah tanda cek $(\sqrt{ })$ pada pilihan jawabanmu untuk masingmasing pertanyaan. Ketujuh pilihan jawaban tersebut yaitu:

$\mathrm{SS}=$ Sangat Setuju ATS $=$ Agak Tidak Setuju

$\mathrm{S}=$ Setuju TS = Tidak Setuju

AS $=$ Agak Setuju $\quad$ STS $=$ Sangat Tidak Setuju

$\mathrm{N} \quad=$ Netral

3. Usahakan setiap pertanyaan terjawab dan tidak ada yang kosong.

4. Jawaban yang kamu berikan akan dijamin kerahasiaannya.

Jawablah pertanyaan berikut:

\begin{tabular}{|c|c|c|c|c|c|c|c|c|}
\hline \multirow[b]{2}{*}{ No } & \multirow[b]{2}{*}{ Pernyataan } & \multicolumn{7}{|c|}{ Jawaban } \\
\hline & & $\begin{array}{l}S \\
S\end{array}$ & $\mathbf{S}$ & $\begin{array}{l}A \\
S\end{array}$ & $\mathbf{N}$ & $\begin{array}{l}\mathbf{A} \\
\mathbf{T} \\
\mathbf{S}\end{array}$ & $\begin{array}{l}\text { S } \\
\text { S }\end{array}$ & $\begin{array}{l}S \\
T \\
S\end{array}$ \\
\hline 1. & $\begin{array}{l}\text { Dengan model pembelajaran } \\
\text { SiMaYang Tipe II, saya memiliki } \\
\text { kemauan yang tinggi untuk mengikuti } \\
\text { mata pelajaran kimia }\end{array}$ & & & & & & & \\
\hline
\end{tabular}




\begin{tabular}{|c|c|c|c|c|c|c|c|c|}
\hline \multirow[b]{2}{*}{ No } & \multirow[b]{2}{*}{ Pernyataan } & \multicolumn{7}{|c|}{ Jawaban } \\
\hline & & $\begin{array}{l}S \\
S\end{array}$ & $\mathbf{S}$ & $\begin{array}{l}\text { A } \\
S\end{array}$ & $\mathbf{N}$ & $\begin{array}{l}\mathbf{A} \\
\mathbf{T} \\
\mathbf{S}\end{array}$ & $\begin{array}{l}\text { T } \\
S\end{array}$ & \\
\hline 2. & $\begin{array}{l}\text { Pembelajaran kimia dengan model } \\
\text { pembelajaran SiMaYang Tipe II } \\
\text { menarik dan tidak membosankan }\end{array}$ & & & & & & & \\
\hline 3. & $\begin{array}{l}\text { Teori-teori dan konsep kimia lebih } \\
\text { mudah saya pahami dengan } \\
\text { menggunakan model pembelajaran } \\
\text { SiMaYang Tipe II yang berbasis } \\
\text { multipel representasi }\end{array}$ & & & & & & & \\
\hline 4. & $\begin{array}{l}\text { Dengan model pembelajaran } \\
\text { SiMaYang Tipe II, saya lebih bisa } \\
\text { mengimajinasikan bentuk molekul } \\
\text { pada level submikroskopik }\end{array}$ & & & & & & & \\
\hline 5. & $\begin{array}{l}\text { Saya bosan mengikuti pelajaran kimia } \\
\text { dengan model pembelajaran } \\
\text { SiMaYang Tipe II }\end{array}$ & & & & & & & \\
\hline 6. & $\begin{array}{l}\text { Dengan model pembelajaran } \\
\text { SiMaYang Tipe II, saya merasa lebih } \\
\text { dihargai dalam mengeluarkan } \\
\text { pendapat }\end{array}$ & & & & & & & \\
\hline 7. & $\begin{array}{l}\text { Dengan model pembelajaran } \\
\text { SiMaYang Tipe II, saya dapat belajar } \\
\text { bersama teman dengan baik }\end{array}$ & & & & & & & \\
\hline 8. & $\begin{array}{l}\text { Pembelajaran kimia dengan model } \\
\text { pembelajaran SiMaYang Tipe II dapat }\end{array}$ & & & & & & & \\
\hline
\end{tabular}




\begin{tabular}{|c|c|c|c|c|c|c|c|c|}
\hline \multirow[b]{2}{*}{ No } & \multirow[b]{2}{*}{ Pernyataan } & \multicolumn{7}{|c|}{ Jawaban } \\
\hline & & $\begin{array}{l}S \\
S\end{array}$ & $\mathbf{S}$ & $\begin{array}{l}A \\
S\end{array}$ & $\mathbf{N}$ & $\begin{array}{l}\text { S } \\
\text { S }\end{array}$ & $\begin{array}{l}T \\
S\end{array}$ & $\begin{array}{l}S \\
T \\
S\end{array}$ \\
\hline & $\begin{array}{l}\text { menumbuhkan rasa saling } \\
\text { menghargai pendapat orang lain }\end{array}$ & & & & & & & \\
\hline 9. & $\begin{array}{l}\text { Saya merasa bahwa model } \\
\text { pembelajaran SiMaYang Tipe II dapat } \\
\text { membangun hubungan yang lebih } \\
\text { baik antar sesama teman }\end{array}$ & & & & & & & \\
\hline 10. & $\begin{array}{l}\text { Model pembelajaran SiMaYang Tipe II } \\
\text { dalam mata pelajaran kimia dapat } \\
\text { meningkatkan kerjasama dengan } \\
\text { sesama teman }\end{array}$ & & & & & & & \\
\hline 11. & $\begin{array}{l}\text { Dengan model pembelajaran } \\
\text { SiMaYang Tipe II, saya lebih berani } \\
\text { mengeluarkan pendapat }\end{array}$ & & & & & & & \\
\hline 12. & $\begin{array}{l}\text { Dengan model pembelajaran } \\
\text { SiMaYang Tipe II, saya lebih tahu } \\
\text { aplikasi materi larutan penyangga } \\
\text { dalam kehidupan sehari-hari }\end{array}$ & & & & & & & \\
\hline 13. & $\begin{array}{l}\text { Pembelajaran dengan model } \\
\text { pembelajaran SiMaYang Tipe II tidak } \\
\text { dapat mengeksplorasi diri saya }\end{array}$ & & & & & & & \\
\hline 14. & $\begin{array}{l}\text { Dengan model pembelajaran } \\
\text { SiMaYang Tipe II, pembelajaran kimia } \\
\text { terasa menarik karena dihubungkan } \\
\text { dengan masalah dunia nyata }\end{array}$ & & & & & & & \\
\hline
\end{tabular}




\begin{tabular}{|c|c|c|c|c|c|c|c|c|}
\hline \multirow[b]{2}{*}{ No } & \multirow[b]{2}{*}{ Pernyataan } & \multicolumn{7}{|c|}{ Jawaban } \\
\hline & & $\begin{array}{l}S \\
S\end{array}$ & $\mathbf{S}$ & $\begin{array}{l}A \\
S\end{array}$ & $\mathbf{N}$ & $\begin{array}{l}\mathbf{A} \\
\mathbf{T} \\
\mathbf{S}\end{array}$ & $\begin{array}{l}\mathrm{T} \\
\mathbf{S}\end{array}$ & $\begin{array}{l}S \\
T \\
S\end{array}$ \\
\hline 15. & $\begin{array}{l}\text { Dengan model pembelajaran } \\
\text { SiMaYang Tipe II saya lebih mudah } \\
\text { mengantuk }\end{array}$ & & & & & & & \\
\hline 16. & $\begin{array}{l}\text { Model pembelajaran SiMaYang Tipe II } \\
\text { cocok diterapkan dalam mata } \\
\text { pelajaran kimia }\end{array}$ & & & & & & & \\
\hline 17. & $\begin{array}{l}\text { Dengan model pembelajaran } \\
\text { SiMaYang Tipe II, saya tidak bisa } \\
\text { menghubungkan level makroskopik } \\
\text { dan level submikroskopik. }\end{array}$ & & & & & & & \\
\hline 18. & $\begin{array}{l}\text { Dengan model pembelajaran } \\
\text { SiMaYang Tipe II, saya bisa } \\
\text { mengerjakan soal yang berbasis multi } \\
\text { level representasi (terdapat level } \\
\text { makroskopik, submikroskopik dan } \\
\text { simbolik). }\end{array}$ & & & & & & & \\
\hline 19. & $\begin{array}{l}\text { Dengan model SiMaYang Tipe II, saya } \\
\text { lebih percaya diri dalam belajar } \\
\text { kimia. }\end{array}$ & & & & & & & \\
\hline 20. & $\begin{array}{l}\text { Saya tidak suka menyelesaikan soal } \\
\text { kimia dengan menghubungkan level } \\
\text { submikroskopik di dalamnya. }\end{array}$ & & & & & & & \\
\hline
\end{tabular}


Lampiran 21. Angket Attitudes toward Chemistry

\section{Kisi-Kisi Angket Attitudes Toward Chemistry:}

Catatan: Indikator dan soal angket Attitudes toward Chemistry pada penelitian ini mengadopsi angket yang dikembangkan Cheung (2011).

\begin{tabular}{|c|l|c|}
\hline No. & \multicolumn{1}{|c|}{ Indikator } & Nomor Soal \\
\hline 1. & Liking for chemistry theory lessons & $1,5,9$ \\
\hline 2. & Liking for chemistry laboratory work & $2,6,10$ \\
\hline 3. & Evaluative beliefs about school chemistry & $3,7,11$ \\
\hline 4. & Behavioral tendencies to learn chemistry & $4,8,12$ \\
\hline
\end{tabular}

Angket Attitudes toward Chemistry:

ANGKET SIKAP TERHADAP KIMIA

(ATTITUDES TOWARD CHEMISTRY INVENTORY)

Nama: Kelas:

Petunjuk: Dalam angket ini, Anda diminta untuk memberikan tanda $(\sqrt{ })$ di samping pernyataan sesuai dengan seberapa besar pernyataan itu mewakili diri Anda.

\section{Keterangan:}

SS $=$ Sangat Setuju $\quad$ S $=$ Setuju $\quad$ AS $=$ Agak Setuju $\quad \mathbf{N}=$ Netral ATS $=$ Agak Tidak Setuju TS $=$ Tidak Setuju STS $=$ Sangat Tidak Setuju Isilah pernyataan berikut ini!

\begin{tabular}{|c|l|c|c|c|c|c|c|c|}
\hline No & \multicolumn{1}{|c|}{ Pernyataan } & SS & S & AS & N & ATS & TS & STS \\
\hline 1. & $\begin{array}{l}\text { Saya menyukai mata } \\
\text { pelajaran kimia } \\
\text { daripada mata } \\
\text { pelajaran lainnya }\end{array}$ & & & & & & & \\
\hline 2. & $\begin{array}{l}\text { Saya senang } \\
\text { melakukan eksperimen } \\
\text { kimia }\end{array}$ & & & & & & \\
\hline
\end{tabular}




\begin{tabular}{|c|c|c|c|c|c|c|c|c|}
\hline No & Pernyataan & SS & $S$ & AS & $\mathbf{N}$ & ATS & TS & STS \\
\hline 3. & $\begin{array}{l}\text { Kimia bermanfaat } \\
\text { untuk menyelesaikan } \\
\text { berbagai permasalahan } \\
\text { sehari-hari }\end{array}$ & & & & & & & \\
\hline 4. & $\begin{array}{l}\text { Saya akan meluangkan } \\
\text { waktu untuk membaca } \\
\text { buku-buku kimia }\end{array}$ & & & & & & & \\
\hline 5. & $\begin{array}{l}\text { Pembelajaran kimia itu } \\
\text { menarik }\end{array}$ & & & & & & & \\
\hline 6. & $\begin{array}{l}\text { Ketika saya bekerja di } \\
\text { laboratorium kimia, } \\
\text { saya merasa sedang } \\
\text { melakukan sesuatu } \\
\text { yang sangat penting }\end{array}$ & & & & & & & \\
\hline 7. & $\begin{array}{l}\text { Orang-orang harus } \\
\text { memahami kimia } \\
\text { karena kimia } \\
\text { mempengaruhi } \\
\text { kehidupan mereka. }\end{array}$ & & & & & & & \\
\hline 8. & $\begin{array}{l}\text { Saya senang } \\
\text { menyelesaikan } \\
\text { permasalahan- } \\
\text { permasalahan baru } \\
\text { dalam kimia }\end{array}$ & & & & & & & \\
\hline 9. & $\begin{array}{l}\text { Kimia adalah salah satu } \\
\text { mata pelajaran favorit } \\
\text { saya }\end{array}$ & & & & & & & \\
\hline 10. & $\begin{array}{l}\text { Melakukan praktikum } \\
\text { kimia di sekolah itu } \\
\text { menyenangkan }\end{array}$ & & & & & & & \\
\hline 11. & $\begin{array}{l}\text { Kimia adalah salah satu } \\
\text { mata pelajaran yang } \\
\text { sangat penting untuk } \\
\text { dipelajari }\end{array}$ & & & & & & & \\
\hline 12. & $\begin{array}{l}\text { Jika saya memiliki } \\
\text { kesempatan, saya akan } \\
\text { melakukan proyek } \\
\text { dalam kimia. }\end{array}$ & & & & & & & \\
\hline
\end{tabular}


Lampiran 22. Uji Normalitas dan Homogenitas Populasi

\section{Data Nilai PAS Kelas XI MIPA}

\section{Semester Ganjil Tahun Ajaran 2019/2020}

\section{Kelas XI MIPA 1 - XI MIPA 4:}

\begin{tabular}{|c|c|c|c|c|c|c|c|c|}
\hline \multirow{2}{*}{ No. Absen } & \multicolumn{2}{|c|}{ XI MIPA 1} & \multicolumn{2}{|c|}{ XI MIPA 2} & \multicolumn{2}{|c|}{ XI MIPA 3} & \multicolumn{2}{|c|}{ XI MIPA 4} \\
\hline & Nilai & $(x-\bar{x})^{2}$ & Nilai & $(x-\bar{x})^{2}$ & Nilai & $(x-\bar{x})^{2}$ & Nilai & $(x-\bar{x})^{2}$ \\
\hline 1 & 50 & 254,23 & 54 & 134,56 & 85 & 259,57 & 54 & 74,0 \\
\hline 2 & 80 & 197,56 & 90 & 595,36 & 76 & 50,57 & 52 & 112,4 \\
\hline 3 & 53 & 167,56 & 60 & 31,36 & 91 & 488,90 & 68 & 29,2 \\
\hline 4 & 70 & 16,45 & 53 & 158,76 & 56 & 166,12 & 42 & 424,4 \\
\hline 5 & 68 & 4,23 & 64 & 2,56 & 55 & 192,90 & 80 & 302,8 \\
\hline 6 & 75 & 82,00 & 75 & 88,36 & 50 & 356,79 & 64 & 2,0 \\
\hline 7 & 77 & 122,23 & 72 & 40,96 & 79 & 102,23 & 46 & 275,6 \\
\hline 8 & 63 & 8,67 & 63 & 6,76 & 60 & 79,01 & 54 & 74,0 \\
\hline 9 & 67 & 1,11 & 69 & 11,56 & 56 & 166,12 & 70 & 54,8 \\
\hline 10 & 52 & 194,45 & 65 & 0,36 & 70 & 1,23 & 54 & 74,0 \\
\hline 11 & 78 & 145,34 & 74 & 70,56 & 56 & 166,12 & 60 & 6,8 \\
\hline 12 & 50 & 254,23 & 89 & 547,56 & 65 & 15,12 & 72 & 88,4 \\
\hline 13 & 62 & 15,56 & 75 & 88,36 & 71 & 4,46 & 64 & 2,0 \\
\hline 14 & 68 & 4,23 & 51 & 213,16 & 69 & 0,01 & 62 & 0,4 \\
\hline 15 & 75 & 82,00 & 81 & 237,16 & 74 & 26,12 & 70 & 54,8 \\
\hline 16 & 60 & 35,34 & 69 & 11,56 & 80 & 123,46 & 60 & 6,8 \\
\hline 17 & 57 & 80,00 & 76 & 108,16 & 60 & 79,01 & 56 & 43,6 \\
\hline 18 & 59 & 48,23 & 59 & 43,56 & 62 & 47,46 & 54 & 74,0 \\
\hline 19 & 91 & 627,78 & 74 & 70,56 & 75 & 37,35 & 68 & 29,2 \\
\hline 20 & 56 & 98,89 & 54 & 134,56 & 73 & 16,90 & 74 & 130,0 \\
\hline 21 & 83 & 290,89 & 70 & 19,36 & 81 & 146,68 & 62 & 0,4 \\
\hline 22 & 51 & 223,34 & 77 & 129,96 & 65 & 15,12 & 72 & 88,4 \\
\hline 23 & 64 & 3,78 & 50 & 243,36 & 53 & 252,46 & 58 & 21,2 \\
\hline 24 & 50 & 254,23 & 51 & 213,16 & 70 & 1,23 & 49 & 185,0 \\
\hline 25 & 70 & 16,45 & 64 & 2,56 & 75 & 37,35 & 68 & 29,2 \\
\hline 26 & 50 & 254,23 & 56 & 92,16 & 82 & 171,90 & 66 & 11,6 \\
\hline 27 & 68 & 4,23 & 84 & 338,56 & 63 & 34,68 & 56 & 43,6 \\
\hline 28 & 72 & 36,67 & 62 & 12,96 & 68 & 0,79 & 62 & 0,4 \\
\hline 29 & 78 & 145,34 & 50 & 243,36 & 60 & 79,01 & 70 & 54,8 \\
\hline 30 & 73 & 49,78 & 55 & 112,36 & 72 & 9,68 & 58 & 21,2 \\
\hline 31 & 80 & 197,56 & 57 & 73,96 & 85 & 259,57 & 76 & 179,6 \\
\hline 32 & 68 & 4,23 & 57 & 73,96 & 68 & 0,79 & 62 & 0,4 \\
\hline 33 & 73 & 49,78 & 75 & 88,36 & 71 & 4,46 & 68 & 29,2 \\
\hline 34 & 69 & 9,34 & 50 & 243,36 & 80 & 123,46 & 76 & 179,6 \\
\hline 35 & 64 & 3,78 & 71 & 29,16 & 61 & 62,23 & 64 & 2,0 \\
\hline 36 & 50 & 254,23 & & & 63 & 34,68 & & \\
\hline Jumlah & 2374 & 4237,889 & 2296 & 4512,400 & 2480 & 3613,556 & 2191 & 2704,400 \\
\hline Nilai tertinggi & 91 & & 90 & & 91 & & 80 & \\
\hline Nilai terendah & 50 & & 50 & & 50 & & 42 & \\
\hline Rata - rata & 65,944 & & 65,600 & & 68,889 & & 62,600 & \\
\hline Rentang & 41 & & 40 & & 41 & & 38 & \\
\hline Banyak kelas & 6,136 & & 6,095 & & 6,136 & & 6,095 & \\
\hline Panjang kelas & 6,682 & & 6,562 & & 6,682 & & 6,234 & \\
\hline SD & 11,004 & & 11,520 & & 10,161 & & 8,919 & \\
\hline
\end{tabular}


Kelas XI MIPA 5 - XI MIPA 7:

\begin{tabular}{|c|c|c|c|c|c|c|}
\hline \multirow{2}{*}{ No. Absen } & \multicolumn{2}{|c|}{ XI MIPA 5} & \multicolumn{2}{|c|}{ XI MIPA 6} & \multicolumn{2}{|c|}{ XI MIPA 7} \\
\hline & $\overline{\bar{x}}$ Nilai & $(x-\bar{x})^{2}$ & Nilai & $(x-\bar{x})^{2}$ & Nilai & $(x-\bar{x})^{2}$ \\
\hline 1 & 60 & 3,68 & 60 & 0,01 & 72 & 57,0864 \\
\hline 2 & 46 & 145,95 & 52 & 62,13 & 60 & 19,7531 \\
\hline 3 & 60 & 3,68 & 56 & 15,07 & 62 & 5,97531 \\
\hline 4 & 68 & 98,38 & 52 & 62,13 & 62 & 5,97531 \\
\hline 5 & 54 & 16,66 & 56 & 15,07 & 56 & 71,3086 \\
\hline 6 & 60 & 3,68 & 52 & 62,13 & 68 & 12,642 \\
\hline 7 & 56 & 4,33 & 70 & 102,37 & 78 & 183,753 \\
\hline 8 & 46 & 145,95 & 76 & 259,78 & 62 & 5,97531 \\
\hline 9 & 60 & 3,68 & 64 & 16,96 & 60 & 19,7531 \\
\hline 10 & 46 & 145,95 & 50 & 97,66 & 64 & 0,19753 \\
\hline 11 & 68 & 98,38 & 52 & 62,13 & 62 & 5,97531 \\
\hline 12 & 52 & 36,98 & 62 & 4,48 & 70 & 30,8642 \\
\hline 13 & 64 & 35,03 & 60 & 0,01 & 76 & 133,531 \\
\hline 14 & 64 & 35,03 & 64 & 16,96 & 58 & 41,5309 \\
\hline 15 & 56 & 4,33 & 58 & 3,54 & 60 & 19,7531 \\
\hline 16 & 56 & 4,33 & 46 & 192,72 & 68 & 12,642 \\
\hline 17 & 40 & 326,93 & 46 & 192,72 & 60 & 19,7531 \\
\hline 18 & 79 & 437,60 & 76 & 259,78 & 76 & 133,531 \\
\hline 19 & 54 & 16,66 & 64 & 16,96 & 57 & 55,4198 \\
\hline 20 & 56 & 4,33 & 70 & 102,37 & 57 & 55,4198 \\
\hline 21 & 50 & 65,30 & 54 & 34,60 & 48 & 270,42 \\
\hline 22 & 58 & 0,01 & 64 & 16,96 & 70 & 30,8642 \\
\hline 23 & 68 & 98,38 & 54 & 34,60 & 62 & 5,97531 \\
\hline 24 & 82 & 572,11 & 66 & 37,43 & 62 & 5,97531 \\
\hline 25 & 50 & 65,30 & 68 & 65,90 & 62 & 5,97531 \\
\hline 26 & 58 & 0,01 & 56 & 15,07 & 74 & 91,3086 \\
\hline 27 & 60 & 3,68 & 64 & 16,96 & 70 & 30,8642 \\
\hline 28 & 72 & 193,74 & 52 & 62,13 & 58 & 41,5309 \\
\hline 29 & 60 & 3,68 & 56 & 15,07 & 68 & 12,642 \\
\hline 30 & 60 & 3,68 & 64 & 16,96 & 66 & 2,41975 \\
\hline 31 & 64 & 35,03 & 58 & 3,54 & 72 & 57,0864 \\
\hline 32 & 62 & 15,36 & 62 & 4,48 & 68 & 12,642 \\
\hline 33 & 54 & 16,66 & 74 & 199,31 & 64 & 0,19753 \\
\hline 34 & 48 & 101,63 & 58 & 3,54 & 74 & 91,3086 \\
\hline 35 & 64 & 35,03 & & & 62 & 5,97531 \\
\hline 36 & 54 & 16,66 & & & 52 & 154,864 \\
\hline 37 & 40 & 326,93 & & & & \\
\hline Jumlah & 2149 & 3124,757 & 2036 & 2071,529 & 2320 & 1710,89 \\
\hline Nilai tertinggi & 82 & & 76 & & 78 & \\
\hline Nilai terendah & 40 & & 46 & & 48 & \\
\hline Rata - rata & 58,081 & & 59,882 & & 64,444 & \\
\hline Rentang & 42 & & 30 & & 30 & \\
\hline Banyak kelas & 6,175 & & 6,054 & & 6,136 & \\
\hline Panjang kelas & 6,802 & & 4,955 & & 4,889 & \\
\hline SD & 9,317 & & 7,923 & & 6,992 & \\
\hline
\end{tabular}




\section{Uji Normalitas XI MIPA 1}

\section{Hipotesis:}

$\mathrm{H}_{0}$ : Data berdistribusi normal

$\mathrm{H}_{a}$ : Data tidak berdistribusi normal

\section{Pengujian Hipotesis:}

$X^{2} h=\sum \frac{\left(f_{o}-f_{h}\right)^{2}}{f_{h}}$

\section{Kriteria yang digunakan:}

$\mathrm{H}_{0}$ diterima jika $X^{2}{ }_{\text {hitung }}<X^{2}$ tabel

\section{Pengujian normalitas data:}

\begin{tabular}{|c|c|c|c|c|c|c|c|}
\hline Interval & Batas kelas & $\mathbf{Z}$ & Luas Z & Luas Tiap Kelas & fh & fo & Chi \\
\hline & 49,5 & $-1,49$ & 0,4319 & & & & \\
\hline $50-56$ & & & & 0,1268 & 4,5648 & 9 & 4,309 \\
\hline & 56,5 & $-0,86$ & 0,3051 & & & & \\
\hline $57-63$ & & & & 0,218 & 7,848 & 5 & 1,034 \\
\hline & 63,5 & $-0,22$ & 0,0871 & & & & \\
\hline $64-70$ & & & & 0,2462 & 8,8632 & 10 & 0,146 \\
\hline & 70,5 & 0,41 & 0,1591 & & & & \\
\hline $71-77$ & & & & 0,8076 & 29,0736 & 6 & 18,312 \\
\hline & 77,5 & 1,05 & 0,3531 & & & & \\
\hline $78-84$ & & & $-0,1014$ & $-3,6504$ & 5 & $-20,499$ \\
\hline & 84,5 & 1,69 & 0,4545 & & & & \\
\hline $85-91$ & & & $-0,0353$ & $-1,2708$ & 1 & $-4,058$ \\
\hline & 91,5 & 2,32 & 0,4898 & & & 36 & $-0,756$ \\
\hline \multicolumn{7}{|c|}{ Jumlah } \\
\hline \multicolumn{7}{|c|}{ Standarata Deviasi } \\
\hline \multicolumn{7}{|c|}{ Interpretasi } \\
\hline
\end{tabular}

Berdasarkan perhitungan dihasilkan $X^{2}{ }_{\text {hitung }}=-0,756$. Selanjutnya $X^{2}$ hitung tersebut dibandingkan dengan $X^{2}$ tabel dengan $\mathrm{dk}=5$ dan taraf signifikansi $5 \%$, sehingga ditetapkan $X^{2}$ tabel $=11,071$. Karena $X^{2}$ hitung $<X^{2}$ tabel, maka $\mathrm{H}_{0}$ diterima, sehingga kelas kontrol dinyatakan berdistribusi normal. 


\section{Uji Normalitas XI MIPA 2}

\section{Hipotesis:}

$\mathrm{H}_{0}$ : Data berdistribusi normal

$\mathrm{H}_{a}$ : Data tidak berdistribusi normal

\section{Pengujian Hipotesis:}

$X^{2} h=\sum \frac{\left(f_{o}-f_{h}\right)^{2}}{f_{h}}$

\section{Kriteria yang digunakan:}

$\mathrm{H}_{0}$ diterima jika $X^{2}{ }_{\text {hitung }}<X^{2}$ tabel

\section{Pengujian normalitas data:}

\begin{tabular}{|c|c|c|c|c|c|c|c|}
\hline Interval & Batas kelas & $\mathbf{Z}$ & Luas Z & Luas Tiap Kelas & fh & fo & Chi \\
\hline & 49,5 & $-1,40$ & 0,4192 & & & & \\
\hline \multirow[t]{2}{*}{$50-56$} & & & & 0,1340 & 4,69 & 10 & 6,012 \\
\hline & 56,5 & $-0,79$ & 0,2852 & & & & \\
\hline \multirow[t]{2}{*}{$57-63$} & & & & 0,2138 & 7,483 & 6 & 0,294 \\
\hline & 63,5 & $-0,18$ & 0,0714 & & & & \\
\hline \multirow[t]{2}{*}{$64-70$} & & & & 0,2378 & 8,323 & 6 & 0,648 \\
\hline & 70,5 & 0,43 & 0,1664 & & & & \\
\hline \multirow[t]{2}{*}{$71-77$} & & & & 0,5149 & 18,0215 & 9 & 4,516 \\
\hline & 77,5 & 1,03 & 0,3485 & & & & \\
\hline \multirow[t]{2}{*}{$78-84$} & & & & $-0,1010$ & $-3,535$ & 2 & $-8,667$ \\
\hline & 84,5 & 1,64 & 0,4495 & & & & \\
\hline \multirow[t]{2}{*}{$85-91$} & & & & $-0,0383$ & $-1,3405$ & 2 & $-8,324$ \\
\hline & 91,5 & 2,25 & 0,4878 & & & & \\
\hline \multicolumn{6}{|c|}{ Jumlah } & 35 & $-5,521$ \\
\hline \multicolumn{6}{|c|}{ Rata-rata } & \multicolumn{2}{|c|}{65,600} \\
\hline \multicolumn{6}{|c|}{ Standar Deviasi } & \multicolumn{2}{|c|}{11,520} \\
\hline \multicolumn{6}{|c|}{ Varians } & \multicolumn{2}{|c|}{132,718} \\
\hline \multicolumn{6}{|c|}{ Chi kuadrat tabel } & \multicolumn{2}{|c|}{11,071} \\
\hline \multicolumn{6}{|c|}{ Interpretasi } & \multicolumn{2}{|c|}{ normal } \\
\hline
\end{tabular}

Berdasarkan perhitungan dihasilkan $X^{2}{ }_{\text {hitung }}=-5,521$. Selanjutnya $X^{2}$ hitung tersebut dibandingkan dengan $X_{\text {tabel }}$ dengan $\mathrm{dk}=5$ dan taraf signifikansi $5 \%$, sehingga ditetapkan $X^{2}$ tabel $=11,071$. Karena $X^{2}$ hitung $<X^{2}$ tabel, maka $H_{0}$ diterima, sehingga kelas kontrol dinyatakan berdistribusi normal. 


\section{Uji Normalitas XI MIPA 3}

\section{Hipotesis:}

$\mathrm{H}_{0}$ : Data berdistribusi normal

$\mathrm{H}_{a}$ : Data tidak berdistribusi normal

\section{Pengujian Hipotesis:}

$X^{2} h=\sum \frac{\left(f_{o}-f_{h}\right)^{2}}{f_{h}}$

\section{Kriteria yang digunakan:}

$\mathrm{H}_{0}$ diterima jika $X^{2}{ }_{\text {hitung }}<X^{2}$ tabel

\section{Pengujian normalitas data:}

\begin{tabular}{|c|c|c|c|c|c|c|c|}
\hline Interval & Batas kelas & $\mathbf{Z}$ & Luas Z & Luas Tiap Kelas & fh & fo & Chi \\
\hline & 49,5 & $-1,91$ & 0,4719 & & & & \\
\hline $50-56$ & & & & 0,0831 & 2,9916 & 6 & 3,025 \\
\hline & 56,5 & $-1,22$ & 0,3888 & & & & \\
\hline $57-63$ & & & & 0,1869 & 6,7284 & 7 & 0,011 \\
\hline & 63,5 & $-0,53$ & 0,2019 & & & & \\
\hline $64-70$ & & & & 0,2655 & 9,558 & 7 & 0,685 \\
\hline & 70,5 & 0,16 & 0,0636 & & & & \\
\hline $71-77$ & & & & 0,3659 & 13,1724 & 8 & 2,031 \\
\hline & 77,5 & 0,85 & 0,3023 & & & & \\
\hline $78-84$ & & & $-0,1359$ & $-4,8924$ & 5 & $-20,002$ \\
\hline & 84,5 & 1,54 & 0,4382 & & & & \\
\hline $85-91$ & & & $-0,0489$ & $-1,7604$ & 3 & $-12,873$ \\
\hline & 91,5 & 2,23 & 0,4871 & & & & \\
\hline \multicolumn{7}{|c|}{ Jumlah } \\
\hline \multicolumn{7}{|c|}{ Chata-rata } \\
\hline \multicolumn{7}{|c|}{ Interpretans } \\
\hline
\end{tabular}

Berdasarkan perhitungan dihasilkan $X^{2}$ hitung $=-27,123$. Selanjutnya $X^{2}$ hitung tersebut dibandingkan dengan $X^{2}$ tabel dengan $\mathrm{dk}=5$ dan taraf signifikansi $5 \%$, sehingga ditetapkan $X_{\text {tabel }}=11,071$. Karena $X^{2}{ }_{\text {hitung }}<X^{2}$ tabel, maka $\mathrm{H}_{0}$ diterima, sehingga kelas kontrol dinyatakan berdistribusi normal. 


\section{Uji Normalitas XI MIPA 4}

\section{Hipotesis:}

$\mathrm{H}_{0}$ : Data berdistribusi normal

$\mathrm{H}_{a}$ : Data tidak berdistribusi normal

\section{Pengujian Hipotesis:}

$X^{2} h=\sum \frac{\left(f_{o}-f_{h}\right)^{2}}{f_{h}}$

\section{Kriteria yang digunakan:}

$\mathrm{H}_{0}$ diterima jika $X^{2}{ }_{\text {hitung }}<X^{2}$ tabel

\section{Pengujian normalitas data:}

\begin{tabular}{|c|c|c|c|c|c|c|c|}
\hline Interval & Batas kelas & $\mathbf{Z}$ & Luas Z & Luas Tiap Kelas & fh & fo & Chi \\
\hline & 41,5 & $-2,37$ & 0,4911 & & & & \\
\hline $42-47$ & & & & 0,0366 & 1,281 & 2 & 0,404 \\
\hline & 47,5 & $-1,69$ & 0,4545 & & & & \\
\hline $48-53$ & & & & 0,1084 & 3,794 & 2 & 0,848 \\
\hline & 53,5 & $-1,02$ & 0,3461 & & & & \\
\hline $54-59$ & & & & 0,2093 & 7,3255 & 8 & 0,062 \\
\hline & 59,5 & $-0,35$ & 0,1368 & & & & \\
\hline $60-65$ & & & & 0,2661 & 9,3135 & 9 & 0,011 \\
\hline & 65,5 & 0,33 & 0,1293 & & & & \\
\hline $66-71$ & & & & $-0,2120$ & $-7,42$ & 8 & $-32,045$ \\
\hline & 71,5 & 1,00 & 0,3413 & & & & \\
\hline $72-77$ & & & & $-0,1112$ & $-3,892$ & 5 & $-20,315$ \\
\hline & 77,5 & 1,67 & 0,4525 & & & & \\
\hline $78-83$ & & & & $\begin{array}{l}-0,0379 \\
\end{array}$ & $-1,3265$ & 1 & $-4,080$ \\
\hline & 83,5 & 2,34 & 0,4904 & & & & \\
\hline \multicolumn{6}{|c|}{ Jumlah } & 35 & $-51,036$ \\
\hline \multicolumn{6}{|c|}{ Rata-rata } & \multicolumn{2}{|c|}{62,600} \\
\hline \multicolumn{6}{|c|}{ Standar Deviasi } & \multicolumn{2}{|c|}{8,919} \\
\hline \multicolumn{6}{|c|}{ Varians } & \multicolumn{2}{|c|}{79,541} \\
\hline \multicolumn{6}{|c|}{ Chi kuadrat tabel } & \multicolumn{2}{|c|}{12,592} \\
\hline \multicolumn{6}{|c|}{ Interpretasi } & \multicolumn{2}{|c|}{ normal } \\
\hline
\end{tabular}

Berdasarkan perhitungan dihasilkan $X^{2}{ }_{\text {hitung }}=-51,036$. Selanjutnya $X^{2}$ hitung tersebut dibandingkan dengan $X^{2}$ tabel dengan $\mathrm{dk}=6$ dan taraf signifikansi 5\%, sehingga ditetapkan $X^{2}$ tabel $=12,592$. Karena $X^{2}{ }_{\text {hitung }}<X^{2}$ tabel, maka $H_{0}$ diterima, sehingga kelas kontrol dinyatakan berdistribusi normal. 


\section{Uji Normalitas XI MIPA 5}

\section{Hipotesis:}

$\mathrm{H}_{0}$ : Data berdistribusi normal

$\mathrm{H}_{a}$ : Data tidak berdistribusi normal

\section{Pengujian Hipotesis:}

$X^{2} h=\sum \frac{\left(f_{o}-f_{h}\right)^{2}}{f_{h}}$

\section{Kriteria yang digunakan:}

$\mathrm{H}_{0}$ diterima jika $X^{2}{ }_{\text {hitung }}<X^{2}$ tabel

\section{Pengujian normalitas data:}

\begin{tabular}{|c|c|c|c|c|c|c|c|}
\hline Interval & Batas kelas & $\mathbf{Z}$ & Luas Z & Luas Tiap Kelas & fh & fo & Chi \\
\hline & 39,5 & $-1,99$ & 0,4767 & & & & \\
\hline $40-46$ & & & & 0,0842 & 3,1154 & 5 & 1,140 \\
\hline & 46,5 & $-1,24$ & 0,3925 & & & & \\
\hline $47-53$ & & & & 0,2046 & 7,5702 & 4 & 1,684 \\
\hline & 53,5 & $-0,49$ & 0,1879 & & & & \\
\hline $54-60$ & & & & 0,2905 & 10,7485 & 17 & 3,636 \\
\hline & 60,5 & 0,26 & 0,1026 & & & & \\
\hline $61-67$ & & & & 0,4464 & 16,5168 & 5 & 8,030 \\
\hline & 67,5 & 1,01 & 0,3438 & & & & \\
\hline $68-74$ & & & $-0,117$ & $-4,329$ & 4 & $-16,025$ \\
\hline & 74,5 & 1,76 & 0,4608 & & & & \\
\hline $75-81$ & & & $-0,0332$ & $-1,2284$ & 2 & $-8,485$ \\
\hline & 81,5 & 2,51 & 0,4940 & & & 37 & $-10,019$ \\
\hline \multicolumn{7}{|c|}{ Jumlah } \\
\hline \multicolumn{7}{|c|}{ Standarata Deviasi } \\
\hline \multicolumn{7}{|c|}{ Interpretasi } \\
\hline
\end{tabular}

Berdasarkan perhitungan dihasilkan $X^{2}$ hitung $=-10,019$. Selanjutnya $X^{2}$ hitung tersebut dibandingkan dengan $X^{2}$ tabel dengan $\mathrm{dk}=5$ dan taraf signifikansi $5 \%$, sehingga ditetapkan $X^{2}$ tabel $=11,071$. Karena $X^{2}{ }_{\text {hitung }}<X^{2}$ tabel, maka $\mathrm{H}_{0}$ diterima, sehingga kelas kontrol dinyatakan berdistribusi normal. 


\section{Uji Normalitas XI MIPA 6}

\section{Hipotesis:}

$\mathrm{H}_{0}$ : Data berdistribusi normal

$\mathrm{H}_{a}$ : Data tidak berdistribusi normal

\section{Pengujian Hipotesis:}

$X^{2} h=\sum \frac{\left(f_{o}-f_{h}\right)^{2}}{f_{h}}$

\section{Kriteria yang digunakan:}

$\mathrm{H}_{0}$ diterima jika $X^{2}{ }_{\text {hitung }}<X^{2}$ tabel

\section{Pengujian normalitas data:}

\begin{tabular}{|c|c|c|c|c|c|c|c|}
\hline Interval & Batas kelas & $\mathbf{Z}$ & Luas Z & Luas Tiap Kelas & fh & fo & Chi \\
\hline & 45,5 & $-1,82$ & 0,4656 & & & & \\
\hline $46-50$ & & & & 0,0846 & 2,8764 & 3 & 0,005 \\
\hline & 50,5 & $-1,18$ & 0,3810 & & & & \\
\hline $51-55$ & & & & 0,1722 & 5,8548 & 7 & 0,224 \\
\hline & 55,5 & $-0,55$ & 0,2088 & & & & \\
\hline $56-60$ & & & & 0,1769 & 6,0146 & 9 & 1,482 \\
\hline & 60,5 & 0,08 & 0,0319 & & & & \\
\hline $61-65$ & & & & 0,2407 & 8,1838 & 8 & 0,004 \\
\hline & 65,5 & 0,71 & 0,2611 & & & & \\
\hline $66-70$ & & & $-0,1488$ & $-5,0592$ & 4 & $-16,222$ \\
\hline & 70,5 & 1,34 & 0,4099 & & & & \\
\hline $71-75$ & & & $-0,0657$ & $-2,2338$ & 1 & $-4,681$ \\
\hline & 75,5 & 1,97 & 0,4756 & & & & \\
\hline $76-80$ & \multicolumn{7}{|c|}{ Jumlah } \\
\hline \multicolumn{7}{|c|}{ Chata-rata } \\
\hline \multicolumn{7}{|c|}{ Interpretasi } \\
\hline
\end{tabular}

Berdasarkan perhitungan dihasilkan $X^{2}{ }_{\text {hitung }}=-19,188$. Selanjutnya $X^{2}$ hitung tersebut dibandingkan dengan $X^{2}$ tabel dengan $\mathrm{dk}=6$ dan taraf signifikansi $5 \%$, sehingga ditetapkan $X^{2}$ tabel $=12,592$. Karena $X^{2}{ }_{\text {hitung }}<X^{2}$ tabel, maka $\mathrm{H}_{0}$ diterima, sehingga kelas kontrol dinyatakan berdistribusi normal. 


\section{Uji Normalitas XI MIPA 7}

\section{Hipotesis:}

$\mathrm{H}_{0}$ : Data berdistribusi normal

$\mathrm{H}_{a}$ : Data tidak berdistribusi normal

\section{Pengujian Hipotesis:}

$X^{2} h=\sum \frac{\left(f_{o}-f_{h}\right)^{2}}{f_{h}}$

\section{Kriteria yang digunakan:}

$\mathrm{H}_{0}$ diterima jika $X^{2}{ }_{\text {hitung }}<X^{2}$ tabel

\section{Pengujian normalitas data:}

\begin{tabular}{|c|c|c|c|c|c|c|c|}
\hline Interval & Batas kelas & $\mathbf{Z}$ & Luas Z & Luas Tiap Kelas & fh & fo & Chi \\
\hline & 48,5 & $-2,28$ & 0,4896 & & & & \\
\hline $48-52$ & & & & 0,0314 & 1,1304 & 2 & 0,669 \\
\hline & 52,5 & $-1,71$ & 0,4582 & & & & \\
\hline $53-57$ & & & & 0,1144 & 4,1184 & 3 & 0,304 \\
\hline & 57,5 & $-0,99$ & 0,3438 & & & & \\
\hline $58-62$ & & & & 0,2297 & 8,2692 & 14 & 3,972 \\
\hline & 62,5 & $-0,28$ & 0,1141 & & & & \\
\hline $63-67$ & & & & 0,2805 & 10,098 & 3 & 4,989 \\
\hline & 67,5 & 0,44 & 0,1664 & & & & \\
\hline $68-72$ & & & & $-0,2085$ & $-7,506$ & 9 & $-36,297$ \\
\hline & 72,5 & 1,15 & 0,3749 & & & & \\
\hline $73-77$ & & & $-0,0944$ & $-3,3984$ & 4 & $-16,106$ \\
\hline & 77,5 & 1,87 & 0,4693 & & & & \\
\hline $78-82$ & 87 & $-0,026$ & $-0,936$ & 1 & $-4,004$ \\
\hline \multicolumn{7}{|c|}{ Jumlah } \\
\hline \multicolumn{7}{|c|}{ Chata-rata } \\
\hline \multicolumn{7}{|c|}{ Interpretasi } \\
\hline
\end{tabular}

Berdasarkan perhitungan dihasilkan $X^{2}$ hitung $=-46,475$. Selanjutnya $X^{2}$ hitung tersebut dibandingkan dengan $X^{2}$ tabel dengan $\mathrm{dk}=6$ dan taraf signifikansi $5 \%$, sehingga ditetapkan $X^{2}$ tabel $=12,592$. Karena $X^{2}$ hitung $<X^{2}$ tabel, maka $\mathrm{H}_{0}$ diterima, sehingga kelas kontrol dinyatakan berdistribusi normal. 


\section{Uji Homogenitas Populasi}

\section{Hipotesis:}

$\mathrm{H}_{0}: \sigma_{1}^{2}=\sigma_{2}^{2}=\sigma_{3}^{2}=\sigma_{4}^{2}=\sigma_{5}^{2}=\sigma_{6}^{2}=\sigma_{7}^{2}$

$\mathrm{H}_{a}: \sigma_{1}^{2} \neq \sigma_{2}^{2} \neq \sigma_{3}^{2} \neq \sigma_{4}^{2} \neq \sigma_{5}^{2} \neq \sigma_{6}^{2} \neq \sigma_{7}^{2}$

\section{Pengujian Hipotesis:}

$X^{2}=(\ln 10)\left\{B-\sum(n-1) \log s_{i}^{2}\right\}$

$\mathrm{H}_{0}$ diterima apabila $X^{2}$ hitung $\leq X^{2}$ tabel

\section{Dari data diperoleh:}

\begin{tabular}{|c|c|c|c|c|c|}
\hline Sampel ke- & dk & $1 / \mathrm{dk}$ & $\mathbf{s i}^{2}$ & $\log \mathrm{si}^{2}$ & $d k \log \left(s i^{2}\right)$ \\
\hline 1 & 35 & 0,029 & 121,083 & 2,083 & \begin{tabular}{|l|}
72,908 \\
\end{tabular} \\
\hline 2 & 34 & 0,029 & 132,718 & 2,123 & 72,180 \\
\hline 3 & 35 & 0,029 & 103,244 & 2,014 & 70,485 \\
\hline 4 & 34 & 0,029 & 79,541 & 1,901 & 64,620 \\
\hline 5 & 36 & 0,028 & 86,799 & 1,939 & 69,786 \\
\hline 6 & 33 & 0,030 & 62,774 & 1,798 & 59,327 \\
\hline 7 & 35 & 0,029 & 48,883 & 1,689 & 59,120 \\
\hline Jumlah & 242 & 0,203 & & & 468,426 \\
\hline $\mathrm{s}^{2}$ & \multicolumn{5}{|c|}{90,808} \\
\hline $\log s^{2}$ & \multicolumn{5}{|c|}{1,958} \\
\hline
\end{tabular}

$\mathrm{B}=\left(\log s^{2}\right) \sum\left(n_{i}-1\right)$

$\mathrm{B}=(1,958)(242-1)$

$\mathrm{B}=471,907$

$X^{2}=(\ln 10)\left\{B-\sum(n-1) \log s_{i}^{2}\right\}$

$X^{2}=(2,3026)(471,907-468,426)$

$X^{2}=8,015$

Taraf signifikan 5\% dengan $\mathrm{dk}=6$ dihasilkan $X_{\text {tabel }}^{2}=12,592$

Karena $X^{2}$ hitung $\leq X^{2}$ tabel, maka $\mathrm{H}_{0}$ diterima dan dapat disimpulkan bahwa populasi homogen. 
Lampiran 23. Daftar Responden Kelas Kontrol dan Kelas Eksperimen

Kelas Kontrol:

\begin{tabular}{|c|l|c|c|}
\hline No. & \multicolumn{1}{|c|}{ Nama } & Kelas & Kode \\
\hline 1 & Aden Marindha Maliana Suprapti & XI MIPA 6 & K-01 \\
\hline 2 & Adrio Luthfi Alghiffari & XI MIPA 6 & K-02 \\
\hline 3 & Ahuramazda Pribadi Suryadilaga B. & XI MIPA 6 & K-03 \\
\hline 4 & Alvita sa si Kirana Syahrani & XI MIPA 6 & K-04 \\
\hline 5 & Angel Eliezer Wijaya & XI MIPA 6 & K-05 \\
\hline 6 & Angelia Yuliza Anggraeny & XI MIPA 6 & K-06 \\
\hline 7 & Apsari Widyadhana & XI MIPA 6 & K-07 \\
\hline 8 & Arindra Dewi Indyastari & XI MIPA 6 & K-08 \\
\hline 9 & Chinue Abyatina Audrey & XI MIPA 6 & K-09 \\
\hline 10 & Della Fadhilah & XI MIPA 6 & K-10 \\
\hline 11 & Dewi Ajeng Hapsari & XI MIPA 6 & K-11 \\
\hline 12 & Dina Agustina Kusumawati & XI MIPA 6 & K-12 \\
\hline 13 & Farida Alvita sari & XI MIPA 6 & K-13 \\
\hline 14 & Ghani Ayang Arjuna & XI MIPA 6 & K-14 \\
\hline 15 & Haedar Said Hanan & XI MIPA 6 & K-15 \\
\hline 16 & Hafidz Rachmad Iqbal & XI MIPA 6 & K-16 \\
\hline 17 & Hana'Lailaturrofi'ah & XI MIPA 6 & K-17 \\
\hline 18 & Herlisa Kartika Jati & XI MIPA 6 & K-18 \\
\hline 19 & Holly Anugerah Patricia Silaen & XI MIPA 6 & K-19 \\
\hline 20 & Imanuel Satrio Kusumo & XI MIPA 6 & K-20 \\
\hline 21 & Inas Shabiya Yumna & XI MIPA 6 & K-21 \\
\hline 22 & Indri Pratiwi & XI MIPA 6 & K-26 \\
\hline 23 & Ivan Widya Kanaka 6 & K-22 \\
\hline 24 & Nisrina Almaida & K-24 \\
\hline 25 & Nur Ashifa & XIPA 6 & K-27 \\
\hline 26 & Pandu Danang Dewantoro & \\
\hline 27 & Perdana Rakasiwi Wibowo & KIPA \\
\hline & & & \\
\hline 19 & & & \\
\hline
\end{tabular}




\begin{tabular}{|c|l|c|c|}
\hline No. & \multicolumn{1}{|c|}{ Nama } & Kelas & Kode \\
\hline 28 & Preditha Kinanti Dewi & XI MIPA 6 & K-28 \\
\hline 29 & Rajendra Azka Yodhaputra & XI MIPA 6 & K-29 \\
\hline 30 & Rama Sandy Putra Andhika & XI MIPA 6 & K-30 \\
\hline 31 & Restianta Dwi Syahputra & XI MIPA 6 & K-31 \\
\hline 32 & Talitha Salvia Adhwa Kurniawan & XI MIPA 6 & K-32 \\
\hline 33 & Taufik Harisman & XI MIPA 6 & K-33 \\
\hline 34 & Toddi Aliffandi & XI MIPA 6 & K-34 \\
\hline
\end{tabular}

Kelas Eksperimen:

\begin{tabular}{|c|l|c|c|}
\hline No. & \multicolumn{1}{|c|}{ Nama } & Kelas & Kode \\
\hline 1 & Adelia Chandra Saffira & XI MIPA 7 & E-01 \\
\hline 2 & Alya Faza Ashari & XI MIPA 7 & E-02 \\
\hline 3 & Amela Dian Ananda & XI MIPA 7 & E-03 \\
\hline 4 & Anindita Ariiba Maitsa & XI MIPA 7 & E-04 \\
\hline 5 & Anissa Aurelia Prasetyo & XI MIPA 7 & E-05 \\
\hline 6 & Aristawidya Khairun Nisa & XI MIPA 7 & E-06 \\
\hline 7 & Aufa Syaihan Azzahidi & XI MIPA 7 & E-07 \\
\hline 8 & Avicenna Ardiansa Yasthafa Yuan & XI MIPA 7 & E-08 \\
\hline 9 & Berliana Martinjung & XI MIPA 7 & E-09 \\
\hline 10 & Danendra Fadilasifa Mahardika & XI MIPA 7 & E-10 \\
\hline 11 & Dita Ayu Rahmawati & XI MIPA 7 & E-11 \\
\hline 12 & Egidea Nada Afifa & XI MIPA 7 & E-12 \\
\hline 13 & Emilia Van Den & XI MIPA 7 & E-13 \\
\hline 14 & Firlana Aghnia Qurrata A'yun & XI MIPA 7 & E-14 \\
\hline 15 & Hanan Luthfan Hafizh & XI MIPA 7 & E-15 \\
\hline 16 & Humaira Adiba Imtinanmumtaz & XI MIPA 7 & E-16 \\
\hline 17 & Irsyad Sukma Bagaskara & XI MIPA 7 & E-17 \\
\hline 18 & Krisna Prabowo & XI MIPA 7 & E-18 \\
\hline 19 & Maheswari Ainun Zhafar & XI MIPA 7 & E-19 \\
\hline 20 & Mahita Candra Sari & XI MIPA 7 & E-20 \\
\hline 21 & Mas'ud Hadad Royhan & II MIPA 7 & E-21 \\
\hline
\end{tabular}




\begin{tabular}{|c|l|c|c|}
\hline No. & \multicolumn{1}{|c|}{ Nama } & Kelas & Kode \\
\hline 22 & Maulana Arya Yoga Juliansyah & XI MIPA 7 & E-22 \\
\hline 23 & Mirza Dzaki Kamal & XI MIPA 7 & E-23 \\
\hline 24 & Muhammad Alvino Firmanda & XI MIPA 7 & E-24 \\
\hline 25 & Muhammad Asdar Widyananda & XI MIPA 7 & E-25 \\
\hline 26 & Muhammad Raihan Tsani & XI MIPA 7 & E-26 \\
\hline 27 & Muhammad Rizky Mahendra P. & XI MIPA 7 & E-27 \\
\hline 28 & Muhammad Zulfikar & XI MIPA 7 & E-28 \\
\hline 29 & Nandini Kamahayanikan & XI MIPA 7 & E-29 \\
\hline 30 & Oxana Amalia Azzahra & XI MIPA 7 & E-30 \\
\hline 31 & Raihan Alwan Arisyi & XI MIPA 7 & E-31 \\
\hline 32 & Rani Wilastra & XI MIPA 7 & E-32 \\
\hline 33 & Salsabila Rohadatul Aisy & XI MIPA 7 & E-33 \\
\hline 34 & Sekar Ayu Putri Santosa & XI MIPA 7 & E-34 \\
\hline 35 & Vio Gian Wasistha & E-35 \\
\hline 36 & Zahra Zevira Andini & XI MIPA 7 & E-36 \\
\hline
\end{tabular}


Lampiran 24. Uji Tahap Awal Penguasaan Konsep

\section{Data Hasil Pretest Penguasaan Konsep}

\begin{tabular}{|c|c|c|c|}
\hline No. & Kode Responden & Nilai & $(x-\bar{x})^{2}$ \\
\hline 1 & K-01 & 30 & 4,74 \\
\hline 2 & $\mathrm{~K}-02$ & 33 & 26,80 \\
\hline 3 & $\mathrm{~K}-03$ & 25 & 7,97 \\
\hline 4 & K-04 & 39 & 124,91 \\
\hline 5 & K-05 & 11 & 283,03 \\
\hline 6 & K-06 & 18 & 96,50 \\
\hline 7 & K-07 & 36 & 66,85 \\
\hline 8 & K-08 & 41 & 173,62 \\
\hline 9 & K-09 & 39 & 124,91 \\
\hline 10 & $\mathrm{~K}-10$ & 30 & 4,74 \\
\hline 11 & K-11 & 10 & 317,68 \\
\hline 12 & $\mathrm{~K}-12$ & 41 & 173,62 \\
\hline 13 & $\mathrm{~K}-13$ & 30 & 4,74 \\
\hline 14 & $\mathrm{~K}-14$ & 31 & 10,09 \\
\hline 15 & $\mathrm{~K}-15$ & 28 & 0,03 \\
\hline 16 & $\mathrm{~K}-16$ & 25 & 7,97 \\
\hline 17 & $\mathrm{~K}-17$ & 0 & 774,15 \\
\hline 18 & $\mathrm{~K}-18$ & 36 & 66,85 \\
\hline 19 & $\mathrm{~K}-19$ & 36 & 66,85 \\
\hline 20 & $\mathrm{~K}-20$ & 23 & 23,27 \\
\hline 21 & $\mathrm{~K}-21$ & 30 & 4,74 \\
\hline 22 & $\mathrm{~K}-22$ & 30 & 4,74 \\
\hline 23 & $\mathrm{~K}-23$ & 25 & 7,97 \\
\hline 24 & $\mathrm{~K}-24$ & 41 & 173,62 \\
\hline 25 & $\mathrm{~K}-25$ & 30 & 4,74 \\
\hline 26 & $\mathrm{~K}-26$ & 28 & 0,03 \\
\hline 27 & $\mathrm{~K}-27$ & 20 & 61,21 \\
\hline 28 & $\mathrm{~K}-28$ & 30 & 4,74 \\
\hline 29 & $\mathrm{~K}-29$ & 34 & 38,15 \\
\hline 30 & $\mathrm{~K}-30$ & 30 & 4,74 \\
\hline 31 & $\mathrm{~K}-31$ & 13 & 219,74 \\
\hline 32 & $\mathrm{~K}-32$ & 30 & 4,74 \\
\hline 33 & $\mathrm{~K}-33$ & 18 & 96,50 \\
\hline 34 & $\mathrm{~K}-34$ & 25 & 7,97 \\
\hline & Jumlah & 946 & 2992,941 \\
\hline & Rata-rata & 27,824 & \\
\hline & Nilai tertinggi & 41 & \\
\hline & Nilai terendah & 0 & \\
\hline & Rentang & 41 & \\
\hline & Banyak kelas & 6,054 & \\
\hline & Panjang kelas & 6,773 & \\
\hline & Standar Deviasi & 9,523 & \\
\hline
\end{tabular}

\begin{tabular}{|c|c|c|c|}
\hline No. & Kode Responden & Nilai & $(x-\bar{x})^{2}$ \\
\hline 1 & E-01 & 10 & 48,61 \\
\hline 2 & E-02 & 28 & 121,61 \\
\hline 3 & E-03 & 8 & 80,50 \\
\hline 4 & E-04 & 25 & 64,45 \\
\hline 5 & E-05 & 25 & 64,45 \\
\hline 6 & E-06 & 0 & 288,06 \\
\hline 7 & E-07 & 28 & 121,61 \\
\hline 8 & E-08 & 23 & 36,33 \\
\hline 9 & E-09 & 28 & 121,61 \\
\hline 10 & E-10 & 25 & 64,45 \\
\hline 11 & E-11 & 18 & 1,06 \\
\hline 12 & E-12 & 13 & 15,78 \\
\hline 13 & E-13 & 16 & 0,95 \\
\hline 14 & E-14 & 13 & 15,78 \\
\hline 15 & E-15 & 13 & 15,78 \\
\hline 16 & E-16 & 30 & 169,72 \\
\hline 17 & E-17 & 20 & 9,17 \\
\hline 18 & E-18 & 14 & 8,83 \\
\hline 19 & E-19 & 0 & 288,06 \\
\hline 20 & E-20 & 28 & 121,61 \\
\hline 21 & E-21 & 0 & 288,06 \\
\hline 22 & E-22 & 18 & 1,06 \\
\hline 23 & E-23 & 25 & 64,45 \\
\hline 24 & E-24 & 18 & 1,06 \\
\hline 25 & E-25 & 28 & 121,61 \\
\hline 26 & E-26 & 18 & 1,06 \\
\hline 27 & E-27 & 0 & 288,06 \\
\hline 28 & E-28 & 18 & 1,06 \\
\hline 29 & E-29 & 15 & 3,89 \\
\hline 30 & E-30 & 0 & 288,06 \\
\hline 31 & E-31 & 15 & 3,89 \\
\hline 32 & E-32 & 19 & 4,11 \\
\hline 33 & E-33 & 21 & 16,22 \\
\hline 34 & E-34 & 28 & 121,61 \\
\hline 35 & E-35 & 18 & 1,06 \\
\hline 36 & E-36 & 5 & 143,33 \\
\hline \multicolumn{2}{|r|}{ Jumlah } & 611 & 3006,972 \\
\hline \multicolumn{2}{|r|}{ Rata-rata } & 16,972 & \\
\hline \multicolumn{2}{|r|}{ Nilai tertinggi } & 30 & \\
\hline \multicolumn{2}{|r|}{ Nilai terendah } & 0 & \\
\hline \multicolumn{2}{|r|}{ Rentang } & 30 & \\
\hline \multicolumn{2}{|r|}{ Banyak kelas } & 6,136 & \\
\hline \multicolumn{2}{|r|}{ Panjang kelas } & 4,889 & \\
\hline \multicolumn{2}{|r|}{ Standar Deviasi } & 9,269 & \\
\hline
\end{tabular}




\section{Uji Normalitas Pretest Penguasaan Konsep \\ Kelas Kontrol}

\section{Hipotesis:}

$\mathrm{H}_{0}$ : Data berdistribusi normal

$\mathrm{H}_{a}$ : Data tidak berdistribusi normal

\section{Pengujian Hipotesis:}

$X^{2} h=\sum \frac{\left(f_{o}-f_{h}\right)^{2}}{f_{h}}$

\section{Kriteria yang digunakan:}

$\mathrm{H}_{0}$ diterima jika $X^{2}{ }_{\text {hitung }}<X^{2}$ tabel

\section{Pengujian normalitas data:}

\begin{tabular}{|c|c|c|c|c|c|c|c|}
\hline Interval & Batas kelas & $\mathbf{Z}$ & Luas Z & Luas Tiap Kelas & fh & fo & Chi kuadrat \\
\hline & $-0,5$ & $-2,97$ & 0,4985 & & & & \\
\hline \multirow[t]{2}{*}{$0-6$} & & & & 0,011 & 0,374 & 1 & 1,048 \\
\hline & 6,5 & $-2,24$ & 0,4875 & & & & \\
\hline \multirow[t]{2}{*}{$7--13$} & & & & 0,0543 & 1,8462 & 3 & 0,721 \\
\hline & 13,5 & $-1,50$ & 0,4332 & & & & \\
\hline \multirow[t]{2}{*}{$14-20$} & & & & 0,7126 & 24,2284 & 3 & 18,600 \\
\hline & 20,5 & $-0,77$ & 0,2794 & & & & \\
\hline \multirow[t]{2}{*}{$21-27$} & & & & 0,2914 & 9,9076 & 5 & 2,431 \\
\hline & 27,5 & $-0,03$ & 0,0120 & & & & \\
\hline \multirow[t]{2}{*}{$28-34$} & & & & $-0,246$ & $-8,364$ & 14 & $-59,798$ \\
\hline & 34,5 & 0,70 & 0,258 & & & & \\
\hline \multirow[t]{2}{*}{$35-41$} & & & & $-0,1671$ & $-5,6814$ & 8 & $-32,946$ \\
\hline & 41,5 & 1,44 & 0,4251 & & & & \\
\hline \multicolumn{6}{|c|}{ Jumlah } & 34 & \begin{tabular}{|l|}
$-69,944$ \\
\end{tabular} \\
\hline \multicolumn{6}{|c|}{ Rata-rata } & \multicolumn{2}{|c|}{27,824} \\
\hline \multicolumn{6}{|c|}{ Standar Deviasi } & \multicolumn{2}{|c|}{9,523} \\
\hline \multicolumn{6}{|c|}{ Varians } & \multicolumn{2}{|c|}{90,695} \\
\hline \multicolumn{6}{|c|}{ Chi kuadrat tabel } & \multicolumn{2}{|c|}{11,071} \\
\hline \multicolumn{6}{|c|}{ Interpretasi } & \multicolumn{2}{|c|}{ normal } \\
\hline
\end{tabular}

Berdasarkan perhitungan dihasilkan $X^{2}$ hitung $=-69,944$. Selanjutnya $X^{2}$ hitung tersebut dibandingkan dengan $X^{2}$ tabel dengan $\mathrm{dk}=5$ dan taraf signifikansi $5 \%$, sehingga ditetapkan $X^{2}$ tabel $=11,071$. Karena $X^{2}$ hitung $<X^{2}$ tabel, maka $\mathrm{H}_{0}$ diterima, sehingga kelas kontrol dinyatakan berdistribusi normal. 


\section{Uji Normalitas Pretest Penguasaan Konsep \\ Kelas Eksperimen}

\section{Hipotesis:}

$\mathrm{H}_{0}$ : Data berdistribusi normal

$\mathrm{H}_{a}$ : Data tidak berdistribusi normal

\section{Pengujian Hipotesis:}

$X^{2} h=\sum \frac{\left(f_{o}-f_{h}\right)^{2}}{f_{h}}$

\section{Kriteria yang digunakan:}

$\mathrm{H}_{0}$ diterima jika $X^{2}{ }_{\text {hitung }}<X^{2}$ tabel

\section{Pengujian normalitas data:}

\begin{tabular}{|c|c|c|c|c|c|c|c|}
\hline Interval & Batas kelas & $\mathbf{Z}$ & Luas Z & Luas Tiap Kelas & fh & fo & Chi Kuadrat \\
\hline & $-0,5$ & $-1,89$ & 0,4706 & & & & \\
\hline \multirow[t]{2}{*}{$0-5$} & & & & 0,0781 & 2,8116 & 6 & 3,616 \\
\hline & 5,5 & $-1,24$ & 0,3925 & & & & \\
\hline \multirow[t]{2}{*}{$6--11$} & & & & 0,1701 & 6,1236 & 2 & 2,777 \\
\hline & 11,5 & $-0,59$ & 0,2224 & & & & \\
\hline \multirow[t]{2}{*}{$12--17$} & & & & 0,2463 & 8,8668 & 7 & 0,393 \\
\hline & 17,5 & 0,06 & 0,0239 & & & & \\
\hline \multirow[t]{2}{*}{$18-23$} & & & & 0,2819 & 10,1484 & 10 & 0,002 \\
\hline & 23,5 & 0,70 & 0,2580 & & & & \\
\hline \multirow[t]{2}{*}{$24-29$} & & & & $-0,1535$ & $-5,526$ & 10 & $-43,622$ \\
\hline & 29,5 & 1,35 & 0,4115 & & & & \\
\hline \multirow[t]{2}{*}{$30-35$} & & & & $-0,0657$ & $-2,3652$ & 1 & $-4,788$ \\
\hline & 35,5 & 2,00 & 0,4772 & & & & \\
\hline \multicolumn{6}{|c|}{ Jumlah } & 36 & $-41,623$ \\
\hline \multicolumn{6}{|c|}{ Rata-rata } & \multicolumn{2}{|c|}{16,972} \\
\hline \multicolumn{6}{|c|}{ Standar Deviasi } & \multicolumn{2}{|c|}{9,269} \\
\hline \multicolumn{6}{|c|}{ Varians } & \multicolumn{2}{|c|}{85,913} \\
\hline \multicolumn{6}{|c|}{ Chi kuadrat tabel } & \multicolumn{2}{|c|}{11,071} \\
\hline \multicolumn{6}{|c|}{ Interpretasi } & \multicolumn{2}{|c|}{ normal } \\
\hline
\end{tabular}

Berdasarkan perhitungan dihasilkan $X^{2}{ }_{\text {hitung }}=-41,623$. Selanjutnya $X^{2}$ hitung tersebut dibandingkan dengan $X^{2}$ tabel dengan $\mathrm{dk}=5$ dan taraf signifikansi $5 \%$, sehingga ditetapkan $X^{2}$ tabel $=11,071$. Karena $X^{2}{ }_{\text {hitung }}<X^{2}$ tabel, maka $H_{0}$ diterima, sehingga kelas eksperimen dinyatakan berdistribusi normal. 


\section{Uji Homogenitas PretestPenguasaan Konsep}

\section{Hipotesis:}

$\mathrm{H}_{0}: \sigma_{1}^{2}=\sigma_{2}^{2}$

$\mathrm{H}_{a}: \sigma_{1}^{2} \neq \sigma_{2}^{2}$

\section{Pengujian Hipotesis:}

$\mathrm{F}=\frac{\text { Varians terbesar }}{\text { Varians terkecil }}$

$\mathrm{H}_{0}$ diterima apabila $\mathrm{F}_{\text {hitung }} \leq \mathrm{F}_{\text {tabel }}$

Dari data diperoleh:

\begin{tabular}{|c|c|c|}
\hline Sumber Variasi & Kelas Eksperimen & Kelas Kontrol \\
\hline Jumlah & 611 & 946 \\
\hline $\mathrm{n}$ & 36 & 34 \\
\hline Rata-rata & 16,972 & 27,824 \\
\hline Standar Deviasi & 9,269 & 9,523 \\
\hline Varians & 85,913 & 90,695 \\
\hline
\end{tabular}

Berdasarkan rumus di atas diperoleh:

$\mathrm{F}=\frac{90,695}{85,913}=1,056$

Taraf signifikan 5\% dengan:

$\mathrm{dk}_{1}=\mathrm{k}-1=2$

$\mathrm{dk}_{2}=\mathrm{N}-\mathrm{k}=67$

Sehingga, $F_{\text {tabel }}=3,134$

Karena $\mathrm{F}_{\text {hitung }}<\mathrm{F}_{\text {tabel, }}$ maka $\mathrm{H}_{0}$ diterima dan dapat disimpulkan bahwa kedua kelas homogen. 


\section{Uji Kesamaan Dua Rata-Rata \\ Pretest Penguasaan Konsep}

\section{Hipotesis:}

$\mathrm{H}_{0}: \mu_{1}=\mu_{2}$

$\mathrm{H}_{a}: \mu_{1} \neq \mu_{2}$

Kriteria Pengujian Hipotesis:

$$
t=\frac{\overline{X_{1}}-\overline{X_{2}}}{\sqrt{\frac{\left(n_{1}-1\right) s_{1}^{2}+\left(n_{2}-1\right) s_{2}^{2}}{n_{1}+n_{2}-2}\left(\frac{1}{n_{1}}+\frac{1}{n_{2}}\right)}}
$$

$\mathrm{H}_{0}$ diterima apabila $\mathrm{t}_{\text {hitung }} \leq \mathrm{t}_{\text {tabel }}$

\section{Uji Hipotesis:}

Dari data diperoleh:

\begin{tabular}{|c|c|c|}
\hline Sumber Variasi & Kelas Eksperimen & Kelas Kontrol \\
\hline Jumlah & 611 & 946 \\
\hline $\mathrm{n}$ & 36 & 34 \\
\hline Rata-rata & 16,972 & 27,824 \\
\hline Standar Deviasi & 9,269 & 9,523 \\
\hline Varians & 85,913 & 90,695 \\
\hline
\end{tabular}

Berdasarkan rumus di atas diperoleh:

$$
\begin{aligned}
& t=\frac{16,972-27,824}{\sqrt{\frac{(36-1) 85,913+(34-1) 90,695}{36+34-2}\left(\frac{1}{36}+\frac{1}{34}\right)}} \\
& \mathrm{t}=-4,831
\end{aligned}
$$

Taraf signifikansi $5 \%$ dan $\mathrm{dk}=68$, sehingga $\mathrm{t}_{\text {tabel }}=1,995$. Karena $t_{\text {hitung }} \leq t_{\text {tabel, }}$, maka $\mathrm{H}_{0}$ diterima. Jadi dapat disimpulkan bahwa tidak ada perbedaan rata-rata dari kelas kontrol dan kelas eksperimen. 
Lampiran 25. Uji Tahap Awal Attitudes toward Chemistry

\section{Data Hasil Pretest Attitudes toward Chemistry}

\begin{tabular}{|c|c|c|c|}
\hline No. & Kode Responden & Nilai & $(x-\bar{x})^{2}$ \\
\hline 1 & K-01 & 35 & 129,56 \\
\hline 2 & $\mathrm{~K}-02$ & 32 & 206,85 \\
\hline 3 & K-03 & 30 & 268,38 \\
\hline 4 & K-04 & 45 & 1,91 \\
\hline 5 & K-05 & 47 & 0,38 \\
\hline 6 & K-06 & 47 & 0,38 \\
\hline 7 & K-07 & 48 & 2,62 \\
\hline 8 & K-08 & 55 & 74,26 \\
\hline 9 & K-09 & 35 & 129,56 \\
\hline 10 & $\mathrm{~K}-10$ & 58 & 134,97 \\
\hline 11 & $\mathrm{~K}-11$ & 57 & 112,73 \\
\hline 12 & $\mathrm{~K}-12$ & 64 & 310,38 \\
\hline 13 & $\mathrm{~K}-13$ & 45 & 1,91 \\
\hline 14 & K-14 & 40 & 40,73 \\
\hline 15 & $\mathrm{~K}-15$ & 49 & 6,85 \\
\hline 16 & K-16 & 41 & 28,97 \\
\hline 17 & $\mathrm{~K}-17$ & 50 & 13,09 \\
\hline 18 & K-18 & 42 & 19,21 \\
\hline 19 & K-19 & 56 & 92,50 \\
\hline 20 & $\mathrm{~K}-20$ & 37 & 88,03 \\
\hline 21 & $\mathrm{~K}-21$ & 37 & 88,03 \\
\hline 22 & $\mathrm{~K}-22$ & 56 & 92,50 \\
\hline 23 & $\mathrm{~K}-23$ & 43 & 11,44 \\
\hline 24 & $\mathrm{~K}-24$ & 60 & 185,44 \\
\hline 25 & $\mathrm{~K}-25$ & 54 & 58,03 \\
\hline 26 & K-26 & 59 & 159,21 \\
\hline 27 & K-27 & 47 & 0,38 \\
\hline 28 & K-28 & 37 & 88,03 \\
\hline 29 & K-29 & 52 & 31,56 \\
\hline 30 & K-30 & 46 & 0,15 \\
\hline 31 & $\mathrm{~K}-31$ & 72 & 656,26 \\
\hline 32 & $\mathrm{~K}-32$ & 44 & 5,68 \\
\hline 33 & K-33 & 21 & 644,26 \\
\hline 34 & K-34 & 36 & 107,79 \\
\hline & Jumlah & 1577 & 3792,029 \\
\hline & Rata-rata & 46,382 & \\
\hline & Nilai tertinggi & 72 & \\
\hline & Nilai terendah & 21 & \\
\hline & Rentang & 51 & \\
\hline & Banyak kelas & 6,054 & \\
\hline & Panjang kelas & 8,424 & \\
\hline & Standar Deviasi & 10,720 & \\
\hline
\end{tabular}

\begin{tabular}{|c|c|c|c|}
\hline No. & Kode Responden & Nilai & $(x-\bar{x})^{2}$ \\
\hline 1 & E-01 & 51 & 89,20 \\
\hline 2 & E-02 & 48 & 41,53 \\
\hline 3 & E-03 & 31 & 111,42 \\
\hline 4 & E-04 & 34 & 57,09 \\
\hline 5 & E-05 & 47 & 29,64 \\
\hline 6 & E-06 & 40 & 2,42 \\
\hline 7 & E-07 & 45 & 11,86 \\
\hline 8 & E-08 & 51 & 89,20 \\
\hline 9 & E-09 & 48 & 41,53 \\
\hline 10 & E-10 & 28 & 183,75 \\
\hline 11 & E-11 & 33 & 73,20 \\
\hline 12 & E-12 & 57 & 238,53 \\
\hline 13 & E-13 & 54 & 154,86 \\
\hline 14 & E-14 & 41 & 0,31 \\
\hline 15 & E-15 & 29 & 157,64 \\
\hline 16 & E-16 & 52 & 109,09 \\
\hline 17 & E-17 & 48 & 41,53 \\
\hline 18 & E-18 & 51 & 89,20 \\
\hline 19 & E-19 & 45 & 11,86 \\
\hline 20 & E-20 & 41 & 0,31 \\
\hline 21 & E-21 & 34 & 57,09 \\
\hline 22 & E-22 & 38 & 12,64 \\
\hline 23 & E-23 & 40 & 2,42 \\
\hline 24 & E-24 & 35 & 42,98 \\
\hline 25 & E-25 & 31 & 111,42 \\
\hline 26 & E-26 & 28 & 183,75 \\
\hline 27 & E-27 & 37 & 20,75 \\
\hline 28 & E-28 & 48 & 41,53 \\
\hline 29 & E-29 & 44 & 5,98 \\
\hline 30 & E-30 & 36 & 30,86 \\
\hline 31 & E-31 & 54 & 154,86 \\
\hline 32 & E-32 & 24 & 308,20 \\
\hline 33 & E-33 & 36 & 30,86 \\
\hline 34 & E-34 & 39 & 6,53 \\
\hline 35 & E-35 & 55 & 180,75 \\
\hline 36 & E-36 & 43 & 2,09 \\
\hline \multicolumn{2}{|r|}{ Jumlah } & 1496 & 2726,889 \\
\hline \multicolumn{2}{|r|}{ Rata-rata } & 41,556 & \\
\hline \multicolumn{2}{|r|}{ Nilai tertinggi } & 57 & \\
\hline \multicolumn{2}{|r|}{ Nilai terendah } & 24 & \\
\hline \multicolumn{2}{|r|}{ Rentang } & 33 & \\
\hline \multicolumn{2}{|r|}{ Banyak kelas } & 6,136 & \\
\hline \multicolumn{2}{|r|}{ Panjang kelas } & 5,378 & \\
\hline \multicolumn{2}{|r|}{ Standar Deviasi } & 8,827 & \\
\hline
\end{tabular}




\section{Uji Normalitas Pretest Attitudes toward Chemistry \\ Kelas Kontrol}

\section{Hipotesis:}

$\mathrm{H}_{0}$ : Data berdistribusi normal

$\mathrm{H}_{a}$ : Data tidak berdistribusi normal

\section{Pengujian Hipotesis:}

$X^{2} h=\sum \frac{\left(f_{o}-f_{h}\right)^{2}}{f_{h}}$

\section{Kriteria yang digunakan:}

$\mathrm{H}_{0}$ diterima jika $X^{2}{ }_{\text {hitung }}<X^{2}$ tabel

\section{Pengujian normalitas data:}

\begin{tabular}{|c|c|c|c|c|c|c|c|}
\hline Interval & Batas kelas & $\mathbf{Z}$ & Luas Z & Luas Tiap Kelas & fh & fo & Chi kuadrat \\
\hline & 20,5 & $-2,41$ & 0,4920 & & & & \\
\hline \multirow[t]{2}{*}{$21-28$} & & & & 0,0395 & 1,343 & 1 & 0,088 \\
\hline & 28,5 & $-1,67$ & 0,4525 & & & & \\
\hline \multirow[t]{2}{*}{$29-36$} & & & & 0,1313 & 4,4642 & 5 & 0,064 \\
\hline & 36,5 & $-0,92$ & 0,3212 & & & & \\
\hline \multirow[t]{2}{*}{$37-44$} & & & & 0,2498 & 8,4932 & 8 & 0,029 \\
\hline & 44,5 & $-0,18$ & 0,0714 & & & & \\
\hline \multirow[t]{2}{*}{$45-52$} & & & & 0,2871 & 9,7614 & 10 & 0,006 \\
\hline & 52,5 & 0,57 & 0,2157 & & & & \\
\hline \multirow[t]{2}{*}{$53-60$} & & & & $-0,1909$ & $-6,4906$ & 8 & $-32,351$ \\
\hline & 60,5 & 1,32 & 0,4066 & & & & \\
\hline \multirow[t]{2}{*}{$61-68$} & & & & $-0,0737$ & $-2,5058$ & 1 & $-4,905$ \\
\hline & 68,5 & 2,06 & 0,4803 & & & & \\
\hline \multirow[t]{2}{*}{$69-76$} & & & & $-0,0172$ & $-0,5848$ & 1 & $-4,295$ \\
\hline & 76,5 & 2,81 & 0,4975 & & & & \\
\hline \multicolumn{6}{|c|}{ Jumlah } & 34 & $-41,364$ \\
\hline \multicolumn{6}{|c|}{ Rata-rata } & \multicolumn{2}{|c|}{46,382} \\
\hline \multicolumn{6}{|c|}{ Standar Deviasi } & \multicolumn{2}{|c|}{10,720} \\
\hline \multicolumn{6}{|c|}{ Varians } & \multicolumn{2}{|c|}{114,910} \\
\hline \multicolumn{6}{|c|}{ Chi kuadrat tabel } & \multicolumn{2}{|c|}{12,592} \\
\hline \multicolumn{6}{|c|}{ Interpretasi } & \multicolumn{2}{|c|}{ normal } \\
\hline
\end{tabular}

Berdasarkan perhitungan dihasilkan $X^{2}{ }_{\text {hitung }}=-41,364$. Selanjutnya $X^{2}$ hitung tersebut dibandingkan dengan $X^{2}$ tabel dengan $\mathrm{dk}=6$ dan taraf signifikansi $5 \%$, sehingga ditetapkan $X^{2}$ tabel $=12,592$. Karena $X^{2}$ hitung $<X^{2}$ tabel, maka $H_{0}$ diterima, sehingga kelas kontrol dinyatakan berdistribusi normal. 


\section{Uji Normalitas PretestAttitudes toward Chemistry \\ Kelas Eksperimen}

\section{Hipotesis:}

$\mathrm{H}_{0}$ : Data berdistribusi normal

$\mathrm{H}_{a}$ : Data tidak berdistribusi normal

\section{Pengujian Hipotesis:}

$X^{2} h=\sum \frac{\left(f_{o}-f_{h}\right)^{2}}{f_{h}}$

\section{Kriteria yang digunakan:}

$\mathrm{H}_{0}$ diterima jika $X^{2}{ }_{\text {hitung }}<X_{\text {tabel }}$

\section{Pengujian normalitas data:}

\begin{tabular}{|c|c|c|c|c|c|c|c|}
\hline Interval & Batas kelas & $\mathbf{Z}$ & Luas Z & Luas Tiap Kelas & fh & fo & Chi Kuadrat \\
\hline & 23,5 & $-2,05$ & 0,4798 & & & & \\
\hline \multirow[t]{2}{*}{$24-28$} & & & & 0,0492 & 1,7712 & 3 & 0,853 \\
\hline & 28,5 & $-1,48$ & 0,4306 & & & & \\
\hline \multirow[t]{2}{*}{$29-33$} & & & & 0,112 & 4,032 & 4 & 0,000 \\
\hline & 33,5 & $-0,91$ & 0,3186 & & & & \\
\hline \multirow[t]{2}{*}{$34-38$} & & & & 0,1818 & 6,5448 & 7 & 0,032 \\
\hline & 38,5 & $-0,35$ & 0,1368 & & & & \\
\hline \multirow[t]{2}{*}{$39-43$} & & & & 0,2239 & 8,0604 & 6 & 0,527 \\
\hline & 43,5 & 0,22 & 0,0871 & & & & \\
\hline \multirow[t]{2}{*}{$44-48$} & & & & $-0,1981$ & $-7,1316$ & 8 & $-32,106$ \\
\hline & 48,5 & 0,79 & 0,2852 & & & & \\
\hline \multirow[t]{2}{*}{$49-53$} & & & & $-0,1263$ & $-4,5468$ & 4 & $-16,066$ \\
\hline & 53,5 & 1,35 & 0,4115 & & & & \\
\hline \multirow[t]{2}{*}{$54-58$} & & & & $-0,0611$ & $-2,1996$ & 4 & $-17,474$ \\
\hline & 58,5 & 1,92 & 0,4726 & & & & \\
\hline \multicolumn{6}{|c|}{ Jumlah } & 36 & $-64,234$ \\
\hline \multicolumn{6}{|c|}{ Rata-rata } & \multicolumn{2}{|c|}{41,556} \\
\hline \multicolumn{6}{|c|}{ Standar Deviasi } & \multicolumn{2}{|c|}{8,827} \\
\hline \multicolumn{6}{|c|}{ Varians } & \multicolumn{2}{|c|}{77,911} \\
\hline \multicolumn{6}{|c|}{ Chi kuadrat tabel } & \multicolumn{2}{|c|}{12,592} \\
\hline \multicolumn{6}{|c|}{ Interpretasi } & \multicolumn{2}{|c|}{ normal } \\
\hline
\end{tabular}

Berdasarkan perhitungan dihasilkan $X^{2}$ hitung $=-64,234$. Selanjutnya $X^{2}$ hitung tersebut dibandingkan dengan $X^{2}$ tabel dengan $\mathrm{dk}=6$ dan taraf signifikansi $5 \%$, sehingga ditetapkan $X^{2}$ tabel $=12,592$. Karena $X^{2}{ }_{\text {hitung }}<X_{\text {tabel, }}^{2}$ maka $\mathrm{H}_{0}$ diterima, sehingga kelas eksperimen dinyatakan berdistribusi normal. 


\section{Uji Homogenitas Pretest Attitudes toward Chemistry}

\section{Hipotesis:}

$\mathrm{H}_{0}: \sigma_{1}^{2}=\sigma_{2}^{2}$

$\mathrm{H}_{a}: \sigma_{1}^{2} \neq \sigma_{2}^{2}$

\section{Pengujian Hipotesis:}

$\mathrm{F}=\frac{\text { Varians terbesar }}{\text { Varians terkecil }}$

$\mathrm{H}_{0}$ diterima apabila $\mathrm{F}_{\text {hitung }} \leq \mathrm{F}_{\text {tabel }}$

Dari data diperoleh:

\begin{tabular}{|c|c|c|}
\hline Sumber Variasi & Kelas Eksperimen & Kelas Kontrol \\
\hline Jumlah & 1496 & 1577 \\
\hline $\mathrm{n}$ & 36 & 34 \\
\hline Rata-rata & 41,556 & 46,382 \\
\hline Standar Deviasi & 8,827 & 10,720 \\
\hline Varians & 77,911 & 114,910 \\
\hline
\end{tabular}

Berdasarkan rumus di atas diperoleh:

$\mathrm{F}=\frac{114,910}{77,911}=1,475$

Taraf signifikan 5\% dengan:

$\mathrm{dk}$ pembilang $=\mathrm{k}-1=2$

$\mathrm{dk}$ penyebut $=\mathrm{N}-\mathrm{k}=67$

Sehingga, $F_{\text {tabel }}=3,134$

Karena $\mathrm{F}_{\text {hitung }}<\mathrm{F}_{\text {tabel, }}$ maka $\mathrm{H}_{0}$ diterima dan dapat disimpulkan bahwa kedua kelas homogen. 


\section{Uji Kesamaan Dua Rata-Rata \\ PretestAttitudes toward Chemistry}

\section{Hipotesis:}

$\mathrm{H}_{0}: \mu_{1}=\mu_{2}$

$\mathrm{H}_{a}: \mu_{1} \neq \mu_{2}$

\section{Kriteria Pengujian Hipotesis:}

$$
t=\frac{\overline{X_{1}}-\overline{X_{2}}}{\sqrt{\frac{\left(n_{1}-1\right) s_{1}^{2}+\left(n_{2}-1\right) s_{2}^{2}}{n_{1}+n_{2}-2}\left(\frac{1}{n_{1}}+\frac{1}{n_{2}}\right)}}
$$

$\mathrm{H}_{0}$ diterima apabila $\mathrm{t}_{\text {hitung }} \leq \mathrm{t}_{\text {tabel }}$

\section{Uji Hipotesis:}

Dari data diperoleh:

\begin{tabular}{|c|c|c|}
\hline Sumber Variasi & Kelas Eksperimen & Kelas Kontrol \\
\hline Jumlah & 1496 & 1577 \\
\hline $\mathrm{n}$ & 36 & 34 \\
\hline Rata-rata & 41,556 & 46,382 \\
\hline Standar Deviasi & 8,827 & 10,720 \\
\hline Varians & 77,911 & 114,910 \\
\hline
\end{tabular}

Berdasarkan rumus di atas diperoleh:

$$
\begin{aligned}
& t=\frac{41,556-46,382}{\sqrt{\frac{(36-1) 77,911+(34-1) 114,910}{36+34-2}\left(\frac{1}{36}+\frac{1}{34}\right)}} \\
& \mathrm{t}=-2,061
\end{aligned}
$$

Taraf signifikansi $5 \%$ dan $d k=68$, sehingga $t_{\text {tabel }}=1,995$. Karena $\mathrm{t}_{\text {hitung }} \leq \mathrm{t}_{\text {tabel, }}$, maka $\mathrm{H}_{0}$ diterima. Jadi dapat disimpulkan bahwa tidak ada perbedaan rata-rata dari kelas kontrol dan kelas eksperimen. 
Lampiran 26. Analisis Pretest Soal Three-tier Multiple Choice

\section{Kelas Kontrol:}

\begin{tabular}{|c|c|c|c|c|c|c|c|c|c|c|c|c|c|c|c|c|}
\hline \multirow{2}{*}{ No. } & \multirow{2}{*}{ Kode } & \multicolumn{15}{|c|}{ Nomor Soal } \\
\hline & & 1 & 2 & 3 & 4 & 5 & 6 & 7 & 8 & 9 & 10 & 11 & 12 & 13 & 14 & 15 \\
\hline 1. & $\mathrm{~K}-01$ & $\mathrm{P}$ & $\mathrm{M}$ & $\mathrm{M}$ & $\mathrm{P}$ & $\mathrm{M}$ & $\mathrm{P}$ & $\mathrm{M}$ & $\mathrm{M}$ & $\mathrm{M}$ & $\mathrm{M}$ & $\mathrm{P}$ & $\mathrm{M}$ & $\mathrm{M}$ & $\mathrm{M}$ & $\mathrm{M}$ \\
\hline 2. & $\mathrm{~K}-02$ & $\mathrm{P}$ & $\mathrm{P}$ & $\mathrm{M}$ & $\mathrm{M}$ & $\mathrm{M}$ & $\mathrm{P}$ & $\mathrm{M}$ & $\mathrm{M}$ & $\mathrm{P}$ & $\mathrm{M}$ & $\mathrm{M}$ & $\mathrm{M}$ & $\mathrm{M}$ & $\mathrm{P}$ & $\mathrm{M}$ \\
\hline 3. & $\mathrm{~K}-03$ & $\mathrm{KP}$ & $\mathrm{M}$ & $\mathrm{KP}$ & $\mathrm{KP}$ & $\mathrm{KP}$ & $\mathrm{M}$ & $\mathrm{KP}$ & $\mathrm{KP}$ & $\mathrm{KP}$ & $\mathrm{KP}$ & $\mathrm{P}$ & $\mathrm{KP}$ & $\mathrm{U}$ & $\mathrm{KP}$ & $\mathrm{KP}$ \\
\hline 4. & K-04 & $\mathrm{P}$ & $\mathrm{KP}$ & $\mathrm{KP}$ & $\mathrm{P}$ & $\mathrm{M}$ & $\mathrm{P}$ & $\mathrm{KP}$ & $\mathrm{M}$ & $\mathrm{P}$ & $\mathrm{KP}$ & $\mathrm{U}$ & $\mathrm{KP}$ & $\mathrm{KP}$ & $\mathrm{KP}$ & KP \\
\hline 5. & K-05 & KP & KP & KP & $\mathrm{KP}$ & KP & $\mathrm{KP}$ & $\mathrm{KP}$ & $\mathrm{KP}$ & $\mathrm{KP}$ & $\mathrm{KP}$ & $\mathrm{U}$ & KP & $\mathrm{KP}$ & $\mathrm{KP}$ & $\mathrm{U}$ \\
\hline 6. & K-06 & $\mathrm{P}$ & $\mathrm{M}$ & $\mathrm{M}$ & $\mathrm{KP}$ & $\mathrm{M}$ & $\mathrm{KP}$ & $\mathrm{KP}$ & $\mathrm{M}$ & $\mathrm{KP}$ & $\mathrm{KP}$ & $\mathrm{KP}$ & $\mathrm{M}$ & $\mathrm{KP}$ & $\mathrm{KP}$ & $\mathrm{KP}$ \\
\hline 7. & K-07 & $\mathrm{P}$ & $\mathrm{KP}$ & $\mathrm{KP}$ & $\mathrm{P}$ & $\mathrm{M}$ & $\mathrm{P}$ & $\mathrm{KP}$ & $\mathrm{KP}$ & $\mathrm{P}$ & $\mathrm{KP}$ & $\mathrm{P}$ & $\mathrm{M}$ & $\mathrm{KP}$ & $\mathrm{KP}$ & $\mathrm{KP}$ \\
\hline 8. & K-08 & $\mathrm{P}$ & $\mathrm{U}$ & $\mathrm{M}$ & KP & $\mathrm{M}$ & $\mathrm{P}$ & $\mathrm{KP}$ & $\mathrm{M}$ & $\mathrm{P}$ & KP & $\mathrm{P}$ & $\mathrm{KP}$ & KP & $\mathrm{U}$ & $\mathrm{M}$ \\
\hline 9. & K-09 & $\mathrm{P}$ & $\mathrm{U}$ & $\mathrm{KP}$ & KP & $\mathrm{M}$ & $\mathrm{P}$ & $\mathrm{KP}$ & $\mathrm{M}$ & $\mathrm{M}$ & KP & $\mathrm{U}$ & $\mathrm{KP}$ & KP & $\mathrm{U}$ & $\mathrm{M}$ \\
\hline 10. & K-10 & $\mathrm{P}$ & $\mathrm{M}$ & $\mathrm{M}$ & $\mathrm{P}$ & $\mathrm{M}$ & $\mathrm{P}$ & $\mathrm{M}$ & $\mathrm{M}$ & $\mathrm{M}$ & $\mathrm{M}$ & $\mathrm{P}$ & $\mathrm{M}$ & $\mathrm{M}$ & $\mathrm{M}$ & $\mathrm{M}$ \\
\hline 11. & $\mathrm{~K}-11$ & $\mathrm{P}$ & $\mathrm{M}$ & $\mathrm{M}$ & $\mathrm{M}$ & $\mathrm{M}$ & $\mathrm{KP}$ & $\mathrm{M}$ & $\mathrm{M}$ & $\mathrm{KP}$ & $\mathrm{KP}$ & $\mathrm{M}$ & $\mathrm{M}$ & $\mathrm{M}$ & $\mathrm{M}$ & $\mathrm{M}$ \\
\hline 12. & $\mathrm{~K}-12$ & $\mathrm{P}$ & $\mathrm{U}$ & $\mathrm{KP}$ & $\mathrm{KP}$ & $\mathrm{M}$ & $\mathrm{P}$ & $\mathrm{KP}$ & $\mathrm{M}$ & $\mathrm{U}$ & $\mathrm{KP}$ & $\mathrm{P}$ & $\mathrm{KP}$ & $\mathrm{KP}$ & $\mathrm{U}$ & $\mathrm{M}$ \\
\hline 13. & $\mathrm{~K}-13$ & $\mathrm{P}$ & $M$ & $\mathrm{M}$ & $\mathrm{P}$ & $\mathrm{M}$ & $\mathrm{P}$ & $\mathrm{M}$ & $\mathrm{M}$ & $\mathrm{M}$ & $\mathrm{M}$ & $\mathrm{P}$ & $\mathrm{M}$ & $\mathrm{M}$ & $\mathrm{M}$ & $M$ \\
\hline 14. & K-14 & $\mathrm{P}$ & $\mathrm{M}$ & $\mathrm{M}$ & $\mathrm{P}$ & $\mathrm{M}$ & $\mathrm{P}$ & $\mathrm{M}$ & $\mathrm{M}$ & $\mathrm{M}$ & $\mathrm{M}$ & $\mathrm{P}$ & $\mathrm{M}$ & $\mathrm{M}$ & $\mathrm{M}$ & $\mathrm{M}$ \\
\hline 15. & K-15 & $\mathrm{M}$ & $\mathrm{M}$ & $\mathrm{M}$ & $\mathrm{P}$ & $\mathrm{M}$ & $\mathrm{P}$ & $\mathrm{M}$ & $\mathrm{M}$ & $\mathrm{M}$ & $\mathrm{M}$ & $\mathrm{P}$ & $\mathrm{M}$ & $\mathrm{M}$ & $\mathrm{M}$ & $\mathrm{M}$ \\
\hline 16. & K-16 & $\mathrm{P}$ & $\mathrm{M}$ & KP & $\mathrm{M}$ & KP & $\mathrm{P}$ & $\mathrm{M}$ & $\mathrm{M}$ & $\mathrm{KP}$ & KP & $\mathrm{P}$ & $\mathrm{KP}$ & $\mathrm{M}$ & $\mathrm{M}$ & KP \\
\hline 17. & K-17 & $\mathrm{KP}$ & $\mathrm{KP}$ & $\mathrm{KP}$ & $\mathrm{KP}$ & KP & $\mathrm{KP}$ & $\mathrm{KP}$ & $\mathrm{KP}$ & $\mathrm{KP}$ & $\mathrm{KP}$ & $\mathrm{KP}$ & $\mathrm{KP}$ & $\mathrm{KP}$ & $\mathrm{KP}$ & $\mathrm{KP}$ \\
\hline 18. & $\mathrm{~K}-18$ & $\mathrm{P}$ & $\mathrm{P}$ & $\mathrm{P}$ & $\mathrm{P}$ & $\mathrm{M}$ & $\mathrm{P}$ & $\mathrm{M}$ & $\mathrm{M}$ & $\mathrm{M}$ & $\mathrm{M}$ & $\mathrm{P}$ & $\mathrm{M}$ & $\mathrm{M}$ & $\mathrm{M}$ & $\mathrm{M}$ \\
\hline 19. & K-19 & $\mathrm{P}$ & $\mathrm{M}$ & $\mathrm{KP}$ & $\mathrm{P}$ & $\mathrm{M}$ & $\mathrm{P}$ & $\mathrm{KP}$ & $\mathrm{M}$ & $\mathrm{P}$ & $\mathrm{KP}$ & $\mathrm{P}$ & $\mathrm{KP}$ & $\mathrm{M}$ & $\mathrm{KP}$ & $\mathrm{KP}$ \\
\hline 20. & $\mathrm{~K}-20$ & $P$ & $M$ & $\mathrm{M}$ & $\mathrm{M}$ & $\mathrm{M}$ & $\mathrm{U}$ & KP & $\mathrm{KP}$ & $\mathrm{KP}$ & KP & KP & $\mathrm{KP}$ & KP & KP & KP \\
\hline 21. & $\mathrm{~K}-21$ & $\mathrm{P}$ & $\mathrm{M}$ & $\mathrm{M}$ & $\mathrm{U}$ & $\mathrm{M}$ & $\mathrm{U}$ & $\mathrm{M}$ & KP & $\mathrm{M}$ & $\mathrm{M}$ & $\mathrm{P}$ & $\mathrm{KP}$ & $\mathrm{M}$ & KP & $\mathrm{M}$ \\
\hline 22. & K-22 & $\mathrm{P}$ & $\mathrm{KP}$ & $\mathrm{M}$ & $\mathrm{P}$ & $\mathrm{KP}$ & $\mathrm{U}$ & $\mathrm{M}$ & $\mathrm{KP}$ & $\mathrm{M}$ & $\mathrm{M}$ & $\mathrm{P}$ & $\mathrm{M}$ & $\mathrm{KP}$ & $\mathrm{KP}$ & $\mathrm{M}$ \\
\hline 23. & $\mathrm{~K}-23$ & $\mathrm{P}$ & $\mathrm{M}$ & $\mathrm{M}$ & $\mathrm{M}$ & $\mathrm{M}$ & $\mathrm{P}$ & $\mathrm{M}$ & $\mathrm{M}$ & $\mathrm{M}$ & $\mathrm{M}$ & $\mathrm{P}$ & $\mathrm{M}$ & $\mathrm{M}$ & $\mathrm{M}$ & $\mathrm{M}$ \\
\hline 24. & K-24 & $\mathrm{P}$ & $\mathrm{U}$ & $\mathrm{M}$ & KP & $\mathrm{M}$ & $\mathrm{P}$ & $\mathrm{KP}$ & $\mathrm{M}$ & $\mathrm{P}$ & KP & $\mathrm{P}$ & $\mathrm{KP}$ & KP & $\mathrm{U}$ & $\mathrm{M}$ \\
\hline 25. & K-25 & $\mathrm{P}$ & $\mathrm{KP}$ & $\mathrm{M}$ & $\mathrm{U}$ & $\mathrm{KP}$ & $\mathrm{P}$ & $\mathrm{M}$ & $\mathrm{M}$ & $\mathrm{M}$ & $\mathrm{M}$ & $\mathrm{U}$ & $\mathrm{KP}$ & $\mathrm{M}$ & $\mathrm{M}$ & $\mathrm{KP}$ \\
\hline 26. & K-26 & $\mathrm{P}$ & $\mathrm{M}$ & $\mathrm{M}$ & $\mathrm{M}$ & $\mathrm{M}$ & $\mathrm{P}$ & $\mathrm{M}$ & $\mathrm{M}$ & $\mathrm{P}$ & $\mathrm{M}$ & $\mathrm{M}$ & $\mathrm{M}$ & $\mathrm{M}$ & $\mathrm{P}$ & $\mathrm{M}$ \\
\hline 27. & K-27 & $\mathrm{U}$ & $\mathrm{KP}$ & $\mathrm{KP}$ & $\mathrm{KP}$ & $\mathrm{KP}$ & $\mathrm{U}$ & $\mathrm{KP}$ & $\mathrm{KP}$ & $\mathrm{KP}$ & $\mathrm{KP}$ & $\mathrm{KP}$ & $\mathrm{KP}$ & $\mathrm{KP}$ & $\mathrm{KP}$ & $\mathrm{KP}$ \\
\hline 28. & $\mathrm{~K}-28$ & $\mathrm{P}$ & $\mathrm{M}$ & $\mathrm{M}$ & $\mathrm{P}$ & $\mathrm{M}$ & $P$ & $\mathrm{M}$ & $\mathrm{M}$ & $\mathrm{M}$ & $\mathrm{M}$ & $\mathrm{P}$ & $\mathrm{M}$ & $\mathrm{M}$ & $\mathrm{M}$ & $\mathrm{M}$ \\
\hline 29. & K-29 & $\mathrm{P}$ & $\mathrm{M}$ & $\mathrm{M}$ & $\mathrm{P}$ & $\mathrm{M}$ & $\mathrm{P}$ & $\mathrm{M}$ & $\mathrm{M}$ & $\mathrm{M}$ & $\mathrm{M}$ & $\mathrm{P}$ & $\mathrm{M}$ & $\mathrm{M}$ & $\mathrm{M}$ & $\mathrm{M}$ \\
\hline 30. & K-30 & $\mathrm{U}$ & $\mathrm{M}$ & $\mathrm{M}$ & $\mathrm{P}$ & $\mathrm{M}$ & $\mathrm{P}$ & $\mathrm{M}$ & $\mathrm{M}$ & $\mathrm{M}$ & $\mathrm{M}$ & $\mathrm{P}$ & $\mathrm{M}$ & $\mathrm{M}$ & $\mathrm{M}$ & $\mathrm{M}$ \\
\hline 31. & $\mathrm{~K}-31$ & $\mathrm{P}$ & $\mathrm{M}$ & $\mathrm{M}$ & $\mathrm{M}$ & $\mathrm{M}$ & $\mathrm{KP}$ & $\mathrm{KP}$ & $\mathrm{M}$ & $\mathrm{M}$ & $\mathrm{M}$ & $\mathrm{M}$ & $\mathrm{M}$ & $\mathrm{M}$ & $\mathrm{M}$ & $\mathrm{M}$ \\
\hline 32. & K-32 & $\mathrm{P}$ & $\mathrm{KP}$ & $\mathrm{KP}$ & $\mathrm{U}$ & $\mathrm{M}$ & $\mathrm{U}$ & $\mathrm{M}$ & M & $\mathrm{M}$ & $\mathrm{M}$ & $\mathrm{P}$ & M & KP & $\mathrm{KP}$ & KP \\
\hline 33. & K-33 & $\mathrm{KP}$ & $\mathrm{KP}$ & $\mathrm{KP}$ & $\mathrm{KP}$ & KP & $\mathrm{U}$ & $\mathrm{KP}$ & $\mathrm{KP}$ & $\mathrm{KP}$ & $\mathrm{KP}$ & $\mathrm{KP}$ & $\mathrm{KP}$ & $\mathrm{KP}$ & $\mathrm{KP}$ & $\mathrm{KP}$ \\
\hline 34 & K-34 & $\mathrm{P}$ & $\mathrm{KP}$ & $\mathrm{M}$ & $\mathrm{KP}$ & $\mathrm{M}$ & $\mathrm{P}$ & $\mathrm{M}$ & $\mathrm{KP}$ & $\mathrm{M}$ & $\mathrm{M}$ & $\mathrm{M}$ & $\mathrm{M}$ & $\mathrm{M}$ & $\mathrm{P}$ & $\mathrm{M}$ \\
\hline & $\sum P$ & 27 & 2 & 1 & 13 & $\mathbf{0}$ & 22 & 0 & $\mathbf{0}$ & 7 & 0 & 20 & $\mathbf{0}$ & 0 & 3 & $\mathbf{0}$ \\
\hline & $\Sigma U$ & 2 & 4 & $\mathbf{0}$ & 3 & 0 & 6 & 0 & 0 & 1 & 0 & 4 & 0 & 1 & 4 & 1 \\
\hline & $\sum M$ & 1 & 18 & 21 & 7 & 26 & 1 & 19 & 24 & 17 & 18 & 5 & 19 & 19 & 14 & 21 \\
\hline & $\sum \mathrm{KP}$ & 4 & 10 & 12 & 11 & 8 & 5 & 15 & 10 & 9 & 16 & 5 & 15 & 14 & 13 & 12 \\
\hline & $\% \mathrm{P}$ & 79 & 5,9 & 2,9 & 38 & 0 & 65 & $\mathbf{0}$ & $\mathbf{0}$ & 21 & 0 & 59 & 0 & 0 & 8,8 & 0 \\
\hline & $\% \mathrm{U}$ & 5,9 & 12 & 0 & 8,8 & 0 & 18 & $\mathbf{0}$ & $\mathbf{0}$ & 2,9 & 0 & 12 & $\mathbf{0}$ & 2,9 & 12 & 2,9 \\
\hline & $\% \mathrm{M}$ & 2,9 & 53 & 62 & 21 & 76 & 2,9 & 56 & 71 & 50 & 53 & 15 & 56 & 56 & 41 & 62 \\
\hline & \% KP & 12 & 29 & 35 & 32 & 24 & 15 & 44 & 29 & 26 & 47 & 15 & 44 & 41 & 38 & 35 \\
\hline To & tal $\% \mathrm{P}$ & & & & & & & & 18,63 & & & & & & & \\
\hline To & tal \% U & & & & & & & & 5,10 & & & & & & & \\
\hline Tot & tal \% M & & & & & & & & 45,10 & & & & & & & \\
\hline Tot & tal \% KP & & & & & & & & 31,18 & & & & & & & \\
\hline
\end{tabular}




\section{Kelas Eksperimen:}

\begin{tabular}{|c|c|c|c|c|c|c|c|c|c|c|c|c|c|c|c|c|}
\hline \multirow{2}{*}{ No. } & \multirow{2}{*}{ Kode } & \multicolumn{15}{|c|}{ Nomor Soal } \\
\hline & & 1 & 2 & 3 & 4 & 5 & 6 & 7 & 8 & 9 & 10 & 11 & 12 & 13 & 14 & 15 \\
\hline 1 & E-01 & KP & KP & KP & KP & KP & KP & KP & KP & KP & $\mathrm{KP}$ & KP & KP & KP & KP & KP \\
\hline 2 & E-02 & KP & $\mathrm{M}$ & $\mathrm{M}$ & $\mathrm{M}$ & $\mathrm{P}$ & M & KP & $\mathrm{U}$ & KP & KP & KP & KP & $\mathrm{U}$ & KP & $\mathrm{U}$ \\
\hline 3 & E-03 & KP & KP & KP & KP & $\mathrm{KP}$ & M & KP & KP & KP & $\mathrm{KP}$ & KP & KP & KP & KP & KP \\
\hline 4 & E-04 & KP & $\mathrm{U}$ & $\mathrm{U}$ & $\mathrm{M}$ & $\mathrm{M}$ & $P$ & $\mathrm{M}$ & $\mathrm{M}$ & $\mathrm{M}$ & $\mathrm{M}$ & $\mathrm{M}$ & $\mathrm{M}$ & $\mathrm{M}$ & $\mathrm{M}$ & $\mathrm{M}$ \\
\hline 5 & E-05 & KP & $\mathrm{U}$ & KP & $\mathrm{U}$ & M & $\mathrm{U}$ & KP & KP & KP & KP & KP & KP & KP & KP & KP \\
\hline 6 & E-06 & KP & KP & KP & KP & KP & KP & KP & KP & KP & KP & KP & KP & KP & KP & KP \\
\hline 7 & E-07 & $\mathrm{M}$ & $\mathrm{M}$ & $\mathrm{M}$ & $\mathrm{M}$ & KP & $\mathrm{U}$ & $\mathrm{M}$ & $\mathrm{U}$ & KP & KP & KP & KP & KP & $\mathrm{M}$ & KP \\
\hline 8 & E-08 & $\mathrm{M}$ & $\mathrm{M}$ & $\mathrm{M}$ & $\mathrm{M}$ & $\mathrm{KP}$ & KP & $\mathrm{M}$ & $\mathrm{U}$ & $\mathrm{M}$ & $\mathrm{M}$ & KP & KP & $\mathrm{M}$ & $\mathrm{M}$ & $\mathrm{M}$ \\
\hline 9 & E-09 & KP & KP & KP & $P$ & KP & $\mathrm{M}$ & $\mathrm{U}$ & KP & $\mathrm{M}$ & KP & M & KP & KP & $\mathrm{M}$ & KP \\
\hline 10 & E-10 & KP & KP & KP & KP & $P$ & $\mathrm{U}$ & KP & KP & KP & $\mathrm{M}$ & KP & $\mathrm{M}$ & KP & KP & M \\
\hline 11 & E-11 & KP & $\mathrm{KP}$ & KP & $\mathrm{M}$ & KP & $P$ & KP & KP & $\mathrm{M}$ & $\mathrm{KP}$ & KP & KP & $\mathrm{KP}$ & KP & KP \\
\hline 12 & E-12 & KP & $\mathrm{KP}$ & KP & KP & KP & KP & KP & KP & KP & $\mathrm{KP}$ & KP & KP & KP & KP & KP \\
\hline 13 & E-13 & $\mathrm{M}$ & $\mathrm{M}$ & $\mathrm{M}$ & $\mathrm{M}$ & KP & KP & KP & $\mathrm{M}$ & KP & $\mathrm{M}$ & $\mathrm{M}$ & KP & KP & $\mathrm{M}$ & KP \\
\hline 14 & E-14 & $\mathrm{M}$ & $\mathrm{M}$ & M & $\mathrm{M}$ & M & $\mathrm{P}$ & $\mathrm{M}$ & $\mathrm{P}$ & $\mathrm{M}$ & $\mathrm{M}$ & $\mathrm{M}$ & $\mathrm{M}$ & $\mathrm{M}$ & $\mathrm{M}$ & $\mathrm{M}$ \\
\hline 15 & E-15 & KP & KP & $\mathrm{M}$ & KP & KP & KP & KP & $\mathrm{U}$ & KP & KP & KP & KP & KP & KP & KP \\
\hline 16 & E-16 & $\mathrm{M}$ & KP & KP & $P$ & KP & $P$ & KP & $\mathrm{U}$ & $\mathrm{M}$ & KP & $\mathrm{M}$ & KP & KP & $M$ & KP \\
\hline 17 & E-17 & KP & KP & KP & KP & $\mathrm{U}$ & KP & $\mathrm{KP}$ & KP & KP & KP & KP & KP & KP & KP & KP \\
\hline 18 & E-18 & KP & KP & KP & KP & KP & KP & KP & KP & KP & KP & KP & $\mathrm{U}$ & KP & KP & KP \\
\hline 19 & E-19 & KP & KP & KP & KP & KP & KP & KP & KP & KP & KP & KP & KP & KP & KP & KP \\
\hline 20 & E-20 & $\mathrm{M}$ & $\mathrm{M}$ & $\mathrm{M}$ & $\mathrm{M}$ & $P$ & KP & KP & $\mathrm{U}$ & KP & KP & KP & KP & $\mathrm{U}$ & KP & $\mathrm{U}$ \\
\hline 21 & E-21 & KP & KP & KP & KP & KP & KP & KP & KP & KP & KP & KP & KP & KP & KP & KP \\
\hline 22 & E-22 & KP & KP & KP & $\mathrm{M}$ & KP & KP & KP & $\mathrm{U}$ & KP & KP & KP & KP & KP & KP & KP \\
\hline 23 & E-23 & KP & $\mathrm{M}$ & M & $\mathrm{M}$ & KP & KP & $\mathrm{M}$ & $\mathrm{U}$ & KP & KP & KP & KP & KP & $\mathrm{M}$ & KP \\
\hline 24 & E-24 & $\mathrm{M}$ & $\mathrm{M}$ & $\mathrm{M}$ & $\mathrm{M}$ & $\mathrm{M}$ & $\mathrm{M}$ & $\mathrm{M}$ & M & $\mathrm{M}$ & $\mathrm{M}$ & $\mathrm{M}$ & $\mathrm{M}$ & $\mathrm{M}$ & $P$ & $\mathrm{M}$ \\
\hline 25 & E-25 & $\mathrm{M}$ & $\mathrm{M}$ & $\mathrm{M}$ & $\mathrm{M}$ & $\mathrm{M}$ & $P$ & $\mathrm{M}$ & $P$ & $\mathrm{M}$ & $\mathrm{M}$ & $\mathrm{M}$ & $\mathrm{M}$ & $\mathrm{M}$ & $\mathrm{M}$ & $\mathrm{M}$ \\
\hline 26 & E-26 & KP & KP & KP & KP & $\mathrm{U}$ & $\mathrm{U}$ & KP & KP & KP & $\mathrm{KP}$ & KP & KP & KP & KP & KP \\
\hline 27 & E-27 & KP & KP & KP & KP & KP & KP & KP & KP & KP & KP & KP & KP & KP & KP & KP \\
\hline 28 & E-28 & KP & KP & KP & KP & $\mathrm{M}$ & KP & KP & $\mathrm{U}$ & KP & KP & KP & KP & KP & KP & KP \\
\hline 29 & E-29 & $\mathrm{M}$ & KP & KP & KP & KP & $\mathrm{P}$ & $\mathrm{M}$ & $P$ & KP & KP & KP & KP & $\mathrm{M}$ & KP & KP \\
\hline 30 & E-30 & KP & KP & KP & KP & KP & KP & KP & KP & KP & KP & KP & KP & KP & KP & KP \\
\hline 31 & E-31 & $\mathrm{M}$ & $M$ & $M$ & KP & $\mathrm{U}$ & KP & $\mathrm{M}$ & KP & $\mathrm{U}$ & $\mathrm{KP}$ & KP & KP & KP & KP & KP \\
\hline 32 & E-32 & KP & $\mathrm{M}$ & $\mathrm{M}$ & $\mathrm{M}$ & $P$ & KP & KP & KP & KP & $\mathrm{M}$ & $\mathrm{M}$ & $\mathrm{M}$ & KP & $\mathrm{M}$ & $\mathrm{M}$ \\
\hline 33 & E-33 & KP & $\mathrm{KP}$ & KP & KP & $\mathrm{M}$ & $\mathrm{U}$ & KP & KP & KP & KP & $\mathrm{U}$ & KP & KP & KP & KP \\
\hline 34 & E-34 & KP & $\mathrm{M}$ & $\mathrm{M}$ & $\mathrm{M}$ & $\mathrm{P}$ & $\mathrm{M}$ & KP & $\mathrm{U}$ & KP & $\mathrm{KP}$ & KP & KP & $\mathrm{U}$ & KP & $\mathrm{U}$ \\
\hline 35 & E-35 & $\mathrm{M}$ & $\mathrm{M}$ & $\mathrm{M}$ & $\mathrm{M}$ & $\mathrm{M}$ & $\mathrm{M}$ & $\mathrm{M}$ & $\mathrm{M}$ & M & $\mathrm{M}$ & $\mathrm{M}$ & $\mathrm{M}$ & $\mathrm{M}$ & $\mathrm{P}$ & $\mathrm{M}$ \\
\hline 36 & E-36 & $\mathrm{M}$ & M & $\mathrm{M}$ & KP & $\mathrm{M}$ & $\mathrm{M}$ & KP & $\mathrm{M}$ & $\mathrm{M}$ & KP & KP & $\mathrm{M}$ & KP & KP & KP \\
\hline & $\sum \mathbf{P}$ & $\mathbf{0}$ & 0 & 0 & 1 & 5 & 5 & $\mathbf{0}$ & 3 & 0 & $\mathbf{0}$ & 0 & 0 & 0 & 2 & 0 \\
\hline & $\Sigma U$ & 0 & 2 & 1 & 2 & 3 & 6 & 1 & 10 & 1 & 0 & 1 & 1 & 3 & 0 & 3 \\
\hline & $\sum \mathbf{M}$ & 12 & 14 & 15 & 15 & 9 & 7 & 10 & 5 & 10 & 9 & 9 & 8 & 7 & 10 & 8 \\
\hline & $\sum \mathrm{KP}$ & 24 & 20 & 20 & 18 & 19 & 18 & 25 & 18 & 25 & 27 & 26 & 27 & 26 & 24 & 25 \\
\hline & $\% \mathrm{P}$ & $\mathbf{0}$ & 0 & $\mathbf{0}$ & 2,8 & 14 & 14 & 0 & 8,3 & 0 & $\mathbf{0}$ & $\mathbf{0}$ & $\mathbf{0}$ & $\mathbf{0}$ & 5,6 & $\mathbf{0}$ \\
\hline & $\% \mathrm{U}$ & 0 & 5,6 & 2,8 & 5,6 & 8,3 & 17 & 2,8 & 28 & 2,8 & 0 & 2,8 & 2,8 & 8,3 & 0 & 8,3 \\
\hline & $\% \mathbf{M}$ & 33 & 39 & 42 & 42 & 25 & 19 & 28 & 14 & 28 & 25 & 25 & 22 & 19 & 28 & 22 \\
\hline & $\% \mathrm{KP}$ & 67 & 56 & 56 & 50 & 53 & 50 & 69 & 50 & 69 & 75 & 72 & 75 & 72 & 67 & 69 \\
\hline Tot & tal \% P & & & & & & & & 2,96 & & & & & & & \\
\hline Tot & tal \% U & & & & & & & & 6,30 & & & & & & & \\
\hline Tot & tal \% $\mathbf{M}$ & & & & & & & & 27,4 & & & & & & & \\
\hline Tot: & al \% KP & & & & & & & & 63,3 & & & & & & & \\
\hline
\end{tabular}


Lampiran 27. Analisis Posttest Soal Three-tier Multiple Choice

\section{Kelas Kontrol:}

\begin{tabular}{|c|c|c|c|c|c|c|c|c|c|c|c|c|c|c|c|c|}
\hline \multirow{2}{*}{ No. } & \multirow{2}{*}{ Kode } & \multicolumn{15}{|c|}{ Nomor Soal } \\
\hline & & 1 & 2 & 3 & 4 & 5 & 6 & 7 & 8 & 9 & 10 & 11 & 12 & 13 & 14 & 15 \\
\hline 1. & K-01 & $\mathrm{P}$ & $\mathrm{P}$ & $\mathrm{P}$ & $\mathrm{P}$ & $\mathrm{M}$ & $\mathrm{P}$ & $\mathrm{M}$ & $\mathrm{M}$ & $\mathrm{P}$ & $\mathrm{P}$ & $\mathrm{P}$ & $\mathrm{M}$ & $\mathrm{M}$ & $\mathrm{M}$ & $\mathrm{M}$ \\
\hline 2. & K-02 & $\mathrm{M}$ & $\mathrm{M}$ & $\mathrm{M}$ & $\mathrm{M}$ & $\mathrm{M}$ & $\mathrm{M}$ & $M$ & $\mathrm{M}$ & $\mathrm{M}$ & $\mathrm{M}$ & $\mathrm{M}$ & $\mathrm{M}$ & $\mathrm{M}$ & $\mathrm{P}$ & $\mathrm{M}$ \\
\hline 3. & K-03 & $\mathrm{M}$ & $\mathrm{M}$ & $\mathrm{M}$ & $\mathrm{KP}$ & $\mathrm{M}$ & $\mathrm{KP}$ & $\mathrm{M}$ & $\mathrm{KP}$ & $\mathrm{KP}$ & $\mathrm{KP}$ & $\mathrm{KP}$ & $\mathrm{M}$ & $\mathrm{KP}$ & $\mathrm{M}$ & $\mathrm{KP}$ \\
\hline 4. & K-04 & $\mathrm{M}$ & $\mathrm{P}$ & $\mathrm{P}$ & $\mathrm{U}$ & $\mathrm{U}$ & $\mathrm{U}$ & $\mathrm{M}$ & $\mathrm{U}$ & $\mathrm{P}$ & $\mathrm{P}$ & $\mathrm{P}$ & $\mathrm{KP}$ & $\mathrm{M}$ & $\mathrm{U}$ & $\mathrm{KP}$ \\
\hline 5. & K-05 & KP & $\mathrm{U}$ & $\mathrm{U}$ & $\mathrm{U}$ & KP & KP & KP & $\mathrm{U}$ & $\mathrm{U}$ & KP & $\mathrm{U}$ & KP & KP & $\mathrm{U}$ & $\mathrm{KP}$ \\
\hline 6. & K-06 & $\mathrm{P}$ & $\mathrm{KP}$ & $\mathrm{U}$ & KP & $\mathrm{KP}$ & $\mathrm{M}$ & $\mathrm{M}$ & $\mathrm{M}$ & $\mathrm{M}$ & $\mathrm{U}$ & $\mathrm{U}$ & $\mathrm{KP}$ & $\mathrm{KP}$ & $\mathrm{KP}$ & KP \\
\hline 7. & K-07 & $M$ & $\mathrm{P}$ & $\mathrm{P}$ & $\mathrm{P}$ & $\mathrm{U}$ & $\mathrm{U}$ & $\mathrm{KP}$ & $\mathrm{P}$ & $\mathrm{P}$ & $P$ & $P$ & $\mathrm{KP}$ & $\mathrm{KP}$ & $\mathrm{KP}$ & KP \\
\hline 8. & K-08 & $M$ & $\mathrm{P}$ & $\mathrm{P}$ & $\mathrm{P}$ & $\mathrm{P}$ & $\mathrm{U}$ & KP & $\mathrm{U}$ & $\mathrm{P}$ & $\mathrm{U}$ & $\mathrm{U}$ & $\mathrm{U}$ & KP & $\mathrm{U}$ & $\mathrm{KP}$ \\
\hline 9. & K-09 & $M$ & $\mathrm{P}$ & $\mathrm{P}$ & $M$ & $M$ & $\mathrm{M}$ & $\mathrm{M}$ & $\mathrm{P}$ & $\mathrm{M}$ & $\mathrm{M}$ & $P$ & $\mathrm{P}$ & $\mathrm{M}$ & $M$ & $M$ \\
\hline 10. & K-10 & $M$ & $M$ & $\mathrm{P}$ & $\mathrm{M}$ & $M$ & $\mathrm{P}$ & $\mathrm{M}$ & $\mathrm{M}$ & $\mathrm{P}$ & $M$ & $\mathrm{P}$ & $M$ & $\mathrm{M}$ & $M$ & $M$ \\
\hline 11. & K-11 & $P$ & $\mathrm{P}$ & $\mathrm{U}$ & KP & $\mathrm{P}$ & $M$ & KP & KP & $M$ & KP & KP & $M$ & KP & $M$ & $M$ \\
\hline 12. & K-12 & $M$ & $\mathrm{P}$ & $\mathrm{P}$ & $\mathrm{P}$ & $\mathrm{P}$ & $\mathrm{U}$ & $\mathrm{M}$ & $\mathrm{P}$ & $\mathrm{P}$ & $\mathrm{P}$ & $\mathrm{P}$ & $\mathrm{U}$ & $\mathrm{KP}$ & $\mathrm{U}$ & $M$ \\
\hline 13. & K-13 & $\mathrm{U}$ & $\mathrm{P}$ & $\mathrm{P}$ & KP & $M$ & $\mathrm{U}$ & KP & KP & $\mathrm{P}$ & $M$ & $M$ & $M$ & $M$ & $M$ & $M$ \\
\hline 14. & K-14 & $\mathrm{KP}$ & $\mathrm{P}$ & $\mathrm{M}$ & $M$ & $\mathrm{M}$ & $M$ & $\mathrm{M}$ & KP & $\mathrm{KP}$ & $\mathrm{KP}$ & $\mathrm{KP}$ & $M$ & $\mathrm{KP}$ & $\mathrm{KP}$ & $M$ \\
\hline 15. & K-15 & $\mathrm{P}$ & $P$ & KP & $M$ & $M$ & $\mathrm{P}$ & $M$ & $M$ & M & M & $\mathrm{M}$ & $M$ & M & M & $M$ \\
\hline 16. & K-16 & $\mathrm{KP}$ & $\mathrm{M}$ & $\mathrm{M}$ & $M$ & $\mathrm{M}$ & $M$ & $\mathrm{M}$ & $M$ & $\mathrm{M}$ & $M$ & $\mathrm{M}$ & $M$ & $\mathrm{M}$ & $M$ & $\mathrm{M}$ \\
\hline 17. & K-17 & $\mathrm{P}$ & $\mathrm{P}$ & $\mathrm{P}$ & $M$ & $\mathrm{P}$ & $\mathrm{P}$ & $\mathrm{M}$ & $\mathrm{P}$ & $\mathrm{P}$ & $M$ & $\mathrm{P}$ & $\mathrm{P}$ & $\mathrm{M}$ & $M$ & $\mathrm{P}$ \\
\hline 18. & K-18 & $P$ & $P$ & $P$ & $M$ & $M$ & $P$ & M & $M$ & $\mathrm{P}$ & $M$ & $M$ & $M$ & $M$ & $M$ & $M$ \\
\hline 19. & K-19 & $M$ & $\mathrm{P}$ & $\mathrm{P}$ & $\mathrm{P}$ & $\mathrm{P}$ & $\mathrm{P}$ & $M$ & $\mathrm{P}$ & $\mathrm{P}$ & $\mathrm{P}$ & $\mathrm{P}$ & $\mathrm{P}$ & $M$ & $\mathrm{P}$ & $M$ \\
\hline 20. & K-20 & $\mathrm{P}$ & $\mathrm{M}$ & $\mathrm{KP}$ & $\mathrm{KP}$ & $M$ & $\mathrm{U}$ & $\mathrm{M}$ & $\mathrm{P}$ & $\mathrm{M}$ & $\mathrm{P}$ & $\mathrm{KP}$ & $\mathrm{KP}$ & $\mathrm{KP}$ & $\mathrm{KP}$ & $\mathrm{KP}$ \\
\hline 21. & K-21 & $\mathrm{P}$ & $\mathrm{P}$ & $\mathrm{P}$ & KP & $M$ & $\mathrm{U}$ & KP & KP & $\mathrm{P}$ & $\mathrm{KP}$ & $\mathrm{M}$ & $\mathrm{M}$ & $\mathrm{M}$ & $\mathrm{M}$ & $M$ \\
\hline 22. & K-22 & $\mathrm{P}$ & $M$ & $M$ & $\mathrm{KP}$ & $\mathrm{M}$ & $\mathrm{P}$ & $\mathrm{KP}$ & KP & $\mathrm{P}$ & $\mathrm{M}$ & $\mathrm{P}$ & $M$ & $M$ & $M$ & $\mathrm{M}$ \\
\hline 23. & K-23 & $M$ & $M$ & $M$ & $M$ & $\mathrm{M}$ & $M$ & $\mathrm{M}$ & $\mathrm{M}$ & $\mathrm{M}$ & $\mathrm{M}$ & $M$ & $M$ & $M$ & $M$ & $M$ \\
\hline 24. & K-24 & $M$ & $\mathrm{P}$ & $M$ & $\mathrm{U}$ & $\mathrm{U}$ & $\mathrm{U}$ & KP & $\mathrm{U}$ & M & $P$ & $\mathrm{P}$ & $\mathrm{U}$ & KP & $\mathrm{U}$ & KP \\
\hline 25. & K-25 & $M$ & $M$ & $M$ & $\mathrm{KP}$ & $M$ & $\mathrm{KP}$ & KP & KP & $\mathrm{P}$ & $\mathrm{KP}$ & $\mathrm{KP}$ & $\mathrm{KP}$ & $\mathrm{KP}$ & KP & $M$ \\
\hline 26. & K-26 & $\mathrm{P}$ & $\mathrm{P}$ & $\mathrm{P}$ & $\mathrm{P}$ & $\mathrm{P}$ & $\mathrm{P}$ & $\mathrm{P}$ & $\mathrm{P}$ & $\mathrm{P}$ & $\mathrm{M}$ & $\mathrm{M}$ & $\mathrm{P}$ & $\mathrm{M}$ & $\mathrm{M}$ & $M$ \\
\hline 27. & K-27 & $\mathrm{P}$ & $M$ & $\mathrm{M}$ & $\mathrm{M}$ & $M$ & $M$ & $M$ & KP & $\mathrm{M}$ & $M$ & $\mathrm{P}$ & $\mathrm{KP}$ & $M$ & $\mathrm{KP}$ & $M$ \\
\hline 28. & K-28 & $\mathrm{P}$ & $\mathrm{P}$ & $\mathrm{P}$ & KP & $M$ & $\mathrm{U}$ & $M$ & $\mathrm{M}$ & $\mathrm{P}$ & $M$ & $M$ & $M$ & $M$ & $\mathrm{M}$ & $M$ \\
\hline 29. & K-29 & $\mathrm{M}$ & $M$ & $\mathrm{M}$ & $\mathrm{M}$ & $\mathrm{P}$ & $\mathrm{P}$ & $M$ & $M$ & $M$ & $M$ & $\mathrm{P}$ & $M$ & $M$ & $M$ & $\mathrm{M}$ \\
\hline 30. & K-30 & $\mathrm{M}$ & $\mathrm{M}$ & $\mathrm{M}$ & $\mathrm{M}$ & $\mathrm{P}$ & $\mathrm{M}$ & $\mathrm{M}$ & $\mathrm{M}$ & $\mathrm{P}$ & $\mathrm{M}$ & $\mathrm{M}$ & $\mathrm{M}$ & $\mathrm{M}$ & $\mathrm{M}$ & $\mathrm{M}$ \\
\hline 31. & K-31 & $\mathrm{P}$ & $M$ & $M$ & $\mathrm{KP}$ & $\mathrm{P}$ & $M$ & $\mathrm{M}$ & $\mathrm{P}$ & $\mathrm{KP}$ & $\mathrm{KP}$ & $\mathrm{M}$ & $\mathrm{M}$ & $\mathrm{KP}$ & $\mathrm{KP}$ & $\mathrm{KP}$ \\
\hline 32. & K-32 & $\mathrm{P}$ & $\mathrm{P}$ & $P$ & $\mathrm{M}$ & $\mathrm{M}$ & $\mathrm{U}$ & KP & KP & $\mathrm{U}$ & $M$ & $P$ & KP & KP & KP & KP \\
\hline 33. & K-33 & M & $\mathrm{M}$ & $\mathrm{KP}$ & $\mathrm{KP}$ & $\mathrm{KP}$ & $\mathrm{KP}$ & $\mathrm{KP}$ & KP & $\mathrm{KP}$ & $\mathrm{KP}$ & $\mathrm{KP}$ & $\mathrm{KP}$ & $\mathrm{KP}$ & $\mathrm{KP}$ & $\mathrm{KP}$ \\
\hline 34 & K-34 & KP & KP & $\mathrm{M}$ & $\mathrm{KP}$ & $\mathrm{M}$ & $\mathrm{P}$ & $\mathrm{M}$ & KP & $\mathrm{M}$ & $\mathrm{M}$ & $\mathrm{M}$ & $\mathrm{M}$ & $\mathrm{M}$ & $\mathrm{KP}$ & $M$ \\
\hline & $P$ & 14 & 18 & 15 & 6 & 9 & 10 & 1 & 8 & 16 & 7 & 13 & 4 & 0 & 2 & 1 \\
\hline & $\sum \mathbf{U}$ & 1 & 1 & 3 & 3 & 3 & 10 & $\mathbf{0}$ & 4 & 2 & 2 & 3 & 3 & $\mathbf{0}$ & 5 & 0 \\
\hline & $\mathrm{M}$ & 15 & 13 & 13 & 13 & 19 & 10 & 22 & 11 & 12 & 17 & 12 & 18 & 20 & 17 & 22 \\
\hline & $\mathrm{KP}$ & 4 & 2 & 3 & 12 & 3 & 4 & 11 & 11 & 4 & 8 & 6 & 9 & 14 & 10 & 11 \\
\hline & $0 \mathrm{P}$ & 41 & 53 & 44 & 18 & 26 & 29 & 2,9 & 24 & 47 & 21 & 38 & 12 & $\mathbf{0}$ & 5,9 & 2,9 \\
\hline & $0 \mathrm{U}$ & 2,9 & 2,9 & 8,8 & 8,8 & 8,8 & 29 & 0 & 12 & 5,9 & 5,9 & 8,8 & 8,8 & 0 & 15 & 0 \\
\hline & o M & 44 & 38 & 38 & 38 & 56 & 29 & 65 & 32 & 35 & 50 & 35 & 53 & 59 & 50 & 65 \\
\hline & KP & 12 & 5,9 & 8,8 & 35 & 8,8 & 12 & 32 & 32 & 12 & 24 & 18 & 26 & 41 & 29 & 32 \\
\hline To & al \% $\mathrm{P}$ & & & & & & & & 24,3 & & & & & & & \\
\hline To & al \% U & & & & & & & & 7,84 & & & & & & & \\
\hline To & $1 \% \mathrm{M}$ & & & & & & & & 45,8 & & & & & & & \\
\hline Tot & $1 \% \mathrm{KP}$ & & & & & & & & 21,9 & & & & & & & \\
\hline
\end{tabular}




\section{Kelas Eksperimen:}

\begin{tabular}{|c|c|c|c|c|c|c|c|c|c|c|c|c|c|c|c|c|}
\hline \multirow{2}{*}{ No. } & \multirow{2}{*}{ Kode } & \multicolumn{15}{|c|}{ Nomor Soal } \\
\hline & & 1 & 2 & 3 & 4 & 5 & 6 & 7 & 8 & 9 & 10 & 11 & 12 & 13 & 14 & 15 \\
\hline 1 & E-01 & $\mathrm{M}$ & $\mathrm{M}$ & $\mathrm{P}$ & $\mathrm{P}$ & $\mathrm{P}$ & $P$ & $\mathrm{P}$ & $\mathrm{P}$ & $P$ & $\mathrm{M}$ & $\mathrm{P}$ & $\mathrm{P}$ & $\mathrm{P}$ & $P$ & $\mathrm{P}$ \\
\hline 2 & E-02 & $P$ & $\mathrm{P}$ & $\mathrm{P}$ & $P$ & $\mathrm{M}$ & KP & KP & KP & $\mathrm{P}$ & KP & $\mathrm{U}$ & KP & KP & KP & KP \\
\hline 3 & E-03 & $\mathrm{M}$ & KP & KP & M & $\mathrm{KP}$ & KP & $\mathrm{KP}$ & KP & KP & $\mathrm{U}$ & KP & KP & KP & KP & KP \\
\hline 4 & E-04 & $\mathrm{M}$ & $\mathrm{M}$ & $\mathrm{P}$ & KP & $\mathrm{KP}$ & $\mathrm{P}$ & KP & $\mathrm{U}$ & $\mathrm{M}$ & KP & $\mathrm{M}$ & KP & $\mathrm{M}$ & KP & $\mathrm{M}$ \\
\hline 5 & E-05 & $\mathrm{P}$ & $\mathrm{P}$ & KP & $\mathrm{M}$ & $\mathrm{KP}$ & $\mathrm{P}$ & M & M & $\mathrm{M}$ & KP & M & $\mathrm{M}$ & KP & KP & M \\
\hline 6 & E-06 & $\mathrm{P}$ & $\mathrm{P}$ & $\mathrm{P}$ & $\mathrm{M}$ & $\mathrm{M}$ & $P$ & $\mathrm{M}$ & $\mathrm{P}$ & $\mathrm{M}$ & $\mathrm{M}$ & $\mathrm{P}$ & $\mathrm{M}$ & $\mathrm{M}$ & KP & $\mathrm{M}$ \\
\hline 7 & E-07 & $\mathrm{P}$ & $\mathrm{M}$ & $\mathrm{P}$ & $\mathrm{P}$ & $\mathrm{P}$ & $\mathrm{P}$ & $\mathrm{P}$ & $\mathrm{P}$ & $\mathrm{P}$ & $\mathrm{M}$ & $\mathrm{P}$ & $\mathrm{P}$ & $\mathrm{P}$ & $\mathrm{P}$ & $\mathrm{M}$ \\
\hline 8 & E-08 & $\mathrm{M}$ & $P$ & $\mathrm{P}$ & $P$ & $\mathrm{M}$ & $P$ & $\mathrm{P}$ & M & M & $\mathrm{M}$ & $P$ & $P$ & $\mathrm{M}$ & $\mathrm{M}$ & $\mathrm{M}$ \\
\hline 9 & E-09 & $P$ & $\mathrm{P}$ & $\mathrm{P}$ & $\mathrm{M}$ & M & $\mathrm{M}$ & $\mathrm{M}$ & $\mathrm{P}$ & $\mathrm{M}$ & $\mathrm{M}$ & $\mathrm{M}$ & $\mathrm{M}$ & $\mathrm{M}$ & $\mathrm{M}$ & $\mathrm{P}$ \\
\hline 10 & E-10 & $P$ & $P$ & $P$ & M & $\mathrm{KP}$ & $P$ & $\mathrm{M}$ & $\mathrm{M}$ & $P$ & $\mathrm{KP}$ & $P$ & $P$ & KP & KP & KP \\
\hline 11 & E-11 & $P$ & $\mathrm{U}$ & $P$ & $\mathrm{M}$ & $\mathrm{P}$ & $P$ & $\mathrm{KP}$ & $P$ & $P$ & $\mathrm{KP}$ & $P$ & KP & $\mathrm{M}$ & $\mathrm{P}$ & $\mathrm{M}$ \\
\hline 12 & E-12 & $\mathrm{P}$ & $\mathrm{P}$ & $\mathrm{U}$ & $\mathrm{P}$ & M & $\mathrm{P}$ & $\mathrm{M}$ & $\mathrm{M}$ & M & $\mathrm{P}$ & $P$ & $P$ & $P$ & $\mathrm{M}$ & $P$ \\
\hline 13 & E-13 & $\mathrm{M}$ & $\mathrm{M}$ & $P$ & $\mathrm{M}$ & $\mathrm{M}$ & $P$ & $\mathrm{M}$ & KP & $P$ & $\mathrm{M}$ & $\mathrm{M}$ & $P$ & $P$ & $P$ & $\mathrm{M}$ \\
\hline 14 & E-14 & $\mathrm{M}$ & $\mathrm{P}$ & $\mathrm{P}$ & $\mathrm{M}$ & $\mathrm{M}$ & $P$ & $\mathrm{M}$ & $\mathrm{P}$ & $P$ & $\mathrm{M}$ & $\mathrm{P}$ & $\mathrm{M}$ & $P$ & KP & KP \\
\hline 15 & E-15 & $\mathrm{M}$ & KP & KP & KP & $P$ & KP & KP & KP & $\mathrm{U}$ & KP & $\mathrm{U}$ & $\mathrm{U}$ & KP & KP & $\mathrm{U}$ \\
\hline 16 & E-16 & $\mathrm{M}$ & $\mathrm{P}$ & $P$ & $P$ & $\mathrm{M}$ & $P$ & $\mathrm{M}$ & $\mathrm{M}$ & $\mathrm{M}$ & $\mathrm{M}$ & $P$ & KP & $P$ & $M$ & KP \\
\hline 17 & E-17 & $P$ & KP & KP & KP & $\mathrm{M}$ & $\mathrm{M}$ & $\mathrm{M}$ & KP & $\mathrm{M}$ & $\mathrm{M}$ & KP & KP & $P$ & KP & $\mathrm{M}$ \\
\hline \begin{tabular}{|l|}
18 \\
\end{tabular} & E-18 & $\mathrm{P}$ & $\mathrm{M}$ & $\mathrm{P}$ & $\mathrm{P}$ & $\mathrm{P}$ & $\mathrm{P}$ & $\mathrm{P}$ & $\mathrm{P}$ & $\mathrm{M}$ & $\mathrm{M}$ & $\mathrm{P}$ & $P$ & $P$ & $\mathrm{M}$ & $P$ \\
\hline \begin{tabular}{|l|}
19 \\
\end{tabular} & E-19 & $M$ & $P$ & $P$ & $P$ & $P$ & $P$ & $P$ & $P$ & $P$ & $\mathrm{M}$ & $P$ & $P$ & $\mathrm{M}$ & $\mathrm{P}$ & $\mathrm{M}$ \\
\hline 20 & E-20 & $P$ & $P$ & $\mathrm{M}$ & $\mathrm{M}$ & M & $P$ & M & M & $\mathrm{M}$ & M & $P$ & M & $\mathrm{M}$ & $\mathrm{M}$ & $P$ \\
\hline \begin{tabular}{|l|}
21 \\
\end{tabular} & E-21 & $P$ & $\mathrm{P}$ & $\mathrm{M}$ & $\mathrm{M}$ & $\mathrm{M}$ & $\mathrm{P}$ & $\mathrm{M}$ & KP & $\mathrm{M}$ & $\mathrm{M}$ & $P$ & $P$ & $\mathrm{M}$ & $\mathrm{M}$ & $\mathrm{M}$ \\
\hline \begin{tabular}{|l|}
22 \\
\end{tabular} & E-22 & $P$ & $\mathrm{M}$ & $\mathrm{M}$ & $\mathrm{M}$ & $\mathrm{M}$ & $\mathrm{M}$ & $\mathrm{P}$ & $\mathrm{M}$ & $\mathrm{M}$ & $\mathrm{M}$ & M & $P$ & $\mathrm{M}$ & M & $\mathrm{M}$ \\
\hline 23 & E-23 & $\mathrm{M}$ & $\mathrm{P}$ & $\mathrm{M}$ & $\mathrm{P}$ & $\mathrm{M}$ & $\mathrm{U}$ & $P$ & $\mathrm{M}$ & $\mathrm{P}$ & $\mathrm{M}$ & $\mathrm{P}$ & $\mathrm{P}$ & $\mathrm{P}$ & KP & $\mathrm{M}$ \\
\hline 24 & E-24 & $P$ & $P$ & $\mathrm{M}$ & KP & $\mathrm{M}$ & $\mathrm{M}$ & $\mathrm{M}$ & M & $\mathrm{M}$ & $M$ & $P$ & $P$ & $\mathrm{M}$ & $\mathrm{M}$ & $\mathrm{M}$ \\
\hline 25 & E-25 & $P$ & $P$ & $P$ & $\mathrm{M}$ & $\mathrm{M}$ & $P$ & $\mathrm{M}$ & $P$ & $\mathrm{M}$ & $\mathrm{M}$ & $\mathrm{M}$ & $\mathrm{M}$ & $\mathrm{M}$ & $\mathrm{M}$ & $\mathrm{M}$ \\
\hline 26 & E-26 & $P$ & $P$ & $P$ & $P$ & $\mathrm{U}$ & $\mathrm{U}$ & $P$ & $\mathrm{U}$ & $P$ & $\mathrm{KP}$ & $P$ & $\mathrm{U}$ & $P$ & $P$ & M \\
\hline 27 & E-27 & $P$ & $\mathrm{M}$ & $\mathrm{M}$ & $P$ & KP & $\mathrm{M}$ & $P$ & $\mathrm{M}$ & $\mathrm{M}$ & $\mathrm{M}$ & M & $\mathrm{M}$ & KP & $\mathrm{M}$ & $\mathrm{M}$ \\
\hline 28 & E-28 & $P$ & $\mathrm{M}$ & $P$ & $P$ & $P$ & $P$ & $P$ & $P$ & $\mathrm{M}$ & $P$ & $P$ & $P$ & $\mathrm{M}$ & $P$ & $P$ \\
\hline 29 & E-29 & $\mathrm{M}$ & $\mathrm{M}$ & $P$ & $\mathrm{M}$ & $\mathrm{M}$ & KP & $\mathrm{M}$ & $P$ & $\mathrm{M}$ & M & $P$ & $P$ & $\mathrm{M}$ & $\mathrm{M}$ & $\mathrm{M}$ \\
\hline 30 & E-30 & KP & KP & $\mathrm{P}$ & $\mathrm{U}$ & KP & KP & KP & KP & $\mathrm{M}$ & KP & $\mathrm{U}$ & $\mathrm{U}$ & $\mathrm{U}$ & $P$ & $\mathrm{M}$ \\
\hline 31 & E-31 & $\mathrm{M}$ & $\mathrm{M}$ & $\mathrm{M}$ & KP & $P$ & M & $\mathrm{M}$ & $\mathrm{M}$ & KP & $\mathrm{U}$ & M & $\mathrm{M}$ & $P$ & KP & $\mathrm{M}$ \\
\hline 32 & E-32 & $\mathrm{M}$ & $P$ & $P$ & $P$ & $\mathrm{M}$ & $P$ & $\mathrm{M}$ & $P$ & $\mathrm{M}$ & $\mathrm{M}$ & $\mathrm{P}$ & $\mathrm{M}$ & $P$ & $P$ & M \\
\hline 33 & E-33 & $P$ & $P$ & $\mathrm{M}$ & $\mathrm{M}$ & $\mathrm{M}$ & $\mathrm{M}$ & $\mathrm{M}$ & $M$ & $\mathrm{M}$ & $\mathrm{M}$ & $P$ & $\mathrm{P}$ & $\mathrm{M}$ & $P$ & $\mathrm{M}$ \\
\hline 34 & E-34 & $P$ & $\mathrm{P}$ & $\mathrm{M}$ & $P$ & $\mathrm{M}$ & $\mathrm{P}$ & $\mathrm{M}$ & $\mathrm{M}$ & $\mathrm{M}$ & $P$ & $\mathrm{P}$ & $\mathrm{M}$ & $P$ & $\mathrm{M}$ & $P$ \\
\hline 35 & E-35 & $P$ & $\mathrm{M}$ & $\mathrm{M}$ & $\mathrm{M}$ & $\mathrm{M}$ & $\mathrm{M}$ & M & $\mathrm{M}$ & $\mathrm{M}$ & $\mathrm{M}$ & $P$ & $\mathrm{M}$ & $\mathrm{M}$ & $P$ & $\mathrm{M}$ \\
\hline 36 & E-36 & $\mathrm{M}$ & $\mathrm{M}$ & $\mathrm{M}$ & $P$ & $\mathrm{M}$ & $\mathrm{M}$ & $\mathrm{M}$ & $\mathrm{M}$ & $P$ & $P$ & $P$ & $\mathrm{M}$ & $\mathrm{M}$ & $\mathrm{M}$ & M \\
\hline & $\sum P$ & 21 & 19 & 20 & 15 & 8 & 20 & 10 & 12 & 11 & 4 & 23 & 15 & 13 & 11 & 7 \\
\hline & $\Sigma U$ & 0 & 1 & 1 & 1 & 1 & 2 & 0 & 2 & 1 & 2 & 3 & 3 & 1 & 0 & 1 \\
\hline & $\sum \mathbf{M}$ & 14 & 12 & 11 & 15 & 21 & 9 & 20 & 15 & 22 & 22 & 8 & 12 & 16 & 14 & 23 \\
\hline & $\sum \mathrm{KP}$ & 1 & 4 & 4 & 5 & 6 & 5 & 6 & 7 & 2 & 8 & 2 & 6 & 6 & 11 & 5 \\
\hline & $\% \mathrm{P}$ & 58 & 53 & 56 & 42 & 22 & 56 & 28 & 33 & 31 & 11 & 64 & 42 & 36 & 31 & 19 \\
\hline & $\% \mathrm{U}$ & 0 & 2,8 & 2,8 & 2,8 & 2,8 & 5,6 & 0 & 5,6 & 2,8 & 5,6 & 8,3 & 8,3 & 2,8 & 0 & 2,8 \\
\hline & $\% \mathbf{M}$ & 39 & 33 & 31 & 42 & 58 & 25 & 56 & 42 & 61 & 61 & 22 & 33 & 44 & 39 & 64 \\
\hline & $\% \mathrm{KP}$ & 2,8 & 11 & 11 & 14 & 17 & 14 & 17 & 19 & 5,6 & 22 & 5,6 & 17 & 17 & 31 & 14 \\
\hline Tot & tal \% P & & & & & & & & 38,7 & & & & & & & \\
\hline Tot & tal \% U & & & & & & & & 3,52 & & & & & & & \\
\hline Tot & tal \% M & & & & & & & & 43,3 & & & & & & & \\
\hline Tot: & al \% KP & & & & & & & & 14,4 & & & & & & & \\
\hline
\end{tabular}


Lampiran 28. Analisis Jawaban Soal Uraian

\section{Pretest Kelas Kontrol:}

\begin{tabular}{|c|c|c|c|c|c|c|c|c|c|c|c|}
\hline \multirow{2}{*}{ No. } & \multirow{2}{*}{ Kode } & \multicolumn{2}{|c|}{ No. 1} & \multicolumn{2}{|c|}{ No. 2} & \multicolumn{2}{|c|}{ No. 3} & \multicolumn{2}{|c|}{ No. 4} & \multicolumn{2}{|c|}{ No. 5} \\
\hline & & Skor & \%Skor & Skor & \%Skor & Skor & \%Skor & Skor & \%Skor & Skor & \%Skor \\
\hline 1 & K-01 & 0 & \begin{tabular}{|l|}
0 \\
\end{tabular} & 0 & \begin{tabular}{|l|}
0 \\
\end{tabular} & 0 & \begin{tabular}{|l|}
0 \\
\end{tabular} & 0 & \begin{tabular}{l|l}
0 & \\
\end{tabular} & 0 & \begin{tabular}{|l|}
0 \\
\end{tabular} \\
\hline 2 & K-02 & 0 & 0 & 0 & 0 & 0 & 0 & 0 & 0 & 0 & 0 \\
\hline 3 & K-03 & 0 & 0 & 0 & 0 & 0 & 0 & 0 & 0 & 0 & 0 \\
\hline 4 & K-04 & 15 & 50 & 0 & 0 & 0 & 0 & 0 & 0 & 0 & 0 \\
\hline 5 & K-05 & 5 & 16,667 & 0 & 0 & 0 & 0 & 0 & 0 & 0 & 0 \\
\hline 6 & K-06 & 0 & 0 & 0 & 0 & 0 & 0 & 0 & 0 & 0 & 0 \\
\hline 7 & K-07 & 15 & 50 & 0 & 0 & 0 & 0 & 0 & 0 & 0 & 0 \\
\hline 8 & K-08 & 5 & 16,667 & 0 & 0 & 0 & 0 & 10 & 50 & 0 & 0 \\
\hline 9 & K-09 & 5 & 16,667 & 0 & 0 & 0 & 0 & 10 & 50 & 0 & 0 \\
\hline 10 & K-10 & 0 & 0 & 1 & 4 & 0 & 0 & 0 & 0 & 0 & 0 \\
\hline 11 & $\mathrm{~K}-11$ & 0 & 0 & 0 & 0 & 0 & 0 & 0 & 0 & 0 & 0 \\
\hline 12 & $\mathrm{~K}-12$ & 5 & 16,667 & 0 & 0 & 0 & 0 & 10 & 50 & 0 & 0 \\
\hline 13 & $\mathrm{~K}-13$ & 0 & 0 & 0 & 0 & 0 & 0 & 0 & 0 & 0 & 0 \\
\hline 14 & K-14 & 0 & 0 & 1 & 4 & 0 & 0 & 0 & 0 & 0 & 0 \\
\hline 15 & K-15 & 5 & 16,667 & 0 & 0 & 0 & 0 & 0 & 0 & 0 & 0 \\
\hline 16 & K-16 & 0 & 0 & 0 & 0 & 0 & 0 & 0 & 0 & 0 & 0 \\
\hline 17 & $\mathrm{~K}-17$ & 0 & 0 & 0 & 0 & 0 & 0 & 0 & 0 & 0 & 0 \\
\hline 18 & $\mathrm{~K}-18$ & 1 & 3,3333 & 1 & 4 & 0 & 0 & 0 & 0 & 0 & 0 \\
\hline 19 & K-19 & 15 & 50 & 0 & 0 & 0 & 0 & 0 & 0 & 0 & 0 \\
\hline 20 & $\mathrm{~K}-20$ & 0 & 0 & 0 & 0 & 0 & 0 & 0 & 0 & 0 & 0 \\
\hline 21 & K-21 & 0 & 0 & 0 & 0 & 0 & 0 & 0 & 0 & 0 & 0 \\
\hline 22 & $\mathrm{~K}-22$ & 0 & 0 & 0 & 0 & 0 & 0 & 0 & 0 & 0 & 0 \\
\hline 23 & $\mathrm{~K}-23$ & 0 & 0 & 0 & 0 & 0 & 0 & 0 & 0 & 0 & 0 \\
\hline 24 & K-24 & 5 & 16,667 & 0 & 0 & 0 & 0 & 15 & 75 & 0 & 0 \\
\hline 25 & $\mathrm{~K}-25$ & 0 & 0 & 0 & 0 & 0 & 0 & 0 & 0 & 0 & 0 \\
\hline 26 & $\mathrm{~K}-26$ & 0 & 0 & 0 & 0 & 0 & 0 & 0 & 0 & 0 & 0 \\
\hline 27 & $\mathrm{~K}-27$ & 0 & 0 & 0 & 0 & 0 & 0 & 0 & 0 & 0 & 0 \\
\hline 28 & $\mathrm{~K}-28$ & 0 & 0 & 1 & 4 & 0 & 0 & 0 & 0 & 0 & 0 \\
\hline 29 & K-29 & 15 & 50 & 0 & 0 & 0 & 0 & 0 & 0 & 0 & 0 \\
\hline 30 & $\mathrm{~K}-30$ & 0 & 0 & 0 & 0 & 0 & 0 & 0 & 0 & 0 & 0 \\
\hline 31 & K-31 & 0 & 0 & 0 & 0 & 0 & 0 & 0 & 0 & 0 & 0 \\
\hline 32 & $\mathrm{~K}-32$ & 0 & 0 & 1 & 4 & 0 & 0 & 0 & 0 & 0 & 0 \\
\hline 33 & $\mathrm{~K}-33$ & 0 & 0 & 0 & 0 & 0 & 0 & 0 & 0 & 0 & 0 \\
\hline 34 & $\mathrm{~K}-34$ & 0 & 0 & 0 & 0 & 0 & 0 & 0 & 0 & 0 & 0 \\
\hline \multicolumn{2}{|c|}{ Jumlah } & 91 & 303,33 & 5 & 20 & 0 & 0 & 45 & 225 & 0 & 0 \\
\hline \multicolumn{2}{|c|}{$\%$ Total } & & \begin{tabular}{|l|}
8,92 \\
\end{tabular} & & 0,59 & & 0,00 & & 6,62 & & 0,00 \\
\hline
\end{tabular}




\section{Posttest Kelas Kontrol:}

\begin{tabular}{|c|c|c|c|c|c|c|c|c|c|c|c|}
\hline \multirow{2}{*}{ No. } & \multirow{2}{*}{ Kode } & \multicolumn{2}{|c|}{ No. 1} & \multicolumn{2}{|c|}{ No. 2} & \multicolumn{2}{|c|}{ No. 3} & \multicolumn{2}{|c|}{ No. 4} & \multicolumn{2}{|c|}{ No. 5} \\
\hline & & Skor & \%Skor & Skor & \%Skor & Skor & \%Skor & Skor & \%Skor & Skor & \%Skor \\
\hline 1 & $\mathrm{~K}-01$ & 10 & 33,333 & 20 & \begin{tabular}{|l|}
80 \\
\end{tabular} & 10 & 40 & 20 & 100 & 20 & 100 \\
\hline 2 & $\mathrm{~K}-02$ & 5 & 16,667 & 5 & 20 & 10 & 40 & 5 & 25 & 5 & 25 \\
\hline 3 & $\mathrm{~K}-03$ & 5 & 16,667 & 5 & 20 & 10 & 40 & 5 & 25 & 5 & 25 \\
\hline 4 & K-04 & 10 & 33,333 & 18 & 72 & 10 & 40 & 5 & 25 & 5 & 25 \\
\hline 5 & K-05 & 5 & 16,667 & 20 & 80 & 15 & 60 & 5 & 25 & 5 & 25 \\
\hline 6 & K-06 & 10 & 33,333 & 20 & 80 & 15 & 60 & 20 & 100 & 15 & 75 \\
\hline 7 & K-07 & 20 & 66,667 & 20 & 80 & 10 & 40 & 15 & 75 & 15 & 75 \\
\hline 8 & $\mathrm{~K}-08$ & 17 & 56,667 & 20 & 80 & 10 & 40 & 15 & 75 & 15 & 75 \\
\hline 9 & K-09 & 5 & 16,667 & 20 & 80 & 10 & 40 & 20 & 100 & 15 & 75 \\
\hline 10 & $\mathrm{~K}-10$ & 5 & 16,667 & 5 & 20 & 10 & 40 & 5 & 25 & 5 & 25 \\
\hline 11 & $\mathrm{~K}-11$ & 17 & 56,667 & 20 & 80 & 15 & 60 & 20 & 100 & 15 & 75 \\
\hline 12 & $\mathrm{~K}-12$ & 5 & 16,667 & 20 & 80 & 10 & 40 & 15 & 75 & 15 & 75 \\
\hline 13 & K-13 & 5 & 16,667 & 5 & 20 & 10 & 40 & 5 & 25 & 5 & 25 \\
\hline 14 & K-14 & 0 & 0 & 5 & 20 & 10 & 40 & 5 & 25 & 5 & 25 \\
\hline 15 & K-15 & 5 & 16,667 & 5 & 20 & 10 & 40 & 5 & 25 & 5 & 25 \\
\hline 16 & K-16 & 5 & 16,667 & 5 & 20 & 10 & 40 & 5 & 25 & 5 & 25 \\
\hline 17 & K-17 & 15 & 50 & 20 & 80 & 10 & 40 & 15 & 75 & 15 & 75 \\
\hline 18 & K-18 & 5 & 16,667 & 5 & 20 & 10 & 40 & 5 & 25 & 5 & 25 \\
\hline 19 & K-19 & 15 & 50 & 20 & 80 & 10 & 40 & 15 & 75 & 15 & 75 \\
\hline 20 & $\mathrm{~K}-20$ & 10 & 33,333 & 20 & 80 & 10 & 40 & 20 & 100 & 10 & 50 \\
\hline 21 & $\mathrm{~K}-21$ & 5 & 16,667 & 5 & 20 & 10 & 40 & 5 & 25 & 5 & 25 \\
\hline 22 & $\mathrm{~K}-22$ & 5 & 16,667 & 5 & 20 & 10 & 40 & 5 & 25 & 5 & 25 \\
\hline 23 & $\mathrm{~K}-23$ & 5 & 16,667 & 5 & 20 & 10 & 40 & 5 & 25 & 5 & 25 \\
\hline 24 & K-24 & 15 & 50 & 20 & 80 & 15 & 60 & 20 & 100 & 20 & 100 \\
\hline 25 & K-25 & 5 & 16,667 & 5 & 20 & 10 & 40 & 5 & 25 & 5 & 25 \\
\hline 26 & K-26 & 20 & \begin{tabular}{|l|}
66,667 \\
\end{tabular} & 5 & 20 & 10 & 40 & 5 & 25 & 5 & 25 \\
\hline 27 & K-27 & 17 & 56,667 & 20 & 80 & 15 & 60 & 20 & 100 & 15 & 75 \\
\hline 28 & $\mathrm{~K}-28$ & 5 & 16,667 & 5 & 20 & 10 & 40 & 5 & 25 & 5 & 25 \\
\hline 29 & K-29 & 5 & 16,667 & 5 & 20 & 10 & 40 & 5 & 25 & 5 & 25 \\
\hline 30 & K-30 & 5 & 16,667 & 5 & 20 & 10 & 40 & 5 & 25 & 5 & 25 \\
\hline 31 & K-31 & 17 & 56,667 & 20 & 80 & 15 & 60 & 20 & 100 & 15 & 75 \\
\hline 32 & K-32 & 5 & 16,667 & 5 & 20 & 10 & 40 & 5 & 25 & 5 & 25 \\
\hline 33 & K-33 & 5 & 16,667 & 5 & 20 & 10 & 40 & 5 & 25 & 5 & 25 \\
\hline 34 & K-34 & 5 & 16,667 & 5 & 20 & 10 & 40 & 5 & 25 & 5 & 25 \\
\hline \multicolumn{2}{|c|}{ Jumlah } & 293 & 976,67 & 393 & 1572 & 370 & 1480 & 340 & 1700 & 305 & 1525 \\
\hline \multicolumn{2}{|c|}{$\%$ Total } & & 28,73 & & 46,24 & & 43,53 & & 50,00 & & 44,85 \\
\hline
\end{tabular}




\section{Pretest Kelas Eksperimen:}

\begin{tabular}{|c|c|c|c|c|c|c|c|c|c|c|c|}
\hline \multirow{2}{*}{ No. } & \multirow{2}{*}{ Kode } & \multicolumn{2}{|c|}{ No. 1} & \multicolumn{2}{|c|}{ No. 2} & \multicolumn{2}{|c|}{ No. 3} & \multicolumn{2}{|c|}{ No. 4} & \multicolumn{2}{|c|}{ No. 5} \\
\hline & & Skor & \%Skor & Skor & \%Skor & Skor & \%Skor & Skor & \%Skor & Skor & \%Skor \\
\hline 1 & E-01 & 0 & 0 & 0 & 0 & 0 & 0 & 0 & 0 & 0 & 0 \\
\hline 2 & E-02 & 10 & 33,333 & 0 & 0 & 0 & 0 & 0 & 0 & 0 & 0 \\
\hline 3 & E-03 & 0 & 0 & 0 & 0 & 0 & 0 & 0 & 0 & 0 & 0 \\
\hline 4 & E-04 & 0 & 0 & 0 & 0 & 0 & 0 & 0 & 0 & 0 & 0 \\
\hline 5 & E-05 & 0 & 0 & 1 & 4 & 0 & 0 & 0 & 0 & 0 & 0 \\
\hline 6 & E-06 & 0 & 0 & 0 & 0 & 0 & 0 & 0 & 0 & 0 & 0 \\
\hline 7 & E-07 & 10 & 33,333 & 0 & 0 & 0 & 0 & 0 & 0 & 0 & 0 \\
\hline 8 & E-08 & 10 & 33,333 & 0 & 0 & 0 & 0 & 0 & 0 & 0 & 0 \\
\hline 9 & E-09 & 0 & 0 & 0 & 0 & 0 & 0 & 0 & 0 & 0 & 0 \\
\hline 10 & E-10 & 10 & 33,333 & 0 & 0 & 0 & 0 & 0 & 0 & 0 & 0 \\
\hline 11 & E-11 & 0 & $\begin{array}{l}0 \\
\end{array}$ & 0 & 0 & 0 & 0 & 0 & 0 & 0 & 0 \\
\hline 12 & E-12 & 10 & 33,333 & 0 & 0 & 0 & 0 & 0 & 0 & 0 & 0 \\
\hline 13 & E-13 & 15 & 50 & 0 & 0 & 0 & 0 & 0 & 0 & 0 & 0 \\
\hline 14 & E-14 & 0 & 0 & 0 & 0 & 0 & 0 & 0 & 0 & 0 & 0 \\
\hline 15 & E-15 & 0 & 0 & 0 & 0 & 0 & 0 & 0 & 0 & 0 & 0 \\
\hline 16 & E-16 & 0 & 0 & 0 & 0 & 0 & 0 & 0 & 0 & 0 & 0 \\
\hline 17 & E-17 & 0 & 0 & 0 & 0 & 0 & 0 & 0 & 0 & 0 & 0 \\
\hline 18 & E-18 & 5 & 16,667 & 0 & 0 & 0 & 0 & 0 & 0 & 0 & 0 \\
\hline 19 & E-19 & 0 & $\begin{array}{l}0 \\
\end{array}$ & 0 & 0 & 0 & 0 & 0 & 0 & 0 & 0 \\
\hline 20 & E-20 & 10 & 33,333 & 0 & 0 & 0 & 0 & 0 & 0 & 0 & 0 \\
\hline 21 & E-21 & 0 & 0 & 0 & 0 & 0 & 0 & 0 & 0 & 0 & 0 \\
\hline 22 & E-22 & 10 & 33,333 & 0 & 0 & 0 & 0 & 0 & 0 & 0 & 0 \\
\hline 23 & E-23 & 10 & 33,333 & 0 & 0 & 0 & 0 & 0 & 0 & 0 & 0 \\
\hline 24 & E-24 & 0 & 0 & 0 & 0 & 1 & 4 & 0 & 0 & 0 & 0 \\
\hline 25 & E-25 & 10 & 33,333 & 0 & 0 & 0 & 0 & 0 & 0 & 0 & 0 \\
\hline 26 & E-26 & 10 & 33,333 & 0 & 0 & 0 & 0 & 0 & 0 & 0 & 0 \\
\hline 27 & E-27 & 0 & 0 & 0 & 0 & 0 & 0 & 0 & 0 & 0 & 0 \\
\hline 28 & E-28 & 0 & 0 & 0 & 0 & 0 & 0 & 0 & 0 & 0 & 0 \\
\hline 29 & E-29 & 0 & 0 & 0 & 0 & 0 & 0 & 0 & 0 & 0 & 0 \\
\hline 30 & E-30 & 0 & 0 & 0 & 0 & 0 & 0 & 0 & 0 & 0 & 0 \\
\hline 31 & E-31 & 0 & 0 & 0 & 0 & 0 & 0 & 0 & 0 & 0 & 0 \\
\hline 32 & E-32 & 15 & 50 & 0 & 0 & 0 & 0 & 0 & 0 & 0 & 0 \\
\hline 33 & E-33 & 1 & 3,3333 & 1 & 4 & 0 & 0 & 0 & 0 & 0 & 0 \\
\hline 34 & E-34 & 10 & 33,333 & 0 & 0 & 0 & 0 & 0 & 0 & 0 & 0 \\
\hline 35 & E-35 & 0 & 0 & 0 & 0 & 1 & 4 & 0 & 0 & 0 & 0 \\
\hline 36 & E-36 & 0 & 0 & 0 & 0 & 0 & 0 & 0 & 0 & 0 & 0 \\
\hline \multicolumn{2}{|c|}{ Jumlah } & 146 & 486,67 & 2 & 8 & 2 & 8 & 0 & 0 & 0 & 0 \\
\hline \multicolumn{2}{|c|}{$\%$ Total } & & 13,52 & & 0,22 & & 0,22 & & 0,00 & & 0,00 \\
\hline
\end{tabular}




\section{Posttest Kelas Eksperimen:}

\begin{tabular}{|c|c|c|c|c|c|c|c|c|c|c|c|}
\hline \multirow{2}{*}{ No. } & \multirow{2}{*}{ Kode } & \multicolumn{2}{|c|}{ No. 1} & \multicolumn{2}{|c|}{ No. 2} & \multicolumn{2}{|c|}{ No. 3} & \multicolumn{2}{|c|}{ No. 4} & \multicolumn{2}{|c|}{ No. 5} \\
\hline & & Skor & \%Skor & Skor & \%Skor & Skor & \%Skor & Skor & \%Skor & Skor & \%Skor \\
\hline 1 & E-01 & 0 & 0 & 0 & 0 & 0 & 0 & 0 & 0 & 0 & 0 \\
\hline 2 & E-02 & 20 & 66,667 & 20 & 80 & 15 & 60 & 20 & 100 & 5 & 25 \\
\hline 3 & E-03 & 20 & 66,667 & 20 & 80 & 15 & 60 & 20 & 100 & 5 & 25 \\
\hline 4 & E-04 & 15 & \begin{tabular}{|l|}
50 \\
\end{tabular} & 20 & 80 & 15 & 60 & 20 & 100 & 5 & 25 \\
\hline 5 & E-05 & 10 & \begin{tabular}{|l}
33,333 \\
\end{tabular} & 5 & 20 & 20 & 80 & 10 & 50 & 5 & 25 \\
\hline 6 & E-06 & 20 & 66,667 & 5 & 20 & 15 & 60 & 5 & 25 & 15 & 75 \\
\hline 7 & E-07 & 20 & 66,667 & 20 & 80 & 15 & 60 & 20 & 100 & 15 & 75 \\
\hline 8 & E-08 & 20 & 66,667 & 20 & 80 & 15 & 60 & 20 & 100 & 15 & 75 \\
\hline 9 & E-09 & 20 & 66,667 & 20 & 80 & 15 & 60 & 20 & 100 & 5 & 25 \\
\hline 10 & E-10 & 15 & 50 & 20 & 80 & 15 & 60 & 20 & 100 & 5 & 25 \\
\hline 11 & E-11 & 20 & 66,667 & 20 & 80 & 15 & 60 & 20 & 100 & 5 & 25 \\
\hline 12 & E-12 & 20 & 66,667 & 20 & 80 & 20 & 80 & 20 & 100 & 15 & 75 \\
\hline 13 & E-13 & 20 & 66,667 & 15 & 60 & 20 & 80 & 20 & 100 & 15 & 75 \\
\hline 14 & E-14 & 20 & 66,667 & 20 & 80 & 15 & 60 & 20 & 100 & 20 & 100 \\
\hline 15 & E-15 & 20 & 66,667 & 17 & 68 & 15 & 60 & 20 & 100 & 5 & 25 \\
\hline 16 & E-16 & 20 & 66,667 & 20 & 80 & 15 & 60 & 5 & 25 & 5 & 25 \\
\hline 17 & E-17 & 0 & 0 & 0 & 0 & 0 & 0 & 0 & 0 & 0 & 0 \\
\hline 18 & E-18 & 0 & 0 & 0 & 0 & 0 & 0 & 0 & 0 & 0 & 0 \\
\hline 19 & E-19 & 0 & 0 & 0 & 0 & 0 & 0 & 0 & 0 & 0 & 0 \\
\hline 20 & E-20 & 15 & 50 & 20 & 80 & 15 & 60 & 20 & 100 & 20 & 100 \\
\hline 21 & E-21 & 20 & 66,667 & 15 & 60 & 15 & 60 & 5 & 25 & 15 & 75 \\
\hline 22 & E-22 & 15 & 50 & 20 & 80 & 15 & 60 & 20 & 100 & 15 & 75 \\
\hline 23 & E-23 & 15 & 50 & 20 & 80 & 15 & 60 & 20 & 100 & 20 & 100 \\
\hline 24 & E-24 & 15 & 50 & 20 & 80 & 15 & 60 & 20 & 100 & 5 & 25 \\
\hline 25 & E-25 & 20 & 66,667 & 20 & 80 & 15 & 60 & 20 & 100 & 5 & 25 \\
\hline 26 & E-26 & 15 & 50 & 20 & 80 & 15 & 60 & 20 & 100 & 5 & 25 \\
\hline 27 & E-27 & 0 & 0 & 0 & 0 & 0 & 0 & 0 & 0 & 0 & 0 \\
\hline 28 & E-28 & 0 & 0 & 0 & 0 & 0 & 0 & 0 & 0 & 0 & 0 \\
\hline 29 & E-29 & 15 & 50 & 20 & 80 & 15 & 60 & 20 & 100 & 5 & 25 \\
\hline 30 & E-30 & 20 & 66,667 & 20 & 80 & 15 & 60 & 20 & 100 & 15 & 75 \\
\hline 31 & E-31 & 0 & 0 & 0 & 0 & 0 & 0 & 0 & 0 & 0 & 0 \\
\hline 32 & E-32 & 20 & 66,667 & 20 & 80 & 20 & 80 & 17 & 85 & 15 & 75 \\
\hline 33 & E-33 & 20 & 66,667 & 5 & 20 & 15 & 60 & 5 & 25 & 15 & 75 \\
\hline 34 & E-34 & 15 & 50 & 20 & 80 & 15 & 60 & 20 & 100 & 20 & 100 \\
\hline 35 & E-35 & 20 & 66,667 & 0 & 0 & 15 & 60 & 5 & 25 & 15 & 75 \\
\hline 36 & E-36 & 15 & 50 & 20 & 80 & 15 & 60 & 20 & 100 & 5 & 25 \\
\hline \multicolumn{2}{|c|}{ Jumlah } & 520 & 1733,3 & 502 & 2008 & 455 & 1820 & 492 & 2460 & 315 & 1575 \\
\hline \multicolumn{2}{|c|}{$\%$ Total } & & 48,15 & & 55,78 & & 50,56 & & 68,33 & & 43,75 \\
\hline
\end{tabular}


Lampiran 29. Uji N-Gain Penguasaan Konsep Peserta Didik

Kelas Kontrol:

\begin{tabular}{|c|c|c|c|c|c|}
\hline No. & Kode & Pretest & Posttest & $\begin{array}{c}\text { Nilai N- } \\
\text { Gain }\end{array}$ & Kategori \\
\hline 1 & K-01 & 30 & 78 & 0,686 & Sedang \\
\hline 2 & K-02 & 33 & 42 & 0,134 & Rendah \\
\hline 3 & K-03 & 25 & 40 & 0,200 & Rendah \\
\hline 4 & K-04 & 39 & 67 & 0,459 & Sedang \\
\hline 5 & K-05 & 11 & 62 & 0,573 & Sedang \\
\hline 6 & K-06 & 18 & 72 & 0,659 & Sedang \\
\hline 7 & K-07 & 36 & 82 & 0,719 & Tinggi \\
\hline 8 & K-08 & 41 & 87 & 0,780 & Tinggi \\
\hline 9 & K-09 & 39 & 70 & 0,508 & Sedang \\
\hline 10 & K-10 & 30 & 43 & 0,186 & Rendah \\
\hline 11 & K-11 & 10 & 75 & 0,722 & Tinggi \\
\hline 12 & K-12 & 41 & 79 & 0,644 & Sedang \\
\hline 13 & K-13 & 30 & 45 & 0,214 & Rendah \\
\hline 14 & K-14 & 31 & 42 & 0,159 & Rendah \\
\hline 15 & K-15 & 28 & 42 & 0,194 & Rendah \\
\hline 16 & K-16 & 25 & 40 & 0,200 & Rendah \\
\hline 17 & K-17 & 0 & 88 & 0,880 & Tinggi \\
\hline 18 & K-18 & 36 & 47 & 0,172 & Rendah \\
\hline 19 & K-19 & 36 & 84 & 0,750 & Tinggi \\
\hline 20 & K-20 & 23 & 63 & 0,519 & Sedang \\
\hline 21 & K-21 & 30 & 45 & 0,214 & Rendah \\
\hline 22 & K-22 & 30 & 43 & 0,186 & Rendah \\
\hline 23 & K-23 & 25 & 40 & 0,200 & Rendah \\
\hline 24 & K-24 & 41 & 88 & 0,797 & Tinggi \\
\hline 25 & K-25 & 30 & 40 & 0,143 & Rendah \\
\hline 26 & K-26 & 28 & 69 & 0,569 & Sedang \\
\hline
\end{tabular}




\begin{tabular}{|c|c|c|c|c|c|}
\hline No. & Kode & Pretest & Posttest & $\begin{array}{c}\text { Nilai N- } \\
\text { Gain }\end{array}$ & Kategori \\
\hline 27 & K-27 & 20 & 65 & 0,563 & Sedang \\
\hline 28 & K-28 & 30 & 45 & 0,214 & Rendah \\
\hline 29 & K-29 & 34 & 42 & 0,121 & Rendah \\
\hline 30 & K-30 & 30 & 45 & 0,214 & Rendah \\
\hline 31 & K-31 & 13 & 67 & 0,621 & Sedang \\
\hline 32 & K-32 & 30 & 47 & 0,243 & Rendah \\
\hline 33 & K-33 & 18 & 40 & 0,268 & Rendah \\
\hline 34 & K-34 & 25 & 40 & 0,200 & Rendah \\
\hline \multicolumn{2}{|c|}{ Jumlah } & 946 & 1964 & 13,912 & \\
\hline \multicolumn{2}{|c|}{ Mean } & 27,824 & 57,765 & 0,409 & Sedang \\
\hline
\end{tabular}

Kelas Eksperimen:

\begin{tabular}{|c|c|c|c|c|c|}
\hline No. & Kode & Pretest & Posttest & $\begin{array}{c}\text { Nilai N- } \\
\text { Gain }\end{array}$ & Kategori \\
\hline 1 & E-01 & 10 & 43 & 0,367 & Sedang \\
\hline 2 & E-02 & 28 & 78 & 0,694 & Sedang \\
\hline 3 & E-03 & 8 & 58 & 0,543 & Sedang \\
\hline 4 & E-04 & 25 & 63 & 0,507 & Sedang \\
\hline 5 & E-05 & 25 & 55 & 0,400 & Sedang \\
\hline 6 & E-06 & 0 & 63 & 0,630 & Sedang \\
\hline 7 & E-07 & 28 & 98 & 0,972 & Tinggi \\
\hline 8 & E-08 & 23 & 83 & 0,779 & Tinggi \\
\hline 9 & E-09 & 28 & 72 & 0,611 & Sedang \\
\hline 10 & E-10 & 25 & 78 & 0,707 & Tinggi \\
\hline 11 & E-11 & 18 & 85 & 0,817 & Tinggi \\
\hline 12 & E-12 & 13 & 94 & 0,931 & Tinggi \\
\hline 13 & E-13 & 16 & 82 & 0,786 & Tinggi \\
\hline 14 & E-14 & 13 & 88 & 0,862 & Tinggi \\
\hline 15 & E-15 & 13 & 69 & 0,644 & Sedang \\
\hline 16 & E-16 & 30 & 68 & 0,543 & Sedang \\
\hline
\end{tabular}




\begin{tabular}{|c|c|c|c|c|c|}
\hline No. & Kode & Pretest & Posttest & $\begin{array}{c}\text { Nilai N- } \\
\text { Gain }\end{array}$ & Kategori \\
\hline 17 & E-17 & 20 & 40 & 0,250 & Rendah \\
\hline 18 & E-18 & 14 & 43 & 0,337 & Sedang \\
\hline 19 & E-19 & 0 & 42 & 0,420 & Sedang \\
\hline 20 & E-20 & 28 & 80 & 0,722 & Tinggi \\
\hline 21 & E-21 & 0 & 63 & 0,630 & Sedang \\
\hline 22 & E-22 & 18 & 68 & 0,610 & Sedang \\
\hline 23 & E-23 & 25 & 68 & 0,573 & Sedang \\
\hline 24 & E-24 & 18 & 66 & 0,585 & Sedang \\
\hline 25 & E-25 & 28 & 75 & 0,653 & Sedang \\
\hline 26 & E-26 & 18 & 93 & 0,915 & Tinggi \\
\hline 27 & E-27 & 0 & 40 & 0,400 & Sedang \\
\hline 28 & E-28 & 18 & 45 & 0,329 & Sedang \\
\hline 29 & E-29 & 15 & 73 & 0,682 & Sedang \\
\hline 30 & E-30 & 0 & 78 & 0,780 & Tinggi \\
\hline 31 & E-31 & 15 & 40 & 0,294 & Rendah \\
\hline 32 & E-32 & 19 & 86 & 0,827 & Tinggi \\
\hline 33 & E-33 & 21 & 57 & 0,456 & Sedang \\
\hline 34 & E-34 & 28 & 87 & 0,819 & Tinggi \\
\hline 35 & E-35 & 18 & 56 & 0,463 & Sedang \\
\hline 36 & E-36 & 5 & 69 & 0,674 & Sedang \\
\hline & Jumlah & 611 & 2446 & 22,213 & \\
\hline & Mean & 16,972 & 67,944 & 0,617 & Sedang \\
\hline
\end{tabular}


Lampiran 30. Uji Hipotesis Penguasaan Konsep

Data Hasil Posttest Penguasaan Konsep

\begin{tabular}{|c|c|c|c|c|c|c|c|}
\hline No. & Kode Responden & Nilai & $(x-\bar{x})^{2}$ & No. & Kode Responden & Nilai & $(x-\bar{x})^{2}$ \\
\hline 1 & K-01 & 78 & 409,47 & 1 & \begin{tabular}{|l|} 
E-01 \\
\end{tabular} & 43 & 622,23 \\
\hline 2 & K-02 & 42 & 248,53 & 2 & E-02 & 78 & 101,11 \\
\hline 3 & K-03 & 40 & 315,58 & 3 & E-03 & 58 & 98,89 \\
\hline 4 & K-04 & 67 & 85,29 & 4 & E-04 & 63 & 24,45 \\
\hline 5 & K-05 & 62 & 17,94 & 5 & E-05 & 55 & 167,56 \\
\hline 6 & K-06 & 72 & 202,64 & 6 & E-06 & 63 & 24,45 \\
\hline 7 & K-07 & 82 & 587,35 & 7 & E-07 & 98 & 903,34 \\
\hline 8 & K-08 & 87 & 854,70 & 8 & E-08 & 83 & 226,67 \\
\hline 9 & K-09 & 70 & 149,70 & 9 & E-09 & 72 & 16,45 \\
\hline 10 & $\mathrm{~K}-10$ & 43 & 218,00 & 10 & E-10 & 78 & 101,11 \\
\hline 11 & K-11 & 75 & 297,06 & 11 & E-11 & 85 & 290,89 \\
\hline 12 & $\mathrm{~K}-12$ & 79 & 450,94 & 12 & E-12 & 94 & 678,89 \\
\hline 13 & K-13 & 45 & 162,94 & 13 & E-13 & 82 & 197,56 \\
\hline 14 & $\mathrm{~K}-14$ & 42 & 248,53 & 14 & E-14 & 88 & 402,23 \\
\hline 15 & K-15 & 42 & 248,53 & 15 & E-15 & 69 & 1,11 \\
\hline 16 & K-16 & 40 & 315,58 & 16 & E-16 & 68 & 0,00 \\
\hline 17 & K-17 & 88 & 914,17 & 17 & E-17 & 40 & 780,89 \\
\hline 18 & $\mathrm{~K}-18$ & 47 & 115,88 & 18 & E-18 & 43 & 622,23 \\
\hline 19 & $\mathrm{~K}-19$ & 84 & 688,29 & 19 & E-19 & 42 & 673,11 \\
\hline 20 & $\mathrm{~K}-20$ & 63 & 27,41 & 20 & E-20 & 80 & 145,34 \\
\hline 21 & $\mathrm{~K}-21$ & 45 & 162,94 & 21 & E-21 & 63 & 24,45 \\
\hline 22 & $\mathrm{~K}-22$ & 43 & 218,00 & 22 & E-22 & 68 & 0,00 \\
\hline 23 & K-23 & 40 & 315,58 & 23 & E-23 & 68 & 0,00 \\
\hline 24 & $\mathrm{~K}-24$ & 88 & 914,17 & 24 & E-24 & 66 & 3,78 \\
\hline 25 & K-25 & 40 & 315,58 & 25 & E-25 & 75 & 49,78 \\
\hline 26 & $\mathrm{~K}-26$ & 69 & 126,23 & 26 & E-26 & 93 & 627,78 \\
\hline 27 & K-27 & 65 & 52,35 & 27 & E-27 & 40 & 780,89 \\
\hline 28 & $\mathrm{~K}-28$ & 45 & 162,94 & 28 & E-28 & 45 & 526,45 \\
\hline 29 & K-29 & 42 & 248,53 & 29 & E-29 & 73 & 25,56 \\
\hline 30 & $\mathrm{~K}-30$ & 45 & 162,94 & 30 & E-30 & 78 & 101,11 \\
\hline 31 & K-31 & 67 & 85,29 & 31 & E-31 & 40 & 780,89 \\
\hline 32 & K-32 & 47 & 115,88 & 32 & E-32 & 86 & 326,00 \\
\hline 33 & $\mathrm{~K}-33$ & 40 & 315,58 & 33 & E-33 & 57 & 119,78 \\
\hline 34 & $\mathrm{~K}-34$ & 40 & 315,58 & 34 & E-34 & 87 & 363,11 \\
\hline \multicolumn{2}{|r|}{ Jumlah } & 1964 & 10070,118 & 35 & E-35 & 56 & 142,67 \\
\hline \multicolumn{2}{|r|}{ Rata-rata } & 57,765 & & 36 & E-36 & 69 & 1,11 \\
\hline \multicolumn{2}{|r|}{ Nilai tertinggi } & 88 & & \multicolumn{2}{|r|}{ Jumlah } & 2446 & 9951,889 \\
\hline \multicolumn{2}{|r|}{ Nilai terendah } & 40 & & \multicolumn{2}{|r|}{ Rata-rata } & 67,944 & \\
\hline \multicolumn{2}{|r|}{ Rentang } & 48 & & \multicolumn{2}{|r|}{ Nilai tertinggi } & 98 & \\
\hline \multicolumn{2}{|r|}{ Banyak kelas } & 6,054 & & \multicolumn{2}{|r|}{ Nilai terendah } & 40 & \\
\hline \multicolumn{2}{|r|}{ Panjang kelas } & 7,929 & & \multicolumn{2}{|r|}{ Rentang } & 58 & \\
\hline \multicolumn{2}{|r|}{ Standar Deviasi } & 17,469 & & \multicolumn{2}{|r|}{ Banyak kelas } & 6,136 & \\
\hline & & & & \multicolumn{2}{|r|}{ Panjang kelas } & 9,453 & \\
\hline & & & & \multicolumn{2}{|r|}{ Standar Deviasi } & 16,862 & \\
\hline
\end{tabular}




\section{Uji Normalitas Posttest Penguasaan Konsep \\ Kelas Kontrol}

\section{Hipotesis:}

$\mathrm{H}_{0}$ : Data berdistribusi normal

$\mathrm{H}_{a}$ : Data tidak berdistribusi normal

\section{Pengujian Hipotesis:}

$X^{2} h=\sum \frac{\left(f_{o}-f_{h}\right)^{2}}{f_{h}}$

\section{Kriteria yang digunakan:}

$\mathrm{H}_{0}$ diterima jika $X^{2}{ }_{\text {hitung }}<X^{2}$ tabel

\section{Pengujian normalitas data:}

\begin{tabular}{|c|c|c|c|c|c|c|c|}
\hline Interval & Batas kelas & $\mathbf{Z}$ & Luas Z & Luas Tiap Kelas & fh & fo & Chi kuadrat \\
\hline & 39,5 & $-1,05$ & 0,3531 & & & & \\
\hline \multirow[t]{2}{*}{$40-47$} & & & & 0,1307 & 4,4438 & 18 & 41,354 \\
\hline & 47,5 & $-0,59$ & 0,2224 & & & & \\
\hline \multirow[t]{2}{*}{$48-55$} & & & & 0,1707 & 5,8038 & 0 & 5,804 \\
\hline & 55,5 & $-0,13$ & 0,0517 & & & & \\
\hline \multirow[t]{2}{*}{$56-63$} & & & & $-0,0776$ & $-2,6384$ & 2 & $-8,154$ \\
\hline & 63,5 & 0,33 & 0,1293 & & & & \\
\hline \multirow[t]{2}{*}{$64-71$} & & & & 0,4145 & 14,093 & 5 & 5,867 \\
\hline & 71,5 & 0,79 & 0,2852 & & & & \\
\hline \multirow[t]{2}{*}{$72-79$} & & & & $-0,1073$ & $-3,6482$ & 4 & $-16,034$ \\
\hline & 79,5 & 1,24 & 0,3925 & & & & \\
\hline \multirow[t]{2}{*}{$80-87$} & & & & $-0,0629$ & $-2,1386$ & 3 & $-12,347$ \\
\hline & 87,5 & 1,70 & 0,4554 & & & & \\
\hline \multirow[t]{2}{*}{$88-94$} & & & & $-0,0267$ & $-0,9078$ & 2 & $-9,314$ \\
\hline & 94,5 & 2,10 & 0,4821 & & & & \\
\hline \multicolumn{6}{|c|}{ Jumlah } & 34 & 7,176 \\
\hline \multicolumn{6}{|c|}{ Rata-rata } & \multicolumn{2}{|c|}{57,765} \\
\hline \multicolumn{6}{|c|}{ SD } & \multicolumn{2}{|c|}{17,469} \\
\hline \multicolumn{6}{|c|}{ Varians } & \multicolumn{2}{|c|}{305,155} \\
\hline \multicolumn{6}{|c|}{ Chi kuadrat tabel } & \multicolumn{2}{|c|}{12,592} \\
\hline \multicolumn{6}{|c|}{ Interpretasi } & \multicolumn{2}{|c|}{ normal } \\
\hline
\end{tabular}

Berdasarkan perhitungan dihasilkan $X^{2}{ }_{\text {hitung }}=7,176$. Selanjutnya $X^{2}$ hitung tersebut dibandingkan dengan $X^{2}$ tabel dengan $\mathrm{dk}=6$ dan taraf signifikansi $5 \%$, sehingga ditetapkan $X_{\text {tabel }}=12,592$. Karena $X^{2}$ hitung $<X_{\text {tabel, }}$ maka $H_{0}$ diterima, sehingga kelas kontrol dinyatakan berdistribusi normal. 


\section{Uji Normalitas PosttestPenguasaan Konsep \\ Kelas Eksperimen}

\section{Hipotesis:}

$\mathrm{H}_{0}$ : Data berdistribusi normal

$\mathrm{H}_{a}$ : Data tidak berdistribusi normal

\section{Pengujian Hipotesis:}

$X^{2} h=\sum \frac{\left(f_{o}-f_{h}\right)^{2}}{f_{h}}$

\section{Kriteria yang digunakan:}

$\mathrm{H}_{0}$ diterima jika $X^{2}{ }_{\text {hitung }}<X_{\text {tabel }}$

\section{Pengujian normalitas data:}

\begin{tabular}{|c|c|c|c|c|c|c|c|}
\hline Interval & Batas kelas & $\mathbf{Z}$ & Luas Z & Luas Tiap Kelas & fh & fo & Chi Kuadrat \\
\hline & 39,5 & $-1,69$ & 0,4545 & & & & \\
\hline \multirow[t]{2}{*}{$40-48$} & & & & 0,0796 & 2,8656 & 7 & 5,965 \\
\hline & 48,5 & $-1,15$ & 0,3749 & & & & \\
\hline \multirow[t]{2}{*}{$49-57$} & & & & 0,1425 & 5,13 & 3 & 0,884 \\
\hline & 57,5 & $-0,62$ & 0,2324 & & & & \\
\hline \multirow[t]{2}{*}{$58-66$} & & & & 0,1965 & 7,074 & 5 & 0,608 \\
\hline & 66,5 & $-0,09$ & 0,0359 & & & & \\
\hline \multirow[t]{2}{*}{$67-75$} & & & & 0,2095 & 7,542 & 8 & 0,028 \\
\hline & 75,5 & 0,45 & 0,1736 & & & & \\
\hline \multirow[t]{2}{*}{$76-84$} & & & & $-0,1629$ & $-5,8644$ & 6 & $-24,003$ \\
\hline & 84,5 & 0,98 & 0,3365 & & & & \\
\hline \multirow[t]{2}{*}{$85-93$} & & & & $-0,0992$ & $-3,5712$ & 5 & $-20,572$ \\
\hline & 93,5 & 1,52 & 0,4357 & & & & \\
\hline \multirow[t]{2}{*}{$94-102$} & & & & $-0,0441$ & $-1,5876$ & 2 & $-8,107$ \\
\hline & 102,5 & 2,05 & 0,4798 & & & & \\
\hline \multicolumn{6}{|c|}{ Jumlah } & 36 & $-45,197$ \\
\hline \multicolumn{6}{|c|}{ Rata-rata } & \multicolumn{2}{|c|}{67,944} \\
\hline \multicolumn{6}{|c|}{ SD } & \multicolumn{2}{|c|}{16,862} \\
\hline \multicolumn{6}{|c|}{ Varians } & \multicolumn{2}{|c|}{284,340} \\
\hline \multicolumn{6}{|c|}{ Chi kuadrat tabel } & \multicolumn{2}{|c|}{12,592} \\
\hline \multicolumn{6}{|c|}{ Interpretasi } & \multicolumn{2}{|c|}{ normal } \\
\hline
\end{tabular}

Berdasarkan perhitungan dihasilkan $X^{2}$ hitung $=-45,197$. Selanjutnya $X^{2}$ hitung tersebut dibandingkan dengan $X^{2}$ tabel dengan $\mathrm{dk}=6$ dan taraf signifikansi $5 \%$, sehingga ditetapkan $X_{\text {tabel }}=12,592$. Karena $X^{2}$ hitung $<X_{\text {tabel, }}$, maka $\mathrm{H}_{0}$ diterima, sehingga kelas eksperimen dinyatakan berdistribusi normal. 


\section{Uji Homogenitas Posttest Penguasaan Konsep}

\section{Hipotesis:}

$\mathrm{H}_{0}: \sigma_{1}^{2}=\sigma_{2}^{2}$

$\mathrm{H}_{a}: \sigma_{1}^{2} \neq \sigma_{2}^{2}$

\section{Pengujian Hipotesis:}

$\mathrm{F}=\frac{\text { Varians terbesar }}{\text { Varians terkecil }}$

$\mathrm{H}_{0}$ diterima apabila $\mathrm{F}_{\text {hitung }} \leq \mathrm{F}_{\text {tabel }}$

Dari data diperoleh:

\begin{tabular}{|c|c|c|}
\hline Sumber Variasi & Kelas Eksperimen & Kelas Kontrol \\
\hline Jumlah & 2446 & 1964 \\
\hline $\mathrm{n}$ & 36 & 34 \\
\hline Rata-rata & 67,944 & 57,765 \\
\hline Standar Deviasi & 16,862 & 17,469 \\
\hline Varians & 284,340 & 305,155 \\
\hline
\end{tabular}

Berdasarkan rumus di atas diperoleh:

$\mathrm{F}=\frac{305,155}{284,340}=1,070$

Taraf signifikan 5\% dengan:

$\mathrm{dk}$ pembilang $=\mathrm{k}-1=2$

$\mathrm{dk}$ penyebut $=\mathrm{N}-\mathrm{k}=67$

Sehingga, $F_{\text {tabel }}=3,134$

Karena $\mathrm{F}_{\text {hitung }}<\mathrm{F}_{\text {tabel, }}$, maka $\mathrm{H}_{0}$ diterima dan dapat disimpulkan bahwa kedua kelas homogen. 


\section{Uji Perbedaan Rata-Rata \\ Data Posttest Penguasaan Konsep}

\section{Hipotesis:}

$\mathrm{H}_{0}: \mu_{1}=\mu_{2}$

$\mathrm{H}_{a}: \mu_{1} \neq \mu_{2}$

Kriteria Pengujian Hipotesis:

$$
t=\frac{\overline{X_{1}}-\overline{X_{2}}}{\sqrt{\frac{\left(n_{1}-1\right) s_{1}^{2}+\left(n_{2}-1\right) s_{2}^{2}}{n_{1}+n_{2}-2}\left(\frac{1}{n_{1}}+\frac{1}{n_{2}}\right)}}
$$

$\mathrm{H}_{0}$ diterima apabila $\mathrm{t}_{\text {hitung }} \leq \mathrm{t}_{\text {tabel }}$

\section{Uji Hipotesis:}

Dari data diperoleh:

\begin{tabular}{|c|c|c|}
\hline Sumber Variasi & Kelas Eksperimen & Kelas Kontrol \\
\hline Jumlah & 2446 & 1964 \\
\hline $\mathrm{n}$ & 36 & 34 \\
\hline Rata-rata & 67,944 & 57,765 \\
\hline Standar Deviasi & 16,862 & 17,469 \\
\hline Varians & 284,340 & 305,155 \\
\hline
\end{tabular}

Berdasarkan rumus di atas diperoleh:

$$
\begin{aligned}
& t=\frac{67,944-57,765}{\sqrt{\frac{(36-1) 284,340+(34-1) 305,155}{36+34-2}\left(\frac{1}{36}+\frac{1}{34}\right)}} \\
& \mathrm{t}=2,481
\end{aligned}
$$

Taraf signifikansi $5 \%$ dan $d k=68$, sehingga $t_{\text {tabel }}=1,995$. Karena $\mathrm{t}_{\text {hitung }} \leq \mathrm{t}_{\text {tabel, }}$, maka $\mathrm{H}_{a}$ diterima. Jadi dapat disimpulkan bahwa terdapat perbedaan rata-rata dari kelas kontrol dan kelas eksperimen. 


\section{Uji Pihak Kanan Data Penguasaan Konsep}

\section{Hipotesis:}

$\mathrm{H}_{0}: \mu_{1} \leq \mu_{2}$

$\mathrm{H}_{a}: \mu_{1}>\mu_{2}$

\section{Kriteria Pengujian Hipotesis:}

$\mathrm{H}_{0}$ diterima apabila $\mathrm{t}_{\text {hitung }}<\mathrm{t}_{\text {tabel }}$

\section{Uji Hipotesis:}

$$
\begin{aligned}
& t=\frac{\overline{X_{1}}-\overline{X_{2}}}{\sqrt{\frac{\left(n_{1}-1\right) s_{1}^{2}+\left(n_{2}-1\right) s_{2}^{2}}{n_{1}+n_{2}-2}\left(\frac{1}{n_{1}}+\frac{1}{n_{2}}\right)}} \\
& t=\frac{67,944-57,765}{\sqrt{\frac{(36-1) 284,340+(34-1) 305,155}{36+34-2}\left(\frac{1}{36}+\frac{1}{34}\right)}} \\
& t=2,481 \\
& \mathrm{dk}=36+34-2=68, \text { sehingga } t_{\text {tabel }}=1,668 .
\end{aligned}
$$

Karena $\mathrm{t}_{\text {hitung }}>\mathrm{t}_{\text {tabel, }}$, sehingga $\mathrm{H}_{0}$ ditolak dan $\mathrm{H}_{a}$ diterima. Jadi dapat disimpulkan bahwa rata-rata penguasaan konsep kelas eksperimen lebih besar dari pada rata-rata penguasaan konsep kelas kontrol. 
Lampiran 31. Analisis Pretest Angket Attitudes toward Chemistry

Tabulasi Data Kelas Kontrol:

\begin{tabular}{|c|c|c|c|c|c|c|c|c|c|c|c|c|}
\hline \multirow{2}{*}{ Kode } & \multicolumn{10}{|c|}{ Nomor Soal } \\
\cline { 2 - 16 } & $\mathbf{1}$ & $\mathbf{2}$ & $\mathbf{3}$ & $\mathbf{4}$ & $\mathbf{5}$ & $\mathbf{6}$ & $\mathbf{7}$ & $\mathbf{8}$ & $\mathbf{9}$ & $\mathbf{1 0}$ & $\mathbf{1 1}$ & $\mathbf{1 2}$ \\
\hline K-01 & STS & AS & N & ATS & TS & N & TS & STS & STS & S & ATS & ATS \\
\hline K-02 & STS & TS & ATS & STS & TS & N & STS & TS & TS & AS & N & AS \\
\hline K-03 & STS & ATS & N & TS & TS & ATS & N & N & STS & TS & ATS & STS \\
\hline K-04 & ATS & ATS & AS & N & TS & N & N & AS & N & ATS & ATS & AS \\
\hline K-05 & N & ATS & N & N & N & N & N & N & N & N & N & N \\
\hline K-06 & N & TS & STS & N & N & S & N & N & AS & S & ATS & N \\
\hline K-07 & N & ATS & N & N & N & N & AS & AS & N & ATS & N & N \\
\hline K-08 & N & N & AS & AS & ATS & S & S & AS & N & S & TS & AS \\
\hline K-09 & STS & TS & ATS & ATS & TS & N & N & TS & STS & N & AS & N \\
\hline K-10 & N & S & AS & N & S & ATS & S & S & N & S & TS & S \\
\hline K-11 & STS & S & ATS & N & AS & S & SS & S & AS & S & N & N \\
\hline K-12 & AS & S & N & N & S & S & SS & S & AS & N & S & AS \\
\hline K-13 & TS & N & N & ATS & ATS & S & N & AS & TS & ATS & N & AS \\
\hline K-14 & N & TS & N & STS & N & N & ATS & N & N & N & TS & N \\
\hline K-15 & N & N & N & N & N & STS & N & AS & ATS & S & AS & AS \\
\hline K-16 & TS & TS & N & TS & N & AS & N & AS & STS & AS & N & ATS \\
\hline K-17 & AS & ATS & AS & N & AS & N & ATS & N & AS & ATS & AS & N \\
\hline
\end{tabular}




\begin{tabular}{|c|c|c|c|c|c|c|c|c|c|c|c|c|}
\hline \multirow{2}{*}{ Kode } & \multicolumn{10}{|c|}{ Nomor Soal } \\
\cline { 2 - 16 } & $\mathbf{1}$ & $\mathbf{2}$ & $\mathbf{3}$ & $\mathbf{4}$ & $\mathbf{5}$ & $\mathbf{6}$ & $\mathbf{7}$ & $\mathbf{8}$ & $\mathbf{9}$ & $\mathbf{1 0}$ & $\mathbf{1 1}$ & $\mathbf{1 2}$ \\
\hline K-18 & N & ATS & N & N & N & N & TS & N & ATS & AS & STS & N \\
\hline K-19 & N & AS & AS & AS & AS & S & N & AS & N & AS & ATS & AS \\
\hline K-20 & ATS & ATS & N & TS & ATS & N & TS & N & TS & N & TS & N \\
\hline K-21 & TS & AS & N & ATS & ATS & ATS & N & TS & STS & N & N & TS \\
\hline K-22 & AS & S & AS & N & ATS & S & AS & AS & ATS & AS & N & AS \\
\hline K-23 & N & N & N & ATS & N & N & N & N & TS & N & N & TS \\
\hline K-24 & N & S & N & S & AS & S & AS & AS & N & N & AS & S \\
\hline K-25 & N & AS & N & AS & AS & ATS & AS & AS & N & N & AS & AS \\
\hline K-26 & N & SS & N & ATS & N & S & ATS & S & N & S & S & S \\
\hline K-27 & N & S & N & N & STS & N & TS & N & N & S & N & N \\
\hline K-28 & ATS & AS & N & TS & ATS & ATS & N & TS & TS & N & N & STS \\
\hline K-29 & N & AS & N & AS & AS & AS & N & AS & N & ATS & AS & ATS \\
\hline K-30 & N & S & ATS & TS & N & AS & ATS & S & TS & STS & S & N \\
\hline K-31 & S & SS & N & SS & S & N & SS & SS & S & AS & S & SS \\
\hline K-32 & ATS & AS & ATS & TS & ATS & N & AS & N & TS & AS & AS & ATS \\
\hline K-33 & STS & STS & ATS & STS & STS & TS & N & STS & STS & STS & N & STS \\
\hline K-34 & TS & TS & AS & TS & TS & ATS & S & TS & TS & AS & ATS & TS \\
\hline
\end{tabular}


Transformasi Data Kelas Kontrol:

\begin{tabular}{|c|c|c|c|c|c|c|c|c|c|c|c|c|c|c|}
\hline \multirow{2}{*}{ No. } & \multirow{2}{*}{ Kode } & \multicolumn{12}{|c|}{ Nomor Soal } & \multirow{2}{*}{ Jumlah } \\
\hline & & 1 & 2 & 3 & 4 & 5 & 6 & 7 & 8 & 9 & 10 & 11 & 12 & \\
\hline 1. & $\mathrm{~K}-01$ & 1 & 5 & 4 & 3 & 2 & 4 & 2 & 1 & 1 & 6 & 3 & 3 & 35 \\
\hline 2. & $\mathrm{~K}-02$ & 1 & 2 & 3 & 1 & 2 & 4 & 1 & 2 & 2 & 5 & 4 & 5 & 32 \\
\hline 3. & $\mathrm{~K}-03$ & 1 & 3 & 4 & 2 & 2 & 3 & 4 & 4 & 1 & 2 & 3 & 1 & 30 \\
\hline 4. & K-04 & 3 & 3 & 5 & 4 & 2 & 4 & 4 & 5 & 4 & 3 & 3 & 5 & 45 \\
\hline 5. & $\mathrm{~K}-05$ & 4 & 3 & 4 & 4 & 4 & 4 & 4 & 4 & 4 & 4 & 4 & 4 & 47 \\
\hline 6. & K-06 & 4 & 2 & 1 & 4 & 4 & 6 & 4 & 4 & 5 & 6 & 3 & 4 & 47 \\
\hline 7. & $\mathrm{~K}-07$ & 4 & 3 & 4 & 4 & 4 & 4 & 5 & 5 & 4 & 3 & 4 & 4 & 48 \\
\hline 8. & $\mathrm{~K}-08$ & 4 & 4 & 5 & 5 & 3 & 6 & 6 & 5 & 4 & 6 & 2 & 5 & 55 \\
\hline 9. & K-09 & 1 & 2 & 3 & 3 & 2 & 4 & 4 & 2 & 1 & 4 & 5 & 4 & 35 \\
\hline 10. & $\mathrm{~K}-10$ & 4 & 6 & 5 & 4 & 6 & 3 & 6 & 6 & 4 & 6 & 2 & 6 & 58 \\
\hline 11. & $\mathrm{~K}-11$ & 1 & 6 & 3 & 4 & 5 & 6 & 7 & 6 & 5 & 6 & 4 & 4 & 57 \\
\hline 12. & $\mathrm{~K}-12$ & 5 & 6 & 4 & 4 & 6 & 6 & 7 & 6 & 5 & 4 & 6 & 5 & 64 \\
\hline 13. & $\mathrm{~K}-13$ & 2 & 4 & 4 & 3 & 3 & 6 & 4 & 5 & 2 & 3 & 4 & 5 & 45 \\
\hline 14. & K-14 & 4 & 2 & 4 & 1 & 4 & 4 & 3 & 4 & 4 & 4 & 2 & 4 & 40 \\
\hline 15. & $\mathrm{~K}-15$ & 4 & 4 & 4 & 4 & 4 & 1 & 4 & 5 & 3 & 6 & 5 & 5 & 49 \\
\hline 16. & $\mathrm{~K}-16$ & 2 & 2 & 4 & 2 & 4 & 5 & 4 & 5 & 1 & 5 & 4 & 3 & 41 \\
\hline 17. & K-17 & 5 & 3 & 5 & 4 & 5 & 4 & 3 & 4 & 5 & 3 & 5 & 4 & 50 \\
\hline 18. & $\mathrm{~K}-18$ & 4 & 3 & 4 & 4 & 4 & 4 & 2 & 4 & 3 & 5 & 1 & 4 & 42 \\
\hline 19. & K-19 & 4 & 5 & 5 & 5 & 5 & 6 & 4 & 5 & 4 & 5 & 3 & 5 & 56 \\
\hline 20. & $\mathrm{~K}-20$ & 3 & 3 & 4 & 2 & 3 & 4 & 2 & 4 & 2 & 4 & 2 & 4 & 37 \\
\hline 21. & $\mathrm{~K}-21$ & 2 & 5 & 4 & 3 & 3 & 3 & 4 & 2 & 1 & 4 & 4 & 2 & 37 \\
\hline 22. & $\mathrm{~K}-22$ & 5 & 6 & 5 & 4 & 3 & 6 & 5 & 5 & 3 & 5 & 4 & 5 & 56 \\
\hline 23. & $\mathrm{~K}-23$ & 4 & 4 & 4 & 3 & 4 & 4 & 4 & 4 & 2 & 4 & 4 & 2 & 43 \\
\hline 24. & K-24 & 4 & 6 & 4 & 6 & 5 & 6 & 5 & 5 & 4 & 4 & 5 & 6 & 60 \\
\hline 25. & $\mathrm{~K}-25$ & 4 & 5 & 4 & 5 & 5 & 3 & 5 & 5 & 4 & 4 & 5 & 5 & 54 \\
\hline 26. & $\mathrm{~K}-26$ & 4 & 7 & 4 & 3 & 4 & 6 & 3 & 6 & 4 & 6 & 6 & 6 & 59 \\
\hline 27. & $\mathrm{~K}-27$ & 4 & 6 & 4 & 4 & 1 & 4 & 2 & 4 & 4 & 6 & 4 & 4 & 47 \\
\hline 28. & $\mathrm{~K}-28$ & 3 & 5 & 4 & 2 & 3 & 3 & 4 & 2 & 2 & 4 & 4 & 1 & 37 \\
\hline 29. & $\mathrm{~K}-29$ & 4 & 5 & 4 & 5 & 5 & 5 & 4 & 5 & 4 & 3 & 5 & 3 & 52 \\
\hline 30. & $\mathrm{~K}-30$ & 4 & 6 & 3 & 2 & 4 & 5 & 3 & 6 & 2 & 1 & 6 & 4 & 46 \\
\hline 31. & $\mathrm{~K}-31$ & 6 & 7 & 4 & 7 & 6 & 4 & 7 & 7 & 6 & 5 & 6 & 7 & 72 \\
\hline 32. & $\mathrm{~K}-32$ & 3 & 5 & 3 & 2 & 3 & 4 & 5 & 4 & 2 & 5 & 5 & 3 & 44 \\
\hline 33. & $\mathrm{~K}-33$ & 1 & 1 & 3 & 1 & 1 & 2 & 4 & 1 & 1 & 1 & 4 & 1 & 21 \\
\hline 34 & K-34 & 2 & 2 & 5 & 2 & 2 & 3 & 6 & 2 & 2 & 5 & 3 & 2 & 36 \\
\hline \multicolumn{2}{|c|}{ Jumlah } & 111 & 141 & 134 & 116 & 123 & 146 & 141 & 144 & 105 & 147 & 134 & 135 & 1577 \\
\hline \multicolumn{2}{|c|}{ Jumlah SA } & 111 & 141 & 134 & 116 & 123 & 146 & 141 & 144 & 105 & 147 & 134 & 135 & \\
\hline \multicolumn{2}{|c|}{ Jumlah SI } & 238 & 238 & 238 & 238 & 238 & 238 & 238 & 238 & 238 & 238 & 238 & 238 & \\
\hline \multicolumn{2}{|c|}{$\%$} & 46,64 & 59,24 & 56,3 & 48,74 & 51,68 & 61,34 & 59,24 & 60,5 & 44,12 & 61,76 & 56,3 & 56,72 & \\
\hline \multicolumn{2}{|r|}{ SAV } & \multicolumn{12}{|c|}{1577} & \\
\hline \multicolumn{2}{|r|}{ SIV } & \multicolumn{12}{|c|}{2856} & \\
\hline \multicolumn{2}{|r|}{$\%$} & \multicolumn{12}{|c|}{55,22} & \\
\hline
\end{tabular}


Tabulasi Data Kelas Eksperimen:

\begin{tabular}{|c|c|c|c|c|c|c|c|c|c|c|c|c|}
\hline \multirow{2}{*}{ Kode } & \multicolumn{12}{|c|}{ Nomor Soal } \\
\hline & 1 & 2 & 3 & 4 & 5 & 6 & 7 & 8 & 9 & 10 & 11 & 12 \\
\hline E-01 & $\mathrm{N}$ & AS & $\mathrm{N}$ & ATS & $\mathrm{N}$ & AS & $\mathrm{S}$ & $\mathrm{N}$ & ATS & $\mathrm{N}$ & AS & $\mathrm{N}$ \\
\hline E-02 & ATS & $\mathrm{N}$ & $\mathrm{N}$ & $\mathrm{N}$ & AS & $\mathrm{S}$ & AS & $\mathrm{N}$ & $\mathrm{N}$ & ATS & $\mathrm{TS}$ & $\mathrm{N}$ \\
\hline E-03 & STS & ATS & $\mathrm{TS}$ & STS & STS & $\mathrm{N}$ & $\mathrm{TS}$ & ATS & STS & $\mathrm{N}$ & $\mathrm{N}$ & AS \\
\hline E-04 & ATS & ATS & $\mathrm{N}$ & $\mathrm{TS}$ & $\mathrm{TS}$ & $\mathrm{N}$ & $\mathrm{N}$ & TS & STS & $\mathrm{N}$ & $\mathrm{N}$ & STS \\
\hline E-05 & ATS & ATS & AS & AS & $\mathrm{N}$ & $\mathrm{N}$ & $\mathrm{N}$ & $\mathrm{N}$ & ATS & $\mathrm{N}$ & AS & ATS \\
\hline E-06 & STS & $\mathrm{N}$ & $\mathrm{N}$ & $\mathrm{N}$ & TS & $\mathrm{N}$ & $\mathrm{AS}$ & ATS & STS & STS & $\mathrm{AS}$ & $\mathrm{S}$ \\
\hline E-07 & TS & ATS & $\mathrm{N}$ & ATS & $\mathrm{N}$ & $\mathrm{N}$ & $\mathrm{N}$ & ATS & TS & $\mathrm{S}$ & $\mathrm{AS}$ & $\mathrm{AS}$ \\
\hline E-08 & $\mathrm{N}$ & AS & $\mathrm{N}$ & $\mathrm{N}$ & $\mathrm{N}$ & AS & $\mathrm{N}$ & $\mathrm{N}$ & $\mathrm{N}$ & AS & $\mathrm{N}$ & $\mathrm{N}$ \\
\hline E-09 & ATS & $\mathrm{N}$ & $\mathrm{N}$ & $\mathrm{N}$ & $\mathrm{N}$ & $\mathrm{S}$ & $\mathrm{N}$ & ATS & ATS & AS & $\mathrm{N}$ & $\mathrm{N}$ \\
\hline E-10 & STS & $\mathrm{TS}$ & $\mathrm{N}$ & TS & STS & ATS & ATS & ATS & STS & STS & $\mathrm{N}$ & ATS \\
\hline E-11 & $\mathrm{N}$ & AS & ATS & STS & $\mathrm{TS}$ & $\mathrm{N}$ & $\mathrm{TS}$ & STS & STS & $\mathrm{N}$ & $\mathrm{N}$ & TS \\
\hline E-12 & ATS & $\mathrm{N}$ & AS & AS & $\mathrm{S}$ & $\mathrm{N}$ & AS & $\mathrm{S}$ & AS & $\mathrm{N}$ & $\mathrm{N}$ & AS \\
\hline E-13 & AS & $\mathrm{AS}$ & AS & $\mathrm{N}$ & $\mathrm{N}$ & ATS & $\mathrm{N}$ & $\mathrm{S}$ & $\mathrm{N}$ & $\mathrm{S}$ & $\mathrm{N}$ & $\mathrm{N}$ \\
\hline E-14 & $\mathrm{N}$ & $\mathrm{N}$ & $\mathrm{N}$ & TS & ATS & $\mathrm{N}$ & $\mathrm{N}$ & ATS & STS & AS & $\mathrm{N}$ & ATS \\
\hline E-15 & STS & $\mathrm{TS}$ & TS & ATS & TS & ATS & ATS & TS & STS & AS & ATS & TS \\
\hline E-16 & $\mathrm{N}$ & $\mathrm{N}$ & ATS & $\mathrm{N}$ & $\mathrm{S}$ & $\mathrm{N}$ & ATS & $\mathrm{N}$ & $\mathrm{N}$ & AS & $\mathrm{S}$ & AS \\
\hline E-17 & $\mathrm{N}$ & ATS & $\mathrm{N}$ & ATS & $\mathrm{N}$ & $\mathrm{N}$ & ATS & AS & $\mathrm{N}$ & $\mathrm{N}$ & AS & AS \\
\hline E-18 & $\mathrm{S}$ & $\mathrm{N}$ & AS & $\mathrm{N}$ & $\mathrm{N}$ & $\mathrm{N}$ & $\mathrm{N}$ & $\mathrm{N}$ & $\mathrm{N}$ & $\mathrm{N}$ & $\mathrm{N}$ & $\mathrm{N}$ \\
\hline
\end{tabular}




\begin{tabular}{|c|c|c|c|c|c|c|c|c|c|c|c|c|}
\hline \multirow{2}{*}{ Kode } & \multicolumn{12}{|c|}{ Nomor Soal } \\
\hline & 1 & 2 & 3 & 4 & 5 & 6 & 7 & 8 & 9 & 10 & 11 & 12 \\
\hline E-19 & AS & STS & $\mathrm{TS}$ & ATS & $S$ & $\mathrm{~N}$ & $\mathrm{~N}$ & $\mathrm{~N}$ & AS & $\mathrm{N}$ & ATS & $\mathrm{N}$ \\
\hline E-20 & TS & $\mathrm{N}$ & ATS & $\mathrm{N}$ & ATS & $\mathrm{N}$ & $\mathrm{N}$ & $\mathrm{N}$ & TS & $\mathrm{N}$ & ATS & $\mathrm{N}$ \\
\hline E-21 & STS & TS & TS & ATS & TS & ATS & $\mathrm{N}$ & $\mathrm{N}$ & STS & AS & $\mathrm{N}$ & ATS \\
\hline E-22 & TS & $\mathrm{N}$ & $\mathrm{N}$ & STS & $\mathrm{N}$ & ATS & $\mathrm{N}$ & $\mathrm{N}$ & STS & ATS & $\mathrm{N}$ & $\mathrm{N}$ \\
\hline E-23 & ATS & ATS & TS & $\mathrm{N}$ & ATS & $\mathrm{N}$ & ATS & $\mathrm{N}$ & TS & $\mathrm{N}$ & $\mathrm{N}$ & $\mathrm{N}$ \\
\hline E-24 & TS & ATS & TS & STS & $\mathrm{N}$ & $\mathrm{N}$ & ATS & $\mathrm{N}$ & TS & $\mathrm{N}$ & $\mathrm{N}$ & TS \\
\hline E-25 & ATS & TS & TS & TS & ATS & ATS & TS & TS & ATS & TS & ATS & $\mathrm{N}$ \\
\hline E-26 & TS & TS & ATS & TS & ATS & TS & TS & STS & TS & ATS & ATS & ATS \\
\hline E-27 & $\mathrm{N}$ & $\mathrm{N}$ & ATS & TS & $\mathrm{N}$ & $\mathrm{N}$ & TS & TS & TS & AS & ATS & TS \\
\hline E-28 & SS & $\mathrm{S}$ & AS & ATS & STS & $\mathrm{N}$ & TS & $\mathrm{N}$ & AS & $\mathrm{N}$ & $\mathrm{N}$ & ATS \\
\hline E-29 & $\mathrm{N}$ & TS & $\mathrm{AS}$ & $\mathrm{N}$ & $\mathrm{N}$ & TS & AS & $\mathrm{N}$ & ATS & ATS & $\mathrm{N}$ & $\mathrm{N}$ \\
\hline E-30 & $\mathrm{N}$ & ATS & $\mathrm{TS}$ & TS & ATS & $\mathrm{TS}$ & ATS & $\mathrm{N}$ & TS & $\mathrm{N}$ & $\mathrm{N}$ & ATS \\
\hline E-31 & $\mathrm{S}$ & $\mathrm{N}$ & $\mathrm{N}$ & ATS & $\mathrm{S}$ & $\mathrm{N}$ & $\mathrm{N}$ & $\mathrm{S}$ & $\mathrm{N}$ & $\mathrm{S}$ & $\mathrm{N}$ & ATS \\
\hline E-32 & STS & ATS & $\mathrm{N}$ & $\mathrm{TS}$ & STS & $\mathrm{TS}$ & ATS & TS & STS & TS & TS & STS \\
\hline E-33 & TS & $\mathrm{N}$ & ATS & $\mathrm{N}$ & TS & $\mathrm{N}$ & $\mathrm{TS}$ & $\mathrm{TS}$ & $\mathrm{N}$ & ATS & $\mathrm{N}$ & TS \\
\hline E-34 & ATS & $\mathrm{N}$ & TS & ATS & $\mathrm{N}$ & ATS & $\mathrm{N}$ & ATS & ATS & $\mathrm{N}$ & TS & $\mathrm{N}$ \\
\hline E-35 & AS & $\overline{A S}$ & AS & $\mathrm{N}$ & $\mathrm{S}$ & AS & ATS & $\mathrm{S}$ & $\mathrm{AS}$ & $\mathrm{N}$ & ATS & $\mathrm{N}$ \\
\hline E-36 & $\mathrm{N}$ & TS & ATS & ATS & $\mathrm{N}$ & $\mathrm{N}$ & $\mathrm{N}$ & $\mathrm{N}$ & ATS & $\mathrm{N}$ & $\mathrm{N}$ & $\mathrm{N}$ \\
\hline
\end{tabular}




\section{Transformasi Data Kelas Eksperimen:}

\begin{tabular}{|c|c|c|c|c|c|c|c|c|c|c|c|c|c|c|}
\hline \multirow{2}{*}{ No. } & \multirow{2}{*}{ Kode } & \multicolumn{12}{|c|}{ Nomor Soal } & \multirow{2}{*}{ Jumlah } \\
\hline & & 1 & 2 & 3 & 4 & 5 & 6 & 7 & 8 & 9 & 10 & 11 & 12 & \\
\hline 1. & $\mathrm{E}-01$ & 4 & 5 & 4 & 3 & 4 & 5 & 6 & 4 & 3 & 4 & 5 & 4 & 51 \\
\hline 2. & $\mathrm{E}-02$ & 3 & 4 & 4 & 4 & 5 & 6 & 5 & 4 & 4 & 3 & 2 & 4 & 48 \\
\hline 3. & $\mathrm{E}-03$ & 1 & 3 & 2 & 1 & 1 & 4 & 2 & 3 & 1 & 4 & 4 & 5 & 31 \\
\hline 4. & E-04 & 3 & 3 & 4 & 2 & 2 & 4 & 4 & 2 & 1 & 4 & 4 & 1 & 34 \\
\hline 5. & $\mathrm{E}-05$ & 3 & 3 & 5 & 5 & 4 & 4 & 4 & 4 & 3 & 4 & 5 & 3 & 47 \\
\hline 6. & E-06 & 1 & 4 & 4 & 4 & 2 & 4 & 5 & 3 & 1 & 1 & 5 & 6 & 40 \\
\hline 7. & E-07 & 2 & 3 & 4 & 3 & 4 & 4 & 4 & 3 & 2 & 6 & 5 & 5 & 45 \\
\hline 8. & $\mathrm{E}-08$ & 4 & 5 & 4 & 4 & 4 & 5 & 4 & 4 & 4 & 5 & 4 & 4 & 51 \\
\hline 9. & E-09 & 3 & 4 & 4 & 4 & 4 & 6 & 4 & 3 & 3 & 5 & 4 & 4 & 48 \\
\hline 10. & E-10 & 1 & 2 & 4 & 2 & 1 & 3 & 3 & 3 & 1 & 1 & 4 & 3 & 28 \\
\hline 11. & E-11 & 4 & 5 & 3 & 1 & 2 & 4 & 2 & 1 & 1 & 4 & 4 & 2 & 33 \\
\hline 12. & $\mathrm{E}-12$ & 3 & 4 & 5 & 5 & 6 & 4 & 5 & 7 & 5 & 4 & 4 & 5 & 57 \\
\hline 13. & E-13 & 5 & 5 & 5 & 4 & 4 & 3 & 4 & 6 & 4 & 6 & 4 & 4 & 54 \\
\hline 14. & E-14 & 4 & 4 & 4 & 2 & 3 & 4 & 4 & 3 & 1 & 5 & 4 & 3 & 41 \\
\hline 15. & E-15 & 1 & 2 & 2 & 3 & 2 & 3 & 3 & 2 & 1 & 5 & 3 & 2 & 29 \\
\hline 16. & E-16 & 4 & 4 & 3 & 4 & 6 & 4 & 3 & 4 & 4 & 5 & 6 & 5 & 52 \\
\hline 17. & E-17 & 4 & 3 & 4 & 3 & 4 & 4 & 3 & 5 & 4 & 4 & 5 & 5 & 48 \\
\hline 18. & E-18 & 6 & 4 & 5 & 4 & 4 & 4 & 4 & 4 & 4 & 4 & 4 & 4 & 51 \\
\hline 19. & E-19 & 5 & 1 & 2 & 3 & 6 & 4 & 4 & 4 & 5 & 4 & 3 & 4 & 45 \\
\hline 20. & E-20 & 2 & 4 & 3 & 4 & 3 & 4 & 4 & 4 & 2 & 4 & 3 & 4 & 41 \\
\hline 21. & E-21 & 1 & 2 & 2 & 3 & 2 & 3 & 4 & 4 & 1 & 5 & 4 & 3 & 34 \\
\hline 22. & E-22 & 2 & 4 & 4 & 1 & 4 & 3 & 4 & 4 & 1 & 3 & 4 & 4 & 38 \\
\hline 23. & E-23 & 3 & 3 & 2 & 4 & 3 & 4 & 3 & 4 & 2 & 4 & 4 & 4 & 40 \\
\hline 24. & E-24 & 2 & 3 & 2 & 1 & 4 & 4 & 3 & 4 & 2 & 4 & 4 & 2 & 35 \\
\hline 25. & E-25 & 3 & 2 & 2 & 2 & 3 & 3 & 2 & 2 & 3 & 2 & 3 & 4 & 31 \\
\hline 26. & E-26 & 2 & 2 & 3 & 2 & 3 & 2 & 2 & 1 & 2 & 3 & 3 & 3 & 28 \\
\hline 27. & E-27 & 4 & 4 & 3 & 2 & 4 & 4 & 2 & 2 & 2 & 5 & 3 & 2 & 37 \\
\hline 28. & E-28 & 7 & 6 & 5 & 3 & 1 & 4 & 2 & 4 & 5 & 4 & 4 & 3 & 48 \\
\hline 29. & E-29 & 4 & 2 & 5 & 4 & 4 & 2 & 5 & 4 & 3 & 3 & 4 & 4 & 44 \\
\hline 30. & $\mathrm{E}-30$ & 4 & 3 & 2 & 2 & 3 & 2 & 3 & 4 & 2 & 4 & 4 & 3 & 36 \\
\hline 31. & E-31 & 6 & 4 & 4 & 3 & 6 & 4 & 4 & 6 & 4 & 6 & 4 & 3 & 54 \\
\hline 32. & $\mathrm{E}-32$ & 1 & 3 & 4 & 2 & 1 & 2 & 3 & 2 & 1 & 2 & 2 & 1 & 24 \\
\hline 33. & E-33 & 2 & 4 & 3 & 4 & 2 & 4 & 2 & 2 & 4 & 3 & 4 & 2 & 36 \\
\hline 34 & E-34 & 3 & 4 & 2 & 3 & 4 & 3 & 4 & 3 & 3 & 4 & 2 & 4 & 39 \\
\hline 35 & E-35 & 5 & 5 & 5 & 4 & 6 & 5 & 3 & 6 & 5 & 4 & 3 & 4 & 55 \\
\hline 36 & E-36 & 4 & 2 & 3 & 3 & 4 & 4 & 4 & 4 & 3 & 4 & 4 & 4 & 43 \\
\hline \multicolumn{2}{|c|}{ Jumlah } & 116 & 125 & 126 & 108 & 125 & 136 & 127 & 129 & 97 & 142 & 138 & 127 & 1496 \\
\hline \multicolumn{2}{|c|}{ Jumlah SA } & 116 & 125 & 126 & 108 & 125 & 136 & 127 & 129 & 97 & 142 & 138 & 127 & \\
\hline \multicolumn{2}{|c|}{ Jumlah SI } & 252 & 252 & 252 & 252 & 252 & 252 & 252 & 252 & 252 & 252 & 252 & 252 & \\
\hline \multicolumn{2}{|c|}{$\%$} & 46,03 & 49,6 & 50 & 42,86 & 49,6 & 53,97 & 50,4 & 51,19 & \begin{tabular}{|l|}
38,49 \\
\end{tabular} & 56,35 & 54,76 & 50,4 & \\
\hline \multicolumn{2}{|c|}{ SAV } & \multicolumn{12}{|c|}{1496} & \\
\hline \multicolumn{2}{|c|}{ SIV } & \multicolumn{12}{|c|}{3024} & \\
\hline \multicolumn{2}{|c|}{$\%$} & \multicolumn{12}{|c|}{49,47} & \\
\hline
\end{tabular}


Lampiran 32. Analisis Posttest Angket Attitudes toward Chemistry

Tabulasi Data Kelas Kontrol:

\begin{tabular}{|c|c|c|c|c|c|c|c|c|c|c|c|c|}
\hline \multirow{2}{*}{ Kode } & \multicolumn{10}{|c|}{ Nomor Soal } \\
\cline { 2 - 15 } & $\mathbf{1}$ & $\mathbf{2}$ & $\mathbf{3}$ & $\mathbf{4}$ & $\mathbf{5}$ & $\mathbf{6}$ & $\mathbf{7}$ & $\mathbf{8}$ & $\mathbf{9}$ & $\mathbf{1 0}$ & $\mathbf{1 1}$ & $\mathbf{1 2}$ \\
\hline K-01 & STS & SS & N & ATS & ATS & SS & TS & STS & STS & SS & ATS & ATS \\
\hline K-02 & TS & TS & N & STS & ATS & N & N & TS & TS & SS & N & AS \\
\hline K-03 & STS & AS & N & TS & TS & N & N & N & STS & AS & ATS & STS \\
\hline K-04 & N & ATS & AS & AS & AS & N & S & AS & N & ATS & S & AS \\
\hline K-05 & N & N & N & N & N & N & N & N & N & N & N & N \\
\hline K-06 & N & S & S & N & AS & S & S & N & AS & S & S & N \\
\hline K-07 & N & S & N & N & AS & N & AS & AS & N & S & N & N \\
\hline K-08 & N & S & AS & AS & AS & S & S & AS & N & S & S & AS \\
\hline K-09 & STS & TS & S & ATS & TS & N & S & TS & STS & N & S & N \\
\hline K-10 & N & S & S & N & S & S & S & S & S & S & S & S \\
\hline K-11 & AS & S & AS & N & AS & S & SS & S & AS & S & S & N \\
\hline K-12 & AS & S & S & N & S & SS & SS & S & AS & SS & S & AS \\
\hline K-13 & TS & N & AS & ATS & ATS & S & N & AS & TS & SS & N & AS \\
\hline K-14 & N & N & N & N & N & N & N & N & N & N & N & N \\
\hline K-15 & N & S & N & N & N & S & N & AS & ATS & S & AS & AS \\
\hline K-16 & TS & S & AS & TS & N & S & N & AS & STS & S & N & ATS \\
\hline
\end{tabular}




\begin{tabular}{|c|c|c|c|c|c|c|c|c|c|c|c|c|}
\hline \multirow{2}{*}{ Kode } & \multicolumn{12}{|c|}{ Nomor Soal } \\
\hline & 1 & 2 & 3 & 4 & 5 & 6 & 7 & 8 & 9 & 10 & 11 & 12 \\
\hline K-17 & AS & AS & AS & $\mathrm{N}$ & AS & $\mathrm{N}$ & $\overline{A S}$ & $\mathrm{~N}$ & AS & AS & $\overline{A S}$ & $\mathrm{~N}$ \\
\hline K-18 & $\mathrm{N}$ & ATS & $\mathrm{S}$ & $\mathrm{N}$ & $\mathrm{N}$ & $\mathrm{N}$ & $\mathrm{S}$ & $\mathrm{N}$ & ATS & AS & $\mathrm{S}$ & $\mathrm{N}$ \\
\hline K-19 & $\mathrm{N}$ & $\mathrm{AS}$ & $\mathrm{AS}$ & $\mathrm{S}$ & AS & $\mathrm{S}$ & $\mathrm{S}$ & AS & $\mathrm{N}$ & $\mathrm{AS}$ & $\mathrm{S}$ & $\mathrm{AS}$ \\
\hline K-20 & ATS & ATS & $\overline{\mathrm{AS}}$ & TS & $\mathrm{N}$ & $\mathrm{N}$ & TS & $\mathrm{N}$ & TS & $\mathrm{N}$ & $\mathrm{N}$ & $\mathrm{N}$ \\
\hline $\mathrm{K}-21$ & TS & AS & $\mathrm{N}$ & ATS & ATS & $S$ & AS & TS & STS & $\mathrm{S}$ & $\mathrm{N}$ & TS \\
\hline $\mathrm{K}-22$ & AS & $\mathrm{S}$ & AS & $\mathrm{N}$ & $\mathrm{N}$ & $\mathrm{S}$ & AS & AS & ATS & $S$ & $\mathrm{~N}$ & AS \\
\hline $\mathrm{K}-23$ & $\mathrm{~N}$ & $\mathrm{~N}$ & $\mathrm{~N}$ & $\mathrm{~N}$ & $\mathrm{~N}$ & $\mathrm{~N}$ & $\mathrm{~N}$ & $\mathrm{~N}$ & $\mathrm{~N}$ & $\mathrm{~N}$ & $\mathrm{~N}$ & $\mathrm{~N}$ \\
\hline $\mathrm{K}-24$ & $\mathrm{~N}$ & $S$ & $S$ & $\mathrm{~S}$ & $\mathrm{~S}$ & $\mathrm{~S}$ & AS & AS & $\mathrm{N}$ & $S$ & AS & $\mathrm{S}$ \\
\hline K-25 & $\mathrm{N}$ & AS & $S$ & AS & AS & AS & AS & AS & $\mathrm{N}$ & $S$ & AS & AS \\
\hline $\mathrm{K}-26$ & $\mathrm{~N}$ & SS & $S$ & ATS & $\mathrm{N}$ & $\mathrm{S}$ & $S$ & $\mathrm{~S}$ & $\mathrm{~N}$ & SS & $\mathrm{S}$ & $S$ \\
\hline $\mathrm{K}-27$ & $\mathrm{~N}$ & $\mathrm{~S}$ & $\mathrm{~N}$ & $\mathrm{~N}$ & $\mathrm{~N}$ & $\mathrm{~N}$ & $\mathrm{~N}$ & $\mathrm{~N}$ & $\mathrm{~N}$ & $\mathrm{~S}$ & $\mathrm{~N}$ & $\mathrm{~N}$ \\
\hline K-28 & ATS & AS & AS & $\mathrm{TS}$ & ATS & ATS & $\mathrm{N}$ & TS & TS & AS & AS & TS \\
\hline K-29 & $\mathrm{N}$ & $\overline{A S}$ & $\mathrm{~S}$ & $\overline{A S}$ & $\mathrm{AS}$ & $\mathrm{AS}$ & $\mathrm{N}$ & AS & $\mathrm{N}$ & $\mathrm{S}$ & AS & $\overline{\mathrm{AS}}$ \\
\hline K-30 & $\mathrm{N}$ & SS & ATS & TS & $\mathrm{N}$ & $\overline{\mathrm{AS}}$ & $\mathrm{S}$ & $\mathrm{S}$ & TS & S & $\mathrm{S}$ & $\mathrm{N}$ \\
\hline K-31 & $\mathrm{S}$ & SS & SS & SS & $\mathrm{S}$ & SS & SS & SS & $\mathrm{S}$ & SS & SS & SS \\
\hline K-32 & ATS & AS & $\mathrm{S}$ & $\mathrm{TS}$ & ATS & $\mathrm{N}$ & AS & $\mathrm{N}$ & TS & AS & $\overline{\mathrm{AS}}$ & ATS \\
\hline K-33 & STS & STS & $\mathrm{N}$ & STS & STS & STS & AS & STS & STS & STS & $\mathrm{N}$ & STS \\
\hline K-34 & TS & TS & $S$ & $\mathrm{TS}$ & TS & $\mathrm{N}$ & $S$ & TS & TS & AS & $\mathrm{N}$ & $\mathrm{TS}$ \\
\hline
\end{tabular}


Transformasi Data Kelas Kontrol:

\begin{tabular}{|c|c|c|c|c|c|c|c|c|c|c|c|c|c|c|}
\hline \multirow{2}{*}{ No. } & \multirow{2}{*}{ Kode } & \multicolumn{12}{|c|}{ Nomor Soal } & \multirow{2}{*}{ Jumlah } \\
\hline & & 1 & 2 & 3 & 4 & 5 & 6 & 7 & 8 & 9 & 10 & 11 & 12 & \\
\hline 1. & $\mathrm{~K}-01$ & 1 & 7 & 4 & 3 & 3 & 7 & 2 & 1 & 1 & 7 & 3 & 3 & 42 \\
\hline 2. & K-02 & 2 & 2 & 4 & 1 & 3 & 4 & 4 & 2 & 2 & 7 & 4 & 5 & 40 \\
\hline 3. & $\mathrm{~K}-03$ & 1 & 5 & 4 & 2 & 2 & 4 & 4 & 4 & 1 & 5 & 3 & 1 & 36 \\
\hline 4. & $\mathrm{~K}-04$ & 4 & 3 & 5 & 5 & 5 & 4 & 6 & 5 & 4 & 3 & 6 & 5 & 55 \\
\hline 5. & $\mathrm{~K}-05$ & 4 & 4 & 4 & 4 & 4 & 4 & 4 & 4 & 4 & 4 & 4 & 4 & 48 \\
\hline 6. & $\mathrm{~K}-06$ & 4 & 6 & 6 & 4 & 5 & 6 & 6 & 4 & 5 & 6 & 6 & 4 & 62 \\
\hline 7. & K-07 & 4 & 6 & 4 & 4 & 5 & 4 & 5 & 5 & 4 & 6 & 4 & 4 & 55 \\
\hline 8. & $\mathrm{~K}-08$ & 4 & 6 & 5 & 5 & 5 & 6 & 6 & 5 & 4 & 6 & 6 & 5 & 63 \\
\hline 9. & K-09 & 1 & 2 & 6 & 3 & 2 & 4 & 6 & 2 & 1 & 4 & 6 & 4 & 41 \\
\hline 10. & $\mathrm{~K}-10$ & 4 & 6 & 6 & 4 & 6 & 6 & 6 & 6 & 6 & 6 & 6 & 6 & 68 \\
\hline 11. & $\mathrm{~K}-11$ & 5 & 6 & 5 & 4 & 5 & 6 & 7 & 6 & 5 & 6 & 6 & 4 & 65 \\
\hline 12. & $\mathrm{~K}-12$ & 5 & 6 & 6 & 4 & 6 & 7 & 7 & 6 & 5 & 7 & 6 & 5 & 70 \\
\hline 13. & $\mathrm{~K}-13$ & 2 & 4 & 5 & 3 & 3 & 6 & 4 & 5 & 2 & 7 & 4 & 5 & 50 \\
\hline 14. & $\mathrm{~K}-14$ & 4 & 4 & 4 & 4 & 4 & 4 & 4 & 4 & 4 & 4 & 4 & 4 & 48 \\
\hline 15. & $\mathrm{~K}-15$ & 4 & 6 & 4 & 4 & 4 & 6 & 4 & 5 & 3 & 6 & 5 & 5 & 56 \\
\hline 16. & $\mathrm{~K}-16$ & 2 & 6 & 5 & 2 & 4 & 6 & 4 & 5 & 1 & 6 & 4 & 3 & 48 \\
\hline 17. & $\mathrm{~K}-17$ & 5 & 5 & 5 & 4 & 5 & 4 & 5 & 4 & 5 & 5 & 5 & 4 & 56 \\
\hline 18. & $\mathrm{~K}-18$ & 4 & 3 & 6 & 4 & 4 & 4 & 6 & 4 & 3 & 5 & 6 & 4 & 53 \\
\hline 19. & $\mathrm{~K}-19$ & 4 & 5 & 5 & 6 & 5 & 6 & 6 & 5 & 4 & 5 & 6 & 5 & 62 \\
\hline 20. & $\mathrm{~K}-20$ & 3 & 3 & 5 & 2 & 4 & 4 & 2 & 4 & 2 & 4 & 4 & 4 & 41 \\
\hline 21. & $\mathrm{~K}-21$ & 2 & 5 & 4 & 3 & 3 & 6 & 5 & 2 & 1 & 6 & 4 & 2 & 43 \\
\hline 22. & $\mathrm{~K}-22$ & 5 & 6 & 5 & 4 & 4 & 6 & 5 & 5 & 3 & 6 & 4 & 5 & 58 \\
\hline 23. & $\mathrm{~K}-23$ & 4 & 4 & 4 & 4 & 4 & 4 & 4 & 4 & 4 & 4 & 4 & 4 & 48 \\
\hline 24. & $\mathrm{~K}-24$ & 4 & 6 & 6 & 6 & 6 & 6 & 5 & 5 & 4 & 6 & 5 & 6 & 65 \\
\hline 25. & $\mathrm{~K}-25$ & 4 & 5 & 6 & 5 & 5 & 5 & 5 & 5 & 4 & 6 & 5 & 5 & 60 \\
\hline 26. & $\mathrm{~K}-26$ & 4 & 7 & 6 & 3 & 4 & 6 & 6 & 6 & 4 & 7 & 6 & 6 & 65 \\
\hline 27. & $\mathrm{~K}-27$ & 4 & 6 & 4 & 4 & 4 & 4 & 4 & 4 & 4 & 6 & 4 & 4 & 52 \\
\hline 28. & $\mathrm{~K}-28$ & 3 & 5 & 5 & 2 & 3 & 3 & 4 & 2 & 2 & 5 & 5 & 2 & 41 \\
\hline 29. & $\mathrm{~K}-29$ & 4 & 5 & 6 & 5 & 5 & 5 & 4 & 5 & 4 & 6 & 5 & 5 & 59 \\
\hline 30. & $\mathrm{~K}-30$ & 4 & 7 & 3 & 2 & 4 & 5 & 6 & 6 & 2 & 6 & 6 & 4 & 55 \\
\hline 31. & K-31 & 6 & 7 & 7 & 7 & 6 & 7 & 7 & 7 & 6 & 7 & 7 & 7 & 81 \\
\hline 32. & $\mathrm{~K}-32$ & 3 & 5 & 6 & 2 & 3 & 4 & 5 & 4 & 2 & 5 & 5 & 3 & 47 \\
\hline 33. & $\mathrm{~K}-33$ & 1 & 1 & 4 & 1 & 1 & 1 & 5 & 1 & 1 & 1 & 4 & 1 & 22 \\
\hline 34 & $\mathrm{~K}-34$ & 2 & 2 & 6 & 2 & 2 & 4 & 6 & 2 & 2 & 5 & 4 & 2 & 39 \\
\hline \multicolumn{2}{|c|}{ Jumlah } & 117 & 166 & 170 & 122 & 138 & 168 & 169 & 144 & 109 & 185 & 166 & 140 & 1794 \\
\hline \multicolumn{2}{|c|}{ Jumlah SA } & 117 & 166 & 170 & 122 & 138 & 168 & 169 & 144 & 109 & 185 & 166 & 140 & \\
\hline \multicolumn{2}{|c|}{ Jumlah SI } & 238 & 238 & 238 & 238 & 238 & 238 & 238 & 238 & 238 & 238 & 238 & 238 & \\
\hline \multicolumn{2}{|c|}{$\%$} & 49,16 & 69,75 & 71,43 & 51,26 & 57,98 & 70,59 & 71,01 & 60,5 & 45,8 & 77,73 & 69,75 & 58,82 & \\
\hline \multicolumn{2}{|c|}{ SAV } & \multicolumn{12}{|c|}{1794} & \\
\hline \multicolumn{2}{|c|}{ SIV } & \multicolumn{12}{|c|}{2856} & \\
\hline \multicolumn{2}{|r|}{$\%$} & \multicolumn{12}{|c|}{62,82} & \\
\hline
\end{tabular}


Tabulasi Data Kelas Eksperimen:

\begin{tabular}{|c|c|c|c|c|c|c|c|c|c|c|c|c|}
\hline \multirow{2}{*}{ Kode } & \multicolumn{12}{|c|}{ Nomor Soal } \\
\hline & 1 & 2 & 3 & 4 & 5 & 6 & 7 & 8 & 9 & 10 & 11 & 12 \\
\hline E-01 & $S$ & SS & SS & SS & SS & SS & SS & SS & $S$ & SS & SS & SS \\
\hline E-02 & SS & SS & $\mathrm{S}$ & SS & $\mathrm{S}$ & $\mathrm{S}$ & $\mathrm{S}$ & $\mathrm{N}$ & $\mathrm{N}$ & $\mathrm{S}$ & $\mathrm{S}$ & SS \\
\hline E-03 & STS & $\mathrm{N}$ & $\mathrm{TS}$ & STS & STS & $\mathrm{N}$ & $\mathrm{N}$ & ATS & STS & $\mathrm{S}$ & $\mathrm{N}$ & SS \\
\hline E-04 & ATS & $\mathrm{N}$ & $\mathrm{N}$ & $\mathrm{TS}$ & $\mathrm{TS}$ & $\mathrm{S}$ & $\mathrm{N}$ & $\mathrm{TS}$ & STS & AS & $\mathrm{N}$ & STS \\
\hline E-05 & ATS & $\mathrm{S}$ & AS & AS & $\mathrm{N}$ & AS & $\mathrm{N}$ & AS & ATS & $\mathrm{N}$ & $\mathrm{S}$ & ATS \\
\hline E-06 & STS & $\mathrm{N}$ & $\mathrm{S}$ & $\mathrm{N}$ & $\mathrm{TS}$ & $\mathrm{N}$ & AS & $\mathrm{S}$ & STS & STS & $\mathrm{S}$ & $\mathrm{S}$ \\
\hline E-07 & $\mathrm{TS}$ & $S$ & $\mathrm{~N}$ & ATS & $\mathrm{N}$ & $\mathrm{S}$ & $\mathrm{N}$ & ATS & $\mathrm{TS}$ & $\mathrm{S}$ & AS & AS \\
\hline E-08 & $\mathrm{N}$ & AS & $\mathrm{N}$ & $\mathrm{N}$ & AS & AS & $\mathrm{N}$ & $\mathrm{N}$ & $\mathrm{N}$ & $\mathrm{S}$ & $\mathrm{N}$ & $\mathrm{N}$ \\
\hline E-09 & ATS & SS & $\mathrm{N}$ & $\mathrm{N}$ & $\mathrm{N}$ & $\mathrm{S}$ & $\mathrm{N}$ & ATS & ATS & SS & $\mathrm{N}$ & $\mathrm{N}$ \\
\hline E-10 & STS & $\mathrm{TS}$ & $\mathrm{S}$ & $\mathrm{TS}$ & STS & ATS & $\mathrm{N}$ & ATS & STS & STS & $\mathrm{N}$ & ATS \\
\hline E-11 & $\mathrm{N}$ & $\mathrm{S}$ & ATS & STS & $\mathrm{TS}$ & $\mathrm{N}$ & $\mathrm{TS}$ & STS & STS & $\mathrm{S}$ & $\mathrm{N}$ & TS \\
\hline E-12 & SS & $S$ & AS & AS & $\mathrm{S}$ & $S$ & AS & SS & SS & $S$ & $\mathrm{~S}$ & AS \\
\hline E-13 & $\mathrm{S}$ & AS & SS & $\mathrm{N}$ & $S$ & AS & $\mathrm{SS}$ & $\mathrm{S}$ & SS & $S$ & AS & $\mathrm{N}$ \\
\hline E-14 & $\mathrm{N}$ & SS & $\mathrm{N}$ & $\mathrm{TS}$ & ATS & SS & $\mathrm{N}$ & ATS & STS & $\mathrm{S}$ & $\mathrm{N}$ & ATS \\
\hline E-15 & STS & TS & $\mathrm{TS}$ & ATS & $\mathrm{TS}$ & ATS & $\mathrm{N}$ & TS & STS & $\mathrm{S}$ & ATS & TS \\
\hline E-16 & AS & $\mathrm{N}$ & ATS & AS & $\mathrm{S}$ & $\mathrm{S}$ & ATS & $\mathrm{N}$ & AS & SS & $\mathrm{S}$ & AS \\
\hline E-17 & $\mathrm{N}$ & $\mathrm{S}$ & $\mathrm{S}$ & AS & AS & $S$ & $\mathrm{~S}$ & AS & $\mathrm{N}$ & $\mathrm{S}$ & $S$ & AS \\
\hline E-18 & $\mathrm{S}$ & SS & SS & SS & SS & SS & SS & SS & SS & SS & SS & SS \\
\hline
\end{tabular}




\begin{tabular}{|c|c|c|c|c|c|c|c|c|c|c|c|c|}
\hline \multirow{2}{*}{ Kode } & \multicolumn{12}{|c|}{ Nomor Soal } \\
\hline & 1 & 2 & 3 & 4 & 5 & 6 & 7 & 8 & 9 & 10 & 11 & 12 \\
\hline E-19 & SS & SS & SS & SS & $S$ & SS & SS & SS & SS & SS & SS & SS \\
\hline E-20 & TS & AS & $\mathrm{N}$ & $\mathrm{N}$ & $\mathrm{N}$ & $\mathrm{S}$ & $\mathrm{N}$ & $\mathrm{N}$ & TS & $\mathrm{N}$ & $\mathrm{N}$ & $\mathrm{N}$ \\
\hline E-21 & STS & TS & TS & ATS & TS & $\mathrm{S}$ & $\mathrm{N}$ & $\mathrm{N}$ & STS & $\mathrm{S}$ & $\mathrm{N}$ & ATS \\
\hline E-22 & TS & AS & $\mathrm{N}$ & STS & $\mathrm{N}$ & SS & $\mathrm{N}$ & AS & STS & SS & $\mathrm{S}$ & $\mathrm{N}$ \\
\hline E-23 & ATS & ATS & $\mathrm{N}$ & $\mathrm{N}$ & $\mathrm{N}$ & $\mathrm{N}$ & AS & $\mathrm{N}$ & $\mathrm{N}$ & AS & AS & $\mathrm{N}$ \\
\hline E-24 & $\mathrm{N}$ & $\mathrm{N}$ & $\mathrm{N}$ & STS & $\mathrm{N}$ & $\mathrm{N}$ & $\mathrm{N}$ & $\mathrm{N}$ & $\mathrm{S}$ & $\mathrm{N}$ & $\mathrm{N}$ & $\mathrm{N}$ \\
\hline E-25 & ATS & AS & AS & TS & ATS & ATS & TS & TS & ATS & $\mathrm{N}$ & $\mathrm{N}$ & $\mathrm{N}$ \\
\hline E-26 & TS & TS & AS & $\mathrm{N}$ & ATS & TS & AS & $\mathrm{N}$ & TS & ATS & $\mathrm{N}$ & ATS \\
\hline E-27 & $\mathrm{N}$ & $\mathrm{AS}$ & $\mathrm{S}$ & TS & $\mathrm{N}$ & $\mathrm{N}$ & AS & $\mathrm{AS}$ & TS & AS & $\mathrm{S}$ & AS \\
\hline E-28 & SS & $\mathrm{S}$ & SS & SS & SS & SS & SS & SS & SS & SS & SS & SS \\
\hline E-29 & $\mathrm{N}$ & $\mathrm{N}$ & AS & $\mathrm{N}$ & $\mathrm{N}$ & $\mathrm{S}$ & AS & $\mathrm{N}$ & ATS & AS & $\mathrm{S}$ & $\mathrm{N}$ \\
\hline E-30 & $\mathrm{N}$ & $\mathrm{N}$ & $\mathrm{N}$ & $\mathrm{TS}$ & AS & $\mathrm{N}$ & AS & AS & $\mathrm{TS}$ & AS & $\mathrm{N}$ & ATS \\
\hline E-31 & $\mathrm{S}$ & SS & SS & SS & $\mathrm{S}$ & SS & SS & $\mathrm{S}$ & SS & $\mathrm{S}$ & SS & SS \\
\hline E-32 & STS & $\mathrm{N}$ & $\mathrm{N}$ & TS & STS & $\mathrm{N}$ & $\mathrm{N}$ & TS & STS & $\mathrm{N}$ & $\mathrm{TS}$ & STS \\
\hline E-33 & TS & $\mathrm{N}$ & ATS & $\mathrm{N}$ & $\mathrm{N}$ & $\mathrm{N}$ & $\mathrm{N}$ & $\mathrm{N}$ & $\mathrm{N}$ & $\mathrm{N}$ & $\mathrm{N}$ & $\mathrm{N}$ \\
\hline E-34 & ATS & $\mathrm{N}$ & $\mathrm{N}$ & $\mathrm{N}$ & $\mathrm{N}$ & $\overline{\mathrm{AS}}$ & $\mathrm{N}$ & $\mathrm{N}$ & ATS & $\mathrm{N}$ & $\mathrm{N}$ & $\mathrm{N}$ \\
\hline E-35 & AS & AS & AS & SS & $\mathrm{S}$ & AS & SS & $\mathrm{S}$ & AS & SS & SS & SS \\
\hline E-36 & $\mathrm{N}$ & $\mathrm{S}$ & $\mathrm{S}$ & AS & $\mathrm{N}$ & $\mathrm{N}$ & $\mathrm{S}$ & $\mathrm{N}$ & $\mathrm{N}$ & $\mathrm{N}$ & $\mathrm{S}$ & $S$ \\
\hline
\end{tabular}




\section{Transformasi Data Kelas Eksperimen:}

\begin{tabular}{|c|c|c|c|c|c|c|c|c|c|c|c|c|c|c|}
\hline \multirow{2}{*}{ No. } & \multirow{2}{*}{ Kode } & \multicolumn{12}{|c|}{ Nomor Soal } & \multirow{2}{*}{ Jumlah } \\
\hline & & 1 & 2 & 3 & 4 & 5 & 6 & \begin{tabular}{|l|}
7 \\
\end{tabular} & 8 & 9 & 10 & 11 & 12 & \\
\hline 1. & $\mathrm{E}-01$ & 6 & 7 & 7 & 7 & 7 & 7 & 7 & 7 & 6 & 7 & 7 & 7 & 82 \\
\hline 2. & E-02 & 7 & 7 & 6 & 7 & 6 & 6 & 6 & 4 & 4 & 6 & 6 & 7 & 72 \\
\hline 3. & E-03 & 1 & 4 & 2 & 1 & 1 & 4 & 4 & 3 & 1 & 6 & 4 & 7 & 38 \\
\hline 4. & $\mathrm{E}-04$ & 3 & 4 & 4 & 2 & 2 & 6 & 4 & 2 & 1 & 5 & 4 & 1 & 38 \\
\hline 5. & E-05 & 3 & 6 & 5 & 5 & 4 & 5 & 4 & 5 & 3 & 4 & 6 & 3 & 53 \\
\hline 6. & E-06 & 1 & 4 & 6 & 4 & 2 & 4 & 5 & 6 & 1 & 1 & 6 & 6 & 46 \\
\hline 7. & E-07 & 2 & 6 & 4 & 3 & 4 & 6 & 4 & 3 & 2 & 6 & 5 & 5 & 50 \\
\hline 8. & E-08 & 4 & 5 & 4 & 4 & 5 & 5 & 4 & 4 & 4 & 6 & 4 & 4 & 53 \\
\hline 9. & E-09 & 3 & 7 & 4 & 4 & 4 & 6 & 4 & 3 & 3 & 7 & 4 & 4 & 53 \\
\hline 10. & E-10 & 1 & 2 & 6 & 2 & 1 & 3 & 4 & 3 & 1 & 1 & 4 & 3 & 31 \\
\hline 11. & E-11 & 4 & 6 & 3 & 1 & 2 & 4 & 2 & 1 & 1 & 6 & 4 & 2 & 36 \\
\hline 12. & $\mathrm{E}-12$ & 7 & 6 & 5 & 5 & 6 & 6 & 5 & 7 & 7 & 6 & 6 & 5 & 71 \\
\hline 13. & E-13 & 6 & 5 & 7 & 4 & 6 & 5 & 7 & 6 & 7 & 6 & 5 & 4 & 68 \\
\hline 14. & $\mathrm{E}-14$ & 4 & 7 & 4 & 2 & 3 & 7 & 4 & 3 & 1 & 6 & 4 & 3 & 48 \\
\hline 15. & E-15 & 1 & 2 & 2 & 3 & 2 & 3 & 4 & 2 & 1 & 6 & 3 & 2 & 31 \\
\hline 16. & E-16 & 5 & 4 & 3 & 5 & 6 & 6 & 3 & 4 & 5 & 7 & 6 & 5 & 59 \\
\hline 17. & $\mathrm{E}-17$ & 4 & 6 & 6 & 5 & 5 & 6 & 6 & 5 & 4 & 6 & 6 & 5 & 64 \\
\hline 18. & E-18 & 6 & 7 & 7 & 7 & 7 & 7 & 7 & 7 & 7 & 7 & 7 & 7 & 83 \\
\hline 19. & E-19 & 7 & 7 & 7 & 7 & 6 & 7 & 7 & 7 & 7 & 7 & 7 & 7 & 83 \\
\hline 20. & $\mathrm{E}-20$ & 2 & 5 & 4 & 4 & 4 & 6 & 4 & 4 & 2 & 4 & 4 & 4 & 47 \\
\hline 21. & E-21 & 1 & 2 & 2 & 3 & 2 & 6 & 4 & 4 & 1 & 6 & 4 & 3 & 38 \\
\hline 22. & $\mathrm{E}-22$ & 2 & 5 & 4 & 1 & 4 & 7 & 4 & 5 & 1 & 7 & 6 & 4 & 50 \\
\hline 23. & $\mathrm{E}-23$ & 3 & 3 & 4 & 4 & 4 & 4 & 5 & 4 & 4 & 5 & 5 & 4 & 49 \\
\hline 24. & E-24 & 4 & 4 & 4 & 1 & 4 & 4 & 4 & 4 & 6 & 4 & 4 & 4 & 47 \\
\hline 25. & $\mathrm{E}-25$ & 3 & 5 & 5 & 2 & 3 & 3 & 2 & 2 & 3 & 4 & 4 & 4 & 40 \\
\hline 26. & E-26 & 2 & 2 & 5 & 4 & 3 & 2 & 5 & 4 & 2 & 3 & 4 & 3 & 39 \\
\hline 27. & E-27 & 4 & 5 & 6 & 2 & 4 & 4 & 5 & 5 & 2 & 5 & 6 & 5 & 53 \\
\hline 28. & $\mathrm{E}-28$ & 7 & 6 & 7 & 7 & 7 & 7 & 7 & 7 & 7 & 7 & 7 & 7 & 83 \\
\hline 29. & $\mathrm{E}-29$ & 4 & 4 & 5 & 4 & 4 & 6 & 5 & 4 & 3 & 5 & 6 & 4 & 54 \\
\hline 30. & $E-30$ & 4 & 4 & 4 & 2 & 5 & 4 & 5 & 5 & 2 & 5 & 4 & 3 & 47 \\
\hline 31. & $E-31$ & 6 & 7 & 7 & 7 & 6 & 7 & 7 & 6 & 7 & 6 & 7 & 7 & 80 \\
\hline 32. & $E-32$ & 1 & 4 & 4 & 2 & 1 & 4 & 4 & 2 & 1 & 4 & 2 & 1 & 30 \\
\hline 33. & $\mathrm{E}-33$ & 2 & 4 & 3 & 4 & 4 & 4 & 4 & 4 & 4 & 4 & 4 & 4 & 45 \\
\hline 34 & E-34 & 3 & 4 & 4 & 4 & 4 & 5 & 4 & 4 & 3 & 4 & 4 & 4 & 47 \\
\hline 35 & E-35 & 5 & 5 & 5 & 7 & 6 & 5 & 7 & 6 & 5 & 7 & 7 & 7 & 72 \\
\hline 36 & E-36 & 4 & 6 & 6 & 5 & 4 & 4 & 6 & 4 & 4 & 4 & 6 & 6 & 59 \\
\hline \multicolumn{2}{|c|}{\begin{tabular}{|l|} 
Jumlah \\
\end{tabular}} & 132 & 177 & 171 & 141 & 148 & 185 & 173 & 156 & 123 & 190 & 182 & 161 & 1939 \\
\hline \multicolumn{2}{|c|}{ Jumlah SA } & 132 & 177 & 171 & 141 & 148 & 185 & 173 & 156 & 123 & 190 & 182 & 161 & \\
\hline \multicolumn{2}{|c|}{ Jumlah SI } & 252 & 252 & 252 & 252 & \begin{tabular}{|l|}
252 \\
\end{tabular} & 252 & 252 & 252 & 252 & 252 & 252 & 252 & \\
\hline \multicolumn{2}{|c|}{$\%$} & 52,38 & 70,24 & 67,86 & 55,95 & \begin{tabular}{|l|}
58,73 \\
\end{tabular} & 73,41 & 68,65 & 61,9 & 48,81 & 75,4 & 72,22 & 63,89 & \\
\hline \multicolumn{2}{|c|}{ SAV } & \multicolumn{12}{|c|}{1939} & \\
\hline \multicolumn{2}{|c|}{ SIV } & \multicolumn{12}{|c|}{3024} & \\
\hline \multicolumn{2}{|r|}{$\%$} & \multicolumn{12}{|c|}{64,12} & \\
\hline
\end{tabular}


Lampiran 33. Uji N-Gain Attitudes toward Chemistry

Kelas Kontrol:

\begin{tabular}{|c|c|c|c|c|c|}
\hline No. & Kode & Pretest & Posttest & $\begin{array}{c}\text { Nilai N- } \\
\text { Gain }\end{array}$ & Kategori \\
\hline 1 & K-01 & 35 & 42 & 0,143 & Rendah \\
\hline 2 & K-02 & 32 & 40 & 0,154 & Rendah \\
\hline 3 & K-03 & 30 & 36 & 0,111 & Rendah \\
\hline 4 & K-04 & 45 & 55 & 0,256 & Rendah \\
\hline 5 & K-05 & 47 & 48 & 0,027 & Rendah \\
\hline 6 & K-06 & 47 & 62 & 0,405 & Sedang \\
\hline 7 & K-07 & 48 & 55 & 0,194 & Rendah \\
\hline 8 & K-08 & 55 & 63 & 0,276 & Rendah \\
\hline 9 & K-09 & 35 & 41 & 0,122 & Rendah \\
\hline 10 & K-10 & 58 & 68 & 0,385 & Sedang \\
\hline 11 & K-11 & 57 & 65 & 0,296 & Rendah \\
\hline 12 & K-12 & 64 & 70 & 0,300 & Sedang \\
\hline 13 & K-13 & 45 & 50 & 0,128 & Rendah \\
\hline 14 & K-14 & 40 & 48 & 0,182 & Rendah \\
\hline 15 & K-15 & 49 & 56 & 0,200 & Rendah \\
\hline 16 & K-16 & 41 & 48 & 0,163 & Rendah \\
\hline 17 & K-17 & 50 & 56 & 0,176 & Rendah \\
\hline 18 & K-18 & 42 & 53 & 0,262 & Rendah \\
\hline 19 & K-19 & 56 & 62 & 0,214 & Rendah \\
\hline 20 & K-20 & 37 & 41 & 0,085 & Rendah \\
\hline 21 & K-21 & 37 & 43 & 0,128 & Rendah \\
\hline 22 & K-22 & 56 & 58 & 0,071 & Rendah \\
\hline 23 & K-23 & 43 & 48 & 0,122 & Rendah \\
\hline 24 & K-24 & 60 & 65 & 0,208 & Rendah \\
\hline 25 & K-25 & 54 & 60 & 0,200 & Rendah \\
\hline 26 & K-26 & 59 & 65 & 0,240 & Rendah \\
\hline
\end{tabular}




\begin{tabular}{|c|c|c|c|c|c|}
\hline No. & Kode & Pretest & Posttest & $\begin{array}{c}\text { Nilai N- } \\
\text { Gain }\end{array}$ & Kategori \\
\hline 27 & K-27 & 47 & 52 & 0,135 & Rendah \\
\hline 28 & K-28 & 37 & 41 & 0,085 & Rendah \\
\hline 29 & K-29 & 52 & 59 & 0,219 & Rendah \\
\hline 30 & K-30 & 46 & 55 & 0,237 & Rendah \\
\hline 31 & K-31 & 72 & 81 & 0,750 & Tinggi \\
\hline 32 & K-32 & 44 & 47 & 0,075 & Rendah \\
\hline 33 & K-33 & 21 & 22 & 0,016 & Rendah \\
\hline 34 & K-34 & 36 & 39 & 0,063 & Rendah \\
\hline \multicolumn{2}{|c|}{ Jumlah } & 1577 & 1794 & 6,629 & \\
\hline \multicolumn{2}{|c|}{ Mean } & 46,382 & 52,765 & 0,195 & Rendah \\
\hline
\end{tabular}

Kelas Eksperimen:

\begin{tabular}{|c|c|c|c|c|c|}
\hline No. & Kode & Pretest & Posttest & $\begin{array}{c}\text { Nilai N- } \\
\text { Gain }\end{array}$ & Kategori \\
\hline 1 & E-01 & 51 & 82 & 0,939 & Tinggi \\
\hline 2 & E-02 & 48 & 72 & 0,667 & Sedang \\
\hline 3 & E-03 & 31 & 38 & 0,132 & Rendah \\
\hline 4 & E-04 & 34 & 38 & 0,080 & Rendah \\
\hline 5 & E-05 & 47 & 53 & 0,162 & Rendah \\
\hline 6 & E-06 & 40 & 46 & 0,136 & Rendah \\
\hline 7 & E-07 & 45 & 50 & 0,128 & Rendah \\
\hline 8 & E-08 & 51 & 53 & 0,061 & Rendah \\
\hline 9 & E-09 & 48 & 53 & 0,139 & Rendah \\
\hline 10 & E-10 & 28 & 31 & 0,054 & Rendah \\
\hline 11 & E-11 & 33 & 36 & 0,059 & Rendah \\
\hline 12 & E-12 & 57 & 71 & 0,519 & Sedang \\
\hline 13 & E-13 & 54 & 68 & 0,467 & Sedang \\
\hline 14 & E-14 & 41 & 48 & 0,163 & Rendah \\
\hline 15 & E-15 & 29 & 31 & 0,036 & Rendah \\
\hline 16 & E-16 & 52 & 59 & 0,219 & Rendah \\
\hline
\end{tabular}




\begin{tabular}{|c|c|c|c|c|c|}
\hline No. & Kode & Pretest & Posttest & $\begin{array}{c}\text { Nilai N- } \\
\text { Gain }\end{array}$ & Kategori \\
\hline 17 & E-17 & 48 & 64 & 0,444 & Sedang \\
\hline 18 & E-18 & 51 & 83 & 0,970 & Tinggi \\
\hline 19 & E-19 & 45 & 83 & 0,974 & Tinggi \\
\hline 20 & E-20 & 41 & 47 & 0,140 & Rendah \\
\hline 21 & E-21 & 34 & 38 & 0,080 & Rendah \\
\hline 22 & E-22 & 38 & 50 & 0,261 & Rendah \\
\hline 23 & E-23 & 40 & 49 & 0,205 & Rendah \\
\hline 24 & E-24 & 35 & 47 & 0,245 & Rendah \\
\hline 25 & E-25 & 31 & 40 & 0,170 & Rendah \\
\hline 26 & E-26 & 28 & 39 & 0,196 & Rendah \\
\hline 27 & E-27 & 37 & 53 & 0,340 & Sedang \\
\hline 28 & E-28 & 48 & 83 & 0,972 & Tinggi \\
\hline 29 & E-29 & 44 & 54 & 0,250 & Rendah \\
\hline 30 & E-30 & 36 & 47 & 0,229 & Rendah \\
\hline 31 & E-31 & 54 & 80 & 0,867 & Tinggi \\
\hline 32 & E-32 & 24 & 30 & 0,100 & Rendah \\
\hline 33 & E-33 & 36 & 45 & 0,188 & Rendah \\
\hline 34 & E-34 & 39 & 47 & 0,178 & Rendah \\
\hline 35 & E-35 & 55 & 72 & 0,586 & Sedang \\
\hline 36 & E-36 & 43 & 59 & 0,390 & Sedang \\
\hline Jumlah & 1496 & 1939 & 11,745 & \\
\hline & Mean & 41,556 & 53,861 & 0,326 & Sedang \\
\hline
\end{tabular}


Lampiran 34. Uji Hipotesis Attitudes toward Chemistry

\section{Data Posttest Attitudes toward Chemistry}

\begin{tabular}{|c|c|c|c|}
\hline No. & Kode & Nilai & $(x-\bar{x})^{2}$ \\
\hline 1 & K-01 & 42 & 115,88 \\
\hline 2 & $\mathrm{~K}-02$ & 40 & 162,94 \\
\hline 3 & $\mathrm{~K}-03$ & 36 & 281,06 \\
\hline 4 & $\mathrm{~K}-04$ & 55 & 5,00 \\
\hline 5 & K-05 & 48 & 22,70 \\
\hline 6 & $\mathrm{~K}-06$ & 62 & 85,29 \\
\hline 7 & K-07 & 55 & 5,00 \\
\hline 8 & $\mathrm{~K}-08$ & 63 & 104,76 \\
\hline 9 & $\mathrm{~K}-09$ & 41 & 138,41 \\
\hline 10 & $\mathrm{~K}-10$ & 68 & 232,11 \\
\hline 11 & $\mathrm{~K}-11$ & 65 & 149,70 \\
\hline 12 & $\mathrm{~K}-12$ & 70 & 297,06 \\
\hline 13 & $\mathrm{~K}-13$ & 50 & 7,64 \\
\hline 14 & $\mathrm{~K}-14$ & 48 & 22,70 \\
\hline 15 & $\mathrm{~K}-15$ & 56 & 10,47 \\
\hline 16 & K-16 & 48 & 22,70 \\
\hline 17 & $\mathrm{~K}-17$ & 56 & 10,47 \\
\hline 18 & $\mathrm{~K}-18$ & 53 & 0,06 \\
\hline 19 & $\mathrm{~K}-19$ & 62 & 85,29 \\
\hline 20 & $\mathrm{~K}-20$ & 41 & 138,41 \\
\hline 21 & $\mathrm{~K}-21$ & 43 & 95,35 \\
\hline 22 & $\mathrm{~K}-22$ & 58 & 27,41 \\
\hline 23 & $\mathrm{~K}-23$ & 48 & 22,70 \\
\hline 24 & $\mathrm{~K}-24$ & 65 & 149,70 \\
\hline 25 & $\mathrm{~K}-25$ & 60 & 52,35 \\
\hline 26 & $\mathrm{~K}-26$ & 65 & 149,70 \\
\hline 27 & $\mathrm{~K}-27$ & 52 & 0,58 \\
\hline 28 & $\mathrm{~K}-28$ & 41 & 138,41 \\
\hline 29 & $\mathrm{~K}-29$ & 59 & 38,88 \\
\hline 30 & $\mathrm{~K}-30$ & 55 & 5,00 \\
\hline 31 & $\mathrm{~K}-31$ & 81 & 797,23 \\
\hline 32 & $\mathrm{~K}-32$ & 47 & 33,23 \\
\hline 33 & $\mathrm{~K}-33$ & 22 & 946,47 \\
\hline 34 & $\mathrm{~K}-34$ & 39 & 189,47 \\
\hline \multicolumn{2}{|c|}{ Jumlah } & 1794 & 4544,118 \\
\hline \multicolumn{2}{|c|}{ Rata-rata } & 52,765 & \\
\hline \multicolumn{2}{|c|}{ Nilai tertinggi } & 81 & \\
\hline \multicolumn{2}{|c|}{ Nilai terendah } & 22 & \\
\hline \multicolumn{2}{|c|}{ Rentang } & 59 & \\
\hline \multicolumn{2}{|c|}{ Banyak kelas } & 6,054 & \\
\hline \multicolumn{2}{|c|}{ Panjang kelas } & 9,746 & \\
\hline \multicolumn{2}{|c|}{ Standar Deviasi } & 11,735 & \\
\hline
\end{tabular}

\begin{tabular}{|c|c|c|c|}
\hline No. & Kode & Nilai & $(x-\bar{x})^{2}$ \\
\hline 1 & E-01 & 82 & 791,80 \\
\hline 2 & E-02 & 72 & 329,02 \\
\hline 3 & E-03 & 38 & 251,57 \\
\hline 4 & E-04 & 38 & 251,57 \\
\hline 5 & E-05 & 53 & 0,74 \\
\hline 6 & E-06 & 46 & 61,80 \\
\hline 7 & E-07 & 50 & 14,91 \\
\hline 8 & E-08 & 53 & 0,74 \\
\hline 9 & E-09 & 53 & 0,74 \\
\hline 10 & E-10 & 31 & 522,63 \\
\hline 11 & E-11 & 36 & 319,02 \\
\hline 12 & E-12 & 71 & 293,74 \\
\hline 13 & E-13 & 68 & 199,91 \\
\hline 14 & E-14 & 48 & 34,35 \\
\hline 15 & E-15 & 31 & 522,63 \\
\hline 16 & E-16 & 59 & 26,41 \\
\hline 17 & E-17 & 64 & 102,80 \\
\hline 18 & E-18 & 83 & 849,07 \\
\hline 19 & E-19 & 83 & 849,07 \\
\hline 20 & E-20 & 47 & 47,07 \\
\hline 21 & E-21 & 38 & 251,57 \\
\hline 22 & E-22 & 50 & 14,91 \\
\hline 23 & E-23 & 49 & 23,63 \\
\hline 24 & E-24 & 47 & 47,07 \\
\hline 25 & E-25 & 40 & 192,13 \\
\hline 26 & E-26 & 39 & 220,85 \\
\hline 27 & E-27 & 53 & 0,74 \\
\hline 28 & E-28 & 83 & 849,07 \\
\hline 29 & E-29 & 54 & 0,02 \\
\hline 30 & E-30 & 47 & 47,07 \\
\hline 31 & E-31 & 80 & 683,24 \\
\hline 32 & E-32 & 30 & 569,35 \\
\hline 33 & E-33 & 45 & 78,52 \\
\hline 34 & E-34 & 47 & 47,07 \\
\hline 35 & E-35 & 72 & 329,02 \\
\hline 36 & E-36 & 59 & 26,41 \\
\hline \multicolumn{2}{|c|}{ Jumlah } & 1939 & 8850,306 \\
\hline \multicolumn{2}{|c|}{ Rata-rata } & 53,861 & \\
\hline \multicolumn{2}{|c|}{ Nilai tertinggi } & 83 & \\
\hline \multicolumn{2}{|c|}{ Nilai terendah } & 30 & \\
\hline \multicolumn{2}{|c|}{ Rentang } & 53 & \\
\hline \multicolumn{2}{|c|}{ Banyak kelas } & 6,136 & \\
\hline \multicolumn{2}{|c|}{ Panjang kelas } & 8,638 & \\
\hline \multicolumn{2}{|c|}{ Standar Deviasi } & 15,902 & \\
\hline
\end{tabular}




\section{Uji Normalitas Posttest Attitudes toward Chemistry Kelas Kontrol}

\section{Hipotesis:}

$\mathrm{H}_{0}$ : Data berdistribusi normal

$\mathrm{H}_{a}$ : Data tidak berdistribusi normal

\section{Pengujian Hipotesis:}

$X^{2} h=\sum \frac{\left(f_{o}-f_{h}\right)^{2}}{f_{h}}$

\section{Kriteria yang digunakan:}

$\mathrm{H}_{0}$ diterima jika $X^{2}{ }_{\text {hitung }}<X^{2}$ tabel

\section{Pengujian normalitas data:}

\begin{tabular}{|c|c|c|c|c|c|c|c|}
\hline Interval & Batas kelas & $\mathbf{Z}$ & Luas Z & Luas Tiap Kelas & fh & fo & Chi kuadrat \\
\hline & 21,5 & $-2,66$ & 0,4961 & & & & \\
\hline \multirow[t]{2}{*}{$22-31$} & & & & 0,0312 & 1,0608 & 1 & 0,003 \\
\hline & 31,5 & $-1,81$ & 0,4649 & & & & \\
\hline \multirow[t]{2}{*}{$32-41$} & & & & 0,1334 & 4,5356 & 6 & 0,473 \\
\hline & 41,5 & $-0,96$ & 0,3315 & & & & \\
\hline \multirow[t]{2}{*}{$42-51$} & & & & 0,3753 & 12,7602 & 8 & 1,776 \\
\hline & 51,5 & $-0,11$ & 0,0438 & & & & \\
\hline \multirow[t]{2}{*}{$52-61$} & & & & 0,3141 & 10,6794 & 10 & 0,043 \\
\hline & 61,5 & 0,74 & 0,2703 & & & & \\
\hline \multirow[t]{2}{*}{$62-71$} & & & & $-0,2184$ & $-7,4256$ & 8 & $-32,044$ \\
\hline & 79,5 & 2,28 & 0,4887 & & & & \\
\hline \multirow[t]{2}{*}{$72-81$} & & & & $-0,0042$ & $-0,1428$ & 1 & $-9,146$ \\
\hline & 81,5 & 2,45 & 0,4929 & & & & \\
\hline \multicolumn{6}{|c|}{ Jumlah } & 34 & $-38,895$ \\
\hline \multicolumn{6}{|c|}{ Rata-rata } & \multicolumn{2}{|c|}{52,765} \\
\hline \multicolumn{6}{|c|}{ SD } & \multicolumn{2}{|c|}{11,735} \\
\hline \multicolumn{6}{|c|}{ Varians } & \multicolumn{2}{|c|}{137,701} \\
\hline \multicolumn{6}{|c|}{ Chi kuadrat tabel } & \multicolumn{2}{|c|}{11,071} \\
\hline \multicolumn{6}{|c|}{ Interpretasi } & \multicolumn{2}{|c|}{ normal } \\
\hline
\end{tabular}

Berdasarkan perhitungan dihasilkan $X^{2}$ hitung $=-38,895$. Selanjutnya $X^{2}$ hitung tersebut dibandingkan dengan $X^{2}$ tabel dengan $\mathrm{dk}=6$ dan taraf signifikansi $5 \%$, sehingga ditetapkan $X_{\text {tabel }}=11,071$. Karena $X^{2}$ hitung $<X_{\text {tabel, }}^{2}$ maka $\mathrm{H}_{0}$ diterima, sehingga kelas kontrol dinyatakan berdistribusi normal. 


\section{Uji Normalitas Posttest Attitudes toward Chemistry Kelas Eksperimen}

\section{Hipotesis:}

$\mathrm{H}_{0}$ : Data berdistribusi normal

$\mathrm{H}_{a}$ : Data tidak berdistribusi normal

\section{Pengujian Hipotesis:}

$X^{2} h=\sum \frac{\left(f_{o}-f_{h}\right)^{2}}{f_{h}}$

\section{Kriteria yang digunakan:}

$\mathrm{H}_{0}$ diterima jika $X^{2}{ }_{\text {hitung }}<X^{2}$ tabel

\section{Pengujian normalitas data:}

\begin{tabular}{|c|c|c|c|c|c|c|c|}
\hline Interval & Batas kelas & $\mathbf{Z}$ & Luas Z & Luas Tiap Kelas & fh & fo & Chi kuadrat \\
\hline & 29,5 & $-1,53$ & 0,4370 & & & & \\
\hline \multirow[t]{2}{*}{$30-38$} & & & & 0,103 & 3,708 & 7 & 2,923 \\
\hline & 38,5 & $-0,97$ & 0,3340 & & & & \\
\hline \multirow[t]{2}{*}{$39-47$} & & & & 0,1786 & 6,4296 & 8 & 0,384 \\
\hline & 47,5 & $-0,40$ & 0,1554 & & & & \\
\hline \multirow[t]{2}{*}{$48-57$} & & & & 0,2464 & 8,8704 & 9 & 0,002 \\
\hline & 57,5 & 0,23 & 0,0910 & & & & \\
\hline \multirow[t]{2}{*}{$58-66$} & & & & 0,3762 & 13,5432 & 3 & 8,208 \\
\hline & 66,5 & 0,79 & 0,2852 & & & & \\
\hline \multirow[t]{2}{*}{$67-75$} & & & & $-0,1279$ & $-4,6044$ & 4 & $-16,079$ \\
\hline & 75,5 & 1,36 & 0,4131 & & & & \\
\hline \multirow[t]{2}{*}{$76-84$} & & & & $-0,0601$ & $-2,1636$ & 5 & $-23,718$ \\
\hline & 84,5 & 1,93 & 0,4732 & & & & \\
\hline \multicolumn{6}{|c|}{ Jumlah } & 36 & $-28,282$ \\
\hline \multicolumn{6}{|c|}{ Rata-rata } & \multicolumn{2}{|c|}{53,861} \\
\hline \multicolumn{6}{|c|}{ SD } & \multicolumn{2}{|c|}{15,902} \\
\hline \multicolumn{6}{|c|}{ Varians } & \multicolumn{2}{|c|}{252,866} \\
\hline \multicolumn{6}{|c|}{ Chi kuadrat tabel } & \multicolumn{2}{|c|}{11,071} \\
\hline \multicolumn{6}{|c|}{ Interpretasi } & \multicolumn{2}{|c|}{ normal } \\
\hline
\end{tabular}

Berdasarkan perhitungan dihasilkan $X^{2}$ hitung $=-28,282$. Selanjutnya $X^{2}$ hitung tersebut dibandingkan dengan $X^{2}$ tabel dengan $\mathrm{dk}=6$ dan taraf signifikansi 5\%, sehingga ditetapkan $X_{\text {tabel }}=11,071$. Karena $X^{2}$ hitung $<X_{\text {tabel, }}$ maka $H_{0}$ diterima, sehingga kelas eksperimen dinyatakan berdistribusi normal. 


\section{Uji Homogenitas Posttest Attitudes toward Chemistry}

\section{Hipotesis:}

$\mathrm{H}_{0}: \sigma_{1}=\sigma_{2}$

$\mathrm{H}_{a}: \sigma_{1} \neq \sigma_{2}$

\section{Pengujian Hipotesis:}

$\mathrm{F}=\frac{\text { Varians terbesar }}{\text { Varians terkecil }}$

$\mathrm{H}_{0}$ diterima apabila $\mathrm{F}_{\text {hitung }} \leq \mathrm{F}_{\text {tabel }}$

\section{Dari data diperoleh:}

\begin{tabular}{|c|c|c|}
\hline Sumber Variasi & Kelas Eksperimen & Kelas Kontrol \\
\hline Jumlah & 1939 & 1794 \\
\hline $\mathrm{n}$ & 36 & 34 \\
\hline Rata-rata & 53,861 & 52,765 \\
\hline Standar Deviasi & 15,902 & 11,735 \\
\hline Varians & 252,866 & 137,701 \\
\hline
\end{tabular}

Berdasarkan rumus di atas diperoleh:

$\mathrm{F}=\frac{252,866}{137,701}=1,836$

Taraf signifikan 5\% dengan:

$\mathrm{dk}$ pembilang $=\mathrm{k}-1=2$

$\mathrm{dk}$ penyebut $=\mathrm{N}-\mathrm{k}=67$

Sehingga, $F_{\text {tabel }}=3,134$

Karena $\mathrm{F}_{\text {hitung }}>\mathrm{F}_{\text {tabel}}$, maka $\mathrm{H}_{0}$ ditolak dan $\mathrm{H}_{a}$ diterima dan dapat disimpulkan bahwa kedua kelas tidak homogen. 


\section{Uji Perbedaan Dua Rata-Rata Posttest Attitudes toward Chemistry}

\section{Hipotesis:}

$\mathrm{H}_{0}: \mu_{1}=\mu_{2}$

$\mathrm{H}_{a}: \mu_{1} \neq \mu_{2}$

\section{Kriteria Pengujian Hipotesis:}

$$
t=\frac{\overline{X_{1}}-\overline{X_{2}}}{\sqrt{\frac{\left(n_{1}-1\right) s_{1}^{2}+\left(n_{2}-1\right) s_{2}^{2}}{n_{1}+n_{2}-2}\left(\frac{1}{n_{1}}+\frac{1}{n_{2}}\right)}}
$$

$\mathrm{H}_{0}$ diterima apabila $\mathrm{t}_{\text {hitung }} \leq \mathrm{t}_{\text {tabel }}$

\section{Uji Hipotesis:}

Dari data diperoleh:

\begin{tabular}{|c|c|c|}
\hline Sumber Variasi & Kelas Eksperimen & Kelas Kontrol \\
\hline Jumlah & 1939 & 1794 \\
\hline $\mathrm{n}$ & 36 & 34 \\
\hline Rata-rata & 53,861 & 52,765 \\
\hline Standar Deviasi & 15,902 & 11,735 \\
\hline Varians & 252,866 & 137,701 \\
\hline
\end{tabular}

Berdasarkan rumus di atas diperoleh:

$$
\begin{aligned}
& t=\frac{53,861-52,765}{\sqrt{\frac{(36-1) 252,866+(34-1) 137,701}{36+34-2}\left(\frac{1}{36}+\frac{1}{34}\right)}} \\
& \mathrm{t}=0,327
\end{aligned}
$$

Taraf signifikansi $5 \%$ dan $d k=68$, sehingga $t_{\text {tabel }}=1,995$. Karena $t_{\text {hitung }} \leq t_{\text {tabel, }}$, maka $\mathrm{H}_{0}$ diterima. Jadi dapat disimpulkan bahwa tidak ada perbedaan rata-rata dari kelas kontrol dan kelas eksperimen. 


\section{Uji Satu Pihak Attitudes toward Chemistry}

\section{Hipotesis:}

$\mathrm{H}_{0}: \mu_{1} \leq \mu_{2}$

$\mathrm{H}_{a}: \mu_{1}>\mu_{2}$

\section{Kriteria Pengujian Hipotesis:}

$\mathrm{H}_{0}$ diterima apabila $\mathrm{t}_{\text {hitung }}<\mathrm{t}_{\text {tabel }}$

\section{Uji Hipotesis:}

$$
t=\frac{\overline{X_{1}}-\overline{X_{2}}}{\sqrt{\frac{\left(n_{1}-1\right) s_{1}^{2}+\left(n_{2}-1\right) s_{2}^{2}}{n_{1}+n_{2}-2}\left(\frac{1}{n_{1}}+\frac{1}{n_{2}}\right)}}
$$

$t=\frac{53,861-52,765}{\sqrt{\frac{(36-1) 252,866+(34-1) 137,701}{36+34-2}\left(\frac{1}{36}+\frac{1}{34}\right)}}$

$t=0,327$

$\mathrm{dk}=36+34-2=68$, sehingga $\mathrm{t}_{\text {tabel }}=1,668$.

Karena $t_{\text {hitung }} \leq \mathrm{t}_{\text {tabel, }}$ sehingga $\mathrm{H}_{0}$ diterima dan $\mathrm{H}_{a}$ ditolak. Jadi dapat disimpulkan bahwa rata-rata attitudes toward chemistry kelas eksperimen lebih kecil atau sama dengan kelas kontrol. 
Lampiran 35. Analisis Angket Respon Peserta Didik terhadap Model Pembelajaran SiMaYang Tipe II

Tabulasi Data:

\begin{tabular}{|c|c|c|c|c|c|c|c|c|c|c|c|c|c|c|c|c|c|c|c|c|}
\hline \multirow{2}{*}{ Kode } & \multicolumn{20}{|c|}{ Nomor Soal } \\
\hline & 1 & 2 & 3 & 4 & 5 & 6 & 7 & 8 & 9 & 10 & 11 & 12 & 13 & 14 & 15 & 16 & 17 & 18 & 19 & 20 \\
\hline E-01 & SS & S & S & $\mathrm{S}$ & $\begin{array}{c}\text { A } \\
\text { TS }\end{array}$ & SS & $\mathrm{S}$ & SS & $\mathrm{S}$ & S & SS & SS & $\begin{array}{c}\text { A } \\
\text { TS }\end{array}$ & S & $\begin{array}{c}\text { A } \\
\text { TS }\end{array}$ & $\begin{array}{c}\text { ST } \\
\text { S }\end{array}$ & S & SS & SS & $\begin{array}{c}\text { A } \\
\text { TS }\end{array}$ \\
\hline E-02 & $\mathrm{S}$ & $\mathrm{S}$ & $\overline{\mathrm{AS}}$ & $\mathrm{S}$ & $\mathrm{N}$ & $\overline{\mathrm{AS}}$ & $\mathrm{S}$ & $\mathrm{S}$ & $\mathrm{S}$ & $\mathrm{S}$ & $\mathrm{S}$ & $\mathrm{S}$ & $\mathrm{N}$ & $\mathrm{S}$ & $\mathrm{N}$ & $\mathrm{S}$ & $\mathrm{S}$ & $\mathrm{S}$ & $\mathrm{S}$ & $\mathrm{N}$ \\
\hline E-03 & $\begin{array}{c}\text { ST } \\
\text { S }\end{array}$ & $\begin{array}{c}\text { ST } \\
\text { S }\end{array}$ & $\begin{array}{c}\text { ST } \\
\text { S }\end{array}$ & $\begin{array}{c}\text { ST } \\
\text { S }\end{array}$ & $\mathrm{N}$ & $\mathrm{N}$ & $\mathrm{N}$ & $\mathrm{N}$ & $\mathrm{N}$ & $\mathrm{N}$ & $\mathrm{N}$ & $\mathrm{N}$ & $\mathrm{N}$ & $\begin{array}{c}\text { A } \\
\text { TS }\end{array}$ & $\mathrm{N}$ & $\mathrm{N}$ & $\mathrm{N}$ & $\mathrm{N}$ & $\mathrm{N}$ & $\mathrm{N}$ \\
\hline E-04 & TS & $\begin{array}{c}\text { A } \\
\text { TS }\end{array}$ & $\begin{array}{c}\mathrm{A} \\
\mathrm{TS}\end{array}$ & $\begin{array}{c}\text { A } \\
\text { TS }\end{array}$ & $\mathrm{N}$ & $\mathrm{N}$ & $\mathrm{N}$ & AS & $\mathrm{N}$ & $\mathrm{N}$ & $\begin{array}{c}\text { A } \\
\text { TS }\end{array}$ & AS & AS & $\mathrm{N}$ & $\mathrm{N}$ & $\mathrm{N}$ & AS & $\mathrm{N}$ & $\mathrm{N}$ & $\mathrm{N}$ \\
\hline E-05 & $\mathrm{AS}$ & $\overline{\mathrm{AS}}$ & $\overline{\mathrm{AS}}$ & $\mathrm{AS}$ & $\mathrm{N}$ & $\overline{\mathrm{AS}}$ & $\overline{\mathrm{AS}}$ & AS & $\mathrm{AS}$ & $\mathrm{AS}$ & $\overline{\mathrm{AS}}$ & AS & AS & AS & $\mathrm{N}$ & AS & $\mathrm{N}$ & $\mathrm{N}$ & $\mathrm{N}$ & $\mathrm{N}$ \\
\hline E-06 & $\mathrm{N}$ & $\mathrm{N}$ & AS & AS & $\begin{array}{c}\text { A } \\
\text { TS }\end{array}$ & $\mathrm{N}$ & $\mathrm{N}$ & $\mathrm{N}$ & $\mathrm{N}$ & $\mathrm{N}$ & $\mathrm{N}$ & $\mathrm{N}$ & $\mathrm{N}$ & S & $\begin{array}{c}\text { A } \\
\text { TS }\end{array}$ & AS & $\mathrm{N}$ & $\mathrm{N}$ & AS & $\begin{array}{c}\text { A } \\
\text { TS }\end{array}$ \\
\hline E-07 & $\mathrm{N}$ & $\mathrm{N}$ & $\mathrm{N}$ & $\mathrm{N}$ & $\begin{array}{c}\mathrm{A} \\
\mathrm{TS}\end{array}$ & AS & $\mathrm{S}$ & S & $\mathrm{S}$ & S & TS & $\mathrm{N}$ & $\mathrm{N}$ & AS & $\begin{array}{c}\text { A } \\
\text { TS }\end{array}$ & AS & $\mathrm{N}$ & $\mathrm{N}$ & $\begin{array}{c}\text { A } \\
\text { TS }\end{array}$ & $\mathrm{N}$ \\
\hline E-08 & $\mathrm{N}$ & $\mathrm{N}$ & $\mathrm{N}$ & $\mathrm{N}$ & $\mathrm{N}$ & $\mathrm{N}$ & $\overline{\mathrm{AS}}$ & $\overline{\mathrm{AS}}$ & $\overline{\mathrm{AS}}$ & $\overline{\mathrm{AS}}$ & $\mathrm{N}$ & $\mathrm{N}$ & $\mathrm{N}$ & $\mathrm{N}$ & $\mathrm{N}$ & $\mathrm{N}$ & $\mathrm{N}$ & $\mathrm{N}$ & $\mathrm{N}$ & $\mathrm{N}$ \\
\hline E-09 & AS & $\overline{\mathrm{AS}}$ & $\overline{\mathrm{AS}}$ & $\overline{\mathrm{AS}}$ & $\mathrm{N}$ & $\overline{\mathrm{AS}}$ & $\mathrm{N}$ & SS & $\mathrm{N}$ & $\overline{\mathrm{AS}}$ & SS & $\mathrm{N}$ & $\mathrm{N}$ & $\mathrm{N}$ & AS & $\mathrm{S}$ & $\mathrm{N}$ & $\mathrm{N}$ & $S$ & $\mathrm{~N}$ \\
\hline E-10 & $\mathrm{N}$ & $\mathrm{N}$ & $\mathrm{N}$ & $\mathrm{N}$ & AS & TS & TS & $\mathrm{N}$ & $\begin{array}{c}\text { A } \\
\text { TS }\end{array}$ & TS & $\begin{array}{c}\text { ST } \\
\text { S }\end{array}$ & $\begin{array}{c}\text { A } \\
\text { TS }\end{array}$ & $\mathrm{S}$ & $\mathrm{N}$ & $\mathrm{N}$ & $\mathrm{N}$ & $\mathrm{N}$ & $\mathrm{N}$ & TS & SS \\
\hline
\end{tabular}




\begin{tabular}{|c|c|c|c|c|c|c|c|c|c|c|c|c|c|c|c|c|c|c|c|c|}
\hline \multirow{2}{*}{ Kode } & \multicolumn{20}{|c|}{ Nomor Soal } \\
\hline & 1 & 2 & 3 & 4 & 5 & 6 & 7 & 8 & 9 & 10 & 11 & 12 & 13 & 14 & 15 & 16 & 17 & 18 & 19 & 20 \\
\hline E-11 & $\mathrm{N}$ & $\mathrm{N}$ & $\mathrm{N}$ & $\mathrm{N}$ & AS & $\mathrm{N}$ & $\begin{array}{c}\text { A } \\
\text { TS }\end{array}$ & $\mathrm{N}$ & $\mathrm{N}$ & $\begin{array}{c}\text { ST } \\
\text { S }\end{array}$ & $\mathrm{N}$ & $\mathrm{N}$ & $\mathrm{N}$ & $\begin{array}{c}\text { ST } \\
\text { S }\end{array}$ & AS & $\mathrm{N}$ & TS & TS & $\begin{array}{c}\text { A } \\
\text { TS }\end{array}$ & $\begin{array}{c}\text { ST } \\
\text { S }\end{array}$ \\
\hline E-12 & $\mathrm{S}$ & $\mathrm{S}$ & $\mathrm{S}$ & $\mathrm{S}$ & $\mathrm{S}$ & $\mathrm{S}$ & SS & $\mathrm{S}$ & $\mathrm{S}$ & $\mathrm{S}$ & $\mathrm{S}$ & $\mathrm{S}$ & $S$ & $\mathrm{~S}$ & AS & $\mathrm{S}$ & $\mathrm{S}$ & $\mathrm{S}$ & $\mathrm{S}$ & $\mathrm{N}$ \\
\hline E-13 & S & S & AS & $\begin{array}{c}\mathrm{A} \\
\mathrm{TS}\end{array}$ & TS & SS & AS & S & S & S & S & S & $\mathrm{N}$ & AS & AS & AS & TS & TS & $\mathrm{N}$ & $\begin{array}{c}\text { A } \\
\text { TS }\end{array}$ \\
\hline E-14 & $\begin{array}{c}\mathrm{A} \\
\mathrm{TS}\end{array}$ & $\mathrm{N}$ & $\mathrm{N}$ & $\begin{array}{c}\mathrm{A} \\
\mathrm{TS}\end{array}$ & $\begin{array}{c}\text { A } \\
\text { TS }\end{array}$ & $\mathrm{N}$ & AS & $\mathrm{N}$ & $S$ & S & $\mathrm{N}$ & $\mathrm{N}$ & $\mathrm{N}$ & $\begin{array}{c}\mathrm{A} \\
\mathrm{TS}\end{array}$ & AS & $\mathrm{N}$ & S & TS & $\begin{array}{c}\mathrm{A} \\
\mathrm{TS}\end{array}$ & SS \\
\hline E-15 & $\begin{array}{c}\mathrm{A} \\
\mathrm{TS}\end{array}$ & $\begin{array}{c}\text { A } \\
\text { TS }\end{array}$ & $\mathrm{N}$ & $\mathrm{N}$ & $\mathrm{N}$ & $\mathrm{N}$ & AS & $\mathrm{N}$ & $\mathrm{N}$ & $\mathrm{N}$ & $\mathrm{N}$ & $\mathrm{N}$ & $\mathrm{N}$ & $\mathrm{N}$ & AS & AS & $\mathrm{N}$ & $\mathrm{N}$ & $\mathrm{N}$ & $\mathrm{N}$ \\
\hline E-16 & S & S & AS & S & $\mathrm{N}$ & S & S & S & S & AS & S & AS & $\mathrm{N}$ & S & $\mathrm{N}$ & AS & AS & AS & $\mathrm{N}$ & $\begin{array}{c}\text { A } \\
\text { TS }\end{array}$ \\
\hline E-17 & AS & S & AS & AS & $\mathrm{N}$ & $\mathrm{N}$ & $\mathrm{S}$ & S & S & S & AS & S & $\begin{array}{c}\text { A } \\
\text { TS }\end{array}$ & $\mathrm{S}$ & $\mathrm{N}$ & S & $\mathrm{N}$ & AS & AS & $\mathrm{N}$ \\
\hline E-18 & $\mathrm{N}$ & $\mathrm{N}$ & $\mathrm{N}$ & $\mathrm{N}$ & $\mathrm{N}$ & $\mathrm{N}$ & $\mathrm{N}$ & $\mathrm{N}$ & $\mathrm{N}$ & $\mathrm{N}$ & $\mathrm{N}$ & $\mathrm{N}$ & $\mathrm{N}$ & $\mathrm{N}$ & $\mathrm{N}$ & $\mathrm{N}$ & $\mathrm{N}$ & $\mathrm{N}$ & $\mathrm{N}$ & $\mathrm{N}$ \\
\hline E-19 & SS & S & S & SS & $\begin{array}{c}\text { A } \\
\text { TS }\end{array}$ & S & $S$ & SS & AS & $\mathrm{S}$ & AS & AS & TS & SS & $\begin{array}{c}\text { ST } \\
\text { S }\end{array}$ & AS & TS & AS & $\mathrm{S}$ & $\begin{array}{c}\text { A } \\
\text { TS }\end{array}$ \\
\hline E-20 & $\begin{array}{c}\text { A } \\
\text { TS }\end{array}$ & $\mathrm{N}$ & $\mathrm{N}$ & $\mathrm{N}$ & $\mathrm{N}$ & S & $S$ & AS & $\mathrm{N}$ & $\mathrm{S}$ & AS & AS & $\mathrm{N}$ & AS & $\mathrm{N}$ & $\mathrm{N}$ & AS & $\mathrm{N}$ & $\begin{array}{c}\mathrm{A} \\
\mathrm{TS}\end{array}$ & $\mathrm{N}$ \\
\hline E-21 & TS & TS & S & S & $\mathrm{N}$ & $\mathrm{N}$ & $\mathrm{N}$ & $\mathrm{N}$ & $\begin{array}{c}\text { SS } \\
\text { S }\end{array}$ & SS & $\mathrm{N}$ & AS & $\begin{array}{c}\text { A } \\
\text { TS }\end{array}$ & AS & AS & $\mathrm{N}$ & $\mathrm{N}$ & $\mathrm{N}$ & $\mathrm{N}$ & $\mathrm{N}$ \\
\hline E-22 & $\mathrm{N}$ & AS & AS & $\mathrm{N}$ & $\begin{array}{c}\text { A } \\
\text { TS }\end{array}$ & $\mathrm{N}$ & $\mathrm{N}$ & $\mathrm{S}$ & S & $\mathrm{S}$ & $\mathrm{N}$ & AS & $\mathrm{N}$ & $\mathrm{S}$ & $\begin{array}{c}\text { A } \\
\text { TS }\end{array}$ & AS & $\mathrm{N}$ & $\mathrm{N}$ & AS & $\mathrm{N}$ \\
\hline
\end{tabular}




\begin{tabular}{|c|c|c|c|c|c|c|c|c|c|c|c|c|c|c|c|c|c|c|c|c|}
\hline \multirow{2}{*}{ Kode } & \multicolumn{20}{|c|}{ Nomor Soal } \\
\hline & 1 & 2 & 3 & 4 & 5 & 6 & 7 & 8 & 9 & 10 & 11 & 12 & 13 & 14 & 15 & 16 & 17 & 18 & 19 & 20 \\
\hline E-23 & $\mathrm{N}$ & $\mathrm{N}$ & $\begin{array}{c}\mathrm{A} \\
\mathrm{TS}\end{array}$ & $\begin{array}{c}\mathrm{A} \\
\mathrm{TS}\end{array}$ & $\mathrm{N}$ & $\mathrm{N}$ & $\mathrm{N}$ & $\mathrm{N}$ & $\mathrm{N}$ & $\mathrm{N}$ & $\mathrm{N}$ & $\mathrm{N}$ & $\mathrm{N}$ & $\mathrm{N}$ & $\mathrm{N}$ & $\mathrm{N}$ & $\mathrm{N}$ & $\mathrm{N}$ & $\mathrm{N}$ & $\mathrm{N}$ \\
\hline E-24 & $\begin{array}{c}\text { ST } \\
\text { S }\end{array}$ & TS & TS & $\mathrm{N}$ & SS & $\mathrm{N}$ & $\mathrm{N}$ & $\mathrm{N}$ & $\mathrm{N}$ & $\mathrm{N}$ & $\mathrm{N}$ & $\mathrm{N}$ & $\mathrm{N}$ & $\mathrm{N}$ & $\mathrm{N}$ & $\mathrm{N}$ & $\mathrm{N}$ & $\mathrm{N}$ & $\mathrm{N}$ & $\mathrm{N}$ \\
\hline E-25 & $\mathrm{N}$ & $\mathrm{N}$ & $\mathrm{AS}$ & $\overline{\mathrm{AS}}$ & $\mathrm{N}$ & $\mathrm{N}$ & $\mathrm{N}$ & $\mathrm{AS}$ & $\mathrm{AS}$ & $\mathrm{AS}$ & $\overline{\mathrm{AS}}$ & $\mathrm{AS}$ & $\mathrm{AS}$ & $\mathrm{AS}$ & $\mathrm{AS}$ & AS & $\mathrm{N}$ & $\mathrm{N}$ & $\mathrm{AS}$ & $\overline{\mathrm{AS}}$ \\
\hline E-26 & $\begin{array}{c}\text { A } \\
\text { TS }\end{array}$ & $\begin{array}{c}\text { A } \\
\text { TS }\end{array}$ & $\mathrm{N}$ & $\begin{array}{c}\text { A } \\
\text { TS }\end{array}$ & $\mathrm{N}$ & $\mathrm{N}$ & $\mathrm{N}$ & $\mathrm{N}$ & $\mathrm{N}$ & $\mathrm{N}$ & $\mathrm{N}$ & $\mathrm{N}$ & $\mathrm{N}$ & $\mathrm{N}$ & $\mathrm{N}$ & $\mathrm{N}$ & AS & $\mathrm{N}$ & $\begin{array}{c}\mathrm{A} \\
\mathrm{TS} \\
\end{array}$ & AS \\
\hline E-27 & $\mathrm{N}$ & $\mathrm{S}$ & AS & AS & $\mathrm{N}$ & $\mathrm{S}$ & $\mathrm{N}$ & S & AS & S & $\mathrm{N}$ & S & AS & AS & $\begin{array}{c}\text { A } \\
\text { TS }\end{array}$ & S & AS & AS & AS & $\mathrm{N}$ \\
\hline E-28 & AS & $\mathrm{S}$ & SS & SS & TS & SS & $S$ & SS & AS & $\mathrm{S}$ & SS & SS & TS & SS & $\begin{array}{c}\mathrm{A} \\
\mathrm{TS}\end{array}$ & SS & TS & S & AS & TS \\
\hline E-29 & $\mathrm{N}$ & $\mathrm{N}$ & $\mathrm{N}$ & $\mathrm{N}$ & $\mathrm{N}$ & $\mathrm{N}$ & $\overline{A S}$ & $\mathrm{~S}$ & $\mathrm{~S}$ & $\mathrm{~S}$ & $\mathrm{~N}$ & $\mathrm{~N}$ & $\mathrm{~N}$ & AS & $\mathrm{N}$ & AS & $\mathrm{N}$ & $\mathrm{N}$ & $\mathrm{N}$ & $\mathrm{N}$ \\
\hline E-30 & AS & $\mathrm{S}$ & $\mathrm{S}$ & $\mathrm{N}$ & $\mathrm{N}$ & $\mathrm{N}$ & $\overline{A S}$ & $\mathrm{~S}$ & AS & $\mathrm{S}$ & $\mathrm{S}$ & $\mathrm{S}$ & $\mathrm{N}$ & $\mathrm{S}$ & $\mathrm{N}$ & $\mathrm{S}$ & $\mathrm{N}$ & $\mathrm{N}$ & $\mathrm{AS}$ & $\mathrm{S}$ \\
\hline E-31 & $S$ & S & $S$ & S & $\begin{array}{c}\text { A } \\
\text { TS }\end{array}$ & $S$ & SS & SS & SS & SS & S & SS & TS & SS & TS & $S$ & $\mathrm{~N}$ & $S$ & SS & AS \\
\hline E-32 & S & $\mathrm{N}$ & $\mathrm{N}$ & $\mathrm{N}$ & $S$ & $\mathrm{~N}$ & $\mathrm{~N}$ & $\mathrm{~N}$ & $\mathrm{~N}$ & $S$ & S & $\mathrm{N}$ & $\mathrm{N}$ & $\begin{array}{c}\text { ST } \\
\text { S }\end{array}$ & SS & $\mathrm{N}$ & $\mathrm{N}$ & $\mathrm{N}$ & $\mathrm{N}$ & SS \\
\hline E-33 & $\mathrm{N}$ & $\mathrm{N}$ & $\mathrm{N}$ & $\mathrm{N}$ & $\mathrm{N}$ & $\mathrm{N}$ & $\mathrm{N}$ & $\mathrm{N}$ & $\mathrm{N}$ & $\mathrm{N}$ & $\mathrm{N}$ & $\mathrm{N}$ & $\mathrm{N}$ & $\mathrm{N}$ & $\mathrm{N}$ & $\mathrm{N}$ & $\mathrm{N}$ & $\mathrm{N}$ & $\mathrm{N}$ & $\mathrm{N}$ \\
\hline E-34 & $\mathrm{N}$ & $\mathrm{N}$ & $\mathrm{N}$ & $\begin{array}{c}\mathrm{A} \\
\mathrm{TS}\end{array}$ & $\mathrm{N}$ & $\mathrm{N}$ & $\mathrm{N}$ & $\mathrm{N}$ & $\mathrm{N}$ & $\mathrm{N}$ & $\mathrm{N}$ & $\mathrm{N}$ & $\mathrm{N}$ & AS & AS & $\mathrm{N}$ & AS & $\mathrm{N}$ & $\mathrm{N}$ & $\mathrm{N}$ \\
\hline E-35 & $\mathrm{N}$ & $\mathrm{N}$ & $\mathrm{N}$ & $\mathrm{N}$ & $\mathrm{N}$ & $\mathrm{N}$ & $\mathrm{N}$ & $\mathrm{N}$ & $\mathrm{N}$ & $\mathrm{N}$ & $\mathrm{N}$ & $\mathrm{N}$ & $\mathrm{N}$ & $\mathrm{N}$ & $\mathrm{N}$ & $\mathrm{N}$ & $\mathrm{N}$ & $\mathrm{N}$ & $\mathrm{N}$ & $\mathrm{N}$ \\
\hline E-36 & $\mathrm{N}$ & $\mathrm{N}$ & $\mathrm{N}$ & $\mathrm{N}$ & $\mathrm{N}$ & $\overline{\mathrm{AS}}$ & $\mathrm{S}$ & $\mathrm{S}$ & $\mathrm{S}$ & $\mathrm{S}$ & $\mathrm{N}$ & $\mathrm{S}$ & $\mathrm{N}$ & $\mathrm{N}$ & $\mathrm{N}$ & $\mathrm{N}$ & $\mathrm{N}$ & AS & $\mathrm{N}$ & $\mathrm{N}$ \\
\hline
\end{tabular}




\begin{tabular}{|c|c|c|c|c|c|c|c|c|c|c|c|c|c|c|c|c|c|c|c|c|c|c|c|}
\hline & \multirow{2}{*}{ No. } & \multirow{2}{*}{ Kode } & \multicolumn{20}{|c|}{ Nomor Soal } & \multirow{2}{*}{ Jumlah } \\
\hline & & & 1 & 2 & 3 & 4 & 5 & 6 & 7 & 8 & 9 & 10 & 11 & 12 & 13 & 14 & 15 & 16 & 17 & 18 & 19 & 20 & \\
\hline & 1. & E-01 & 7 & 6 & 6 & 6 & 5 & 7 & 6 & 7 & 6 & 6 & 7 & 7 & 5 & 6 & 5 & 7 & 6 & 7 & 7 & 5 & 124 \\
\hline & 2. & E-02 & 6 & 6 & 5 & 6 & 4 & 5 & 6 & 6 & 6 & 6 & 6 & 6 & 4 & 6 & 4 & 6 & 2 & 6 & 6 & 4 & 106 \\
\hline & 3. & E-03 & 1 & 1 & 1 & 1 & 4 & 4 & 4 & 4 & 4 & 4 & 4 & 4 & 4 & 3 & 4 & 4 & 4 & 4 & 4 & 4 & 67 \\
\hline & 4. & E-04 & 2 & 3 & 3 & 3 & 4 & 4 & 4 & 5 & 4 & 4 & 3 & 5 & 3 & 4 & 4 & 4 & 3 & 4 & 4 & 4 & 74 \\
\hline & 5. & E-05 & 5 & 5 & 5 & 5 & 4 & 5 & 5 & 5 & 5 & 5 & 5 & 5 & 3 & 5 & 4 & 5 & 4 & 4 & 4 & 4 & 92 \\
\hline \multirow{38}{*}{ 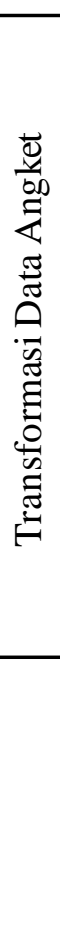 } & 6. & E-06 & 4 & 4 & 5 & 5 & 5 & 4 & 4 & 4 & 4 & 4 & 4 & 4 & 4 & 6 & 5 & 5 & 4 & 4 & 5 & 5 & 89 \\
\hline & 7. & E-07 & 4 & 4 & 4 & 4 & 5 & 5 & 6 & 6 & 6 & 6 & 2 & 4 & 4 & 5 & 5 & 5 & 4 & 4 & 3 & 4 & 90 \\
\hline & 8. & E-08 & 4 & 4 & 4 & 4 & 4 & 4 & 5 & 5 & 5 & 5 & 4 & 4 & 4 & 4 & 4 & 4 & 4 & 4 & 4 & 4 & 84 \\
\hline & \begin{tabular}{|l|}
9. \\
\end{tabular} & E-09 & 5 & 5 & 5 & 5 & 4 & 5 & 4 & 7 & 4 & 5 & 7 & 4 & 4 & 4 & 3 & 6 & 4 & 4 & 6 & 4 & 95 \\
\hline & \begin{tabular}{|l|}
10. \\
\end{tabular} & E-10 & 4 & 4 & 4 & 4 & 3 & 2 & 2 & 4 & 3 & 2 & 1 & 3 & 2 & 4 & 4 & 4 & 4 & 4 & 2 & 1 & 61 \\
\hline & \begin{tabular}{|l|}
11. \\
\end{tabular} & E-11 & 4 & 4 & 4 & 4 & 3 & 4 & 3 & 4 & 4 & 1 & 4 & 4 & 4 & 1 & 3 & 4 & 6 & 2 & 3 & 7 & 73 \\
\hline & 12. & E-12 & 6 & 6 & 6 & 6 & 2 & 6 & 7 & 6 & 6 & 6 & 6 & 6 & 2 & 6 & 3 & 6 & 2 & 6 & 6 & 4 & 104 \\
\hline & \begin{tabular}{|l|}
13. \\
13.
\end{tabular} & E-13 & 6 & 6 & 5 & 3 & 6 & 7 & 5 & 6 & 6 & 6 & 6 & 6 & 4 & 5 & 3 & 5 & 6 & 2 & 4 & 5 & 102 \\
\hline & \begin{tabular}{|l|}
14. \\
\end{tabular} & E-14 & 3 & 4 & 4 & 3 & 5 & 4 & 5 & 4 & 6 & 6 & 4 & 4 & 4 & 3 & 3 & 4 & 2 & 2 & 3 & 1 & 74 \\
\hline & 15. & E-15 & 3 & 3 & 4 & 4 & 4 & 4 & 5 & 4 & 4 & 4 & 4 & 4 & 4 & 4 & 3 & 5 & 4 & 4 & 4 & 4 & 79 \\
\hline & 16. & E-16 & 6 & 6 & 5 & 6 & 4 & 6 & 6 & 6 & 6 & 5 & 6 & 5 & 4 & 6 & 4 & 5 & 3 & 5 & 4 & 5 & 103 \\
\hline & \begin{tabular}{|l|}
17. \\
\end{tabular} & E-17 & 5 & 6 & 5 & 5 & 4 & 4 & 6 & 6 & 6 & 6 & 5 & 6 & 5 & 6 & 4 & 6 & 4 & 5 & 5 & 4 & 103 \\
\hline & \begin{tabular}{|l|}
18. \\
\end{tabular} & E-18 & 4 & 4 & 4 & 4 & 4 & 4 & 4 & 4 & 4 & 4 & 4 & 4 & 4 & 4 & 4 & 4 & 4 & 4 & 4 & 4 & 80 \\
\hline & 19. & E-19 & 7 & 6 & 6 & 7 & 5 & 6 & 6 & 7 & 5 & 6 & 5 & 5 & 6 & 7 & 7 & 5 & 6 & 5 & 6 & 5 & 118 \\
\hline & 20. & E-20 & 3 & 4 & 4 & 4 & 4 & 6 & 6 & 5 & 4 & 6 & 5 & 5 & 4 & 5 & 4 & 4 & 3 & 4 & 3 & 4 & 87 \\
\hline & \begin{tabular}{|l|}
21. \\
\end{tabular} & E-21 & 2 & 2 & 6 & 6 & 4 & 4 & 4 & 4 & 7 & 7 & 4 & 5 & 5 & 5 & 3 & 4 & 4 & 4 & 4 & 4 & 88 \\
\hline & 22. & E-22 & 4 & 5 & 5 & 4 & 5 & 4 & 4 & 6 & 6 & 6 & 4 & 5 & 4 & 6 & 5 & 5 & 4 & 4 & 5 & 4 & 95 \\
\hline & 23. & E-23 & 4 & 4 & 3 & 3 & 4 & 4 & 4 & 4 & 4 & 4 & 4 & 4 & 4 & 4 & 4 & 4 & 4 & 4 & 4 & 4 & 78 \\
\hline & 24. & E-24 & 1 & 2 & 2 & 4 & 1 & 4 & 4 & 4 & 4 & 4 & 4 & 4 & 4 & 4 & 4 & 4 & 4 & 4 & 4 & 4 & 70 \\
\hline & 25. & E-25 & 4 & 4 & 5 & 5 & 4 & 4 & 4 & 5 & 5 & 5 & 5 & 5 & 3 & 5 & 3 & 5 & 4 & 4 & 5 & 3 & 87 \\
\hline & 26. & E-26 & 3 & 3 & 4 & 3 & 4 & 4 & 4 & 4 & 4 & 4 & 4 & 4 & 4 & 4 & 4 & 4 & 3 & 4 & 3 & 3 & 74 \\
\hline & 27. & E-27 & 4 & 6 & 5 & 5 & 4 & 6 & 4 & 6 & 5 & 6 & 4 & 6 & 3 & 5 & 5 & 6 & 3 & 5 & 5 & 4 & 97 \\
\hline & 28. & E-28 & 5 & 6 & 7 & 7 & 6 & 7 & 6 & 7 & 5 & 6 & 7 & 7 & 6 & 7 & 5 & 7 & 6 & 6 & 5 & 6 & 124 \\
\hline & 29. & E-29 & 4 & 4 & 4 & 4 & 4 & 4 & 5 & 6 & 6 & 6 & 4 & 4 & 4 & 5 & 4 & 5 & 4 & 4 & 4 & 4 & 89 \\
\hline & 30. & $\mathrm{E}-30$ & 5 & 6 & 6 & 4 & 4 & 4 & 5 & 6 & 5 & 6 & 6 & 6 & 4 & 6 & 4 & 6 & 4 & 4 & 5 & 2 & 98 \\
\hline & 31. & E-31 & 6 & 6 & 6 & 6 & 5 & 6 & 7 & 7 & 7 & 7 & 6 & 7 & 6 & 7 & 6 & 6 & 4 & 6 & 7 & 3 & 121 \\
\hline & 32. & E-32 & 6 & 4 & 4 & 4 & 2 & 4 & 4 & 4 & 4 & 6 & 6 & 4 & 4 & 1 & 1 & 4 & 4 & 4 & 4 & 1 & 75 \\
\hline & 33. & E-33 & 4 & 4 & 4 & 4 & 4 & 4 & 4 & 4 & 4 & 4 & 4 & 4 & 4 & 4 & 4 & 4 & 4 & 4 & 4 & 4 & 80 \\
\hline & 34 & E-34 & 4 & 4 & 4 & 3 & 4 & 4 & 4 & 4 & 4 & 4 & 4 & 4 & 4 & 5 & 3 & 4 & 3 & 4 & 4 & 4 & 78 \\
\hline & 35 & E-35 & 4 & 4 & 4 & 4 & 4 & 4 & 4 & 4 & 4 & 4 & 4 & 4 & 4 & 4 & 4 & 4 & 4 & 4 & 4 & 4 & 80 \\
\hline & \begin{tabular}{|l|l}
36 \\
\end{tabular} & E-36 & 4 & 4 & 4 & $\begin{array}{ll}4 \\
\end{array}$ & 4 & 5 & 6 & 6 & 6 & 6 & 4 & 6 & 4 & 4 & 4 & 4 & 4 & 5 & 4 & 4 & 92 \\
\hline & \multicolumn{2}{|c|}{\begin{tabular}{|l|} 
Jumlah \\
\end{tabular}} & 153 & 159 & 162 & 159 & 146 & 168 & 172 & 186 & 178 & 182 & 166 & 174 & 145 & 170 & 143 & 174 & 142 & 154 & 158 & 140 & 3231 \\
\hline & \multicolumn{2}{|c|}{ Jumlah SA } & 153 & 159 & 162 & 159 & 146 & 168 & 172 & 186 & 178 & 182 & 166 & 174 & 145 & 170 & 143 & 174 & 142 & 154 & 158 & 140 & \\
\hline & \multirow{2}{*}{\multicolumn{2}{|c|}{ Jumlah SI }} & 252 & 252 & 252 & 252 & 252 & 252 & 252 & 252 & 252 & 252 & 252 & 252 & 252 & 252 & 252 & 252 & 252 & 252 & 252 & 252 & \\
\hline & \multirow{2}{*}{\multicolumn{2}{|c|}{$\begin{array}{c}\% \\
\text { SAV }\end{array}$}} & 60,7 & 63,1 & 64,3 & 63,1 & 57,9 & 66,7 & 68,3 & 73,8 & 70,6 & 72,2 & 65,9 & 69 & 57,5 & 67,5 & 56,7 & 69 & 56,3 & 61,1 & 62,7 & 55,6 & \\
\hline & & & \multicolumn{20}{|c|}{3231} & \\
\hline & \multicolumn{2}{|r|}{ SIV } & \multicolumn{20}{|c|}{5040} & \\
\hline & \multicolumn{2}{|r|}{$\%$} & \multicolumn{20}{|c|}{64,11} & \\
\hline
\end{tabular}




\section{Lampiran 36.}

\section{DOKUMENTASI}

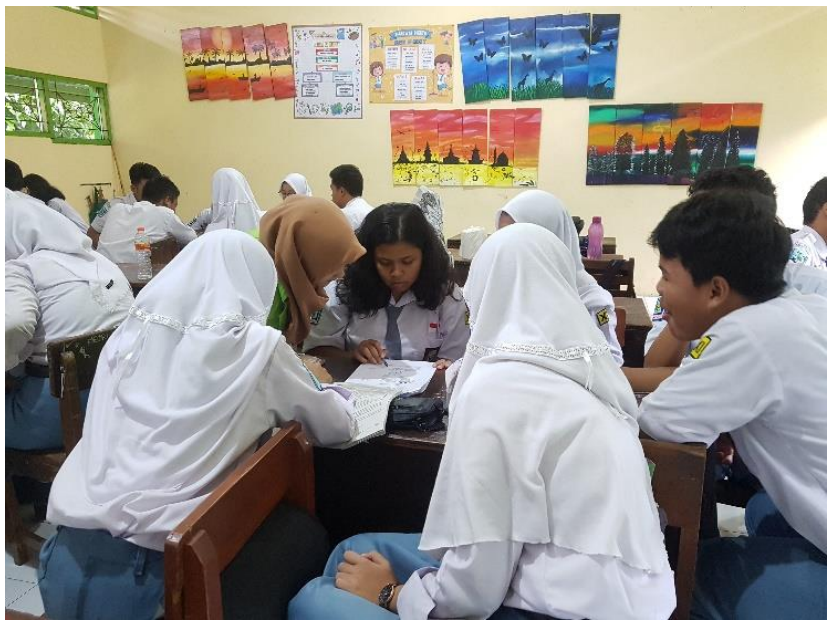

Gambar 1. Kegiatan diskusi dalam fase eksplorasi - imajinasi

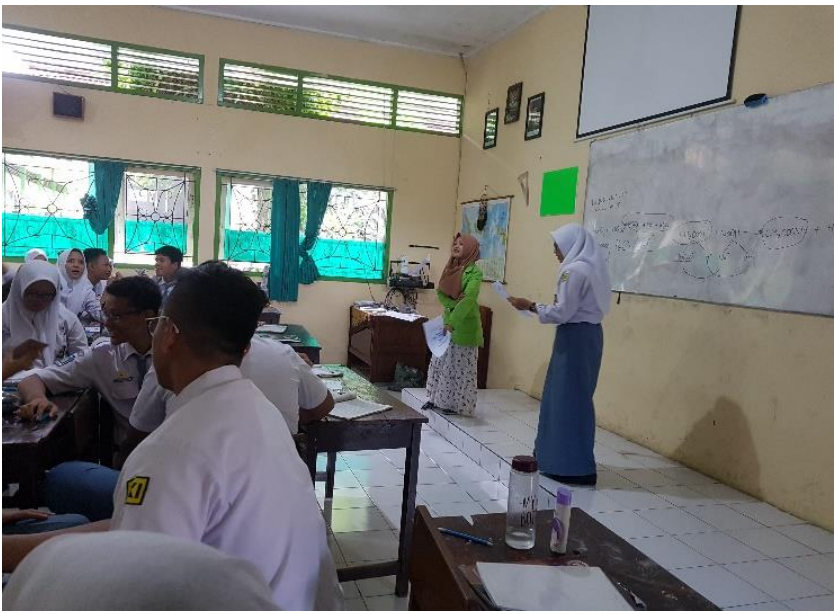

Gambar 2. Perwakilan kelompok melakukan presentasi 


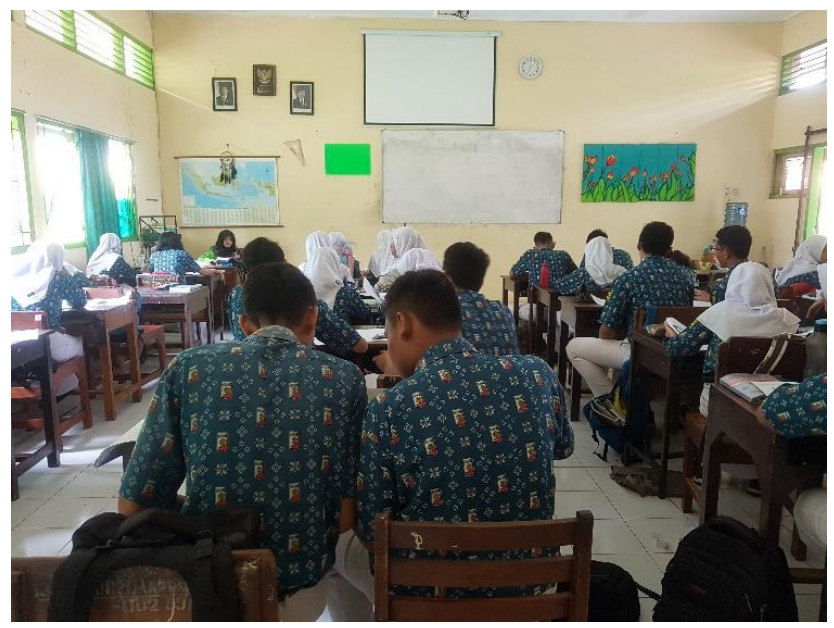

Gambar 3. Peserta didik mengerjakan LKS Individu pada Fase Internalisasi

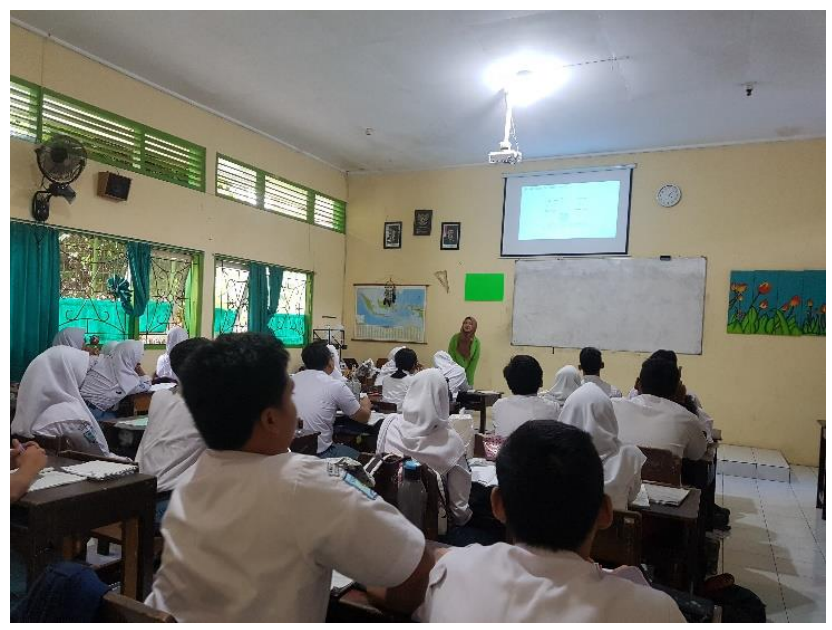

Gambar 4. Peserta didik menyimak hasil reviu dari guru pada fase evaluasi 


\section{Lampiran 37. Surat Keterangan Telah Melakukan Riset}

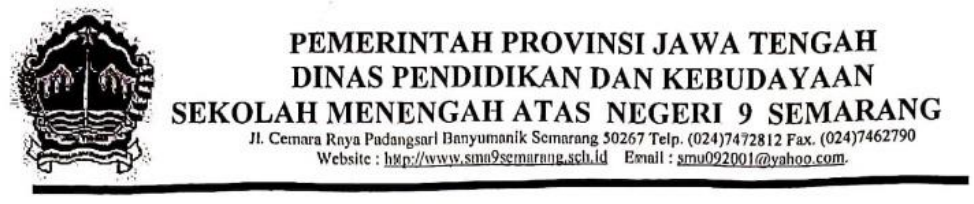

\section{SURAT - KETERANGAN \\ Nomor :421.3/203/2019}

Yang bertanda tangan di bawalo ini :

$\begin{array}{ll}\text { Nama } & : \text { Drs. Khoirul Imdad, Ed.M. } \\ \text { NIP } & : 196006181986031010 \\ \text { Pangkat, Gol } & : \text { Pembina, IV -a } \\ \text { Jabatan } & : \text { Kepala SMA N 9 Semarang }\end{array}$

Dengan ini menerangkan dengan sebenamya bahwa

$\begin{array}{ll}\text { Nama } & : \text { DINI LESTARI } \\ \text { NIM } & : 1608076052 \\ \text { Program Studi } & : \text { Pendidikan Kimia } \\ \text { Fakultas } & : \text { Sains dan Teknologi } \\ \text { Universitas } & : \text { UIN Walisongo Semarang }\end{array}$

Telah melaksanakan Penelitian di SMA Negeri 9 Semarang

Untuk Menyusun Skripsi dengan Judul “Efektivitas Model Pembelajaran SiMaYang Tipe II

Berbasis Multipel Representasi Terhadap Penguasaan Konsep dan Attitudes toward Chemistry pada Materi Larutan Penyangga “

Yang dilaksanakan pada tanggal, 20 Mei 2019 s.d 5 Mei 2020

Demikian surat keterangan ini dikeluarkan agar dapat dipergunakan sebagaimana mestinya.

Semarang, 5 Juni 2020

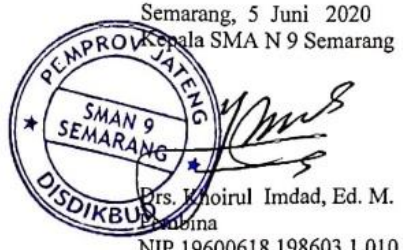

NIP 196006181986031010 


\title{
Lampiran 38. Surat Keterangan telah Melakukan Uji Lab Statistika
}

LABORATORIUM MATEMATIKA

FAKULTAS SAINS DAN TEKNOLOGI

UIN WALISONGO SEMARANG

Jin. Prof. Dr. Hamka Kampus 2 (Gidg. Lab. MIPA Terpadu Li.3) \$27601295 Fax. 7615387 Semarang 50182

\author{
PENELITI : Dini Lestari \\ NIM : 1608076052 \\ JURUSAN : Pendidikan Kimia \\ JUDUL : EFEKTIVITAS MODEL PEMBELAJARAN SIMAYANG TIPE \\ II BERBASIS MULTIPEL REPRESENTASI TERHADAP \\ PENGUASAAN KONSEP DAN ATTITUDES TOWARD \\ CHEMISTRY PADA MATERI LARUTAN PENYANGGA
}

\section{HIPOTESIS :}

a. Hipotesis Varians :

$\mathrm{H}_{0}$ : Varians rata-rata penguaasaan konsep peserta didik kelas eksperimen dan kontrol adalah identik.

$\mathrm{H}_{1}$ : Varians rata-rata penguaasaan konsep peserta didik kelas eksperimen dan kontrol adalah tidak identik.

$\mathrm{H}_{0}$ : Varians rata-rata attitudes toward chemistry peserta didik kelas eksperimen dan kontrol adalah identik.

$\mathrm{H}_{1}$ : Varians rata-rata attitudes toward chemistry peserta didik kelas eksperimen dan kontrol adalah tidak identik.

b. Hipotesis Rata-rata :

$\mathrm{H}_{0} \quad$ : Rata-rata penguaasaan konsep peserta didik kelas eksperimen kurang dari atau sama dengan rata-rata penguasaan konsep kelas kontrol.

$\mathrm{H}_{1}$ : Rata-rata penguaasaan konsep peserta didik kelas eksperimen lebih dari ratarata penguasaan konsep kelas kontrol.

$\mathrm{H}_{0}$ : Rata-rata attitudes toward chemistry peserta didik kelas eksperimen kurang dari atau sama dengan rata-rata attitudes toward chemistry kelas kontrol.

$\mathrm{H}_{1} \quad$ : Rata-rata attitudes toward chemistry peserta didik kelas eksperimen lebih dari rata-rata attitudes toward chemistry kelas kontrol.

\section{DASAR PENGAMBILAN KEPUTUSAN :}

$\mathrm{H}_{0}$ DITERIMA, jika nilai $\mathrm{t} \_$hitung $\leq \mathrm{t} \_$tabel

$\mathrm{H}_{0}$ DITOLAK, jika nilai t_hitung $>$ t_tabel

HASIL DAN ANALISIS DATA :

\begin{tabular}{|l|l|r|r|r|r|}
\hline & Kelas & \multicolumn{1}{|c|}{ G } & \multicolumn{1}{c|}{ Mean } & Std. Deviation & Std. Error Mean \\
\hline \multirow{3}{*}{ Penguasaan Konsep Statistics } & Eksperimen & 36 & 67.9444 & 16.86237 & 2.81040 \\
& Kontrol & 34 & 57.7647 & 17.46869 & 2.99586 \\
\multirow{3}{*}{ Attitudes } & Eksperimen & 36 & 53.8611 & 15.90176 & 2.65029 \\
& Kontrol & 34 & 52.7647 & 11.73459 & 2.01247 \\
\hline
\end{tabular}


LABORATORIUM MATEMATIKA

FAKULTAS SAINS DAN TEKNOLOGI

UIN WALISONGO SEMARANG

Jin. Prof. Dr. Hamka Kampus 2 (Gdg. Lab. MIPA Terpadu Lt.3) $\mathbb{2} 7601295$ Fax. 7615387 Semarang 50182

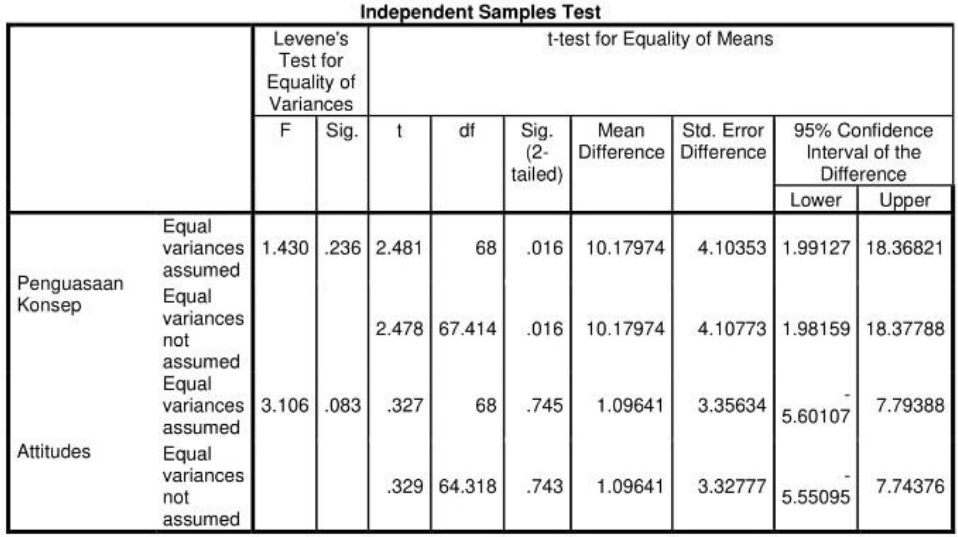

1. Pada kolom Levenes Test for Equality of Variances, diperoleh nilai sig. $=0,236$. Karena sig. $=0,236 \geq 0,05$, maka $H_{0}$ DITERIMA, artinya kedua varians rata-rata penguaasaan konsep peserta didik kelas eksperimen dan kontrol adalah identik.

2. Karena identiknya varians rata-rata penguaasaan konsep peserta didik kelas eksperimen dan kontrol, maka untuk membandingkan rata-rata penguaasaan konsep peserta didik kelas eksperimen dan kontrol dengan menggunakan t-test adalah menggunakan dasar nilai t_hitung pada baris pertama (Equal variances assumed), yaitu t_hitung $=2,481$.

3. Nilai t_tabel $(68 ; 0,05)=1,667$ (one tail). Berarti nilai t_hitung $=2,481>$ t_tabel $=$ 1,667 hal ini berarti $\mathrm{H}_{0}$ DITOLAK, artinya : Rata-rata penguaasaan konsep peserta didik kelas eksperimen lebih baik dari rata-rata penguaasaan konsep peserta didik kelas kontrol.

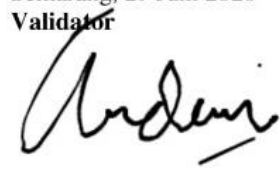

Riska Ayu Ardani, M.Pd. 199307262019032020 


\section{RIWAYAT HIDUP}

\section{A. Identitas Diri}

Nama Lengkap $\quad$ : Dini Lestari

Tempat, Tanggal Lahir : Cianjur, 17 Juli 1997

Alamat Rumah $\quad$ : Perum. Kayu Manis Residence 1

A7 RT 004 RW 005, Kel.

Kayumanis, Kec. Tanah Sareal, Kota Bogor - 16169

No. HP

: 085213641124

E-mail

: dinilestari369@gmail.com

\section{B. Riwayat Pendidikan}

1. SDN Margaluyu

(2004-2010)

2. SMPN 16 Bogor

(2010 - 2013)

3. SMAN 7 Bogor

(2013 - 2016)

4. UIN Walisongo Semarang

(2016 - 2020)

\section{Prestasi Akademik}

1. 100 penulis puisi terbaik antologi lomba puisi pendidikan nasional KMP UNY 2019

2. 120 penulis puisi terbaik antologi Arunika dalam lomba Cipta Puisi Nasional 2019 